\title{
Total synthesis of ht-13-A and ht-13-B, total synthesis of aurantioclavine, progress towards the synthesis of cycloclavine
}

Yilin Zhang

Follow this and additional works at: https://researchrepository.wvu.edu/etd

Part of the Chemistry Commons

\section{Recommended Citation}

Zhang, Yilin, "Total synthesis of ht-13-A and ht-13-B, total synthesis of aurantioclavine, progress towards the synthesis of cycloclavine" (2016). Graduate Theses, Dissertations, and Problem Reports. 7040.

https://researchrepository.wvu.edu/etd/7040

This Dissertation is protected by copyright and/or related rights. It has been brought to you by the The Research Repository @ WVU with permission from the rights-holder(s). You are free to use this Dissertation in any way that is permitted by the copyright and related rights legislation that applies to your use. For other uses you must obtain permission from the rights-holder(s) directly, unless additional rights are indicated by a Creative Commons license in the record and/ or on the work itself. This Dissertation has been accepted for inclusion in WVU Graduate Theses, Dissertations, and Problem Reports collection by an authorized administrator of The Research Repository @ WVU.

For more information, please contact researchrepository@mail.wvu.edu. 


\title{
Total synthesis of ht-13-A and ht-13-B, total synthesis of aurantioclavine, progress towards the synthesis of cycloclavine.
}

\author{
Yilin Zhang \\ Dissertation submitted to the \\ Eberly College of Arts and Sciences \\ at West Virginia University \\ in partial fulfillment of the requirements \\ for the degree of \\ Doctor of Philosophy \\ in \\ Chemistry \\ Björn C. G. Söderberg, Ph.D., Chair \\ Kung K. Wang, Ph.D. \\ John H. Penn, Ph.D. \\ Glen P. Jackson, Ph.D. \\ Yon Rojanasakul, Ph.D. \\ Department of Chemistry \\ Morgantown, West Virginia \\ 2016
}

Keywords: indole, ht-13-B, ht-13-A, aurantioclavine, cycloclavine,

palladium-catalyzed

Copyright 2016 Yilin Zhang 


\begin{abstract}
Total synthesis of ht-13-A and ht-13-B, total synthesis of aurantioclavine, progress towards the synthesis of cycloclavine.
\end{abstract}

Yilin Zhang

Total synthesis of tetracyclic indole alkaloid ht-13-A and ht-13-B has been accomplished from commercially available (S)-4-amino-2-hydroxybutyric acid and trans4-hydroxy-L-proline respectively. The key synthetic steps include an acyliminium ion allylation, a Mitsunobu reaction, a palladium-catalyzed Stille-Kelly cross coupling reaction, and a carbon monoxide mediated palladium-catalyzed reductive $\mathrm{N}$ heterocyclization. The total synthesis of aurantioclavine has been studied. The synthesis commenced with 2-amino-3-nitrophenol. Key synthetic steps include a Stille coupling reaction, a Heck reaction, a Lewis acid mediated cyclization and a carbon monoxide mediated palladium-catalyzed reductive $N$-heterocyclization. In addition, the first asymmetric total synthesis of (+)-cycloclavine has been studied. Key synthetic steps include a ring closing metathesis, an acyliminium ion allylation and a Stille coupling. 


\section{Dedicated to my Parents, Kun Zhang and Yuling Sun}




\section{Acknowledgements}

First and foremost, I would like to thank my research advisor, Dr. Björn Söderberg, for all of his support for me to complete Ph.D. With his patience, I have learned organic chemistry and organic laboratory skills. In addition, I am very grateful to his guidance through all the difficulties I encountered during my research work. Furthermore, I sincerely appreciate the members of my committee, Drs. Kung Wang, John Penn, Glen Jackson, and Yon Rojanasakul for their valuable involvement throughout my entire graduate study.

I appreciate the assistance and friendship of my co-workers in the Söderberg group, Dr. Jeremiah W. Hubbard, Dr. Matthew M. Cummings, Dr. Hong Yin, Ganesh Ghimire, Nurul Ansari, Katharine Lambson, Ian McArdle. Part of the work in Chapter 1 was continued from Dr. Jeremiah W. Hubbard's previous work. Some of the data in Chapter 3 was collected with Ian McArdle. I would like to thank all of their help, enabling me to complete my research projects efficiently.

I want to express my appreciation to my family in China for their endless support and encouragement.

Finally, I gratefully acknowledge the financial support from C. Eugene Bennett Department of Chemistry in West Virginia University (John R. Conard Fellowship and travel support) and the National Science Foundation. 


\section{Table of Contents}

Title page

Abstract

Dedication

Acknowledgements

Table of Contents

List of Tables

List of Schemes

List of Figures

Chapter 1: Total synthesis of ht-13-B

A: Introduction

B: Results and Discussion

C: Conclusions

Chapter 2: Total synthesis of ht-13-A 21

A: Introduction 21

B: Results and Discussion $\quad 23$

C: Conclusions $\quad 30$

Chapter 3: Total synthesis of aurantioclavine 31

A: Introduction 31

B: Results and Discussion $\quad 35$

C: Conclusions $\quad 47$

Chapter 4: Progress towards the synthesis of cycloclavine 48

$\begin{array}{ll}\text { A: Introduction } & 48\end{array}$

B: Results and Discussion $\quad 50$

C: Conclusions $\quad 57$

Chapter 5: Experimental $\quad 58$

A: General Procedures $\quad 58$

B: Experimental $\quad 58$

References and Footnotes 109

$\begin{array}{ll}\text { Appendix } & 114\end{array}$ 


\section{List of Tables}

Table 1: Allylation of $\mathbf{1}$ using 2-bromo-2-propen-1-yltrimethylsilane $\mathbf{1 3}$

Table 2: Stille-Kelly reaction of $\mathbf{1 9}$

Table 3: Lewis acid mediated allylation of $\mathbf{2 8}$

Table 4: Moc deprotection of $\mathbf{7 3}$ 


\section{List of Schemes}

Scheme 1: Synthesis of 3,4-fused indoles $\quad 2$

Scheme 2: Intramolecular Fischer indole synthesis 3

Scheme 3: Intramolecular oxidative annulation 3

Scheme 4: Intramolecular Heck reaction and $N$-heterocyclization 3

Scheme 5: Retrosynthetic analysis of ht-13-B 5

Scheme 6: Synthesis of pyrrolidine 126

Scheme 7: Lewis acid mediated allylation 6

Scheme 8: Titanium tetrachloride mediated allylation $\quad 7$

Scheme 9: Boc protection and TBAF deprotection of 5

Scheme 10: Mitsunobu and intramolecular Heck reactions 9

Scheme 11: Modified oxepine cyclization precursor 10

Scheme 12: Synthesis of 2-bromo-2-propen-1-yltrimethylsilane 13

Scheme 13: Synthesis of pyrrolidine $14 \quad 11$

Scheme 14: Allylation without loss of Boc group $\quad 12$

Scheme 15: Synthesis of methyl carbamate $19 \quad 14$

Scheme 16: Intramolecular Suzuki coupling of $19 \quad 16$

Scheme 17: Previous synthesis using reductive $N$-heterocyclization reactions $\quad 17$

Scheme 18: Reductive $N$-heterocyclization of $20 \quad 17$

$\begin{array}{ll}\text { Scheme 19: Synthesis of ht-13-B } & 18\end{array}$

Scheme 20: Retrosynthetic analysis of ht-13-A 23

Scheme 21: Synthesis of pyrrolidin-2-one $22 \quad 24$

Scheme 22: Synthesis of $N, O$-acetal $28 \quad 25$

Scheme 23: Two-step procedure toward compound $32 \quad 26$

Scheme 24: Synthesis of methyl carbamate $35 \quad 27$

Scheme 25: Synthesis of ht-13-A 29

Scheme 26: Hegedus's synthesis of aurantioclavine 32

Scheme 27: Ellman's synthesis of (-)-aurantioclavine 32

Scheme 28: Jia's synthesis of (-)-aurantioclavine 33

Scheme 29: Takemoto's synthesis of (-)-aurantioclavine 34

Scheme 30: Retrosynthetic analysis of aurantioclavine 35

Scheme 31: Synthesis of Heck precursor $\mathbf{4 5} 36$

Scheme 32: Alternative pathway toward Heck precursor 45

Scheme 33: Synthesis of triflate $\mathbf{5 3} 38$

Scheme 34: Synthesis of phenol 54

Scheme 35: Synthesis of triflate 60039

Scheme 36: Heck and Sonogashira coupling of $60 \quad 40$

Scheme 37: Synthesis of building block $\mathbf{5 3} 41$

Scheme 38: Alternative pathway toward $54 \quad 42$

Scheme 39: Synthesis of dehydrated ergotryptamine 43

Scheme 40: Failed intramolecular cyclization of 69

Scheme 41: Synthesis of indole $73 \quad 44$

Scheme 42: Synthesis of ergotryptamine 46

Scheme 43: Retrosynthetic analysis of cycloclavine 51

Scheme 44: Synthesis of acetate $\mathbf{8 1}$ and trimethylstannane $\mathbf{8 7} 52$ 
Scheme 45: Kosugi-Migita-Stille coupling toward $\mathbf{8 8}$ and $\mathbf{8 0}$

Scheme 46: Elimination of acetate $\mathbf{8 0}$

Scheme 47: Synthesis of triflate $\mathbf{9 8}$ 


\section{List of Figures}

Figure 1: Structure of ht-13-A and ht-13-B 1

Figure 2: X-ray analysis of compound 11

Figure 3: X-ray analysis of indole precursor $20 \quad 16$

Figure 4: X-ray analysis of ht-13-B 19

Figure 5: Derivatives of ht-13-A 22

Figure 6: Structure of aurantioclavine $\quad 31$

Figure 7: Structure of cycloclavine 48

Figure 8: ${ }^{1} \mathrm{H}$ NMR of 3(R)-[(t-butyldimethylsilyl)oxy]-5(R)- 115

methyl-2-(2-propen-1-yl)pyrrolidine (5)

Figure 9: ${ }^{13} \mathrm{C}$ NMR of 3(R)-[(t-butyldimethylsilyl)oxy]-5(R)- 116 methyl-2-(2-propen-1-yl)pyrrolidine (5)

Figure 10: ${ }^{1} \mathrm{H}$ NMR of 1-( $t$-butoxycarbonyl)-3(R)-[( $t$-butyldimethylsilyl)- $\quad 117$ oxy]-5(R)-methyl-2-(2-propen-1-yl)-pyrrolidine (6)

Figure 11: ${ }^{13} \mathrm{C}$ NMR of 1-( $t$-butoxycarbonyl)-3(R)-[(t-butyldimethylsilyl)- 118 oxy]-5(R)-methyl-2-(2-propen-1-yl)-pyrrolidine (6)

Figure 12: ${ }^{1} \mathrm{H}$ NMR of 1-( $t$-butoxycarbonyl)-3(R)-hydroxy-5(R)-methyl-2(R)- 119 (2-propen-1-yl)pyrrolidine (7)

Figure 13: ${ }^{13} \mathrm{C}$ NMR of 1-(t-butoxycarbonyl)-3(R)-hydroxy-5(R)-methyl-2(R)- 120 (2-propen-1-yl)pyrrolidine (7)

Figure 14: ${ }^{1} \mathrm{H}$ NMR $\left(60{ }^{\circ} \mathrm{C}\right)$ of 1-(t-butoxycarbonyl)-3(R)-hydroxy-5(R)methyl-2(R)-(2-propen-1-yl)pyrrolidine (7)

Figure 15: ${ }^{13} \mathrm{C}$ NMR $\left(60{ }^{\circ} \mathrm{C}\right)$ of 1-(t-butoxycarbonyl)-3(R)-hydroxy-5(R)- 122 methyl-2(R)-(2-propen-1-yl)pyrrolidine (7)

Figure 16: ${ }^{1} \mathrm{H}$ NMR of 1-( $t$-butoxycarbonyl)-3(R)-hydroxy-5(R)-methyl- 123 2(S)-(2-propen-1-yl)pyrrolidine (8)

Figure 17: ${ }^{13} \mathrm{C}$ NMR of 1-(t-butoxycarbonyl)-3(R)-hydroxy-5(R)-methyl2(S)-(2-propen-1-yl)pyrrolidine (8)

Figure 18: ${ }^{1} \mathrm{H}$ NMR $\left(60{ }^{\circ} \mathrm{C}\right)$ of 1-( $t$-butoxycarbonyl)-3(R)-hydroxy-5(R)- 125 methyl-2(S)-(2-propen-1-yl)pyrrolidine (8)

Figure 19: ${ }^{13} \mathrm{C}$ NMR $\left(60^{\circ} \mathrm{C}\right)$ of 1-(t-butoxycarbonyl)-3(R)-hydroxy-5(R)- 126 methyl-2(S)-(2-propen-1-yl)pyrrolidine (8)

Figure 20: ${ }^{1} \mathrm{H}$ NMR of 2(R)-(2-propen-1-yl)-1-(t-butoxycarbonyl)-3(S)- 127 (2-bromo-3-nitrophenoxy-5(R)-methylpyrrolidine (10)

Figure 21: ${ }^{13} \mathrm{C}$ NMR of 2(R)-(2-propen-1-yl)-1-( $t$-butoxycarbonyl)-3(S)- $\quad 128$ (2-bromo-3-nitrophenoxy-5(R)-methylpyrrolidine (10)

Figure 22: ${ }^{1} \mathrm{H}$ NMR of tricyclic compound 11 
Figure 23: ${ }^{1} \mathrm{H}$ NMR $\left(60^{\circ} \mathrm{C}\right)$ of tricyclic compound $\mathbf{1 1} 130$

Figure 24: ${ }^{13} \mathrm{C}$ NMR $\left(60^{\circ} \mathrm{C}\right)$ of tricyclic compound $\mathbf{1 1} 131$

Figure 25: ${ }^{1} \mathrm{H}$ NMR of 2(R)-(2-bromo-2-propen-1-yl)-3(R)-[(t- 132 butyldimethylsilyl)-oxy]-5(R)-methylpyrrolidine (14)

Figure 26: ${ }^{13} \mathrm{C}$ NMR of 2(R)-(2-bromo-2-propen-1-yl)-3(R)-[( $t$ butyldimethylsilyl)-oxy]-5(R)-methylpyrrolidine (14)

Figure 27: ${ }^{1} \mathrm{H}$ NMR of 5(R)-[(t-butyldimethylsilyl)oxy]-(4a)-hexahydro3-methylene-7(R)-methyl-1H-pyrrolo[1,2-c][1,3]oxazin-1-one (15)

Figure 28: ${ }^{13} \mathrm{C}$ NMR of 5(R)-[(t-butyldimethylsilyl)oxy]-(4a)-hexahydro3-methylene-7(R)-methyl-1H-pyrrolo[1,2-c][1,3]oxazin-1-one (15)

Figure 29: ${ }^{1} \mathrm{H}$ NMR of 2(R)-(2-bromo-2-propen-1-yl)-3(R)-[(t134 butyldimethylsilyl)-oxy]-1-( $t$-butoxycarbonyl)-5(R)-methylpyrrolidine (16)

Figure 30: ${ }^{13} \mathrm{C}$ NMR $\left(65^{\circ} \mathrm{C}\right)$ of 2(R)-(2-bromo-2-propen-1-yl)-3(R)-[(tbutyldimethylsilyl)-oxy]-1-(t-butoxycarbonyl)-5(R)-methylpyrrolidine (16)

Figure 31: ${ }^{1} \mathrm{H}$ NMR $\left(65^{\circ} \mathrm{C}\right)$ of 2(R)-(2-bromo-2-propen-1-yl)-3(R)-[( $t$ butyldimethylsilyl)-oxy]-1-(methoxycarbonyl)-5(R)-methylpyrrolidine (17)

Figure 32: ${ }^{13} \mathrm{C}$ NMR $\left(65{ }^{\circ} \mathrm{C}\right)$ of 2(R)-(2-bromo-2-propen-1-yl)-3(R)-[(tbutyldimethylsilyl)-oxy]-1-(methoxycarbonyl)-5(R)-methylpyrrolidine (17)

Figure 33: ${ }^{1} \mathrm{H}$ NMR of 2(R)-(2-bromo-2-propen-1-yl)-3(R)-hydroxy-1(methoxycarbonyl)-5(R)-methylpyrrolidine (18)

Figure 34: ${ }^{13} \mathrm{C}$ NMR of 2(R)-(2-bromo-2-propen-1-yl)-3(R)-hydroxy-1(methoxycarbonyl)-5(R)-methylpyrrolidine (18)

135

Figure 35: ${ }^{1} \mathrm{H}$ NMR of 3(S)-(2-bromo-3-nitrophenoxy)-2(R)-(2-bromo-propen- 142 1-yl)-1-(methoxycarbonyl)-5(R)-methylpyrrolidine (19)

Figure 36: ${ }^{13} \mathrm{C}$ NMR of 3(S)-(2-bromo-3-nitrophenoxy)-2(R)-(2-bromo-propen- 143 1-yl)-1-(methoxycarbonyl)-5(R)-methylpyrrolidine (19)

Figure 37: ${ }^{1} \mathrm{H}$ NMR $\left(65^{\circ} \mathrm{C}\right)$ of tricyclic Compound 20144

Figure 38: ${ }^{13} \mathrm{C}$ NMR $\left(65^{\circ} \mathrm{C}\right)$ of tricyclic Compound 20 145

Figure 39: ${ }^{1} \mathrm{H}$ NMR of (6aR,8R,9aS)-7-methoxycarbonyl-6,6a,7,8,9,9a- 146 hexahydro-8-methyl-H-pyrrolo[2',3':6,7] oxepino[4,3,2-cd]indole (21)

Figure 40: ${ }^{13} \mathrm{C}$ NMR of (6aR,8R,9aS)-7-methoxycarbonyl-6,6a,7,8,9,9ahexahydro-8-methyl-H-pyrrolo[2',3':6,7]oxepino[4,3,2-cd]indole (21)

Figure 41: ${ }^{1} \mathrm{H}$ NMR of ht-13-B

Figure $42:{ }^{13} \mathrm{C}$ NMR of ht-13-B 148

Figure 43: ${ }^{1} \mathrm{H}$ NMR of 3-(t-butyl-dimethyl-silanyloxy)-2-methoxy- 150 pyrrolidine-1-carboxylic acid $t$-butyl ester (28)

Figure $44:{ }^{13} \mathrm{C}$ NMR of 3-(t-butyl-dimethyl-silanyloxy)-2-methoxy- 
pyrrolidine-1-carboxylic acid $t$-butyl ester (28)

Figure 45 : ${ }^{1} \mathrm{H}$ NMR $\left(65^{\circ} \mathrm{C}\right)$ of 2-(2-bromo-allyl)-3-(t-butyl-dimethyl-

silanyloxy)pyrrolidine-1-carboxylic acid $t$-butyl ester (29)

Figure $46:{ }^{13} \mathrm{C}$ NMR $\left(65^{\circ} \mathrm{C}\right)$ of 2-(2-bromo-allyl)-3-(t-butyl-dimethylsilanyloxy)pyrrolidine-1-carboxylic acid $t$-butyl ester (29)

Figure 47: ${ }^{1} \mathrm{H}$ NMR of 5-( $t$-butyl-dimethyl-silanyloxy)-3-methylenehexahydropyrrolo[1,2-c][1,3]oxazin-1-one (30)

Figure 48: ${ }^{13} \mathrm{C}$ NMR of 5-(t-butyl-dimethyl-silanyloxy)-3-methylenehexahydropyrrolo[1,2-c][1,3] oxazin-1-one (30)

Figure 49: ${ }^{1} \mathrm{H}$ NMR of 2-(2-bromo-allyl)-3-( $t$-butyl-dimethyl-silanyloxy)pyrrolidine (31)

Figure 50: ${ }^{13} \mathrm{C}$ NMR of 2-(2-bromo-allyl)-3-(t-butyl-dimethyl-silanyloxy)pyrrolidine (31)

Figure 51: ${ }^{1} \mathrm{H}$ NMR of 3(R)-t-butyldimethylsilyloxy-1-(methoxycarbonyl)pyrrolidin-2-one (33)

Figure 52: ${ }^{13} \mathrm{C}$ NMR of 3(R)-t-butyldimethylsilyloxy-1-(methoxycarbonyl)pyrrolidin-2-one (33)

Figure 53: ${ }^{1} \mathrm{H}$ NMR $\left(65^{\circ} \mathrm{C}\right)$ of $3(\mathrm{R})$-t-butyldimethylsilyloxy-2(R/S)hydroxy-1-(methoxycarbonyl)pyrrolidine (34)

Figure 54: ${ }^{13} \mathrm{C}$ NMR of 3(R)-t-butyldimethylsilyloxy-2(R/S)-hydroxy-1(methoxycarbonyl)pyrrolidine (34)

Figure 55: ${ }^{1} \mathrm{H}$ NMR $\left(65^{\circ} \mathrm{C}\right)$ of 2(R/S)-(2-bromo-2-propen-1-yl)-3(R)-tbutyldimethylsilyloxy-1-(methoxycarbonyl)pyrrolidine (32)

Figure $56:{ }^{13} \mathrm{C}$ NMR $\left(65^{\circ} \mathrm{C}\right)$ of $2(\mathrm{R} / \mathrm{S})$-(2-bromo-2-propen-1-yl)-3(R)- $t$ butyldimethylsilyloxy-1-(methoxycarbonyl)pyrrolidine (32)

Figure 57: ${ }^{1} \mathrm{H}$ NMR $\left(65^{\circ} \mathrm{C}\right)$ of 2(R)-(2-bromo-2-propen-1-yl)-3(R)hydroxy-1-(methoxycarbonyl)pyrrolidine (35)

Figure 58: ${ }^{13} \mathrm{C}$ NMR $\left(65{ }^{\circ} \mathrm{C}\right)$ of 2(R)-(2-bromo-2-propen-1-yl)-3(R)hydroxy-1-(methoxycarbonyl)pyrrolidine (35)

Figure 59: ${ }^{1} \mathrm{H}$ NMR $\left(60{ }^{\circ} \mathrm{C}\right)$ of 2(S)-(2-bromo-2-propen-1-yl)-3(R)hydroxy-1-(methoxycarbonyl)pyrrolidine (36)

Figure 60: ${ }^{13} \mathrm{C}$ NMR of 2(S)-(2-bromo-2-propen-1-yl)-3(R)-hydroxy1-(methoxycarbonyl)pyrrolidine (36)

Figure 61: ${ }^{1} \mathrm{H}$ NMR $\left(65^{\circ} \mathrm{C}\right)$ of 3(S)-(2-bromo-3-nitrophenyl)-2(R)-(2-bromo- 168 2-propen-1-yl)-1-(methoxycarbonyl)-pyrrolidine (37)

Figure 62: ${ }^{13} \mathrm{C}$ NMR $\left(65{ }^{\circ} \mathrm{C}\right)$ of 3(S)-(2-bromo-3-nitrophenyl)-2(R)-(2-bromo- 169 2-propen-1-yl)-1-(methoxycarbonyl)-pyrrolidine (37)

Figure 63: ${ }^{1} \mathrm{H}$ NMR of 2,3,3a $(S), 9,10,10 \mathrm{a}(R)$-hexahydro-1-(methoxycarbonyl)- $\quad 170$ 8-nitro- $1 H$-benzoxepino[3,2-b]pyrrole (38)

Figure 64: ${ }^{13} \mathrm{C}$ NMR of 2,3,3a( $(S), 9,10,10 \mathrm{a}(R)$-hexahydro-1-(methoxycarbonyl)- 171 8-nitro-1 $H$-benzoxepino[3,2-b]pyrrole (38) 
Figure $65:{ }^{1} \mathrm{H}$ NMR $\left(65^{\circ} \mathrm{C}\right)$ of $6,6 \mathrm{a}(R), 7,8,9,9 \mathrm{a}(S)$-hexahydro-7-(methoxycarbonyl)-4H-pyrrolo[2',3':6,7] oxepino-[4,3,2-cd]indole (39)

Figure 66: ${ }^{13} \mathrm{C}$ NMR $\left(65^{\circ} \mathrm{C}\right)$ of $6,6 \mathrm{a}(R), 7,8,9,9 \mathrm{a}(S)$-hexahydro-7-(methoxycarbonyl)-4H-pyrrolo[2',3':6,7] oxepino-[4,3,2-cd] indole (39)

Figure 67: ${ }^{1} \mathrm{H}$ NMR of ht-13-A

Figure 68: ${ }^{13} \mathrm{C}$ NMR of ht-13-A

175

Figure 69: ${ }^{1} \mathrm{H}$ NMR of trifluoro-methanesulfonic acid 2-bromo-6-nitro-

176

Figure 70: ${ }^{13} \mathrm{C}$ NMR of trifluoro-methanesulfonic acid 2-bromo-6-nitrophenyl ester (43)

Figure 71: ${ }^{1} \mathrm{H}$ NMR $\left(65^{\circ} \mathrm{C}\right)$ of [3-(2-bromo-6-nitro-phenyl)-but-3-enyl]carbamic acid methyl ester (45)

Figure 72: ${ }^{13} \mathrm{C}$ NMR of [3-(2-bromo-6-nitro-phenyl)-but-3-enyl]carbamic acid methyl ester (45)

Figure 73: ${ }^{1} \mathrm{H}$ NMR of (2-bromo-6-nitro-phenyl)-trimethyl-stannane (50)

Figure 74: ${ }^{13} \mathrm{C}$ NMR of (2-bromo-6-nitro-phenyl)-trimethyl-stannane (50)

Figure 75: ${ }^{1} \mathrm{H}$ NMR of trifluoro-methanesulfonic acid 2-iodo-3-nitro-

Figure 76: ${ }^{13} \mathrm{C}$ NMR of trifluoro-methanesulfonic acid 2-iodo-3-nitrophenyl ester (52)

Figure 77: ${ }^{1} \mathrm{H}$ NMR of (2-benzyloxy-6-nitro-phenyl)-trimethyl-stannane (56) 184

Figure 78: ${ }^{13} \mathrm{C}$ NMR of (2-benzyloxy-6-nitro-phenyl)-trimethyl-stannane (56) 185

Figure 79: ${ }^{1} \mathrm{H}$ NMR $\left(65^{\circ} \mathrm{C}\right)$ of [3-(2-benzyloxy-6-nitro-phenyl)-but-3-enyl]- 186 carbamic acid methyl ester (57)

Figure 80: ${ }^{13} \mathrm{C}$ NMR of [3-(2-benzyloxy-6-nitro-phenyl)-but-3-enyl]carbamic acid methyl ester (57)

Figure 81: ${ }^{1} \mathrm{H}$ NMR $\left(65^{\circ} \mathrm{C}\right)$ of [2-(4-benzyloxy-1H-indol-3-yl)-ethyl]carbamic acid methyl ester (58)

Figure 82: ${ }^{13} \mathrm{C}$ NMR of [2-(4-benzyloxy-1H-indol-3-yl)-ethyl]carbamic acid methyl ester (58)

Figure 83: ${ }^{1} \mathrm{H}$ NMR of [2-(4-hydroxy-1H-indol-3-yl)-ethyl]carbamic acid methyl ester (59)

Figure 84: ${ }^{13} \mathrm{C}$ NMR of [2-(4-hydroxy-1H-indol-3-yl)-ethyl]carbamic acid methyl ester (59)

Figure 85: ${ }^{1} \mathrm{H}$ NMR of trifluoro-methanesulfonic acid 3-(2-methoxycarbonylamino-ethyl)-1H-indol-4-yl ester (60)

Figure 86: ${ }^{13} \mathrm{C}$ NMR of trifluoro-methanesulfonic acid 3-(2-methoxycarbonylamino-ethyl)-1H-indol-4-yl ester (60)

Figure 87: ${ }^{1} \mathrm{H}$ NMR of 2-iodo-1-(4-methoxy-benzyloxy)-3-nitro-benzene (63) 194

Figure 88: ${ }^{13} \mathrm{C}$ NMR of 2-iodo-1-(4-methoxy-benzyloxy)-3-nitro-benzene (63) 195

Figure 89: ${ }^{1} \mathrm{H}$ NMR of [2-(4-methoxy-benzyloxy)-6-nitro-phenyl]- 196 
trimethyl-stannane (64)

Figure 90: ${ }^{13} \mathrm{C}$ NMR of [2-(4-methoxy-benzyloxy)-6-nitro-phenyl]- 197 trimethyl-stannane (64)

Figure 91: ${ }^{1} \mathrm{H}$ NMR $\left(65^{\circ} \mathrm{C}\right)$ of \{3-[2-(4-methoxy-benzyloxy)-6-nitro-phenyl]- 198 but-3-enyl $\}$-carbamic acid methyl ester (65)

Figure 92: ${ }^{13} \mathrm{C}$ NMR $\left(65^{\circ} \mathrm{C}\right)$ of $\{3$-[2-(4-methoxy-benzyloxy)-6-nitro-phenyl]but-3-enyl $\}$-carbamic acid methyl ester (65)

Figure 93: ${ }^{1} \mathrm{H}$ NMR of 2-iodo-1-methoxymethoxy-3-nitro-benzene (66) 200

Figure 94: ${ }^{13} \mathrm{C}$ NMR of 2-iodo-1-methoxymethoxy-3-nitro-benzene (66) 201

Figure 95: ${ }^{1} \mathrm{H}$ NMR of (2-methoxymethoxy-6-nitro-phenyl)-trimethyl- 202 stannane (67)

Figure 96: ${ }^{13} \mathrm{C}$ NMR of (2-methoxymethoxy-6-nitro-phenyl)-trimethyl- 203 stannane (67)

Figure 97: ${ }^{1} \mathrm{H}$ NMR $\left(65{ }^{\circ} \mathrm{C}\right)$ of [3-(2-methoxymethoxy-6-nitro-phenyl)- 204 but-3-enyl]-carbamic acid methyl ester (68)

Figure 98: ${ }^{13} \mathrm{C}$ NMR of [3-(2-methoxymethoxy-6-nitro-phenyl)-but-3- 205 enyl]-carbamic acid methyl ester (68)

Figure 99: ${ }^{1} \mathrm{H}$ NMR $\left(65^{\circ} \mathrm{C}\right)$ of [3-(2-hydroxy-6-nitro-phenyl)-but-3-enyl]- 206 carbamic acid methyl ester (54)

Figure 100: ${ }^{13} \mathrm{C}$ NMR $\left(65^{\circ} \mathrm{C}\right)$ of [3-(2-hydroxy-6-nitro-phenyl)-but-3-enyl]- 207 carbamic acid methyl ester (54)

Figure 101: ${ }^{1} \mathrm{H}$ NMR $\left(65^{\circ} \mathrm{C}\right)$ of trifluoro-methanesulfonic acid 2-(3- 208 methoxy-carbonylamino-1-methylene-propyl)-3-nitrophenyl ester (53)

Figure 102: ${ }^{13} \mathrm{C}$ NMR $\left(65^{\circ} \mathrm{C}\right)$ of trifluoro-methanesulfonic acid 2-(3- 209 methoxy-carbonylamino-1-methylene-propyl)-3-nitrophenyl ester (53)

Figure 103: ${ }^{1} \mathrm{H}$ NMR $\left(65^{\circ} \mathrm{C}\right)$ of \{3-[2-(3-hydroxy-3-methyl-but-1-enyl)-6- 210 nitro-phenyl]-but-3-enyl -carbamic acid methyl ester (69)

Figure 104: ${ }^{13} \mathrm{C}$ NMR of \{3-[2-(3-hydroxy-3-methyl-but-1-enyl)-6-nitro- 211 phenyl]-but-3-enyl $\}$-carbamic acid methyl ester (69)

Figure 105: ${ }^{1} \mathrm{H}$ NMR $\left(65^{\circ} \mathrm{C}\right)$ of $\{2$-[4-(3-methyl-buta-1,3-dienyl)-1H-indol- 212 3-yl]-ethyl $\}$-carbamic acid methyl ester (70)

Figure 106: ${ }^{13} \mathrm{C}$ NMR of \{2-[4-(3-methyl-buta-1,3-dienyl)-1H-indol-3-yl]- 213 ethyl $\}$-carbamic acid methyl ester (70)

Figure 107: ${ }^{1} \mathrm{H}$ NMR of methyl-\{2-[4-(3-methyl-buta-1,3-dienyl)-1H- 214 indol-3-yl]-ethyl $\}$-amine (dehydrated ergotryptamine)

Figure 108: ${ }^{13} \mathrm{C}$ NMR of methyl-\{2-[4-(3-methyl-buta-1,3-dienyl)-1H- 215 indol-3-yl]-ethyl $\}$-amine (dehydrated ergotryptamine)

Figure 109: ${ }^{1} \mathrm{H}$ NMR of \{3-[2-(3-methyl-buta-1,3-dienyl)-6-nitro-phenyl]- 216 but-3-enyl\}-carbamic acid methyl ester (71) 
Figure 110: ${ }^{1} \mathrm{H}$ NMR $\left(75^{\circ} \mathrm{C}\right)$ of 5-methylene-1-(2-methyl-propenyl)6-nitro-1,3,4,5-tetrahydro-benzo[c]azepine-2-carboxylic acid methyl ester (72)

Figure 111: ${ }^{13} \mathrm{C}$ NMR $\left(65^{\circ} \mathrm{C}\right)$ of 5-methylene-1-(2-methyl-propenyl)6-nitro-1,3,4,5-tetrahydro-benzo[c]azepine-2-carboxylic acid methyl ester (72)

Figure 112: ${ }^{1} \mathrm{H}$ NMR of 6-(2-methyl-propenyl)-3,4-dihydro-1H,6Hazepino[5,4,3-cd]indole-5-carboxylic acid methyl ester (73)

Figure 113: ${ }^{13} \mathrm{C}$ NMR of 6-(2-methyl-propenyl)-3,4-dihydro-1H,6Hazepino[5,4,3-cd]indole-5-carboxylic acid methyl ester (73)

Figure 114: ${ }^{1} \mathrm{H}$ NMR of 3-[2-(3-methoxycarbonylamino-1-methylenepropyl)-3-nitro-phenyl]-acrylic acid methyl ester (74)

Figure 115: ${ }^{13} \mathrm{C}$ NMR of 3-[2-(3-methoxycarbonylamino-1-methylenepropyl)-3-nitro-phenyl]-acrylic acid methyl ester (74)

Figure 116: ${ }^{1} \mathrm{H}$ NMR of 3-[3-(2-methoxycarbonylamino-ethyl)-1Hindol-4-yl]-acrylic acid methyl ester (75)

Figure 117: ${ }^{13} \mathrm{C}$ NMR of 3-[3-(2-methoxycarbonylamino-ethyl)-1Hindol-4-yl]-acrylic acid methyl ester (75)

Figure 118: ${ }^{1} \mathrm{H}$ NMR of $\{2$-[4-(3-hydroxy-3-methyl-but-1-enyl)-1Hindol-3-yl]-ethyl -carbamic acid methyl ester (61)

Figure 119: ${ }^{13} \mathrm{C}$ NMR of $\{2$-[4-(3-hydroxy-3-methyl-but-1-enyl)-1Hindol-3-yl]-ethyl \}-carbamic acid methyl ester (61)

Figure 120: ${ }^{1} \mathrm{H}$ NMR of acetic acid 1,4-dimethyl-2,5-dioxo-pyrrolidin3-yl ester (86)

Figure 121: ${ }^{1} \mathrm{H}$ NMR of acetic acid 3-acetoxy-1,4-dimethyl-5-oxopyrrolidin-2-yl ester (82)

Figure 122: ${ }^{1} \mathrm{H}$ NMR of acetic acid 2-(2-bromo-allyl)-1,4-dimethyl5-oxo-pyrrolidin-3-yl ester (81)

Figure 123: ${ }^{13} \mathrm{C}$ NMR of acetic acid 2-(2-bromo-allyl)-1,4-dimethyl5-oxo-pyrrolidin-3-yl ester (81)

Figure 124: ${ }^{1} \mathrm{H}$ NMR of acetic acid 1,4-dimethyl-5-oxo-2-(2-trimethylstannanyl-allyl)-pyrrolidin-3-yl ester (87)

Figure 125: ${ }^{1} \mathrm{H}$ NMR of acetic acid 2-\{2-[2-(4-methoxy-benzyloxy)6-nitro-phenyl]-allyl \}-1,4-dimethyl-5-oxo-pyrrolidin-3yl ester (80)

Figure 126: ${ }^{1} \mathrm{H}$ NMR of 5-\{2-[2-(4-methoxy-benzyloxy)-6-nitro-phenyl]allylidene $\}$-1,3-dimethyl-1,5-dihydro-pyrrol-2-one (89)

Figure 127: ${ }^{1} \mathrm{H}$ NMR of tricyclic compound 90

Figure 128: ${ }^{1} \mathrm{H}$ NMR of $N$-allyl-2-methyl- $N$-(1-phenyl-ethyl)acrylamide (92)

Figure 129: ${ }^{13} \mathrm{C}$ NMR of $N$-allyl-2-methyl- $N$-(1-phenyl-ethyl)- 
acrylamide (92)

Figure 130: ${ }^{1} \mathrm{H}$ NMR of 3-methyl-1-(1-phenyl-ethyl)-1,5-dihydro-pyrrol- 237 2-one (93)

Figure 131: ${ }^{13} \mathrm{C}$ NMR of 3-methyl-1-(1-phenyl-ethyl)-1,5-dihydro-pyrrol- 238 2-one (93)

Figure 132: ${ }^{1} \mathrm{H}$ NMR of 5-hydroxy-3-methyl-1-(1-phenyl-ethyl)-1,5- 239 dihydro-pyrrol-2-one (94)

Figure 133: ${ }^{1} \mathrm{H}$ NMR of 5-(2-bromo-allyl)-3-methyl-1-(1-phenyl-ethyl)- 240 1,5-dihydro-pyrrol-2-one (95)

Figure 134: ${ }^{13} \mathrm{C}$ NMR of 5-(2-bromo-allyl)-3-methyl-1-(1-phenyl-ethyl)- 241 1,5-dihydro-pyrrol-2-one (95)

Figure 135: ${ }^{1} \mathrm{H}$ NMR $\left(65^{\circ} \mathrm{C}\right)$ of 5-[2-(2-methoxymethoxy-6-nitrophenyl)-allyl]-3-methyl-1-(1-phenyl-ethyl)-1,5-dihydropyrrol-2-one (96)

Figure 136: ${ }^{1} \mathrm{H}$ NMR $\left(65{ }^{\circ} \mathrm{C}\right)$ of 5-[2-(2-hydroxy-6-nitro-phenyl)-allyl]-3methyl-1-(1-phenyl-ethyl)-1,5-dihydro-pyrrol-2-one (97)

Figure 137: ${ }^{1} \mathrm{H}$ NMR $\left(65^{\circ} \mathrm{C}\right)$ of trifluoro-methanesulfonic acid 2-\{1-[4methyl-5-oxo-1-(1-phenyl-ethyl)-2,5-dihydro-1H-pyrrol-2ylmethyl]-vinyl\}-3-nitro-phenyl ester (98) 


\section{Chapter 1 Total synthesis of ht-13-B}

\section{A. Introduction}

Two unique tetracyclic indole alkaloids were isolated in 2000 from Streptomyces sp. (PA-48561) by Kamiguchi and Yasui ${ }^{1}$. The alkaloids were named ht-13-A and ht-13-B, and their structures were elucidated by ${ }^{1} \mathrm{H}$ and ${ }^{13} \mathrm{C}$ NMR, UV, IR, and LRMS analyses (Figure 1). The indoles showed an affinity for serotonin receptors so that they may be used in treatment of central nervous system diseases such as depression, neurosis, senility, and Parkinson's disease. To the best of our knowledge, ht-13-A and ht-13-B are the only two examples of naturally occurring 3,4-oxepino-fused indoles and they haven't been synthesized before. Since they have very similar structural skeletons to compounds we have previously synthesized, they were chosen as target molecules by our group. A general synthetic strategy toward 3,4-fused indole alkaloids developed by our group can be applied in this synthesis which includes a Heck coupling reaction and a carbon monoxide mediated palladium-catalyzed reductive $\mathrm{N}$-heterocyclization.

Figure 1 Structure of ht-13-A and ht-13-B

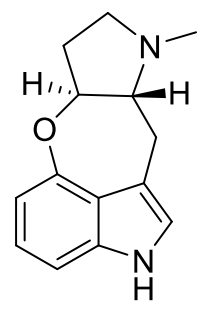

ht-13-A

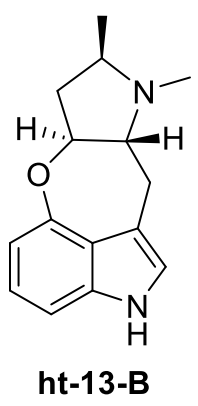


3,4-Fused indoles are usually prepared by the installation of additional ring(s) onto a preformed indole framework. Pertinent to the synthesis of ht-13-B, 3,4-oxepine-fused indoles have been prepared by intramolecular $\mathrm{C}-\mathrm{O}$ coupling reactions at the 4-position of the indole skeleton via enolate $\mathrm{O}$-arylation of a benzyne intermediate ${ }^{2}$, copper-catalyzed O-arylation of an alcohol ${ }^{3}$, and nucleophilic aromatic substitution of a 4-nitro group ${ }^{4}$.

Scheme 1 Synthesis of 3,4-fused indoles

Boger's Synthesis :
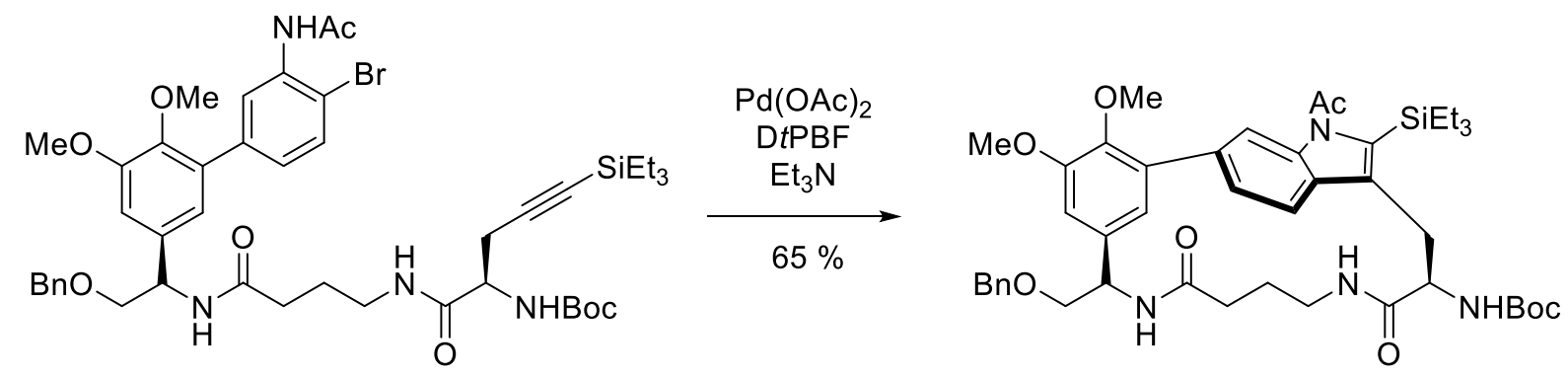

Jia's Synthesis :
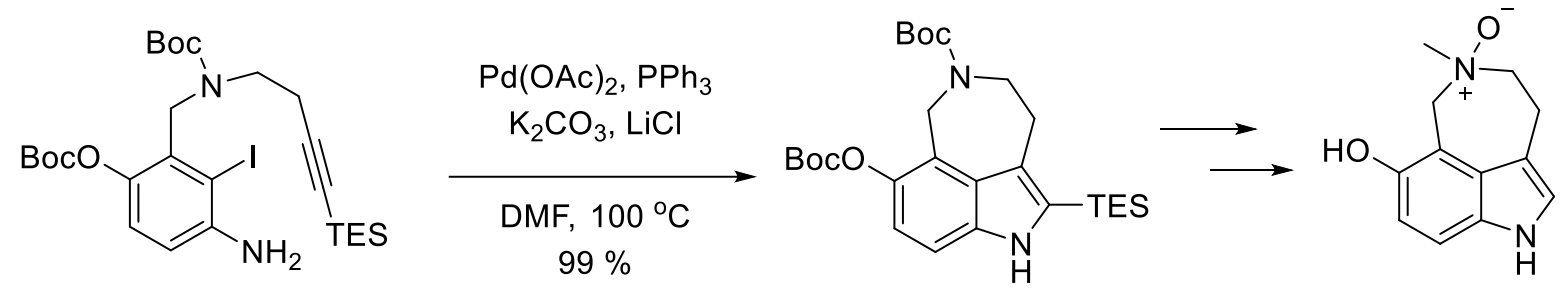

fargesine

A handful of examples have been reported wherein both the 3,4-fused ring and the pyrrole ring were sequentially assembled onto a functionalized benzene ring. This includes an intramolecular variation of the Larock indole synthesis ${ }^{5,6}$ (Scheme 1) and an intramolecular Fischer indole synthesis (Scheme 2). ${ }^{7}$ In addition, interesting rhodium(III)catalyzed intramolecular amidoarylation and hydroarylation have recently been described 
by three different research groups (Scheme 3 ). ${ }^{8}$ We have previously reported a sequential intramolecular Heck reaction and palladium-catalyzed N-heterocyclization sequence to afford 3,4-fused indoles, including a 3,4-oxepine-fused ring system (Scheme 4). ${ }^{9}$

Scheme 2 Intramolecular Fischer indole synthesis

Cho's Synthesis :

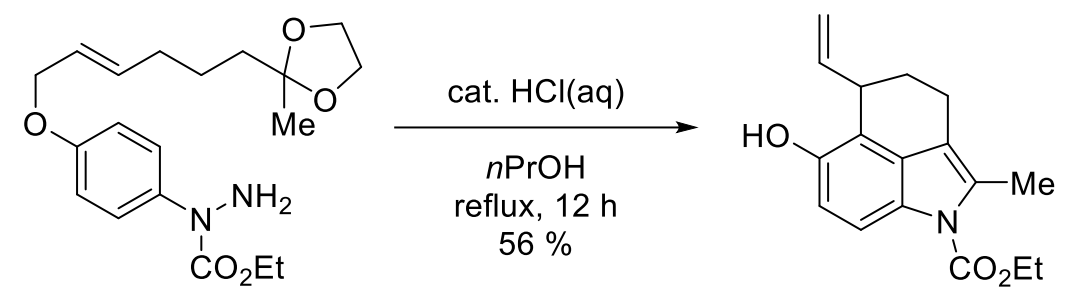

Scheme 3 Intramolecular oxidative annulation

\section{Li's Synthesis :}

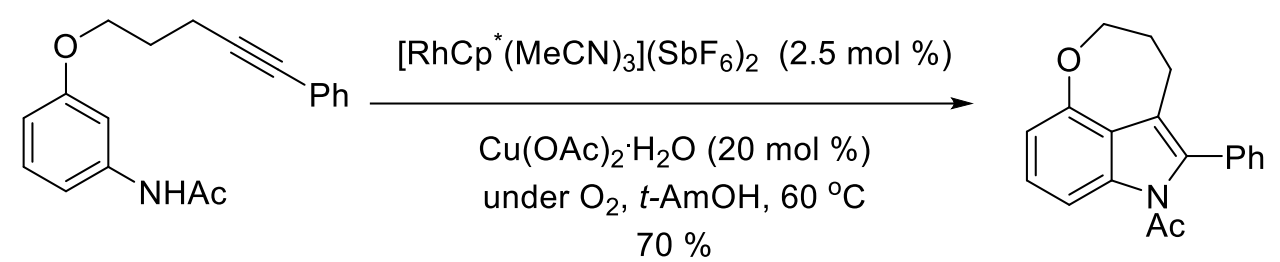

Scheme 4 Intramolecular Heck reaction and N-heterocyclization

Soderberg's Synthesis :

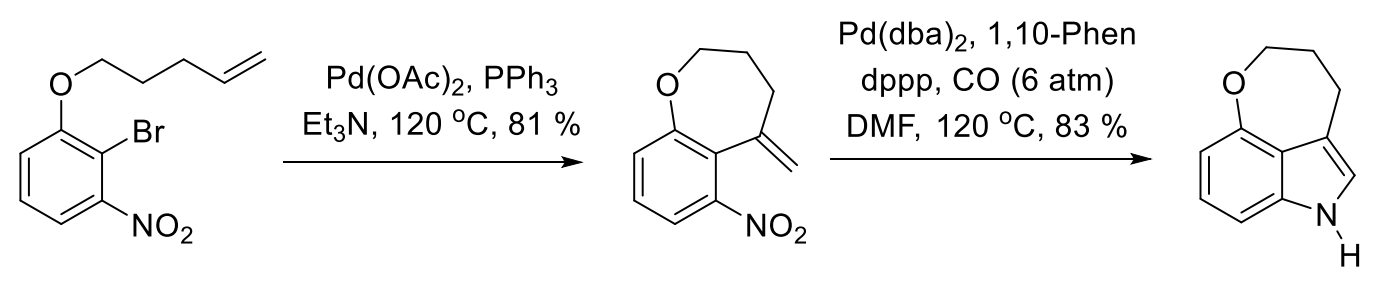




\section{B. Results and Discussion}

The sequence depicted in Scheme 4 forms the basis of the initial retrosynthetic analysis of ht-13-B (Scheme 5). Hydride reduction of an $\mathrm{N}$-alkoxycarbonyl protecting group should furnish ht-13-B. The carbamate would serve both as a protecting group limiting undesired coordination to palladium in earlier steps and as a source of the N-methyl group found in ht-13-B. In line with Scheme 4, the pyrrole ring of the indole would be formed via a palladium-catalyzed $\mathrm{N}$-heterocyclization in the presence of carbon monoxide. ${ }^{10}$ The pyrrolidine and benzene rings may be connected utilizing a Mitsunobu reaction of 2bromo-3-nitrophenol with the allyl-substituted $\mathrm{N}$-protected pyrrolidine $4(\mathrm{R}=\mathrm{t}-\mathrm{Bu})$. A trans configuration is expected after the Mitsunobu reaction. Compound $\mathbf{4}$ was thought to be derived from diastereoselective allylation of the pyrrolidine $\mathbf{1}$ via an acyliminium ion type intermediate. Finally, pyrrolidine $\mathbf{1}$ can be achieved from commercially available trans-4-Hydroxy-L-proline in 9 steps according to the literature procedure. ${ }^{11}$ 
Scheme 5 Retrosynthetic analysis of ht-13-B

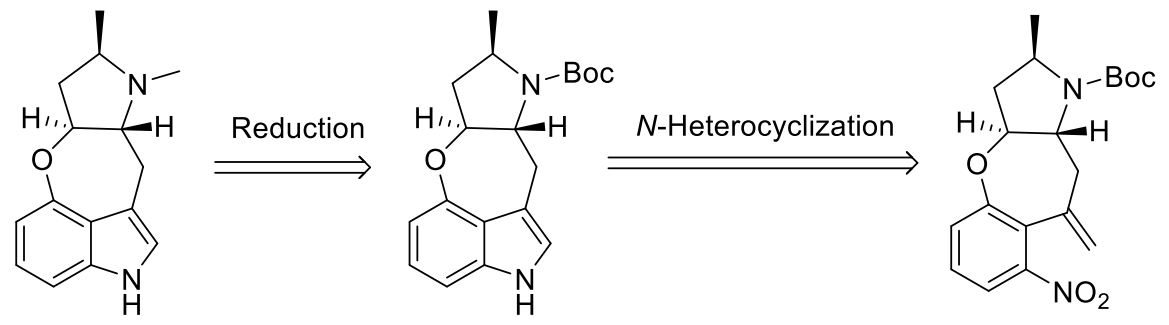

Ht-13-B
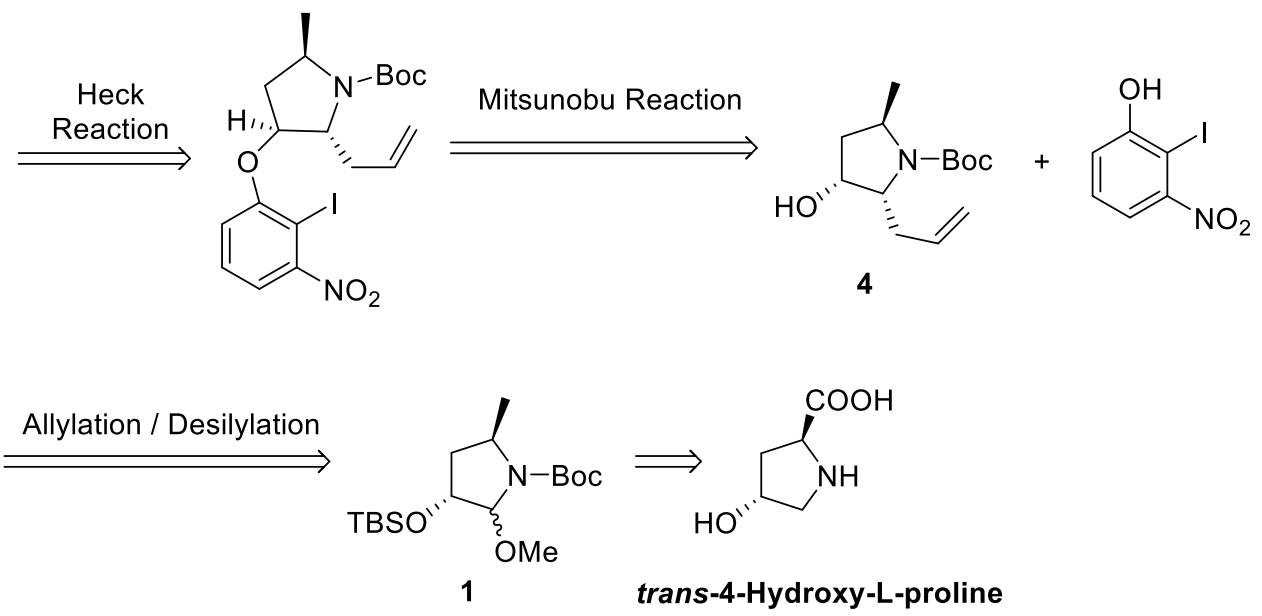

Pyrrolidine 1 was prepared from commercially available trans-4-hydroxy-L-proline following the procedure by Tanaka and Sawanishi (Scheme 6). ${ }^{11}$ The synthesis of pyrrolidine 1 started with a methylation reaction of trans-4-hydroxy-L-proline using thionyl chloride in methanol. Protection of the amine and hydroxyl group with corresponding tert-butyloxycarbonyl (Boc) and tert-butyldimethylsilyl (TBS) group led to the formation of compound $\mathbf{3}$. Treating the newly formed $\mathbf{3}$ with sodium borohydride and lithium chloride provided the corresponding alcohol, which was converted to mesylate following standard procedure. The resulting mesylate was first reduced by lithium triethylborohydride and then oxidized using ruthenium oxide and sodium periodate to yield pyrrolidin-2-one $\mathbf{2}$. The carbonyl group in $\mathbf{2}$ was reduced by lithium 
triethylborohydride and the resulting hydroxyl group was methylated using methyl iodide under basic condition to afford pyrrolidine $\mathbf{1}$.

Scheme 6 Synthesis of pyrrolidine $\mathbf{1}^{\mathrm{a}}$
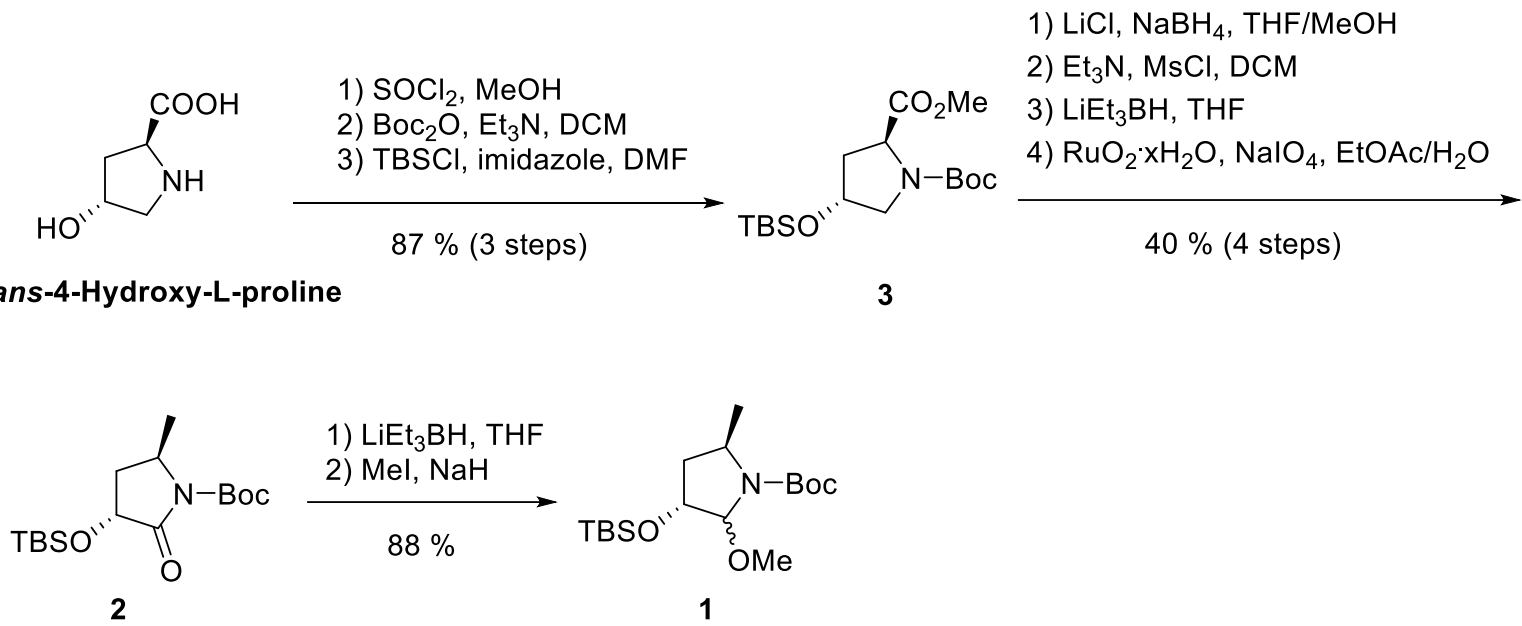

a Prepared by colleague Jeremiah Hubbard

Recently, Hart and co-workers have reported a Lewis acid mediated allylation reaction from a related pyrrolidine (Scheme 7). ${ }^{12}$ They showed that the cis-isomer was the major product in this reaction probably due to the directing effect of the tert(butyldimethylsilyl)oxy (OTBS) group.

Scheme 7 Lewis acid mediated allylation

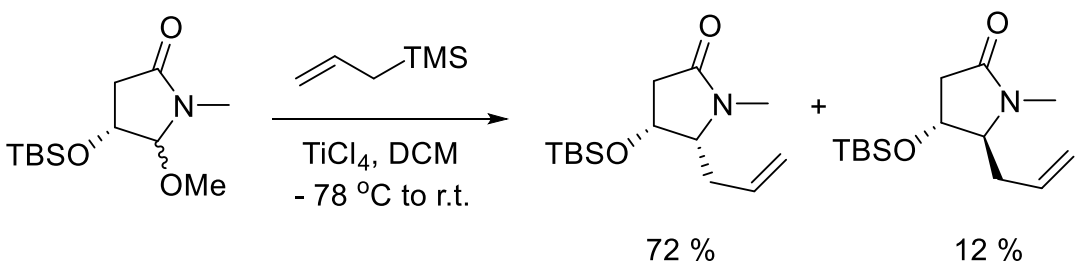


According to Hart's procedure, introduction of the allyl side chain was achieved using allyl trimethylsilane in the presence of titanium tetrachloride to afford $\mathbf{5}$ (Scheme 8) ${ }^{12}$ The Boc protecting group was unexpectedly removed during the course of the reaction prior to purification. ${ }^{13}$ In addition, the product mixture proved to be sensitive to purification by chromatography on silica gel. Compound $\mathbf{5}$ was obtained as a mixture of two inseparable diastereomers in an approximate 5:1 ratio. The stereochemistry of either isomer could not be confirmed at this point in the synthesis. However, the major isomer was expected, based on Hart's results, to have a cis relationship between the allyl and the OTBS groups. ${ }^{11,12,14}$

Scheme 8 Titanium tetrachloride mediated allylation

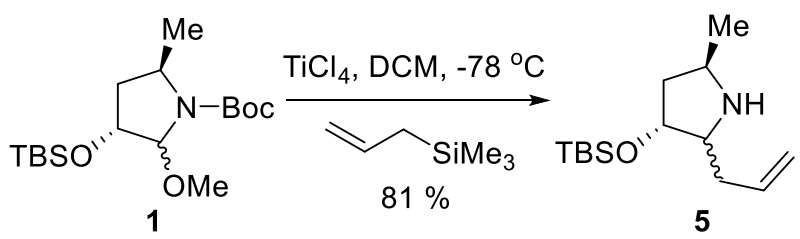

The pyrolidine nitrogen in compound 5 was reprotected using $\mathrm{Boc}_{2} \mathrm{O}$ to give $\mathbf{6}$ (Scheme 9). We were unable to separate the isomers, and interpretation of the NMR spectra after chromatography was complicated not only by the presence of two diastereomers but also by the fact that each of the diastereomers exists as a mixture of amide bond rotamers. Removal of the tert-butyldimethylsilyl group using tetrabutylammonium fluoride (TBAF) afforded the diastereomeric compounds $\mathbf{7}$ and $\mathbf{8}$. Gratifyingly, the diastereomers were readily separated by chromatography on silica gel at this point in the synthesis. The cis stereochemistry between the allyl chain and OTBS group in compound $\mathbf{7}$ was established by nOe NMR experiments. In addition, executing the sequence from $\mathbf{1}$ to $\mathbf{7}$ and $\mathbf{8}$ without 
purification of the intermediates gave a better overall yield.

Scheme 9 Boc protection and TBAF deprotection of $\mathbf{5}$

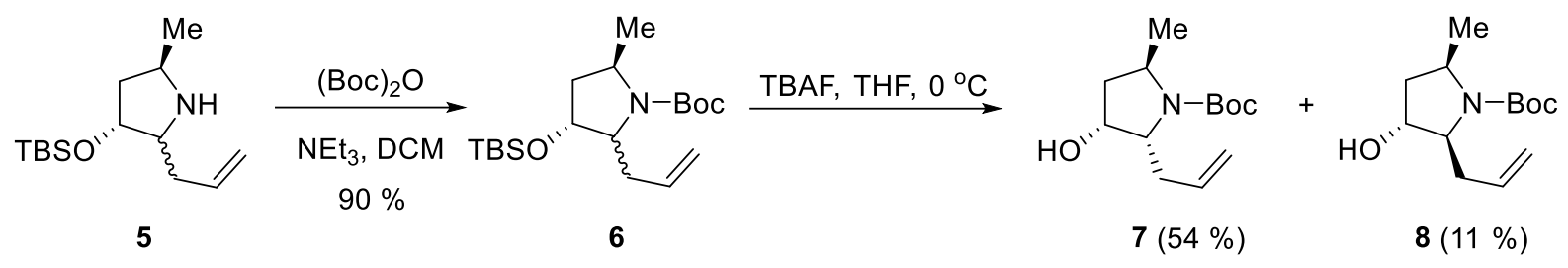

With cis-isomer 7 in hand, a Mitsunobu reaction was attempted in the next step. The Mitsunobu reaction was firstly reported by professor Oyo Mitsunobu in $1967 .{ }^{15}$ It has been used in the synthesis of a variety of substrates such as esters, ethers, etc. It has been widely applied to invert the stereochemistry of an existing stereocenters in many complicate molecules.

In this synthesis, a Mitsunobu reaction of major isomer 7 with 2-bromo-3-nitrophenol 9 using triphenylphosphine and diisopropylazodicarboxylate (DIAD) gave the expected product 10 in $70 \%$ isolated yield (Scheme 10). The inverted trans stereochemistry between the aryl ether and OTBS group was established by NOE NMR experiments. This in turn confirms the cis stereochemistry of major product $\mathbf{5}$ from the initial allylation reaction.

The Heck reaction is one of the well-known coupling reactions used in preparation of functionalized aromatic species. In the next step, an intramolecular Heck reaction ${ }^{16}$ of $\mathbf{1 0}$ gave only the 8 -endo trig cyclization product $\mathbf{1 1}$ in low isolated yield. ${ }^{17,18}$ The expected 7-exo trig cyclization to afford 12 was not observed by ${ }^{1} \mathrm{H}$ NMR of the crude reaction mixture. Several additional catalyst systems were examined, all affording 8-endo product 11 in similar or lower isolated yields. Although the tricyclic compound cannot be used in 
the synthesis of ht-13-B, the trans stereochemistry of the pyrrolidine-oxepine ring fusion was confirmed by single crystal X-ray analysis of $\mathbf{1 1}$ (Figure 2).

Scheme 10 Mitsunobu and intramolecular Heck reactions

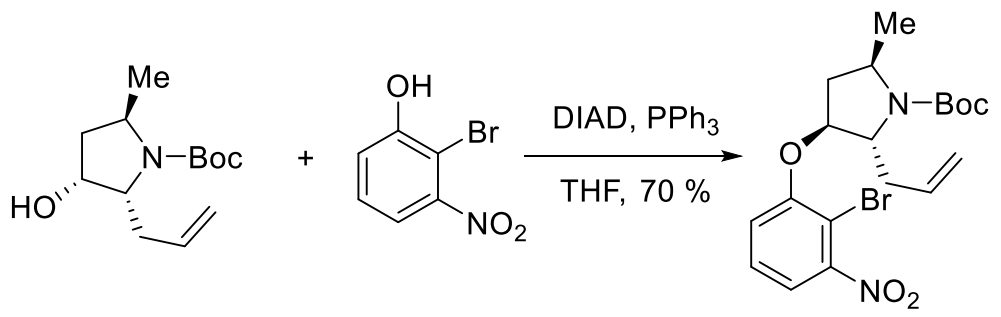

7

9

10

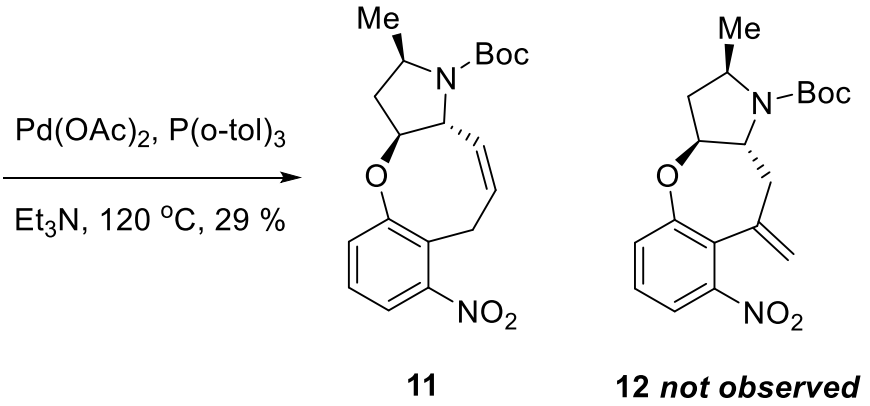

Figure 2 X-ray analysis of compound 11

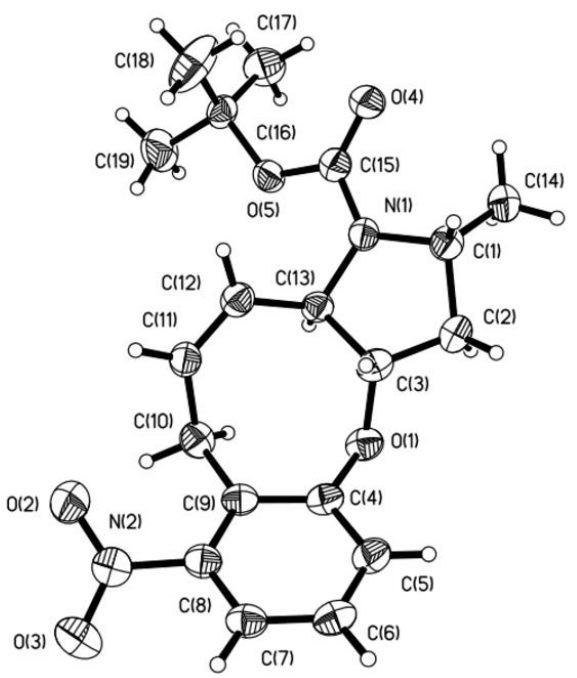


Considering the exclusive formation of 8-endo cyclization product $\mathbf{1 1}$ from the Heck reaction of 10, a different approach was needed for the preparation of key intermediate 12. Palladium(0)-catalyzed intramolecular coupling reactions of substrates containing two separate electrophilic sites (e.g., a halide or triflate) both able to undergo oxidative addition have been reported. One such coupling is the Stille-Kelly reaction. ${ }^{19,20}$ In this reaction, one electrophilic site undergoes intermolecular palladium-catalyzed trialkylstannylation using hexaalkylditin followed by an intramolecular Kosugi-MigitaStille reaction. This one-pot coupling reaction has mostly been used for aryl-aryl couplings, ${ }^{20 c, 21}$ although coupling reactions of a few aryl electrophiles with vinyl triflates, ${ }^{20 a, b, 22}$ and a vinyl bromide with a vinyl triflate, ${ }^{20 \mathrm{~d}}$ have been reported. No aryl electrophile-vinyl bromide couplings have been reported to the best of our knowledge. In contrast to the Heck reaction, the ring size of the product depends on the position of the two electrophilic sites; thus, a halide on the internal alkene carbon of the allyl group of the pyrrolidine ring should give rise to a seven-membered ring with an exocyclic alkene (Scheme 11).

Scheme 11 Modified oxepine cyclization precursor

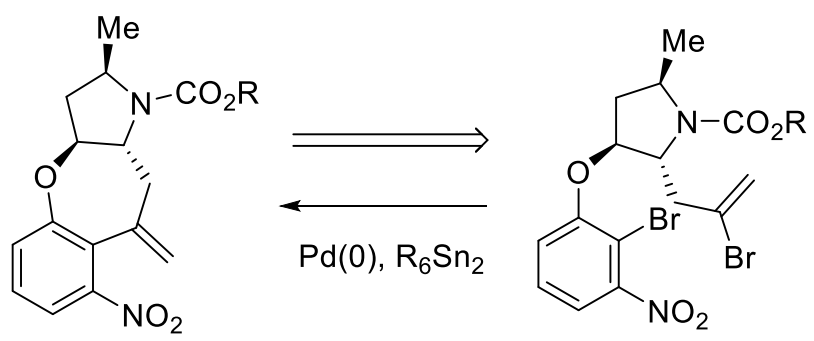

The new cyclization precursor was prepared in a fashion similar to compound 10. In the Lewis acid mediated allylation reaction, an alternative allyl compound $\mathbf{1 3}$ was used 
which was prepared from commercially available 2,3-dibromopropene according to the literature (Scheme 12). ${ }^{23}$

Scheme 12 Synthesis of 2-bromo-2-propen-1-yltrimethylsilane 13

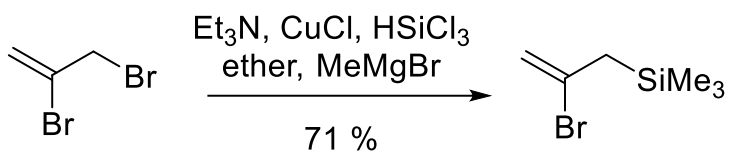

2,3-Dibromopropene

13

Treatment of 1 with an excess of 2-bromo-2-propen-1-yltrimethylsilane $13^{23}$ in the presence of titanium tetrachloride afforded allylation product 14, again with the loss of the Boc protecting group (Scheme 13). ${ }^{24}$ In addition to 14, bicyclic compound $\mathbf{1 5}$ was also isolated as a mixture of diastereomers. Related bicyclic compounds have been reported from gold-catalyzed cyclizations between an N-Boc group and an alkyne ${ }^{25}$ or an allene. ${ }^{26}$ Compound 14 was isolated as a 9:1 mixture of isomers after chromatography. The relative cis stereochemistry between the allyl and the OTBS groups of the major isomer of $\mathbf{1 4}$ was elucidated by double pulsed field gradient spin echo nuclear Overhauser effect (DPFGSENOE) NMR experiments. It should be noted that the mixture of isomers could not be separated at any point in the synthesis prior to the final product.

Scheme 13 Synthesis of pyrrolidine 14
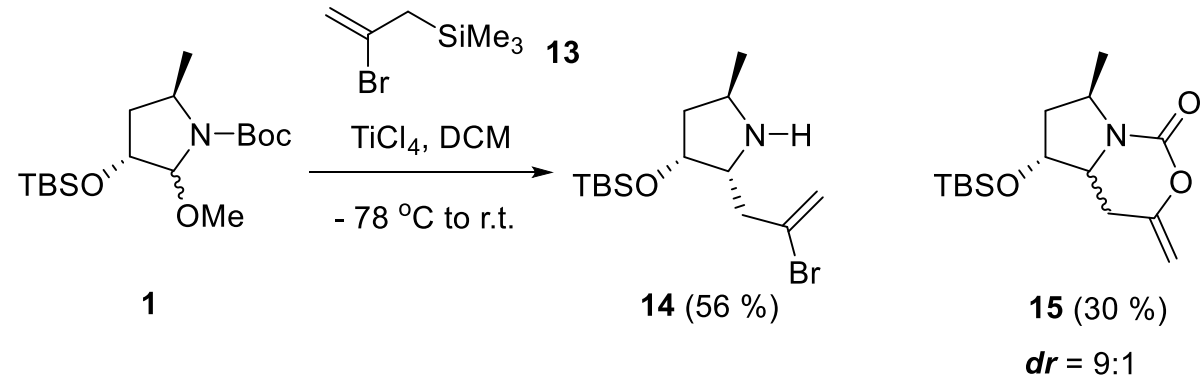
Other Lewis acids have been employed in reactions of acyliminium ion intermediates with nucleophiles. For example, no loss of the Boc group was observed using boron trifluoride diethyl etherate $\left(\mathrm{BF}_{3} \cdot \mathrm{OEt}_{2}\right)($ Scheme 14$) .{ }^{14,27}$

Scheme 14 Allylation without loss of Boc group

Rhee's synthesis :
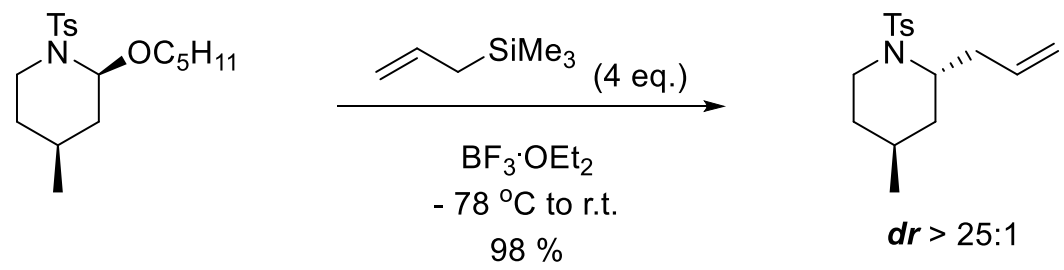

Zhang's synthesis :<smiles>CC(=O)OC1CC(C(C)=O)C(OC(C)=O)C1[O+]</smiles>
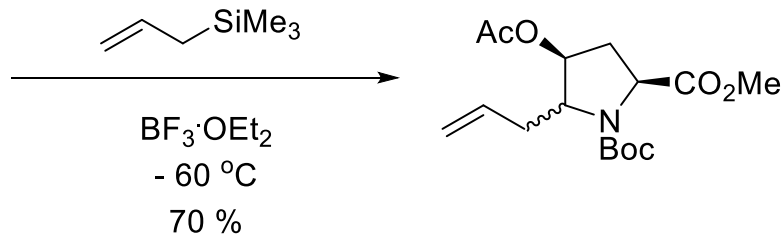

$70 \%$

Thus, the reaction of $\mathbf{1}$ with $\mathbf{1 3}$ in the presence of $\mathrm{BF}_{3} \cdot \mathrm{OEt}_{2}$ as the Lewis acid and the influence of the reaction temperature was briefly investigated (Table 1). Under an identical temperature profile as used for the reaction in the presence of titanium tetrachloride $\left(\mathrm{TiCl}_{4}\right)$, an inferior yield of an inseparable mixture of isomeric 14 mixed with unknown side products was obtained (Table 1 , entry 2 ). Treatment of 1 with 13 at $-78^{\circ} \mathrm{C}$ did not go to completion even after extended reaction times (Table 1, entry 3 ). In addition to a significant amount of starting material, a low yield of the allylated pyrrolidine $\mathbf{1 6}$ having an intact Boc group was isolated. Finally, all of the starting material was consumed at a higher reaction temperature $\left(-30^{\circ} \mathrm{C}\right)$, but the yield of $\mathbf{1 6}$ was still unsatisfactory (Table 1 , 
entry 4). As was the case employing $\mathrm{TiCl}_{4}$, a significant amount of bicyclic product $\mathbf{1 5}$ was also isolated. It was concluded that $\mathrm{BF}_{3} \cdot \mathrm{OEt}_{2}$ did not significantly improve the outcome of the reaction.

Table 1 Allylation of 1 using 2-bromo-2-propen-1-yltrimethylsilane 13

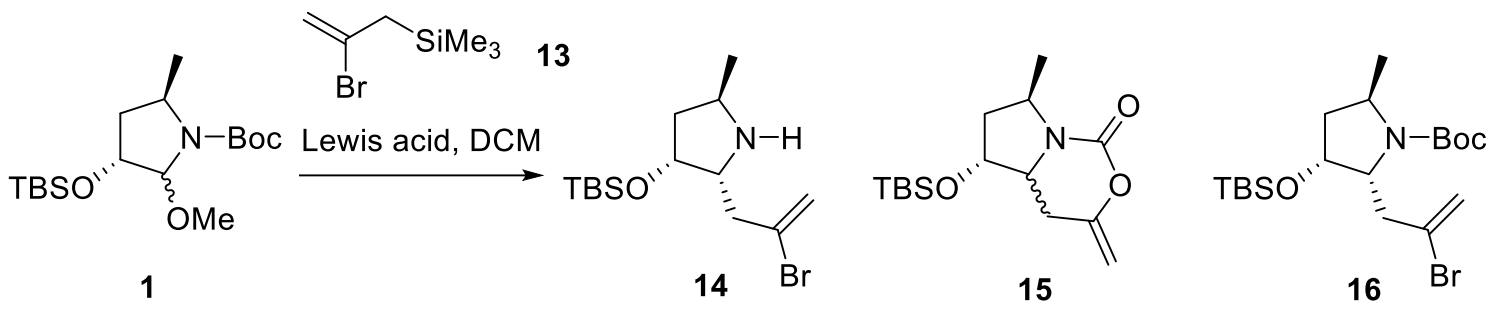

Entry Lewis acid Temperature $\quad$ Products (\% isolated yield)

\begin{tabular}{|c|c|c|c|c|c|}
\hline 1 & $\mathrm{TiCl}_{4}$ & $-78^{\circ} \mathrm{C}$ to r.t. & $14(56 \%)$ & $15(30 \%)$ & \\
\hline 2 & $\mathrm{BF}_{3} \cdot \mathrm{OEt}_{2}$ & $-78^{\circ} \mathrm{C}$ to r.t. & $\mathbf{1 4}(<41 \%)^{\mathrm{a}}$ & 15 (trace) & \\
\hline 3 & $\mathrm{BF}_{3} \cdot \mathrm{OEt}_{2}$ & $-78^{\circ} \mathrm{C}$ & $\mathbf{1}(47 \%)$ & & $16(19 \%)$ \\
\hline 4 & $\mathrm{BF}_{3} \cdot \mathrm{OEt}_{2}$ & $-78^{\circ} \mathrm{C}$ to $-30{ }^{\circ} \mathrm{C}$ & & $15(23 \%)$ & $16(43 \%)$ \\
\hline
\end{tabular}

Purified amine 14 was re-protected as a methyl carbamate using methyl chloroformate to afford 14 (Scheme 15). A significantly higher overall yield of 14 from 1 was obtained without purification of crude 14 (55\% vs $23 \%)$. Removal of the TBS group with TBAF gave compound 18. Mitsunobu reaction was attempted in next step. Treatment of $\mathbf{1 8}$ with 2-bromo-3-nitrophenol 9 in the presence of 1.1 eq. of DIAD simply resulted in the recovery of starting material 18. To our delight, the use of 4.0 eq. of DIAD in the Mitsunobu 
reaction led to the formation of anticipated compound $\mathbf{1 9}$ in $66 \%$ yield.

Scheme 15 Synthesis of methyl carbamate 19
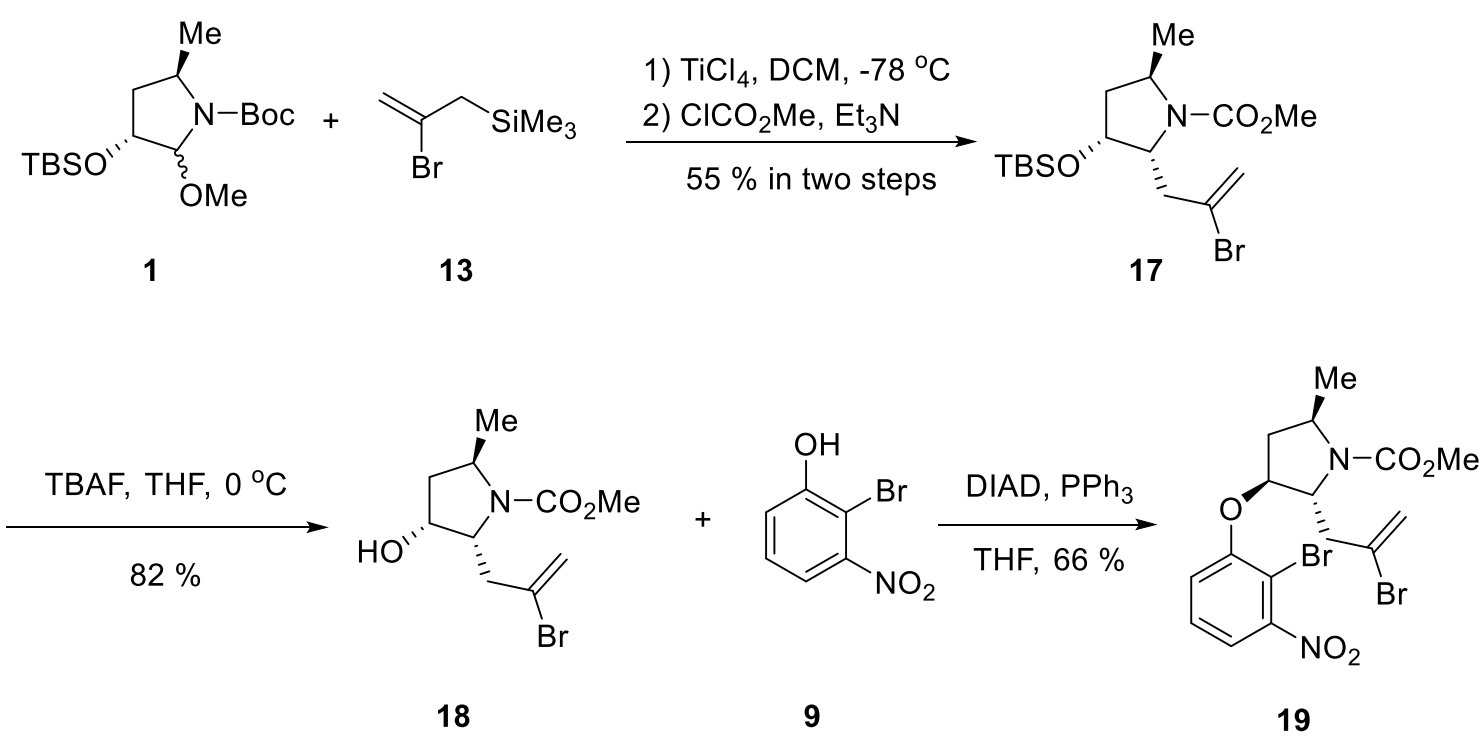

Stille-Kelly reaction of $\mathbf{1 9}$ with hexamethylditin in the presence of a catalyst system consisting of bis(dibenzylidenacetone)palladium(0)-triphenylphosphine produced desired tricyclic compound $\mathbf{2 0}$ (Table 2, entry 2). Although the starting material was completely consumed, no other products were isolated. A few additional catalyst systems were examined in an attempt to improve the yield of the reaction. However, inferior results were obtained in all cases (Table 2). Considering the two active coupling sites exists in the starting material, we believe that polymerization may occur during the transformation which gave rise to uninterpretable byproducts and lowered the isolated yield of desired product. Comparing all the conditions attempted, the Stille-Kelly reaction of $\mathbf{1 9}$ using $\mathrm{PPh}_{3}$ as the ligand in toluene at $140{ }^{\circ} \mathrm{C}$ provided the best isolated yield (44\%) (Table 2, entry 2). Lower temperature resulted only in decomposition or polymerization of the 
starting material (Table 2, entry 1). Likewise, poor yield of desired product was obtained when other ligand-solvent systems were employed (Table 2, entry 3-6).

Table 2 Stille-Kelly reaction of $\mathbf{1 9}$

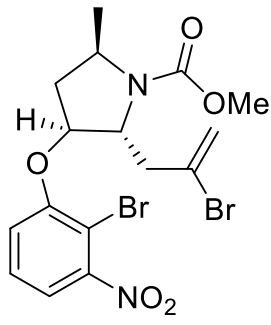

19
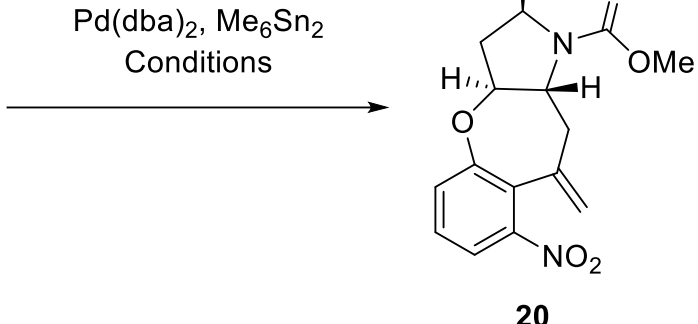

\begin{tabular}{cccccc}
\hline Entry & Ligand/Additive & Solvent & Temperature & Time & Yield \\
\hline 1 & $\mathrm{PPh}_{3}$ & toluene & $80{ }^{\circ} \mathrm{C}$ & $3 \mathrm{~h}$ & trace \\
2 & $\mathbf{P P h}_{3}$ & toluene & $\mathbf{1 4 0}{ }^{\circ} \mathbf{C}$ & $\mathbf{3 ~ h}$ & $\mathbf{4 4} \%$ \\
3 & $\mathrm{AsPh}_{3}$ & toluene & $140{ }^{\circ} \mathrm{C}$ & $1.5 \mathrm{~h}$ & $39 \%$ \\
4 & $\mathrm{PPh}_{3}$ & DMF & $140{ }^{\circ} \mathrm{C}$ & $3 \mathrm{~h}$ & $33 \%$ \\
5 & $\mathrm{PPh}_{3}$ & dioxane & $140{ }^{\circ} \mathrm{C}$ & $5.5 \mathrm{~h}$ & $38 \%$ \\
& & & & \\
\hline
\end{tabular}

As an alternative to coupling of tin reagents, a boron variant wherein one of the halides is transformed to borate followed by intramolecular Suzuki coupling has been reported, for example, using bis(pinacolato)-diborane (Scheme 16). ${ }^{21,28}$ All attempted couplings of 19 using the latter strategy were unsuccessful, resulting only in complete loss of starting 
material and the formation of intractable products.

Scheme 16 Intramolecular Suzuki coupling of 19

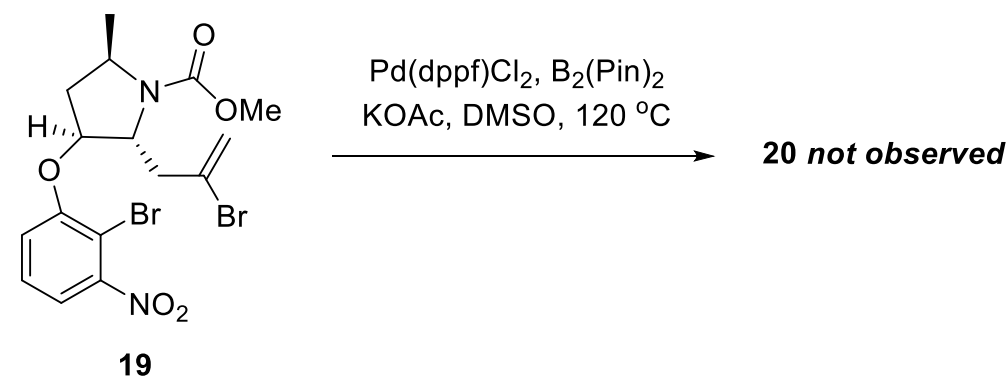

The structure and relative stereochemistry of indole precursor $\mathbf{2 0}$ were confirmed by extensive NMR experiments and single crystal X-ray analysis (Figure 3).

Figure 3 X-ray analysis of indole precursor 20

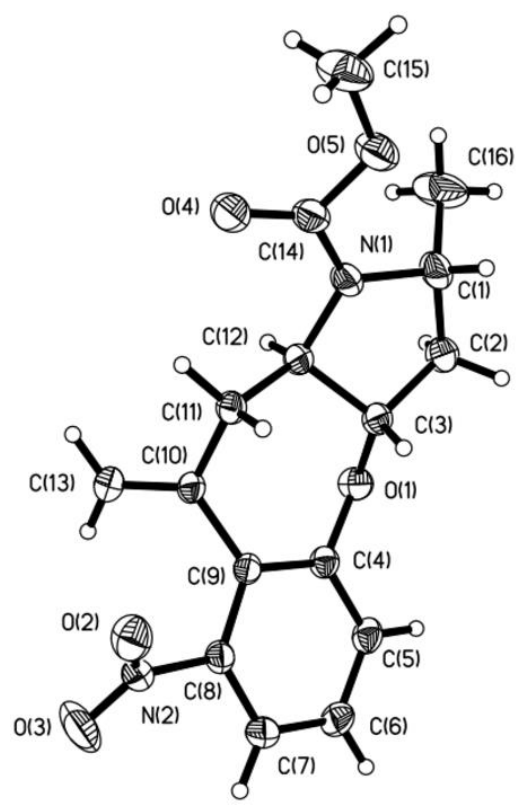


In the next step, the indole precursor $\mathbf{2 0}$ was subjected to a palladium-catalyzed reductive $\mathrm{N}$-heterocyclization reaction developed by our group ${ }^{10}$. Utilizing this reaction, our group have accomplished the total synthesis of several indole natural products such as murrayaquinone A, clausenalene, and salviadione (Scheme 17).

Scheme 17 Previous synthesis using reductive N-heterocyclization reactions<smiles>CC1CCC=C(c2ccccc2[N+](=O)[O-])C1=O</smiles>

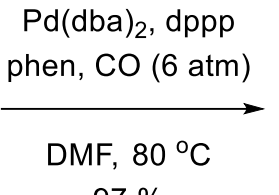

$97 \%$

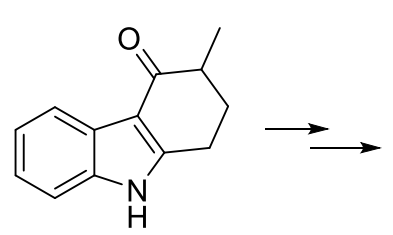

Murrayaquinone A<smiles>CC1CC(=O)C=C(c2cc3c(cc2[N+](=O)[O-])OCO3)C1</smiles>

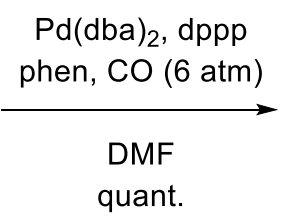<smiles>CC1CC(=O)c2[nH]c3cc4c(cc3c2C1)OCO4</smiles><smiles>Cc1ccc2[nH]c3cc4c(cc3c2c1)OCO4</smiles>

Clausenalene
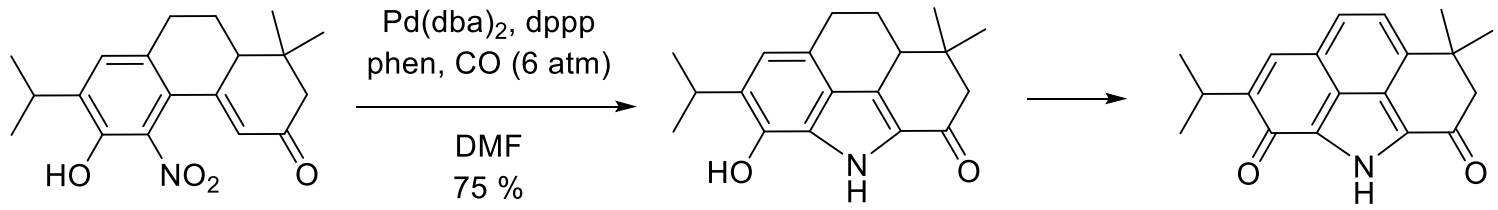

Salviadione

As expected, $\mathrm{N}$-heterocyclization of $\mathbf{2 0}$ gave the tetracyclic indole $\mathbf{2 1}$, the immediate precursor to the alkaloid ht-13-B, as a single isomer (Scheme 18).

Scheme 18 Reductive N-heterocyclization of 20<smiles>C=C1c2c(cccc2[N+](=O)[O-])O[C@@H]2CC(=C)N(C(=O)OC)[C@@H](C)C[C@H]12</smiles>

20
$\mathrm{Pd}(\mathrm{dba})_{2}$, Phen, dppp, CO (6 atm) DMF, $120^{\circ} \mathrm{C}$

$71 \%$<smiles>COC(=O)N1[C@@H](C)[C@@H]2Cc3c[nH]c4cccc(c34)O[C@H]2C[C@H]1C</smiles>

21 
Finally, the N-methoxycarbonyl protecting group of $\mathbf{2 1}$ was reduced to a methyl group using sodium bis(2-methoxyethoxy)aluminum hydride (Red-Al) in toluene at $110{ }^{\circ} \mathrm{C}$ to afford ht-13-B in high isolated yield (Scheme 19). ${ }^{29}$ Reduction of 21 using a large excess of lithium aluminum hydride (LAH) in refluxing tetrahydrofuran (THF) was also attempted; however, this only resulted in complete recovery of the starting material.

Scheme 19 Synthesis of ht-13-B

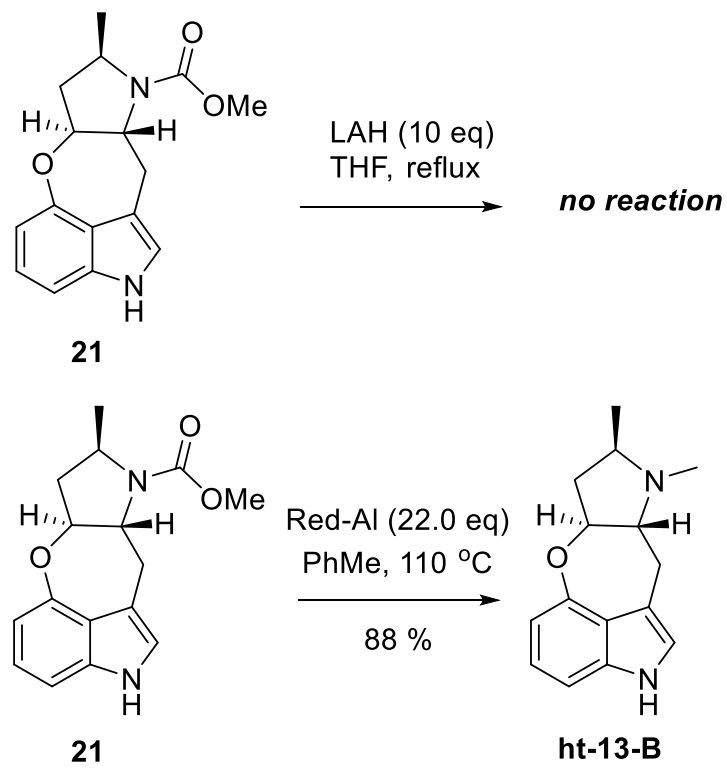

The structure of the final product was elucidated by extensive NMR experiments and single crystal X-ray analysis (Figure 4). The NMR, IR, HRMS, melting point, ${ }^{30}$ and optical rotation were compared with literature data, which all corroborated the originally proposed structure. The overall yield of ht-13-B in seven steps starting from compound $\mathbf{1}$ was $8 \%$. 
Figure 4 X-ray analysis of ht-13-B

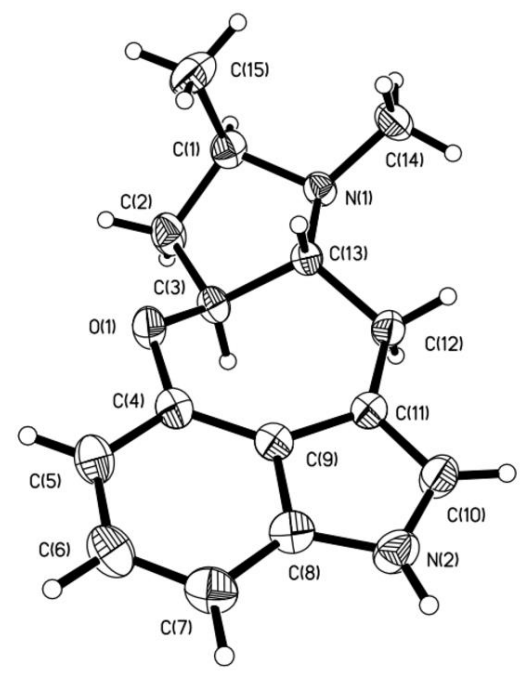




\section{Conclusions}

An expedient synthesis corroborating the proposed structure of the tetracyclic indole

alkaloid ht-13-B has been accomplished. ${ }^{31}$ Key synthetic steps include a Lewis acid mediated allylation, a Mitsunobu reaction, a palladium-catalyzed Stille-Kelly cross coupling reaction, and a carbon monoxide mediated palladium-catalyzed reductive $\mathrm{N}$ heterocyclization. The chiral centers are ultimately derived from commercially available trans-4-hydroxy-L-proline. 


\section{Chapter 2 Total synthesis of ht-13-A}

\section{A. Introduction}

The indole alkaloid ht-13-A has one less methyl group than ht-13-B. It was the major biosynthetic product isolated from Streptomyces sp. (PA-48561) according to Kamiguchi and Yasui's patent. ${ }^{1}$ In addition, the patent claims that ht-13-A is an important starting material for the synthesis of a variety of derivatives (Figure 5) which are believed to have significant biological activities. Therefore, the proposed total synthesis of ht-13-A offers an approach for its preparation, which would be significantly beneficial to the understanding of its biological functions. 
Figure 5 Derivatives of ht-13-A

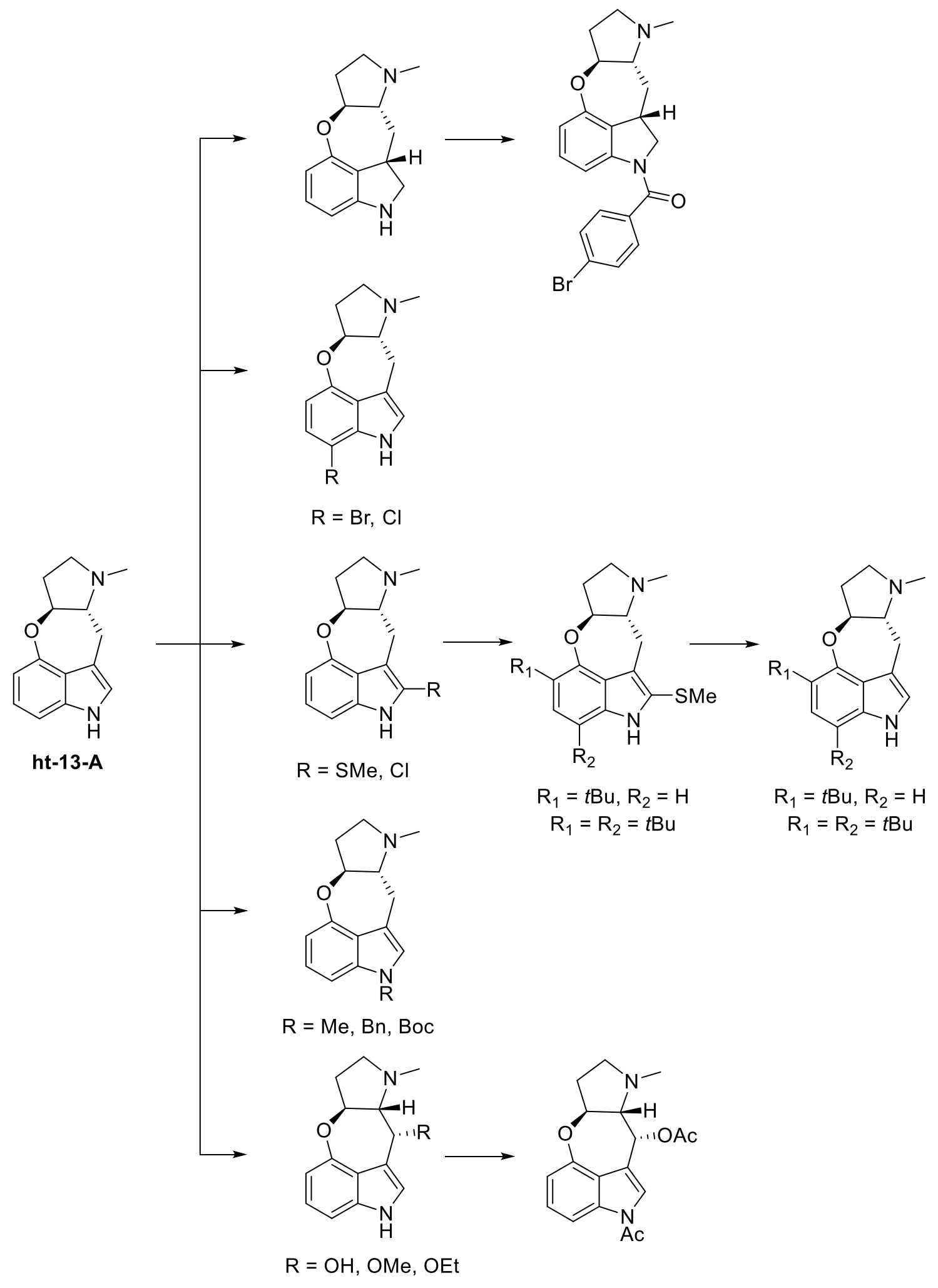




\section{B. Results and Discussions}

The retro-synthetic analysis of ht-13-A has been developed based on the synthetic strategy of ht-13-B (Scheme 20). The N-methyl group found in ht-13-A should be obtained from a hydride reduction of an $\mathrm{N}$-alkoxycarbonyl protecting group. The palladium-catalyzed N-heterocyclization would build the desired indole core in ht-13-A. In our previous study, the 7-member ring in ht-13-B was successfully obtained via a StilleKelly cross-coupling reaction, whereas, a Heck cross-coupling reaction only gave an unexpected 8-endo cyclization product (Scheme 10, Table 2). Thus, in the synthesis of ht13-A, the desired 7-exo trig cyclization product is expected after Stille-Kelly reaction. The benzene ring could be installed by a Mitsunobu reaction between 2-bromo-3nitrophenol and the allyl-substituted N-protected pyrrolidine 24 . The pyrrolidine in turn could be prepared from diastereoselective allylation of the $\mathrm{N}, O$-acetal species $\mathbf{2 3}$ which can be obtained from the known 2-pyrrolidinone 22 .

Scheme 20 Retrosynthetic analysis of ht-13-A
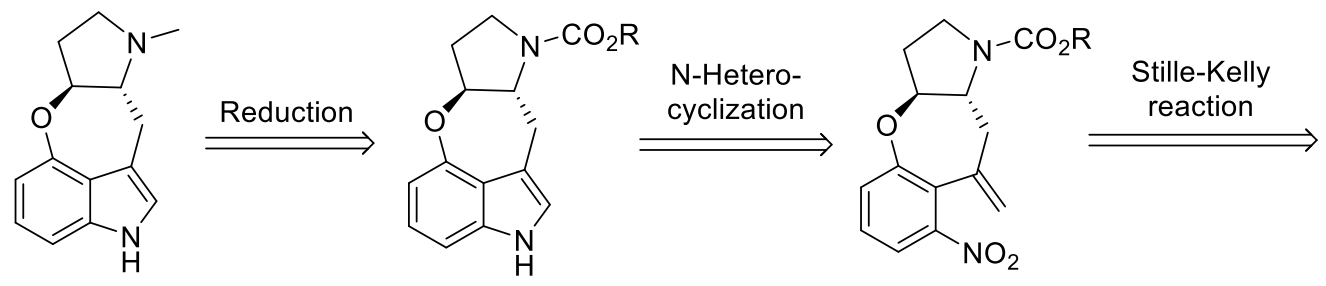

ht-13-A
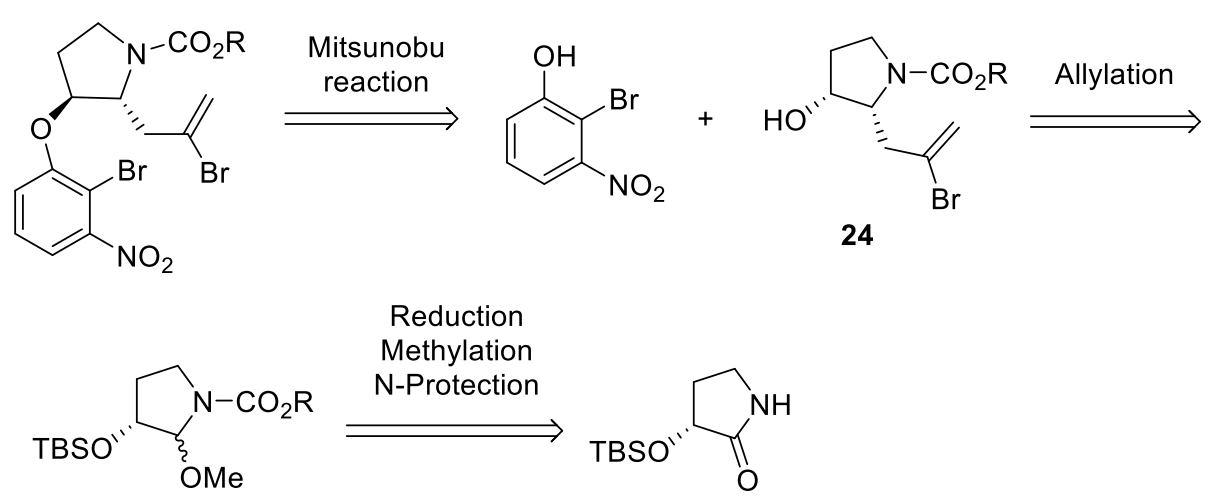
3(R)- $t$-Butyldimethylsilyloxypyrrolidin-2-one $\mathbf{2 2}^{32}$ was prepared in four steps from commercially available 4-amino-2(S)-hydroxybutyric acid (Scheme 21). Thus, treatment of 4-amino-2(S)-hydroxybutyric acid with sulfuric acid in methanol followed by neutralization using potassium carbonate gave pyrrolidin-2-one 25 . Compound 25 was converted to the benzoic acid ester via a Mitsunobu reaction. The stereochemistry was reversed in this transformation. Next, pyrrolidin-2-one 26, which has R-configuration at C-3, was formed by the saponification using potassium carbonate. The hydroxyl group was then protected as a TBS ether giving compound 22. ${ }^{33}$ The $3(\mathrm{R})$-OTBS group in 22 was anticipated to be the initial source of the two chiral centers of the target molecule.

Scheme 21 Synthesis of pyrrolidin-2-one 22<smiles>NCCC(O)C(=O)O</smiles>

4-amino-2-hydroxybutyric acid

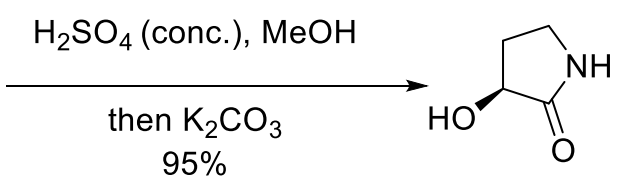

$95 \%$ 4-nitrobenzoic acid, DIAD $\mathrm{PPh}_{3}, \mathrm{THF}$

then $\mathrm{K}_{2} \mathrm{CO}_{3}, \mathrm{MeOH}$

TBSCl, imidazole, DMF, $90^{\circ} \mathrm{C}$

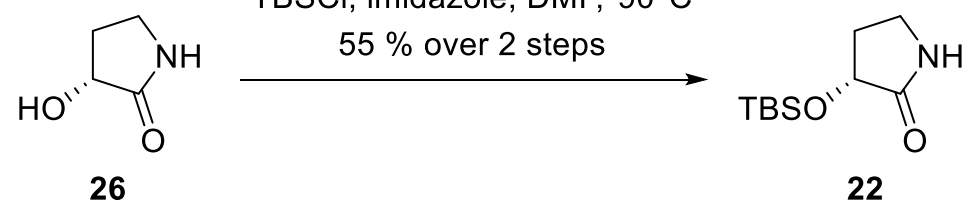

The nitrogen in pyrrolidin-2-one $\mathbf{2 2}$ was protected using di-tert-butyl dicarbonate (Scheme 22). Regioselective reduction by lithium triethylborohydride was observed at the carbonyl group on the pyrrolidinone ring of 27. The resulting hydroxyl group was methylated using sodium hydride and methyl iodide to afford the $\mathrm{N}, \mathrm{O}$-acetal $\mathbf{2 8}$ having trans-stereochemistry. 
Scheme 22 Synthesis of $N, O$-acetal 28

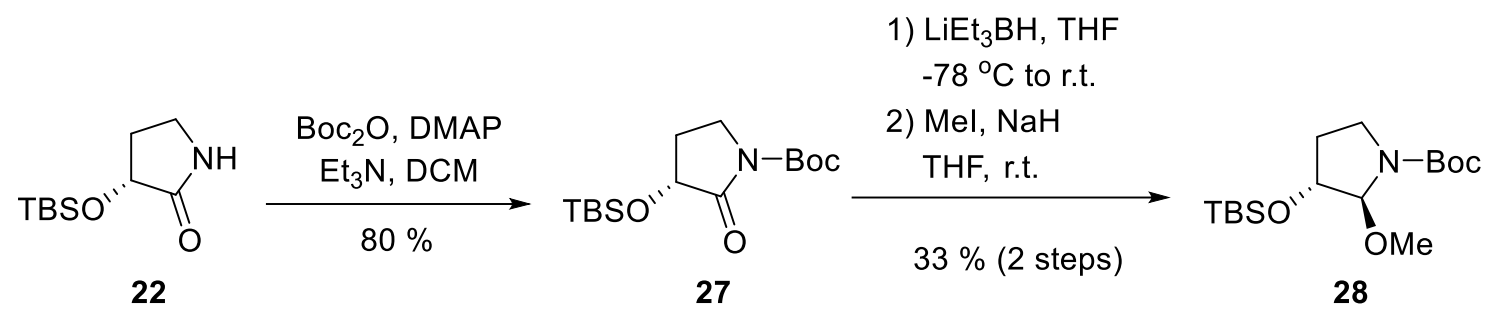

In the next step, the allyl side chain was installed via the Lewis acid mediated allylation reaction. Two different Lewis acid, boron trifluoride diethyl etherate and titanium tetrachloride were examined in this reaction and the results were compared in Table 3. Treatment of 28 with $\mathrm{BF}_{3} \cdot \mathrm{OEt}_{2}$ at $-60{ }^{\circ} \mathrm{C}$ gave the cis allylation product as the major product $(\boldsymbol{d} \boldsymbol{r}=6: 1)$ without loss of the Boc protecting group (Table 3, entry 1). Herein, the stereoselectivity arose due to the directing effect of the OTBS group in 28. Meanwhile, the minor trans product was converted to a bicyclic compound $\mathbf{3 0}$ in the same transformation. No product was isolated wherein the Boc protecting group was lost during the reaction. When compound $\mathbf{2 8}$ was subjected to the $\mathrm{TiCl}_{4}$ condition (Table 3, entry 2), the Boc protecting group was removed and the allyl compound $\mathbf{3 1}$ was isolated in $50 \%$ yield. Similar results was found in the synthesis of ht-13-B (Table 1). Compound $\mathbf{3 0}$ was isolated at the same time in $9 \%$ yield as mixture of two diastereomers $(\boldsymbol{d} \boldsymbol{r}=9: 1)$.

In addition, an alternative synthetic pathway was attempted in order to compare with the results in Table 3 (Scheme 23). The $N, O$-acetal 28 was subjected to the $\mathrm{TiCl}_{4}$ mediated allylation to give 31, which was treated with methyl chloroformate and triethyl amine without further purification to afford methyl carbamate 32. The overall yield in two steps was $44 \%$. 
Table 3 Lewis acid mediated allylation of $\mathbf{2 8}$

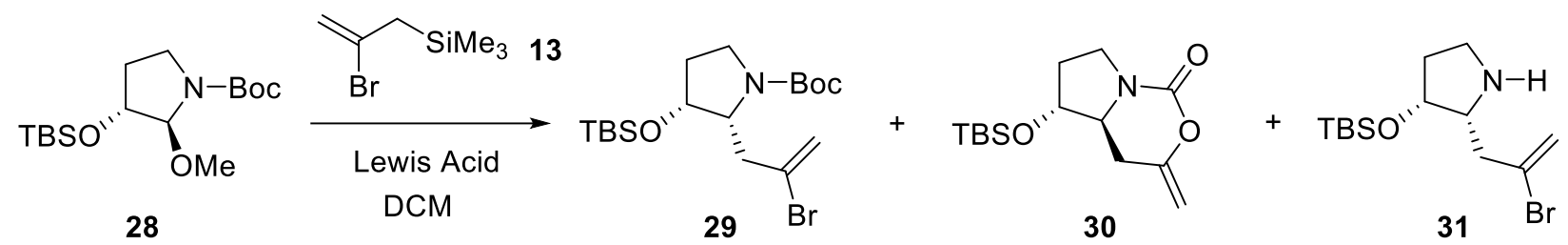

\begin{tabular}{|c|c|c|c|c|c|c|}
\hline Entry & Lewis Acid & Temperature & Time & 29 & 30 & 31 \\
\hline 1 & $\mathrm{BF}_{3} \cdot \mathrm{OEt}_{2}$ & $-60^{\circ} \mathrm{C}$ & $1 \mathrm{~h}$ & $\begin{array}{c}40 \% \\
(\boldsymbol{d r}=6: 1)\end{array}$ & $10 \%$ & none \\
\hline 2 & $\mathrm{TiCl}_{4}$ & $-78^{\circ} \mathrm{C}$ to r.t. & $\begin{array}{c}-78^{\circ} \mathrm{C} 15 \mathrm{~min} \\
\text { then r.t. } 1 \mathrm{~h}\end{array}$ & none & $\begin{array}{c}9 \% \\
(\boldsymbol{d} r=12: 1)\end{array}$ & $50 \%$ \\
\hline
\end{tabular}

Scheme 23 Two-step procedure toward compound 32

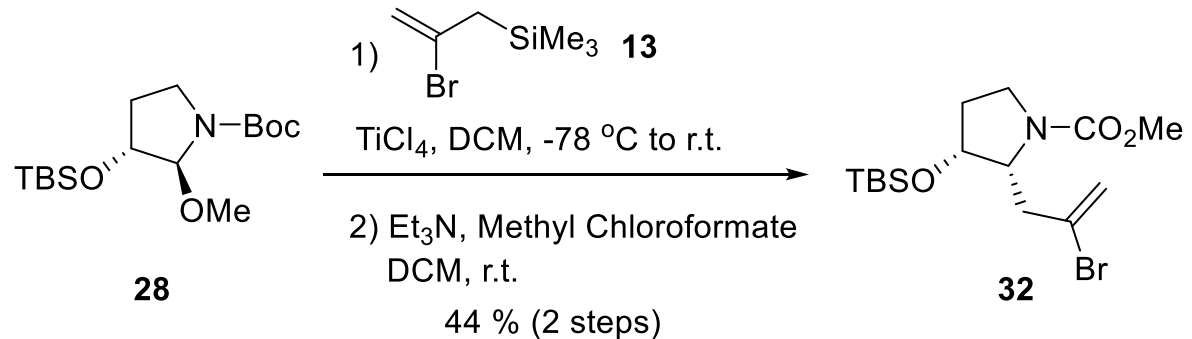

Because $\mathrm{BF}_{3} \cdot \mathrm{OEt}_{2}$ used in the allylation reaction gave only a moderate yield of tertbutyl carbamate 29, and $\mathrm{TiCl}_{4}$ used in this reaction required extra synthetic step to reprotect the amine group in the starting material, the synthetic route toward ht-13-A was modified at the early stage. $\mathrm{In} \mathrm{TiCl}_{4}$ mediated allylation reaction, another common $\mathrm{N}$ - 
protecting group, methyloxycarbonyl (Moc), exhibits excellent stability. Thus, the $\mathrm{N}$ protection of pyrrolidinone $\mathbf{2 2}$ using methyl chloroformate was performed following the standard procedure, giving methyl carbamate $\mathbf{3 3}$ in $79 \%$ yield (Scheme 24).

Scheme 24 Synthesis of methyl carbamate 35
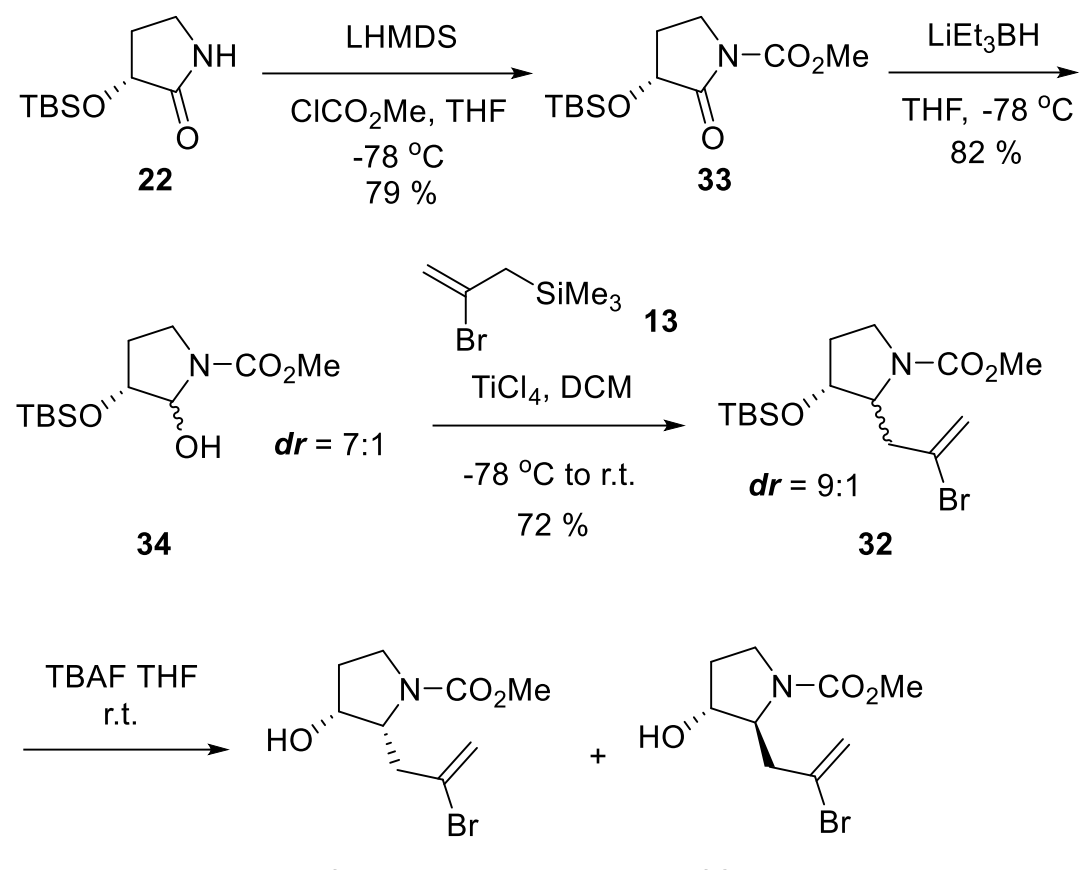

$3568 \%$

$3616 \%$

Regioselective reduction of $\mathbf{3 3}$ using lithium triethylborohydride gave the $\mathrm{N}, \mathrm{O}$ hemiacetal $\mathbf{3 4}$ as an inseparable mixture of diastereomers. In our previous synthesis of ht$13-\mathrm{B}^{31}$, a related compound was initially $O$-methylated prior to a Lewis acid mediated allylation. However, in this synthesis, introduction of the allyl side chain via an acyliminium ion was achieved directly from $\mathbf{3 4}$. In the event, reaction of $\mathbf{3 4}$ with 2-bromo2-propen-1-yl trimethylsilane $\mathbf{1 3}^{23}$ in the presence of an excess of titanium tetrachloride gave compound $\mathbf{3 2}$ as an approximately 6:1 mixture of two inseparable diastereomers. The major isomer was predicted to have a cis-relationship between the allyl and the OTBS groups based on literature precedence. ${ }^{11,12,13 \mathrm{~d}, 24}$ However, the stereochemistry of either of 
the isomer could not be confirmed at this point in the synthesis. The tertbutyldimethylsilyl group was removed using tetrabutylammonium fluoride (TBAF) and at this point the diastereomers were readily separated by chromatography on silica gel affording pure pyrrolidines $\mathbf{3 5}$ and $\mathbf{3 6}$. The expected stereochemistry of the major isomer 35 and the minor isomer $\mathbf{3 6}$ was cis and trans, respectively, as confirmed by nOe NMR experiments.

Mitsunobu reaction of the major isomer 35 with 2-bromo-3-nitrophenol 9 in the presence of triphenylphosphine and diisopropylazodicarboxylate (DIAD) furnished compound 37 (Scheme 25). The expected cis to trans inversion of stereochemistry was again confirmed by nOe NMR experiments. With the correct stereochemistry established, two sequential palladium catalyzed reactions were employed to build the oxepane and pyrrole rings of ht-13-A. The oxepane was obtained using an intramolecular Stille-Kelly ${ }^{19}$ reaction. Compound $\mathbf{3 7}$ was treated with hexamethylditin in the presence of a catalyst system consisting of bis(dibenzylidenacetone)palladium-triphenylphosphine producing the tricyclic compound 38. All attempts to improve the yield of the coupling reaction from 37 to 38 , by modification of the catalyst system and the reaction conditions, failed to improve the yield. In addition to palladium based systems, bis(1,5-cyclooctadiene)nickel catalyzed intermolecular cross coupling reactions between aromatic bromides have recently been reported. ${ }^{34}$ However, the same catalyst system in this transformation only resulted in decomposition of the starting material to an intractable mixture. Palladium catalyzed reductive $N$-heterocyclization of $\mathbf{3 8}$ in the presence of carbon monoxide gave the expected tetracyclic indole 39. ${ }^{10}$ Finally, the methoxycarbonyl group was reduced to a methyl group using sodium bis(2-methoxyethoxy)aluminum hydride (Red-Al) in toluene affording ht-13-A in high isolated yield. The ${ }^{1} \mathrm{H}$ and ${ }^{13} \mathrm{C}$ NMR, IR, HRMS, 
melting point and optical rotation data of synthetic ht-13-A were identical to the literature values of the compound isolated by Kamiguchi and Yasui. ${ }^{1}$

Scheme 25 Synthesis of ht-13-A
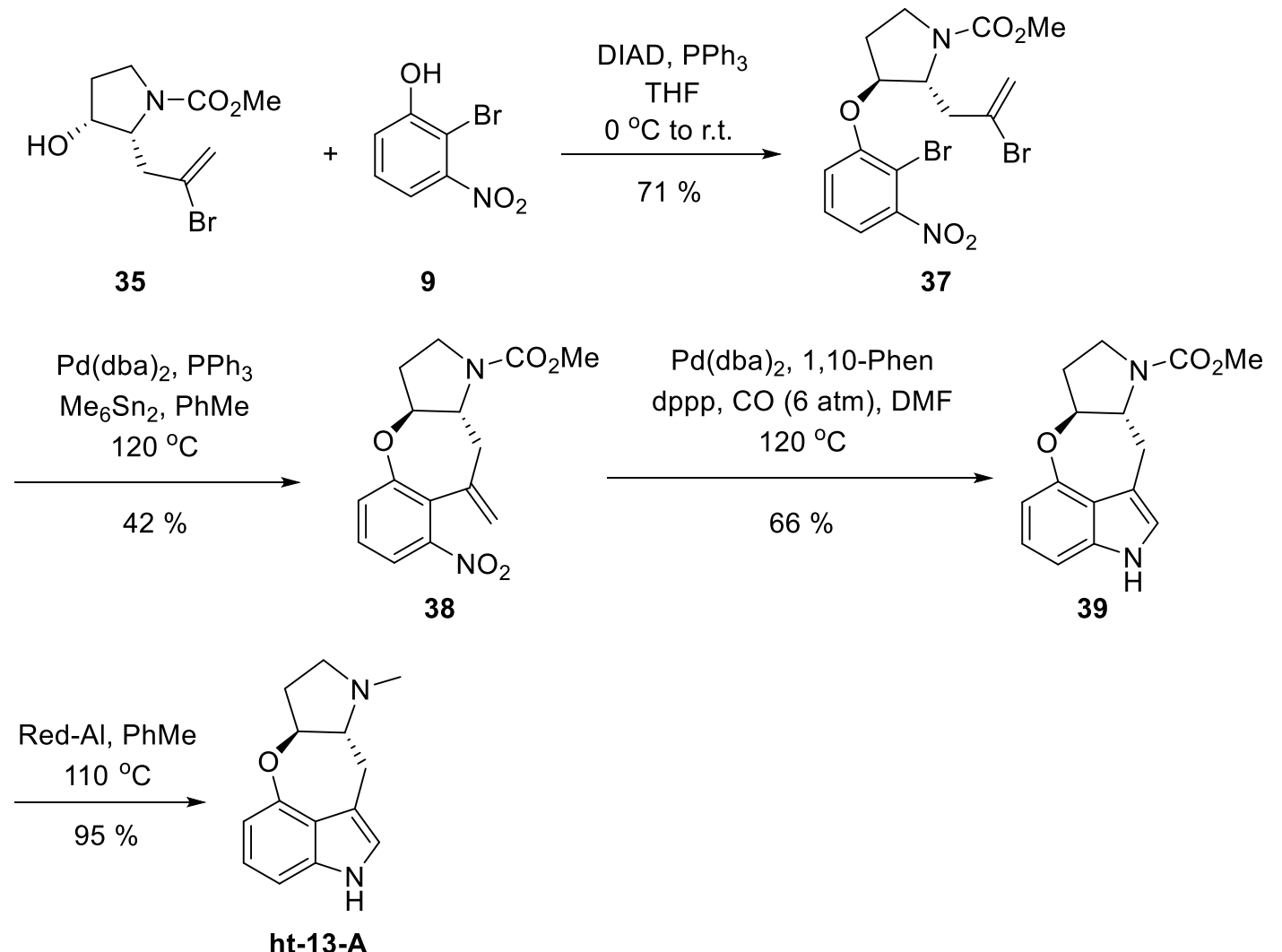


\section{Conclusions}

In summary, a total synthesis of the tetracyclic indole alkaloid ht-13-A was achieved starting from commercially available (-)-4-amino-2-hydroxybutyric acid. The overall yield of ht-13-A in eight steps from pyrrolidinone 22 was $6 \%$. The trans stereochemistry was obtained from an acyliminium ion allylation followed by a Mitsunobu reaction. The 7-membered oxepane ring was obtained via an intramolecular Stille-Kelly reaction and the pyrrole ring was synthesized in a late stage carbon monoxide mediated palladium catalyzed reductive $N$-heterocyclization. This synthesis exemplifies a strategy for the synthesis of 3,4-fused indole alkaloids via nitrostyrene precursors. 


\section{Chapter 3 Total synthesis of aurantioclavine}

\section{A. Introduction}

(-)-Aurantioclavine was firstly isolated from Penicillium aurantiovirens in 1981 by Kozlovskii and co-workers. ${ }^{35}$ (-)-Aurantioclavine is one of a number of 3,4-fused indole alkaloids containing a 7-membered azepino ring as well as a $\mathrm{R}$ chiral center (Figure 6). It has been proven to be an important intermediate in the biosynthesis of communesin family natural products.

Figure 6 Structure of aurantioclavine

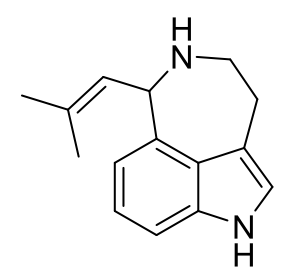

aurantioclavine

After its discovery, several total synthesis pathways of this molecule have been designed. ${ }^{36}$ The first synthesis of aurantioclavine was reported by Hegedus and co-workers in 1987 (Scheme 26). In their synthetic strategy, the C-4 side chain was installed through a Heck coupling and then the 7-membered ring found in aurantioclavine was obtained via an acid-catalyzed intramolecular cyclization. Finally, the synthesis of aurantioclavine was completed after removal of a tosylate. The overall yield of aurantioclavine was $23 \%$ in 13 steps from a commercially available compound. 
Scheme 26 Hegedus's synthesis of aurantioclavine
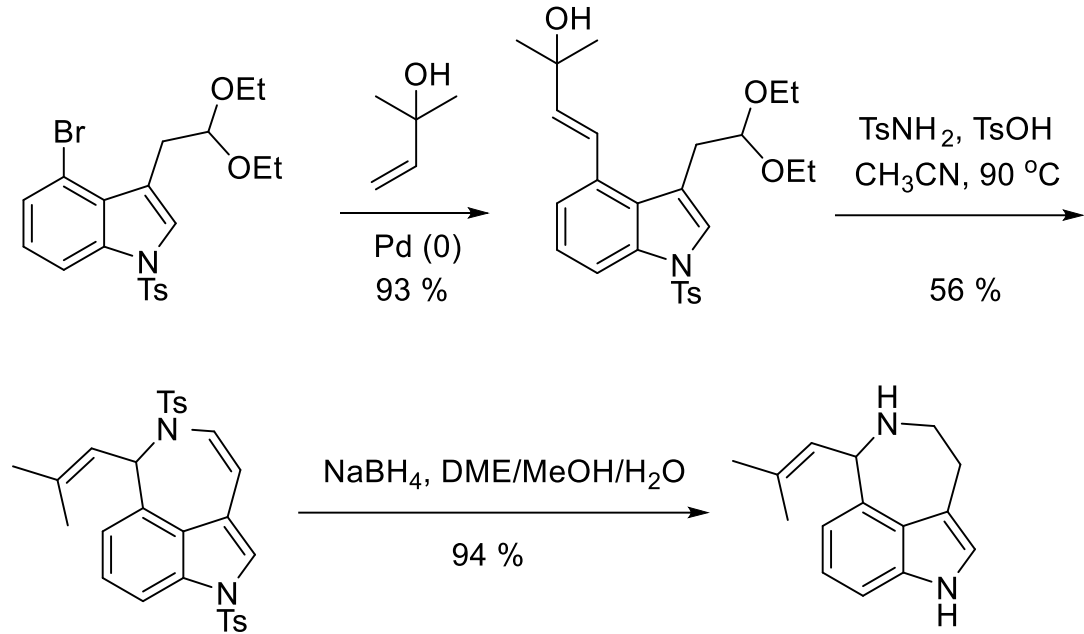

(士)-aurantioclavine

In 2010, Ellman and co-workers reported an asymmetric total synthesis of aurantioclavine starting with 4-bromotryptophol (Scheme 27). The chiral center was obtained from an asymmetric alkenylation of an $\mathrm{N}$-tert-butanesulfinyl imine intermediate. The desired 7-member ring was built in the late stage via a basic substitution reaction.

Scheme 27 Ellman's synthesis of (-)-aurantioclavine<smiles>OCCc1c[nH]c2cccc(Br)c12</smiles><smiles>CC(C)(C)S(=O)/N=C/c1cccc2c1c(CCO[Na])cn2S</smiles><smiles>CC(C)=C[C@H](NS(=O)C(C)(C)C)c1cccc2c1c(CCOC(F)(F)F)cn2S</smiles><smiles>CC(C)=C[C@H]1c2cccc3c2c(cn3S)CCN1S(=O)C(C)(C)C</smiles>

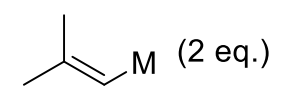

$[\mathrm{Rh}(\mathrm{OH})(\mathrm{cod})]_{2}(2.5 \mathrm{~mol} \%)$ dppbenz (5.0 mol \%)

$$
\begin{gathered}
\text { base (2 eq.) } \\
\mathrm{H}_{2} \mathrm{O} / \text { cosolvent (3:2), } 60{ }^{\circ} \mathrm{C} \\
\mathrm{M}=\text { BMIDA } \\
81 \%, \boldsymbol{d r}=97: 3
\end{gathered}
$$

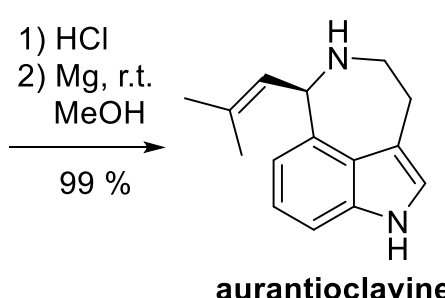


In the same year, Jia and co-worker reported another asymmetric synthetic strategy toward (-)-aurantiocalvine (Scheme 28). The chiral center in the molecule was derived from methyl (S)-2-di-tert-butoxycarbonylamino-5-oxopentanoate. The structural skeleton of aurantioclavine was accomplished through a one pot Heck-aminocyclization reaction.

Scheme 28 Jia's synthesis of (-)-aurantioclavine
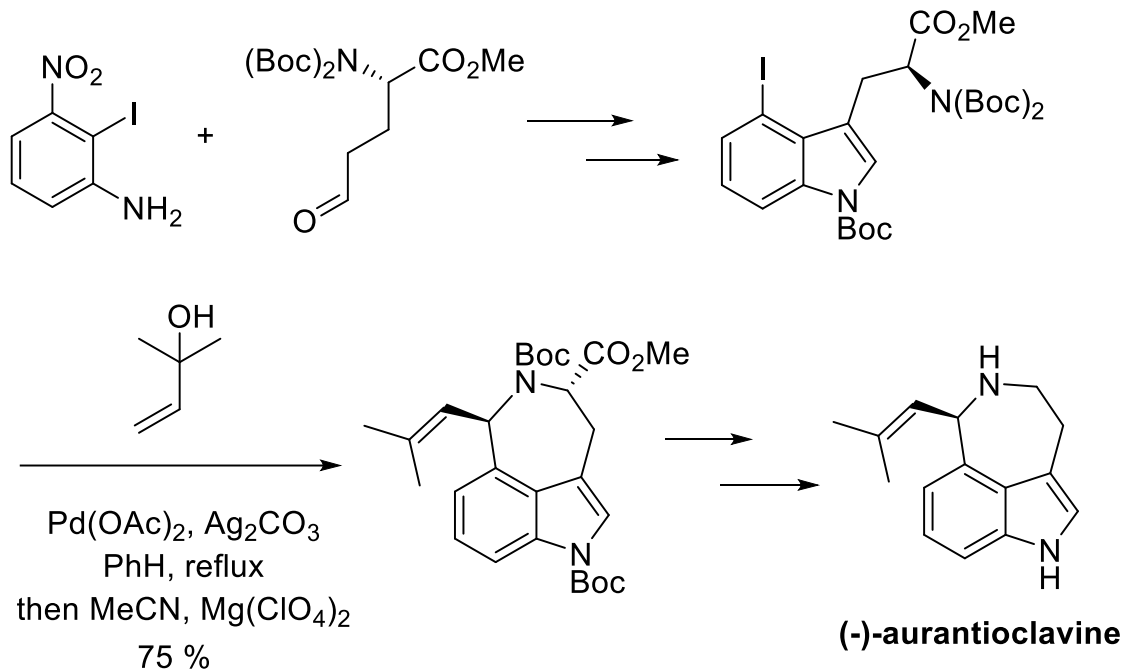

Recently, Takemoto's group has developed a novel asymmetric allylic amination reaction to complete the synthesis of (-)-aurantiocalvine (Scheme 29). Using (S)-tBuPHOX as the chiral ligand in this reaction furnished the desired 7-member ring with $95 \%$ enantiomeric excess. 
Scheme 29 Takemoto's synthesis of (-)-aurantioclavine
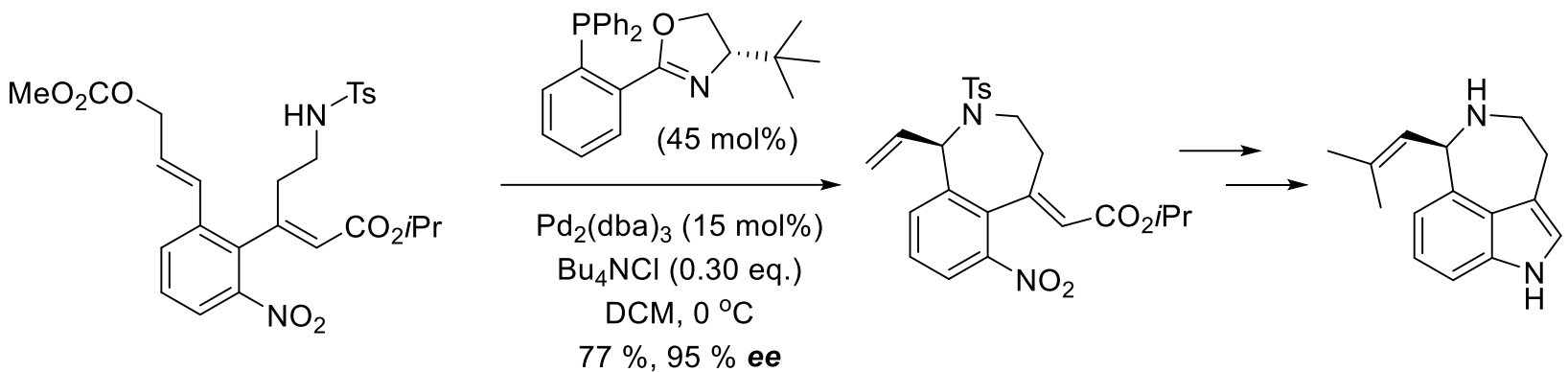


\section{B. Results and Discussions}

Most of the previous syntheses of aurantioclavine started with a preformed indole framework. It is essential to protect the nitrogen in the indole core to avoid side reactions and this requires additional synthetic steps.

Herein, we present a shorter synthetic pathway to aurantioclavine (Scheme 30). Although a similar strategy as Takemoto's was employed, our approach avoided the extra steps necessary in their synthesis to prepare the propenyl group and the indole core. The strategy proposed is as following. The indole core should be prepared from the palladium catalyzed N-heterocyclization of a nitrostyrene precursor. The 7-member azepino ring could be generated through a Lewis acid mediated intramolecular cyclization. The two side chains in intermediate $\mathbf{4 0}$ may be derived from nitrobenzene $\mathbf{4 1}$ via metal catalyzed cross-coupling reactions.

Scheme 30 Retrosynthetic analysis of aurantioclavine

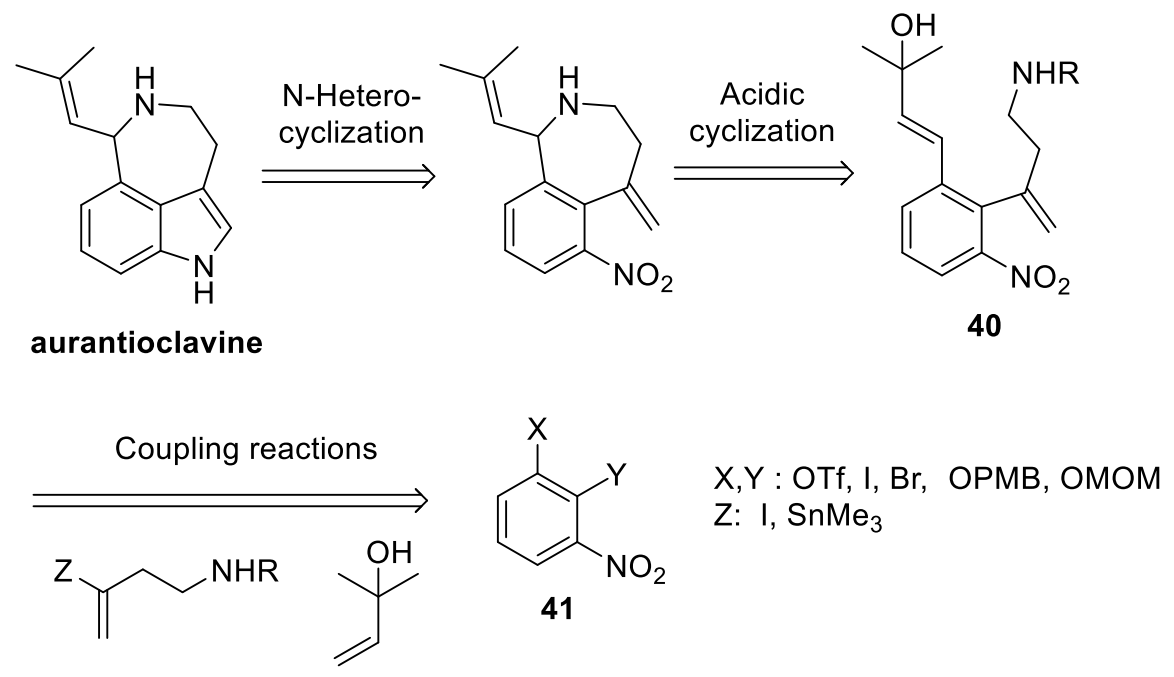


The synthesis commenced with installation of the side chains onto nitrobenzene $\mathbf{4 1}$ via a regioselective Kosugi-Migta-Stille coupling reaction. Phenol 42 was firstly prepared from commercially available 2-bromophenol according to a literature procedure. ${ }^{37}$ Treatment of $\mathbf{4 2}$ with triethylamine and trifluoromethanesulfonic anhydride in methylene chloride gave triflate 43 (Scheme 31), which was subsequently reacted with methyl carbamate $\mathbf{4 4}^{38}$ prepared from 3-butyn-1-ol. This cross coupling reaction was carried out using a bis(triphenylphosphine)-palladium(II) dichloride and lithium chloride system. As expected, selective coupling at the OTf position was observed. Although the correct regioselectivity was established, the Heck precursor $\mathbf{4 5}$ was isolated in a relatively low yield (19\%), which may be caused by the steric hindrance encountered at the OTf position.

Scheme 31 Synthesis of Heck precursor 45
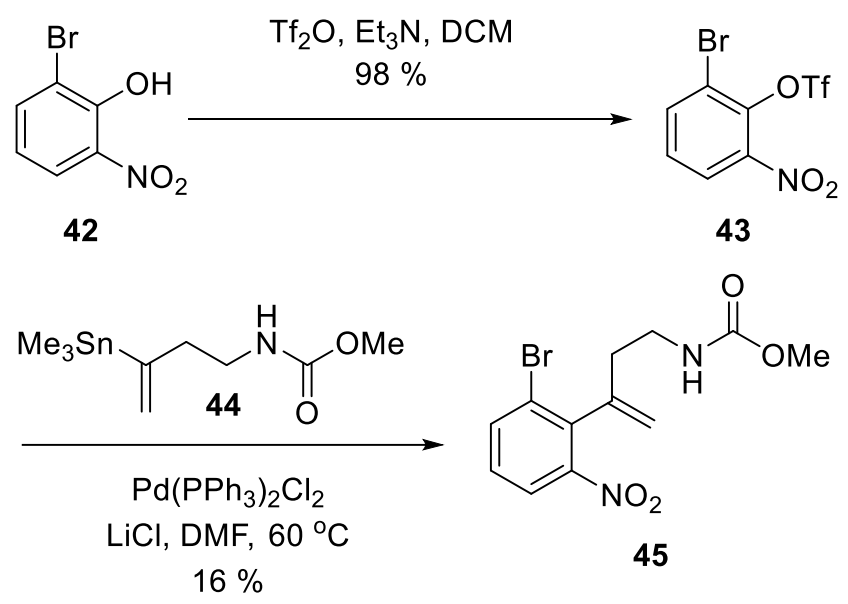

Since a low yield was observed in the above coupling, an alternative pathway was investigated toward building block $\mathbf{4 5}$. The synthesis started with commercially available 2-bromoaniline (Scheme 32). Protection of the amino group in 2-bromoaniline using 4toluenesulfonyl chloride $(\mathrm{TsCl})$ gave tosylate 46. Based on a recently described nitration ${ }^{39}$, 
46 was converted to nitrobenzene 47. Next, the tosyl group was removed using sulfuric acid and the resulting aniline 48 was transformed to 1-bromo-2-iodo-3-nitrobenzene 49 by a Sandmeyer-type reaction. Arylstannane $\mathbf{5 0}$ was obtained from 49 using hexamethylditin. Finally, compound $\mathbf{5 0}$ was subjected to the Stille coupling condition with the known methyl carbamate $\mathbf{5 1} \mathbf{1}^{38}$, however, an inferior yield of $\mathbf{4 5}$ was observed again.

Scheme 32 Alternative pathway toward Heck precursor $\mathbf{4 5}$
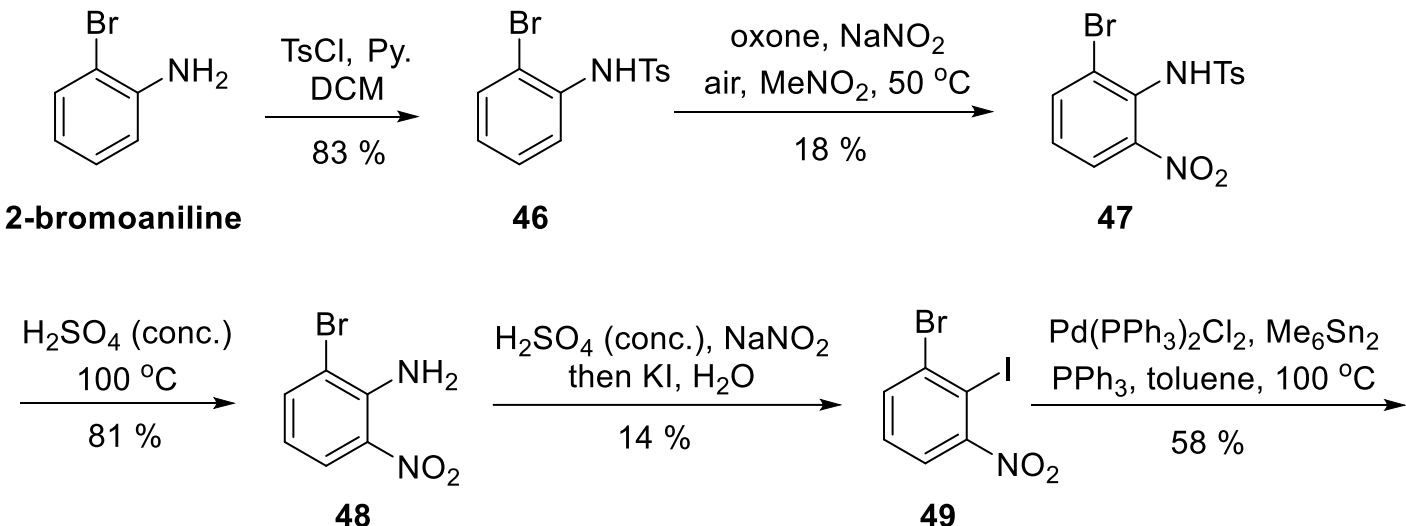<smiles>C=C(I)CCNC(=O)OCC(=O)OC</smiles>

Since all attempts to improve the yield of $\mathbf{4 5}$ were unsuccessful, the following work was focused on synthesis of a similar Heck precursor 53 (Scheme 33). Triflate 52 was prepared from 2-iodo-3-nitrophenol following the standard procedure. Kosugi-MigitaStille coupling using methyl carbamate 44 gave the desired Heck precursor 53. Unfortunately, the yield was still unsatisfactory. All efforts using selective Stille coupling reaction for the synthesis of the Heck precursors made no contribution to the improvement 
of reaction yield. The reason might be the slow reaction rate of the transmetalation in Stille coupling due to a steric hindrance problem.

Scheme 33 Synthesis of triflate 53

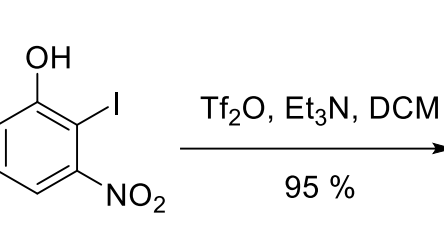

2-iodo-3-nitrophenol

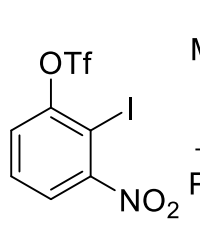

52<smiles>C=C(CCNC(=O)OC)c1c(OCC)cccc1[N+](=O)[O-]</smiles>

53

In addition, 2-iodo-3-nitrophenol was subjected to Stille coupling condition with methyl carbamate 44 (Scheme 34). Since the unprotected hydroxyl group may cause numerous side reactions, the desired phenol $\mathbf{5 4}$ was isolated in a low yield.

Scheme 34 Synthesis of phenol 54

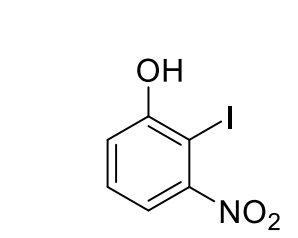

2-iodo-3-nitrophenol

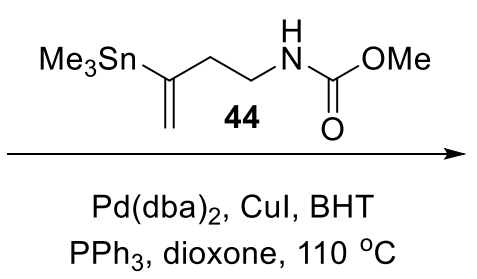

$22 \%$

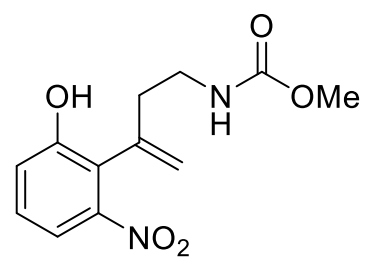

54

Considering the unsatisfactory yield of $\mathbf{5 4}$ found in the above coupling, a protecting group for the hydroxyl in 2-iodo-3-nitrophenol was introduced to avoid possible side reactions (Scheme 35). Protection of the hydroxyl group using benzyl chloride and potassium carbonate gave nitrobenzene $\mathbf{5 5}$ in high yield. Compound $\mathbf{5 5}$ was transformed to arylstannane 56 using hexamethylditin in the presence of bis(triphenylphosphine) palladium dichloride. Pleasingly, the Stille coupling between $\mathbf{5 6}$ and methyl carbamate $\mathbf{5 1}$ 
successfully accomplished the desired 2-nitrostyrene $\mathbf{5 7}$ in good yield. As removal of the benzyl at this point may lead to a reduction of the vinyl group and unexpected loss of methyloxycarbonyl protecting group, $\mathbf{5 7}$ was transformed to indole $\mathbf{5 8}$ first under the Nheterocyclization condition previously developed in our group. ${ }^{10} \mathrm{With}$ indole $\mathbf{5 8}$ in hand, the reactions focused on functionalization of $\mathrm{C}-4$ on the indole core were examined. The benzyl protecting group was smoothly removed using $10 \mathrm{wt} . \%$ palladium on carbon in the presence of hydrogen gas. An alternative deprotection was examined using palladium and ammonium formate in absolute ethanol, resulting in unexpected removal of the methyloxycarbonyl group. Next, 4-hydroxyindole 59 was converted to triflate $\mathbf{6 0}$. When methylene chloride was used as solvent in this transformation, extremely low yield was found probably due to the very low solubility of $\mathbf{5 9}$ in this solvent. Gratifyingly, using acetonitrile as solvent led to formation of triflate $\mathbf{6 0}$ in better yield.

Scheme 35 Synthesis of triflate 60

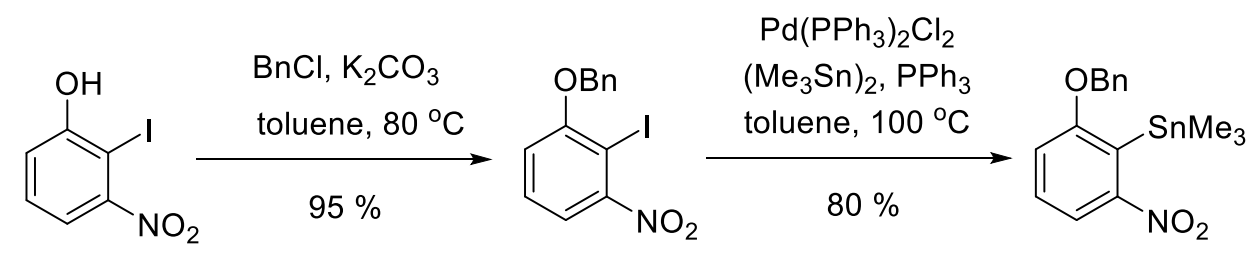

2-iodo-3-nitrophenol

55

56

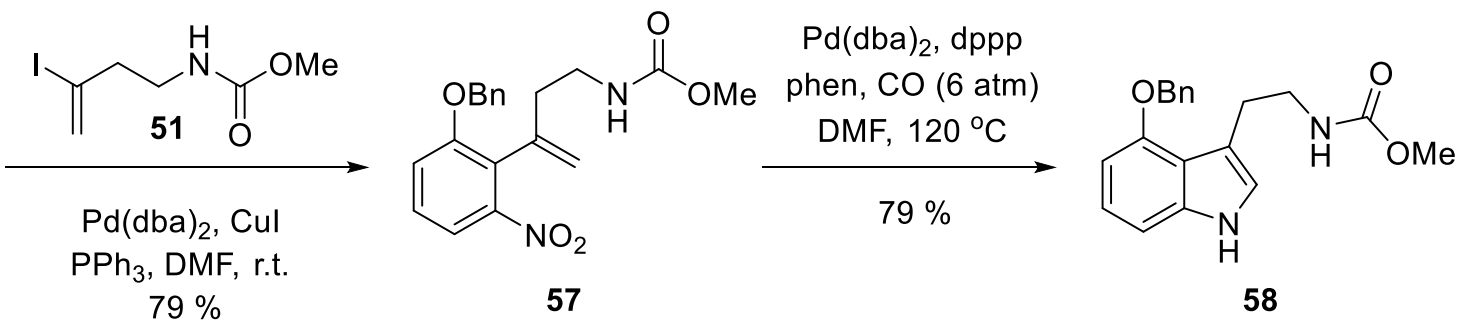<smiles>CCOCCN(C)CCOC</smiles>

59<smiles>COC(=O)NCCc1c[nH]c2cccc(OC)c12</smiles>

60 
We next turned attention to the construction of side chain at C-4 using a Heck reaction (Scheme 36). However, only a trace amount of product was found under various Heck conditions. The failure of those Heck coupling methods prompted us to pursue a synthesis of 61 to 2 steps, namely introducing a propargyl alcohol (62) which could be reduced to 61. Unfortunately, no desired product 62 was formed under Sonogashira conditions.

Scheme 36 Heck and Sonogashira coupling of $\mathbf{6 0}$

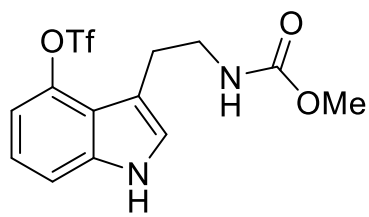

60

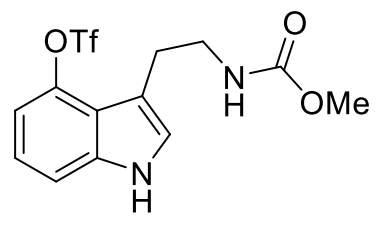

60

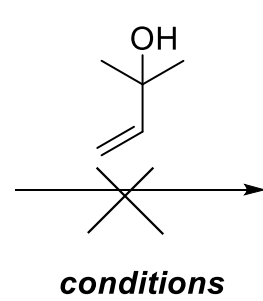

conditions
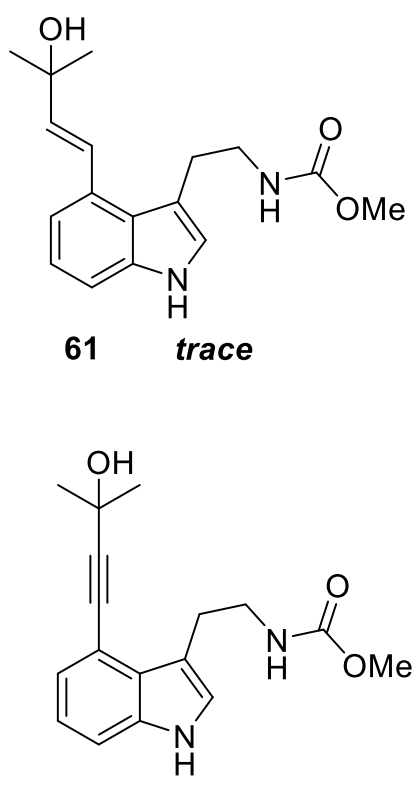

62 not observed

As none of the coupling product was obtained from indole $\mathbf{6 0}$, we came back to the building block 53. Instead of using a benzyl protection approach, we anticipated that 4methoxybenzyl protection might give the desired building block $\mathbf{5 3}$ via a concise procedure (Scheme 37). Reaction of 2-iodo-3-nitrophenol with a mixture of 4methoxybenzyl chloride and potassium carbonate in refluxing acetonitrile gave 4methoxybenzyl phenyl ether 63. Arylstannane 64 was obtained when 63 was treated with bis(triphenylphosphine)palladium dichloride, hexamethylditin and triphenylphosphine in 
refluxing toluene. Reacting arylstannane $\mathbf{6 4}$ with methyl carbamate $\mathbf{5 1}$ under standard Kosugi-Migita-Stille conditions produced $\mathbf{6 5}$ in $81 \%$ yield. In order to selectively remove the 4-methoxylbenzyl protecting group, 65 was treated with 2,3-dichloro-5,6-dicyano-1,4benzoquinone (DDQ) in refluxing chloroform. When this deprotection was performed at ambient temperature, none of desired 54, only starting material was recovered. Furthermore, the yield of $\mathbf{5 4}$ decreased significantly upon scaled-up of the reaction. Next, triflate $\mathbf{5 3}$ was easily obtained from $\mathbf{5 4}$ in $86 \%$ yield.

Scheme 37 Synthesis of building block $\mathbf{5 3}$
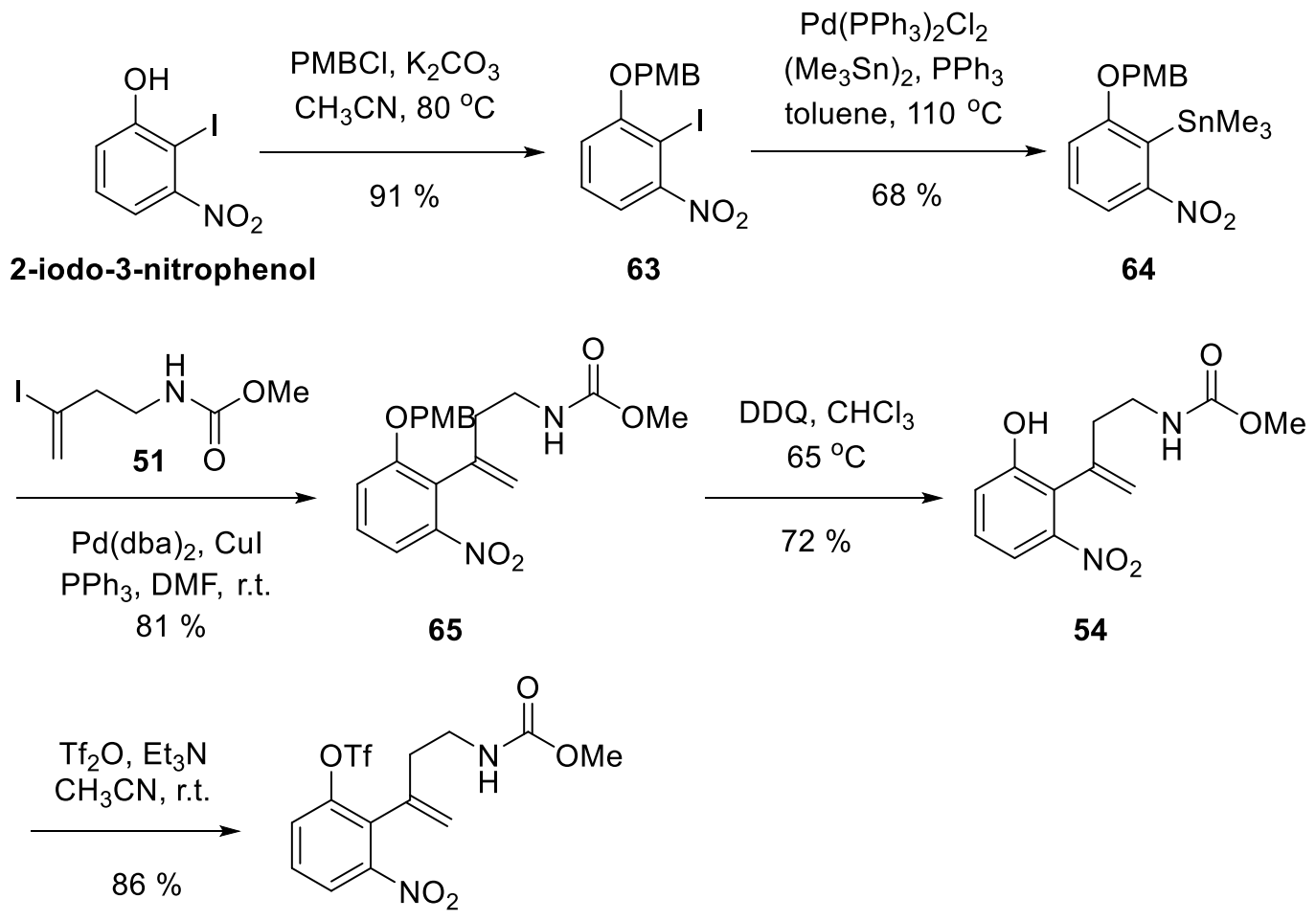

53

Because of the failure in the removal of PMB group in the scaled-up reaction, an alternative pathway to $\mathbf{5 4}$ has been studied (Scheme 38). Methoxymethyl phenyl ether 66 was prepared by reacting 2-iodo-3-nitrophenol with chloromethyl methyl ether and 
potassium carbonate in DMF at room temperature. Under the same condition as described for the synthesis of compound 64, arylstannane $\mathbf{6 7}$ was obtained in 74\% yield from $\mathbf{6 6}$. Through a Kosugi-Migita-Stille coupling, arylstannane 67 was converted to 2-nitrostyrene 68. The latter successfully lost the methoxy methyl (MOM) protecting group using concentrated $\mathrm{HCl}$ in methanol. Gratifyingly, the scaled-up reaction from $\mathbf{6 8}$ to $\mathbf{5 4}$ was accomplished in a comparable yield.

Scheme 38 Alternative pathway toward 54

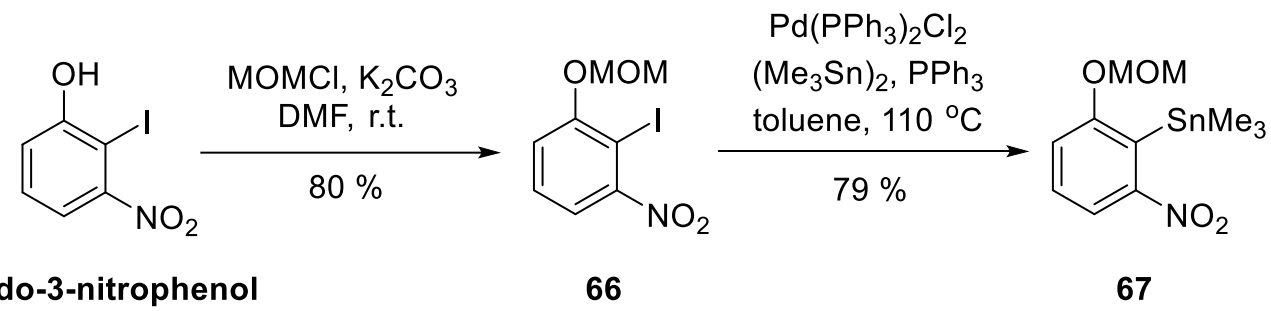

2-iodo-3-nitrophenol

66<smiles>C=C(CCNC(=O)OC)c1c(O)cccc1[N+](=O)[O-]</smiles>

In previous reactions, it was found that iodole $\mathbf{6 0}$ was unreactive under Heck reaction conditions. Therefore, 2-nitrostyrene $\mathbf{5 3}$ was examined as a possible substrate for the installation of C-4 side chain (Scheme 39). As expected, compound 69 was readily obtained in 55\% yield via the Heck reaction between triflate $\mathbf{5 3}$ and 2-methyl-3-buten-2-ol. Next, the indole core was successfully prepared through the N-heterocyclization reaction, whereas, dehydration occurred at the same time due to the harsh reaction condition, resulting in a formation of diene 70. To our delight, reduction of methyloxycarbonyl group in $\mathbf{7 0}$ using 
sodium bis(2-methoxyethoxy)-aluminumhydride in reflux toluene formed another natural product, dehydrated ergotryptamine isolated in 2015 by Panaccione. ${ }^{39}$

Scheme 39 Synthesis of dehydrated ergotryptamine<smiles>C=C(CCNC(=O)OC)c1c(O)cccc1[N+](=O)[O-]</smiles>

53

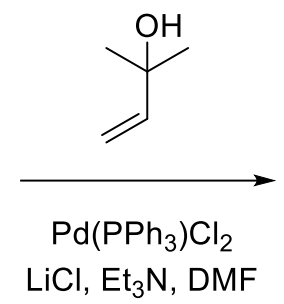

$120{ }^{\circ} \mathrm{C}$ $55 \%$<smiles>C=C(CCNC(=O)OC)c1c(/C=C/C(C)(C)O)cccc1[N+](=O)[O-]</smiles>

69
$P d(d b a)_{2}, d p p p$, phen CO (6 atm), DMF $120^{\circ} \mathrm{C}, 25 \mathrm{~h}$

$52 \%$<smiles>C=C(C)/C=C/c1cccc2[nH]cc(CCNC(=O)OC)c12</smiles>

70

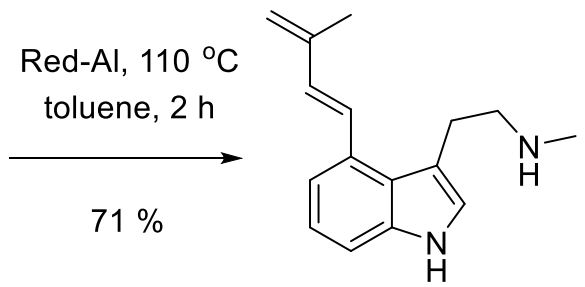

dehydrated ergotryptamine

As mentioned, the $\mathrm{N}$-heterocyclization performed prior to the generation of 7 membered azepino ring caused unexpected dehydration, therefore attempts were made to cyclize the 7 -membered ring prior to indole formation. Treating compound 69 with pyridinium p-toluenesulfonate (PPTS) in chloroform at $55^{\circ} \mathrm{C}$ again resulted in dehydration affording product 71 (Scheme 40). Gratifyingly, the desired cyclization product 72 was formed when 69 was subjected to a Lewis acid $\left(\mathrm{BF}_{3} \cdot \mathrm{OEt}_{2}\right)$ in ether at ambient temperature (Scheme 41). The N-heterocyclization of $\mathbf{7 2}$ successfully furnished indole 73 which contained the basic framework of aurantioclavine. 
Scheme 40 Failed intramolecular cyclization of 69

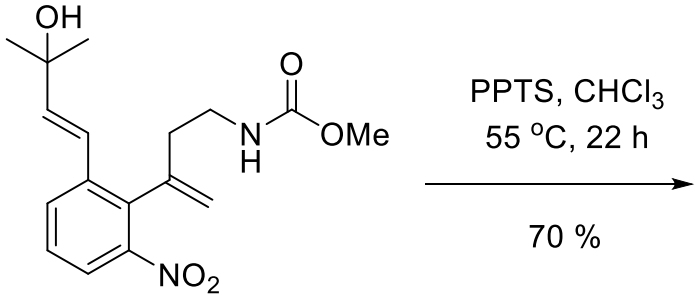

69

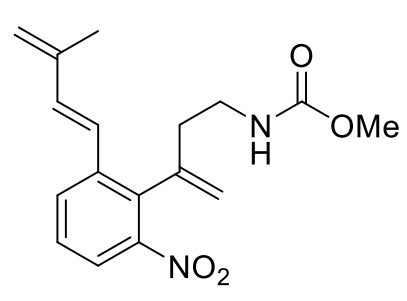

71

Scheme 41 Synthesis of indole 73<smiles>C=C(CCNC(=O)OC)c1c(/C=C/C(C)(C)O)cccc1[N+](=O)[O-]</smiles>

69

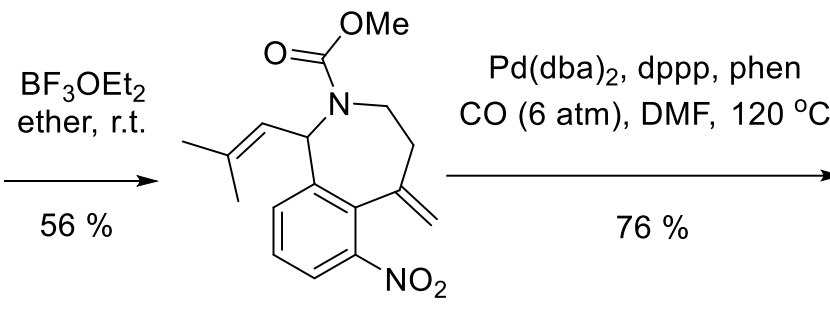

72

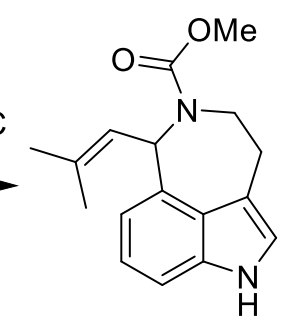

73

Finally, the Moc deprotection of methyl carbamate $\mathbf{7 3}$ was attempted to finish the synthesis of aurantioclavine. As summarized in Table 4, several conditions were examined, however, no satisfactory results were obtained. Treatment of $\mathbf{7 3}$ with trimethylsilyl chloride with sodium iodide or trimethylsilyl iodide only caused decomposition of the starting material (Table 4 , entry 1 and 2). When $\mathbf{7 3}$ was exposed to the condition in entry 3 , only starting material was recovered because of the low solubility of $\mathbf{7 3}$ in methanol. The solubility of $\mathbf{7 3}$ was highly improved when 1-propanol was used as solvent in this reaction, however, no desired product was found either (Table 4, entry 4). Other basic reagents including methyllithium and lithium triethylborohydride (Table 4, entry 5-7) were tried in this reaction, but none of them afforded the desired product. 
Table 4 Moc deprotection of $\mathbf{7 3}$

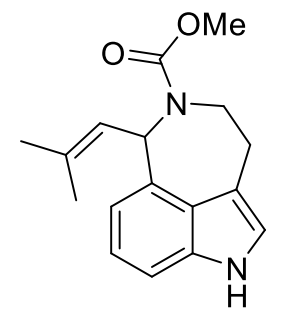

73

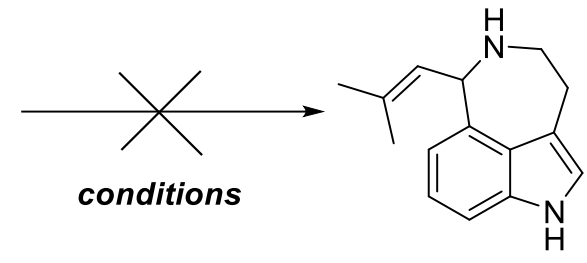

aurantioclavine

\begin{tabular}{|c|c|c|}
\hline Entry & Conditions & Yield \\
\hline 1 & TMSCl, NaI, $\mathrm{CH}_{3} \mathrm{CN}$, reflux, $2 \mathrm{~h}$ & not observed \\
\hline 2 & TMSI, DCM, r.t., 2 h & not observed \\
\hline 3 & $\mathrm{NaOH}(3.0 \mathrm{M}$, aq.), $\mathrm{MeOH}$, reflux, $12 \mathrm{~h}$ & no reaction \\
\hline 4 & KOH (3.0 M, aq.), 1-Propanol, reflux, 2 days & no reaction \\
\hline 5 & $\mathrm{MeLi}\left(1.6 \mathrm{M}\right.$ in ether), THF, $0{ }^{\circ} \mathrm{C}, 4 \mathrm{~h}$ & not observed \\
\hline 6 & $\mathrm{LiEt}_{3} \mathrm{BH}$ (1.0 $\mathrm{M}$ in THF, 3.0 eq.), THF, r.t., 3 days & no reaction \\
\hline 7 & $\mathrm{LiEt}_{3} \mathrm{BH}$ (1.0 M in THF, 10.0 eq.), THF, $60^{\circ} \mathrm{C}, 9 \mathrm{~h}$ & no reaction \\
\hline
\end{tabular}

In addition to auratioclavine, triflate $\mathbf{5 3}$ was thought to be the precursor of another natural product, ergotryptamine. ${ }^{39}$ In three subsequent steps, triflate $\mathbf{5 3}$ was elaborated to indole 61 (scheme 42). First, Heck reaction of $\mathbf{5 3}$ with methyl acrylate gave 2-nitrostyrene $\mathbf{7 4}$ in $61 \%$ yield. Next, the N-heterocyclization of $\mathbf{7 4}$ resulted in the formation of indole 75 which was treated with methyl magnesium bromide in ether to afford indole $\mathbf{6 1}$. Eventually, the Moc protecting group in $\mathbf{6 1}$ was smoothly reduced to N-methyl group 
using Red-Al at $50{ }^{\circ} \mathrm{C}$. The ${ }^{1} \mathrm{H}-\mathrm{NMR}$ experiment of crude reaction mixture confirmed the formation of the desired ergotryptamine. However, the product was proved to be sensitive to purification by chromatography on silica gel. Other purification methods have been attempted, such as reversed phase chromatography, but no effective method has been developed to isolate pure ergotryptamine.

Scheme 42 Synthesis of ergotryptamine

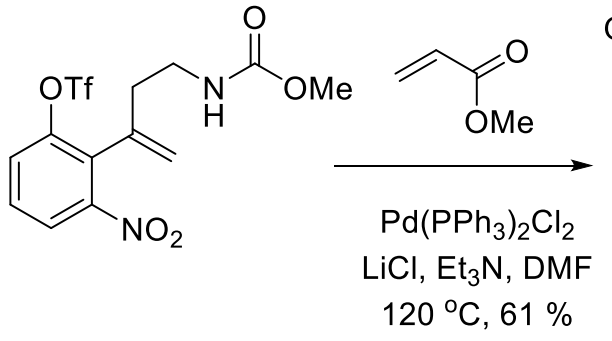

53

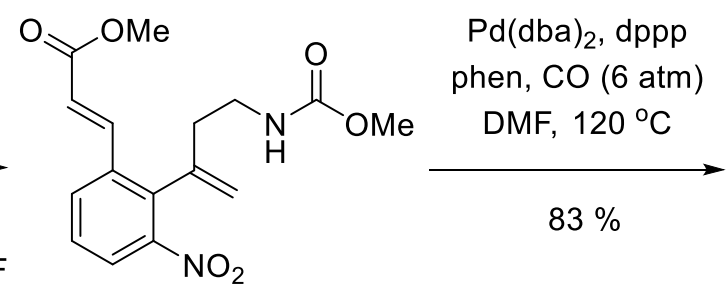

74

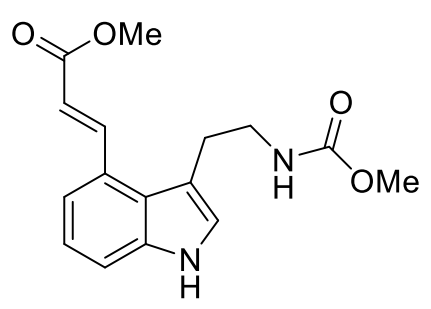

75

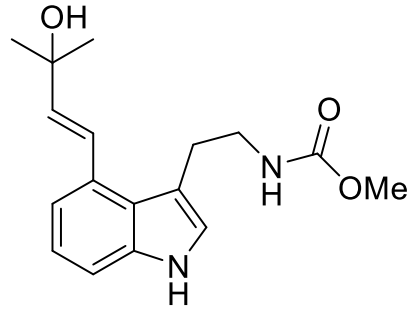

61

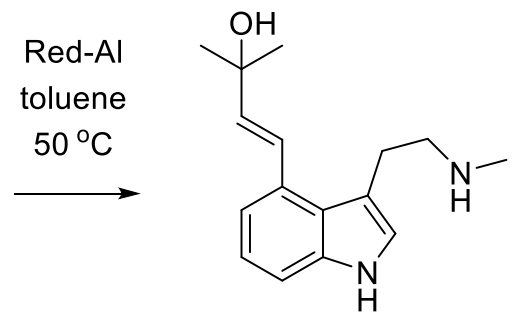

ergotryptamine 


\section{Conclusions}

A concise total synthesis of aurantioclavine has been investigated starting from 2-iodo3-nitrophenol. Key steps include a Kosugi-Migita-Stille coupling reaction, a Heck coupling reaction, a Lewis acid mediated intramolecular cyclization and an $\mathrm{N}$ heterocyclization. The MOM group used in this synthesis as a protecting group successfully stabilized the phenol oxygen. The amine moiety was protected by a Moc group, however, no suitable condition for the Moc removal has been discovered. Meanwhile, the preparation of Heck precursor $\mathbf{4 5}$ and $\mathbf{5 3}$ utilizing selective KosugiMigita-Stille coupling has been studied, but none of the attempts succeeded. Moreover, natural products ergotryptamine and dehydrated ergotryptamine have been achieved from the building block 53. Development of a feasible purification procedure is necessary to isolate ergotryptamine in the future. In general, this work provides a novel strategy for the synthesis of cycloclavine discussed in chapter 4 and other 3,4-fused indole alkaloids. 


\section{Chapter 4 Progress towards the synthesis of cycloclavine}

\section{A. Introduction}

Cycloclavine is one of the clavine-type ergot alkaloids initially isolated from African morning glory seeds (ipomoea hildebrandtii VATKE) by Hofmann and co-workers in 1969. ${ }^{40}$ To the best of our knowledge, cycloclavine is the only example of ergot alkaloid containing a fused pentacyclic framework (Figure 7). Recently, O'Connor and co-workers have reported a biosynthetic pathway to cycloclavine from a common intermediate chanoclavine-I via an enzyme catalyzed rearrangement process. ${ }^{41}$ So far, cycloclavine has been synthesized by five research groups ${ }^{42}$ however, no asymmetric synthesis has been reported.

Cycloclavine has three chiral centers at C-5, C-8 and C-10, a unique cyclopropane ring moiety, and a fused pentacyclic framework, which makes its synthesis very challenging, especially an asymmetric total synthesis.

Figure 7 Structure of cycloclavine

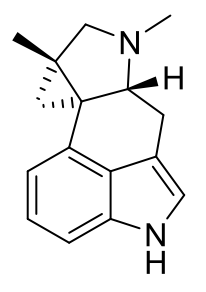

cycloclavine

This chapter focus on the first asymmetric total synthesis of (+)-cycloclavine. We anticipated that the chirality at C-5 on cycloclavine could be achieved using the Lewis acid mediated allylation strategy applied in our previous syntheses ${ }^{31}$. Furthermore, the 
pyrrolidine ring in cycloclavine could be produced following a similar synthetic route used in the synthesis of ht-13-A and ht-13-B. The indole core could be achieved in 2 steps including a Kosugi-Migita-Stille coupling and a N-heterocyclization in a late stage during the synthesis. A late formation of desired indole core will ensure a lower possibility of side reactions occurring in the early steps. Overall, the synthesis of cycloclavine is expected to be achieved via a short synthetic pathway based on our general strategy toward 3,4-fused indole alkaloids. 


\section{B. Results and Discussions}

Based on our previous strategy for the synthesis of 3,4-fused indole alkaloid, retrosynthetic analysis of (-)-cycloclavine is described in Scheme 43. Cycloclavine could be prepared from a reduction of the carbonyl group in pyrrolidinone 76. The indole core would be obtained from the carbon monoxide mediated $\mathrm{N}$-heterocyclization of 2nitrostyrene 77. Installation of cyclopropane ring onto $\alpha, \beta$-unsaturated amide $\mathbf{7 8}$ may furnished the tetracyclic intermediate 77. The middle 6-membered ring in $\mathbf{7 8}$ may be obtained from an intramolecular Heck reaction of triflate 79. The 1,5-dihydro-pyrrol-2one ring in $\mathbf{7 9}$ may be achieved via a base promoted elimination reaction of $\mathbf{8 0}$. In addition, deprotection of 4-methoxybenzyl group (PMB) followed by a reaction with $\mathrm{Tf}_{2} \mathrm{O}$ should give the desired trifluoromethanesulfonate group in 79. The benzene ring should be connected to the allyl side chain via a Kosugi-Migita-Stille coupling using the condition for the synthesis of $\mathbf{6 5}$ (Scheme 37). Compound $\mathbf{8 1}$ could be prepared from $N, O$-acetal 82 through a Lewis acid mediated allylation. Finally, compound $\mathbf{8 2}$ was thought to be prepared from known compound $\mathbf{8 3}$ via three-step procedure including a reported cyclization reaction, ${ }^{43}$ a regioselective reduction, and an acetylation. 
Scheme 43 Retrosynthetic analysis of cycloclavine

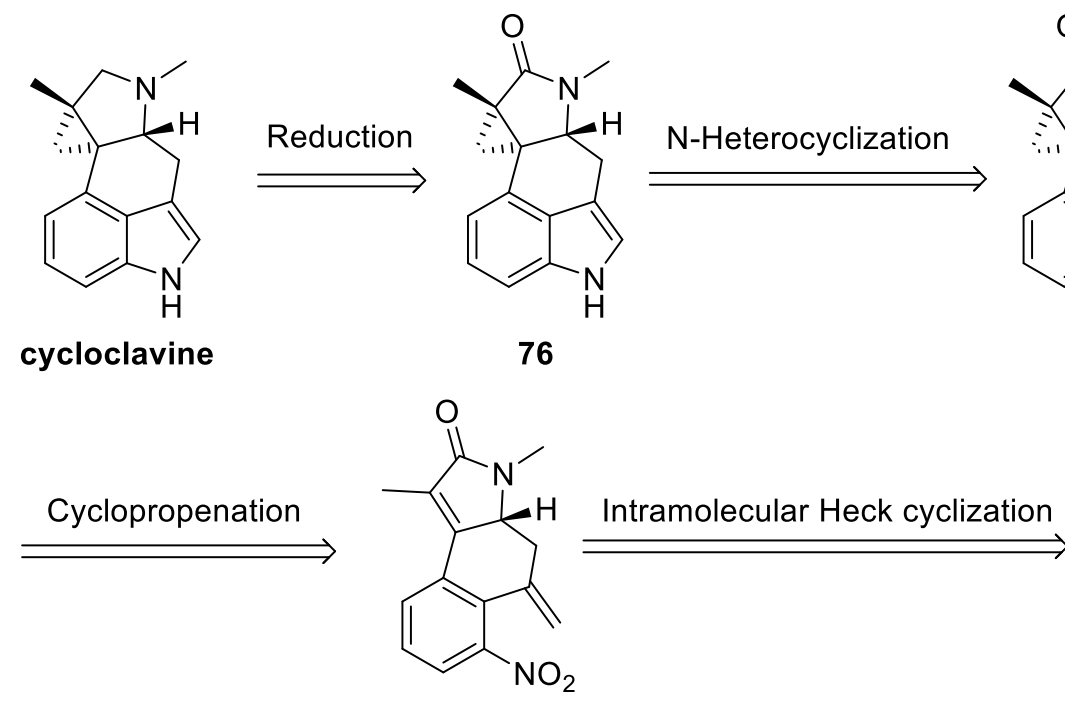

78<smiles>C=C1C[C@@H]2C(=C1[N+](=O)[O-])C[C@]1(C)N(C)C(=O)[C@H](C)C[C@@]21C</smiles>

77<smiles>C=C(C[C@@H]1C=C(C)C(=O)N1C)c1c(O)cccc1[N+](=O)[O-]</smiles>

79

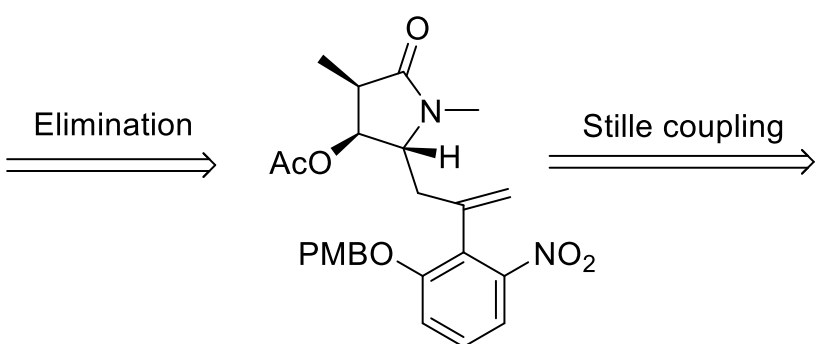

80<smiles>C=C(Br)C[C@H]1[C@H](OC(C)=O)[C@@H](C)C(=O)N1C=CC(=O)O</smiles>

81<smiles>CC(=O)O[C@@H]1C(=O)N(C)C(=O)[C@@H]1OC(C)=O</smiles>

82<smiles>C=C=CC(=O)O</smiles>

83

The synthesis began with the methylation of (S)-malic acid (Scheme 44). Treating (S)malic acid in refluxing methanol with concentrated $\mathrm{HCl}$ afforded ester $\mathbf{8 4}$. Compound $\mathbf{8 4}$ was then exposed to lithium bis(trimethylsilyl)amide in THF to generate an enolate intermediate which reacted with methyl iodide to give ester $\mathbf{8 5}$ as a 15:1 mixture of two inseparable diastereomers. In the next step, hydrolysis of $\mathbf{8 5}$ using potassium hydroxide in a mixture of THF and methanol gave methyl malic acid $\mathbf{8 3}$, which was subsequently reacted with acetyl chloride and methylamine to form succinimide $\mathbf{8 6}$ with the same 
diastereomeric ratio as $\mathbf{8 5}$. Gratifyingly, the regioselective reduction of $\mathbf{8 6}$ using sodium borohydride at $-40{ }^{\circ} \mathrm{C}$ produced a $\mathrm{N}, \mathrm{O}$-hemiacetal intermediate as a single stereoisomer. Reduction of $\mathbf{8 6}$ at higher temperature $\left(-20{ }^{\circ} \mathrm{C}\right.$ to r.t.) resulted in a partial decomposition of the starting material as well as decreased diastereoselectivity. Acetylation of the remaining hydroxyl group was carried out to afford compound $\mathbf{8 2}$ in $42 \%$ yield ( 2 steps). The $N, O$-acetal moiety was activated by treating 82 with $\mathrm{TiCl}_{4}$ leading to the formation of an acyliminium ion intermediate. After addition of 2-bromo-2-propen-1-yl trimethylsilane $\mathbf{1 3}$ to the reaction mixture, vinyl bromide $\mathbf{8 1}$ was formed as a single stereometric isomer in $94 \%$ yield. Replacement of the bromine in $\mathbf{8 1}$ by a trimethyltin group was readily achieved in the $\operatorname{Pd}(0)$-hexamethylditin system giving trimethylstannane $\mathbf{8 7}$. Both $\mathbf{8 1}$ and 87 can serve as starting materials for Kosugi-Migita-Stille coupling reaction in the next step.

Scheme 44 Synthesis of acetate 81 and trimethylstannane 87

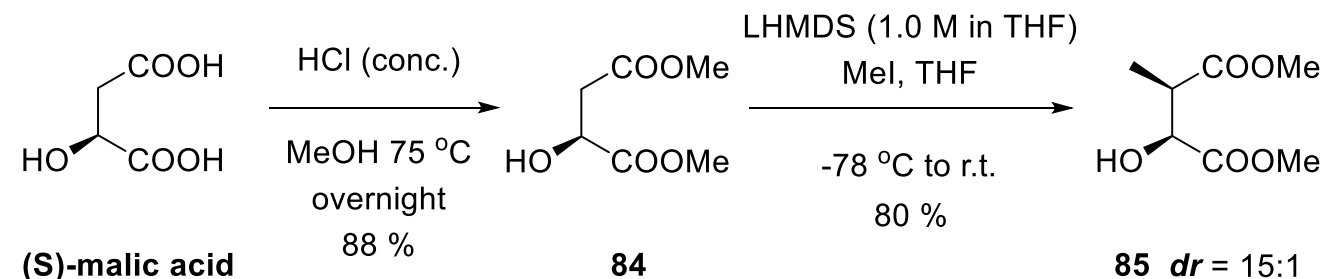

(S)-malic acid

84

$85 d r=15: 1$
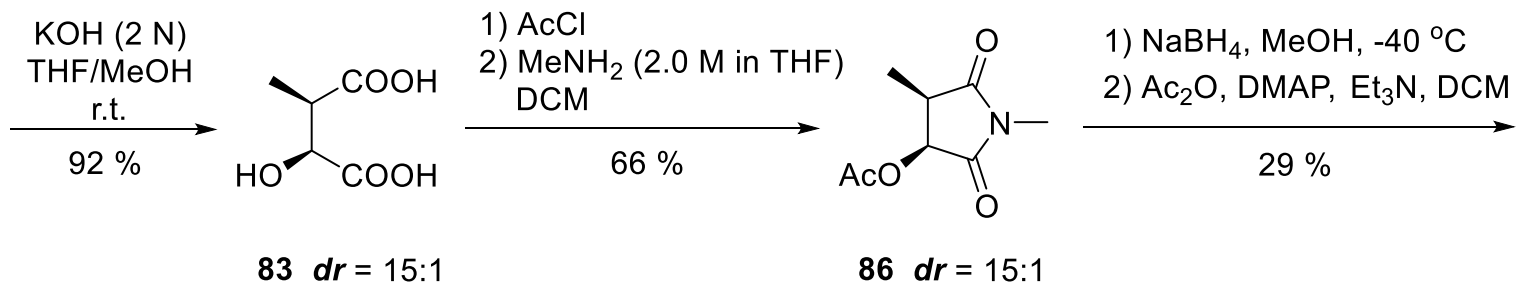

OAc

82

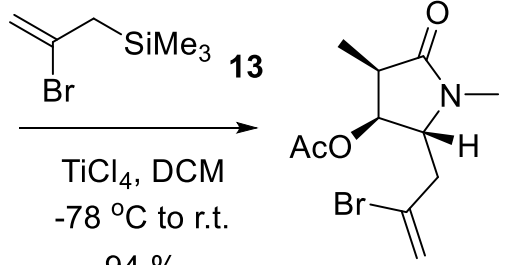

$94 \%$
$\mathrm{Pd}(\mathrm{dba})_{2}, \mathrm{Me}_{6} \mathrm{Sn}_{2}$, DIPEA $\mathrm{PPh}_{3}$, toluene, $80^{\circ} \mathrm{C}$

$67 \%$

81

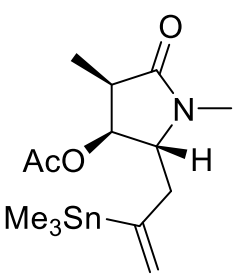

87 
We next focused on the Kosugi-Migita-Stille coupling reaction to connect the desired benzene ring to the pyrrolidin-2-one species (Scheme 45). The first attempt was made by reacting trimethylstannane 87 with 2 -iodo-3-bromo-nitrobenzene $\mathbf{4 9}$, but target product $\mathbf{8 8}$ was not observed. Likewise, reaction between vinyl bromide $\mathbf{8 1}$ and trimethylstannane $\mathbf{5 0}$ gave no product. It is inferred that a steric hindrance problem might cause the failure of these two reactions. Nevertheless, compound $\mathbf{8 0}$ was successfully prepared by KosugiMigita-Stille coupling reaction of 81 and 64.

Scheme 45 Kosugi-Migita-Stille coupling toward $\mathbf{8 8}$ and $\mathbf{8 0}^{\mathrm{a}}$<smiles>C=C(CC1C(C)C(=O)N(C)[C@H]1C)[Hg]OC(C)=O</smiles>

87<smiles>C=C(Br)CC1C(OC(C)=O)C(C)C(=O)N1C</smiles>

81<smiles>C=C(Br)CC1C(OC(C)=O)C(C)C(=O)N1C</smiles>

81<smiles>O=[N+]([O-])c1cccc(Br)c1I</smiles>

49<smiles>CSc1c(Br)cccc1[N+](=O)[O-]</smiles>

$\mathrm{Pd}(\mathrm{dba})_{2}, \mathrm{Cul}$<smiles>CCC(C)(C)C(C)(O[Na])c1ccccc1</smiles>

50

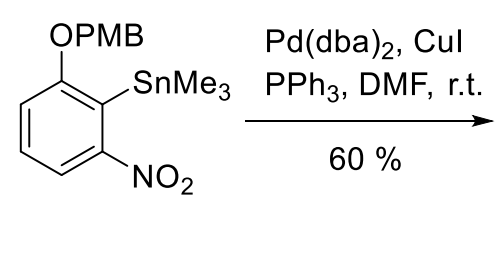

64<smiles>C=C(C[C@H]1[C@H](OC(C)=O)C(C)C(=O)N1C)c1c(Br)cccc1[N+](=O)[O-]</smiles>

88 not observed<smiles>C=C(C[C@H]1[C@H](OC(C)=O)[C@@H](C)C(=O)N1C)c1c(OC(C)=O)cccc1[N+](=O)[O-]</smiles>

80

a. Preparations of compound 49, 50 and 64 were discussed in chapter 3 (Scheme 31 and 36). 
All attempted elimination reactions of $\mathbf{8 0}$ to build 1,5-dihydro-pyrrol-2-one moiety was unsuccessful and only two byproduct $\mathbf{8 9}$ and 90 were found (Scheme 46). A mechanism for this transformation was proposed. Treating compound 80 with 1,8diazabicycloundec-7-ene (DBU) led to the formation of an enolate, which rapidly oxidized when trace $\mathrm{O}_{2}$ remained in the system. Meanwhile, some of the enolates likely go through an intermolecular substitution reaction to afford spiro compound 90. The oxidized intermediate underwent a dehydration process in the basic environment and eventually generated compound 89. The elimination strategy used in this synthetic route resulted in a rapid deprotonation at $\mathrm{C}-5$, which led to the formation of several byproducts and the loss of chirality.

Scheme 46 Elimination of acetate 80

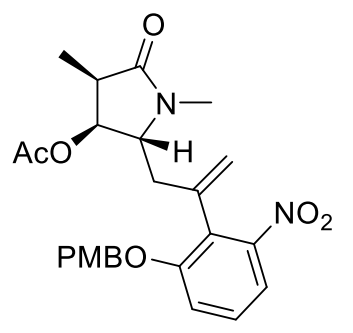

80

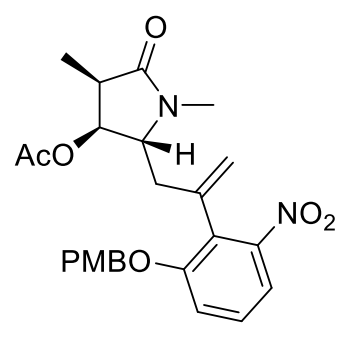

80

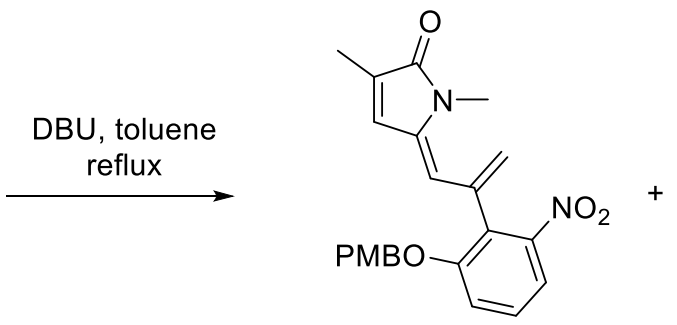

$8911 \%$

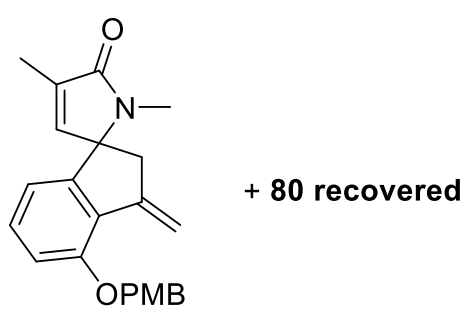

$903 \%$ $25 \%$

Considering the unsuccessful elimination reaction in the previous synthetic route, an alternative pathway has been developed as described in Scheme 47. The synthesis 
commenced with the preparation of amide $\mathbf{9 1}$ using commercially available methacryloyl chloride and (S)- $\alpha$-methylbenzylamine. Allylation of $\mathbf{9 1}$ using sodium hydride and allyl bromide in DMF formed amide 92 which underwent ring closing metathesis with $1^{\text {st }}$ generation Grubbs's catalyst to provide 1,5-dihydro-pyrrol-2-one 93. Treatment of $\mathbf{9 3}$ with lithium diisopropylamide (LDA) in THF delivered the enolate intermediate. The latter was oxidized by $\mathrm{O}_{2}$ to provide $\mathrm{N}, \mathrm{O}$-hemiacetal 94. A high concentration of $\mathrm{O}_{2}$ proved to be critical for the production of $\mathbf{9 4}$ in high yield. Following the allylation of 94 using $\mathrm{TiCl}_{4}$ and 2-bromo-2-propen-1-yl trimethylsilane 13, vinyl bromide 95 was obtained as a 3:1 mixture of two diastereomers. Compound $\mathbf{9 5}$ was converted into methoxymethyl phenyl ether 96 by Kosugi-Migita-Stille coupling. After attempts under several reaction conditions, we found that the MOM group could be slowly removed from 96 by a complex of sodium bisulfate and silica ge ${ }^{44}$ forming phenol 97 . Finally, 97 was treated with potassium carbonate and N-phenyl-bis(trifluoromethanesulfonimide) to give triflate $\mathbf{9 8 .}$ 
Scheme 47 Synthesis of triflate 98

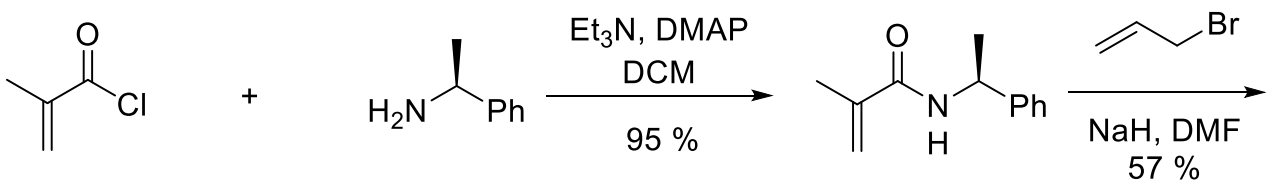

methacryloyl chloride (S)- $\alpha$-methylbenzylamine

91

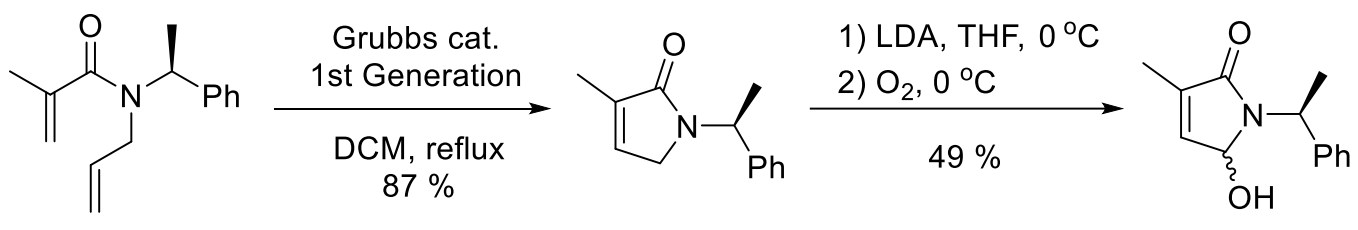

92

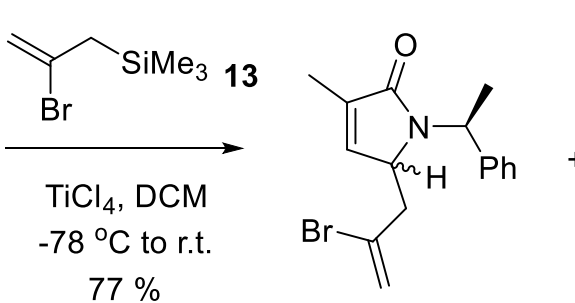

$95 d r=3: 1$

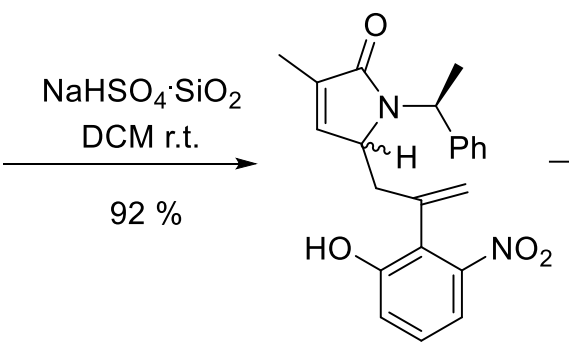

$97 d r=3: 1$
93

$94 d r=1.6: 1$

$$
67 d r=3: 1
$$

$\mathrm{Pd}(\mathrm{dba})_{2}, \mathrm{Cul}, \mathrm{PPh}_{3}$ DMF, r.t.

$75 \%$

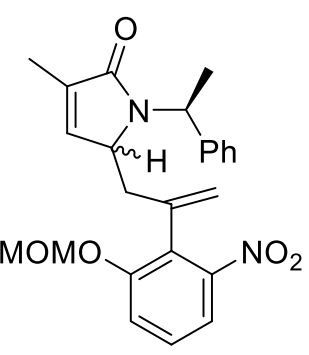

$96 d r=3: 1$

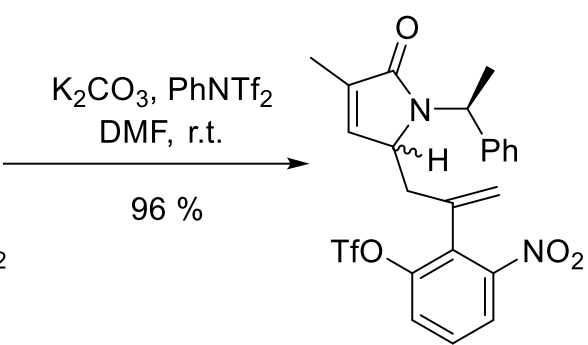

$98 d r=3: 1$ 


\section{Conclusions}

The first asymmetric total synthesis of (+)-cycloclavine has been studied. The 1,5dihydro-pyrrol-2-one core was achieved early in the synthesis via the ring closing metathesis strategy. The C-5 chiral center has been successfully installed utilizing a Lewis acid mediated allylation. Introduction of the benzene ring was achieved by a following Stille coupling reaction. Eventually, this synthesis fulfilled the production of triflate $\mathbf{9 8}$, which is an important precursor of (+)-cycloclavine.

Future effort will be focused on the study of intramolecular Heck cyclization reaction and finally the accomplishment of (+)-cycloclavine synthesis. 


\section{Chapter 5 Experimental}

\section{A. General Procedures}

All NMR spectra were recorded in $\mathrm{CDCl}_{3}$ at $600 \mathrm{MHz}\left({ }^{1} \mathrm{H} \mathrm{NMR}\right)$ and $150 \mathrm{MHz}\left({ }^{13} \mathrm{C} \mathrm{NMR}\right.$, 1H-broadband decoupled) at ambient temperature unless otherwise stated. Chemical shifts are expressed in $\delta$ values relative to $\mathrm{Me}_{4} \mathrm{Si}\left(0.0 \mathrm{ppm},{ }^{1} \mathrm{H}\right.$ and $\left.{ }^{13} \mathrm{C}\right)$ or $\mathrm{CDCl}_{3}\left(77.0 \mathrm{ppm},{ }^{13} \mathrm{C}\right)$ internal standards. HRMS data were obtained via electrospray ionization (ESI) with an ion trap mass analyzer. THF was purified and dried via two consecutive columns composed of activated alumina and Q5 catalyst on a Glass Contours solvent purification system. Dichloromethane and toluene were purified and dried via two consecutive columns composed of activated alumina on a Glass Contours solvent purification system. Hexanes and ethyl acetate were distilled from calcium hydride. Chemicals prepared according to literature procedures are referenced the first time they are used in the Experimental Section; all other reagents were obtained from commercial sources and used as received. All reactions were performed under a nitrogen atmosphere in oven-dried glassware unless otherwise stated. Solvents were removed from reaction mixtures and products on a rotary evaporator at water aspirator pressure.

\section{B. Experimental}

\section{3(R)-[(tert-Butyldimethylsilyl)oxy]-5(R)-methyl-2-(2-propen-1-yl)pyrrolidine (5)}

A solution of $\mathbf{1}^{11}(762 \mathrm{mg}, 2.21 \mathrm{mmol})$ and allyltrimethylsilane $(1.40 \mathrm{~mL}, 8.81 \mathrm{mmol})$ in $\mathrm{CH}_{2} \mathrm{Cl}_{2}(10 \mathrm{~mL})$ was cooled to $-78{ }^{\circ} \mathrm{C}$ and stirred for $15 \mathrm{~min}$. $\mathrm{TiCl}_{4}(490 \mu \mathrm{L}, 4.46 \mathrm{mmol})$ dissolved in $\mathrm{CH}_{2} \mathrm{Cl}_{2}(5 \mathrm{~mL})$ was slowly added via an addition funnel. The cold bath was removed after $5 \mathrm{~min}$, and the mixture was stirred at ambient temperature for an additional 2 h. The reaction mixture was poured into a slurry of $\mathrm{Na}_{2} \mathrm{CO}_{3} \cdot 10 \mathrm{H}_{2} \mathrm{O}(6 \mathrm{~g})$ in $\mathrm{CH}_{2} \mathrm{Cl}_{2}(7 \mathrm{~mL})$. 
After being stirred for $15 \mathrm{~min}$, the mixture was dried $\left(\mathrm{MgSO}_{4}\right)$ and filtered, and the solvent was removed to afford the crude mixture of isomeric $5(511 \mathrm{mg})$. The product decomposed upon purification, and $\mathbf{5}$ was thus used as such to prepare $\mathbf{6}$.

Spectral data from the 5:1 mixture of isomers of $\mathbf{5}$.

Major isomer: ${ }^{1} \mathrm{H} \mathrm{NMR}\left(600 \mathrm{MHz}, \mathrm{CDCl}_{3}\right) \delta 5.82(\mathrm{ddt}, J=16.8,10.2,6.6 \mathrm{~Hz}, 1 \mathrm{H}), 5.09(\mathrm{~d}$, $J=17.4 \mathrm{~Hz}, 1 \mathrm{H}), 5.02(\mathrm{~d}, J=10.2 \mathrm{~Hz}, 1 \mathrm{H}), 4.20($ br s, $1 \mathrm{H}), 3.58(\mathrm{dt}, J=14.4,7.2 \mathrm{~Hz}, 1 \mathrm{H})$, $3.13(\mathrm{dt}, J=7.1,3.4 \mathrm{~Hz}, 1 \mathrm{H}), 2.33$ (pent, $J=6.6 \mathrm{~Hz}, 1 \mathrm{H}), 2.26$ (pent, $J=7.2 \mathrm{~Hz}, 1 \mathrm{H}$ ), 1.92 $(\mathrm{dd}, J=12.6,6.6 \mathrm{~Hz}, 1 \mathrm{H}), 1.49(\mathrm{ddd}, J=13.2,9.0,4.8 \mathrm{~Hz}, 1 \mathrm{H}), 1.18(\mathrm{~d}, J=6.6 \mathrm{~Hz}, 3 \mathrm{H})$, 0.88 (s, 9H), 0.05 (s, 3H), 0.04 (s, 3H); $\left.{ }^{13} \mathrm{C} \mathrm{NMR} \mathrm{(150} \mathrm{MHz,} \mathrm{CDCl}_{3}\right) \delta 136.0,116.5,73.9$, $62.9,51.3,43.8,33.7,25.8,22.1,18.0,-4.4,-5.0$.

Partial spectral data for the minor isomer of 5: ${ }^{1} \mathrm{H}$ NMR $\left(600 \mathrm{MHz}, \mathrm{CDCl}_{3}\right) \delta 3.87$ (pent, $J=$ $4.2 \mathrm{~Hz}, 1 \mathrm{H}), 3.37$ (ddd, $J=15.0,12.6,6.0 \mathrm{~Hz}, 2 \mathrm{H}), 2.95$ (dt, $J=7.6,5.3 \mathrm{~Hz}, 1 \mathrm{H}), 2.14$ (pent, $J=7.4 \mathrm{~Hz}, 1 \mathrm{H}), 1.75(\mathrm{ddd}, J=13.2,6.6,3.6 \mathrm{~Hz}, 1 \mathrm{H}), 1.15(\mathrm{~d}, J=6.6 \mathrm{~Hz}, 3 \mathrm{H}), 0.87(\mathrm{~s}, 9 \mathrm{H})$, $0.03(\mathrm{~s}, 3 \mathrm{H}), 0.03(\mathrm{~s}, 3 \mathrm{H}) ;{ }^{13} \mathrm{C} \mathrm{NMR}\left(150 \mathrm{MHz}, \mathrm{CDCl}_{3}\right) \delta 135.7,116.9,67.0,52.3,43.5$, $38.3,21.3,18.0,-4.5,-4.7$.

\section{1-(tert-Butoxycarbonyl)-3(R)-[(tert-butyldimethylsilyl)oxy]-5(R)-methyl-2-(2-propen-1-}

\section{yl)-pyrrolidine (6)}

To a suspension of $5(511 \mathrm{mg}, 2.00 \mathrm{mmol})$ and $\mathrm{CH}_{2} \mathrm{Cl}_{2}(5 \mathrm{~mL})$ was added trimethylamine (0.84 $\mathrm{mL}, 6.03 \mathrm{mmol})$. The solution was cooled to $-20{ }^{\circ} \mathrm{C}$ followed by addition of di-t-butyl dicarbonate (475 mg, $2.18 \mathrm{mmol}$ ), and the reaction mixture was stirred for $20 \mathrm{~h}$ slowly reaching ambient temperature. The reaction mixture was washed with $\mathrm{H}_{3} \mathrm{PO}_{4}$ (aqueous, $1 \mathrm{M}$, $2 \times 5 \mathrm{~mL}$ ) and saturated $\mathrm{NaHCO}_{3}$ (aqueous, $2 \times 5 \mathrm{~mL}$ ). The organic phase was dried $\left(\mathrm{MgSO}_{4}\right)$ and filtered, and the solvents were removed giving crude $6(627 \mathrm{mg})$. The material was used 
as such to prepare $\mathbf{7}$ and $\mathbf{8}$. In a separate experiment on an $8.21 \mathrm{mmol}$ scale of $\mathbf{5}$, the crude product was purified by chromatography (hexanes/EtOAc, 1:1), affording a mixture of isomers used for characterization.

Spectral data from the mixture for the major isomer/rotamer of ${ }^{6}:{ }^{1} \mathrm{H}$ NMR $(600 \mathrm{MHz}$, $\left.\mathrm{CDCl}_{3}\right) \delta 5.86$ (pent, $\left.J=8.0 \mathrm{~Hz}, 1 \mathrm{H}\right), 5.02(\mathrm{~d}, J=18.6 \mathrm{~Hz}, 1 \mathrm{H}), 4.95(\mathrm{~d}, J=9.6 \mathrm{~Hz}, 1 \mathrm{H})$, 4.45-4.43 (m, 1H), 4.03-3.76 (m, 2H), 2.61-2.49 (m, 1H), 2.26-2.24 (m, 1H), 1.93-2.08 (m, 1H), 1.69-1.65 (m, 1H), $1.47(\mathrm{~s}, 9 \mathrm{H}), 1.19(\mathrm{~d}, J=6.0 \mathrm{~Hz}, 3 \mathrm{H}), 0.90(\mathrm{~s}, 9 \mathrm{H}), 0.07(\mathrm{~s}, 6 \mathrm{H})$. Partial spectral data for minor isomer/rotamer of 6: ${ }^{1} \mathrm{H}$ NMR $\left(600 \mathrm{MHz}, \mathrm{CDCl}_{3}\right) \delta 5.78$ (pent, $J=8.6 \mathrm{~Hz}, 1 \mathrm{H}), 1.45(\mathrm{~s}, 9 \mathrm{H}), 1.15(\mathrm{~d}, J=6.0 \mathrm{~Hz}, 3 \mathrm{H}), 0.84(\mathrm{~s}, 9 \mathrm{H}), 0.03(\mathrm{~s}, 3 \mathrm{H}), 0.02$ $(\mathrm{s}, 3 \mathrm{H})$.

Spectral data for the mixture of both isomers of $6:{ }^{13} \mathrm{C} \mathrm{NMR}\left(150 \mathrm{MHz}, \mathrm{CDCl}_{3}\right) \delta 154.0$, $146.7,136.7,136.5,135.1,116.9,116.3,85.1,79.2,78.9,78.9,70.8,70.2,67.2,60.4,60.1$, $52.4,51.7,50.6,50.4,40.0,39.0,33.7,32.3,28.6,28.5,27.4,25.8,25.7,22.3,21.2,18.1$, 17.9, -4.9; IR (ATR) 2957, 2930, 1693, $1383 \mathrm{~cm}^{-1}$; HRMS (ESI) calcd for $\mathrm{C}_{19} \mathrm{H}_{37} \mathrm{NNaO}_{3} \mathrm{Si}$ $\left(\mathrm{M}+\mathrm{Na}^{+}\right)$378.2440, found 378.2440.

1-(t-Butoxycarbonyl)-3(R)-hydroxy-5(R)-methyl-2(R)-(2-propen-1-yl)pyrrolidine and 1-(t-Butoxycarbonyl)-3(R)-hydroxy-5(R)-methyl-2(S)-(2-propen-1-yl)pyrrolidine (8)

To a $0{ }^{\circ} \mathrm{C}$ cold solution of $6(626 \mathrm{mg}, 1.76 \mathrm{mmol})$ in $\mathrm{THF}(10 \mathrm{~mL})$ was added tetrabutylammonium fluoride $(1.0 \mathrm{M}$ in THF, $3.8 \mathrm{~mL})$. The reaction mixture was stirred for $26 \mathrm{~h}$ slowly allowing for the cold bath to reach ambient temperature. The reaction mixture was poured into $\mathrm{H}_{2} \mathrm{O}(50 \mathrm{~mL})$ and extracted with EtOAc $(4 \times 25 \mathrm{~mL})$. The combined organic phases were dried $\left(\mathrm{MgSO}_{4}\right)$ and filtered, and the solvents were removed. Purification by 
chromatography (hexanes/EtOAc, 7:3) gave 7 (286 mg, $1.18 \mathrm{mmol}, 54 \%$ ) followed by 8 (56 $\mathrm{mg}, 0.23 \mathrm{mmol}, 11 \%) .{ }^{45}$

Spectral data of 7 as a mixture of rotamers at ambient temperature: ${ }^{1} \mathrm{H}$ NMR $(600 \mathrm{MHz}$, $\left.\mathrm{CDCl}_{3}\right) \delta 5.95-5.88(\mathrm{~m}, 1 \mathrm{H}), 5.10(\mathrm{~d}, J=17.4 \mathrm{~Hz}, 1 \mathrm{H}), 5.02(\mathrm{~d}, J=10.2 \mathrm{~Hz}, 1 \mathrm{H}), 4.54(\mathrm{~s}$, 1H), 3.89 (br s, 2H), 2.91 (br s, 1H), 2.55 (s, 1H), 2.37 (s, 1H), 2.08-2.04 (m, 1H), 1.82-1.78 (m, 1H), 1.47 (s, 9H), 1.19 (br s, 3H); ${ }^{13} \mathrm{C} \mathrm{NMR}\left(150 \mathrm{MHz}, \mathrm{CDCl}_{3}\right) \delta 154.0,136.3,116.5$, 79.3, 70.4, 70.1, 59.5, 50.5, 39.2, 38.2, 33.6, 32.3, 28.4, 21.8, 20.7; IR (ATR) 3436, 1663, 1366, 1172, $1063 \mathrm{~cm}^{-1} ;[\alpha]^{25}=-39.6$ ( $c$ 1.02, $\mathrm{CHCl}_{3}$ ); HRMS (ESI) calcd for $\mathrm{C}_{13} \mathrm{H}_{24} \mathrm{NO}_{3}$ $\left(\mathrm{M}+\mathrm{H}^{+}\right)$242.1756, found 242.1751.

Partial spectral data for 7 as a mixture of rotamers at $60{ }^{\circ} \mathrm{C}:{ }^{1} \mathrm{H} \mathrm{NMR}\left(600 \mathrm{MHz}, \mathrm{CDCl}_{3}\right) \delta$ $5.91(\mathrm{ddt}, J=17.4,10.2,7.2 \mathrm{~Hz}, 1 \mathrm{H}), 5.11(\mathrm{dq}, J=17.4,1.8 \mathrm{~Hz}, 1 \mathrm{H}), 5.02$ (d with further fine splitting, $J=10.2 \mathrm{~Hz}, 1 \mathrm{H}), 4.51$ (dt, $J=16.8,7.2 \mathrm{~Hz}, 1 \mathrm{H}), 3.93$ (br s, 1H), 3.87 (pent, $J$ $=6.6 \mathrm{~Hz}, 1 \mathrm{H}$ ), 2.54 (pent, $J=7.2 \mathrm{~Hz}, 1 \mathrm{~Hz}, 0.5 \mathrm{H}$ ), 2.45 (br s, 1H), 2.21 (br s, 1H), 2.04 (ddt, $J=12.0,10.8,9.0 \mathrm{~Hz}, 1 \mathrm{H}), 1.79(\mathrm{ddd}, J=12.0,6.6,1.8 \mathrm{~Hz}, 1 \mathrm{H}), 1.47(\mathrm{~s}, 9 \mathrm{H}), 1.19(\mathrm{~d}, J=$ $6.0 \mathrm{~Hz}, 3 \mathrm{H}) ;{ }^{13} \mathrm{C} \mathrm{NMR}\left(150 \mathrm{MHz}, \mathrm{CDCl}_{3}\right) \delta 154.1,136.5,129.9,116.5,79.3,70.6,59.7$, $50.7,39.2,33.0,28.5,28.4,21.3$.

Spectral data for $\mathbf{8}$ as a mixture of rotamers at ambient temperature: ${ }^{1} \mathrm{H}$ NMR $(600 \mathrm{MHz}$, $\left.\mathrm{CDCl}_{3}\right) \delta 5.77-5.84(\mathrm{~m}, 1 \mathrm{H}), 5.09-5.06(\mathrm{~m}, 2 \mathrm{H}), 4.11(\mathrm{~s}, 1 \mathrm{H}), 4.00($ br s, $1 \mathrm{H}), 3.78(\mathrm{~s}, 1 \mathrm{H})$, $2.42($ br s, $1 \mathrm{H}), 2.06-2.09(\mathrm{~m}, 3 \mathrm{H}), 1.74-1.79(\mathrm{~m}, 1 \mathrm{H}), 1.47(\mathrm{~s}, 9 \mathrm{H}), 1.27$ (br s, $3 \mathrm{H}) ;{ }^{13} \mathrm{C}$ NMR (150 MHz, $\left.\mathrm{CDCl}_{3}\right) \delta 155.1,134.8,117.2,79.3,73.2,66.8,52.1,40.6,38.6,28.5,21.9 ;$ IR (ATR) 3405, 1664, 1390, 1169, $1096 \mathrm{~cm}^{-1} ;[\alpha]^{25} \mathrm{D}=-8.1 \pm 0.7(c$ 5.75, MeOH); HRMS (ESI) calcd for $\mathrm{C}_{13} \mathrm{H}_{24} \mathrm{NO}_{3}\left(\mathrm{M}+\mathrm{H}^{+}\right)$242.1756, found 242.1751.

Partial spectral data for 8 as a mixture of rotamers at $60{ }^{\circ} \mathrm{C}:{ }^{1} \mathrm{H} \mathrm{NMR}\left(600 \mathrm{MHz}, \mathrm{CDCl}_{3}\right) \delta$ $5.81(\mathrm{ddt}, J=16.8,10.2,6.9 \mathrm{~Hz}, 1 \mathrm{H}), 5.09-5.05(\mathrm{~m}, 2 \mathrm{H}), 4.11(\mathrm{t}, J=1.2 \mathrm{~Hz}, 1 \mathrm{H}), 4.00(\mathrm{q}, J$ 
$=6.6 \mathrm{~Hz}, 1 \mathrm{H}), 3.76(\mathrm{br} \mathrm{s}, 1 \mathrm{H}), 2.44-2.42(\mathrm{~m}, 1 \mathrm{H}), 2.09(\mathrm{dt}$ with further fine splitting, $J=$ 15.0, 7.8 Hz, 1H), 2.05 (dddd, $J=13.7,7.4,2.7,1.3 \mathrm{~Hz}, 1 \mathrm{H}), 1.76(\mathrm{ddd}, J=13.8,8.4,4.8$ $\mathrm{Hz}, 1 \mathrm{H}), 1.73($ br s, $1 \mathrm{H}), 1.47(\mathrm{~s}, 9 \mathrm{H}), 1.26(\mathrm{~d}, J=6.6 \mathrm{~Hz}, 3 \mathrm{H})$; Ambient temperature: ${ }^{13} \mathrm{C}$ NMR $\left(150 \mathrm{MHz}, \mathrm{CDCl}_{3}\right) \delta 155.1,134.9,117.1,79.3,73.7,67.0,52.3,40.8,38.6,28.6,22.1$.

\section{2(R)-(2-Propen-1-yl)-1-(t-butoxycarbonyl)-3(S)-(2-bromo-3-nitrophenoxy-5(R)-methyl- pyrrolidine (10)}

To a solution of 7 (423 mg, $1.75 \mathrm{mmol})$ in THF (5 mL) were added triphenylphosphine (690 $\mathrm{mg}, 2.63 \mathrm{mmol})$ and $9(574 \mathrm{mg}, 2.63 \mathrm{mmol})$. The solution was cooled to $0{ }^{\circ} \mathrm{C}$ in an ice bath, and diisopropylazodicarboxylate $(520 \mu \mathrm{L}, 2.62 \mathrm{mmol})$ was added dropwise. The mixture was stirred at ambient temperature for $2 \mathrm{~h}$. The solvent was removed, and the resulting mixture was diluted with $\mathrm{CH}_{2} \mathrm{Cl}_{2}(25 \mathrm{~mL})$ and washed with saturated $\mathrm{NaHCO}_{3}$ (sat. aqueous, $25 \mathrm{~mL})$ and $\mathrm{HCl}(10 \%$ aqueous, $25 \mathrm{~mL})$. The organic phase was dried $\left(\mathrm{MgSO}_{4}\right)$ and filtered, and the solvent was removed. Purification by chromatography (hexanes/EtOAc, 7:3) gave 10 (542 mg, $1.23 \mathrm{mmol}, 70 \%)$ as a pale yellow oil.

Spectral data for $\mathbf{1 0}$ as a mixture of rotamers: ${ }^{1} \mathrm{H}$ NMR $\left(600 \mathrm{MHz}, \mathrm{CDCl}_{3}\right) \delta 7.38(\mathrm{t}, J=7.8$ $\mathrm{Hz}, 0.5 \mathrm{H}), 7.35(\mathrm{t}, J=7.2 \mathrm{~Hz}, 0.5 \mathrm{H}), 7.30(\mathrm{~d}, J=9.0 \mathrm{~Hz}, 0.5 \mathrm{H}), 7.29(\mathrm{~d}, J=8.4 \mathrm{~Hz}, 0.5 \mathrm{H})$, $7.05(\mathrm{~d}, J=8.4 \mathrm{~Hz}, 1 \mathrm{H}), 5.90-5.80(\mathrm{~m}, 1 \mathrm{H}), 5.19(\mathrm{~d}, J=16.8 \mathrm{~Hz}, 1 \mathrm{H}), 5.18(\mathrm{~d}, J=10.8 \mathrm{~Hz}$, 1H), $4.70(\mathrm{~s}, 0.5 \mathrm{H}), 4.69(\mathrm{~s}, 0.5 \mathrm{H}), 3.96-4.14(\mathrm{~m}, 2 \mathrm{H}), 2.77(\mathrm{~d}, J=13.2 \mathrm{~Hz}, 0.5 \mathrm{H}), 2.62(\mathrm{~d}, J$ $=9.6 \mathrm{~Hz}, 0.5 \mathrm{H}), 2.52-2.44(\mathrm{~m}, 1 \mathrm{H}), 2.20-2.14(\mathrm{~m}, 1 \mathrm{H}), 2.04-1.96(\mathrm{~m}, 1 \mathrm{H}), 1.48(\mathrm{~s}, 9 \mathrm{H}) ;{ }^{13} \mathrm{C}$ NMR $\left(150 \mathrm{MHz}, \mathrm{CDCl}_{3}\right) \delta 155.3,155.2,153.8,153.3,152.2,152.2,134.3,134.0,128.4$, $128.3,118.7,118.6,116.6,116.5,116.1,116.0,105.5,105.3,82.4,81.1,79.6,79.6,62.9$, 62.7, 60.3, 53.2, 53.1, 37.4, 36.4, 36.1, 35.5, 28.4, 21.7, 20.5; IR (ATR) 2976, 1682, 1534, 
$1387,1269 \mathrm{~cm}^{-1} ;[\alpha]^{25} \mathrm{D}=0.12 \pm 0.01(c 1.0, \mathrm{MeOH}) ; \mathrm{HRMS}$ (ESI) calcd for $\mathrm{C}_{19} \mathrm{H}_{26} \mathrm{BrN}_{2} \mathrm{O}_{5}$ $\left(\mathrm{M}+\mathrm{H}^{+}\right)$441.1026, found 441.1023.

\section{Tricyclic Compound 11}

A solution of $10(200 \mathrm{mg}, 0.45 \mathrm{mmol}), \mathrm{Pd}(\mathrm{OAc})_{2}(7.4 \mathrm{mg}, 0.03 \mathrm{mmol})$, and tri(otolyl)phosphine (39 $\mathrm{mg}, 0.13 \mathrm{mmol})$ in triethylamine $(7 \mathrm{~mL})$ in a Teflon screw-capped ACEGlass pressure tube was stirred at $120^{\circ} \mathrm{C}$ for $31 \mathrm{~h}$. The solvent was removed, and the resulting residue was purified by chromatography (hexanes/EtOAc, 9:1) to give (47 mg, 0.13 mmol, $29 \%)$ as a white solid. ${ }^{46}$

Spectral data for $\mathbf{1 1}$ as a 1:1 mixture of rotamers: mp $125-127{ }^{\circ} \mathrm{C} ;{ }^{1} \mathrm{H}$ NMR $(600 \mathrm{MHz}$, CDCl3) $\delta 7.63(\mathrm{dd}, J=7.2,2.4 \mathrm{~Hz}, 1 \mathrm{H}), 7.28-7.24(\mathrm{~m}, 2 \mathrm{H}), 6.08(\mathrm{br} \mathrm{s}, 1 \mathrm{H}), 5.83$ (br s, $0.5 \mathrm{H}), 5.73(\mathrm{br} \mathrm{s}, 0.5 \mathrm{H}), 4.90(\mathrm{br} \mathrm{s}, 1 \mathrm{H}), 3.80(\mathrm{ddt}, J=16.8,10.2,7.2 \mathrm{~Hz}, 3 \mathrm{H}), 3.29(\mathrm{dd}, J=$ 12.6, 7.2 Hz, 1H), 2.57 (br s, 1H), $1.93(\mathrm{dt}, J=12.6,10.8 \mathrm{~Hz}, 1 \mathrm{H}), 1.48$ (s, 9H), 1.45 (s, 3H);

${ }^{13} \mathrm{C}$ NMR $\left(150 \mathrm{MHz}, \mathrm{CDCl}_{3}\right) \delta 158.8,153.9,149.9,136.2,134.3,133.2,128.4,128.2,127.7$, $127.3,126.8,125.9,120.6,120.5,87.3,86.8,80.0,61.8,56.4,52.2,51.6,40.3,37.4,28.4$, 26.4, 21.8, 20.1; IR (ATR) 1691,1528, 1154, 1031, $712 \mathrm{~cm}^{-1} ;[\alpha]^{25} \mathrm{D}=159.0 \pm 0.6(c 1.0$, $\mathrm{MeOH})$; HRMS (ESI) calcd for $\mathrm{C}_{19} \mathrm{H}_{25} \mathrm{~N}_{2} \mathrm{O}_{5}\left(\mathrm{M}+\mathrm{H}^{+}\right) 361.1758$, found 361.1758 .

\section{2(R)-(2-Bromo-2-propen-1-yl)-3(R)-[(tert-butyldimethylsilyl)-oxy]-5(R)-methyl-}

pyrrolidine (14) and 5(R)-[(tert-Butyldimethylsilyl)oxy]-(4a)-hexahydro-3-methylene7(R)-methyl-1H-pyrrolo[1,2-c][1,3]oxazin-1-one (15)

A solution of 1 (123 mg, $0.36 \mathrm{mmol}$ ) and 2-bromo-2-propen-1-yl trimethylsilane (13) (250 $\mu \mathrm{L}, 1.43 \mathrm{mmol})$ in $\mathrm{CH}_{2} \mathrm{Cl}_{2}(4 \mu \mathrm{L})$ was cooled to $-78{ }^{\circ} \mathrm{C}$ and stirred for $15 \mathrm{~min}$. A solution of $\mathrm{TiCl}_{4}(74 \mu \mathrm{L}, 0.67 \mathrm{mmol})$ in $\mathrm{CH}_{2} \mathrm{Cl}_{2}(1.5 \mathrm{~mL})$ was added slowly. The cold bath was 
removed after $5 \mathrm{~min}$, and the mixture was stirred at ambient temperature for an additional 1 h. $\mathrm{Na}_{2} \mathrm{CO}_{3} \cdot 10 \mathrm{H}_{2} \mathrm{O}(1.2 \mathrm{~g})$ was added slowly. After stirring for $30 \mathrm{~min}$, the mixture was dried $\left(\mathrm{MgSO}_{4}\right)$ and filtered, and the solvent was removed. Purification by chromatography (hexanes/EtOAc, 1:1) gave, in order of elution, $15(32 \mathrm{mg}, 0.11 \mathrm{mmol}, 30 \%, \boldsymbol{d r}=1.8: 1)$ as a pale brown oil and $14(67 \mathrm{mg}, 0.20 \mathrm{mmol}, 56 \%, \boldsymbol{d r} \text { approximately } 9: 1)^{47}$ as a brown oil.

Spectral data for the major isomer of 14: ${ }^{1} \mathrm{H}$ NMR $\left(400 \mathrm{MHz}, \mathrm{CDCl}_{3}\right) \delta 5.74(\mathrm{~d}, J=1.2 \mathrm{~Hz}$, 1H), $5.49(\mathrm{~d}, J=1.6 \mathrm{~Hz}, 1 \mathrm{H}), 4.58$ (br s, $1 \mathrm{H}), 4.30$ (br dt, $1 \mathrm{H}), 3.66$ (dpent, $J=8.6,6.7 \mathrm{~Hz}$, 1H), $3.58(\mathrm{dt}, J=6.7,3.9 \mathrm{~Hz}, 1 \mathrm{H}), 2.69(\mathrm{~d}, J=6.7 \mathrm{~Hz}, 2 \mathrm{H}), 1.96(\mathrm{ddd}, J=13.3,7.0,2.0 \mathrm{~Hz}$, 1H), $1.60(\mathrm{ddd}, J=13.3,9.0,4.3 \mathrm{~Hz}, 1 \mathrm{H}), 1.26(\mathrm{~d}, J=6.2 \mathrm{~Hz}, 3 \mathrm{H}), 0.89$ (s, 9H), 0.07 (s, 3H), $0.06(\mathrm{~s}, 3 \mathrm{H}) ;{ }^{13} \mathrm{C} \mathrm{NMR}\left(100 \mathrm{MHz}, \mathrm{CDCl}_{3}\right) \delta 131.3,118.8,73.4,61.0,51.7,43.4,40.9$, $25.8,21.4,18.0,-4.4,-4.9 ;$ IR (ATR) 2956, 1701, 1125, 1051, 833, $773 \mathrm{~cm}^{-1} ;[\alpha]^{25} \mathrm{D}=-12 \pm$ 2 (c 0.1, $\mathrm{CHCl}_{3}$ ); HRMS (ESI) calcd for $\mathrm{C}_{14} \mathrm{H}_{29} \mathrm{BrNOSi}\left(\mathrm{M}+\mathrm{H}^{+}\right)$334.1202, found 334.1197. Spectral data from a 1:1 mixture of diastereomeric 15: ${ }^{1} \mathrm{H}\left(600 \mathrm{MHz}, \mathrm{CDCl}_{3}\right) \mathrm{NMR} \delta$ 4.65$4.63($ br m, 2H), 4.24 (t, $J=1.8 \mathrm{~Hz}, 1 \mathrm{H}), 4.22(\mathrm{t}, J=1.8 \mathrm{~Hz}, 1 \mathrm{H}), 4.17(\mathrm{t}, J=3.0 \mathrm{~Hz}, 1 \mathrm{H})$, $4.10(\mathrm{dp}, J=6.8,4.0 \mathrm{~Hz}, 1 \mathrm{H}), 4.06$ (br dp, $J=5.2,4.4 \mathrm{~Hz}, 1 \mathrm{H}), 3.96$ (ddd, $J=14.4,7.8,6.6$ $\mathrm{Hz}, 1 \mathrm{H}), 3.59$ (ddd, $J=12.0,4.2,3.6 \mathrm{~Hz}, 1 \mathrm{H}), 3.27(\mathrm{ddd}, J=11.4,7.8,3.0 \mathrm{~Hz}, 1 \mathrm{H}), 2.81$ $(\mathrm{dd}, J=13.8,3.0 \mathrm{~Hz}, 1 \mathrm{H}), 2.51(\mathrm{ddt}, J=13.5,11.8,1.8 \mathrm{~Hz}, 1 \mathrm{H}), 2.37(\mathrm{dd}, J=13.2,4.2 \mathrm{~Hz}$, 1H), 2.16 (ddt, $J=13.8,12.0,1.8 \mathrm{~Hz}, 1 \mathrm{H}), 2.07$ (dd, $J=13.2,6.6 \mathrm{~Hz}, 1 \mathrm{H}), 1.95$ (ddd, $J=$ 19.2, 10.2, 8.4 Hz, 1H), $1.84(\mathrm{dd}, J=12.6,6.0 \mathrm{~Hz}, 1 \mathrm{H}), 1.57(\mathrm{ddd}, J=13.8,10.2,3.6 \mathrm{~Hz}$, $1 \mathrm{H}), 1.35(\mathrm{~d}, J=6.0 \mathrm{~Hz}, 3 \mathrm{H}), 1.28(\mathrm{~d}, J=6.6 \mathrm{~Hz}, 3 \mathrm{H}), 0.88(\mathrm{~s}, 9 \mathrm{H}), 0.85(\mathrm{~s}, 9 \mathrm{H}), 0.08(\mathrm{~s}$, 3H), 0.07 (s, 3H), 0.06 (s, 3H), 0.04 (s, 3H); ${ }^{13} \mathrm{C} \mathrm{NMR}\left(100 \mathrm{MHz}, \mathrm{CDCl}_{3}\right) \delta$ 152.7, 152.3, 150.4, 149.0, 92.9, 92.8, 74.4, 71.3, 60.6, 60.0, 53.2, 51.9, 41.8, 39.6, 31.7, 26.5, 25.6, 25.5, 20.8, 19.9, 17.9, 17.8, -4.6, -4.7, -4.9, -5.1; IR (ATR) 2930, 1721, 1251, 1057, $832 \mathrm{~cm}^{-1}$; HRMS (ESI) calcd for $\mathrm{C}_{15} \mathrm{H}_{28} \mathrm{NO}_{3} \mathrm{Si}\left(\mathrm{M}+\mathrm{H}^{+}\right)$298.1838, found 298.1829 . 


\section{2(R)-(2-Bromo-2-propen-1-yl)-3(R)-[(tert-butyldimethylsilyl)-oxy]-1-(t-}

\section{butoxycarbonyl)-5(R)-methyl-pyrrolidine (16) and (15)}

A solution of $1(100 \mathrm{mg}, 0.29 \mathrm{mmol})$ and 2-bromoallyltrimethylsilane (13) $(200 \mu \mathrm{L}, 1.16$ mmol) in $\mathrm{CH}_{2} \mathrm{Cl}_{2}(2 \mathrm{~mL})$ was cooled to $-78{ }^{\circ} \mathrm{C}$ and stirred for $15 \mathrm{~min}$. $\mathrm{BF}_{3} \cdot \mathrm{Et}_{2} \mathrm{O}(82 \mu \mathrm{L}, 0.66$ mmol) was added slowly. The mixture was stirred at $-78{ }^{\circ} \mathrm{C}$ for $1 \mathrm{~h}$ and then slowly warmed to $-30{ }^{\circ} \mathrm{C}$ in $1 \mathrm{~h}$ and stirred for additional $1.5 \mathrm{~h}$. Then, the mixture was quenched by pouring it into $\mathrm{NaHCO}_{3}$ (sat. aqueous, $10 \mathrm{~mL}$ ) at $-30{ }^{\circ} \mathrm{C}$. The mixture was warmed to ambient temperature and extracted with EtOAc $(3 \times 10 \mathrm{~mL})$. The combined organic phases were dried $\left(\mathrm{MgSO}_{4}\right)$ and filtered, and the solvents were removed. The resulting residue was purified by chromatography (hexanes/EtOAc, 60:1) to afford, in order of elution, 16 (54 mg, $0.12 \mathrm{mmol}$, $43 \%, \boldsymbol{d} \boldsymbol{r}=8: 1)$ as a colorless oil and $\mathbf{1 5}(20 \mathrm{mg}, 0.07 \mathrm{mmol}, 23 \%, \boldsymbol{d} \boldsymbol{r}=1.1: 1)$ as a brown oil.

Spectral data for major isomer/rotamer of $16:{ }^{1} \mathrm{H}$ NMR $\left(400 \mathrm{MHz}, \mathrm{CDCl}_{3}, 65{ }^{\circ} \mathrm{C}\right) \delta 5.59(\mathrm{~d}$, $J=1.0 \mathrm{~Hz}, 1 \mathrm{H}), 5.39(\mathrm{~s}, 1 \mathrm{H}), 4.46(\mathrm{dt}, J=10.8,6.8 \mathrm{~Hz}, 1 \mathrm{H}), 4.17-4.08(\mathrm{~m}, 1 \mathrm{H}), 3.84$ (pent, $J=6.6 \mathrm{~Hz}, 1 \mathrm{H}), 2.86(\mathrm{dd}, J=15.1,6.4 \mathrm{~Hz}, 1 \mathrm{H}), 2.67-2.53(\mathrm{~m}, 1 \mathrm{H}), 2.10-2.0(\mathrm{~m}, 1 \mathrm{H}), 1.66$ (dd, $J=11.0,6.6 \mathrm{~Hz}, 1 \mathrm{H}), 1.45(\mathrm{~s}, 9 \mathrm{H}), 1.19(\mathrm{~d}, J=6.3 \mathrm{~Hz}, 3 \mathrm{H}), 0.88(\mathrm{~s}, 9 \mathrm{H}), 0.06(\mathrm{~s}, 6 \mathrm{H})$.

Partial spectral data for minor isomer/rotamer of 16: ${ }^{1} \mathrm{H}$ NMR $\left(400 \mathrm{MHz}, \mathrm{CDCl}_{3}, 65{ }^{\circ} \mathrm{C}\right) \delta$ $5.58(\mathrm{~s}, 1 \mathrm{H}), 5.46(\mathrm{~d}, J=0.9 \mathrm{~Hz}, 1 \mathrm{H}), 4.31$ (pent, $J=4.7 \mathrm{~Hz}, 1 \mathrm{H}), 3.41(\mathrm{dd}, J=11.2,4.8 \mathrm{~Hz}$, 1H), 2.7 (br d, 1H), 1.44 (s, 9H).

Spectral data for mixture of both isomers of $\mathbf{1 6}:{ }^{13} \mathrm{C} \mathrm{NMR}\left(100 \mathrm{MHz}, \mathrm{CDCl}_{3}\right) \delta 155.3,153.9$, 132.0, 131.8, 118.9, 118.4, 118.2, 79.8, 79.3, 78.9, 70.6, 70.0, 66.2, 58.5, 58.3, 52.5, 51.7, $50.4,50.1,40.8,39.5,39.4,38.6,28.5,25.8,25.7,25.6,22.1,21.0,18.2,17.9,17.8,-4.7$, 4.8, -4.8, -4.9, -4.9; IR (ATR) 2957,1694, 1384, 1068, $774 \mathrm{~cm}^{-1}$; HRMS (ESI) calcd for $\mathrm{C}_{19} \mathrm{H}_{37} \mathrm{BrNO}_{3} \mathrm{Si}\left(\mathrm{M}+\mathrm{H}^{+}\right)$434.1726, found 434.1722. 


\section{2(R)-(2-Bromo-2-propen-1-yl)-3(R)-[(tert-butyldimethylsilyl)-oxy]-1- (methoxycarbonyl)-5(R)-methylpyrrolidine (17)}

To a suspension of $14(61 \mathrm{mg}, 0.18 \mathrm{mmol})$ and $\mathrm{CH}_{2} \mathrm{Cl}_{2}(1.0 \mathrm{~mL})$ was added triethylamine (73 $\mu \mathrm{L}, 0.52 \mathrm{mmol})$, followed by dropwise addition of methyl chloroformate $(30 \mu \mathrm{L}, 0.39$ $\mathrm{mmol})$. The reaction mixture was stirred at ambient temperature for $20 \mathrm{~h}$ then poured into brine $(20 \mathrm{~mL})$ and extracted with EtOAc $(3 \times 20 \mathrm{~mL})$. The organic phases were combined, dried $\left(\mathrm{MgSO}_{4}\right)$, and filtered. The solvents were removed, and the resulting residue was purified by chromatography (hexanes/EtOAc, 40:1) to give 17 (29 mg, $0.074 \mathrm{mmol}, 41 \%$, $\boldsymbol{d r}$ approximately 9:1) as a colorless oil.

Spectral data for 17 from the mixture of isomers. Major isomer: ${ }^{1} \mathrm{H}$ NMR $\left(600 \mathrm{MHz}, \mathrm{CDCl}_{3}\right.$, $\left.65^{\circ} \mathrm{C}\right) \delta 5.55(\mathrm{~s}, 1 \mathrm{H}), 5.39(\mathrm{~s}, 1 \mathrm{H}), 4.48(\mathrm{dt}, J=11.4,7.2 \mathrm{~Hz}, 1 \mathrm{H}), 4.19(\mathrm{q}, J=6.0 \mathrm{~Hz}, 1 \mathrm{H})$, 3.91 (pent, $J=6.6 \mathrm{~Hz}, 1 \mathrm{H}), 3.63(\mathrm{~s}, 3 \mathrm{H}), 2.87$ (dd, $J=15.0,5.4 \mathrm{~Hz}, 1 \mathrm{H}), 2.53$ (br s, 1H), 2.11-2.02 (q, $J=9.6 \mathrm{~Hz}, 1 \mathrm{H}), 1.70(\mathrm{dd}, J=12.6,6.6 \mathrm{~Hz}, 1 \mathrm{H}), 1.22(\mathrm{~d}, J=6.1 \mathrm{~Hz}, 3 \mathrm{H}), 0.90$ $(\mathrm{s}, 9 \mathrm{H}), 0.08(\mathrm{~s}, 6 \mathrm{H})$.

Partial spectral data for the minor isomer: ${ }^{1} \mathrm{H}$ NMR $\left(600 \mathrm{MHz}, \mathrm{CDCl}_{3}, 65{ }^{\circ} \mathrm{C}\right) \delta 4.35$ (pent, $J$ $=4.8 \mathrm{~Hz}, 1 \mathrm{H}), 4.00(\mathrm{~m}, 1 \mathrm{H}), 3.67(\mathrm{~s}, 3 \mathrm{H})$.

From the mixture of isomers/rotamers at ambient temperature: ${ }^{13} \mathrm{C} \mathrm{NMR}\left(150 \mathrm{MHz}, \mathrm{CDCl}_{3}\right)$ $\delta 155.3,132.2,118.5,117.8,70.1,59.0,58.2,52.0,51.4,50.3,41.3,39.6,39.4,38.5,25.8$, $25.7,21.9,21.0,18.1,-4.9,-4.9 ;$ IR (ATR) 2955,1702, 1371, 1079, $774 \mathrm{~cm}^{-1} ;[\alpha]^{25} \mathrm{D}=2.4 \pm$ 0.1 (c 1.0, $\mathrm{CHCl}_{3}$ ); HRMS (ESI) calcd for $\mathrm{C}_{16} \mathrm{H}_{30} \mathrm{BrNNaO}_{3} \mathrm{Si}\left(\mathrm{M}+\mathrm{Na}^{+}\right)$414.1076, found 414.1072. 


\section{Alternative synthesis of 17}

A solution of $1(687 \mathrm{mg}, 1.99 \mathrm{mmol})$ and 2-bromoallyltrimethylsilane (13) (1.37 mL, 7.97 mmol $)$ in $\mathrm{CH}_{2} \mathrm{Cl}_{2}(22 \mathrm{~mL})$ was cooled to $-78{ }^{\circ} \mathrm{C}$ and stirred for $15 \mathrm{~min}$. $\mathrm{TiCl}_{4}(410 \mu \mathrm{L}, 3.74$ mmol) in $\mathrm{CH}_{2} \mathrm{Cl}_{2}(8 \mathrm{~mL})$ was added slowly. The cold bath was removed after $5 \mathrm{~min}$, and the mixture was stirred at ambient temperature for an additional $1 \mathrm{~h} . \mathrm{Na}_{2} \mathrm{CO}_{3} \cdot 10 \mathrm{H}_{2} \mathrm{O}(6.68 \mathrm{~g})$ was added slowly. After stirring for $30 \mathrm{~min}$, the mixture was dried $\left(\mathrm{MgSO}_{4}\right)$ and filtered, and the solvent was removed to give a light yellow residue $(802 \mathrm{mg})$. The residue was dissolved in $\mathrm{CH}_{2} \mathrm{Cl}_{2}(6 \mathrm{~mL})$, and triethylamine $(960 \mu \mathrm{L}, 6.92 \mathrm{mmol})$ was added followed by dropwise addition of methyl chloroformate $(400 \mu \mathrm{L}, 5.16 \mathrm{mmol})$. The reaction mixture was stirred at ambient temperature for $18 \mathrm{~h}$. Brine $(50 \mathrm{~mL})$ was added, and the mixture was extracted with EtOAc $(3 \times 50 \mathrm{~mL})$. The combined organic phases were dried $\left(\mathrm{MgSO}_{4}\right)$ and filtered, and the solvents were removed. The resulting residue was purified by chromatography (hexanes/EtOAc, 40:1) to give $17(426 \mathrm{mg}, 1.09 \mathrm{mmol}, 55 \%, \boldsymbol{d r}$ approximately 9:1) as a colorless oil.

\section{2(R)-(2-Bromo-2-propen-1-yl)-3(R)-hydroxy-1-(methoxycarbonyl)-5(R)-}

\section{methylpyrrolidine (18)}

To a solution of 17 (191 mg, $0.49 \mathrm{mmol})$ in THF (4 mL) was added tetrabutylammonium fluoride (1.0 M in THF, $0.93 \mathrm{~mL})$. The reaction mixture was stirred at ambient temperature for $2 \mathrm{~h}$. The resulting mixture was poured into $\mathrm{H}_{2} \mathrm{O}(20 \mathrm{~mL})$ and extracted with EtOAc $(3 \times 20 \mathrm{~mL})$. The combined organic phases were dried $\left(\mathrm{MgSO}_{4}\right)$ and filtered, and the solvents were removed. Purification by chromatography (hexanes/EtOAc, 3:1) gave 18 (112 mg, 0.40 mmol, $82 \%)^{48}$ as a white solid. 
Spectral data for $\mathbf{1 8}$ as a mixture of rotamers: $\mathrm{mp} 65-66{ }^{\circ} \mathrm{C} ;{ }^{1} \mathrm{H}$ NMR $\left(600 \mathrm{MHz}, \mathrm{CDCl}_{3}\right) \delta$ $5.69(\mathrm{~s}, 0.4 \mathrm{H}), 5.62(\mathrm{~s}, 0.6 \mathrm{H}), 5.46(\mathrm{~s}, 1 \mathrm{H}), 4.57(\mathrm{~m}, 1 \mathrm{H}), 4.18(\mathrm{td}, J=6.0,4.2 \mathrm{~Hz}, 1 \mathrm{H}), 3.94$ (s, 1H), $3.66(\mathrm{~s}, 3 \mathrm{H}), 2.98(\mathrm{~s}, 0.4 \mathrm{H}), 2.87$ (dd, $J=14.4,7.2 \mathrm{~Hz}, 1 \mathrm{H}), 2.57$ (s, 0.6H), 2.00-2.35 (br m, 2H), $1.84(\mathrm{dd}, J=11.4,5.4 \mathrm{~Hz}, 1 \mathrm{H}), 1.22(\mathrm{~s}, 3 \mathrm{H}) ;{ }^{13} \mathrm{C} \mathrm{NMR}\left(150 \mathrm{MHz}, \mathrm{CDCl}_{3}\right)$ major rotamer $\delta 155.2,131.6,118.0,69.1,57.8,51.4,50.3,40.9,37.4,20.4$; Partial ${ }^{13} \mathrm{C}$ NMR $(150$ $\mathrm{MHz}, \mathrm{CDCl}_{3}$ ) spectral data for minor rotamer $\delta 131.1,118.6,58.8,51.9,50.7,39.0,38.7$, 21.3; IR (ATR) 3359, 2965, 1668, 1376, 1068, $734 \mathrm{~cm}^{-1} ;[\alpha]^{25} \mathrm{D}=-11.6 \pm 0.1\left(c 1.0, \mathrm{CHCl}_{3}\right)$; HRMS (ESI) calcd for $\mathrm{C}_{10} \mathrm{H}_{16} \mathrm{BrNNaO}_{3}\left(\mathrm{M}+\mathrm{Na}^{+}\right)$300.0211, found 300.0200 .

\section{3(S)-(2-Bromo-3-nitrophenoxy)-2(R)-(2-bromo-propen-1-yl)-1-(methoxycarbonyl)- 5(R)-methylpyrrolidine (19)}

To a solution of $\mathbf{1 8}(607 \mathrm{mg}, 2.18 \mathrm{mmol})$ in THF $(32 \mathrm{~mL})$ were added triphenylphosphine (1.95 g, $7.45 \mathrm{mmol})$ and $9(713 \mathrm{mg}, 3.27 \mathrm{mmol})$. The solution was cooled to $0{ }^{\circ} \mathrm{C}$, and diisopropylazodicarboxylate $(1.74 \mathrm{~mL}, 8.84 \mathrm{mmol})$ was added dropwise. The mixture was stirred at ambient temperature for $19 \mathrm{~h}$; brine $(50 \mathrm{~mL})$ was added, and the mixture was extracted with EtOAc $(3 \times 50 \mathrm{~mL})$. The combined organic phases were dried $\left(\mathrm{MgSO}_{4}\right)$ and filtered, and the solvent was removed at reduced pressure. Purification by chromatography $\left(\mathrm{CH}_{2} \mathrm{Cl}_{2} /\right.$ hexanes, 1:1, then $\left.\mathrm{CH}_{2} \mathrm{Cl}_{2}\right)$ gave 19 (693 $\left.\mathrm{mg}, 1.45 \mathrm{mmol}, 66 \%\right)$ as a pale yellow oil.

Spectral data for 19 as a mixture of rotamers: ${ }^{1} \mathrm{H}$ NMR $\left(600 \mathrm{MHz}, \mathrm{CDCl}_{3}\right) \delta 7.38(\mathrm{t}, J=8.2$ $\mathrm{Hz}, 0.5 \mathrm{H}), 7.37(\mathrm{t}, J=8.1 \mathrm{~Hz}, 0.5 \mathrm{H}), 7.32(\mathrm{~d}, J=7.0 \mathrm{~Hz}, 0.5 \mathrm{H}), 7.31(\mathrm{~d}, J=7.9 \mathrm{~Hz}, 0.5 \mathrm{H})$, $7.11(\mathrm{~d}, J=8.2 \mathrm{~Hz}, 0.5 \mathrm{H}), 7.10(\mathrm{~d}, J=8.2 \mathrm{~Hz}, 0.5 \mathrm{H}), 5.73(\mathrm{~s}, 0.5 \mathrm{H}), 5.71(\mathrm{~s}, 0.5 \mathrm{H}), 5.61(\mathrm{~s}$, $1 \mathrm{H}), 4.88(\mathrm{~d}, J=4.7 \mathrm{~Hz}, 0.5 \mathrm{H}), 4.83(\mathrm{~d}, J=4.6 \mathrm{~Hz}, 0.5 \mathrm{H}), 4.40(\mathrm{dd}, J=10.0,2.3 \mathrm{~Hz}, 0.5 \mathrm{H})$, $4.31(\mathrm{dd}, J=9.9,2.8 \mathrm{~Hz}, 0.5 \mathrm{H}), 4.16(\mathrm{pd}, J=6.3,2.3 \mathrm{~Hz}, 0.5 \mathrm{H}), 4.08(\mathrm{~d}, J=6.4 \mathrm{~Hz}, 0.5 \mathrm{H})$, 
$3.72(\mathrm{~s}, 1.5 \mathrm{H}), 3.71(\mathrm{~s}, 1.5 \mathrm{H}), 3.19(\mathrm{dd}, J=14.5,2.8 \mathrm{~Hz}, 0.5 \mathrm{H}), 2.94(\mathrm{dd}, J=14.3,3.0 \mathrm{~Hz}$, $0.5 \mathrm{H}), 2.56-2.39(\mathrm{~m}, 2 \mathrm{H}), 2.08(\mathrm{~d}, J=14.2 \mathrm{~Hz}, 0.5 \mathrm{H}), 2.06(\mathrm{~d}, J=14.5 \mathrm{~Hz}, 0.5 \mathrm{H}), 1.54(\mathrm{~d}, J$ $=6.4 \mathrm{~Hz}, 1.5 \mathrm{H}), 1.48(\mathrm{~d}, J=6.5 \mathrm{~Hz}, 1.5 \mathrm{H}) ;{ }^{13} \mathrm{C} \mathrm{NMR}\left(150 \mathrm{MHz}, \mathrm{CDCl}_{3}\right) \delta 154.9,154.8$, $154.8,154.3,152.0,152.0,129.2,129.2,128.5,128.5,120.4,120.4,116.9,116.8,116.3$, $116.3,105.4,105.3,81.4,80.4,62.6,61.5,53.5,53.0,52.2,52.1,44.1,42.4,36.2,35.3,21.5$, 20.4; IR (ATR) 2954, 1686, 1533, 1357, 1268, $732 \mathrm{~cm}^{-1} ;[\alpha]^{25} \mathrm{D}=-1.4 \pm 0.1\left(c 1.0, \mathrm{CHCl}_{3}\right)$; HRMS (ESI) calcd for $\mathrm{C}_{16} \mathrm{H}_{18} \mathrm{Br}_{2} \mathrm{~N}_{2} \mathrm{NaO}_{5}\left(\mathrm{M}+\mathrm{Na}^{+}\right)$498.9480, found 498.9462.

\section{Tricyclic Compound 20}

A solution of $19(100 \mathrm{mg}, 0.21 \mathrm{mmol}), \mathrm{Pd}(\mathrm{dba})_{2}(30 \mathrm{mg}, 0.05 \mathrm{mmol})$, triphenylphosphine (55 mg, $0.21 \mathrm{mmol})$, and hexamethylditin $(105 \mathrm{mg}, 0.32 \mathrm{mmol})$ in toluene $(2 \mathrm{~mL})$ was stirred at $140{ }^{\circ} \mathrm{C}$ for $3 \mathrm{~h}$. The mixture was cooled to ambient temperature, diluted with EtOAc $(4 \mathrm{~mL})$, and washed with $\mathrm{NH}_{4} \mathrm{OH}(10 \%$ aqueous, $4 \times 2 \mathrm{~mL})$. The organic phase was dried $\left(\mathrm{MgSO}_{4}\right)$ and filtered. The solvent was removed, and the resulting residue was purified by chromatography (hexanes/EtOAc, 10:1) to give $20(29 \mathrm{mg}, 0.09 \mathrm{mmol}, 44 \%)^{49}$ as a brown solid.

Spectral data for 20 as a mixture of rotamers: ${ }^{50} \mathrm{mp} 139-142{ }^{\circ} \mathrm{C} ;{ }^{1} \mathrm{H} \mathrm{NMR}\left(600 \mathrm{MHz}, \mathrm{CDCl}_{3}\right.$, $\left.65{ }^{\circ} \mathrm{C}\right) \delta 7.35($ br s, $1 \mathrm{H}), 7.22(\mathrm{t}, J=7.8 \mathrm{~Hz}, 1 \mathrm{H}), 7.08($ br s, $1 \mathrm{H}), 5.26($ br s, $1 \mathrm{H}), 4.94(\mathrm{~s}$, 1H), 3.91 (br m, 2H), $3.70(\mathrm{~s}, 3 \mathrm{H}), 2.53(\mathrm{dt}, J=12.6,7.2 \mathrm{~Hz}, 1 \mathrm{H}), 2.31$ (br s, $1 \mathrm{H}), 1.74$ (dd, $J=15.6,9.6 \mathrm{~Hz}, 1 \mathrm{H}), 1.36(\mathrm{~s}, 3 \mathrm{H}) ;{ }^{13} \mathrm{C} \mathrm{NMR}\left(150 \mathrm{MHz}, \mathrm{CDCl}_{3}\right) \delta 158.0,155.2,155.1$, $154.7,151.7,139.3,138.7,129.3,128.8,128.3,124.0,121.9,120.7,119.7,118.9,116.1$, $85.3,78.6,62.1,57.5,52.7,52.0,51.3,43.5,42.4,39.5,38.3,37.7,21.6,20.1$; IR (ATR) $2955,1695,1527,1251,1071,733 \mathrm{~cm}^{-1} ;[\alpha]^{25} \mathrm{D}=-240.9 \pm 0.3\left(c 1.0, \mathrm{CHCl}_{3}\right) ; \mathrm{HRMS}(\mathrm{ESI})$ calcd for $\mathrm{C}_{16} \mathrm{H}_{18} \mathrm{~N}_{2} \mathrm{NaO}_{5}\left(\mathrm{M}+\mathrm{Na}^{+}\right)$341.1113, found 341.1111 . 
(6aR,8R,9aS)-7-Methoxycarbonyl-6,6a,7,8,9,9a-hexahydro-8-methyl-Hpyrrolo[2',3':6,7]oxepino[4,3,2-cd]indole (21)

A solution of $\mathbf{2 0}(119 \mathrm{mg}, 0.37 \mathrm{mmol}), \quad \operatorname{Pd}(\mathrm{dba})_{2} \quad(12.9 \mathrm{mg}, \quad 0.02 \mathrm{mmol}), \quad 1,3-$ bis(diphenylphosphino)propane $(9.23 \mathrm{mg}, 0.02 \mathrm{mmol})$, and 1,10-phenanthroline $(8.12 \mathrm{mg}$, $0.05 \mathrm{mmol})$ in anhydrous DMF $(1.2 \mathrm{~mL})$ in a Teflon screw-capped ACE-Glass pressure tube was saturated with carbon monoxide (4 cycles to 6 atm of $\mathrm{CO}$ ). The reaction mixture was stirred under $\mathrm{CO}(6 \mathrm{~atm})$ at $120^{\circ} \mathrm{C}$ for $37 \mathrm{~h}$. The mixture was cooled to ambient temperature, diluted with EtOAc $(10 \mathrm{~mL})$, and washed with brine $(2 \times 10 \mathrm{~mL})$. The organic phase was dried $\left(\mathrm{MgSO}_{4}\right)$ and filtered. The solvent was removed, and the resulting residue was purified by chromatography (hexanes/EtOAc, 4:1) to afford 21 (76 $\mathrm{mg}, 0.27 \mathrm{mmol}, 71 \%)$ as a white solid.

Spectral data for 21 from a mixture of rotamers: mp 190-193 ${ }^{\circ} \mathrm{C} ;{ }^{1} \mathrm{H}$ NMR $(600 \mathrm{MHz}$, $\left.\mathrm{CDCl}_{3}\right) \delta 8.27(\mathrm{br} \mathrm{s}, 1 \mathrm{H}), 7.07(\mathrm{t}, J=7.8 \mathrm{~Hz}, 1 \mathrm{H}), 6.99(\mathrm{dd}, J=7.8,0.6 \mathrm{~Hz}, 1 \mathrm{H}), 6.97$ (br s, 1H), 6.65 (d, $J=7.8 \mathrm{~Hz}, 1 \mathrm{H}), 4.44$ (apparent dt, $J=7.8,1.8 \mathrm{~Hz}, 1 \mathrm{H}), 4.35$ (br s, 0.5H), 4.02 (br pent, $J=4.6 \mathrm{~Hz}, 1 \mathrm{H}$ ), 3.95 (dpent, $J=9.6,6.6 \mathrm{~Hz}, 1 \mathrm{H}$ ), partially overlapping 3.9 (br s, $0.5 \mathrm{H}), 3.75(\mathrm{~s}, 3 \mathrm{H}), 2.64$ (br s, 1H), 2.54 (br s, 1H), 2.01 (dt, $J=12.6,9.6 \mathrm{~Hz}, 1 \mathrm{H}), 1.53$ (br s, $1.5 \mathrm{H}), 1.43$ (br s, $1.5 \mathrm{H}) ;{ }^{13} \mathrm{C} \mathrm{NMR}\left(150 \mathrm{MHz}, \mathrm{CDCl}_{3}\right) \delta 155.2,151.5,138.6,122.6,120.8$, $116.8,109.7,105.6,104.3,84.4,63.4,52.3,51.9,39.7,31.4,30.1,21.5,20.0 ;$ IR (ATR) $3323,2925,1676,1074,733 \mathrm{~cm}^{-1} ;[\alpha]^{25} \mathrm{D}=-286.5 \pm 0.4\left(c\right.$ 1.0, $\left.\mathrm{CHCl}_{3}\right) ; \mathrm{HRMS}(\mathrm{ESI})$ calcd for $\mathrm{C}_{16} \mathrm{H}_{19} \mathrm{~N}_{2} \mathrm{O}_{3}\left(\mathrm{M}+\mathrm{H}^{+}\right)$287.1396, found 287.1391. 


\section{6,6a(R),7,8,9,9a(S)-Hexahydro-7,8(R)-dimethyl-H-pyrrolo-[2',3' :6,7]oxepino[4,3,2- cd]indole (ht-13-B)}

To a solution of 21 (116 mg, $0.41 \mathrm{mmol})$ in anhydrous toluene (40 mL) was added sodium bis(2-methoxyethoxy)aluminumhydride (in toluene $\sim 3.5 \mathrm{M}, 2.56 \mathrm{~mL}, 8.96 \mathrm{mmol}$ ) dropwise. The mixture was stirred at $110{ }^{\circ} \mathrm{C}$ for $5 \mathrm{~h}$ and then allowed to cool to ambient temperature. Brine $(80 \mathrm{~mL})$ was added, and the mixture was extracted with EtOAc $(3 \times 80 \mathrm{~mL})$. The organic phases were combined, dried $\left(\mathrm{MgSO}_{4}\right)$, and filtered. The solvent was removed, and the resulting residue was purified by chromatography (EtOAc) to give ht-13-B ( $88 \mathrm{mg}, 0.36$ mmol, $88 \%$ ) as a white solid.

Spectral data for synthetic ht-13-B: mp 180-182 ${ }^{\circ} \mathrm{C}$; $1 \mathrm{H} \mathrm{NMR}\left(600 \mathrm{MHz}, \mathrm{CDCl}_{3}\right) \delta 8.35$ (br s, $1 \mathrm{H}), 7.07(\mathrm{t}, J=7.8 \mathrm{~Hz}, 1 \mathrm{H}), 6.98(\mathrm{~s}, 1 \mathrm{H}), 6.97(\mathrm{~d}, J=7.8 \mathrm{~Hz}, 1 \mathrm{H}), 6.64(\mathrm{~d}, J=7.8 \mathrm{~Hz}$ 1H), 4.45 (ddd, $J=10.2,6.0,4.2 \mathrm{~Hz}, 1 \mathrm{H}), 3.45$ (dpent, $J=6.6,2.4 \mathrm{~Hz}, 1 \mathrm{H}), 3.37(\mathrm{dd}, J=$ 15.0, 4.2 Hz, 1H), 3.17 (ddd, $J=12.0,6.0,4.2 \mathrm{~Hz}, 1 \mathrm{H}), 2.73(\mathrm{ddd}, J=14.4,10.2,7.8 \mathrm{~Hz}$, 1H), 2.65 (ddd, $J=14.4,12.0,1.8 \mathrm{~Hz}, 1 \mathrm{H}), 2.45(\mathrm{~s}, 3 \mathrm{H}), 1.87$ (ddd, $J=13.8,3.6,2.4 \mathrm{~Hz}$, $1 \mathrm{H}), 1.19(\mathrm{~d}, J=6.6 \mathrm{~Hz}, 3 \mathrm{H}) ;{ }^{13} \mathrm{C}$ NMR $\left(150 \mathrm{MHz}, \mathrm{CDCl}_{3}\right) \delta 152.0,138.8,122.7,120.3$, 117.0, 110.7, 106.0, 104.0, 86.1, 67.3, 57.9, 38.6, 35.0, 29.0, 14.2; IR (ATR) 3400, 3154, 2925, 1244, 1067, $733 \mathrm{~cm}^{-1} ;[\alpha]^{25}=-202.1 \pm 0.1\left(c\right.$ 1.0, $\left.\mathrm{CHCl}_{3}\right)$; HRMS (ESI) calcd for $\mathrm{C}_{15} \mathrm{H}_{19} \mathrm{~N}_{2} \mathrm{O}\left(\mathrm{M}+\mathrm{H}^{+}\right)$243.1497, found 243.1492.

3-(tert-Butyl-dimethyl-silanyloxy)-2-methoxy-pyrrolidine-1-carboxylic acid tert-butyl ester (28)

Lithium triethylborohydride in THF (1.0 M in THF, $18.8 \mathrm{~mL})$ was added to a solution of 27 $(9.89 \mathrm{~g}, 31.33 \mathrm{mmol})$ in THF $(125 \mathrm{~mL})$ at $-78^{\circ} \mathrm{C}$. After $40 \mathrm{~min}$, the reaction was quenched with $\mathrm{H}_{2} \mathrm{O}(100 \mathrm{~mL})$ and the mixture was allowed to warm to room temperature. The mixture 
was extracted with EtOAc $(3 \times 100 \mathrm{~mL})$, dried $\left(\mathrm{MgSO}_{4}\right)$ and the solvents were removed on a rotary evaporator at water aspirator pressure. The crude product was dissolved in THF (370 $\mathrm{mL})$, methyl iodide $(5.02 \mathrm{~mL}, 80.59 \mathrm{mmol})$ and $\mathrm{NaH}(60 \%, 2.15 \mathrm{~g}, 53.75 \mathrm{mmol})$ were added, and the mixture was stirred at room temperature for $16 \mathrm{~h}$. The reaction was quenched with $\mathrm{H}_{2} \mathrm{O}(500 \mathrm{~mL})$ and extracted with EtOAc $(3 \times 200 \mathrm{~mL})$, dried $\left(\mathrm{MgSO}_{4}\right)$ and the solvents were removed on a rotary evaporator at water aspirator pressure. Purification by chromatography (hexanes/EtOAc, 10:1) gave 28 (3.46 g, $10.43 \mathrm{mmol}, 33 \%)$ as a yellow oil. Spectral data for 28 as mixture of rotamers: ${ }^{1} \mathrm{H}$ NMR(400 MHz, $\left.\mathrm{CDCl}_{3}\right) \delta 4.88(\mathrm{~s}, 0.5 \mathrm{H})$, $4.76(\mathrm{~s}, 0.5 \mathrm{H}), 4.10(\mathrm{~s}, 0.5 \mathrm{H}), 4.09(\mathrm{~s}, 0.5 \mathrm{H}), 3.54-3.64(\mathrm{~m}, 0.5 \mathrm{H}), 3.43-3.54(\mathrm{~m}, 0.5 \mathrm{H}), 3.38$ (s, 1.5H), 3.37-3.38 (m, 0.5H), 3.34-3.35 (m, 0.5H), $3.33(\mathrm{~s}, 1.5 \mathrm{H}), 1.98-2.13(\mathrm{~m}, 1 \mathrm{H}), 1.70-$ $1.80(\mathrm{~m}, 1 \mathrm{H}), 1.48(\mathrm{~s}, 9 \mathrm{H}), 0.91(\mathrm{~s}, 2 \mathrm{H}), 0.86(\mathrm{~s}, 7 \mathrm{H}), 0.09(\mathrm{~s}, 1 \mathrm{H}), 0.07(\mathrm{~s}, 2.5 \mathrm{H}), 0.06(\mathrm{~s}$, 2.5H). $\left.{ }^{13} \mathrm{C} \mathrm{NMR(150} \mathrm{MHz,} \mathrm{CDCl}_{3}\right) \delta 155.8,155.2,94.2,94.1,79.8,79.6,75.0,74.2,55.9$, $55.4,44.5,43.9,31.6,30.8,28.4,28.3,25.6,25.6,17.9,17.9,-4.8,-4.9,-5.0$; IR (ATR) 2930, $2858,1703,1386,1364,1080,832,773 \mathrm{~cm}^{-1} ;[\alpha]^{25} \mathrm{D}=+1.0 \pm 0.2(c$ 1.0, MeOH$) ; \mathrm{HRMS}$ (ESI) calcd for $\mathrm{C}_{16} \mathrm{H}_{33} \mathrm{NNaO}_{4} \mathrm{Si}\left(\mathrm{M}+\mathrm{Na}^{+}\right)$354.2077, found 354.2080.

2-(2-Bromo-allyl)-3-(tert-butyl-dimethyl-silanyloxy)-pyrrolidine-1-carboxylic acid tertbutyl ester (29) and 5-(tert-Butyl-dimethyl-silanyloxy)-3-methylene-hexahydropyrrolo[1,2-c][1,3]oxazin-1-one (30)

A solution of $28(100 \mathrm{mg}, 0.30 \mathrm{mmol})$ and 2-bromoallyltrimethylsilane (13) $(0.21 \mathrm{~mL}, 1.22$ mmol) in $\mathrm{CH}_{2} \mathrm{Cl}_{2}(2 \mathrm{~mL})$ was cooled to $-78{ }^{\circ} \mathrm{C}$ under $\mathrm{N}_{2}$ and stirred for $15 \mathrm{~min}$. $\mathrm{BF}_{3} \cdot \mathrm{OEt}_{2}$ (48 \%, $86 \mu \mathrm{L}, 0.685 \mathrm{mmol}$ ) was added slowly. The mixture was stirred under $\mathrm{N}_{2}$ for $1 \mathrm{~h}$ during which time the temperature raised to $-60{ }^{\circ} \mathrm{C}$. The reaction was quenched with saturated $\mathrm{NaHCO}_{3}$ (aq. $8 \mathrm{~mL}$ ) at $-60{ }^{\circ} \mathrm{C}$. Then the mixture was warmed to room temperature 
and extracted with EtOAc $(3 \times 10 \mathrm{~mL})$, dried $\left(\mathrm{MgSO}_{4}\right)$ and the solvents were removed on a rotary evaporator at water aspirator pressure. Purification by chromatography (hexanes/EtOAc, 10:1) gave $29(51 \mathrm{mg}, 0.12 \mathrm{mmol}, 40 \%, \boldsymbol{d r}=6: 1)$ as a colorless oil and (hexanes/EtOAc, 3:1) gave $\mathbf{3 0}(8.3 \mathrm{mg}, 0.029 \mathrm{mmol}, 10 \%)$ as a white solid.

Spectral data for major isomer of 29: ${ }^{1} \mathrm{H} \mathrm{NMR}\left(400 \mathrm{MHz}, \mathrm{CDCl}_{3}, 65{ }^{\circ} \mathrm{C}\right) \delta 5.60(\mathrm{~s}, 1 \mathrm{H}), 5.41$ $(\mathrm{s}, 1 \mathrm{H}), 4.34(\mathrm{dd}, J=14.6,6.6 \mathrm{~Hz}, 1 \mathrm{H}), 4.10(\mathrm{q}, J=6.2 \mathrm{~Hz}, 1 \mathrm{H}), 3.31-3.46(\mathrm{~m}, 3 \mathrm{H}), 2.84(\mathrm{dd}$, $J=14.9,5.9 \mathrm{~Hz}, 1 \mathrm{H}), 1.94-2.02(\mathrm{~m}, 1 \mathrm{H}), 1.76-1.85(\mathrm{~m}, 1 \mathrm{H}), 1.46(\mathrm{~s}, 9 \mathrm{H}), 0.91(\mathrm{~s}, 9 \mathrm{H}), 0.08$ $(\mathrm{s}, 6 \mathrm{H})$.

Spectral data for 29 as mixture of isomers: ${ }^{13} \mathrm{C} \mathrm{NMR}\left(100 \mathrm{MHz}, \mathrm{CDCl}_{3}, 65{ }^{\circ} \mathrm{C}\right) \delta 154.7$, $131.8,118.9,118.8,118.1,118.0,79.6,79.0,72.0,58.7,42.9,40.3,31.8,28.5,28.5,25.9$, 25.8, 25.8, 18.1, 18.0, 18.0, 17.9, -4.7, -4.7, -4.9, -4.9; IR (ATR) 2971, 1740, 1696, 1388, $1365,1217,1115,834,774 \mathrm{~cm}^{-1}$; HRMS (ESI) calcd for $\mathrm{C}_{18} \mathrm{H}_{35} \mathrm{BrNO}_{3} \mathrm{Si}\left(\mathrm{M}+\mathrm{H}^{+}\right)$420.1570, found 420.1555 .

Spectral data for 30: $\mathrm{mp} 69-70{ }^{\circ} \mathrm{C} ;{ }^{1} \mathrm{H} \mathrm{NMR}\left(400 \mathrm{MHz}, \mathrm{CDCl}_{3}\right) \delta 4.68(\mathrm{~s}, 1 \mathrm{H}), 4.28-4.31(\mathrm{~m}$, $1 \mathrm{H}), 4.26(\mathrm{t}, J=1.7 \mathrm{~Hz}, 1 \mathrm{H}), 3.60-3.70(\mathrm{~m}, 1 \mathrm{H}), 3.50-3.60(\mathrm{~m}, 2 \mathrm{H}), 2.48-2.58(\mathrm{~m}, 1 \mathrm{H})$, $2.42(\mathrm{dd}, J=13.8,4.1 \mathrm{~Hz}, 1 \mathrm{H}), 1.89-1.95(\mathrm{~m}, 2 \mathrm{H}), 0.88(\mathrm{~s}, 9 \mathrm{H}), 0.09$ (s, 2H), 0.08 (s, 3H); ${ }^{13} \mathrm{C}$ NMR $\left(100 \mathrm{MHz}, \mathrm{CDCl}_{3}\right) \delta 152.9,150.5,93.2,72.1,59.8,44.6,32.6,26.8,25.6,18.0$, -4.7, -5.0; IR (ATR) 3457, 3017, 2971, 2929, 2857, 1737, 1664, 1417, 1354, 1217, 1099, 835, $777 \mathrm{~cm}^{-1}$; HRMS (ESI) calcd for $\mathrm{C}_{14} \mathrm{H}_{26} \mathrm{NO}_{3} \mathrm{Si}\left(\mathrm{M}+\mathrm{H}^{+}\right)$284.1682, found 284.1668.

\section{2-(2-Bromo-allyl)-3-(tert-butyl-dimethyl-silanyloxy)-pyrrolidine (31) and and 5-(tert-} Butyl-dimethyl-silanyloxy)-3-methylene-hexahydro-pyrrolo[1,2-c][1,3]oxazin-1-one (30) A solution of $28(306 \mathrm{mg}, 0.92 \mathrm{mmol})$ and 2-bromoallyltrimethylsilane (13) $(0.64 \mathrm{~mL}, 3.69$ mmol $)$ in $\mathrm{CH}_{2} \mathrm{Cl}_{2}(10 \mathrm{~mL})$ was cooled to $-78{ }^{\circ} \mathrm{C}$ under $\mathrm{N}_{2}$ and stirred for $15 \mathrm{~min}$. $\mathrm{TiCl}_{4}(0.2$ 
$\mathrm{mL}, 1.85 \mathrm{mmol})$ in $\mathrm{CH}_{2} \mathrm{Cl}_{2}(4 \mathrm{~mL})$ was added slowly. The cold bath was removed after 15 min and the mixture was stirred at ambient temperature for an additional $1 \mathrm{~h}$. $\mathrm{Na}_{2} \mathrm{CO}_{3} \cdot 10 \mathrm{H}_{2} \mathrm{O}(3.1 \mathrm{~g})$ was added slowly. After stirring for $15 \mathrm{~min}$, the mixture was dried $\left(\mathrm{MgSO}_{4}\right)$, filtered, and the solvent was removed on a rotary evaporator at water aspirator pressure. Purification by chromatography (hexanes/EtOAc, 3:1) gave 30 (24 mg, 0.085 mmol, $9 \%, \boldsymbol{d} r=12: 1)$ as a white solid and (MeOH/EtOAc, 1:10) gave 31 (148 mg, 0.46 mmol, $50 \%$ ) as a yellow solid.

Spectral data for 31: ${ }^{1} \mathrm{H} \mathrm{NMR}\left(400 \mathrm{MHz}, \mathrm{CDCl}_{3}\right) \delta 5.82(\mathrm{~s}, 1 \mathrm{H}), 5.62(\mathrm{br} \mathrm{s}, 1 \mathrm{H}), 5.52(\mathrm{~d}, J=$ $1.6 \mathrm{~Hz}, 1 \mathrm{H}), 4.26-4.32(\mathrm{~m}, 1 \mathrm{H}), 3.37-3.47(\mathrm{~m}, 1 \mathrm{H}), 3.29(\mathrm{dd}, J=19.2,8.4 \mathrm{~Hz}, 1 \mathrm{H}), 3.07-$ $3.17(\mathrm{~m}, 1 \mathrm{H}), 2.82(\mathrm{dd}, J=15.1,7.7 \mathrm{~Hz}, 1 \mathrm{H}), 2.74(\mathrm{dd}, J=15.0,5.7 \mathrm{~Hz}, 1 \mathrm{H}), 1.98-2.09(\mathrm{~m}$, 1H), 1.81-1.90 (m, 1H), $0.90(\mathrm{~s}, 9 \mathrm{H}), 0.08$ (s, 3H), 0.07 (s, 3H); ${ }^{13} \mathrm{C}$ NMR (100 MHz, CDCl $)$ $\delta 130.6,119.2,72.6,61.8,43.3,40.4,35.0,25.8,18.0,-4.4,-4.9$; IR (ATR) 2928, 2857, 1738, 1708, 1364, 834, $775 \mathrm{~cm}^{-1}$; HRMS (ESI) calcd for $\mathrm{C}_{13} \mathrm{H}_{27} \mathrm{BrNOSi}\left(\mathrm{M}+\mathrm{H}^{+}\right) 320.1045$, found 320.1030 .

\section{3(R)-tert-Butyldimethylsilyloxy-1-(methoxycarbonyl)pyrrolidin-2-one (33)}

Lithium bis(trimethylsilyl)amide (1.0 M in THF, $251 \mu \mathrm{L}, 0.25 \mathrm{mmol})$ was added to a solution of 3(R)-hydroxypyrrolidin-2-one (22) (54 mg, $0.25 \mathrm{mmol})$ in THF (1.0 mL) at -78 ${ }^{\circ} \mathrm{C}$. The mixture was stirred at $-78{ }^{\circ} \mathrm{C}$ under an atmosphere of $\mathrm{N}_{2}$ for $30 \mathrm{~min}$. Methyl chloroformate $(21 \mu \mathrm{L}, 0.28 \mathrm{mmol})$ was added slowly. The mixture was allowed to warm to ambient temperature over $1.5 \mathrm{~h}$, then quenched by $\mathrm{H}_{2} \mathrm{O}(10 \mathrm{~mL})$ and extracted with EtOAc (3x10 mL). The combined organic phases were dried $\left(\mathrm{MgSO}_{4}\right)$, filtered, and the solvents were removed. Purification by chromatography on silica gel (hexanes/EtOAc, 8:1) gave 33 (54 mg, $0.20 \mathrm{mmol}, 79 \%$ ) as a white solid. 
Spectral data for 33: $\mathrm{mp} 66-66.5{ }^{\circ} \mathrm{C} ;{ }^{1} \mathrm{H}$ NMR $\left(600 \mathrm{MHz}, \mathrm{CDCl}_{3}\right) \delta 4.33(\mathrm{dd}, J=9.4,7.9$ $\mathrm{Hz}, 1 \mathrm{H}), 3.85(\mathrm{~s}, 3 \mathrm{H}), 3.84(\mathrm{ddd}, J=11.1,8.7,2.3 \mathrm{~Hz}, 1 \mathrm{H}), 3.52(\mathrm{ddd}, J=10.9,9.7,6.8$ $\mathrm{Hz}, 1 \mathrm{H}), 2.28-2.34(\mathrm{~m}, 1 \mathrm{H}), 1.95(\mathrm{dq}, J=12.6,9.4 \mathrm{~Hz}, 1 \mathrm{H}), 0.89(\mathrm{~s}, 9 \mathrm{H}), 0.15$ (s, 3H), $0.11(\mathrm{~s}, 3 \mathrm{H}) ;{ }^{13} \mathrm{C} \mathrm{NMR}\left(100 \mathrm{MHz}, \mathrm{CDCl}_{3}\right) \delta 171.8,151.4,70.7,52.6,41.1,27.6,24.9$, 17.4, -5.3, -6.0; IR (ATR) 2956, 2929, 2857, 1790, 1699, 1442, 1388, 1358, 1323, 1150, 1051, 1003, 905, 838, 778, $697 \mathrm{~cm}^{-1}$; HRMS (ESI) calcd for $\mathrm{C}_{12} \mathrm{H}_{24} \mathrm{NO}_{4} \mathrm{Si}\left(\mathrm{M}+\mathrm{H}^{+}\right)$ 274.1475, found 274.1470; $[\alpha]^{25} \mathrm{D}=51.9 \pm 0.2\left(c 1.0, \mathrm{CHCl}_{3}\right)$.

\section{3(R)-tert-Butyldimethylsilyloxy-2(R/S)-hydroxy-1-(methoxycarbonyl)pyrrolidine}

Lithium triethylborohydride (1.0 M in THF, $5.64 \mathrm{~mL}, 5.64 \mathrm{mmol}$ ) was added to a solution of $33(1.29 \mathrm{~g}, 4.70 \mathrm{mmol})$ in THF $(20 \mathrm{~mL})$ at $-78{ }^{\circ} \mathrm{C}$. The mixture was stirred under $\mathrm{N}_{2}$ for 30 min at $-78{ }^{\circ} \mathrm{C}$ then quenched with $\mathrm{H}_{2} \mathrm{O}(40 \mathrm{~mL})$. The mixture was warmed to ambient temperature and extracted with EtOAc $(3 \times 30 \mathrm{~mL})$. The combined organic phases were dried $\left(\mathrm{MgSO}_{4}\right)$, filtered, and the solvents were removed. Purification by chromatography on silica gel (hexanes/EtOAc, 5:1) gave $\mathbf{3 4}(1.06 \mathrm{~g}, 3.85 \mathrm{mmol}, 82 \%, \boldsymbol{d r}=7: 1)$ as a yellow oil.

Spectral data for the major isomer/rotamer of 34: ${ }^{1} \mathrm{H}$ NMR $\left(600 \mathrm{MHz}, \mathrm{CDCl}_{3}, 65{ }^{\circ} \mathrm{C}\right) \delta$ $5.19(\mathrm{~s}, 1 \mathrm{H}), 4.18(\mathrm{~s}, 1 \mathrm{H}), 3.75(\mathrm{~s}, 3 \mathrm{H}), 3.50-3.58(\mathrm{~m}, 2 \mathrm{H}), 2.11-2.19(\mathrm{~m}, 1 \mathrm{H}), 1.75-1.81$ (m, 1H), $0.90(\mathrm{~s}, 9 \mathrm{H}), 0.11(\mathrm{~s}, 3 \mathrm{H}), 0.10(\mathrm{~s}, 3 \mathrm{H})$.

Spectral data from the mixture of both isomers of 34: ${ }^{13} \mathrm{C}$ NMR $\left(150 \mathrm{MHz}, \mathrm{CDCl}_{3}\right) \delta$ 156.0, 155.2, 87.0, 86.4, 76.6, 75.7, 52.1, 44.0, 43.6, 31.2, 30.3, 25.4, 17.6, -5.2; IR (ATR) 3427, 2955, 2931, 2858, 1689, 1453, 1380, 1253, 1103, 1056, 831, $774 \mathrm{~cm}^{-1}$; HRMS (ESI) calcd for $\mathrm{C}_{12} \mathrm{H}_{25} \mathrm{NNaO}_{4} \mathrm{Si}\left(\mathrm{M}+\mathrm{Na}^{+}\right)$298.1451, found 298.1447. 
2(R/S)-(2-Bromo-2-propen-1-yl)-3(R)-tert-butyldimethylsilyloxy-1-(methoxycarbonyl)pyrrolidine (32)

A solution of 34 (996 mg, $3.62 \mathrm{mmol}$ ) and 2-bromo-2-propen-1-yl trimethylsilane (13) (2.50 mL, $14.5 \mathrm{mmol}$ ) in $\mathrm{CH}_{2} \mathrm{Cl}_{2}(60 \mathrm{~mL})$ was cooled to $-78{ }^{\circ} \mathrm{C}$ and stirred for $15 \mathrm{~min}$. $\mathrm{TiCl}_{4}(800 \mu \mathrm{L}, 7.30 \mathrm{mmol})$ was added slowly under a $\mathrm{N}_{2}$ atmosphere. The cold bath was removed after $15 \mathrm{~min}$, and the mixture was stirred at ambient temperature for an additional $1.5 \mathrm{~h} . \mathrm{Na}_{2} \mathrm{CO}_{3} \cdot 10 \mathrm{H}_{2} \mathrm{O}(12.8 \mathrm{~g})$ was added slowly. After stirring for $30 \mathrm{~min}$, the mixture was dried $\left(\mathrm{MgSO}_{4}\right)$ and filtered. The solvents were removed and the crude product was purified by chromatography on silica gel (hexanes/EtOAc, 10:1) to give 32 (988 mg, 2.61 mmol, $72 \%, \boldsymbol{d r}=6: 1)$ as a colorless oil.

Spectral data for the major isomer/rotamer of 32 from the mixture: ${ }^{1} \mathrm{H}$ NMR $(600 \mathrm{MHz}$, $\left.\mathrm{CDCl}_{3}, 65^{\circ} \mathrm{C}\right) \delta 5.49(\mathrm{~s}, 1 \mathrm{H}), 5.32(\mathrm{~s}, 1 \mathrm{H}), 4.28(\mathrm{dt}, J=7.9,6.4 \mathrm{~Hz}, 1 \mathrm{H}), 4.05(\mathrm{q}, J=6.2$ Hz, 1H), $3.56(\mathrm{~s}, 3 \mathrm{H}), 3.28-3.40(\mathrm{~m}, 2 \mathrm{H}), 2.74(\mathrm{dd}, J=14.9,5.6 \mathrm{~Hz}, 1 \mathrm{H}), 2.55$ (br s, 1H), 1.86-1.96 (m, 1H), 1.68-1.79 (m, 1H), $0.82(\mathrm{~s}, 9 \mathrm{H}), 0.01(\mathrm{~s}, 3 \mathrm{H}), 0.00(\mathrm{~s}, 3 \mathrm{H}) ;{ }^{13} \mathrm{C} \mathrm{NMR}$ $\left(150 \mathrm{MHz}, \mathrm{CDCl}_{3}, 65^{\circ} \mathrm{C}\right) \delta 155.5,131.5,117.6,71.7,58.8,51.6,42.9,40.0,31.6,25.6$, $17.8,-5.0,-5.2$.

Spectral data for the mixture of both isomers of 32: IR (ATR) 2955, 2930, 2894, 2857, 1702, 1448, 1383, 1119, 833, $772 \mathrm{~cm}^{-1}$; HRMS (ESI) calcd for $\mathrm{C}_{15} \mathrm{H}_{28} \mathrm{BrNNaO}_{3} \mathrm{Si}$ $\left(\mathrm{M}+\mathrm{Na}^{+}\right)$400.0920, found 400.0919.

\section{Alternative synthesis of 32}

A solution of 28 (195 mg, $0.59 \mathrm{mmol})$ and 2-bromoallyltrimethylsilane (13) (455 mg, 2.36 mmol) in $\mathrm{CH}_{2} \mathrm{Cl}_{2}(6.5 \mathrm{~mL})$ was cooled to $-78{ }^{\circ} \mathrm{C}$ and stirred for $15 \mathrm{~min}$. $\mathrm{TiCl}_{4}(130 \mu \mathrm{L}, 1.18$ mmol) was added slowly. The cold bath was removed after $5 \mathrm{~min}$, and the mixture was 
stirred at ambient temperature for an additional $1 \mathrm{~h} . \mathrm{Na}_{2} \mathrm{CO}_{3} \cdot 10 \mathrm{H}_{2} \mathrm{O}(2 \mathrm{~g})$ was added slowly. After stirring for $30 \mathrm{~min}$, the mixture was dried $\left(\mathrm{MgSO}_{4}\right)$ and filtered, and the solvent was removed to give a light yellow residue $(210 \mathrm{mg})$. The residue was dissolved in $\mathrm{CH}_{2} \mathrm{Cl}_{2}(2$ $\mathrm{mL})$, and triethylamine $(267 \mu \mathrm{L}, 1.91 \mathrm{mmol})$ was added followed by dropwise addition of methyl chloroformate $(110 \mu \mathrm{L}, 1.38 \mathrm{mmol})$. The reaction mixture was stirred at ambient temperature for $4 \mathrm{~h}$. Brine $(10 \mathrm{~mL})$ was added, and the mixture was extracted with EtOAc ( $3 \times 10 \mathrm{~mL})$. The combined organic phases were dried $\left(\mathrm{MgSO}_{4}\right)$ and filtered, and the solvents were removed. The resulting residue was purified by chromatography (hexanes/EtOAc, 20:1) to give 32 (98 mg, $0.26 \mathrm{mmol}, 44 \%$ ) as a colorless oil.

\section{2(R)-(2-Bromo-2-propen-1-yl)-3(R)-hydroxy-1-(methoxycarbonyl)pyrrolidine (35) and 2(S)-(2-bromo-2-propen-1-yl)-3(R)-hydroxy-1-(methoxycarbonyl)pyrrolidine (36)}

To a solution of $32(928 \mathrm{mg}, 2.45 \mathrm{mmol})$ in THF (22 mL) was added tetrabutylammonium fluoride (1.0 M in THF, $4.63 \mathrm{~mL}, 4.63 \mathrm{mmol})$. The reaction mixture was stirred at ambient temperature for $1 \mathrm{~h}$. The resulting mixture was poured into $\mathrm{H}_{2} \mathrm{O}(50 \mathrm{~mL})$ and extracted with EtOAc $(3 \times 30 \mathrm{~mL})$. The combined organic phases were dried $\left(\mathrm{MgSO}_{4}\right)$, filtered, and the solvents were removed. Purification by chromatography on silica gel (hexanes/EtOAc, 4:1 followed by 2:1) gave, in order of elution, 35 (438 mg, $1.66 \mathrm{mmol}, 68 \%)$ and 36 (103 $\mathrm{mg}, 0.39 \mathrm{mmol}, 16 \%$ ) both as colorless oils.

Spectral data for 35: ${ }^{1} \mathrm{H}$ NMR $\left(600 \mathrm{MHz}, \mathrm{CDCl}_{3}, 65^{\circ} \mathrm{C}\right) \delta 5.69(\mathrm{~s}, 1 \mathrm{H}), 5.48(\mathrm{~d}, J=1.3$ $\mathrm{Hz}, 1 \mathrm{H}), 4.43-4.50(\mathrm{~m}, 1 \mathrm{H}), 4.07(\mathrm{dt}, J=8.3,5.4 \mathrm{~Hz}, 1 \mathrm{H}), 3.67(\mathrm{~s}, 3 \mathrm{H}), 3.55(\mathrm{ddd}, J=$ $10.9,8.2,5.1 \mathrm{~Hz}, 1 \mathrm{H}), 3.44(\mathrm{dt}, J=10.9,7.5 \mathrm{~Hz}, 1 \mathrm{H}), 3.01$ (br s, 1H), 2.82 (dd, $J=14.5$, $8.3 \mathrm{~Hz}, 1 \mathrm{H}), 2.17$ (br s, $1 \mathrm{H}), 1.95-2.05(\mathrm{~m}, 1 \mathrm{H}), 1.88(\mathrm{ddt}, J=12.7,7.3,5.2 \mathrm{~Hz}, 1 \mathrm{H}) ;{ }^{13} \mathrm{C}$ NMR $\left(150 \mathrm{MHz}, \mathrm{CDCl}_{3}, 65{ }^{\circ} \mathrm{C}\right) \delta 155.8,131.0,118.3,70.8,59.5,51.9,43.7,39.6,31.7$; 
IR (ATR) 3415, 2954, 2897, 1671, 1451, 1385, 1196, 1108, 1062, 887, $771 \mathrm{~cm}^{-1}$; HRMS

(ESI) calcd for $\mathrm{C}_{9} \mathrm{H}_{15} \mathrm{BrNO}_{3}\left(\mathrm{M}+\mathrm{H}^{+}\right)$264.0235, found 264.0231; $[\alpha]^{25} \mathrm{D}=-28.4 \pm 0.1(c$ $\left.1.0, \mathrm{CHCl}_{3}\right)$.

Spectral data for 36: ${ }^{1} \mathrm{H}$ NMR $\left(600 \mathrm{MHz}, \mathrm{CDCl}_{3}, 60{ }^{\circ} \mathrm{C}\right) \delta 5.63(\mathrm{~s}, 1 \mathrm{H}), 5.51-5.52(\mathrm{~m}, 1 \mathrm{H})$, $4.32(\mathrm{~d}, J=2.7 \mathrm{~Hz}, 1 \mathrm{H}), 4.03(\mathrm{dd}, J=9.4,4.2 \mathrm{~Hz}, 1 \mathrm{H}), 3.71(\mathrm{~s}, 3 \mathrm{H}), 3.55-3.65(\mathrm{~m}, 1 \mathrm{H})$, 3.44-3.50 (m, 1H), 2.91 (br s, 1H), 2.34 (ddd, $J=14.8,9.4,0.6 \mathrm{~Hz}, 1 \mathrm{H}), 2.03-2.10$ (m, 1H), 1.96 (br s, 1H), 1.90-1.94 (m, 1H); $\left.{ }^{13} \mathrm{C} \mathrm{NMR} \mathrm{(150} \mathrm{MHz,} \mathrm{CDCl}_{3}\right) \delta$ 155.8, 155.7, 129.7, 129.6, 119.2, 119.1, 74.1, 73.2, 65.4, 64.3, 52.4, 44.4, 44.4, 44.2, 43.4, 31.7, 31.0; IR (ATR) 3422, 2955, 1673, 1451, 1384, 1197, 1119, 1093, 985, 892, $772 \mathrm{~cm}^{-1}$; HRMS (ESI) calcd for $\mathrm{C}_{9} \mathrm{H}_{15} \mathrm{BrNO}_{3}\left(\mathrm{M}+\mathrm{H}^{+}\right)$264.0235, found 264.0231; $[\alpha]^{25} \mathrm{D}=3.2 \pm 0.1$ (c 1.0, $\left.\mathrm{CHCl}_{3}\right)$.

\section{3(S)-(2-Bromo-3-nitrophenyl)-2(R)-(2-bromo-2-propen-1-yl)-1-(methoxycarbonyl)-}

\section{pyrrolidine (37)}

To a solution of 35 (422 mg, $1.60 \mathrm{mmol})$ in THF (25 mL) was added triphenylphosphine (1.46 g, $5.58 \mathrm{mmol}$ ) and 2-bromo-3-nitrophenol (9) (525 mg, $2.41 \mathrm{mmol})$. The solution was cooled to $0{ }^{\circ} \mathrm{C}$, and diisopropylazodicarboxylate $(1.26 \mathrm{~mL}, 6.40 \mathrm{mmol})$ was added dropwise. The mixture was stirred at ambient temperature for $17 \mathrm{~h}$, brine $(50 \mathrm{~mL})$ was added, and the resulting mixture was extracted with EtOAc $(3 \times 50 \mathrm{~mL})$. The combined organic phases were dried $\left(\mathrm{MgSO}_{4}\right)$, filtered, and the solvent was removed. The crude product was purified by chromatography on silica gel $\left(\mathrm{CH}_{2} \mathrm{Cl}_{2} /\right.$ hexanes, $1: 1$, then $\left.\mathrm{CH}_{2} \mathrm{Cl}_{2}\right)$ to give 37 (530 mg, $1.14 \mathrm{mmol}, 71 \%$ ) as a pale yellow oil.

Spectral data for 37: ${ }^{1} \mathrm{H}$ NMR $\left(600 \mathrm{MHz}, \mathrm{CDCl}_{3}, 65^{\circ} \mathrm{C}\right) \delta 7.39(\mathrm{t}, J=8.2 \mathrm{~Hz}, 1 \mathrm{H}), 7.34$ $(\mathrm{dd}, J=8.0,1.3 \mathrm{~Hz}, 1 \mathrm{H}), 7.17(\mathrm{dd}, J=8.2,1.1 \mathrm{~Hz}, 1 \mathrm{H}), 5.72(\mathrm{~s}, 1 \mathrm{H}), 5.58(\mathrm{~d}, J=1.6 \mathrm{~Hz}$, 
1H), $4.93(\mathrm{~s}, 1 \mathrm{H}), 4.26-4.35(\mathrm{~m}, 1 \mathrm{H}), 3.69-3.79(\mathrm{~m}, 1 \mathrm{H}), 3.72(\mathrm{~s}, 3 \mathrm{H}), 3.57-3.64(\mathrm{~m}, 1 \mathrm{H})$, 3.01 (br s, $1 \mathrm{H}), 2.50(\mathrm{dd}, J=14.6,9.7 \mathrm{~Hz}, 1 \mathrm{H}), 2.22-2.29(\mathrm{~m}, 2 \mathrm{H}) ;{ }^{13} \mathrm{C} \mathrm{NMR}(150 \mathrm{MHz}$, $\left.\mathrm{CDCl}_{3}, 65^{\circ} \mathrm{C}\right) \delta 155.2,154.8,151.9,128.9,128.4,120.0,118.2,117.4,106.4,81.7,61.9$, 52.2, 44.4, 43.8, 29.1; IR (ATR) 2955, 1693, 1533, 1449, 1386, 1357, 1270, 1196, 1121, 1010, 903, $773 \mathrm{~cm}^{-1}$; HRMS (ESI) calcd for $\mathrm{C}_{15} \mathrm{H}_{16} \mathrm{Br}_{2} \mathrm{~N}_{2} \mathrm{NaO}_{5}\left(\mathrm{M}+\mathrm{Na}^{+}\right)$484.9324, found 484.9322; $[\alpha]^{25} \mathrm{D}=30.6 \pm 0.1\left(c 1.0, \mathrm{CHCl}_{3}\right)$;

\section{2,3,3a $(S), 9,10,10 a(R)-H e x a h y d r o-1-(m e t h o x y c a r b o n y l)-8-n i t r o-1 H$-benzoxepino[3,2- b]pyrrole (38)}

A solution of $37(60 \mathrm{mg}, 0.13 \mathrm{mmol}), \mathrm{Pd}(\mathrm{dba})_{2}(15 \mathrm{mg}, 0.026 \mathrm{mmol})$, triphenylphosphine (27 mg, $0.10 \mathrm{mmol})$, and hexamethylditin $(51.5 \mathrm{mg}, 0.16 \mathrm{mmol})$ in toluene $(1.5 \mathrm{~mL})$ was stirred at $120{ }^{\circ} \mathrm{C}$ for $12 \mathrm{~h}$. The mixture was cooled to ambient temperature, the solvent was removed and the resulting residue was purified by chromatography on silica gel (hexanes/EtOAc, 6:1) to give $\mathbf{3 8}(16.5 \mathrm{mg}, 0.054 \mathrm{mmol}, 42 \%$ ) as a brown oil.

Spectral data for 38: ${ }^{1} \mathrm{H}$ NMR $\left(600 \mathrm{MHz} \mathrm{CDCl}_{3}\right) \delta 7.42(\mathrm{~d}, J=7.6 \mathrm{~Hz}, 0.5 \mathrm{H})$, 7.16-7.30 $(\mathrm{m}, 2 \mathrm{H}), 6.96(\mathrm{~d}, J=7.1 \mathrm{~Hz}, 0.5 \mathrm{H}), 5.29(\mathrm{~s}, 0.5 \mathrm{H}), 5.10-5.21(\mathrm{~m}, 0.5 \mathrm{H}), 4.93-4.99(\mathrm{~m}, 1 \mathrm{H})$, 3.23-4.06 (m, 8H), $2.48(\mathrm{t}, J=11.3 \mathrm{~Hz}, 0.5 \mathrm{H}), 2.18-2.32(\mathrm{~m}, 1.5 \mathrm{H}), 1.95-2.13(\mathrm{~m}, 1 \mathrm{H}) ;{ }^{13} \mathrm{C}$ NMR $\left(150 \mathrm{MHz}, \mathrm{CDCl}_{3}\right) \delta 158.1,156.1,155.3,152.0,151.8,139.1,138.6,128.9,128.8$, $128.3,123.9,121.9,121.5,120.8,119.9,119.7,118.9,116.1,86.8,80.7,80.3,62.5,57.0$, 56.6, 52.4, 44.2, 44.0, 43.1, 42.4, 39.3, 38.8, 30.8, 30.6, 29.3; IR (ATR) 2956, 2893, 1697, 1526, 1446, 1386, 1357, 1249, 1191, 1137, 1072, $825 \mathrm{~cm}^{-1}$; HRMS (ESI) calcd for

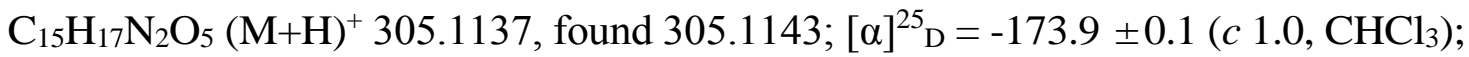




\section{6,6a $(R), 7,8,9,9 \mathrm{a}(S)$-Hexahydro-7-(methoxycarbonyl)-4H-pyrrolo[2',3':6,7]oxepino-}

\section{$[4,3,2-c d]$ indole $(39)$}

A solution of 38 (49 mg, $0.16 \mathrm{mmol}), \mathrm{Pd}(\mathrm{dba})_{2} \quad(5.6 \mathrm{mg}, 0.0097 \mathrm{mmol}), 1,3-$ bis(diphenylphosphino)propane $(4.0 \mathrm{mg}, 0.0096 \mathrm{mmol})$, and 1,10-phenanthroline $(3.5 \mathrm{mg}$, $0.019 \mathrm{mmol})$ in anhydrous DMF $(800 \mu \mathrm{L})$ in an ACE-Glass pressure tube with an attached pressure head was saturated with carbon monoxide ( 4 cycles to 6 atm of $\mathrm{CO}$ ). The reaction was stirred under $\mathrm{CO}(6 \mathrm{~atm})$ at $120{ }^{\circ} \mathrm{C}$ for $72 \mathrm{~h}$. The mixture was cooled to ambient temperature, diluted with EtOAc $(5 \mathrm{~mL})$, and washed with brine $(2 \times 5 \mathrm{~mL})$. The organic phase was dried $\left(\mathrm{MgSO}_{4}\right)$ and filtered. The solvent was removed, and the resulting residue was purified by chromatography on silica gel (hexanes/EtOAc, 2:1) to afford 39 (29 mg, $0.11 \mathrm{mmol}, 66 \%$ ) as a white solid.

Spectral data for 39: $\mathrm{mp} 262.5-263{ }^{\circ} \mathrm{C} ;{ }^{1} \mathrm{H}$ NMR $\left(600 \mathrm{MHz}, \mathrm{CDCl}_{3}, 65^{\circ} \mathrm{C}\right) \delta 8.05$ (br s, 1H), $7.07(\mathrm{t}, J=7.9 \mathrm{~Hz}, 1 \mathrm{H}), 6.99(\mathrm{~d}, J=8.1 \mathrm{~Hz}, 1 \mathrm{H}), 6.98(\mathrm{~s}, 1 \mathrm{H}), 6.66(\mathrm{~d}, J=7.7 \mathrm{~Hz}$, $1 \mathrm{H}), 4.54(\mathrm{dt}, J=10.6,6.8 \mathrm{~Hz}, 1 \mathrm{H}), 3.88-4.01(\mathrm{~m}, 3 \mathrm{H}), 3.75(\mathrm{~s}, 3 \mathrm{H}), 3.36(\mathrm{dt}, J=12.2,5.6$ $\mathrm{Hz}, 1 \mathrm{H}), 2.61(\mathrm{t}, J=13.2 \mathrm{~Hz}, 1 \mathrm{H}), 2.38-2.44(\mathrm{~m}, 1 \mathrm{H}), 2.21-2.30(\mathrm{~m}, 1 \mathrm{H}) ;{ }^{13} \mathrm{C} \mathrm{NMR}(150$ $\left.\mathrm{MHz}, \mathrm{CDCl}_{3}, 65{ }^{\circ} \mathrm{C}\right) \delta 155.6,151.9,139.1,122.9,120.7,117.2,110.1,106.1,104.4,86.4$, 62.5, 52.3, 44.2, 31.3, 31.2; IR (ATR) 3280, 1680, 1450, 1390, 1250, 1077, 769, $735 \mathrm{~cm}^{-1}$; HRMS (ESI) calcd for $\mathrm{C}_{15} \mathrm{H}_{17} \mathrm{~N}_{2} \mathrm{O}_{3}\left(\mathrm{M}+\mathrm{H}^{+}\right)$273.1239, found 273.1238; $[\alpha]^{25} \mathrm{D}=-288.6 \pm$ $0.2\left(c 0.5, \mathrm{CHCl}_{3}\right)$;

\section{6,6a $(R), 7,8,9,9 \mathrm{a}(S)$-Hexahydro-7-methyl-4H-pyrrolo[2',3':6,7]oxepino[4,3,2-cd]indole (ht-13-A)}

To a solution of $39(21 \mathrm{mg}, 0.077 \mathrm{mmol})$ in anhydrous toluene $(8.5 \mathrm{~mL})$ was added sodium bis(2-methoxyethoxy)aluminumhydride (in toluene $\sim 3.5 \mathrm{M}, 500 \mu \mathrm{L}, 1.75 \mathrm{mmol}$ ) 
dropwise. The mixture was stirred at $110^{\circ} \mathrm{C}$ for $5 \mathrm{~h}$ and then allowed to cool to ambient temperature. Brine $(20 \mathrm{~mL})$ was added, and the mixture was extracted with EtOAc $(3 \times 15$ $\mathrm{mL})$. The combined organic phases were dried $\left(\mathrm{MgSO}_{4}\right)$, filtered and the solvent was removed. The resulting residue was purified by chromatography on silica gel (EtOAc/MeOH, 9:1) to give ht-13-A (16.8 mg, $0.074 \mathrm{mmol}, 95 \%)$ as a white solid.

Spectral data for ht-13-A: $\operatorname{mp} 228-230{ }^{\circ} \mathrm{C} ;{ }^{1} \mathrm{H}$ NMR $\left(600 \mathrm{MHz}, \mathrm{CDCl}_{3}\right) \delta 8.08($ br s, 1H), $7.07(\mathrm{~d}, J=8.0 \mathrm{~Hz}, 1 \mathrm{H}), 7.00($ br s, $1 \mathrm{H}), 6.99(\mathrm{t}, J=8.3 \mathrm{~Hz}, 1 \mathrm{H}), 6.63(\mathrm{~d}, J=7.7$ $\mathrm{Hz}, 1 \mathrm{H}), 4.45(\mathrm{ddd}, J=9.4,6.1,2.9 \mathrm{~Hz}, 1 \mathrm{H}), 3.42(\mathrm{dd}, J=14.6,3.4 \mathrm{~Hz}, 1 \mathrm{H}), 3.11(\mathrm{t}, J=$ $8.5 \mathrm{~Hz}, 1 \mathrm{H}), 2.62-2.68(\mathrm{~m}, 1 \mathrm{H}), 2.52-2.62(\mathrm{~m}, 2 \mathrm{H}), 2.46-2.52(\mathrm{~m}, 1 \mathrm{H}), 2.43(\mathrm{~s}, 3 \mathrm{H})$, 2.05-2.11 (m, 1H); ${ }^{13} \mathrm{C}$ NMR (100 $\left.\mathrm{MHz}, \mathrm{CDCl}_{3}\right) \delta 151.8,138.7,122.8,120.1,117.1$, 111.0, 106.1, 104.0, 86.7, 72.9, 55.6, 40.5, 30.8, 29.2; IR (ATR) 3063, 2833, 1620, $1515,1457,1343,1294,1240,1065,776,733 \mathrm{~cm}^{-1}$; HRMS (ESI) calcd for $\mathrm{C}_{14} \mathrm{H}_{17} \mathrm{~N}_{2} \mathrm{O}$ $\left(\mathrm{M}+\mathrm{H}^{+}\right)$229.1341, found 229.1336; $[\alpha]^{25} \mathrm{D}=-185.1 \pm 0.4\left(c 0.36, \mathrm{CHCl}_{3}\right)$.

\section{Trifluoro-methanesulfonic acid 2-bromo-6-nitro-phenyl ester (43)}

Trifluoromethane-sulfonic anhydride $(2.25 \mathrm{~mL}, 13.4 \mathrm{mmol})$ was added to a solution of 2bromo-6-nitrophenol (42) $(2.44 \mathrm{~g}, 11.17 \mathrm{mmol})$ and triethylamine $(2.34 \mathrm{~mL}, 16.8 \mathrm{mmol})$ in $\mathrm{CH}_{2} \mathrm{Cl}_{2}(35 \mathrm{~mL})$ at $0{ }^{\circ} \mathrm{C}$. The mixture was warmed to room temperature and stirred for $1 \mathrm{~h}$. The reaction was quenched with $\mathrm{H}_{2} \mathrm{O}(100 \mathrm{~mL})$ and extracted with EtOAc $(3 \times 60 \mathrm{~mL})$, dried $\left(\mathrm{MgSO}_{4}\right)$ and the solvents were removed on a rotary evaporator at water aspirator pressure. Purification by chromatography (hexanes/EtOAc, 10:1) gave 43 (3.84 g, 10.97 mmol, $98 \%$,) as a yellow oil.

Spectral data for 43: ${ }^{1} \mathrm{H} \mathrm{NMR}\left(600 \mathrm{MHz}, \mathrm{CDCl}_{3}\right) \delta 8.04(\mathrm{dd}, J=8.2,1.6 \mathrm{~Hz}, 1 \mathrm{H}), 7.98(\mathrm{dd}$, $J=8.2,1.7 \mathrm{~Hz}, 1 \mathrm{H}), 7.45(\mathrm{t}, J=8.2 \mathrm{~Hz}, 1 \mathrm{H}) .{ }^{13} \mathrm{C} \mathrm{NMR}\left(150 \mathrm{MHz}, \mathrm{CDCl}_{3}\right) \delta 143.4,139.2$, 
139.2, 129.5, 125.6, 121.5, 119.4, 118.7, 117.2, 115.1; IR (ATR) 1539, 1431, 1347, 1208, 1129, 886, 855, 750, $717 \mathrm{~cm}^{-1}$; HRMS (ESI) calcd for $\mathrm{C}_{7} \mathrm{H}_{3} \mathrm{BrF}_{3} \mathrm{NNaO}_{5} \mathrm{~S}\left(\mathrm{M}+\mathrm{Na}^{+}\right)$ 371.8765 , found 371.8765 .

\section{[3-(2-Bromo-6-nitro-phenyl)-but-3-enyl]-carbamic acid methyl ester (45)}

A solution of $43(930 \mathrm{mg}, 2.66 \mathrm{mmol}), 44(822 \mathrm{mg}, 2.82 \mathrm{mmol}), \mathrm{Pd}\left(\mathrm{PPh}_{3}\right)_{2} \mathrm{Cl}_{2}(37.3 \mathrm{mg}$, $0.053 \mathrm{mmol}$ ) and lithium chloride (338 $\mathrm{mg}, 7.97 \mathrm{mmol})$ in DMF $(14 \mathrm{~mL})$ was stirred at 60 ${ }^{\circ} \mathrm{C}$ for $5 \mathrm{~h}$. The reaction was diluted with $\mathrm{H}_{2} \mathrm{O}(60 \mathrm{~mL})$ and extracted with EtOAc $(3 \times 30$ $\mathrm{mL})$, dried $\left(\mathrm{MgSO}_{4}\right)$ and the solvents were removed on a rotary evaporator at water aspirator pressure. Purification by chromatography (hexanes/EtOAc, 20:1) gave 42 (457 mg, 2.10 mmol, $79 \%$ ) as a yellow solid, then (hexanes/EtOAc, 4:1) gave 45 (139 mg, $0.42 \mathrm{mmol}, 16$ $\%)$ as a brown solid.

Spectral data for 45: mp 53.5-54 ${ }^{\circ} \mathrm{C} ;{ }^{1} \mathrm{H}$ NMR $\left(400 \mathrm{MHz}, \mathrm{CDCl}_{3} 65{ }^{\circ} \mathrm{C}\right) \delta 7.80(\mathrm{~d}, J=8.0 \mathrm{~Hz}$, 1H), $7.73(\mathrm{~d}, J=8.1 \mathrm{~Hz}, 1 \mathrm{H}), 7.28(\mathrm{t}, J=8.1 \mathrm{~Hz}, 1 \mathrm{H}), 5.34$ (s, 1H), 5.04 (s, 1H), 4.88 (br s, 1H), $3.66(\mathrm{~s}, 3 \mathrm{H}), 3.46(\mathrm{q}, J=6.3 \mathrm{~Hz}, 2 \mathrm{H}), 2.59-2.79(\mathrm{~m}, 2 \mathrm{H}) .{ }^{13} \mathrm{C} \mathrm{NMR}\left(100 \mathrm{MHz}, \mathrm{CDCl}_{3}\right)$ $\delta 156.9,150.2,142.2,137.5,136.9,129.0,124.4,122.8,116.8,52.0,38.5,35.3$; IR (ATR) $3337,1699,1525,1353,1256,914,748,711 \mathrm{~cm}^{-1}$; HRMS (ESI) calcd for $\mathrm{C}_{12} \mathrm{H}_{14} \mathrm{BrN}_{2} \mathrm{O}_{4}$ $\left(\mathrm{M}+\mathrm{H}^{+}\right)$329.0137, found 329.0137.

\section{Alternative synthesis of 45}

A solution of $\mathbf{5 0}(16 \mathrm{mg}, 0.044 \mathrm{mmol}), \mathbf{5 1}(9.32 \mathrm{mg}, 0.037 \mathrm{mmol}), \mathrm{Pd}(\mathrm{dba})_{2}(1.05 \mathrm{mg}$, $0.0018 \mathrm{mmol})$, copper (I) iodide $(5.22 \mathrm{mg}, 0.027 \mathrm{mmol})$ and triphenylphosphine $(1.92 \mathrm{mg}$, $0.0073 \mathrm{mmol})$ in DMF $(0.65 \mathrm{~mL})$ was stirred at room temperature for $16 \mathrm{~h}$. The reaction was diluted with $\mathrm{H}_{2} \mathrm{O}(10 \mathrm{~mL})$ and extracted with EtOAc $(3 \times 10 \mathrm{~mL})$, dried $\left(\mathrm{MgSO}_{4}\right)$ and the 
solvents were removed on a rotary evaporator at water aspirator pressure. Purification by chromatography (hexanes/EtOAc, 5:1) gave $45(2.5 \mathrm{mg}, 0.0076 \mathrm{mmol}, 21 \%)$ as a brown solid.

\section{(2-Bromo-6-nitro-phenyl)-trimethyl-stannane (50)}

$\operatorname{Pd}\left(\mathrm{PPh}_{3}\right)_{2} \mathrm{Cl}_{2} \quad(1.6 \mathrm{mg}, 0.0023 \mathrm{mmol})$, hexamethylditin $(37.5 \mathrm{mg} 0.11 \mathrm{mmol})$ and triphenylphosphine $(0.96 \mathrm{mg}, 0.0037 \mathrm{mmol})$ were added to a solution of 1-bromo-2-iodo-3nitrobenzene (49) $(25 \mathrm{mg}, 0.076 \mathrm{mmol})$ in toluene $(0.5 \mathrm{~mL})$ at room temperature. The mixture was stirred under $\mathrm{N}_{2}$ at $105{ }^{\circ} \mathrm{C}$ for $16 \mathrm{~h}$. The reaction was quenched with $\mathrm{H}_{2} \mathrm{O}(5$ $\mathrm{mL})$ and extracted with EtOAc $(3 \times 5 \mathrm{~mL})$, dried $\left(\mathrm{MgSO}_{4}\right)$ and the solvents were removed on a rotary evaporator at water aspirator pressure. Purification by chromatography (hexanes/EtOAc, 20:1) gave $\mathbf{5 0}$ (16 mg, $0.044 \mathrm{mmol}, 58 \%$ ) as a brown oil.

Spectral data for 50: ${ }^{1} \mathrm{H}$ NMR $\left(600 \mathrm{MHz}, \mathrm{CDCl}_{3}\right) \delta 7.92(\mathrm{~d}, J=8.0 \mathrm{~Hz}, 1 \mathrm{H}), 7.75(\mathrm{~d}, J=7.9$ $\mathrm{Hz}, 1 \mathrm{H}), 7.29(\mathrm{t}, J=8.0 \mathrm{~Hz}, 1 \mathrm{H}), 0.45(\mathrm{~s}, 9 \mathrm{H}) . \delta{ }^{13} \mathrm{C} \mathrm{NMR}\left(150 \mathrm{MHz}, \mathrm{CDCl}_{3}\right) \delta 157.1,142.5$, 137.1, 133.2, 130.3, 122.3, -3.8; IR (ATR) 2988, 2909, 1521, 1345, 1078, 773, 737, 714 $\mathrm{cm}^{-1}$; HRMS (ESI) calcd for $\mathrm{C}_{8} \mathrm{H}_{9} \mathrm{BrNO}_{2} \mathrm{Sn}\left(\mathrm{M}_{-} \mathrm{CH}_{3}{ }^{+}\right) 349.8839$, found 349.8838 .

\section{Trifluoro-methanesulfonic acid 2-iodo-3-nitro-phenyl ester (52)}

Trifluoromethanesulfonic anhydride $(0.075 \mathrm{~mL}, 0.45 \mathrm{mmol})$ was added to a solution of 2iodo-3-nitrophenol $(100 \mathrm{mg}, 0.38 \mathrm{mmol})$ and triethylamine $(0.058 \mathrm{~mL}, 0.42 \mathrm{mmol})$ in $\mathrm{CH}_{2} \mathrm{Cl}_{2}(1 \mathrm{~mL})$ at $0{ }^{\circ} \mathrm{C}$. The mixture was stirred for $1 \mathrm{~h}$ at $0{ }^{\circ} \mathrm{C}$. The reaction was quenched with brine $(10 \mathrm{~mL})$ and extracted with EtOAc $(3 \times 10 \mathrm{~mL})$, dried $\left(\mathrm{MgSO}_{4}\right)$ and the solvents were removed on a rotary evaporator at water aspirator pressure. Purification by chromatography (hexanes/EtOAc, 5:1) gave 52 (143 mg, $0.36 \mathrm{mmol}, 95 \%$ ) as a yellow oil. 
Spectral data for 52: ${ }^{1} \mathrm{H}$ NMR $\left(600 \mathrm{MHz}, \mathrm{CDCl}_{3}\right) \delta 7.76(\mathrm{dd}, J=8.0,1.1 \mathrm{~Hz}, 1 \mathrm{H}), 7.62(\mathrm{t}, J$ $=8.3 \mathrm{~Hz}, 1 \mathrm{H}), 7.55(\mathrm{dd}, J=8.3,1.2 \mathrm{~Hz}, 1 \mathrm{H}) .{ }^{13} \mathrm{C} \mathrm{NMR}\left(150 \mathrm{MHz}, \mathrm{CDCl}_{3}\right) \delta 155.6,151.4$, 130.8, 125.0, 124.2, 121.8, 119.6, 117.5, 115.4, 84.6; IR (ATR) 1535, 1425, 1211, 1131, 938, 838, 804, $733 \mathrm{~cm}^{-1}$; HRMS (ESI) calcd for $\mathrm{C}_{7} \mathrm{H}_{3} \mathrm{~F}_{3} \mathrm{INNaO}_{5} \mathrm{~S}\left(\mathrm{M}+\mathrm{Na}^{+}\right)$419.8626, found 419.8624 .

\section{(2-Benzyloxy-6-nitro-phenyl)-trimethyl-stannane (56)}

$\mathrm{Pd}\left(\mathrm{PPh}_{3}\right)_{2} \mathrm{Cl}_{2} \quad\left(\begin{array}{lllllll}360 & \mathrm{mg}, & 0.51 & \mathrm{mmol}\end{array}\right)$, hexamethylditin $\left(\begin{array}{llll}8.86 & \mathrm{~g}, & 27 & \mathrm{mmol}\end{array}\right)$ and triphenylphosphine $(223 \mathrm{mg}, 0.85 \mathrm{mmol})$ were added to a solution of $\mathbf{5 5}(6.39 \mathrm{~g}, 18 \mathrm{mmol})$ in toluene $(115 \mathrm{~mL})$ at room temperature. The mixture was stirred under $\mathrm{N}_{2}$ at $110{ }^{\circ} \mathrm{C}$ for 14 h. The reaction was quenched with $\mathrm{H}_{2} \mathrm{O}(200 \mathrm{~mL})$ and extracted with EtOAc $(3 \times 100 \mathrm{~mL})$, dried $\left(\mathrm{MgSO}_{4}\right)$ and the solvents were removed on a rotary evaporator at water aspirator pressure. Purification by chromatography (hexanes/EtOAc, 80:1) gave 56 (5.64 g, 14.39 mmol, $80 \%$,) as a yellow solid.

Spectral data for 56: $\mathrm{mp} 87-88{ }^{\circ} \mathrm{C} ;{ }^{1} \mathrm{H}$ NMR $\left(600 \mathrm{MHz}, \mathrm{CDCl}_{3}\right) \delta 7.72(\mathrm{~d}, J=8.0 \mathrm{~Hz}, 1 \mathrm{H})$, 7.35-7.44 (m, 6H), $7.09(\mathrm{~d}, J=8.1 \mathrm{~Hz}, 1 \mathrm{H}), 5.11(\mathrm{~s}, 2 \mathrm{H}), 0.29(\mathrm{~s}, 9 \mathrm{H}) ;{ }^{13} \mathrm{C} \mathrm{NMR}(150 \mathrm{MHz}$, $\left.\mathrm{CDCl}_{3}\right) \delta 164.0,156.0,135.9,130.4,128.6,128.3,127.9,127.8,116.5,115.4,71.0,-5.6 ; \mathrm{IR}$ (ATR) 3069, 3035, 2979, 2917, 1591, 1251, 1021, 738, $698 \mathrm{~cm}^{-1}$; HRMS (ESI) calcd for $\mathrm{C}_{16} \mathrm{H}_{19} \mathrm{NNaO}_{3} \mathrm{Sn}\left(\mathrm{M}+\mathrm{Na}^{+}\right)$416.0285, found 416.0283.

\section{[3-(2-Benzyloxy-6-nitro-phenyl)-but-3-enyl]-carbamic acid methyl ester (57)}

A solution of 56 (2.0 g, $5.10 \mathrm{mmol}), \mathbf{5 1}(1.09 \mathrm{~g}, 4.27 \mathrm{mmol}), \mathrm{Pd}(\mathrm{dba}) 2(123 \mathrm{mg}, 0.21 \mathrm{mmol})$, triphenylphosphine (218 $\mathrm{mg}, 0.83 \mathrm{mmol})$ and copper (I) iodide (600 mg, $3.15 \mathrm{mmol})$ in DMF $(75 \mathrm{~mL})$ was stirred at r.t. for $14 \mathrm{~h}$. The reaction was diluted with $\mathrm{H}_{2} \mathrm{O}(500 \mathrm{~mL})$ and 
extracted with EtOAc $(3 \times 200 \mathrm{~mL})$, dried $\left(\mathrm{MgSO}_{4}\right)$ and the solvents were removed on a rotary evaporator at water aspirator pressure. Purification by chromatography (hexanes/EtOAc, 5:1) gave $57(1.21 \mathrm{~g}, 3.40 \mathrm{mmol}, 79 \%)$ as an orange oil.

Spectral data for 57: ${ }^{1} \mathrm{H} \mathrm{NMR}\left(400 \mathrm{MHz}, \mathrm{CDCl}_{3}, 65{ }^{\circ} \mathrm{C}\right) \delta 7.23-7.39(\mathrm{~m}, 7 \mathrm{H}), 7.12(\mathrm{~d}, J=$ $7.7 \mathrm{~Hz}, 1 \mathrm{H}), 5.23(\mathrm{~s}, 1 \mathrm{H}), 5.11(\mathrm{~s}, 2 \mathrm{H}), 4.98(\mathrm{~s}, 1 \mathrm{H}), 4.92$ (br s, 1H), 3.59 (s, 3H), 3.33 (q, J $=6.3 \mathrm{~Hz}, 2 \mathrm{H}), 2.67(\mathrm{t}, J=6.5 \mathrm{~Hz}, 2 \mathrm{H}) .{ }^{13} \mathrm{C} \mathrm{NMR}\left(100 \mathrm{MHz}, \mathrm{CDCl}_{3}\right) \delta 156.9,156.3,150.5$, $139.7,135.6,128.7,128.6,128.2,127.1,126.2,116.9,115.9,115.8,71.1,51.8,38.7,36.3$;

IR (ATR) 3431, 2950, 1707, 1526, 1259, 1043, 801, 736, $697 \mathrm{~cm}^{-1}$; HRMS (ESI) calcd for $\mathrm{C}_{19} \mathrm{H}_{21} \mathrm{~N}_{2} \mathrm{O}_{5}\left(\mathrm{M}+\mathrm{H}^{+}\right)$357.1450, found 357.1449.

\section{[2-(4-Benzyloxy-1H-indol-3-yl)-ethyl]-carbamic acid methyl ester (58)}

A solution of $57(300 \mathrm{mg}, 0.84 \mathrm{mmol}), \quad \mathrm{Pd}(\mathrm{dba})_{2} \quad(29 \mathrm{mg}, \quad 0.050 \mathrm{mmol}), \quad 1,3-$ bis(diphenylphosphino)propane $(21 \mathrm{mg}, 0.051 \mathrm{mmol})$, and 1,10-phenanthroline $(18 \mathrm{mg}, 0.1$ mmol) in anhydrous DMF (4 mL) in a Teflon screw-capped ACE-Glass pressure tube was saturated with carbon monoxide (4 cycles to $6 \mathrm{~atm}$ of $\mathrm{CO}$ ). The reaction mixture was stirred under $\mathrm{CO}(6 \mathrm{~atm})$ at $120{ }^{\circ} \mathrm{C}$ for $24 \mathrm{~h}$. The mixture was cooled to ambient temperature, diluted with EtOAc $(15 \mathrm{~mL})$, and washed with brine $(2 \times 30 \mathrm{~mL})$. The organic phase was dried $\left(\mathrm{MgSO}_{4}\right)$ and filtered. The solvent was removed, and the resulting residue was purified by chromatography (hexanes/EtOAc, 2:1) to afford 58 (216 mg, $0.67 \mathrm{mmol}, 79 \%)$ as a white solid.

Spectral data for 58: $\mathrm{mp} 97-98{ }^{\circ} \mathrm{C}$; ${ }^{1} \mathrm{H}$ NMR (400 $\left.\mathrm{MHz}, \mathrm{CDCl}_{3}, 65{ }^{\circ} \mathrm{C}\right) \delta 8.25$ (br s, $1 \mathrm{H}$ ), $7.51(\mathrm{~d}, J=7.5 \mathrm{~Hz}, 2 \mathrm{H}), 7.40-7.47(\mathrm{~m}, 2 \mathrm{H}), 7.35-7.40(\mathrm{~m}, 1 \mathrm{H}), 7.10(\mathrm{t}, J=8.0 \mathrm{~Hz}, 1 \mathrm{H}), 6.98$ $(\mathrm{d}, J=8.1 \mathrm{~Hz}, 1 \mathrm{H}), 6.83(\mathrm{~s}, 1 \mathrm{H}), 6.61(\mathrm{~d}, J=7.7 \mathrm{~Hz}, 1 \mathrm{H}), 5.21(\mathrm{~s}, 2 \mathrm{H}), 4.71(\mathrm{br} \mathrm{s}, 1 \mathrm{H}), 3.65$ $(\mathrm{s}, 3 \mathrm{H}), 3.47(\mathrm{q}, J=6.6 \mathrm{~Hz}, 2 \mathrm{H}), 3.08(\mathrm{t}, J=6.7 \mathrm{~Hz}, 2 \mathrm{H}) ;{ }^{13} \mathrm{C} \mathrm{NMR}\left(100 \mathrm{MHz}, \mathrm{CDCl}_{3}\right) \delta$ 
157.1, 153.4, 138.2, 137.1, 128.5, 127.9, 127.5, 122.6, 121.4, 117.2, 112.9, 104.9, 100.2, 69.8, 51.8, 42.5, 27.1; IR (ATR) 3412, 3319, 2944, 1698, 1505, 1251, 1071, $730 \mathrm{~cm}^{-1}$; HRMS (ESI) calcd for $\mathrm{C}_{19} \mathrm{H}_{21} \mathrm{~N}_{2} \mathrm{O}_{3}\left(\mathrm{M}+\mathrm{H}^{+}\right)$325.1552, found 325.1549.

\section{[2-(4-Hydroxy-1H-indol-3-yl)-ethyl]-carbamic acid methyl ester (59)}

A solution of $\mathbf{5 8}$ (478 mg, $1.47 \mathrm{mmol})$ and $\mathrm{Pd} / \mathrm{C}(10 \%$ wt., $57.4 \mathrm{mg}, 0.054 \mathrm{mmol})$ in $\mathrm{MeOH}$ $(19 \mathrm{~mL})$ in a Teflon screw-capped ACE-Glass pressure tube was saturated with hydrogen (4 cycles to $1.5 \mathrm{~atm}$ of $\left.\mathrm{H}_{2}\right)$. The reaction mixture was stirred under $\mathrm{H}_{2}(1.5 \mathrm{~atm})$ at r.t. for $16 \mathrm{~h}$. The solvent were removed on a rotary evaporator at water aspirator pressure. The mixture was diluted with EtOAc $(20 \mathrm{~mL})$, and washed with brine $(2 \times 20 \mathrm{~mL})$. The organic phase was dried $\left(\mathrm{MgSO}_{4}\right)$ and filtered. The solvent was removed, and the resulting residue was purified by chromatography (hexanes/EtOAc, 2:1) to afford $\mathbf{5 9}(286 \mathrm{mg}, 1.22 \mathrm{mmol}, 83 \%)$ as a pink solid.

Spectral data for 59: mp $165-167{ }^{\circ} \mathrm{C} ;{ }^{1} \mathrm{H}$ NMR (400 MHz, d-DMSO) $\delta 10.58(\mathrm{~s}, 1 \mathrm{H}), 9.28(\mathrm{~s}$, 1H), $7.10(\mathrm{t}, J=5.2 \mathrm{~Hz}, 1 \mathrm{H}), 6.89(\mathrm{~d}, J=2.2 \mathrm{~Hz}, 1 \mathrm{H}), 6.79(\mathrm{dd}, J=8.1,7.2 \mathrm{~Hz}, 1 \mathrm{H}), 6.75$ $(\mathrm{dd}, J=8.1,1.1 \mathrm{~Hz}, 1 \mathrm{H}), 6.29(\mathrm{dd}, J=7.2,1.2 \mathrm{~Hz}, 1 \mathrm{H}), 3.50(\mathrm{~s}, 3 \mathrm{H}), 3.24-3.31(\mathrm{~m}, 2 \mathrm{H})$, $2.92(\mathrm{t}, J=7.4 \mathrm{~Hz}, 2 \mathrm{H}) ;{ }^{13} \mathrm{C} \mathrm{NMR}(100 \mathrm{MHz}, \mathrm{d}-\mathrm{DMSO}) \delta 156.6,151.7,138.6,121.7,120.9$, 116.5, 111.9, 102.9, 102.7, 51.0, 42.2, 26.8; IR (ATR) 3396, 2971, 1739, 1454, 1366, 1217 , 1040, $737 \mathrm{~cm}^{-1}$; HRMS (ESI) calcd for $\mathrm{C}_{12} \mathrm{H}_{15} \mathrm{~N}_{2} \mathrm{O}_{3}\left(\mathrm{M}+\mathrm{H}^{+}\right)$235.1083, found 235.1083.

\section{Trifluoro-methanesulfonic acid 3-(2-methoxycarbonylamino-ethyl)-1H-indol-4-yl ester} (60)

Trifluoromethanesulfonic anhydride $(0.423 \mathrm{~mL}, 2.51 \mathrm{mmol})$ was added to a solution of $\mathbf{5 9}$ (141 mg, $0.60 \mathrm{mmol})$ and triethylamine $(1.7 \mathrm{~mL}, 12.20 \mathrm{mmol})$ in $\mathrm{CH}_{3} \mathrm{CN}(17 \mathrm{~mL})$ at $0{ }^{\circ} \mathrm{C}$. 
The mixture was warmed to room temperature and stirred for $3 \mathrm{~h}$. The reaction was quenched with $\mathrm{H}_{2} \mathrm{O}(50 \mathrm{~mL})$ and extracted with EtOAc $(3 \times 30 \mathrm{~mL})$, dried $\left(\mathrm{MgSO}_{4}\right)$ and the solvents were removed on a rotary evaporator at water aspirator pressure. Purification by chromatography (hexanes/EtOAc, 1:1) and then recrystallization $\left(\mathrm{CH}_{2} \mathrm{Cl}_{2} /\right.$ hexanes, $\left.2: 1\right)$ gave $\mathbf{6 0}$ (120 mg, $0.33 \mathrm{mmol}, 54 \%$,) as a yellow solid.

Spectral data for 60: mp 105-106 ${ }^{\circ} \mathrm{C}$; ${ }^{1} \mathrm{H}$ NMR (400 MHz, $\left.\mathrm{CDCl}_{3}\right) \delta 8.63(\mathrm{br} \mathrm{s}, 1 \mathrm{H}), 7.36(\mathrm{~d}$, $J=8.1 \mathrm{~Hz}, 1 \mathrm{H}), 7.15(\mathrm{t}, J=8.0 \mathrm{~Hz}, 1 \mathrm{H}), 7.01(\mathrm{~d}, J=7.8 \mathrm{~Hz}, 1 \mathrm{H}), 6.95(\mathrm{~s}, 1 \mathrm{H}), 4.88(\mathrm{br} \mathrm{s}$, 1H), $3.67(\mathrm{~s}, 3 \mathrm{H}), 3.51(\mathrm{q}, J=6.8 \mathrm{~Hz}, 2 \mathrm{H}), 3.07(\mathrm{t}, J=7.2 \mathrm{~Hz}, 2 \mathrm{H}) .{ }^{13} \mathrm{C} \mathrm{NMR}(150 \mathrm{MHz}$, $\left.\mathrm{CDCl}_{3}\right) \delta 157.3,142.7,139.1,124.5,121.9,121.8,119.7,119.5,117.5,115.4,111.8,111.3$, 110.9, 52.1, 41.8, 26.4; IR (ATR) 3341, 2971, 1711, 1413, 1217, 1136, 1001, 865, $735 \mathrm{~cm}^{-1}$; HRMS (ESI) calcd for $\mathrm{C}_{13} \mathrm{H}_{14} \mathrm{~F}_{3} \mathrm{~N}_{2} \mathrm{O}_{5} \mathrm{~S}\left(\mathrm{M}+\mathrm{H}^{+}\right)$367.0576, found 367.0581.

\section{2-Iodo-1-(4-methoxy-benzyloxy)-3-nitro-benzene (63)}

4-Methoxybenzyl chloride $(1.04 \mathrm{~mL}, 7.67 \mathrm{mmol})$ was added to a solution of 2-iodo-3nitrophenol $(2.00 \mathrm{~g}, 7.55 \mathrm{mmol})$ and potassium carbonate $(1.14 \mathrm{~g}, 8.25 \mathrm{mmol})$ in $\mathrm{CH}_{3} \mathrm{CN}(40$ $\mathrm{mL}$ ). The mixture was stirred under $\mathrm{N}_{2}$ at $80{ }^{\circ} \mathrm{C}$ for $17 \mathrm{~h}$. The reaction was quenched with $\mathrm{H}_{2} \mathrm{O}(80 \mathrm{~mL})$ and extracted with EtOAc $(3 \times 60 \mathrm{~mL})$, dried $\left(\mathrm{MgSO}_{4}\right)$ and the solvents were removed on a rotary evaporator at water aspirator pressure. Purification by chromatography (hexanes/EtOAc, 10:1) gave $63(2.64 \mathrm{~g}, 6.85 \mathrm{mmol}, 91 \%$,) as a yellow solid.

Spectral data for 63: mp 123-124 ${ }^{\circ} \mathrm{C} ;{ }^{1} \mathrm{H}$ NMR (400 MHz, $\left.\mathrm{CDCl}_{3}\right) \delta 7.39(\mathrm{~d}, J=8.8 \mathrm{~Hz}, 2 \mathrm{H})$, $7.36(\mathrm{t}, J=8.1 \mathrm{~Hz}, 1 \mathrm{H}), 7.26(\mathrm{dd}, J=8.1,1.3 \mathrm{~Hz}, 1 \mathrm{H}), 7.00(\mathrm{dd}, J=8.2,1.3 \mathrm{~Hz}, 1 \mathrm{H}), 6.92$ $(\mathrm{d}, J=8.8 \mathrm{~Hz}, 2 \mathrm{H}), 5.13(\mathrm{~s}, 2 \mathrm{H}), 3.81(\mathrm{~s}, 3 \mathrm{H}) . \delta{ }^{13} \mathrm{C} \mathrm{NMR}\left(100 \mathrm{MHz}, \mathrm{CDCl}_{3}\right) \delta 159.5,158.8$, 155.5, 129.8, 128.8, 127.4, 116.9, 115.2, 114.0, 80.8, 71.7, 55.2; IR (ATR) 3014, 2971, 1738, 1515, 1374, 1218, 1012, $734 \mathrm{~cm}^{-1}$; HRMS (ESI) calcd for $\mathrm{C}_{14} \mathrm{H}_{12} \mathrm{INNaO}_{4}\left(\mathrm{M}+\mathrm{Na}^{+}\right)$ 
407.9709, found 407.9704.

[2-(4-Methoxy-benzyloxy)-6-nitro-phenyl]-trimethyl-stannane (64)

$\mathrm{Pd}\left(\mathrm{PPh}_{3}\right)_{2} \mathrm{Cl}_{2} \quad(79.3 \mathrm{mg}, \quad 0.11 \mathrm{mmol})$, hexamethylditin $(1.94 \mathrm{~g}, 5.92 \mathrm{mmol})$ and triphenylphosphine (49 mg, $0.19 \mathrm{mmol})$ were added to a solution of $\mathbf{6 3}(1.52 \mathrm{~g}, 3.95 \mathrm{mmol})$ in toluene $(33 \mathrm{~mL})$ at room temperature. The mixture was stirred under $\mathrm{N}_{2}$ at $110{ }^{\circ} \mathrm{C}$ for $18 \mathrm{~h}$. The reaction was quenched with $\mathrm{H}_{2} \mathrm{O}(60 \mathrm{~mL})$ and extracted with EtOAc $(3 \times 40 \mathrm{~mL})$, dried $\left(\mathrm{MgSO}_{4}\right)$ and the solvents were removed on a rotary evaporator at water aspirator pressure. Purification by chromatography (hexanes/EtOAc, 40:1) gave 64 (1.125 g, 2.67 mmol, $68 \%$ ) as a yellow solid.

Spectral data for 64: $\mathrm{mp} 78.5-79{ }^{\circ} \mathrm{C} ;{ }^{1} \mathrm{H}$ NMR $\left(400 \mathrm{MHz}, \mathrm{CDCl}_{3}\right) \delta 7.70(\mathrm{dd}, J=8.1,0.8 \mathrm{~Hz}$, 1H), $7.36(\mathrm{t}, J=8.1 \mathrm{~Hz}, 1 \mathrm{H}), 7.33(\mathrm{~d}, J=8.7 \mathrm{~Hz}, 2 \mathrm{H}), 7.11(\mathrm{dd}, J=8.2,0.6 \mathrm{~Hz}, 1 \mathrm{H}), 6.94(\mathrm{~d}$, $J=8.8 \mathrm{~Hz}, 2 \mathrm{H}), 5.02(\mathrm{~s}, 2 \mathrm{H}), 3.83(\mathrm{~s}, 3 \mathrm{H}), 0.27(\mathrm{~s}, 9 \mathrm{H}) ;{ }^{13} \mathrm{C} \mathrm{NMR}\left(100 \mathrm{MHz}, \mathrm{CDCl}_{3}\right) \delta$ 164.0, 159.6, 155.9, 130.4, 129.6, 127.9, 127.8, 116.4, 115.3, 113.9, 70.7, 55.2, -5.6; IR (ATR) 3355, 2930, 1666, 1612, 1512, 1247, 1017, 861, $741 \mathrm{~cm}^{-1}$; HRMS (ESI) calcd for $\mathrm{C}_{17} \mathrm{H}_{21} \mathrm{NNaO}_{4} \mathrm{Sn}\left(\mathrm{M}+\mathrm{Na}^{+}\right)$446.0390, found 446.0385.

\section{\{3-[2-(4-Methoxy-benzyloxy)-6-nitro-phenyl]-but-3-enyl\}-carbamic acid methyl ester} (65)

A solution of 64 (3.3 g, $7.82 \mathrm{mmol}), 51$ (1.66 g, $6.51 \mathrm{mmol}), \mathrm{Pd}(\mathrm{dba})_{2}(187 \mathrm{mg}, 0.33 \mathrm{mmol})$, triphenylphosphine (341.6 mg, $1.30 \mathrm{mmol})$, and copper (I) iodide (930.4 mg, $4.89 \mathrm{mmol}) \mathrm{in}$ DMF (116.5 mL) was stirred at r.t. for $22 \mathrm{~h}$. The reaction was diluted with $\mathrm{H}_{2} \mathrm{O}(1 \mathrm{~L})$ and extracted with EtOAc $(3 \times 300 \mathrm{~mL})$, dried $\left(\mathrm{MgSO}_{4}\right)$ and the solvents were removed on a rotary evaporator at water aspirator pressure. Purification by chromatography 
(hexanes/EtOAc, 10:1, then hexanes/EtOAc, 5:1) gave $65(2.05 \mathrm{~g}, 5.31 \mathrm{mmol}, 81 \%)$ as a yellow solid.

Spectral data for 65: $\mathrm{mp} 77-77.5{ }^{\circ} \mathrm{C} ;{ }^{1} \mathrm{H}$ NMR $\left(600 \mathrm{MHz}, \mathrm{CDCl}_{3}, 65{ }^{\circ} \mathrm{C}\right) \quad \delta$ 7.29-7.34 (m, 2H), $7.28(\mathrm{~d}, J=8.5 \mathrm{~Hz}, 2 \mathrm{H}), 7.13(\mathrm{dd}, J=7.9,1.3 \mathrm{~Hz}, 1 \mathrm{H}), 6.90(\mathrm{~d}, J=8.6 \mathrm{~Hz}, 2 \mathrm{H}), 5.21(\mathrm{~s}$, 1H), $5.03(\mathrm{~s}, 2 \mathrm{H}), 4.96(\mathrm{~s}, 1 \mathrm{H}), 4.89$ (br s, 1H), $3.80(\mathrm{~s}, 3 \mathrm{H}), 3.60(\mathrm{~s}, 3 \mathrm{H}), 3.31$ (q, J = $6.4 \mathrm{~Hz}$, 2H), $2.95(\mathrm{t}, J=6.4 \mathrm{~Hz}, 2 \mathrm{H}) .{ }^{13} \mathrm{C} \mathrm{NMR}\left(150 \mathrm{MHz}, \mathrm{CDCl}_{3}, 65{ }^{\circ} \mathrm{C}\right) \delta 160.0,156.9,156.8$, $150.8,140.0,129.1,128.6,127.9,126.8,116.9,116.3,115.8,114.4,71.4,55.3,51.7,39.1$, 36.6; IR (ATR) 2933, 1706, 1514, 1247, 1029, 817, $741 \mathrm{~cm}^{-1}$; HRMS (ESI) calcd for $\mathrm{C}_{20} \mathrm{H}_{22} \mathrm{~N}_{2} \mathrm{NaO}_{6}\left(\mathrm{M}+\mathrm{Na}^{+}\right)$409.1376, found 409.1370.

\section{2-Iodo-1-methoxymethoxy-3-nitro-benzene (66)}

Chloromethyl methyl ether $(8.68 \mathrm{~mL}, 114.28 \mathrm{mmol})$ was added to a solution of 2-iodo-3nitrophenol (13.41 g, $50.60 \mathrm{mmol})$ and potassium carbonate (28 g, $202.59 \mathrm{mmol})$ in DMF (73 mL). The mixture was stirred under $\mathrm{N}_{2}$ at room temperature for $1.5 \mathrm{~h}$. The reaction was quenched with $\mathrm{H}_{2} \mathrm{O}(300 \mathrm{~mL})$ and extracted with Ether $(3 \times 150 \mathrm{~mL})$, dried $\left(\mathrm{MgSO}_{4}\right)$ and the solvents were removed on a rotary evaporator at water aspirator pressure. Purification by chromatography (hexanes/EtOAc, 20:1) gave 66 (12.55 g, $40.61 \mathrm{mmol}, 80 \%)$ as a yellow solid.

Spectral data for 66: $\mathrm{mp} 64-64.5{ }^{\circ} \mathrm{C} ;{ }^{1} \mathrm{H} \mathrm{NMR}\left(400 \mathrm{MHz}, \mathrm{CDCl}_{3}\right) \delta 7.37(\mathrm{t}, J=7.7 \mathrm{~Hz}, 1 \mathrm{H})$, $7.29(\mathrm{dd}, J=8.0,1.4 \mathrm{~Hz}, 1 \mathrm{H}), 7.22(\mathrm{dd}, J=8.2,1.4 \mathrm{~Hz}, 1 \mathrm{H}), 5.28(\mathrm{~s}, 2 \mathrm{H}), 3.49(\mathrm{~s}, 3 \mathrm{H}) ;{ }^{13} \mathrm{C}$ NMR (100 MHz, $\left.\mathrm{CDCl}_{3}\right) \delta 157.5,155.3,129.9,117.7,117.2,95.2,80.8,56.6$; IR (ATR) 2937, 1535, 1458, 1375, 1254, 1152, 1002, $895 \mathrm{~cm}^{-1}$; HRMS (ESI) calcd for $\mathrm{C}_{8} \mathrm{H}_{9} \mathrm{INO}_{4}$ $\left(\mathrm{M}+\mathrm{H}^{+}\right)$309.9576, found 309.9574. 


\section{(2-Methoxymethoxy-6-nitro-phenyl)-trimethyl-stannane (67)}

$\mathrm{Pd}\left(\mathrm{PPh}_{3}\right)_{2} \mathrm{Cl}_{2} \quad(402 \mathrm{mg}, \quad 0.57 \mathrm{mmol})$, hexamethylditin $\left(\begin{array}{llll}9.38 & \mathrm{~g} & 28.63 \mathrm{mmol}\end{array}\right)$ and triphenylphosphine $(235 \mathrm{mg}, 0.90 \mathrm{mmol})$ were added to a solution of $66(5.9 \mathrm{~g}, 19.09 \mathrm{mmol})$ in toluene $(165 \mathrm{~mL})$ at room temperature. The mixture was stirred under $\mathrm{N}_{2}$ at $110{ }^{\circ} \mathrm{C}$ for 15 h. The reaction was quenched with $\mathrm{H}_{2} \mathrm{O}(300 \mathrm{~mL})$ and extracted with EtOAc $(3 \times 150 \mathrm{~mL})$, dried $\left(\mathrm{MgSO}_{4}\right)$ and the solvents were removed on a rotary evaporator at water aspirator pressure. Purification by chromatography (hexanes/EtOAc, 40:1) gave 67 (5.23 g, 15.12 mmol, $79 \%)$ as a red oil.

Spectral data for 67: ${ }^{1} \mathrm{H} \mathrm{NMR}\left(400 \mathrm{MHz}, \mathrm{CDCl}_{3}\right) \delta 7.78(\mathrm{dd}, J=7.8,1.0 \mathrm{~Hz}, 1 \mathrm{H}), 7.40(\mathrm{t}, J$ $=8.1 \mathrm{~Hz}, 1 \mathrm{H}), 7.34(\mathrm{dd}, J=8.2,1.0 \mathrm{~Hz}, 1 \mathrm{H}), 5.19(\mathrm{~s}, 2 \mathrm{H}), 3.48(\mathrm{~s}, 3 \mathrm{H}), 0.36(\mathrm{~s}, 9 \mathrm{H}) ;{ }^{13} \mathrm{C}$ $\operatorname{NMR}\left(100 \mathrm{MHz}, \mathrm{CDCl}_{3}\right) \delta 162.8,155.6,130.5,128.0,117.7,117.4,94.4,56.2,-5.5 ; \mathrm{IR}$ (ATR) 2976, 2907, 1522, 1345, 1242, 1148, 1008, 895, $739 \mathrm{~cm}^{-1}$; HRMS (ESI) calcd for $\mathrm{C}_{10} \mathrm{H}_{14} \mathrm{NO}_{4} \mathrm{Sn}\left(\mathrm{M}-\mathrm{CH}_{3}{ }^{+}\right) 331.9945$, found 331.9942.

\section{[3-(2-Methoxymethoxy-6-nitro-phenyl)-but-3-enyl]-carbamic acid methyl ester (68)}

A solution of $\mathbf{6 7}(4.25 \mathrm{~g}, 12.30 \mathrm{mmol}), \mathbf{5 1}(2.61 \mathrm{~g}, 10.23 \mathrm{mmol}), \mathrm{Pd}(\mathrm{dba})_{2}(353.8 \mathrm{mg}, 0.62$ mmol), triphenylphosphine (643 mg, $2.45 \mathrm{mmol})$, and copper (I) iodide (1.76 g, $9.24 \mathrm{mmol})$ in DMF (190 mL) was stirred at room temperature under $\mathrm{N}_{2}$ for $24 \mathrm{~h}$. The reaction was diluted with $\mathrm{H}_{2} \mathrm{O}(1 \mathrm{~L})$ and extracted with EtOAc $(3 \times 300 \mathrm{~mL})$, dried $\left(\mathrm{MgSO}_{4}\right)$ and the solvents were removed on a rotary evaporator at water aspirator pressure. Purification by chromatography $\left(\mathrm{CH}_{2} \mathrm{Cl}_{2}\right.$ then hexanes/EtOAc, 2:1) gave $68(2.50 \mathrm{~g}, 8.04 \mathrm{mmol}, 79 \%)$ as a yellow oil.

Spectral data for 68: ${ }^{1} \mathrm{H}$ NMR $\left(600 \mathrm{MHz}, \mathrm{CDCl}_{3}, 65{ }^{\circ} \mathrm{C}\right) \delta 7.39(\mathrm{t}, J=4.6 \mathrm{~Hz}, 1 \mathrm{H}), 7.32(\mathrm{~d}$, $J=4.6 \mathrm{~Hz}, 2 \mathrm{H}), 5.25(\mathrm{~s}, 1 \mathrm{H}), 5.19(\mathrm{~s}, 2 \mathrm{H}), 5.03(\mathrm{br} \mathrm{s}, 1 \mathrm{H}), 4.98(\mathrm{~s}, 1 \mathrm{H}), 3.65$ (s, 3H), 3.47 (s, 
$3 \mathrm{H}), 3.38(\mathrm{q}, J=6.4 \mathrm{~Hz}, 2 \mathrm{H}), 2.68(\mathrm{t}, J=6.4 \mathrm{~Hz}, 2 \mathrm{H}) ;{ }^{13} \mathrm{C} \mathrm{NMR}\left(100 \mathrm{MHz}, \mathrm{CDCl}_{3}\right) \delta 156.5$, $154.4,149.8,139.7,128.2,126.2,117.6,116.0,115.7,94.3,55.8,51.2,38.5,35.7$; IR (ATR) 2955, 1708, 1526, 1252, 1152, 1006, 905, $727 \mathrm{~cm}^{-1}$; HRMS (ESI) calcd for $\mathrm{C}_{14} \mathrm{H}_{19} \mathrm{~N}_{2} \mathrm{O}_{6}$ $\left(\mathrm{M}+\mathrm{H}^{+}\right)$311.1243, found 311.1240.

\section{[3-(2-Hydroxy-6-nitro-phenyl)-but-3-enyl]-carbamic acid methyl ester (54)}

$\mathrm{HCl}$ (conc., $8.2 \mathrm{~mL}$ ) was added to a solution of $\mathbf{6 8}(2.53 \mathrm{~g}, 8.15 \mathrm{mmol})$ in $\mathrm{MeOH}(82 \mathrm{~mL})$ at room temperature. The mixture was stirred at room temperature for $23 \mathrm{~h}$. The reaction was neutralized with $\mathrm{NaHCO}_{3}$ (aqueous, $\left.100 \mathrm{~mL}\right)$ and extracted with EtOAc $(3 \times 100 \mathrm{~mL})$, dried $\left(\mathrm{MgSO}_{4}\right)$ and the solvents were removed on a rotary evaporator at water aspirator pressure. Purification by chromatography (hexanes/EtOAc, 4:1, then hexanes/EtOAc, 2:1) gave 54 $(1.80 \mathrm{~g}, 6.76 \mathrm{mmol}, 83 \%)$ as a yellow solid.

Spectral data for 54: $\mathrm{mp} 121-121.5{ }^{\circ} \mathrm{C} ;{ }^{1} \mathrm{H} \mathrm{NMR}\left(600 \mathrm{MHz}, \mathrm{CDCl}_{3}, 65{ }^{\circ} \mathrm{C}\right) \quad \delta 7.49(\mathrm{dd}, J=$ 8.1, 1.0 Hz, 1H), $7.29(\mathrm{t}, J=8.2 \mathrm{~Hz}, 1 \mathrm{H}), 7.20(\mathrm{dd}, J=8.2,1.1 \mathrm{~Hz}, 1 \mathrm{H}), 7.06(\mathrm{br} \mathrm{s}, 1 \mathrm{H}), 5.50$ (s, 1H), 5.19 (s, 1H), 4.97 (br s, 1H), $3.68(\mathrm{~s}, 3 \mathrm{H}), 3.35(\mathrm{q}, J=6.2 \mathrm{~Hz}, 2 \mathrm{H}), 2.60(\mathrm{t}, J=6.2$ $\mathrm{Hz}, 2 \mathrm{H}) ;{ }^{13} \mathrm{C} \mathrm{NMR}\left(150 \mathrm{MHz}, \mathrm{CDCl}_{3}, 65^{\circ} \mathrm{C}\right) \delta 157.9,154.2,149.2,139.5,128.7,123.9$, 121.0, 119.2, 116.1, 52.3, 39.6, 37.7; IR (ATR) 3411, 1688, 1521, 1449, 1360, 1267, 818, $737 \mathrm{~cm}^{-1}$; HRMS (ESI) calcd for $\mathrm{C}_{12} \mathrm{H}_{14} \mathrm{~N}_{2} \mathrm{NaO}_{5}\left(\mathrm{M}+\mathrm{Na}^{+}\right)$289.0800, found 289.0795.

\section{Alternative synthesis of 54}

A solution of 2-iodo-3-nitrophenol (72 mg, $0.27 \mathrm{mmol}), 44$ (100 mg, $0.34 \mathrm{mmol}), \operatorname{Pd}(\mathrm{dba})_{2}$ (3.12 mg, $0.0054 \mathrm{mmol})$, butylated hydroxytoluene $(3.0 \mathrm{mg}, \quad 0.014 \mathrm{mmol})$, triphenylphosphine $(5.7 \mathrm{mg}, 0.022 \mathrm{mmol})$, and copper (I) iodide $(52.8 \mathrm{mg}, 0.28 \mathrm{mmol})$ in dioxane $(5 \mathrm{~mL})$ was stirred at $110{ }^{\circ} \mathrm{C}$ under $\mathrm{N}_{2}$ for $20 \mathrm{~h}$. The reaction was diluted with $\mathrm{H}_{2} \mathrm{O}$ 
$(10 \mathrm{~mL})$ and extracted with EtOAc $(3 \times 10 \mathrm{~mL})$, dried $\left(\mathrm{MgSO}_{4}\right)$ and the solvents were removed on a rotary evaporator at water aspirator pressure. Purification by chromatography (hexanes/EtOAc, 3:1) gave 54 (16 mg, $0.06 \mathrm{mmol}, 22 \%$ ) as a yellow solid.

\section{Trifluoro-methanesulfonic acid 2-(3-methoxycarbonylamino-1-methylene-propyl)-3- nitro-phenyl ester (53)}

Trifluoromethanesulfonic anhydride $(0.41 \mathrm{~mL}, 2.44 \mathrm{mmol})$ was added to a solution of $\mathbf{5 4}$ (599 mg, $2.25 \mathrm{mmol})$ and triethylamine $(1.03 \mathrm{~mL}, 7.39 \mathrm{mmol})$ in $\mathrm{CH}_{3} \mathrm{CN}(10 \mathrm{~mL})$ at $0{ }^{\circ} \mathrm{C}$. The mixture was warmed to room temperature and stirred for $2 \mathrm{~h}$. The reaction was quenched with $\mathrm{H}_{2} \mathrm{O}(30 \mathrm{~mL})$ and extracted with EtOAc $(3 \times 20 \mathrm{~mL})$, dried $\left(\mathrm{MgSO}_{4}\right)$ and the solvents were removed on a rotary evaporator at water aspirator pressure. Purification by chromatography (hexanes/EtOAc, 2:1) gave 53 (773 mg, $1.94 \mathrm{mmol}, 86 \%$ ) as a yellow oil. Spectral data for 53: ${ }^{1} \mathrm{H} \mathrm{NMR}\left(600 \mathrm{MHz}, \mathrm{CDCl}_{3}, 65{ }^{\circ} \mathrm{C}\right) \delta 7.85(\mathrm{dd}, J=6.5,2.8 \mathrm{~Hz}, 1 \mathrm{H})$, 7.52-7.56 (m, 2H), $5.47(\mathrm{~s}, 1 \mathrm{H}), 5.19(\mathrm{~s}, 1 \mathrm{H}), 4.89$ (br s, 1H), $3.66(\mathrm{~s}, 3 \mathrm{H}), 3.42$ (q, $J=6.5$ $\mathrm{Hz}, 2 \mathrm{H}), 2.66(\mathrm{t}, J=6.6 \mathrm{~Hz}, 2 \mathrm{H}) .{ }^{13} \mathrm{C} \mathrm{NMR}\left(150 \mathrm{MHz}, \mathrm{CDCl}_{3}, 65{ }^{\circ} \mathrm{C}\right) \delta 160.0,150.6,147.2$, $137.1,131.9,129.4,125.5,123.7,121.8,120.1,119.7,117.5,115.4,51.9,39.0,36.3$; IR (ATR) 3344, 1702, 1533, 1423, 1211, 1136, 947, $845 \mathrm{~cm}^{-1}$; HRMS (ESI) calcd for $\mathrm{C}_{13} \mathrm{H}_{13} \mathrm{~F}_{3} \mathrm{~N}_{2} \mathrm{NaO}_{7} \mathrm{~S}\left(\mathrm{M}+\mathrm{Na}^{+}\right)$421.0293, found 421.0288 .

\section{Alternative synthesis of 53}

A solution of 52 (34 mg, $0.086 \mathrm{mmol}), 44$ (30 mg, $0.10 \mathrm{mmol}), \mathrm{Pd}\left(\mathrm{PPh}_{3}\right)_{2} \mathrm{Cl}_{2}(3 \mathrm{mg}, 0.0043$ $\mathrm{mmol})$, triphenylphosphine $(2.25 \mathrm{mg}, 0.0086 \mathrm{mmol})$, and copper (I) iodide $(12.2 \mathrm{mg}, 0.064$ mmol) in DMF (1 mL) was stirred at room temperature under $\mathrm{N}_{2}$ for $26 \mathrm{~h}$. The reaction was diluted with $\mathrm{H}_{2} \mathrm{O}(5 \mathrm{~mL})$ and extracted with EtOAc $(3 \times 5 \mathrm{~mL})$, dried $\left(\mathrm{MgSO}_{4}\right)$ and the 
solvents were removed on a rotary evaporator at water aspirator pressure. Purification by chromatography (hexanes/EtOAc, 5:1) gave $\mathbf{5 3}(7.5 \mathrm{mg}, 0.019 \mathrm{mmol}, 22 \%$ ) as a yellow oil.

\{3-[2-(3-Hydroxy-3-methyl-but-1-enyl)-6-nitro-phenyl]-but-3-enyl\}-carbamic acid methyl ester (69)

$\mathrm{Pd}\left(\mathrm{PPh}_{3}\right)_{2} \mathrm{Cl}_{2}(272.6 \mathrm{mg}, 0.39 \mathrm{mmol})$, triethylamine $(1.22 \mathrm{~mL}, 8.75 \mathrm{mmol})$, lithium chloride (247 $\mathrm{mg}, 5.83 \mathrm{mmol})$ and 2-methyl-3-buten-2-ol (2.03 $\mathrm{mL}, 19.42 \mathrm{mmol})$ were added to a solution of $\mathbf{5 3}(773 \mathrm{mg}, 1.94 \mathrm{mmol})$ in DMF (41 mL) at room temperature. The mixture was stirred under $\mathrm{N}_{2}$ at $120{ }^{\circ} \mathrm{C}$ for $14 \mathrm{~h}$. The reaction was quenched with $\mathrm{H}_{2} \mathrm{O}(150 \mathrm{~mL})$ and extracted with EtOAc $(3 \times 60 \mathrm{~mL})$, dried $\left(\mathrm{MgSO}_{4}\right)$ and the solvents were removed on a rotary evaporator at water aspirator pressure. Purification by chromatography (hexanes/EtOAc, 2:1) gave 69 (355 mg, $1.06 \mathrm{mmol}, 55 \%)$ as a brown oil.

Spectral data for 69: ${ }^{1} \mathrm{H}$ NMR $\left(600 \mathrm{MHz}, \mathrm{CDCl}_{3}, 65{ }^{\circ} \mathrm{C}\right) \delta 7.67(\mathrm{~d}, J=7.9 \mathrm{~Hz}, 1 \mathrm{H}), 7.63(\mathrm{~d}$, $J=7.5 \mathrm{~Hz}, 1 \mathrm{H}), 7.35(\mathrm{t}, J=7.9 \mathrm{~Hz}, 1 \mathrm{H}), 6.79(\mathrm{~d}, J=16.0 \mathrm{~Hz}, 1 \mathrm{H}), 6.31(\mathrm{~d}, J=16.0 \mathrm{~Hz}, 1 \mathrm{H})$, $5.31(\mathrm{~s}, 1 \mathrm{H}), 5.03(\mathrm{~s}, 1 \mathrm{H}), 4.93(\mathrm{br} \mathrm{s}, 1 \mathrm{H}), 3.66(\mathrm{~s}, 3 \mathrm{H}), 3.41$ (br s, 2H), 2.61 (br s, 2H), 1.42 (s, 6H); ${ }^{13} \mathrm{C}$ NMR $\left(150 \mathrm{MHz}, \mathrm{CDCl}_{3}\right) \delta 157.1,149.9,142.3,141.8,137.8,135.2,129.7$, 127.8, 122.9, 122.1, 115.8, 70.8, 52.2, 38.8, 36.3, 30.0, 29.3; IR (ATR) 3429, 2975, 1698, 1525, 1359, 1265, 908, $658 \mathrm{~cm}^{-1}$; HRMS (ESI) calcd for $\mathrm{C}_{17} \mathrm{H}_{22} \mathrm{~N}_{2} \mathrm{NaO}_{5}\left(\mathrm{M}+\mathrm{Na}^{+}\right) 357.1426$, found 357.1415 .

\{2-[4-(3-Methyl-buta-1,3-dienyl)-1H-indol-3-yl]-ethyl\}-carbamic acid methyl ester (70) A solution of $69(153 \mathrm{mg}, 0.46 \mathrm{mmol}), \mathrm{Pd}(\mathrm{dba})_{2}(15.79 \mathrm{mg}, 0.028 \mathrm{mmol}), 1,3-$ bis(diphenylphosphino)propane $(11.32 \mathrm{mg}, 0.028 \mathrm{mmol})$ and 1,10-phenanthroline $(9.9 \mathrm{mg}$, $0.055 \mathrm{mmol})$ in anhydrous DMF $(1.5 \mathrm{~mL})$ in a Teflon screw-capped ACE-Glass pressure 
tube was saturated with carbon monoxide (4 cycles to 6 atm of $\mathrm{CO}$ ). The reaction mixture was stirred under $\mathrm{CO}(6 \mathrm{~atm})$ at $120{ }^{\circ} \mathrm{C}$ for $24 \mathrm{~h}$. The mixture was cooled to ambient temperature, diluted with EtOAc $(10 \mathrm{~mL})$, and washed with brine $(2 \times 10 \mathrm{~mL})$. The organic phase was dried $\left(\mathrm{MgSO}_{4}\right)$ and filtered. The solvent was removed, and the resulting residue was purified by chromatography (hexanes/EtOAc, $2: 1)$ to afford 70 (67 mg, $0.24 \mathrm{mmol}, 52$ $\%)$ as a yellow solid.

Spectral data for 70: mp 129.5-130 ${ }^{\circ} \mathrm{C} ;{ }^{1} \mathrm{H} \mathrm{NMR}\left(600 \mathrm{MHz}, \mathrm{CDCl}_{3}, 65{ }^{\circ} \mathrm{C}\right) \delta 7.93(\mathrm{br} \mathrm{s}, 1 \mathrm{H})$, 7.11-7.22 (m, 3H), $7.06(\mathrm{t}, J=7.7 \mathrm{~Hz}, 1 \mathrm{H}), 6.91(\mathrm{~s}, 1 \mathrm{H}), 6.75(\mathrm{~d}, J=15.8 \mathrm{~Hz}, 1 \mathrm{H}), 5.04(\mathrm{~s}$, 1H), 4.99 (s, 1H), 4.55 (br s, 1H), $3.56(\mathrm{~s}, 3 \mathrm{H}), 3.43(\mathrm{q}, J=6.3 \mathrm{~Hz}, 2 \mathrm{H}), 3.04(\mathrm{t}, J=6.7 \mathrm{~Hz}$, 2H), $1.94(\mathrm{~s}, 3 \mathrm{H}) ;{ }^{13} \mathrm{C} \mathrm{NMR}\left(150 \mathrm{MHz}, \mathrm{CDCl}_{3}\right) \delta$ 157.0, 142.2, 137.3, 133.2, 131.5, 127.0, 124.6, 123.3, 122.4, 117.1, 117.1, 113.3, 110.5, 52.0, 41.5, 28.1, 18.7; IR (ATR) 3387, 3295, 2943, 1695, 1521, 1342, 1254, 1234, 963, $745 \mathrm{~cm}^{-1}$; HRMS (ESI) calcd for $\mathrm{C}_{17} \mathrm{H}_{20} \mathrm{~N}_{2} \mathrm{NaO}_{2}$ $\left(\mathrm{M}+\mathrm{Na}^{+}\right)$307.1422, found 307.1419.

Methyl-\{2-[4-(3-methyl-buta-1,3-dienyl)-1H-indol-3-yl]-ethyl\}-amine

(dehydrated ergotryptamine)

To a solution of 70 (42 mg, $0.15 \mathrm{mmol})$ in anhydrous toluene (14 mL) was added sodium bis(2-methoxyethoxy)aluminumhydride (in toluene $~ 3.5 \mathrm{M}, 0.94 \mathrm{~mL}, 3.29 \mathrm{mmol}$ ) dropwise. The mixture was stirred at $110{ }^{\circ} \mathrm{C}$ for $2 \mathrm{~h}$ and then allowed to cool to ambient temperature. Brine $(30 \mathrm{~mL})$ was added, and the mixture was extracted with EtOAc $(5 \times 20 \mathrm{~mL})$. The organic phases were combined, dried $\left(\mathrm{MgSO}_{4}\right)$, and filtered. The solvent was removed, and the resulting residue was purified by chromatography ( $1 \% \mathrm{Et}_{3} \mathrm{~N}$ in EtOAc/MeOH, 5:1 ) to give dehydrated ergotryptamine $(25.3 \mathrm{mg}, 0.11 \mathrm{mmol}, 71 \%)$ as a yellow solid. Spectral data for dehydrated ergotryptamine: mp $157.5-158{ }^{\circ} \mathrm{C}$; ${ }^{1} \mathrm{H}$ NMR $(600 \mathrm{MHz}$, 
$\left.\mathrm{CDCl}_{3}\right) \delta 8.04$ (br s, 1H), $7.30(\mathrm{~d}, J=7.4 \mathrm{~Hz}, 1 \mathrm{H}), 7.29(\mathrm{~d}, J=15.8 \mathrm{~Hz}, 1 \mathrm{H}), 7.26(\mathrm{~d}, J=7.9$

$\mathrm{Hz}, 1 \mathrm{H}), 7.16(\mathrm{t}, J=7.7 \mathrm{~Hz}, 1 \mathrm{H}), 7.05(\mathrm{~d}, J=2.1 \mathrm{~Hz}, 1 \mathrm{H}), 6.87(\mathrm{~d}, J=16.0 \mathrm{~Hz}, 1 \mathrm{H}), 5.13(\mathrm{~s}$, 1H), $5.08(\mathrm{~s}, 1 \mathrm{H}), 3.14(\mathrm{t}, J=6.9 \mathrm{~Hz}, 2 \mathrm{H}), 2.94(\mathrm{t}, J=6.8 \mathrm{~Hz}, 2 \mathrm{H}), 2.44(\mathrm{~s}, 3 \mathrm{H}), 2.03(\mathrm{~s}, 3 \mathrm{H})$. ${ }^{13} \mathrm{C} \mathrm{NMR}\left(150 \mathrm{MHz}, \mathrm{CDCl}_{3}\right) \delta 142.3,137.3,132.8,131.5,127.3,124.8,123.2,122.3,116.9$, $116.8,114.3,110.5,52.2,36.3,28.1,18.7$; IR (ATR) 2935, 2851, 1608, 1450, 1343, 1103 , 962, $737 \mathrm{~cm}^{-1}$; HRMS (ESI) calcd for $\mathrm{C}_{16} \mathrm{H}_{21} \mathrm{~N}_{2}\left(\mathrm{M}+\mathrm{H}^{+}\right)$241.1705, found 241.1699.

\{3-[2-(3-Methyl-buta-1,3-dienyl)-6-nitro-phenyl]-but-3-enyl\}-carbamic acid methyl ester (71)

Pyridinium p-toluenesulfonate $(0.2 \mathrm{mg}, 0.00081 \mathrm{mmol})$ was added to a solution of 69 (4.5 $\mathrm{mg}, 0.014 \mathrm{mmol})$ in $\mathrm{CHCl}_{3}(0.8 \mathrm{~mL})$ at room temperature. The mixture was stirred at $55^{\circ} \mathrm{C}$ for $22 \mathrm{~h}$ then cooled to room temperature. The solvent was removed on a rotary evaporator at water aspirator pressure. Purification by chromatography (hexanes/EtOAc, 3:1) gave 71 (3 $\mathrm{mg}, 0.0095 \mathrm{mmol}, 70 \%$ ) as a colorless oil.

Spectral data for 71: ${ }^{1} \mathrm{H}$ NMR $\left(400 \mathrm{MHz}, \mathrm{CDCl}_{3}\right) \delta 7.77(\mathrm{dd}, J=7.9,0.9 \mathrm{~Hz}, 1 \mathrm{H}), 7.65(\mathrm{dd}$, $J=8.1,1.2 \mathrm{~Hz}, 1 \mathrm{H}), 7.38(\mathrm{td}, J=8.0,0.5 \mathrm{~Hz}, 1 \mathrm{H}), 6.83(\mathrm{~d}, J=16.1 \mathrm{~Hz}, 1 \mathrm{H}), 6.59(\mathrm{~d}, J=16.1$ Hz, 1H), 5.35 (s, 1H), $5.18(\mathrm{~s}, 1 \mathrm{H}), 5.16(\mathrm{~s}, 1 \mathrm{H}), 5.04$ (s, 1H), 4.95 (br s, 1H), 3.66 (s, 3H), 3.32-3.53 (m, 2H), 2.49-2.69 (m, 2H), $1.94(\mathrm{~s}, 3 \mathrm{H})$.

\section{5-Methylene-1-(2-methyl-propenyl)-6-nitro-1,3,4,5-tetrahydro-benzo[c]azepine-2- carboxylic acid methyl ester (72)}

$\mathrm{BF}_{3} \cdot \mathrm{OEt}_{2}\left(48 \% \mathrm{BF}_{3}, 0.024 \mathrm{~mL}\right)$ was added to a solution of $69(30 \mathrm{mg}, 0.0897 \mathrm{mmol})$ in diethyl ether $(3 \mathrm{~mL})$ at $-78{ }^{\circ} \mathrm{C}$ under $\mathrm{N}_{2}$. The mixture was stirred for $1.5 \mathrm{~h}$ at $-78{ }^{\circ} \mathrm{C}$ then warmed to room temperature and stirred for $1 \mathrm{~h}$. Additional $\mathrm{BF}_{3} \cdot \mathrm{OEt}_{2}\left(48 \% \mathrm{BF}_{3}, 0.01 \mathrm{~mL}\right)$ 
was added and the mixture was stirred for additional $0.5 \mathrm{~h}$ at room temperature. The reaction was quenched with $\mathrm{Na}_{2} \mathrm{CO}_{3} \cdot 10 \mathrm{H}_{2} \mathrm{O}$ and dried $\left(\mathrm{MgSO}_{4}\right)$. The mixture was filtered and the solvents were removed on a rotary evaporator at water aspirator pressure. Purification by chromatography (hexanes/EtOAc, 10:1) gave $72(16 \mathrm{mg}, 0.051 \mathrm{mmol}, 56 \%)$ as a yellow solid.

Spectral data for major rotamer of 72: ${ }^{1} \mathrm{H}$ NMR $\left(600 \mathrm{MHz}, \mathrm{d}-\mathrm{DMSO}, 75{ }^{\circ} \mathrm{C}\right) \delta 7.67(\mathrm{dd}, J=$ 7.9, $1.1 \mathrm{~Hz}, 1 \mathrm{H}), 7.49(\mathrm{~d}, J=7.1 \mathrm{~Hz}, 1 \mathrm{H}), 7.44(\mathrm{t}, J=7.9 \mathrm{~Hz}, 1 \mathrm{H}), 5.88(\mathrm{~d}, J=6.2 \mathrm{~Hz}, 1 \mathrm{H})$, $5.50(\mathrm{~d}, J=8.2 \mathrm{~Hz}, 1 \mathrm{H}), 5.27(\mathrm{~s}, 1 \mathrm{H}), 4.94(\mathrm{~s}, 1 \mathrm{H}), 3.86-3.96(\mathrm{~m}, 1 \mathrm{H}), 3.60(\mathrm{~s}, 3 \mathrm{H}), 3.40$ (ddd, $J=14.3,10.7,3.9 \mathrm{~Hz}, 1 \mathrm{H}), 2.61(\mathrm{td}, J=13.1,3.8 \mathrm{~Hz}, 1 \mathrm{H}), 2.50-2.55(\mathrm{~m}, 1 \mathrm{H}), 1.75(\mathrm{~s}$, 3H), 1.69 (s, 3H).

Spectral data for 72 as mixture of rotamers: $\mathrm{mp} 94-94.5{ }^{\circ} \mathrm{C} ;{ }^{13} \mathrm{C} \mathrm{NMR}\left(150 \mathrm{MHz}, \mathrm{CDCl}_{3}, 65\right.$ $\left.{ }^{\circ} \mathrm{C}\right) \delta 156.0,151.4,143.5,142.0,138.3,135.0,131.7,127.5,121.9,121.3,117.9,59.1,52.7$, 52.6, 43.5, 37.1, 25.6, 25.6, 18.3; IR (ATR) 2956, 1694, 1528, 1439, 1364, 1247, 912, 729 $\mathrm{cm}^{-1}$; HRMS (ESI) calcd for $\mathrm{C}_{17} \mathrm{H}_{21} \mathrm{~N}_{2} \mathrm{O}_{4}\left(\mathrm{M}+\mathrm{H}^{+}\right)$317.1501, found 317.1498.

6-(2-Methyl-propenyl)-3,4-dihydro-1H,6H-azepino[5,4,3-cd]indole-5-carboxylic acid methyl ester (73)

A solution of $72(203 \mathrm{mg}, 0.64 \mathrm{mmol}), \quad \mathrm{Pd}(\mathrm{dba})_{2}(22 \mathrm{mg}, 0.038 \mathrm{mmol}), \quad 1,3-$ bis(diphenylphosphino)propane $(15.87 \mathrm{mg}, 0.039 \mathrm{mmol})$, and 1,10-phenanthroline (13.84 $\mathrm{mg}, 0.077 \mathrm{mmol})$ in anhydrous DMF $(3.5 \mathrm{~mL})$ in a Teflon screw-capped ACE-Glass pressure tube was saturated with carbon monoxide ( 4 cycles to $6 \mathrm{~atm}$ of $\mathrm{CO}$ ). The reaction mixture was stirred under $\mathrm{CO}(6 \mathrm{~atm})$ at $120{ }^{\circ} \mathrm{C}$ for $24 \mathrm{~h}$. The mixture was cooled to ambient temperature, diluted with EtOAc $(20 \mathrm{~mL})$, and washed with brine $(2 \times 20 \mathrm{~mL})$. The organic phase was dried $\left(\mathrm{MgSO}_{4}\right)$ and filtered. The solvent was removed, and the resulting residue 
was purified by chromatography (hexanes/EtOAc, 2:1) to afford 73 (138 mg, $0.49 \mathrm{mmol}, 76$ $\%)$ as a yellow solid.

Spectral data for 73 as mixture of rotamers: mp 180.5-181 ${ }^{\circ} \mathrm{C} ;{ }^{1} \mathrm{H}$ NMR $\left(600 \mathrm{MHz}, \mathrm{CDCl}_{3}\right) \delta$ $8.12(\mathrm{~s}, 0.5 \mathrm{H}), 8.09(\mathrm{~s}, 0.5 \mathrm{H}), 7.22(\mathrm{~d}, J=8.1 \mathrm{~Hz}, 0.5 \mathrm{H}), 7.19(\mathrm{~d}, J=8.0 \mathrm{~Hz}, 0.5 \mathrm{H}), 7.11(\mathrm{t}, J$ $=7.4 \mathrm{~Hz}, 0.5 \mathrm{H}), 7.10(\mathrm{t}, J=7.5 \mathrm{~Hz}, 0.5 \mathrm{H}), 7.00(\mathrm{~s}, 0.5 \mathrm{H}), 6.98(\mathrm{~s}, 0.5 \mathrm{H}), 6.87(\mathrm{~d}, J=7.3 \mathrm{~Hz}$, $0.5 \mathrm{H}), 6.82(\mathrm{~d}, J=7.3 \mathrm{~Hz}, 0.5 \mathrm{H}), 6.56(\mathrm{~d}, J=8.2 \mathrm{~Hz}, 0.5 \mathrm{H}), 6.36(\mathrm{~d}, J=8.0 \mathrm{~Hz}, 0.5 \mathrm{H}), 5.37$ $(\mathrm{d}, J=8.6 \mathrm{~Hz}, 0.5 \mathrm{H}), 5.36(\mathrm{~d}, J=8.2 \mathrm{~Hz}, 0.5 \mathrm{H}), 4.08(\mathrm{td}, J=13.9,3.1 \mathrm{~Hz}, 0.5 \mathrm{H}), 3.95(\mathrm{td}, J$ $=14.1,3.1 \mathrm{~Hz}, 0.5 \mathrm{H}), 3.73(\mathrm{~s}, 1.5 \mathrm{H}), 3.71(\mathrm{~s}, 1.5 \mathrm{H}), 3.50-3.60(\mathrm{~m}, 1 \mathrm{H}), 3.30-3.38(\mathrm{~m}, 0.5 \mathrm{H})$, 3.19-3.27 (m, 0.5H), 3.01-3.04 (m, 0.5H), 2.98-3.01 (m, 0.5H), $1.89(\mathrm{~s}, 1.5 \mathrm{H}), 1.84(\mathrm{~s}$, 1.5H), $1.72(\mathrm{~s}, 3 \mathrm{H}) ;{ }^{13} \mathrm{C} \mathrm{NMR}\left(150 \mathrm{MHz}, \mathrm{CDCl}_{3}\right) \delta 156.4,155.8,137.3,137.2,137.0,136.0$, $135.7,125.2,124.2,124.1,121.9,121.7,121.4,121.0,118.3,117.7,114.7,114.4,109.3$, 109.1, 58.2, 58.1, 52.6, 52.5, 43.1, 42.8, 27.5, 26.6, 25.7, 25.7, 18.7, 18.4; IR (ATR) 3324, 2956, 1676, 1439, 1406, 1319, 913, 746, $730 \mathrm{~cm}^{-1}$; HRMS (ESI) calcd for $\mathrm{C}_{17} \mathrm{H}_{20} \mathrm{~N}_{2} \mathrm{NaO}_{2}$ $\left(\mathrm{M}+\mathrm{Na}^{+}\right)$307.1422, found 307.1418.

3-[2-(3-Methoxycarbonylamino-1-methylene-propyl)-3-nitro-phenyl]-acrylic

acid methyl ester (74)

$\mathrm{Pd}\left(\mathrm{PPh}_{3}\right)_{2} \mathrm{Cl}_{2}(90 \mathrm{mg}, 0.13 \mathrm{mmol})$, triethylamine $(0.40 \mathrm{~mL}, 2.89 \mathrm{mmol})$, lithium chloride $(81.5 \mathrm{mg}, 1.92 \mathrm{mmol})$ and methyl acrylate $(0.57 \mathrm{~mL}, 6.37 \mathrm{mmol})$ were added to a solution of 53 (255 mg, $0.64 \mathrm{mmol})$ in DMF $(13.5 \mathrm{~mL})$ at room temperature. The mixture was stirred under $\mathrm{N}_{2}$ at $120{ }^{\circ} \mathrm{C}$ for $12 \mathrm{~h}$. The reaction was quenched with $\mathrm{H}_{2} \mathrm{O}(80 \mathrm{~mL})$ and extracted with EtOAc $(3 \times 30 \mathrm{~mL})$, dried $\left(\mathrm{MgSO}_{4}\right)$ and the solvents were removed on a rotary evaporator at water aspirator pressure. Purification by chromatography (hexanes/EtOAc, 4:1) gave 74 (130 mg, $0.39 \mathrm{mmol}, 61 \%)$ as a brown oil. 
Spectral data for 74: ${ }^{1} \mathrm{H}$ NMR $\left(600 \mathrm{MHz}, \mathrm{CDCl}_{3}\right) \delta 7.79-7.83(\mathrm{~m}, 2 \mathrm{H}), 7.77(\mathrm{~d}, J=16.1 \mathrm{~Hz}$, 1H), $7.46(\mathrm{t}, J=8.0 \mathrm{~Hz}, 1 \mathrm{H}), 6.42(\mathrm{~d}, J=16.0 \mathrm{~Hz}, 1 \mathrm{H}), 5.42(\mathrm{~s}, 1 \mathrm{H}), 5.06(\mathrm{~s}, 1 \mathrm{H}), 5.03(\mathrm{br} \mathrm{s}$, $1 \mathrm{H}), 3.82(\mathrm{~s}, 3 \mathrm{H}), 3.66(\mathrm{~s}, 3 \mathrm{H}), 3.42(\mathrm{q}, J=6.1 \mathrm{~Hz}, 2 \mathrm{H}), 2.58-2.67(\mathrm{~m}, 1 \mathrm{H}), 2.49-2.58(\mathrm{~m}$, $1 \mathrm{H}) ;{ }^{13} \mathrm{C} \mathrm{NMR}\left(150 \mathrm{MHz}, \mathrm{CDCl}_{3}\right) \delta 166.5,160.0,149.9,140.8,140.4,137.0,135.0,130.4$, 128.3, 124.9, 121.8, 117.9, 52.1, 52.0, 38.5, 37.3; IR (ATR) 3343, 2952, 1709, 1527, 1318, 1245, 1174, $752 \mathrm{~cm}^{-1}$; HRMS (ESI) calcd for $\mathrm{C}_{16} \mathrm{H}_{18} \mathrm{~N}_{2} \mathrm{NaO}_{6}\left(\mathrm{M}+\mathrm{Na}^{+}\right)$357.1063, found 357.1058 .

\section{3-[3-(2-Methoxycarbonylamino-ethyl)-1H-indol-4-yl]-acrylic acid methyl ester (75)}

A solution of $74(121 \mathrm{mg}, 0.36 \mathrm{mmol}), \operatorname{Pd}(\mathrm{dba})_{2} \quad(12.46 \mathrm{mg}, 0.022 \mathrm{mmol}), \quad 1,3-$ bis(diphenylphosphino)propane $(8.95 \mathrm{mg}, 0.022 \mathrm{mmol})$, and 1,10-phenanthroline (7.82 $\mathrm{mg}$, $0.043 \mathrm{mmol})$ in anhydrous DMF $(1.4 \mathrm{~mL})$ in a Teflon screw-capped ACE-Glass pressure tube was saturated with carbon monoxide (4 cycles to 6 atm of $\mathrm{CO}$ ). The reaction mixture was stirred under $\mathrm{CO}(6 \mathrm{~atm})$ at $120{ }^{\circ} \mathrm{C}$ for $28 \mathrm{~h}$. The mixture was cooled to ambient temperature, diluted with EtOAc $(10 \mathrm{~mL})$, and washed with brine $(2 \times 10 \mathrm{~mL})$. The organic phase was dried $\left(\mathrm{MgSO}_{4}\right)$ and filtered. The solvent was removed, and the resulting residue was purified by chromatography (hexanes/EtOAc, 2:1) to afford 75 (91 mg, $0.30 \mathrm{mmol}, 83$ $\%)$ as a yellow oil.

Spectral data for 75: ${ }^{1} \mathrm{H}$ NMR $\left(600 \mathrm{MHz}, \mathrm{CDCl}_{3}\right) \delta 8.63$ (br s, $\left.1 \mathrm{H}\right), 8.43(\mathrm{~d}, J=15.8 \mathrm{~Hz}, 1 \mathrm{H})$, $7.39(\mathrm{~d}, J=8.0 \mathrm{~Hz}, 1 \mathrm{H}), 7.37(\mathrm{~d}, J=7.4 \mathrm{~Hz}, 1 \mathrm{H}), 7.17(\mathrm{t}, J=7.8 \mathrm{~Hz}, 1 \mathrm{H}), 7.06(\mathrm{~s}, 1 \mathrm{H}), 6.45$ $(\mathrm{d}, J=15.8 \mathrm{~Hz}, 1 \mathrm{H}), 5.09(\mathrm{br} \mathrm{s}, 1 \mathrm{H}), 3.83(\mathrm{~s}, 3 \mathrm{H}), 3.67(\mathrm{~s}, 3 \mathrm{H}), 3.52(\mathrm{q}, J=6.5 \mathrm{~Hz}, 2 \mathrm{H})$, $3.13(\mathrm{t}, J=7.0 \mathrm{~Hz}, 2 \mathrm{H}) ;{ }^{13} \mathrm{C} \mathrm{NMR}\left(100 \mathrm{MHz}, \mathrm{CDCl}_{3}\right) \delta 167.8,157.2,143.5,137.4,127.6$, 125.4, 124.4, 122.0, 118.2, 118.1, 113.3, 113.0, 52.0, 51.7, 41.3, 28.2; IR (ATR) 3329, 3212, 2948, 1689, 1526, 1251, 1161, 1042, 977, 746, $727 \mathrm{~cm}^{-1}$; HRMS (ESI) calcd for 
$\mathrm{C}_{16} \mathrm{H}_{18} \mathrm{~N}_{2} \mathrm{NaO}_{4}\left(\mathrm{M}+\mathrm{Na}^{+}\right)$325.1164, found 325.1159.

\{2-[4-(3-Hydroxy-3-methyl-but-1-enyl)-1H-indol-3-yl]-ethyl\}-carbamic acid methyl ester (61)

Methylmagnesium bromide $(3.0 \mathrm{M}$ in diethyl ether, $0.38 \mathrm{~mL}, 1.13 \mathrm{mmol}$ ) was added to a solution of $75(34 \mathrm{mg}, 0.11 \mathrm{mmol})$ in THF $(4 \mathrm{~mL})$ at $0{ }^{\circ} \mathrm{C}$ under $\mathrm{N}_{2}$. The mixture was warmed to room temperature and stirred for $1 \mathrm{~h}$. The reaction was quenched with $\mathrm{H}_{2} \mathrm{O}(10$ $\mathrm{mL})$ and extracted with EtOAc $(3 \times 10 \mathrm{~mL})$, dried $\left(\mathrm{MgSO}_{4}\right)$ and the solvents were removed on a rotary evaporator at water aspirator pressure. Purification by chromatography (hexanes/EtOAc, 2:1) gave 61 (13.2 mg, $0.044 \mathrm{mmol}, 39 \%)$ as a yellow solid.

Spectral data for 61: $\mathrm{mp} 100-100.5{ }^{\circ} \mathrm{C} ;{ }^{1} \mathrm{H}$ NMR (400 MHz, $\left.\mathrm{CDCl}_{3}\right) \delta 8.09$ (br s, $\left.1 \mathrm{H}\right), 7.41$ $(\mathrm{d}, J=15.7 \mathrm{~Hz}, 1 \mathrm{H}), 7.25(\mathrm{~d}, J=6.7 \mathrm{~Hz}, 1 \mathrm{H}), 7.11-7.21(\mathrm{~m}, 2 \mathrm{H}), 7.00(\mathrm{~s}, 1 \mathrm{H}), 6.32(\mathrm{~d}, J=$ $15.7 \mathrm{~Hz}, 1 \mathrm{H}), 5.04$ (br s, $1 \mathrm{H}), 3.68(\mathrm{~s}, 3 \mathrm{H}), 3.36-3.47(\mathrm{~m}, 2 \mathrm{H}), 3.05-3.13(\mathrm{~m}, 2 \mathrm{H}), 1.45$ (s, $6 \mathrm{H}) ;{ }^{13} \mathrm{C} \mathrm{NMR}\left(100 \mathrm{MHz}, \mathrm{CDCl}_{3}\right) \delta 157.2,140.4,137.1,131.7,124.6,124.2,123.2,122.3$, 117.5, 113.4, 110.2, 70.9, 52.2, 43.0, 30.0, 28.8; IR (ATR) 3392, 2967, 1701, 1525, 1264, 1148, 969, $748 \mathrm{~cm}^{-1}$; HRMS (ESI) calcd for $\mathrm{C}_{17} \mathrm{H}_{22} \mathrm{~N}_{2} \mathrm{NaO}_{3}\left(\mathrm{M}+\mathrm{Na}^{+}\right)$325.1528, found 325.1526.

\section{Acetic acid 1,4-dimethyl-2,5-dioxo-pyrrolidin-3-yl ester (86)}

A mixture of 2-hydroxy-3-methyl-succinic acid (83) $(200 \mathrm{mg}, 1.35 \mathrm{mmol})$ and $\mathrm{AcCl}(0.79$ $\mathrm{mL}$ ) was heated at $45^{\circ} \mathrm{C}$ for $1 \mathrm{~h}$, then another $0.51 \mathrm{~mL}$ of $\mathrm{AcCl}$ was added and heated for another $4 \mathrm{~h}$. The solvent was removed on a rotary evaporator at water aspirator pressure, and the residue was dissolved in $\mathrm{CH}_{2} \mathrm{Cl}_{2}(3 \mathrm{~mL})$ and cooled to $-78{ }^{\circ} \mathrm{C}$. To this was added a solution of methylamine $(2.0 \mathrm{M}$ in $\mathrm{THF}, 0.83 \mathrm{~mL})$ at $-78^{\circ} \mathrm{C}$. The resulting mixture was 
allowed to warm to room temperature and stirred overnight. The solvents were removed on a rotary evaporator at water aspirator pressure and $\mathrm{AcCl}(1.7 \mathrm{~mL})$ was added. The resulting mixture stirred at $50{ }^{\circ} \mathrm{C}$ for $11 \mathrm{~h}$. The $\mathrm{AcCl}$ was removed and purification by chromatography (hexanes/EtOAc, 4:1) gave $86(165 \mathrm{mg}, 0.89 \mathrm{mmol}, 66 \%, \boldsymbol{d r}=15: 1)$ as a colorless oil.

Spectral data for major isomer of 86: ${ }^{1} \mathrm{H} \mathrm{NMR}\left(400 \mathrm{MHz}, \mathrm{CDCl}_{3}\right) \delta 5.58(\mathrm{~d}, J=8.4 \mathrm{~Hz}, 1 \mathrm{H})$, 3.11 (pent, $J=7.8 \mathrm{~Hz}, 1 \mathrm{H}), 2.99(\mathrm{~s}, 3 \mathrm{H}), 2.15(\mathrm{~s}, 3 \mathrm{H}), 1.14(\mathrm{~d}, J=7.6 \mathrm{~Hz}, 3 \mathrm{H})$.

Partial spectral data for minor isomer of 86: ${ }^{1} \mathrm{H}$ NMR $\left(400 \mathrm{MHz}, \mathrm{CDCl}_{3}\right) \delta 5.13(\mathrm{~d}, J=5.2$ $\mathrm{Hz}, 1 \mathrm{H}), 2.75-2.82(\mathrm{~m}, 1 \mathrm{H}), 1.39(\mathrm{~d}, J=7.5 \mathrm{~Hz}, 3 \mathrm{H})$.

\section{Acetic acid 3-acetoxy-1,4-dimethyl-5-oxo-pyrrolidin-2-yl ester (82)}

To a solution of $\mathbf{8 6}$ (400 mg, $2.16 \mathrm{mmol})$ in $\mathrm{MeOH}(5 \mathrm{~mL})$ was added sodium borohydride (122.72 $\mathrm{mg}, 3.24 \mathrm{mmol})$ in one portion at $-40{ }^{\circ} \mathrm{C}$. After stirring for $10 \mathrm{~min}$ at $-40{ }^{\circ} \mathrm{C}$, saturated $\mathrm{NH}_{4} \mathrm{Cl}(10 \mathrm{~mL})$ was added and the solution was extracted with EtOAc $(4 \times 10 \mathrm{~mL})$. The combined organic phases were dried $\left(\mathrm{MgSO}_{4}\right)$, filtered, and the solvents were removed on a rotary evaporator at water aspirator pressure giving crude product as a white solid. The product was dissolved in $\mathrm{CH}_{2} \mathrm{Cl}_{2}(3.75 \mathrm{~mL})$ and added DMAP (14.67 $\left.\mathrm{mg}, 0.12 \mathrm{mmol}\right)$. The mixture was cooled to $0{ }^{\circ} \mathrm{C}$ and added acetic anhydride $(0.34 \mathrm{~mL}, 3.59 \mathrm{mmol})$ followed by triethylamine $(0.5 \mathrm{~mL}, 3.58 \mathrm{mmol})$. Then the mixture was warmed to room temperature and stirred for $2.5 \mathrm{~h}$. Brine $(15 \mathrm{~mL})$ was added, and the solution was extracted by EtOAc $(3 \times 15$ $\mathrm{mL})$. The combined organic phases were dried $\left(\mathrm{MgSO}_{4}\right)$, filtered, and the solvents were removed on a rotary evaporator at water aspirator pressure. Purification by chromatography (hexanes/EtOAc, 2:1) gave 82 (146 mg, $0.64 \mathrm{mmol}, 29 \%$ ) as a colorless oil.

Spectral data for 82: ${ }^{1} \mathrm{H}$ NMR $\left(400 \mathrm{MHz}, \mathrm{CDCl}_{3}\right) \delta 6.24(\mathrm{~d}, J=5.4 \mathrm{~Hz}, 1 \mathrm{H}), 5.28(\mathrm{dd}, J=$ 
8.2, $5.3 \mathrm{~Hz}, 1 \mathrm{H}), 2.82(\mathrm{~s}, 3 \mathrm{H}), 2.70$ (pent, $J=7.8 \mathrm{~Hz}, 1 \mathrm{H}), 2.06(\mathrm{~s}, 3 \mathrm{H}), 2.04$ (s, 3H), 1.17 (d, $J=7.6 \mathrm{~Hz}, 3 \mathrm{H})$.

\section{Acetic acid 2-(2-bromo-allyl)-1,4-dimethyl-5-oxo-pyrrolidin-3-yl ester (81)}

A solution of 82 (121 mg, $0.53 \mathrm{mmol})$ and 2-bromo-2-propen-1-yl trimethylsilane (13) (365 $\mu \mathrm{L}, 2.12 \mathrm{mmol})$ in $\mathrm{CH}_{2} \mathrm{Cl}_{2}(2.74 \mathrm{~mL})$ was cooled to $-78{ }^{\circ} \mathrm{C}$ and stirred for $15 \mathrm{~min}$. A solution of $\mathrm{TiCl}_{4}(116.4 \mu \mathrm{L}, 1.06 \mathrm{mmol})$ in $\mathrm{CH}_{2} \mathrm{Cl}_{2}(1.37 \mathrm{~mL})$ was added slowly. The cold bath was removed after $30 \mathrm{~min}$, and the mixture was stirred at ambient temperature for an additional 1 h. $\mathrm{Na}_{2} \mathrm{CO}_{3} \cdot 10 \mathrm{H}_{2} \mathrm{O}(1.76 \mathrm{~g})$ was added slowly. After stirring for $30 \mathrm{~min}$, the mixture was dried $\left(\mathrm{MgSO}_{4}\right)$ and filtered, and the solvent was removed. Purification by chromatography (hexanes/EtOAc, 2:1) gave 81 (144 mg, $0.50 \mathrm{mmol}, 94 \%$ ) as a colorless oil.

Spectral data for 81: ${ }^{1} \mathrm{H}$ NMR $\left(400 \mathrm{MHz}, \mathrm{CDCl}_{3}\right) \delta 5.71-5.74(\mathrm{~m}, 1 \mathrm{H}), 5.57(\mathrm{~d}, J=2.0 \mathrm{~Hz}$, $1 \mathrm{H}), 5.20(\mathrm{~d}, J=6.2 \mathrm{~Hz}, 1 \mathrm{H}), 3.65-3.71(\mathrm{~m}, 1 \mathrm{H}), 2.89(\mathrm{~d}, J=0.8 \mathrm{~Hz}, 3 \mathrm{H}), 2.67-2.78(\mathrm{~m}, 2 \mathrm{H})$, $2.59(\mathrm{ddd}, J=14.6,7.3,0.9 \mathrm{~Hz}, 1 \mathrm{H}), 2.07(\mathrm{~s}, 3 \mathrm{H}), 1.10(\mathrm{~d}, J=7.4 \mathrm{~Hz}, 3 \mathrm{H}) ;{ }^{13} \mathrm{C}$ NMR $(100$ $\left.\mathrm{MHz}, \mathrm{CDCl}_{3}\right) \delta 174.2,170.2,128.2,120.7,73.1,63.5,42.3,38.5,28.7,20.7,8.7$.

\section{Acetic acid 1,4-dimethyl-5-oxo-2-(2-trimethylstannanyl-allyl)-pyrrolidin-3-yl ester (87)}

A solution of $\mathbf{8 1}(30 \mathrm{mg}, 0.10 \mathrm{mmol}), \mathrm{Pd}(\mathrm{dba})_{2}(4.44 \mathrm{mg}, 0.0078 \mathrm{mmol})$, hexamethylditin (67.78 $\mathrm{mg}, 0.21 \mathrm{mmol})$, triphenylphosphine $(5.43 \mathrm{mg}, 0.021 \mathrm{mmol})$ and DIPEA $(3.6 \mu \mathrm{L}$, $0.021 \mathrm{mmol})$ in benzene $(0.6 \mathrm{~mL})$ was stirred at $80{ }^{\circ} \mathrm{C}$ for $4 \mathrm{~h}$. The mixture was cooled to ambient temperature and purified by chromatography (hexanes/EtOAc, 2:1) to afford 87 (26 $\mathrm{mg}, 0.07 \mathrm{mmol}, 67 \%$ ) as a yellow oil.

Spectral data for 87: ${ }^{1} \mathrm{H}$ NMR $\left(400 \mathrm{MHz}, \mathrm{CDCl}_{3}\right) \delta 5.77(\mathrm{~d}, J=1.2 \mathrm{~Hz}, 1 \mathrm{H}), 5.35(\mathrm{~d}, J=1.9$ $\mathrm{Hz}, 1 \mathrm{H}), 5.20(\mathrm{~d}, J=6.1 \mathrm{~Hz}, 1 \mathrm{H}), 3.38(\mathrm{dd}, J=9.4,4.7 \mathrm{~Hz}, 1 \mathrm{H}), 2.87(\mathrm{~s}, 3 \mathrm{H}), 2.65-2.76(\mathrm{~m}$, 
2H), $2.26(\mathrm{dd}, J=14.0,9.6 \mathrm{~Hz}, 1 \mathrm{H}), 2.04(\mathrm{~s}, 3 \mathrm{H}), 1.08(\mathrm{~d}, J=7.4 \mathrm{~Hz}, 3 \mathrm{H}), 0.17$ (s, 9H).

Acetic acid 2-\{2-[2-(4-methoxy-benzyloxy)-6-nitro-phenyl]-allyl\}-1,4-dimethyl-5-oxopyrrolidin-3-yl ester (80)

A solution of 81 (16 mg, $0.055 \mathrm{mmol}), 64(28 \mathrm{mg}, 0.066 \mathrm{mmol}), \mathrm{Pd}(\mathrm{dba})_{2}(1.6 \mathrm{mg}, 0.0028$ mmol), triphenylphosphine $(2.89 \mathrm{mg}, 0.011 \mathrm{mmol})$, and copper (I) iodide $(7.88 \mathrm{mg}, 0.041$ mmol) in DMF $(1 \mathrm{~mL})$ was stirred at room temperature for $22 \mathrm{~h}$. The reaction was diluted with $\mathrm{H}_{2} \mathrm{O}(5 \mathrm{~mL})$ and extracted with EtOAc $(3 \times 5 \mathrm{~mL})$, dried $\left(\mathrm{MgSO}_{4}\right)$ and the solvents were removed on a rotary evaporator at water aspirator pressure. Purification by chromatography (hexanes/EtOAc, 10:1, then hexanes/EtOAc, 2:1) gave $80(15.6 \mathrm{mg}, 0.033 \mathrm{mmol}, 60 \%$ ) as a yellow oil.

Spectral data for 80: ${ }^{1} \mathrm{H}$ NMR $\left(400 \mathrm{MHz}, \mathrm{CDCl}_{3}\right) \delta 7.37(\mathrm{~d}, J=3.6 \mathrm{~Hz}, 1 \mathrm{H}), 7.37(\mathrm{~d}, J=5.7$ $\mathrm{Hz}, 1 \mathrm{H}), 7.30(\mathrm{~d}, J=8.6 \mathrm{~Hz}, 2 \mathrm{H}), 7.16(\mathrm{dd}, J=5.7,3.7 \mathrm{~Hz}, 1 \mathrm{H}), 6.91(\mathrm{~d}, J=8.7 \mathrm{~Hz}, 2 \mathrm{H})$, $5.36(\mathrm{~d}, J=5.8 \mathrm{~Hz}, 1 \mathrm{H}), 5.23(\mathrm{~s}, 1 \mathrm{H}), 5.05(\mathrm{~d}, J=11.2 \mathrm{~Hz}, 1 \mathrm{H}), 5.03(\mathrm{~s}, 1 \mathrm{H}), 5.00(\mathrm{~d}, J=$ $11.1 \mathrm{~Hz}, 1 \mathrm{H}), 3.82(\mathrm{~s}, 3 \mathrm{H}), 3.67(\mathrm{dd}, J=11.1,3.1 \mathrm{~Hz}, 1 \mathrm{H}), 2.70-2.86(\mathrm{~m}, 4 \mathrm{H}), 2.38(\mathrm{br} \mathrm{s}$, 2H), $2.03(\mathrm{~s}, 3 \mathrm{H}), 0.96(\mathrm{~d}, J=5.3 \mathrm{~Hz}, 3 \mathrm{H})$.

\section{5-\{2-[2-(4-Methoxy-benzyloxy)-6-nitro-phenyl]-allylidene\}-1,3-dimethyl-1,5-dihydro- pyrrol-2-one (89) and tricyclic compound 90}

To a solution of $80(15 \mathrm{mg}, 0.032 \mathrm{mmol})$ in toluene $(0.65 \mathrm{~mL})$ was added DBU $(5.27 \mu \mathrm{L}$, $0.035 \mathrm{mmol})$. The mixture was stirred at $110{ }^{\circ} \mathrm{C}$ for $12 \mathrm{~h}$, then cooled to room temperature. Purification by chromatography (hexanes/EtOAc, 3:1) gave 89 (1.4 mg, $0.0034 \mathrm{mmol}, 11 \%$ ) followed by 90 (0.4 mg, $0.0011 \mathrm{mmol}, 3 \%$ ), then (hexanes/EtOAc, 2:1) gave 80 (3.7 mg, $0.0079 \mathrm{mmol}, 25 \%)$. 
Spectral data for 89: ${ }^{1} \mathrm{H}$ NMR $\left(600 \mathrm{MHz}, \mathrm{CDCl}_{3}\right) \delta 7.46(\mathrm{dd}, J=8.2,1.4 \mathrm{~Hz}, 1 \mathrm{H}), 7.43(\mathrm{t}, J$ $=8.0 \mathrm{~Hz}, 1 \mathrm{H}), 7.18(\mathrm{dd}, J=7.9,1.3 \mathrm{~Hz}, 1 \mathrm{H}), 7.14(\mathrm{~d}, J=8.5 \mathrm{~Hz}, 2 \mathrm{H}), 6.81(\mathrm{~d}, J=8.7 \mathrm{~Hz}$, 2H), $6.10(\mathrm{~s}, 1 \mathrm{H}), 6.05-6.07(\mathrm{~m}, 1 \mathrm{H}), 5.48(\mathrm{~s}, 1 \mathrm{H}), 5.12(\mathrm{~s}, 1 \mathrm{H}), 5.01(\mathrm{~s}, 2 \mathrm{H}), 3.79(\mathrm{~s}, 3 \mathrm{H})$, $3.14(\mathrm{~s}, 3 \mathrm{H}), 1.78(\mathrm{~d}, J=1.2 \mathrm{~Hz}, 3 \mathrm{H})$.

Spectral data for 90: ${ }^{1} \mathrm{H}$ NMR (600 MHz, $\left.\mathrm{CDCl}_{3}\right) \delta 7.37(\mathrm{~d}, J=8.5 \mathrm{~Hz}, 2 \mathrm{H}), 7.01(\mathrm{t}, J=8.1$ $\mathrm{Hz}, 1 \mathrm{H}), 6.92(\mathrm{~d}, J=8.5 \mathrm{~Hz}, 2 \mathrm{H}), 6.62(\mathrm{~d}, J=1.6 \mathrm{~Hz}, 1 \mathrm{H}), 6.43(\mathrm{~d}, J=8.2 \mathrm{~Hz}, 1 \mathrm{H}), 6.21(\mathrm{~d}$, $J=8.1 \mathrm{~Hz}, 1 \mathrm{H}), 6.01(\mathrm{~d}, J=1.0 \mathrm{~Hz}, 1 \mathrm{H}), 5.15(\mathrm{~s}, 1 \mathrm{H}), 5.03(\mathrm{~s}, 2 \mathrm{H}), 3.82(\mathrm{~s}, 3 \mathrm{H}), 2.89(\mathrm{~s}$, $3 \mathrm{H}), 2.84(\mathrm{~d}, J=13.4 \mathrm{~Hz}, 1 \mathrm{H}), 2.49(\mathrm{~d}, J=13.2 \mathrm{~Hz}, 1 \mathrm{H}), 1.89(\mathrm{~d}, J=1.2 \mathrm{~Hz}, 3 \mathrm{H})$.

\section{N-Allyl-2-methyl-N-(1-phenyl-ethyl)-acrylamide (92)}

To a solution of sodium hydride (60\% dispersion in mineral oil, $3.47 \mathrm{~g}, 144.58 \mathrm{mmol}$ ) in DMF (44 mL) was added $91(8.22 \mathrm{~g}, 43.42 \mathrm{mmol})$ in DMF $(46 \mathrm{~mL})$ dropwisely at $0{ }^{\circ} \mathrm{C}$. After addition, the mixture was warmed to room temperature and stirred for $30 \mathrm{~min}$. Then the mixture was cooled to $0{ }^{\circ} \mathrm{C}$ and added allyl bromide $(6.16 \mathrm{~mL}, 71.18 \mathrm{mmol})$ in DMF (44 $\mathrm{mL}$ ) slowly. Then the mixture was warmed to room temperature again and stirred for $1 \mathrm{~h}$; brine $(200 \mathrm{~mL})$ was added, and the mixture was extracted with EtOAc $(3 \times 150 \mathrm{~mL})$. The combined organic phases were dried $\left(\mathrm{MgSO}_{4}\right)$ and filtered, and the solvent was removed at reduced pressure. Purification by chromatography (hexanes/EtOAc, 10:1) gave 92 (5.65 g, $24.60 \mathrm{mmol}, 57 \%$ ) as a pale yellow oil.

Spectral data for 92: ${ }^{1} \mathrm{H}$ NMR $\left(400 \mathrm{MHz}, \mathrm{CDCl}_{3}, 65^{\circ} \mathrm{C}\right) \delta$ 7.21-7.33 (m, 5H), 5.62-5.76 (m, 1H), $5.58(\mathrm{~s}, 1 \mathrm{H}), 5.13(\mathrm{~s}, 1 \mathrm{H}), 5.08(\mathrm{~s}, 1 \mathrm{H}), 4.99(\mathrm{~s}, 1 \mathrm{H}), 4.95(\mathrm{~s}, 1 \mathrm{H}), 3.98(\mathrm{dd}, J=16.0$, $4.0 \mathrm{~Hz}, 1 \mathrm{H}), 3.50(\mathrm{dd}, J=16.0,5.6 \mathrm{~Hz}, 1 \mathrm{H}), 1.99(\mathrm{~s}, 3 \mathrm{H}), 1.58(\mathrm{~d}, J=7.2 \mathrm{~Hz}, 3 \mathrm{H}) ;{ }^{13} \mathrm{C} \mathrm{NMR}$ $\left(100 \mathrm{MHz}, \mathrm{CDCl}_{3}\right) \delta 172.5,141.2,140.6,135.2,128.2,127.1,126.9,115.8,114.2,54.1$, 45.6, 20.3, 17.6; IR (ATR) 2978, 1619, 1451, 1409, 1201, 910, $697 \mathrm{~cm}^{-1} ;[\alpha]^{25} \mathrm{D}=-106.6 \pm$ 
0.1 (c 1.0, $\left.\mathrm{CHCl}_{3}\right)$; HRMS (ESI) calcd for $\mathrm{C}_{15} \mathrm{H}_{20} \mathrm{NO}\left(\mathrm{M}+\mathrm{H}^{+}\right)$230.1545, found 230.1538.

\section{3-Methyl-1-(1-phenyl-ethyl)-1,5-dihydro-pyrrol-2-one (93)}

To a solution of $92(288 \mathrm{mg}, 1.26 \mathrm{mmol})$ in anhydrous $\mathrm{CH}_{2} \mathrm{Cl}_{2}(43 \mathrm{~mL})$ was added Grubbs catalyst, 1st generation $(103.3 \mathrm{mg}, 0.13 \mathrm{mmol})$. The mixture was stirred at $45{ }^{\circ} \mathrm{C}$ for $13 \mathrm{~h}$ and then allowed to cool to ambient temperature. The solvent was removed at reduced pressure and the resulting residue was purified by chromatography (hexanes/EtOAc $=5: 1$ ) to give 93 (220 mg, $1.09 \mathrm{mmol}, 87 \%$ ) as a brown solid.

Spectral data for 93: $\mathrm{mp}$ 67.5-68.5 ${ }^{\circ} \mathrm{C} ;{ }^{1} \mathrm{H}$ NMR (400 MHz, $\left.\mathrm{CDCl}_{3}\right) \delta$ 7.25-7.34 (m, 4H), 7.18-7.24 (m, 1H), $6.60(\mathrm{~d}, J=1.3 \mathrm{~Hz}, 1 \mathrm{H}), 5.54(\mathrm{q}, J=7.1 \mathrm{~Hz}, 1 \mathrm{H}), 3.76(\mathrm{td}, J=19.7,1.7$ $\mathrm{Hz}, 1 \mathrm{H}), 3.45(\mathrm{td}, J=19.6,1.7 \mathrm{~Hz}, 1 \mathrm{H}), 1.90(\mathrm{~d}, J=1.7 \mathrm{~Hz}, 3 \mathrm{H}), 1.57(\mathrm{~d}, J=7.2 \mathrm{~Hz}, 3 \mathrm{H})$. ${ }^{13} \mathrm{C} \mathrm{NMR}\left(100 \mathrm{MHz}, \mathrm{CDCl}_{3}\right) \delta 171.0,140.7,134.9,134.9,134.8,128.0,126.8,126.4,48.8$, 46.0, 17.2, 10.8; IR (ATR) 3425, 2986, 1663, 1452, 1402, 1224, 819, 790, 762, 700, 678 $\mathrm{cm}^{1}$; HRMS (ESI) calcd for $\mathrm{C}_{13} \mathrm{H}_{16} \mathrm{NO}\left(\mathrm{M}+\mathrm{H}^{+}\right)$202.1232, found 202.1225.

\section{5-Hydroxy-3-methyl-1-(1-phenyl-ethyl)-1,5-dihydro-pyrrol-2-one (94)}

To a solution of LDA (1.5 M in tetrahydrofuran/ethylbenzene/heptane, $0.19 \mathrm{~mL})$ in THF $(0.85 \mathrm{~mL})$ was added a solution of $93(57 \mathrm{mg}, 0.28 \mathrm{mmol})$ in THF $(1.02 \mathrm{~mL})$ at $0{ }^{\circ} \mathrm{C}$. The mixture was stirred at $0{ }^{\circ} \mathrm{C}$ for $3 \mathrm{~h}$, then charged in $\mathrm{O}_{2}$ and stirred for additional $30 \mathrm{~min}$. The reaction was quenched by $\mathrm{NH}_{4} \mathrm{Cl}(5 \mathrm{~mL})$, then warmed to room temperature and extracted by EtOAc $(3 \times 5 \mathrm{~mL})$. The organic phase was dried $\left(\mathrm{MgSO}_{4}\right)$ and filtered. The solvent was removed, and the resulting residue was purified by chromatography (hexanes/EtOAc, 4:1) to give 94 (30 mg, $0.14 \mathrm{mmol}, 49 \%)$ as a colorless oil. 
Spectral data for the major isomer of 94: ${ }^{1} \mathrm{H} \mathrm{NMR}\left(400 \mathrm{MHz}, \mathrm{CDCl}_{3}\right) \delta$ 7.17-7.50 (m, 5H), $6.46(\mathrm{~d}, J=1.6 \mathrm{~Hz}, 1 \mathrm{H}), 5.43(\mathrm{~d}, J=9.7 \mathrm{~Hz}, 1 \mathrm{H}), 5.17(\mathrm{q}, J=7.2 \mathrm{~Hz}, 1 \mathrm{H}), 2.70(\mathrm{~d}, J=10.0$ Hz, 1H), 1.84 (s, 3H), $1.74(\mathrm{~d}, J=7.3 \mathrm{~Hz}, 3 \mathrm{H})$.

Partial spectral data for the minor isomer of 94 : ${ }^{1} \mathrm{H}$ NMR $\left(400 \mathrm{MHz}, \mathrm{CDCl}_{3}\right) \delta$ 6.36-6.39 (m, 1H), $5.33(\mathrm{q}, J=7.4 \mathrm{~Hz}, 1 \mathrm{H}), 5.06(\mathrm{~d}, J=10.4 \mathrm{~Hz}, 1 \mathrm{H}), 2.96(\mathrm{~d}, J=10.6 \mathrm{~Hz}, 1 \mathrm{H}), 1.84(\mathrm{~s}$, $3 \mathrm{H}), 1.72(\mathrm{~d}, J=7.3 \mathrm{~Hz}, 3 \mathrm{H})$.

Spectral data for mixture of both isomers of 94: IR (ATR) 3339, 2923, 1676, 1653, 1449, 1397, 1359, 1226, 1053, $699 \mathrm{~cm}^{-1}$; HRMS (ESI) calcd for $\mathrm{C}_{13} \mathrm{H}_{15} \mathrm{NNaO}_{2}\left(\mathrm{M}+\mathrm{Na}^{+}\right) 240.1000$, found 240.0994 .

\section{5-(2-Bromo-allyl)-3-methyl-1-(1-phenyl-ethyl)-1,5-dihydro-pyrrol-2-one (95)}

A solution of 94 (105 mg, $0.48 \mathrm{mmol})$ and 2-bromo-2-propen-1-yl trimethylsilane (13) (334 $\mu \mathrm{L}, 1.94 \mathrm{mmol})$ in $\mathrm{CH}_{2} \mathrm{Cl}_{2}(7.8 \mathrm{~mL})$ was cooled to $-78{ }^{\circ} \mathrm{C}$ and stirred for $15 \mathrm{~min}$. $\mathrm{TiCl}_{4}(106 \mu \mathrm{L}, 0.97 \mathrm{mmol})$ was added slowly under a $\mathrm{N}_{2}$ atmosphere. The cold bath was removed after $30 \mathrm{~min}$, and the mixture was stirred at ambient temperature for an additional $1 \mathrm{~h} . \mathrm{Na}_{2} \mathrm{CO}_{3} \cdot 10 \mathrm{H}_{2} \mathrm{O}(1.67 \mathrm{~g})$ was added slowly. After stirring for $30 \mathrm{~min}$, the mixture was dried $\left(\mathrm{MgSO}_{4}\right)$ and filtered. The solvents were removed and the crude product was purified by chromatography on silica gel (hexanes/EtOAc, 10:1) to give 95 (119 mg, $0.37 \mathrm{mmol}$, $77 \%, \boldsymbol{d r}=3: 1)$ as a colorless oil.

Spectral data for the major isomer of 95: ${ }^{1} \mathrm{H}$ NMR $\left(400 \mathrm{MHz}, \mathrm{CDCl}_{3}\right) \delta$ 7.19-7.47 (m, 5H), $6.70(\mathrm{~s}, 1 \mathrm{H}), 5.40-5.52(\mathrm{~m}, 3 \mathrm{H}), 4.32-4.44(\mathrm{~m}, 1 \mathrm{H}), 2.46(\mathrm{dd}, J=14.0,3.9 \mathrm{~Hz}, 1 \mathrm{H}), 1.92(\mathrm{~s}$, $3 \mathrm{H}), 1.88(\mathrm{dd}, J=13.9,10.6 \mathrm{~Hz}, 1 \mathrm{H}), 1.73(\mathrm{~d}, J=7.3 \mathrm{~Hz}, 3 \mathrm{H})$. 
Partial spectral data for the minor isomer of 95: ${ }^{1} \mathrm{H} \mathrm{NMR}\left(400 \mathrm{MHz}, \mathrm{CDCl}_{3}\right) \delta 6.64(\mathrm{~s}, 1 \mathrm{H})$, $5.37(\mathrm{q}, J=7.4 \mathrm{~Hz}, 1 \mathrm{H}), 3.95-4.03(\mathrm{~m}, 1 \mathrm{H}), 3.00(\mathrm{dd}, J=13.6,4.0 \mathrm{~Hz}, 1 \mathrm{H}), 2.25(\mathrm{dd}, J=$ 13.5, 10.7 Hz, 1H), $1.90(\mathrm{~d}, J=1.2 \mathrm{~Hz}, 3 \mathrm{H}) .1 .69(\mathrm{~d}, J=7.2 \mathrm{~Hz}, 3 \mathrm{H})$.

Spectral data for the mixture of both isomers of $95:{ }^{13} \mathrm{C} \mathrm{NMR}\left(100 \mathrm{MHz}, \mathrm{CDCl}_{3}\right) \delta 171.9$, $171.8,141.6,140.1,139.3,139.3,139.2,139.2,134.8,134.7,128.7,128.4,128.3,128.2$, 127.3, 127.1, 127.1, 126.8, 119.6, 58.4, 57.3, 51.4, 49.3, 44.4, 44.1, 18.5, 17.1, 11.0, 11.0; IR (ATR) 2975, 1677, 1397, 1229, 894, 836, 754, $699 \mathrm{~cm}^{-1}$; HRMS (ESI) calcd for $\mathrm{C}_{16} \mathrm{H}_{19} \mathrm{BrNO}\left(\mathrm{M}+\mathrm{H}^{+}\right)$320.0650, found 320.0642.

\section{5-[2-(2-Methoxymethoxy-6-nitro-phenyl)-allyl]-3-methyl-1-(1-phenyl-ethyl)-1,5- dihydro-pyrrol-2-one (96)}

A solution of 95 (106 mg, $0.33 \mathrm{mmol}), 67(137.43 \mathrm{mg}, 0.40 \mathrm{mmol}), \mathrm{Pd}(\mathrm{dba})_{2}(9.52 \mathrm{mg}$, $0.017 \mathrm{mmol})$, triphenylphosphine $(17.35 \mathrm{mg}, 0.066 \mathrm{mmol})$, and copper (I) iodide (47.3 $\mathrm{mg}$, $0.25 \mathrm{mmol}$ ) in DMF (6 mL) was stirred at room temperature for $24 \mathrm{~h}$. The reaction was diluted with $\mathrm{H}_{2} \mathrm{O}(15 \mathrm{~mL})$ and extracted with EtOAc $(3 \times 15 \mathrm{~mL})$, dried $\left(\mathrm{MgSO}_{4}\right)$ and the solvents were removed on a rotary evaporator at water aspirator pressure. Purification by chromatography (hexanes/EtOAc, 2:1) gave $96(105 \mathrm{mg}, 0.25 \mathrm{mmol}, 75 \%, \boldsymbol{d r}=3: 1)$ as a yellow oil.

Spectral data for the major isomer of 96: ${ }^{1} \mathrm{H} \mathrm{NMR}\left(400 \mathrm{MHz}, \mathrm{CDCl}_{3}, 65{ }^{\circ} \mathrm{C}\right) \delta 7.13-7.36$ $(\mathrm{m}, 8 \mathrm{H}), 6.83(\mathrm{~s}, 1 \mathrm{H}), 5.28(\mathrm{q}, J=7.2 \mathrm{~Hz}, 1 \mathrm{H}), 5.17(\mathrm{~s}, 1 \mathrm{H}), 4.98-5.09(\mathrm{~m}, 2 \mathrm{H}), 4.96(\mathrm{~s}$, $1 \mathrm{H}), 4.21(\mathrm{~d}, J=11.5 \mathrm{~Hz}, 1 \mathrm{H}), 3.33(\mathrm{~s}, 3 \mathrm{H}), 2.79(\mathrm{~d}, J=14.7 \mathrm{~Hz}, 1 \mathrm{H}), 1.91(\mathrm{dd}, J=14.8$, $11.7 \mathrm{~Hz}, 1 \mathrm{H}), 1.88(\mathrm{~s}, 3 \mathrm{H}), 1.64(\mathrm{~d}, J=7.3 \mathrm{~Hz}, 3 \mathrm{H})$.

Spectral data for the minor isomer of 96: ${ }^{1} \mathrm{H}$ NMR $\left(400 \mathrm{MHz}, \mathrm{CDCl}_{3}, 65{ }^{\circ} \mathrm{C}\right) \delta 7.13-7.36$ (m, 8H), $6.78(\mathrm{~s}, 1 \mathrm{H}), 5.33(\mathrm{q}, J=7.3 \mathrm{~Hz}, 1 \mathrm{H}), 5.11(\mathrm{~s}, 1 \mathrm{H}), 4.98-5.09(\mathrm{~m}, 2 \mathrm{H}), 4.92$ (s, 
1H), 3.81 (d, $J=10.5 \mathrm{~Hz}, 1 \mathrm{H}), 3.36(\mathrm{~s}, 3 \mathrm{H}), 3.19$ (d, $J=14.8 \mathrm{~Hz}, 1 \mathrm{H}), 2.19$ (dd, $J=14.4$, $11.6 \mathrm{~Hz}, 1 \mathrm{H}), 1.88(\mathrm{~s}, 3 \mathrm{H}), 1.67(\mathrm{~d}, J=7.3 \mathrm{~Hz}, 3 \mathrm{H})$.

Spectral data for the mixture of both isomers of 96: HRMS (ESI) calcd for $\mathrm{C}_{24} \mathrm{H}_{27} \mathrm{~N}_{2} \mathrm{O}_{5}$ $\left(\mathrm{M}+\mathrm{H}^{+}\right)$423.1920, found 423.1918.

\section{5-[2-(2-Hydroxy-6-nitro-phenyl)-allyl]-3-methyl-1-(1-phenyl-ethyl)-1,5-dihydro-pyrrol-}

\section{2-one (97)}

To a stirred solution of the $96(29 \mathrm{mg}, 0.069 \mathrm{mmol})$ in $\mathrm{CH}_{2} \mathrm{Cl}_{2}(0.75 \mathrm{~mL})$ was added activated (while hot) $\mathrm{NaHSO}_{4}: \mathrm{SiO}_{2}(27.5 \mathrm{mg}, 0.15 \mathrm{mmol})$ (the catalyst was kept in an oven at $120{ }^{\circ} \mathrm{C}$ for $48 \mathrm{~h}$ before using it) at room temperature. After completion of the reaction (monitored by TLC, overnight), the catalyst was filtered off and washed with $\mathrm{CH}_{2} \mathrm{Cl}_{2}(2 \times 2$ $\mathrm{mL}$ ). The filtrate and washings were combined, and the solvents were removed under vacuum. Purification by chromatography (hexanes/EtOAc, 1:1) gave 97 (24 mg, 0.063 mmol, $92 \%, \boldsymbol{d r}=3: 1)$ as a colorless oil.

Spectral data for the major isomer of 97: ${ }^{1} \mathrm{H} \mathrm{NMR}\left(600 \mathrm{MHz}, \mathrm{CDCl}_{3}, 65{ }^{\circ} \mathrm{C}\right) \delta 7.11-7.43$ $(\mathrm{m}, 8 \mathrm{H}), 6.70(\mathrm{~s}, 1 \mathrm{H}), 5.25(\mathrm{q}, J=7.2 \mathrm{~Hz}, 1 \mathrm{H}), 5.16(\mathrm{~s}, 1 \mathrm{H}), 5.05(\mathrm{~s}, 1 \mathrm{H}), 4.18(\mathrm{~d}, J=10.0$ $\mathrm{Hz}, 1 \mathrm{H}), 2.77(\mathrm{~d}, J=14.8 \mathrm{~Hz}, 1 \mathrm{H}), 2.10(\mathrm{dd}, J=14.0,11.2 \mathrm{~Hz}, 1 \mathrm{H}), 1.80(\mathrm{~s}, 3 \mathrm{H}), 1.65(\mathrm{~d}$, $J=7.3 \mathrm{~Hz}, 3 \mathrm{H})$.

Spectral data for the minor isomer of 97: ${ }^{1} \mathrm{H}$ NMR $\left(600 \mathrm{MHz}, \mathrm{CDCl} 3,65^{\circ} \mathrm{C}\right) \delta 7.11-7.43$ $(\mathrm{m}, 8 \mathrm{H}), 6.73(\mathrm{~s}, 1 \mathrm{H}), 5.31(\mathrm{q}, J=7.1 \mathrm{~Hz}, 1 \mathrm{H}), 5.23(\mathrm{~s}, 1 \mathrm{H}), 5.06(\mathrm{~s}, 1 \mathrm{H}), 3.81(\mathrm{~d}, J=10.7$ Hz, 1H), $3.16(\mathrm{~d}, J=14.3 \mathrm{~Hz}, 1 \mathrm{H}), 2.29(\mathrm{dd}, J=12.8,11.6 \mathrm{~Hz}, 1 \mathrm{H}), 1.82(\mathrm{~s}, 3 \mathrm{H}), 1.66$ (d, $J=7.5 \mathrm{~Hz}, 3 \mathrm{H})$. 


\section{Trifluoro-methanesulfonic acid 2-\{1-[4-methyl-5-oxo-1-(1-phenyl-ethyl)-2,5-dihydro-}

\section{H-pyrrol-2-ylmethyl]-vinyl\}-3-nitro-phenyl ester (98)}

$N$-Phenyl-bis(trifluoromethanesulfonimide) $(23 \mathrm{mg}, 0.064 \mathrm{mmol})$ was added to a solution of 97 (24 mg, $0.063 \mathrm{mmol})$ and $\mathrm{K}_{2} \mathrm{CO}_{3}(13 \mathrm{mg}, 0.094 \mathrm{mmol})$ in DMF $(0.35 \mathrm{~mL})$. The mixture was stirred at room temperature for $30 \mathrm{~min}$. The reaction was diluted with $\mathrm{H}_{2} \mathrm{O}(2 \mathrm{~mL})$ and extracted with EtOAc $(3 \times 2 \mathrm{~mL})$, dried $\left(\mathrm{MgSO}_{4}\right)$ and the solvents were removed on a rotary evaporator at water aspirator pressure. Purification by chromatography (hexanes/EtOAc, 2:1) gave 98 (31 mg, $0.061 \mathrm{mmol}, 96 \%, \boldsymbol{d r}=3: 1)$ as a yellow oil.

Spectral data for major isomer of 98: ${ }^{1} \mathrm{H} \mathrm{NMR}\left(600 \mathrm{MHz}, \mathrm{CDCl}_{3}, 65{ }^{\circ} \mathrm{C}\right) \delta 7.84(\mathrm{~d}, J=6.8$ $\mathrm{Hz}, 1 \mathrm{H}), 7.52(\mathrm{t}, J=8.3 \mathrm{~Hz}, 1 \mathrm{H}), 7.48-7.51(\mathrm{~m}, 1 \mathrm{H}), 7.34(\mathrm{~d}, J=7.4 \mathrm{~Hz}, 2 \mathrm{H}), 7.24(\mathrm{~d}, J=$ $7.7 \mathrm{~Hz}, 2 \mathrm{H}), 7.15-7.18(\mathrm{~m}, 1 \mathrm{H}), 6.84(\mathrm{~s}, 1 \mathrm{H}), 5.41(\mathrm{~s}, 1 \mathrm{H}), 5.35(\mathrm{q}, J=7.3 \mathrm{~Hz}, 1 \mathrm{H}), 5.18(\mathrm{~s}$, $1 \mathrm{H}), 4.25(\mathrm{~d}, J=11.2 \mathrm{~Hz}, 1 \mathrm{H}), 2.63(\mathrm{~d}, J=13.0 \mathrm{~Hz}, 1 \mathrm{H}), 1.91(\mathrm{t}, J=1.7 \mathrm{~Hz}, 3 \mathrm{H}), 1.84(\mathrm{dd}$, $J=15.9,11.3 \mathrm{~Hz}, 1 \mathrm{H}), 1.66(\mathrm{~d}, J=7.3 \mathrm{~Hz}, 3 \mathrm{H})$.

Spectral data for minor isomer of 98: ${ }^{1} \mathrm{H}$ NMR $\left(600 \mathrm{MHz}, \mathrm{CDCl}_{3}, 65{ }^{\circ} \mathrm{C}\right) \delta 7.46-7.50(\mathrm{~m}$, 1H), 7.30-7.32 (m, 1H), 7.21-7.26 (m, 3H), 7.15-7.20 (m, 2H), $7.11(\mathrm{t}, J=7.3 \mathrm{~Hz}, 1 \mathrm{H}), 6.80$ $(\mathrm{t}, J=1.4 \mathrm{~Hz}, 1 \mathrm{H}), 5.37(\mathrm{q}, J=7.3 \mathrm{~Hz}, 1 \mathrm{H}), 5.35(\mathrm{~s}, 1 \mathrm{H}), 5.16(\mathrm{~s}, 1 \mathrm{H}), 3.79(\mathrm{~d}, J=11.2 \mathrm{~Hz}$, $1 \mathrm{H}), 3.10(\mathrm{~d}, J=10.8 \mathrm{~Hz}, 1 \mathrm{H}), 2.18(\mathrm{t}, J=12.9 \mathrm{~Hz}, 1 \mathrm{H}), 1.90(\mathrm{t}, J=1.7 \mathrm{~Hz}, 3 \mathrm{H}), 1.67(\mathrm{~d}, J$ $=7.3 \mathrm{~Hz}, 3 \mathrm{H})$. 


\section{References and Footnotes}

1. Kamigauchi, T.; Yasui, M. PCT Int. Appl. (2000), WO 2000059909 [CAN 133:267009].

2. Huters, A. D.; Quasdorf, K. W.; Styduhar, E. D.; Garg, N. K. J. Am. Chem. Soc. 2011, 133, 15797-15799.

3. Mari, M.; Bartoccini, F.; Piersanti, G. J. Org. Chem. 2013, 78, 7728-7734.

4. Samet, A. V.; Yamskov, A. N.; Strelenko, Y. A.; Semenov, V. V. Tetrahedron 2009, 65, 6868-6872.

5. Breazzano, S. P.; Poudel, Y. B.; Boger, D. L. J. Am. Chem. Soc. 2013, 135, 1600-1606.

6. (a) Gao, Y.; Shan, D.; Jia, Y. Tetrahedron 2014, 70, 5136-5141. (b) Shan, D.; Gao, Y.; Jia, Y. Angew. Chem., Int. Ed. 2013, 52, 4902-4905.

7. (a) Park, I-.K.; Park, J.; Cho, C.-G. Angew. Chem., Int. Ed. 2012, 51, 24962499. (b) Park, J.; Kim, S.-Y.; Kim, J.-E.; Cho, C.-G. Org. Lett. 2014, 16, 178181.

8. (a) Zhou, B.; Yang, Y.; Tang, H.; Du, J.; Feng, H.; Li, Y. Org. Lett. 2014, 16, 3900-3903. (b) Tao, P.; Jia, Y. Chem. Commun. 2014, 50, 7367-7370. (c) Zhang, X.; Li, Y.; Shi, H.; Zhang, L.; Zhang, S.; Xu, X.; Liu, Q. Chem. Commun. 2014, 50, 7306-7309.

9. (a) Söderberg, B. C. G.; Hubbard, J. W.; Rector, S. R.; O’Neil, S. N. Tetrahedron 2005, 61, 3637-3649. (b) Söderberg, B. C. G.; Rector, S. R.; O’Neil, S. N. Tetrahedron Lett. 1999, 40, 3657-3660.

10. For applications of this type of cyclization in total synthesis, see: (a) Cummings, M. M.; Clawson, R. W.; Sharma, S. B.; Byerly, R. A.; Akhmedov, N. G.; Söderberg, B. C. G. Tetrahedron 2011, 67, 4753-4757. (b) Clawson, R. W.; Dacko, C. A.; Deavers, R. E.; Akhmedov, N. G.; Söderberg, B. C. G. Tetrahedron 2009, 65, 8786-8793. (c) Clawson, R. W.; Söderberg, B. C. G. Tetrahedron Lett. 2007, 48, 6019-6021. (d) Kuethe, J. T.; Wong, A.; Davies, 
I. W. Org. Lett. 2003, 5, 3721-3723. (e) Scott, T. L.; Söderberg, B. C. G. Tetrahedron 2003, 59, 6323-6332. (f) Dantale, S. W.; Söderberg, B. C. G. Tetrahedron 2003, 59, 5507-5514. (g) Söderberg, B. C.; Chisnell, A. C.; O’Neil, S. N.; Shriver, J. A. J. Org. Chem. 1999, 64, 9731-9734.

11. Tanaka, K.-i.; Sawanishi, H. Tetrahedron 1998, 54, 10029-10042.

12. Hart, D. J.; Sun, L.-Q.; Kozikowski, A. P. Tetrahedron Lett. 1995, 36, 77877790 .

13. Methyl, benzyl, trimethylsilylethyl, and t-butyl carbamates all remained intact from allylations of closely related compounds using $\mathrm{TiCl}_{4}$ : (a) Si, C.-M.; Mao, Z.-Y.; Ren, R.-G.; Du, Z.-T.; Wei, B.-G. Tetrahedron 2014, 70, 7936-7941. (b) Shiigi, H.; Mori, H.; Tanaka, T.; Demizu, Y.; Onomura, O. Tetrahedron Lett. 2008, 49, 5247-5251. (c) Barrett, A. G. M.; Philipaukas, D. J. Org. Chem. 1991, 56, 2787-2800. (d) Thaning, M.; Wistrand, L.-G. J. Org. Chem. 1990, $55,1406-1408$.

14. (a) Kim, H.; Lim, W.; Im, D.; Kim, D.-g.; Rhee, Y. H. Angew. Chem., Int. Ed. 2012, 51, 12055-12058. (b) Dhudshia, B.; Cooper, B. F. T.; Macdonald, C. L. B.; Thadani, A. N. Chem. Commun. 2009, 463-465. (c) Keum, G.; Kim, G. Bull. Korean Chem. Soc. 1994, 15, 278-279.

15. Mitsunobu, O.; Yamada, M. Bull. Chem. Soc. Jpn. 1967, 40, 2380-2382.

16. For extensive reviews on the intramolecular Heck reaction, see: (a) Heravi, M. M.; Fazeli, A. Heterocycles 2010, 81, 1979-2026. (b) Link, J. T. Org. React. 2002, $60,157-534$.

17. A high, or exclusive, 7-exo/8-endo ratio has been observed from Heck reactions of oxygen tethered substrates: (a) Denieul, M.-P.; Luarsen, B.; Hazell, R.; Skrydstrup, T. J. Org. Chem. 2000, 65, 6052-6060. (b) Ma, S.; Ni, B. J. Org. Chem. 2002, 67, 8280-8283. (c) Söderberg, B. C. G.; Hubbard, J. W.; Rector, S. R.; O’Neil, S. N. Tetrahedron 2005, 61, 3637-3649. (d) Lee, T. S.; Das, A.; Khosla, C. Bioorg. Med. Chem. 2007, 15, 5207-5218.

18. For examples of the more unusual 8-endo-trig cyclization, see (a) Majumdar, K. C.; Chattopadhyay, B.; Sinha, B. Synthesis 2008, 3857-3863. (b) Jäger, M.; Görls, H.; Günther, W.; Schubert, U. S. Chem. Eur. J. 2013, 19, 2150-2157. 
19. Kelly, T. R.; Li, Q.; Bhushan, V. Tetrahedron Lett. 1990, 31, 161-164.

20. For applications in total synthesis, see: (a) Smith, A. B., III; Davulcu, A. H.; Cho, Y. S.; Ohmoto, K.; Kuerti, L.; Ishiyama, H. J. Org. Chem. 2007, 72, 4596-4610. (b) Trost, B. M.; Pissot-Soldermann, C.; Chen, I. Chem. Eur. J. 2005, 11, 951-959. (c) Fukuyama, Y.; Yaso, H.; Mori, T.; Takahashi, H.; Minami, H.; Kodama, M. Heterocycles 2001, 54, 259-274. (d) Huang, A.; Xiong, Z.; Corey, E. J. J. Am. Chem. Soc. 1999, 121, 9999-10003.

21. (a) Olivera, R.; SanMartin, R.; Tellitu, I.; Dominguez, E. Tetrahedron 2002, 58, 3021-3037. (b) Beddoes, R. L.; Cheeseright, T.; Wang, J.; Quayle, P. Tetrahedron Lett. 1995, 36, 283-286.

22. Mori, M.; Kaneta, N.; Shibasaki, M. J. Org. Chem. 1991, 56, 3486-3493.

23. Trost, B. M.; Grese, T. A.; Chan, D. M. T. J. Am. Chem. Soc. 1991, 113, 73507362.

24. For a related cis-selective allylation using 13, see: Lennartz, M.; Sadakane, M.; Steckhan, E. Tetrahedron 1999, 55, 14407-14420.

25. (a) Lee, E.-S.; Yeom, H.-S.; Hwang, J.-H.; Shin, S. Eur. J. Org. Chem. 2007, 3503-3507. (b) Buzas, A.; Gagosz, F. Synlett 2006, 2727-2730.

26. Alcaide, B.; Almendros, P.; Quiros, M. T.; Fernandez, I. Beilstein J. Org. Chem. 2013, 9, 818-826.

27. Zhang, X.; Schmitt, A. C.; Jiang, W. Tetrahedron Lett. 2001, 42, 5335-5338.

28. Knowles, R. R.; Carpenter, J.; Blakey, S. B.; Kayano, A.; Mangion, I. K.; Sinz, C. J.; MacMillan, D. W. C. Chem. Sci. 2011, 2, 308-311.

29. For a few examples of Red-Al reductions of N-methoxycarbonyl groups in the total synthesis of alkaloids, see: (a) Araki, T.; Manabe, Y.; Fujioka, K.; Yokoe, H.; Kanematsu, M.; Yoshida, M.; Shishido, K. Tetrahedron Lett. 2013, 54, 1012-1014. (b) Newhouse, T.; Lewis, C. A.; Eastman, K. J.; Baran, P. S. J. Am. Chem. Soc. 2010, 132, 7119-7137. (c) Movassaghi, M.; Schmidt, M. A. Angew. Chem., Int. Ed. 2007, 46, 3725-3728.

30. $\mathrm{Mp} 180-182^{\circ} \mathrm{C}$; lit. $\mathrm{mp}(\operatorname{ref} 1) 182-184^{\circ} \mathrm{C}$.

31. Zhang, Y.; Hubbard, J. W.; Akhmedov, N. G.; Petersen, J. L.; Söderberg, B. 
C. G. J. Org. Chem. 2015, 80, 4783-4790.

32. Zheng, X.; Feng, C.; Ye, J.; Huang, P. Org. Lett. 2005, 7, 553-556.

33. Bjornson, K.; Canales, E.; Cottell, J. J.; Karki, K. K.; Katana, A. A.; Kato, D.; Kobayashi, T.; Link, J. O.; Martinez, R.; Phillips, B. W.; Pyun, H.-J.; Sangi, M.; Schrier, A. J.; Siegel, D.; Taylor, J. G.; Tran, C. V.; Trejo M., Teresa A.; Vivian, R. W.; Yang, Z.-Y.; Zablocki, J.; Zipfel, S. PCT Int. Appl. (2014), WO 2014008285, [CAN 160:190332].

34. Huang, C.; Huang, Y.; Akhmedov, N. G.; Popp, B. V.; Petersen, J. L.; Wang, K. K. Org. Lett. 2014, 16, 2672-2675.

35. Kozlovskii, A. G.; Solov'eva, T. F.; Sakharovskii, V. G.; Adanin, V. M. Dokl. Akad. Nauk SSSR 1981, 260, 230.

36. For previous synthesis of aurantioclavine, see: (a) Yamada, F.; Makita, Y.; Suzuki, T.; Somei, M. Chem. Pharm. Bull. 1985, 33, 2162. (b) Hegedus, L. S.; Toro, J. L.; Miles, W. H.; Harrington, P. J. J. Org. Chem. 1987, 52, 3319-3322. (c) Somei, M.; Yamada, F. Heterocycles 2007, 74, 943-950. (d) Yamada, K.; Namerikawa, Y.; Haruyama, T.; Miwa, Y.; Yanada, R.; Ishikura, M. Eur. J. Org. Chem. 2009, 33, 5752-5759. (e) Krishnan, S.; Bagdanoff, J. T.; Ebner, D. C.; Ramtohul, Y. K.; Tambar, U. K.; Stoltz, B. M. J. Am. Chem. Soc. 2008, 130, 13745-13754. (f) Behenna, D. C.; Krishnan, S.; Stoltz, B. M. Tetrahedron Lett. 2011, 52, 2152-2154. (g) Brak, K.; Ellman, J. A. Org. Lett. 2010, 12, 2004-2007. (h) Xu, Z.; Hu, W.; Liu, Q.; Zhang, L.; Jia, Y. J. Org. Chem. 2010, $75,7626-7635$.

37. Habibi D.; Zolfigol, M.A.; Shiri M.; Sedaghat, A. S. Afr. J. Chem., 2006, 59, 93-96.

38. Sugiyama, H.; Yokokawa, F.; Shioiri, T. Tetrahedron 2003, 59, 6579-6593.

39. Ryan, K.L.; Akhmedov, N. G.; Panaccione, D.G. J. Agric. Food Chem. 2015, 63, 61-67.

40. Stauffacher, D.; Niklaus, P.; Tscherter, H.; Weber, H. P.; Hofmann, A. Tetrahedron 1969, 25, 5879-5887.

41. Jacubczyk, D.; Caputi, L.; Hatsch, A.; Nielsen, C. A. F.; Diefenbacher, M.; Klein, J.; Molt, A.; Schroder, H.; Cheng, J. Z.; Naesby, M.; O'Connor, S. E. 
Angew. Chem., Int. Ed. 2015, 54, 5117-5121.

42. (a) Incze, M.; Dörnyei, G.; Moldvai, I.; Temesvari-Major, E.; Egyed, O.; Szantay, C. Tetrahedron 2008, 64, 2924-2929. (b) Petronijevic, F. R.; Wipf, P. J. Am. Chem. Soc. 2011, 133, 7704-7707. (c) Wang, W.; Lu, J.-T.; Zhang, H.-L.; Shi, Z.-F.; Wen, J.; Cao, X.-P. J. Org. Chem. 2014, 79, 122-127. (d) Jabre, N. D.; Watanabe, T.; Brewer, M. Tetrahedron Lett. 2014, 55, 197-199. (e) Netz, N.; Opatz, T. J. Org. Chem. 2016, 81, 1723-1730.

43. Hart, D.J.; Sun, L.-Q.; Kozikowski, A.P. Tetrahedron Lett. 1995, 36, 77877790 .

44. Ramesh, C.; Ravindranath, N.; Das, B. J. Org. Chem. 2003, 68, 7101-7103.

45. Overall yield starting from 1 .

46. A small amount of a second unidentified product was observed in the NMR spectra, but the products could not be separated by chromatography.

47. The diastereomeric ratio varied from 2:1 to 1:1 between different runs.

48. We were unable to determine $d r$ due to broad unresolved NMR resonances.

49. Integration of the two resolved methyl doublets at d 1.32 and 1.27 in the ${ }^{1} \mathrm{H}$ NMR spectrum at $65^{\circ} \mathrm{C}$ suggest a $d r$ of $15: 1$.

50. Most of the ${ }^{1} \mathrm{H}$ NMR signals were unresolved even at $65^{\circ} \mathrm{C}$. 


\section{Appendix}




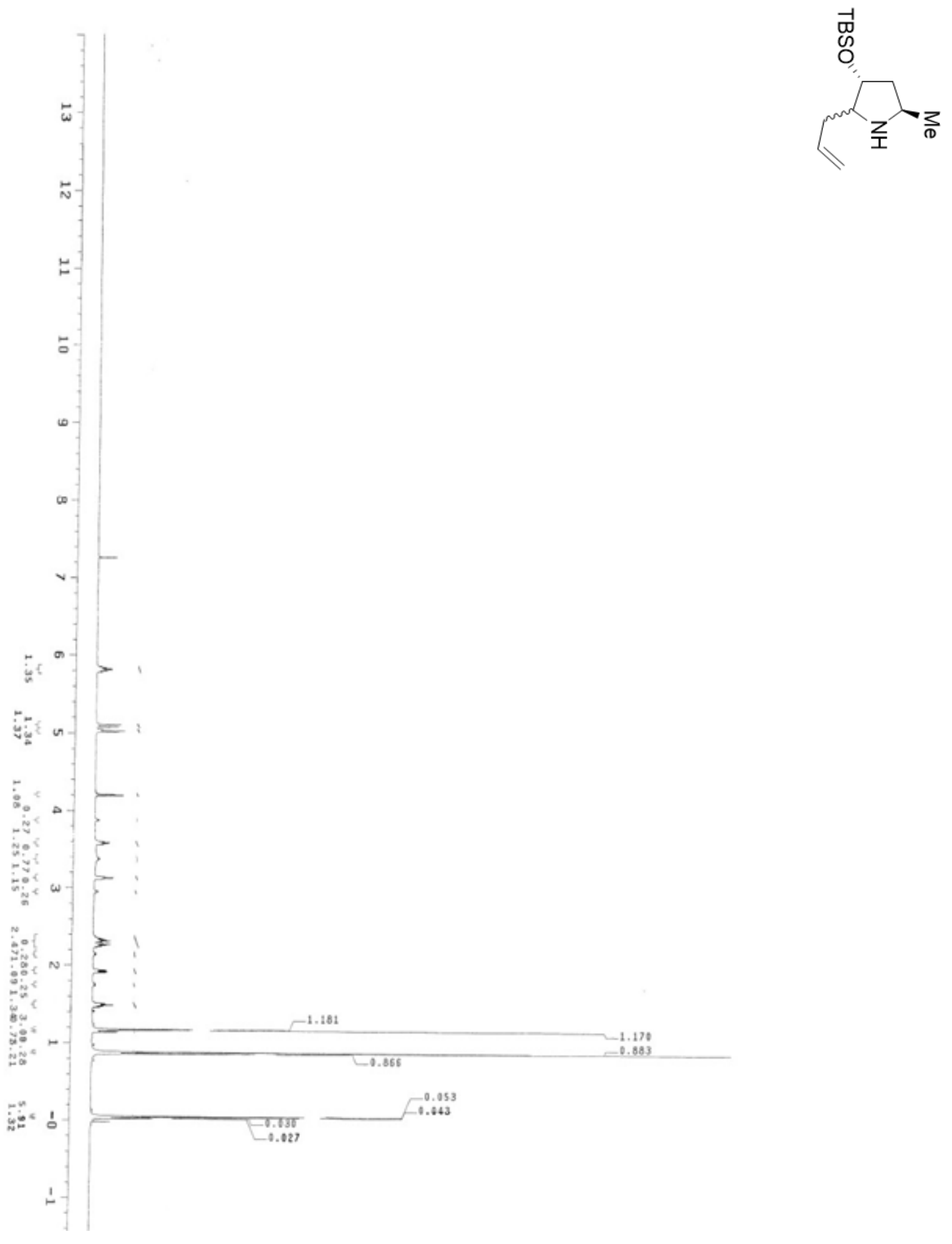

Figure 8: ${ }^{1} \mathrm{H}$ NMR of 3(R)-[(t-butyldimethylsilyl)oxy]-5(R)-methyl-2-(2-propen-1yl)pyrrolidine (5) 


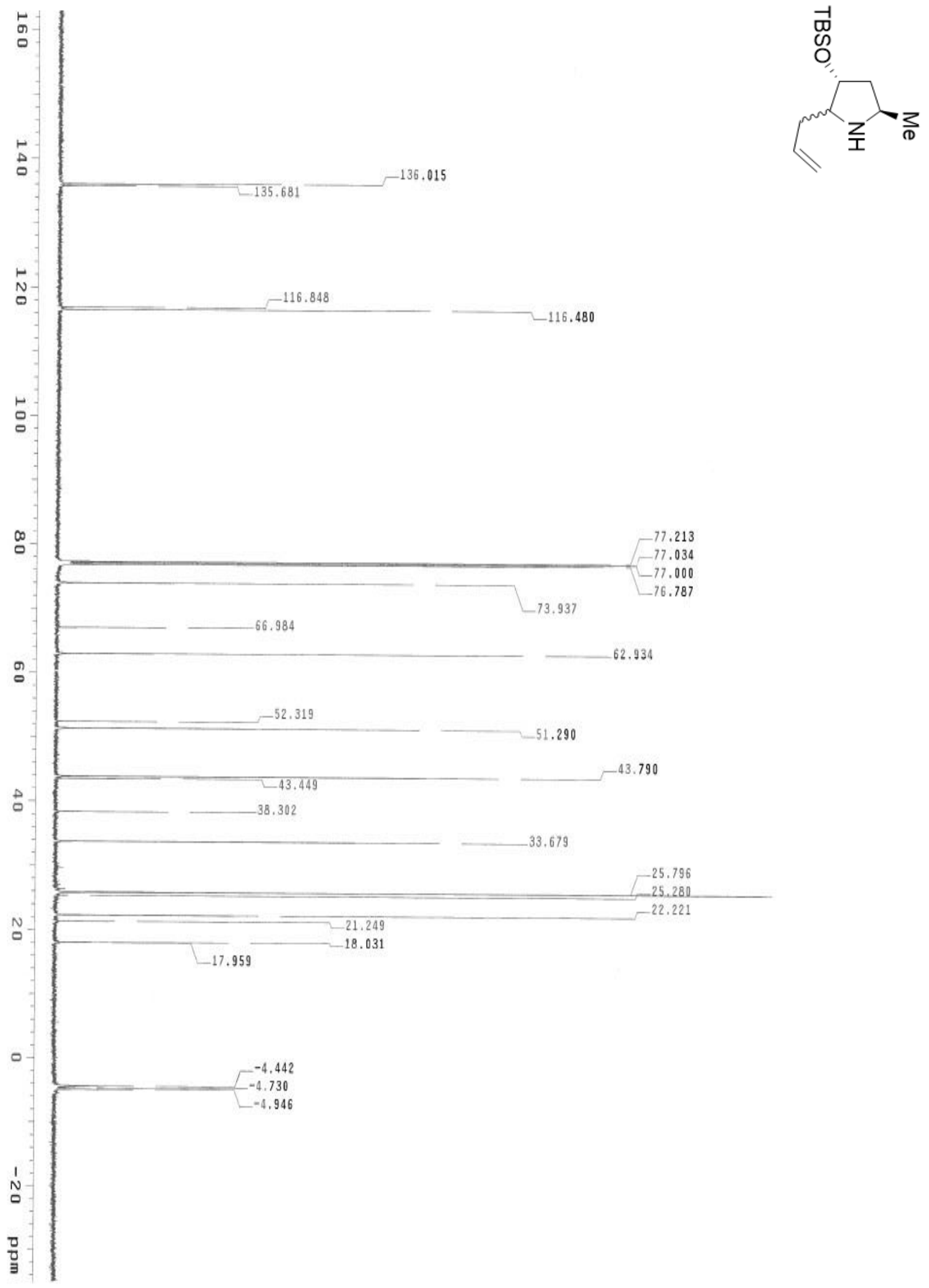

Figure 9: ${ }^{13} \mathrm{C}$ NMR of 3(R)-[(t-butyldimethylsilyl)oxy]-5(R)-methyl-2-(2-propen-1yl)pyrrolidine (5) 


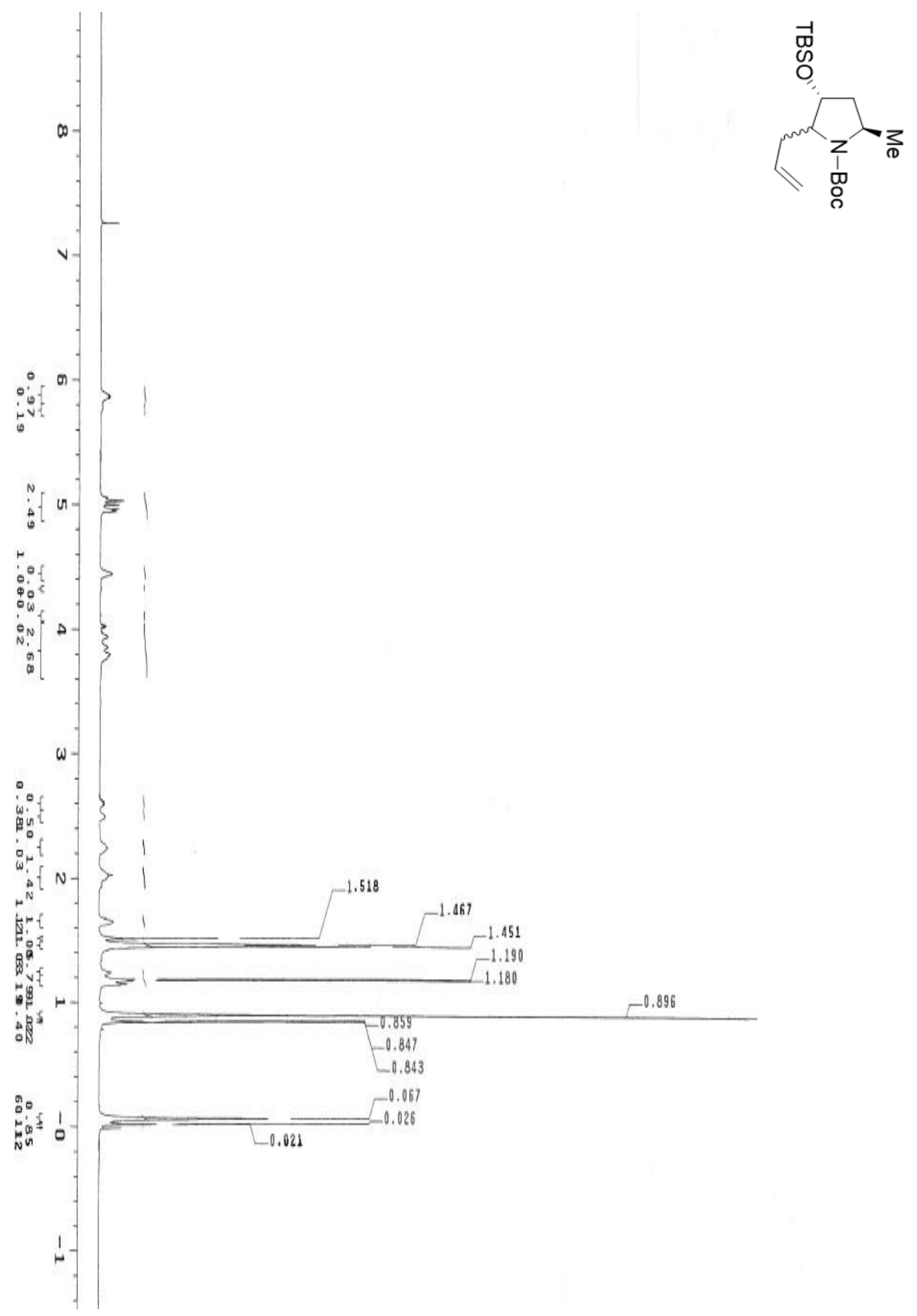

Figure 10: ${ }^{1} \mathrm{H}$ NMR of 1-( $t$-butoxycarbonyl)-3(R)-[( $t$-butyldimethylsilyl)oxy]-5(R)methyl-2-(2-propen-1-yl)-pyrrolidine (6) 


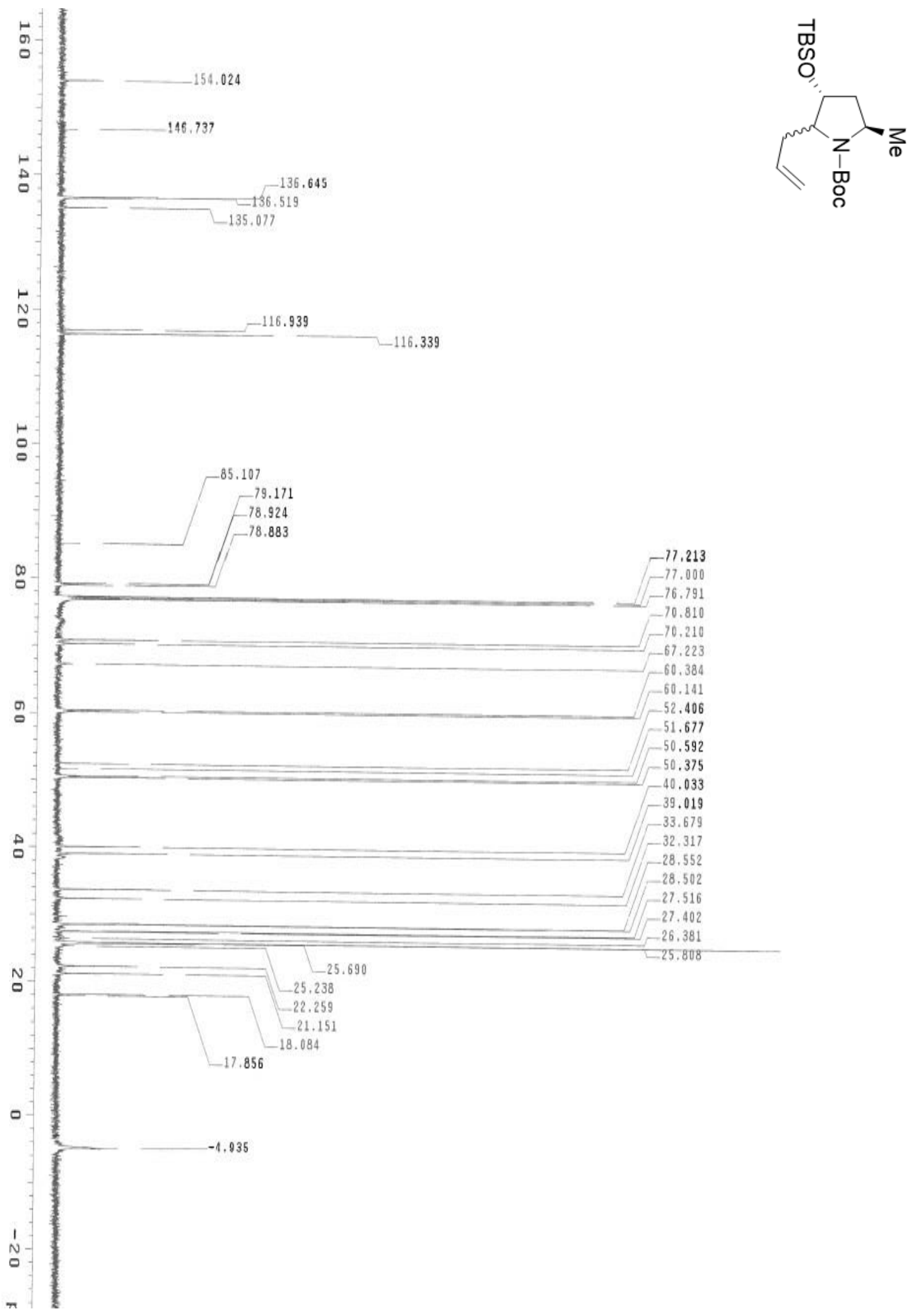

Figure 11: ${ }^{13} \mathrm{C}$ NMR of 1-( $t$-butoxycarbonyl)-3(R)-[(t-butyldimethylsilyl)oxy]-5(R)methyl-2-(2-propen-1-yl)-pyrrolidine (6) 


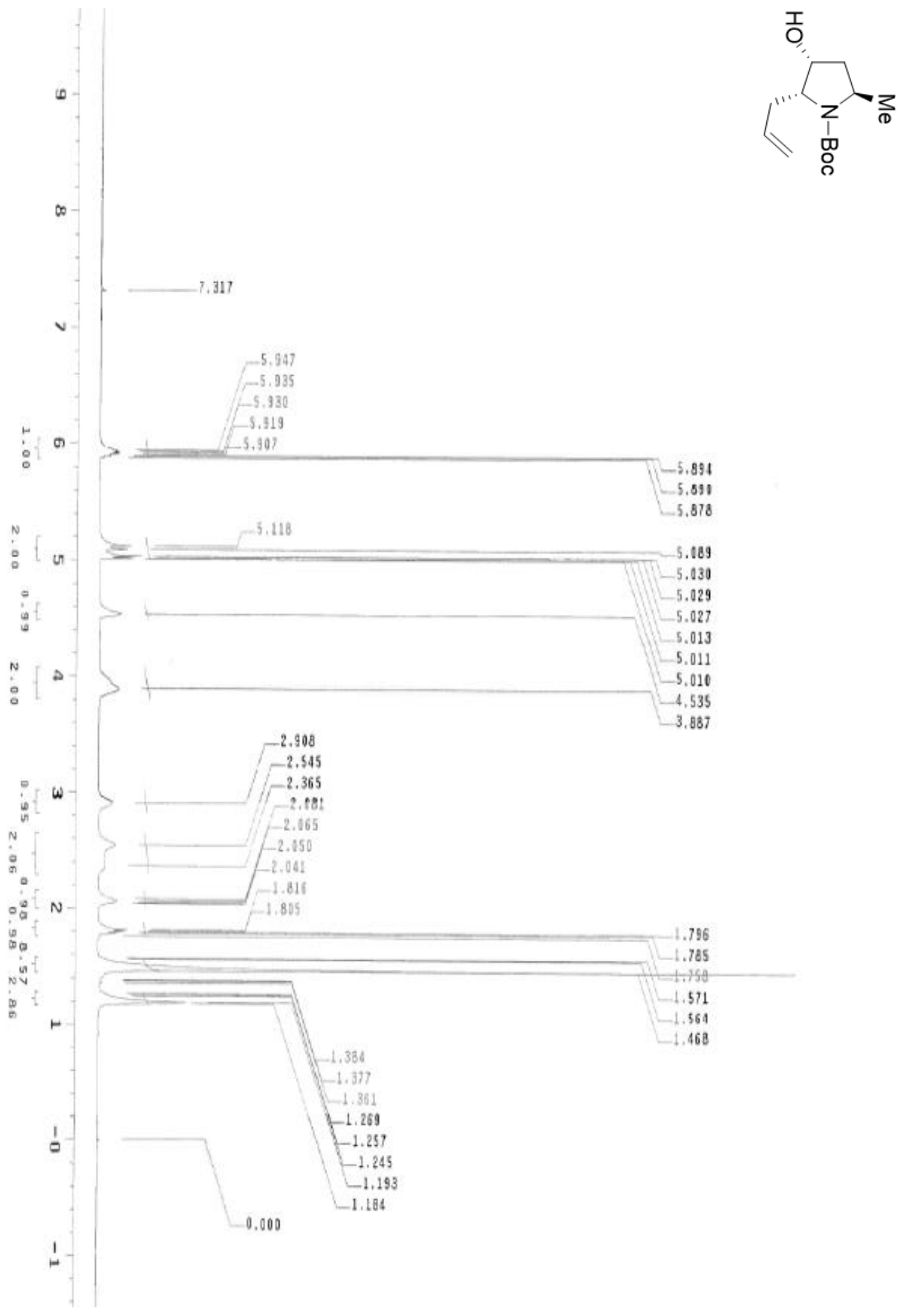

Figure 12: ${ }^{1} \mathrm{H}$ NMR of 1-(t-butoxycarbonyl)-3(R)-hydroxy-5(R)-methyl-2(R)-(2-propen1-yl)pyrrolidine (7) 


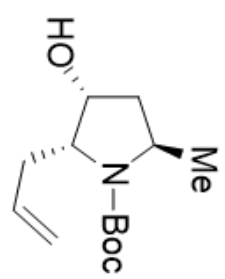

$-136.337$
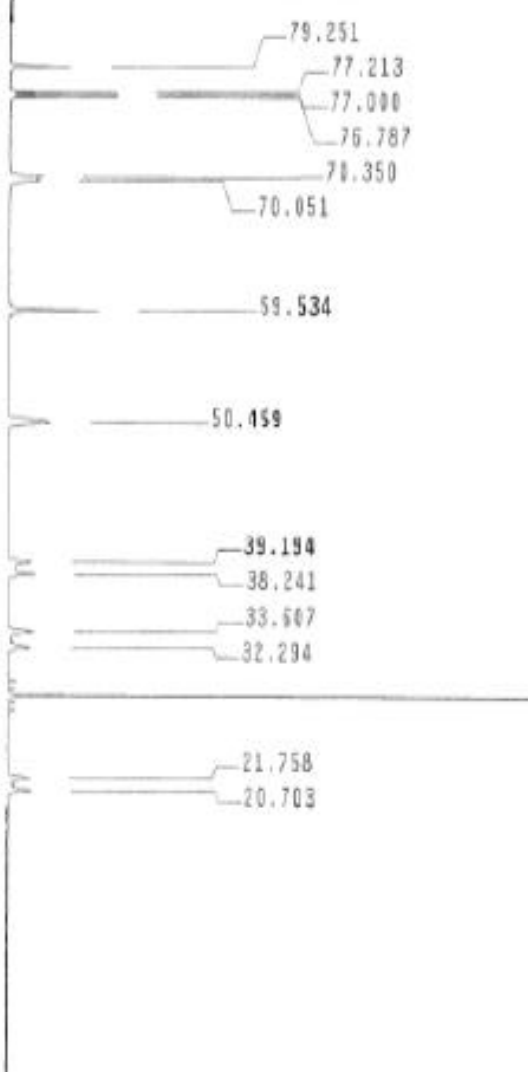

28,389

Figure 13: ${ }^{13} \mathrm{C}$ NMR of 1-(t-butoxycarbonyl)-3(R)-hydroxy-5(R)-methyl-2(R)-(2-propen-1yl)pyrrolidine (7) 


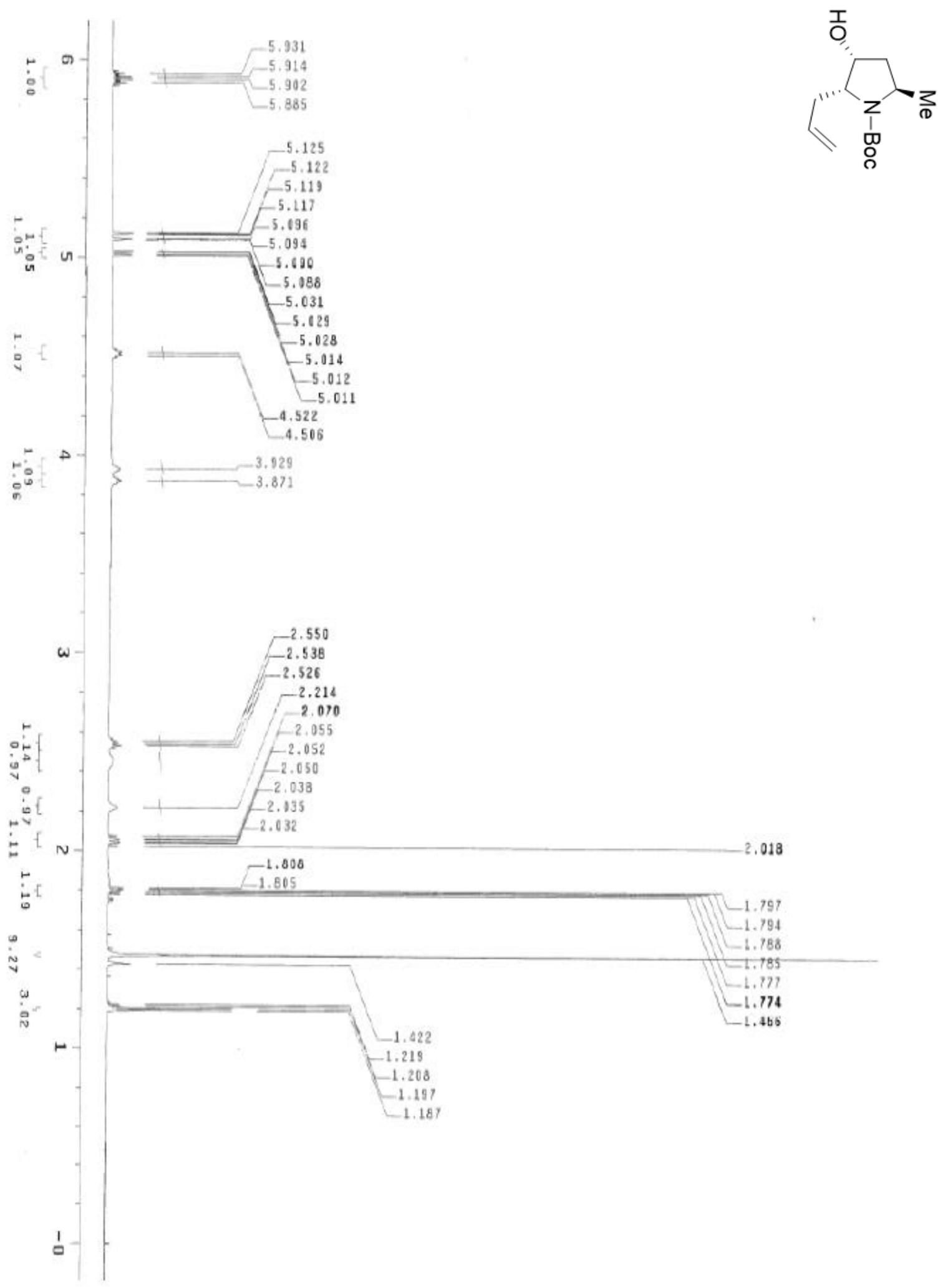

Figure 14: ${ }^{1} \mathrm{H}$ NMR $\left(60^{\circ} \mathrm{C}\right)$ of 1-(t-butoxycarbonyl)-3(R)-hydroxy-5(R)-methyl-2(R)-(2propen-1-yl)pyrrolidine (7) 


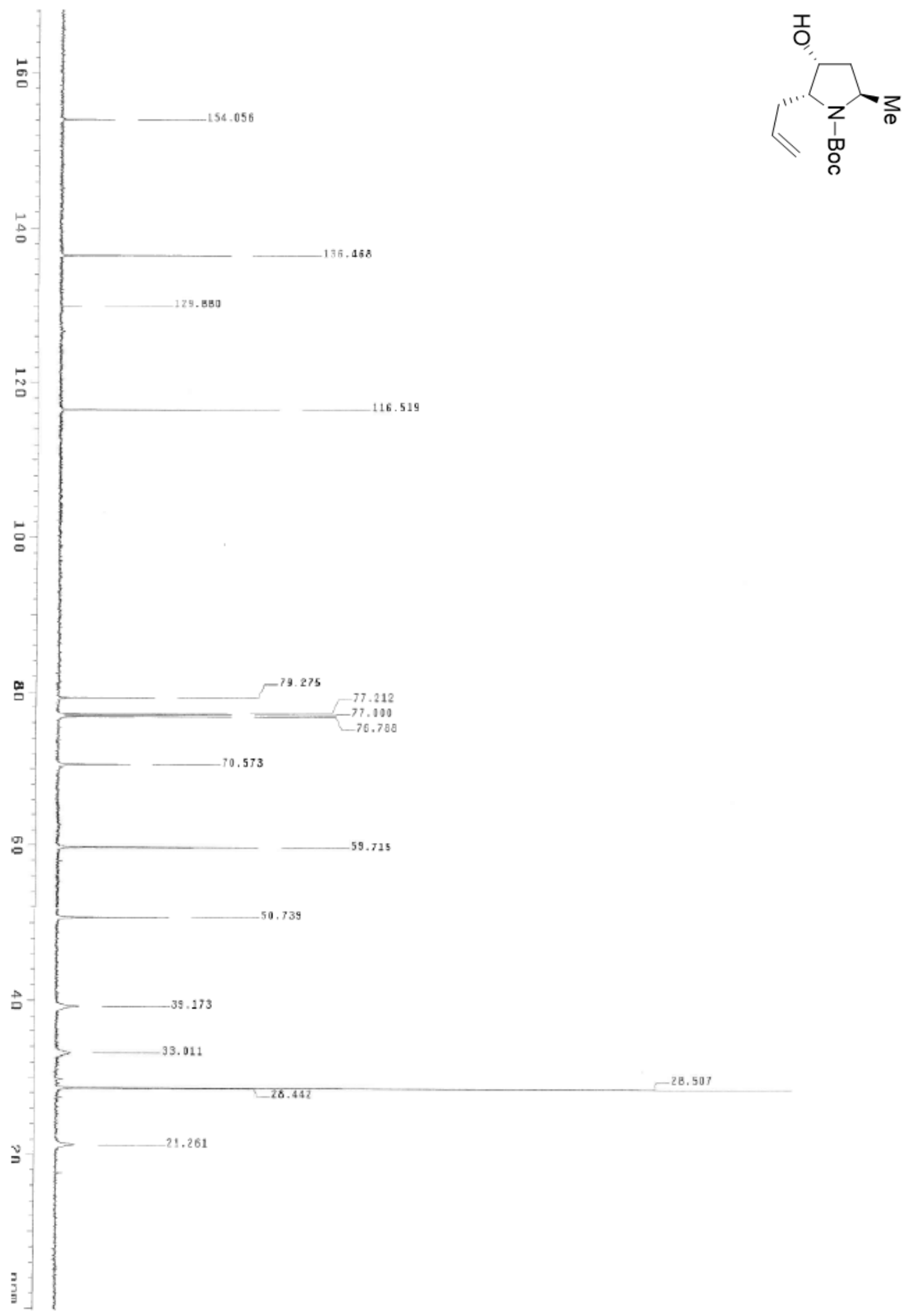

Figure $15:{ }^{13} \mathrm{C}$ NMR $\left(60{ }^{\circ} \mathrm{C}\right)$ of 1-(t-butoxycarbonyl)-3(R)-hydroxy-5(R)-methyl-2(R)-(2propen-1-yl)pyrrolidine (7) 


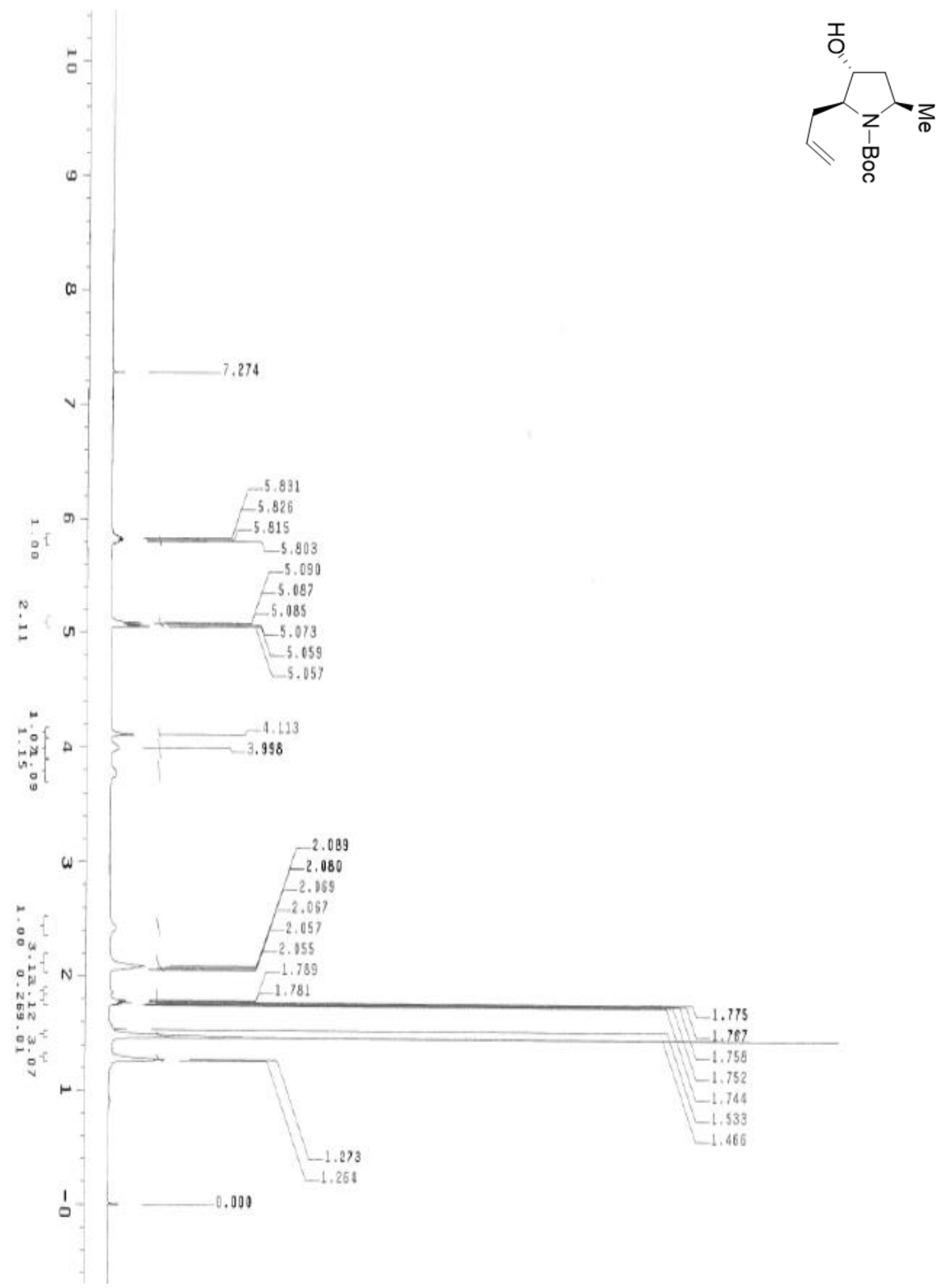

Figure 16: ${ }^{1} \mathrm{H}$ NMR of 1-(t-butoxycarbonyl)-3(R)-hydroxy-5(R)-methyl-2(S)-(2-propen-1yl)pyrrolidine (8) 


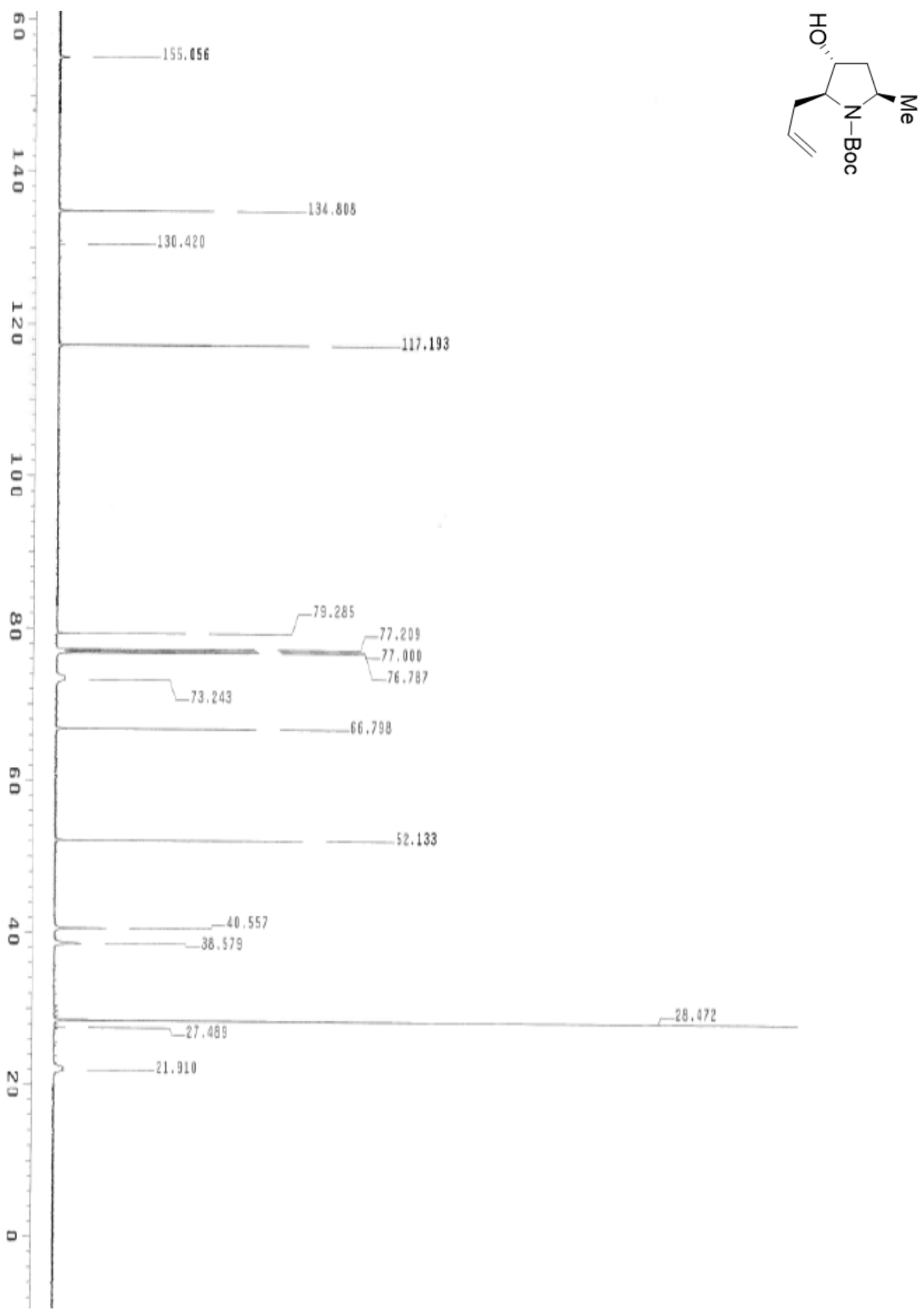

Figure 17: ${ }^{13} \mathrm{C}$ NMR of 1-(t-butoxycarbonyl)-3(R)-hydroxy-5(R)-methyl-2(S)-(2-propen-1yl)pyrrolidine (8) 


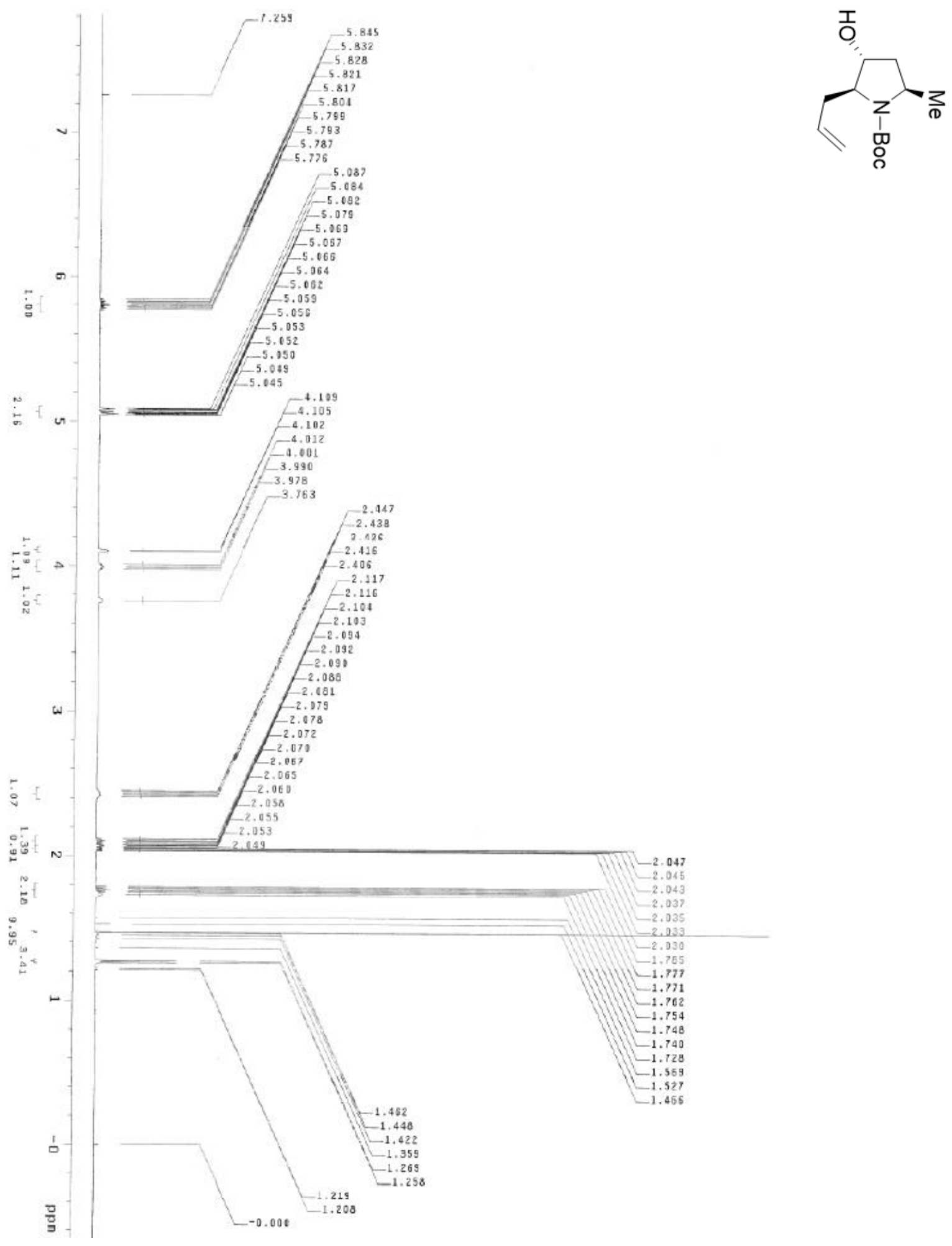

Figure $18:{ }^{1} \mathrm{H}$ NMR $\left(60{ }^{\circ} \mathrm{C}\right)$ of 1-(t-butoxycarbonyl)-3(R)-hydroxy-5(R)-methyl-2(S)-(2propen-1-yl)pyrrolidine (8) 


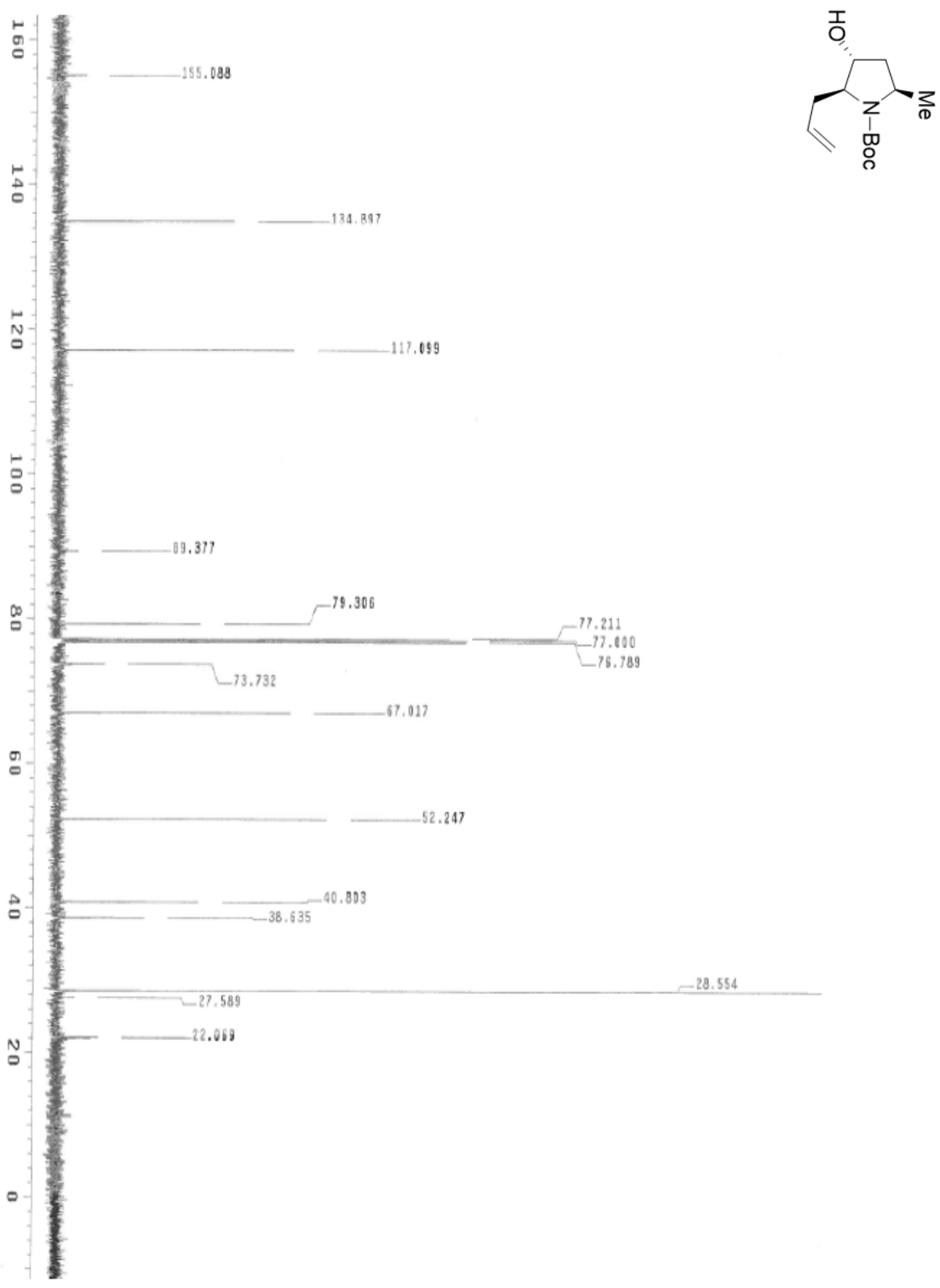

Figure 19: ${ }^{13} \mathrm{C}$ NMR $\left(60^{\circ} \mathrm{C}\right)$ of 1-(t-butoxycarbonyl)-3(R)-hydroxy-5(R)-methyl-2(S)-(2propen-1-yl)pyrrolidine (8) 


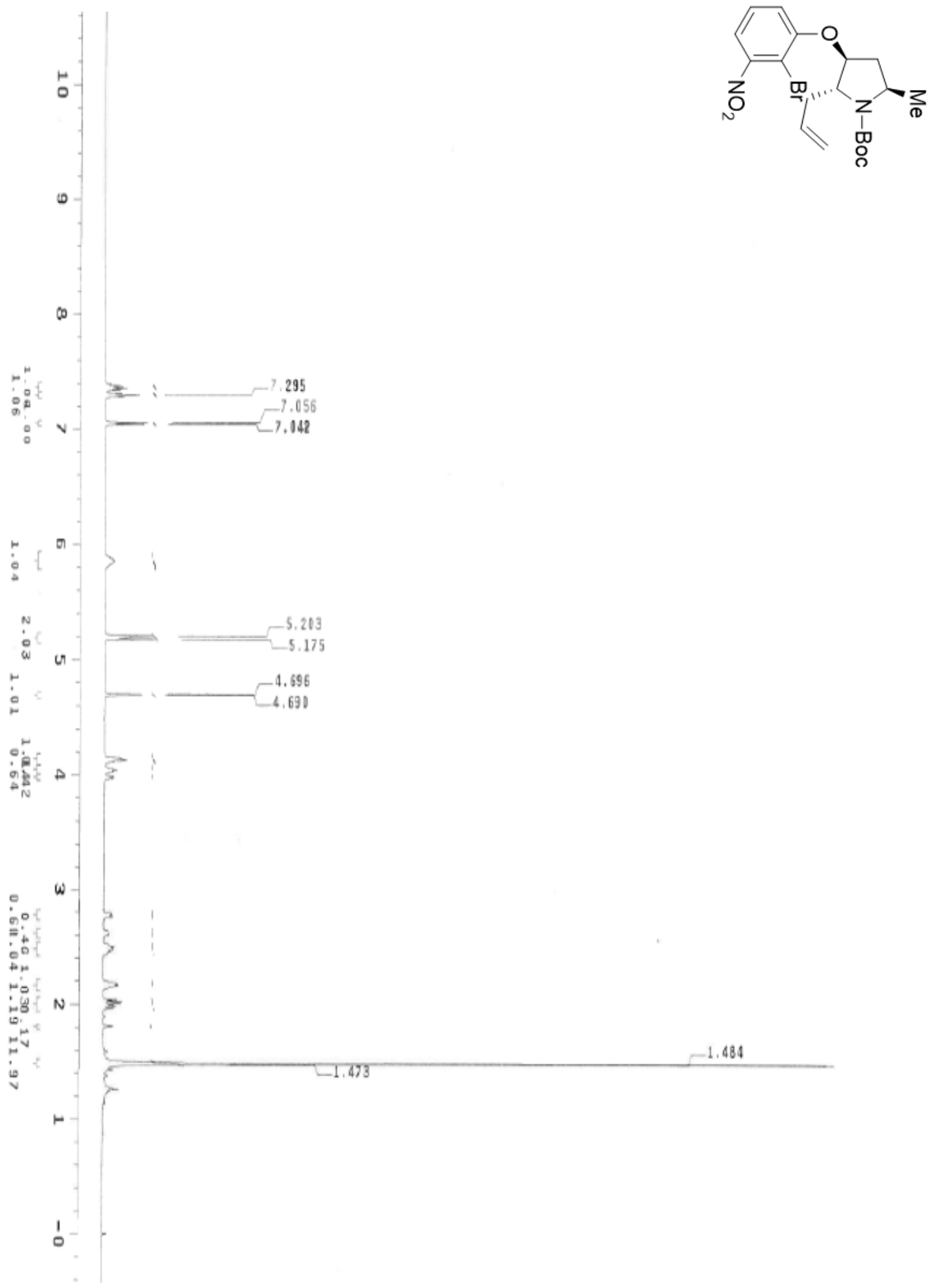

Figure 20: ${ }^{1} \mathrm{H}$ NMR of 2(R)-(2-propen-1-yl)-1-(t-butoxycarbonyl)-3(S)-(2-bromo-3nitrophenoxy-5(R)-methylpyrrolidine (10) 


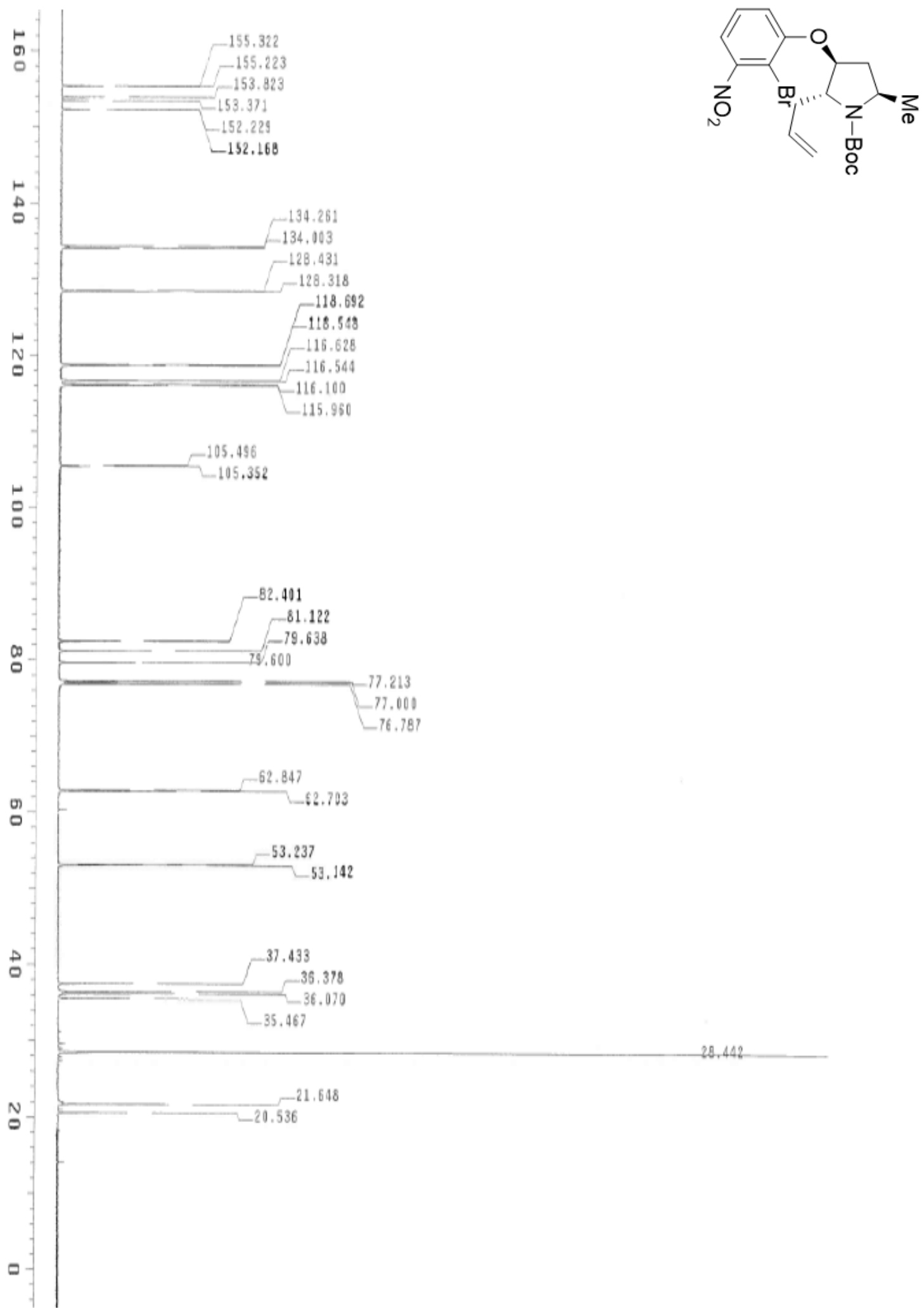

Figure 21: ${ }^{13} \mathrm{C}$ NMR of 2(R)-(2-propen-1-yl)-1-(t-butoxycarbonyl)-3(S)-(2-bromo-3nitrophenoxy-5(R)-methylpyrrolidine (10) 


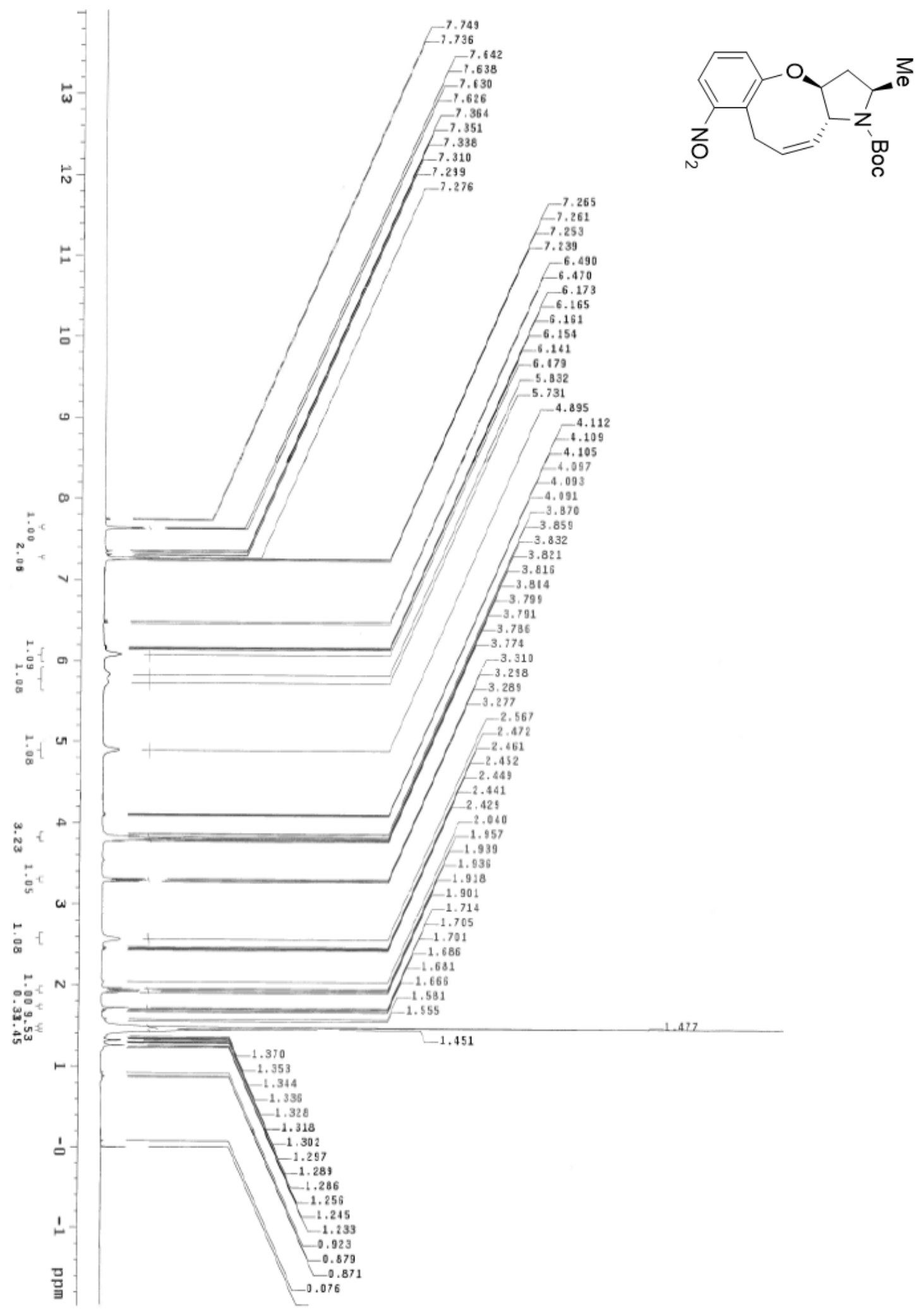

Figure 22: ${ }^{1} \mathrm{H}$ NMR of tricyclic compound 11 


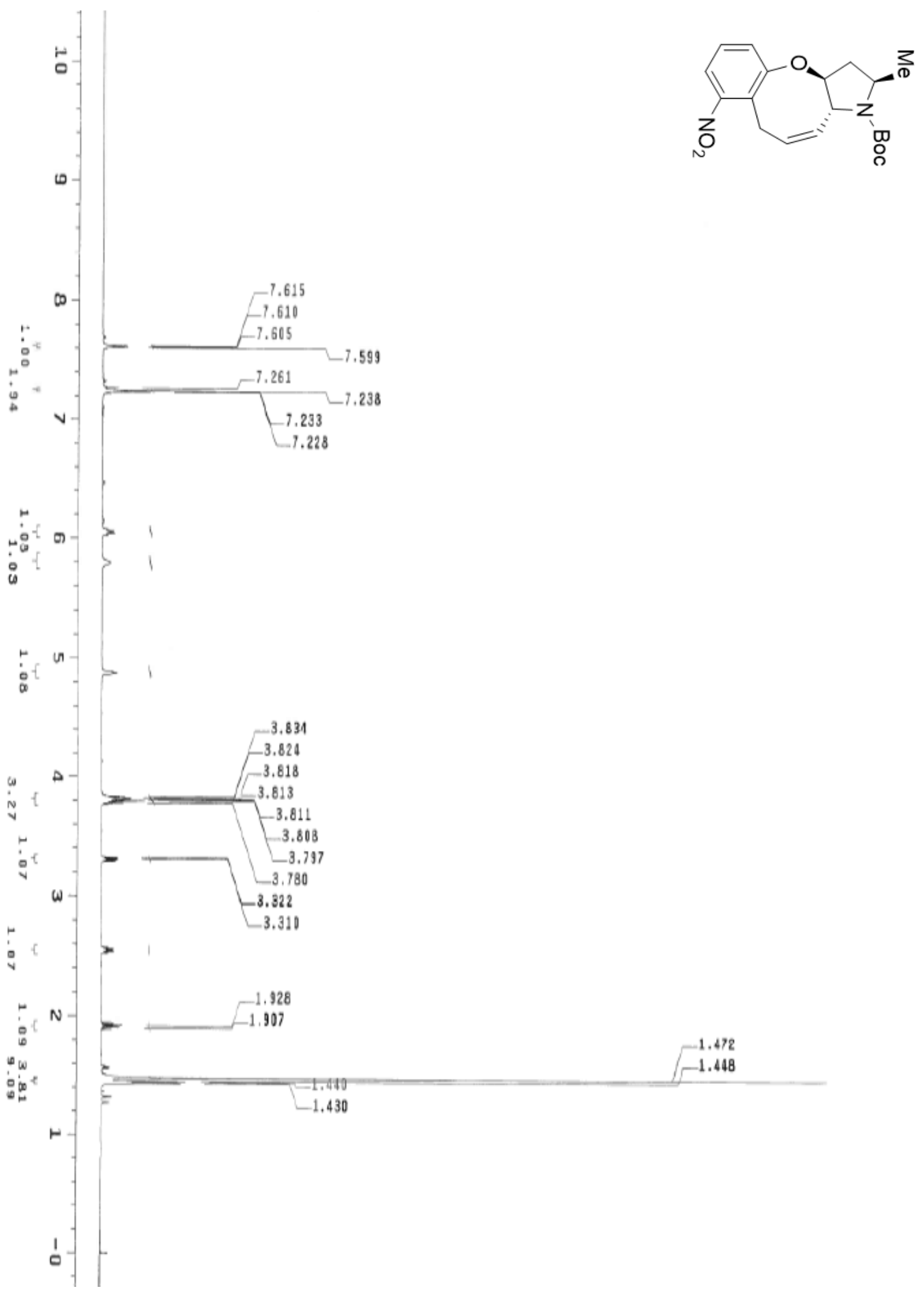

Figure 23: ${ }^{1} \mathrm{H}$ NMR $\left(60^{\circ} \mathrm{C}\right)$ of tricyclic compound $\mathbf{1 1}$ 


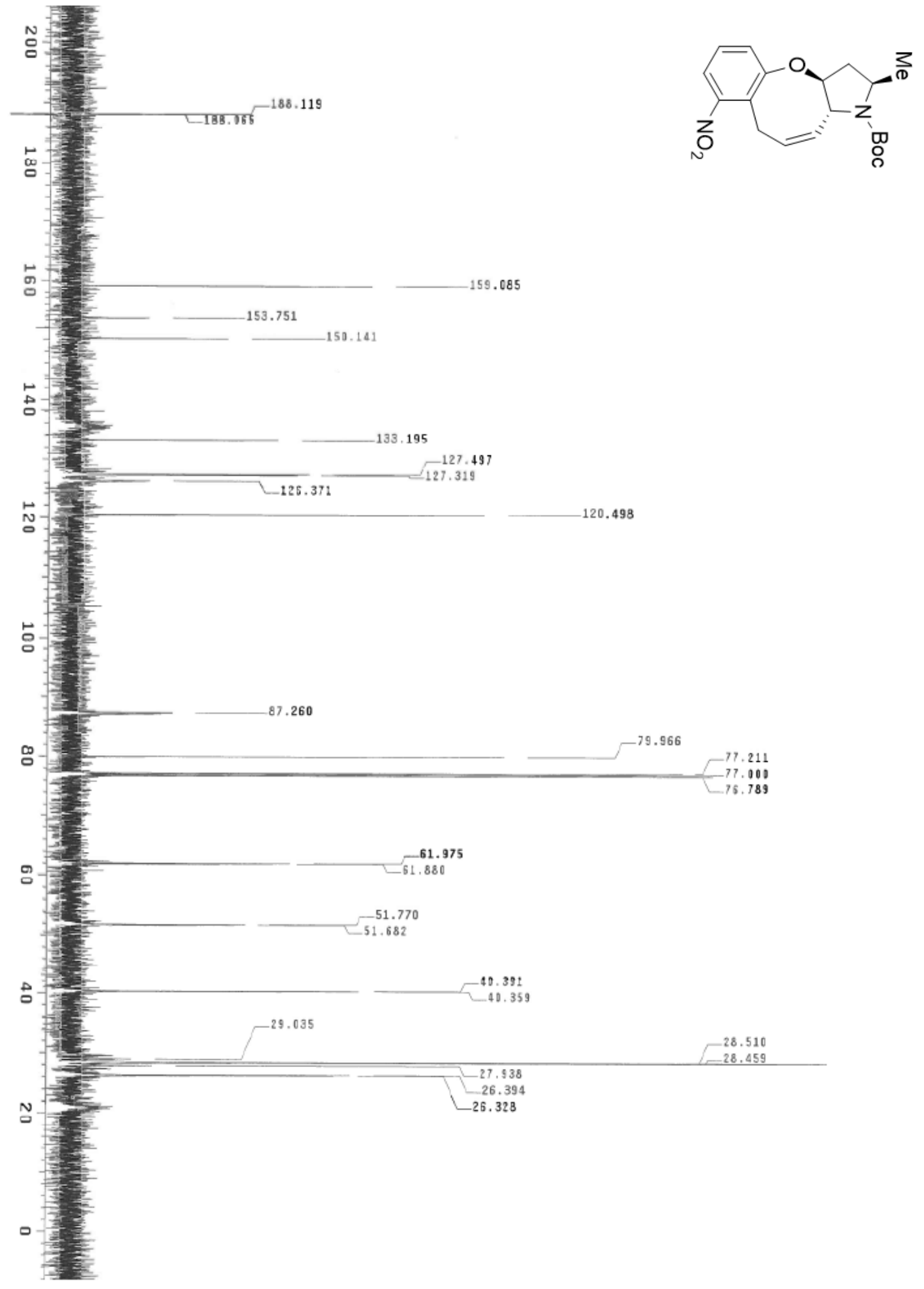

Figure $24:{ }^{13} \mathrm{C}$ NMR $\left(60^{\circ} \mathrm{C}\right)$ of tricyclic compound $\mathbf{1 1}$ 

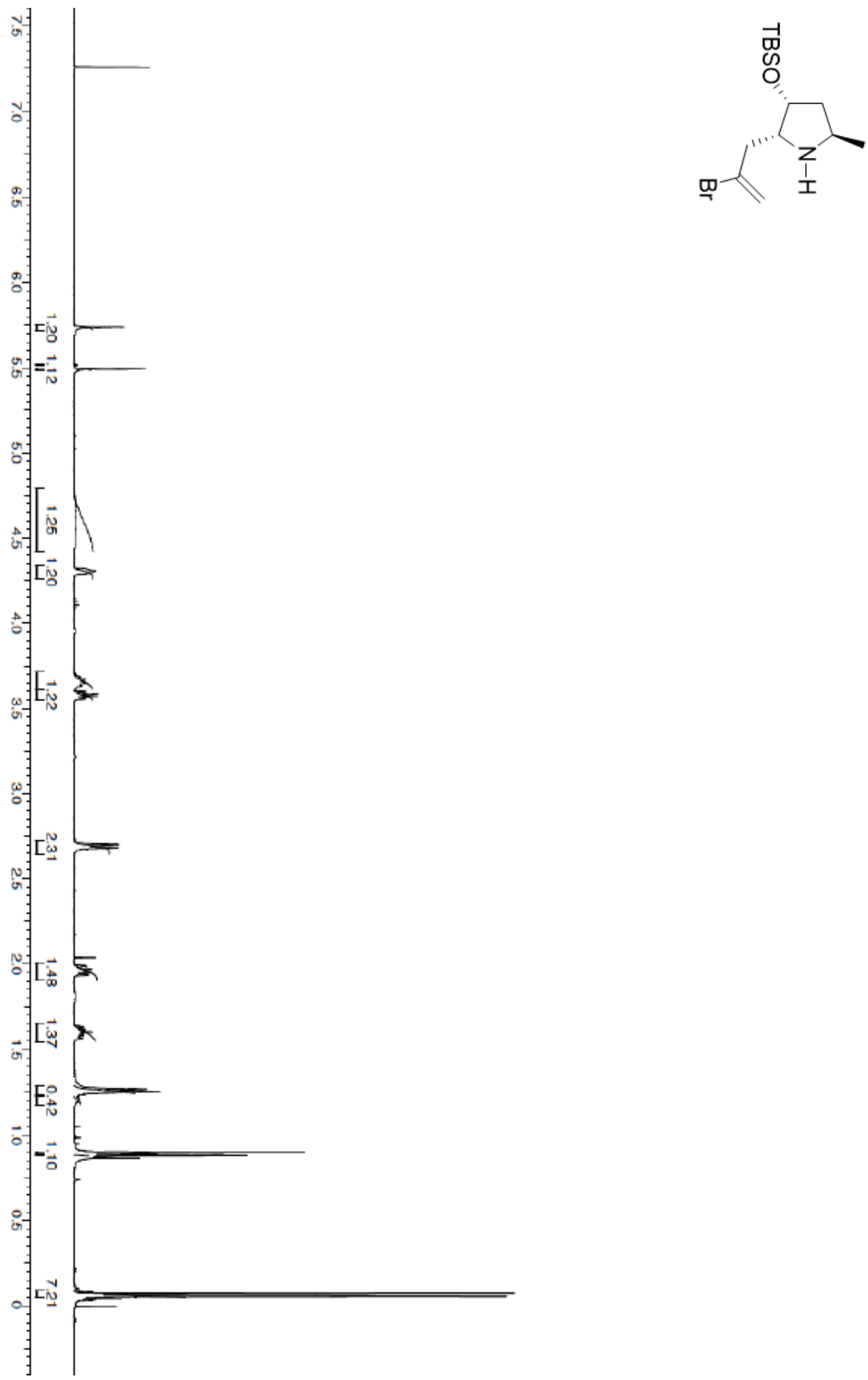

Figure 25: ${ }^{1} \mathrm{H}$ NMR of 2(R)-(2-bromo-2-propen-1-yl)-3(R)-[(t-butyldimethylsilyl)-oxy]5(R)-methylpyrrolidine (14) 


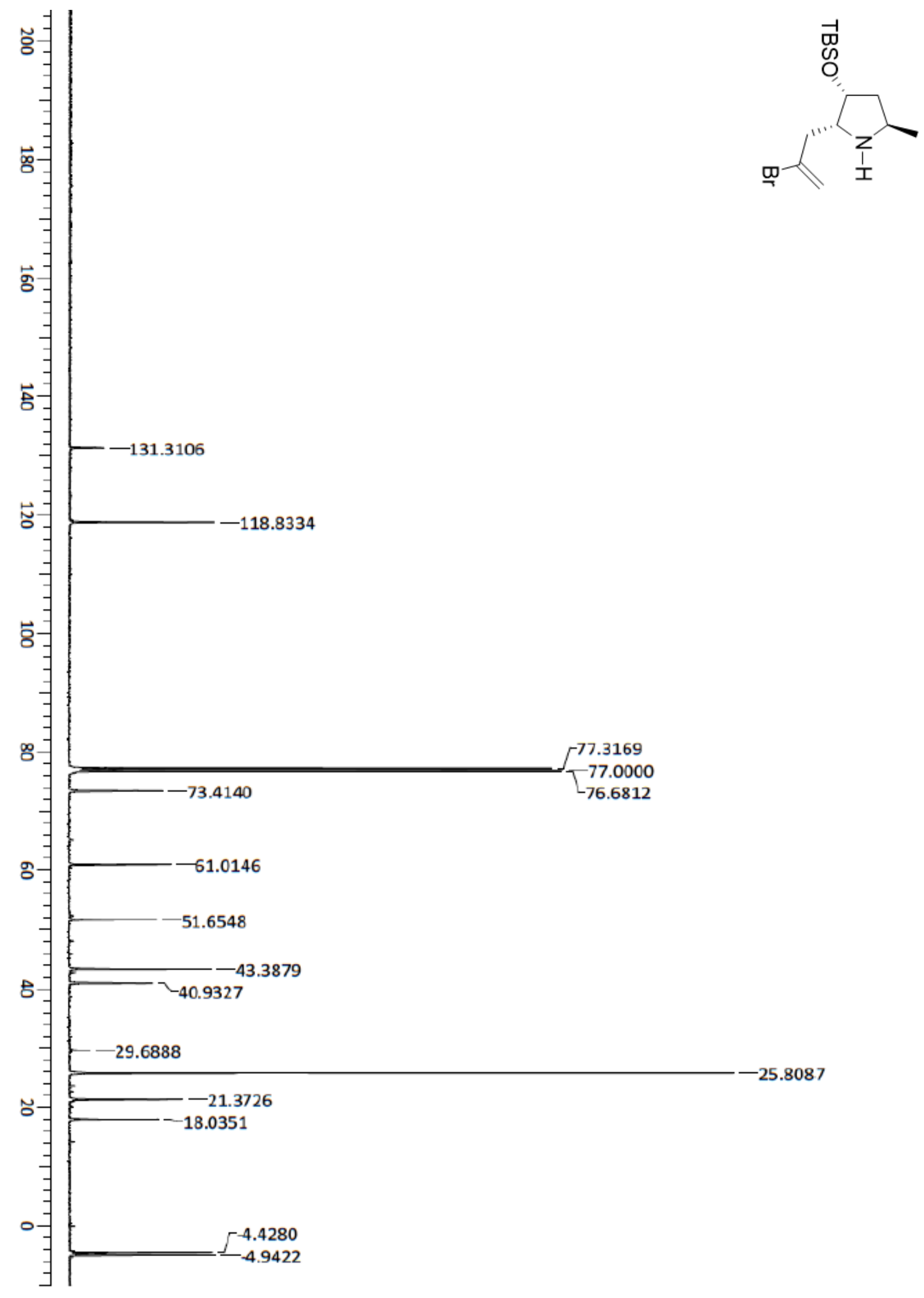

Figure 26: ${ }^{13} \mathrm{C}$ NMR of 2(R)-(2-bromo-2-propen-1-yl)-3(R)-[(t-butyldimethylsilyl)-oxy]5(R)-methylpyrrolidine (14) 


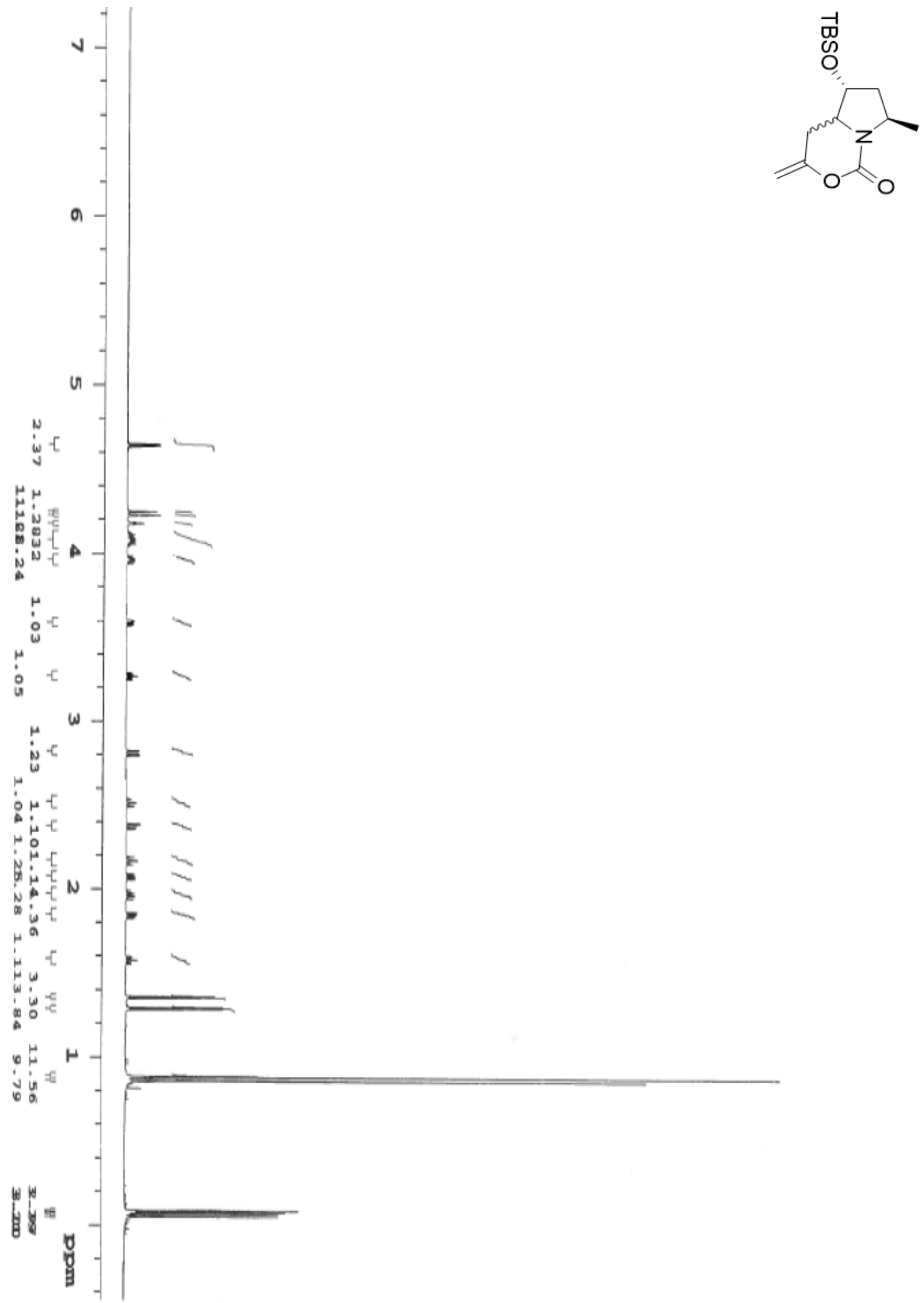

Figure 27: ${ }^{1} \mathrm{H}$ NMR of 5(R)-[(t-butyldimethylsilyl)oxy]-(4a)-hexahydro-3-methylene-7(R)methyl-1H-pyrrolo[1,2-c][1,3]oxazin-1-one (15) 


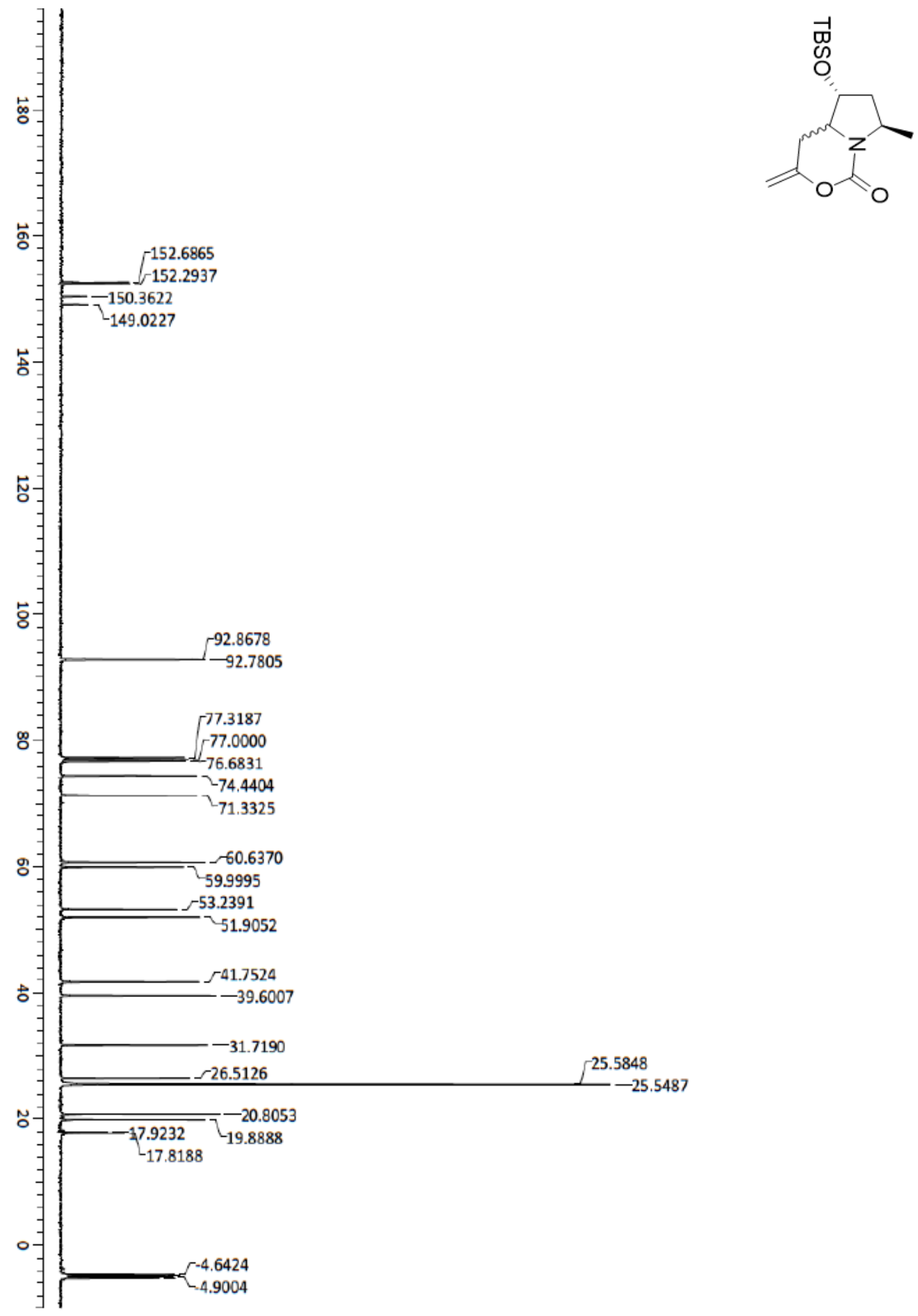

Figure 28: ${ }^{13} \mathrm{C}$ NMR of 5(R)-[(t-butyldimethylsilyl)oxy]-(4a)-hexahydro-3-methylene-7(R)methyl-1H-pyrrolo[1,2-c][1,3]oxazin-1-one (15) 


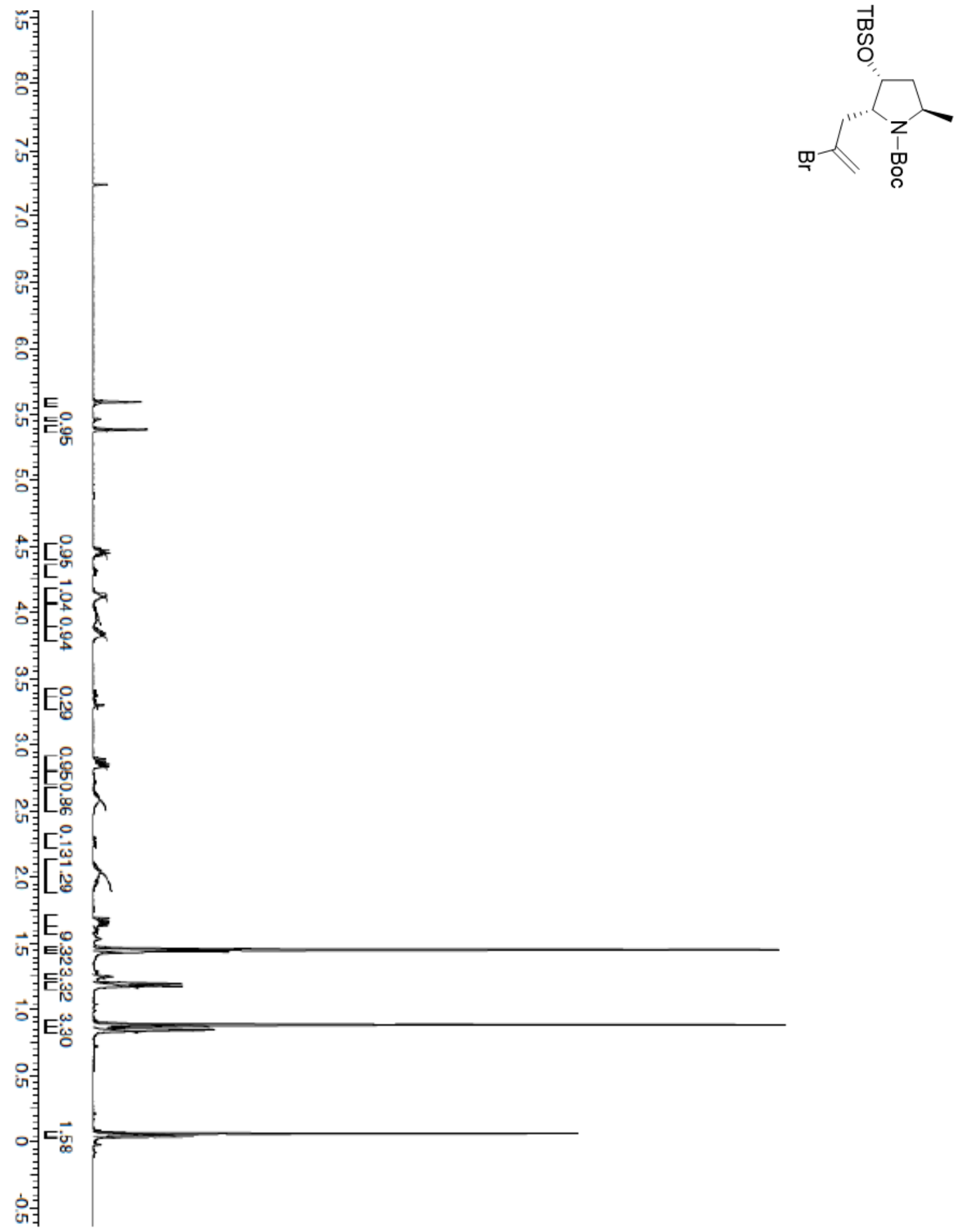

Figure 29: ${ }^{1} \mathrm{H}$ NMR of 2(R)-(2-bromo-2-propen-1-yl)-3(R)-[(t-butyldimethylsilyl)-oxy]-1-( $t$ butoxycarbonyl)-5(R)-methyl-pyrrolidine (16) 


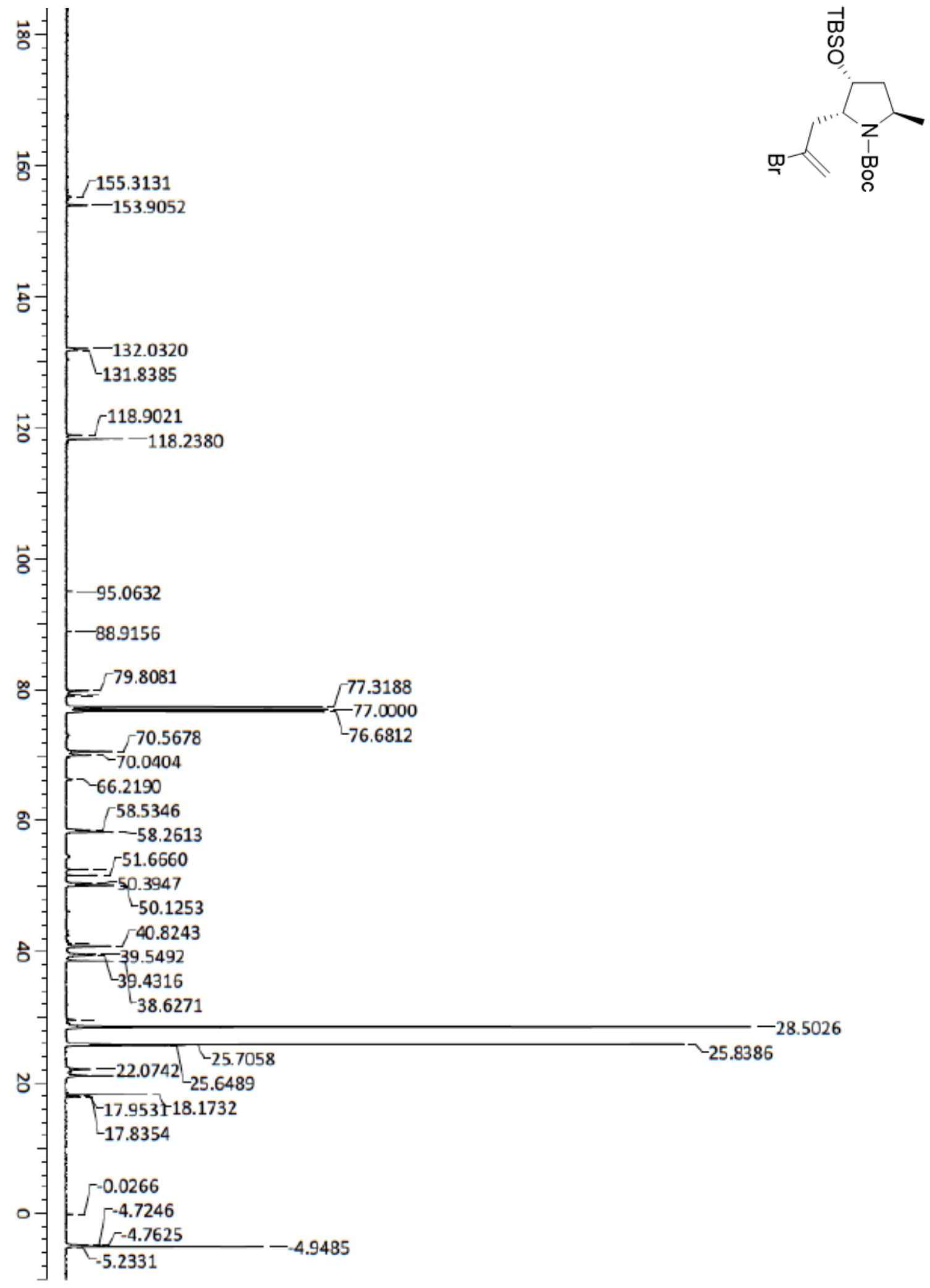

Figure 30: ${ }^{13} \mathrm{C}$ NMR $\left(65^{\circ} \mathrm{C}\right)$ of 2(R)-(2-bromo-2-propen-1-yl)-3(R)-[(t-butyldimethylsilyl)oxy]-1-(t-butoxycarbonyl)-5(R)-methyl-pyrrolidine (16) 


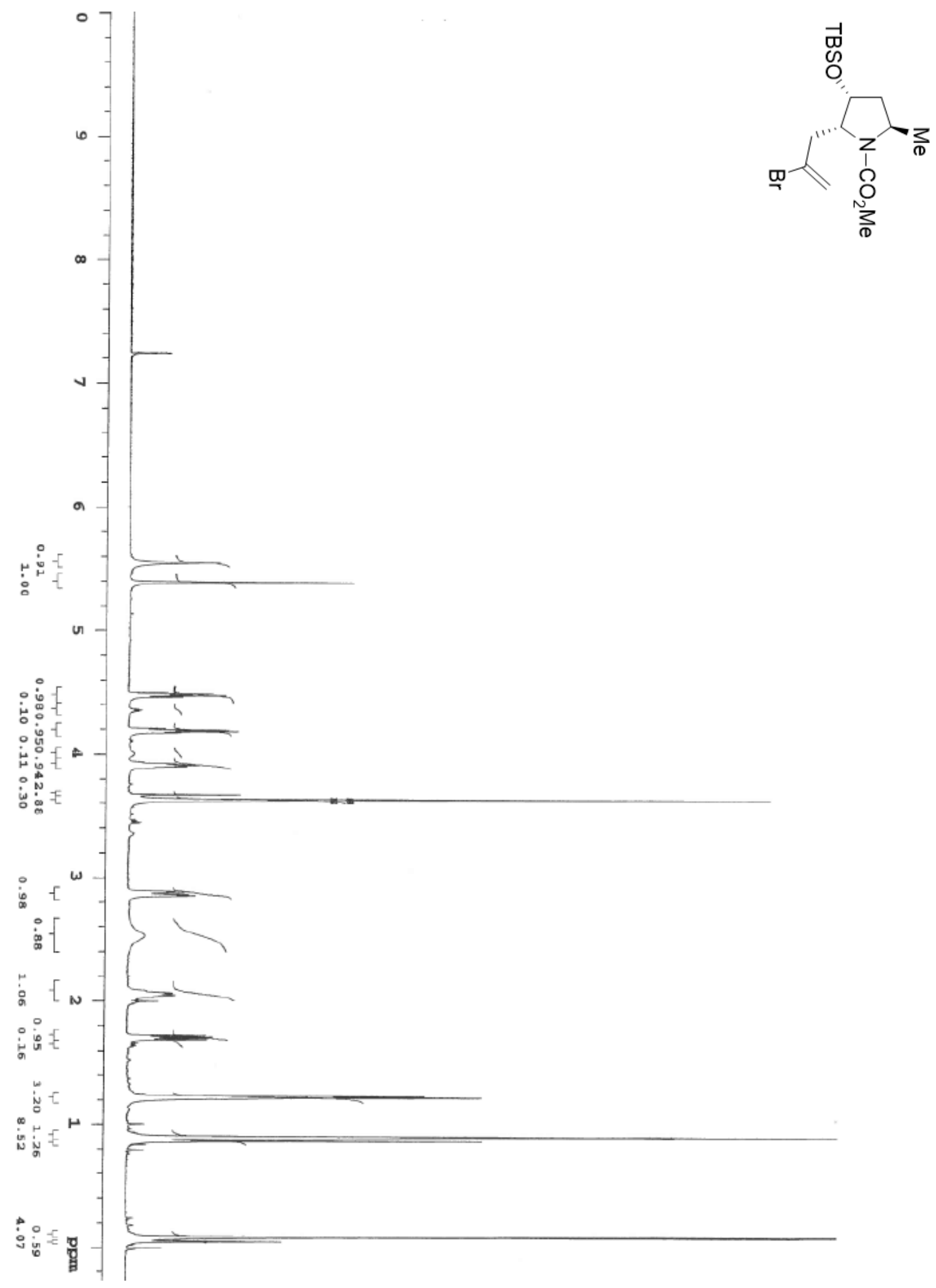

Figure 31: ${ }^{1} \mathrm{H}$ NMR $\left(65{ }^{\circ} \mathrm{C}\right)$ of 2(R)-(2-bromo-2-propen-1-yl)-3(R)-[(t-butyldimethylsilyl)oxy]-1-(methoxycarbonyl)-5(R)-methylpyrrolidine (17) 


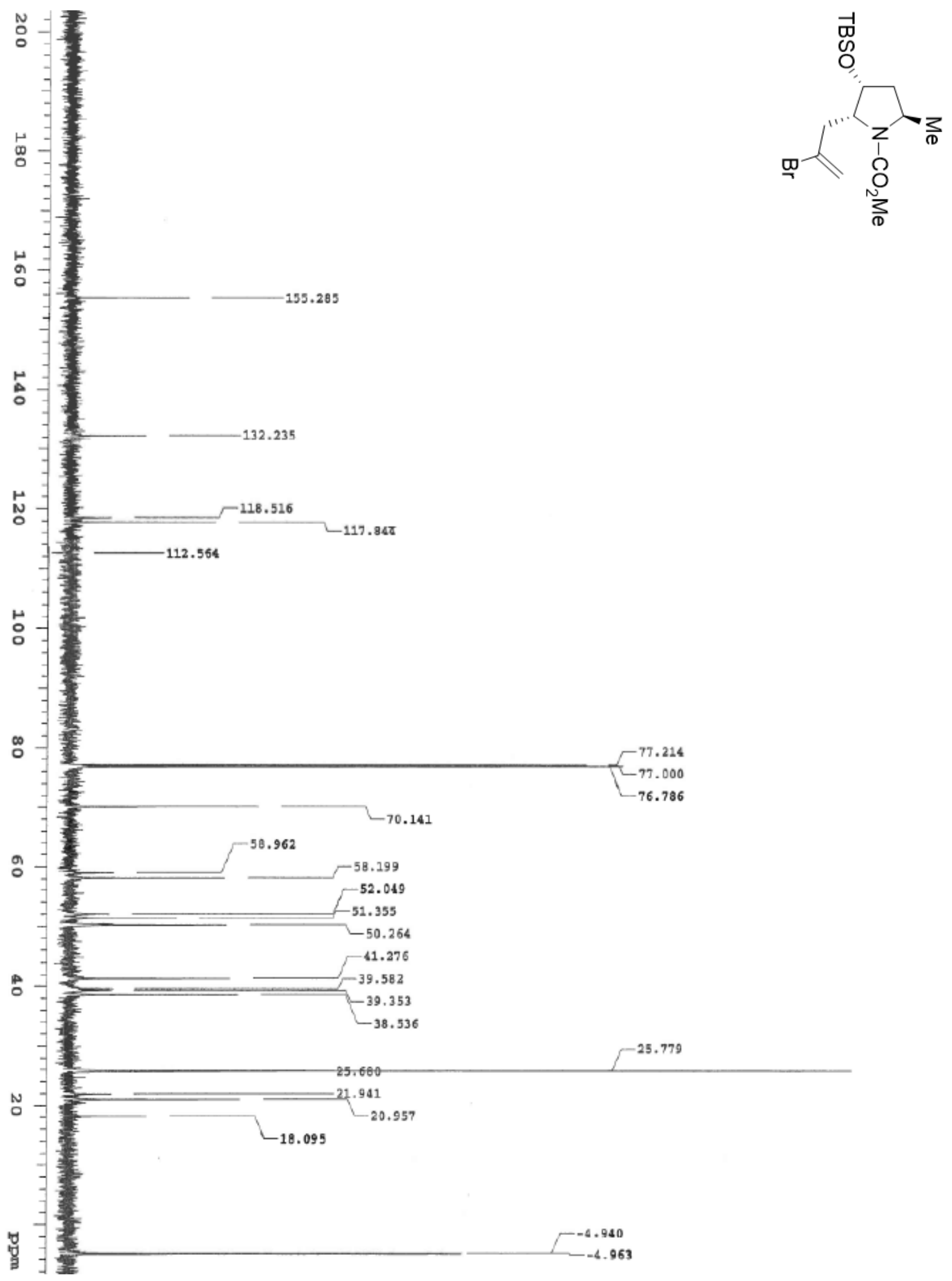

Figure 32: ${ }^{13} \mathrm{C}$ NMR $\left(65{ }^{\circ} \mathrm{C}\right)$ of 2(R)-(2-bromo-2-propen-1-yl)-3(R)-[( $t$-butyldimethylsilyl)oxy]-1-(methoxycarbonyl)-5(R)-methylpyrrolidine (17) 


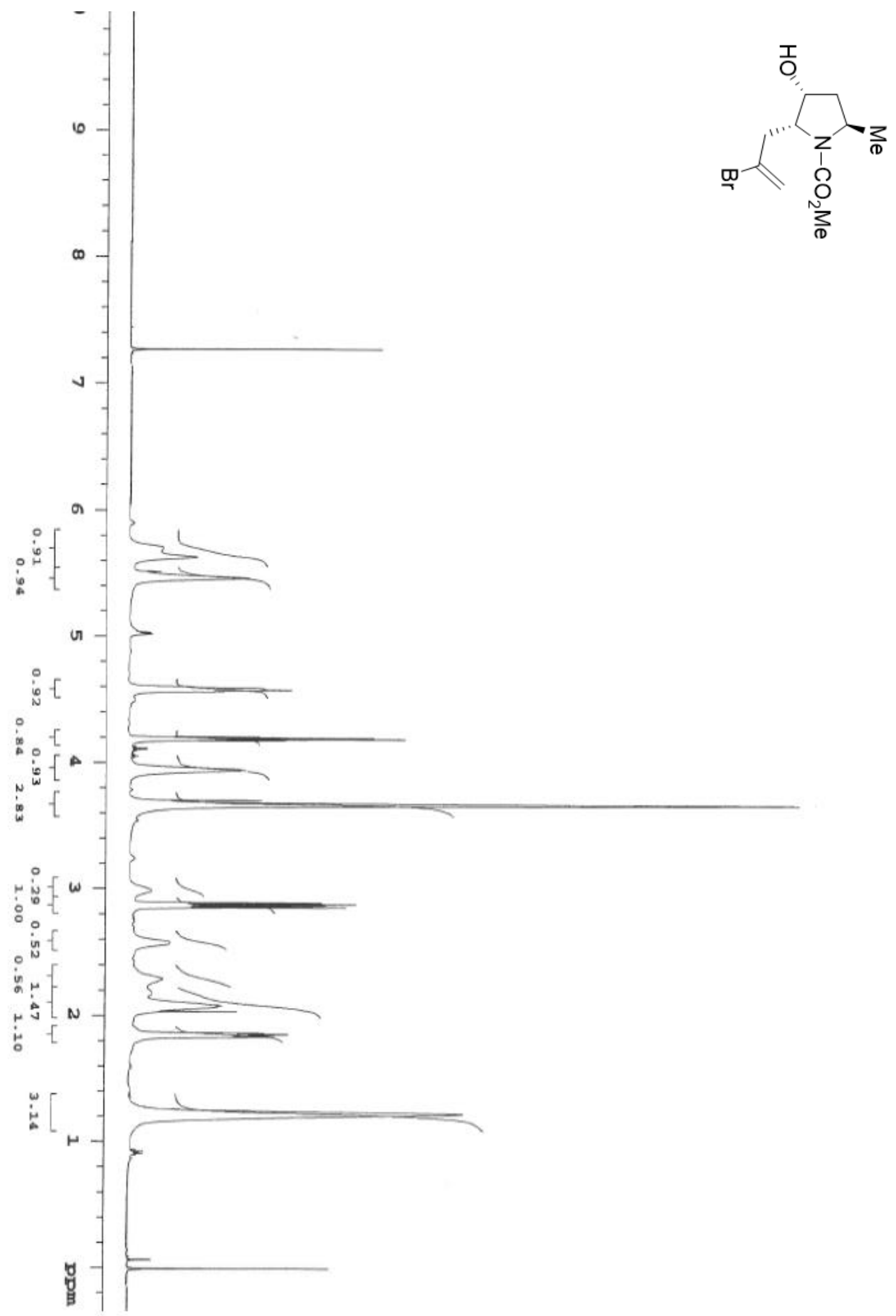

Figure 33: ${ }^{1} \mathrm{H}$ NMR of 2(R)-(2-bromo-2-propen-1-yl)-3(R)-hydroxy-1-(methoxycarbonyl)5(R)-methylpyrrolidine (18) 


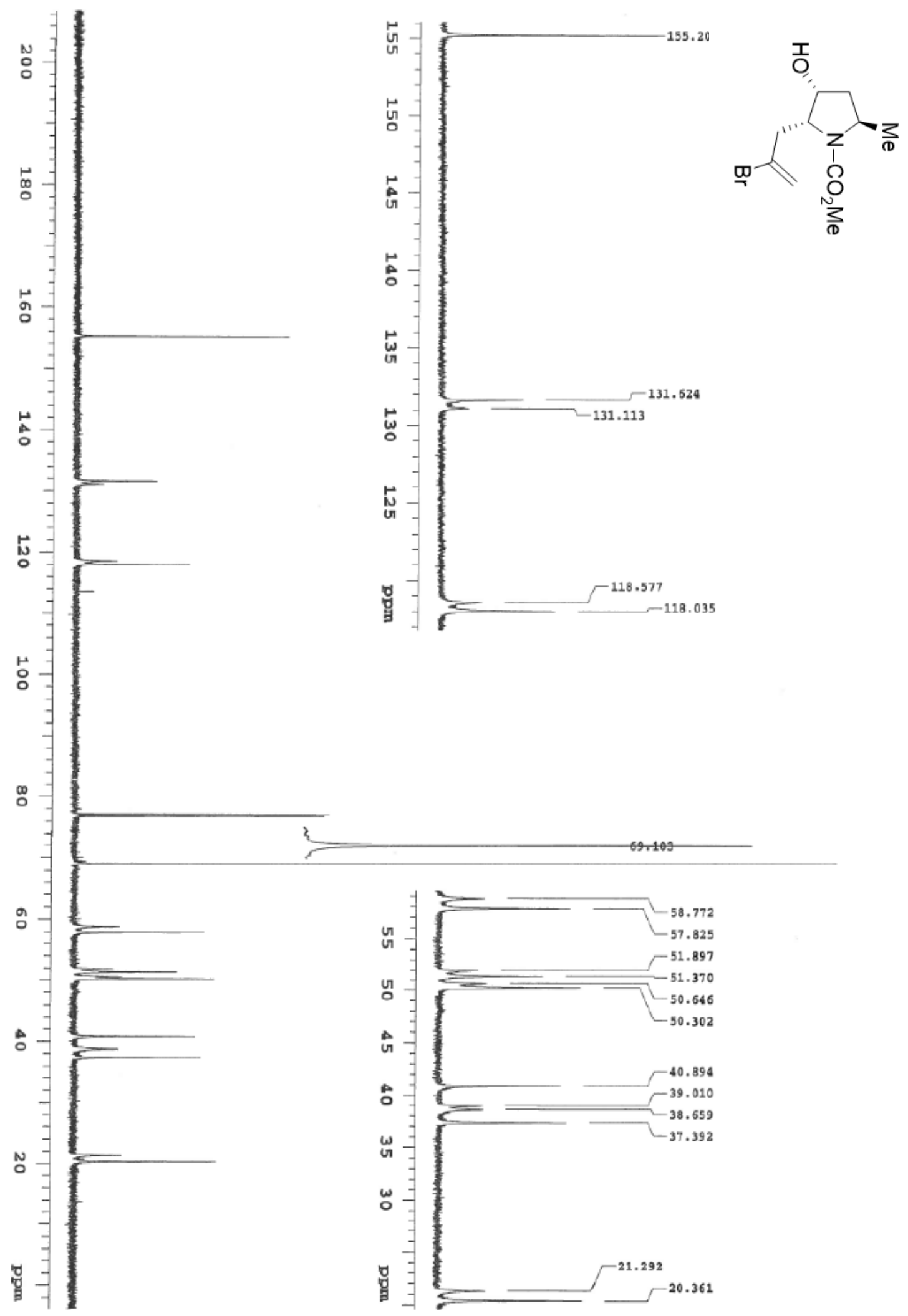

Figure $34:{ }^{13} \mathrm{C}$ NMR of 2(R)-(2-bromo-2-propen-1-yl)-3(R)-hydroxy-1-(methoxycarbonyl)5(R)-methylpyrrolidine (18) 


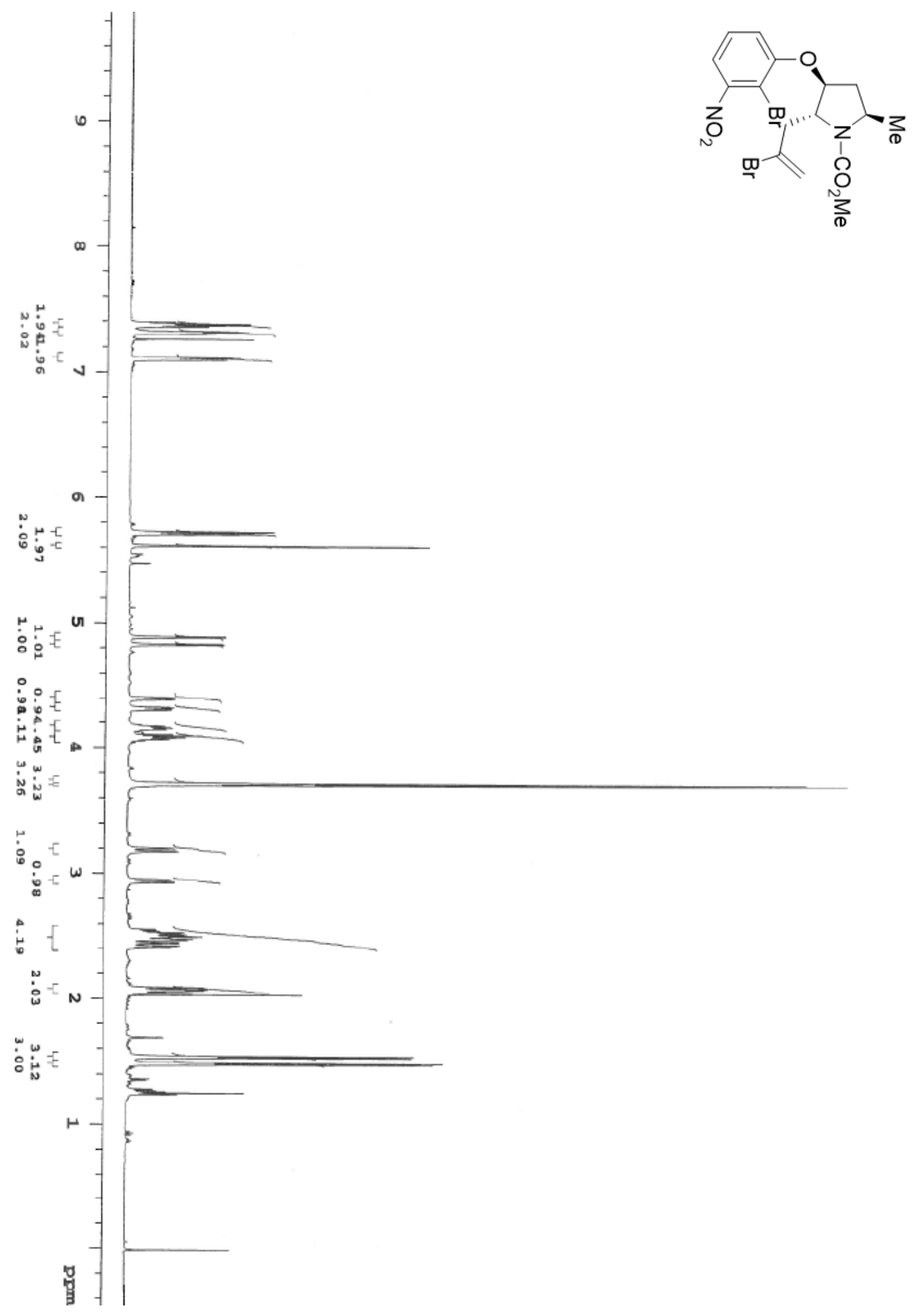

Figure 35: ${ }^{1} \mathrm{H}$ NMR of 3(S)-(2-bromo-3-nitrophenoxy)-2(R)-(2-bromo-propen-1-yl)-1(methoxycarbonyl)-5(R)-methylpyrrolidine (19) 


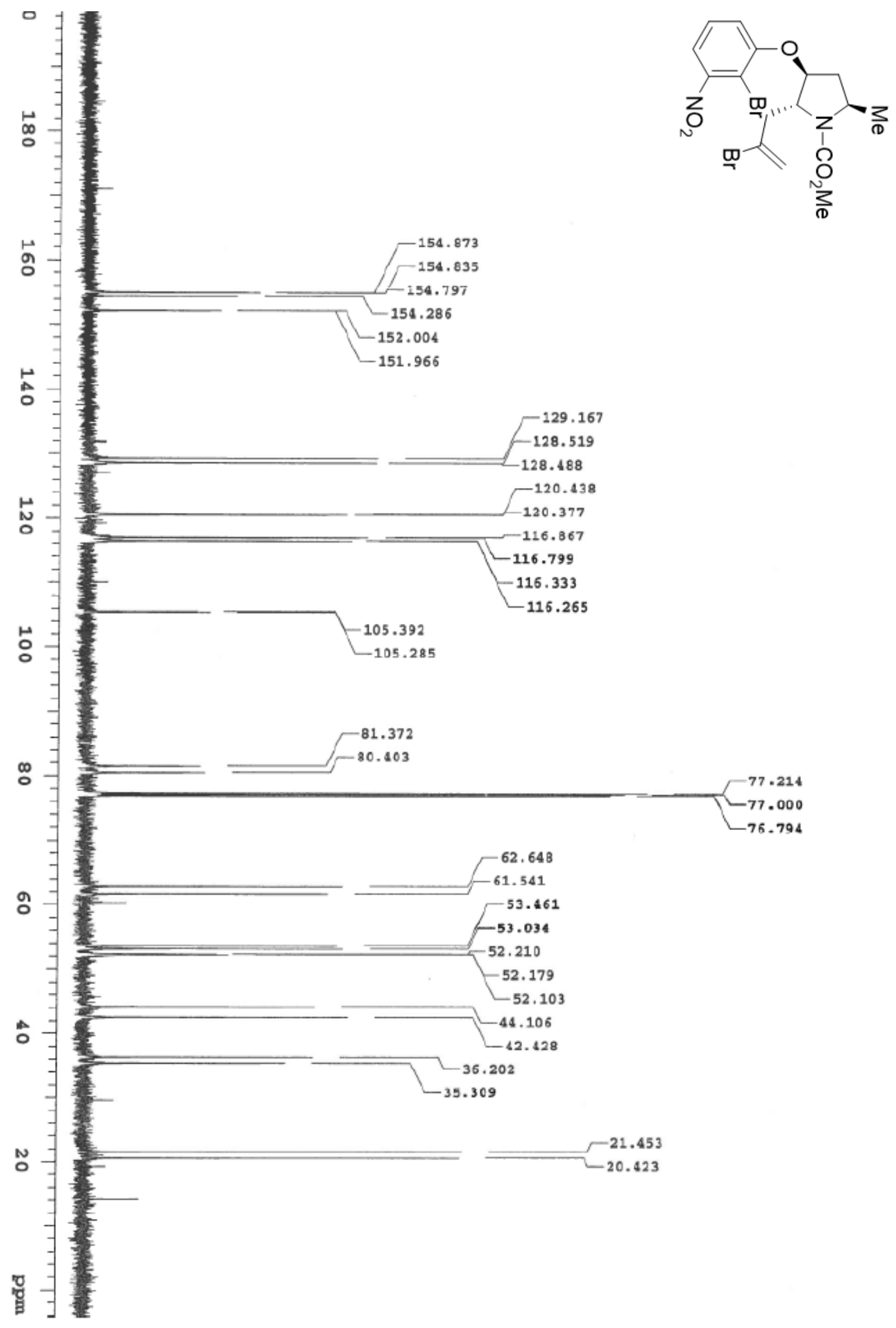

Figure 36: ${ }^{13} \mathrm{C}$ NMR of 3(S)-(2-bromo-3-nitrophenoxy)-2(R)-(2-bromo-propen-1-yl)-1(methoxycarbonyl)-5(R)-methylpyrrolidine (19) 


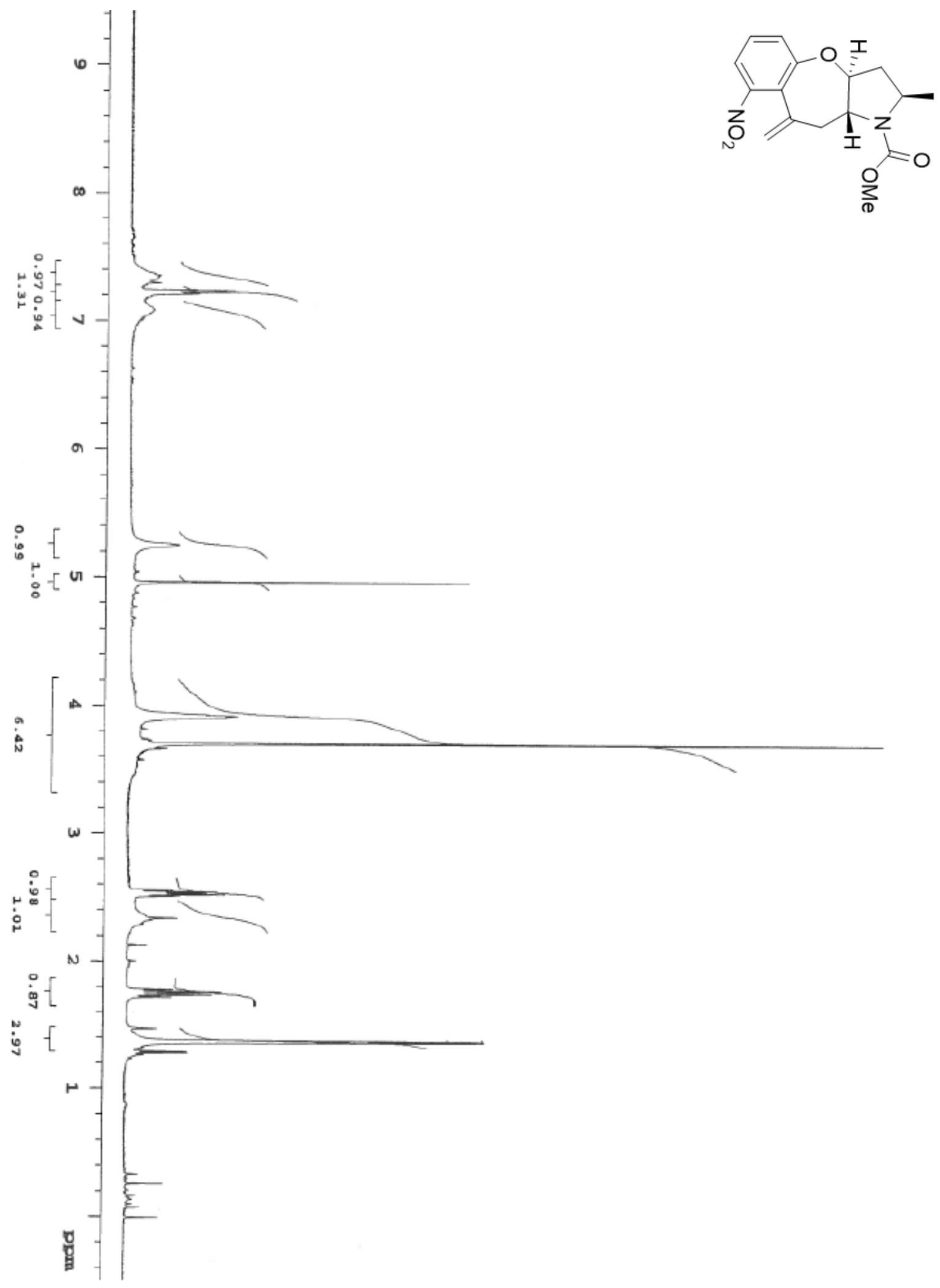

Figure 37: ${ }^{1} \mathrm{H}$ NMR $\left(65^{\circ} \mathrm{C}\right)$ of tricyclic Compound 20 

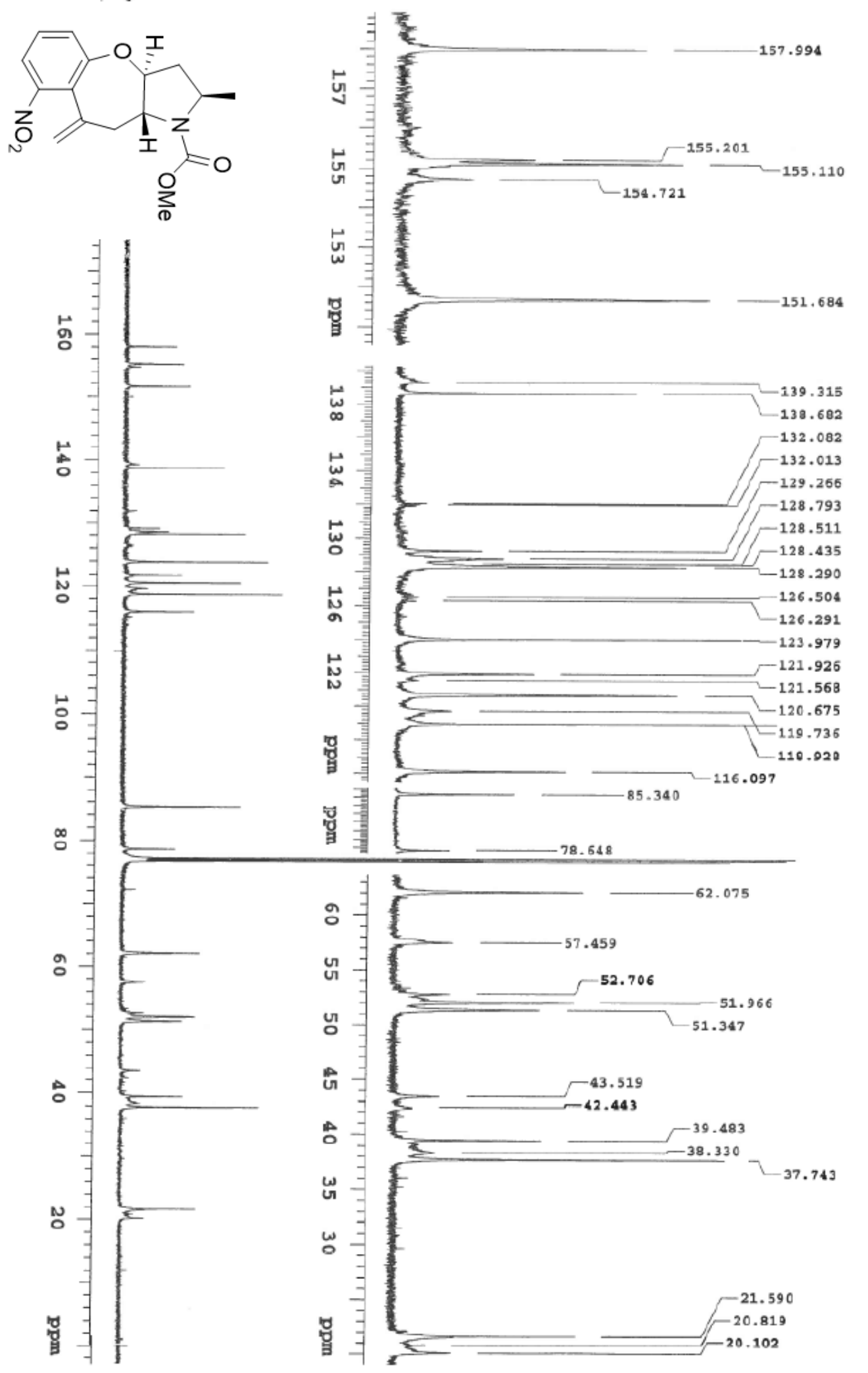

$$
\text { 虫 }
$$

a

$\stackrel{N}{N}$
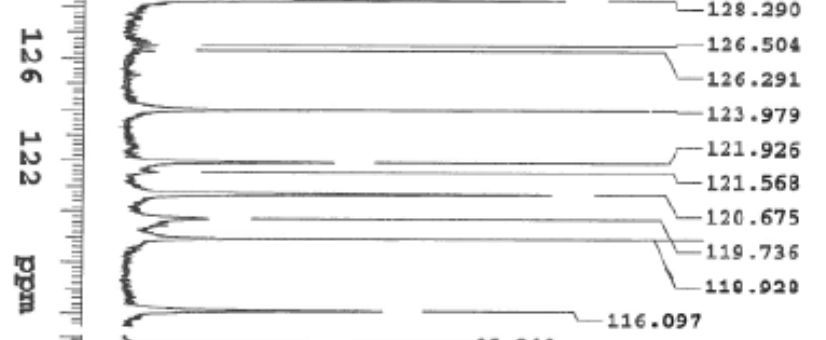

習
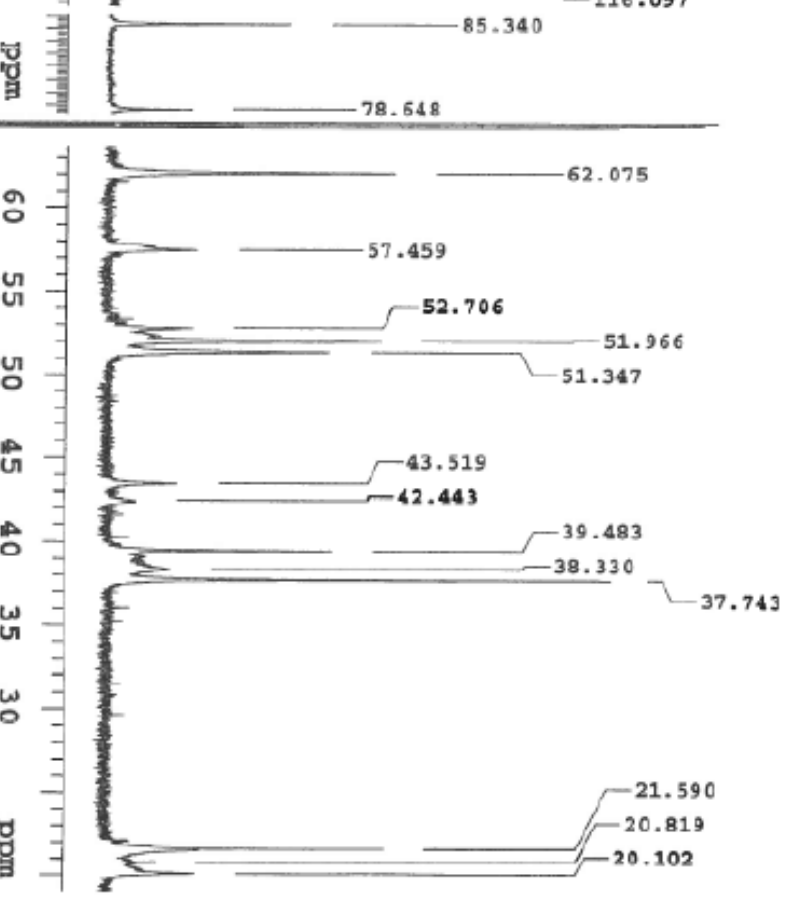

Figure $38:{ }^{13} \mathrm{C}$ NMR of $\left(65{ }^{\circ} \mathrm{C}\right)$ of tricyclic Compound 20 


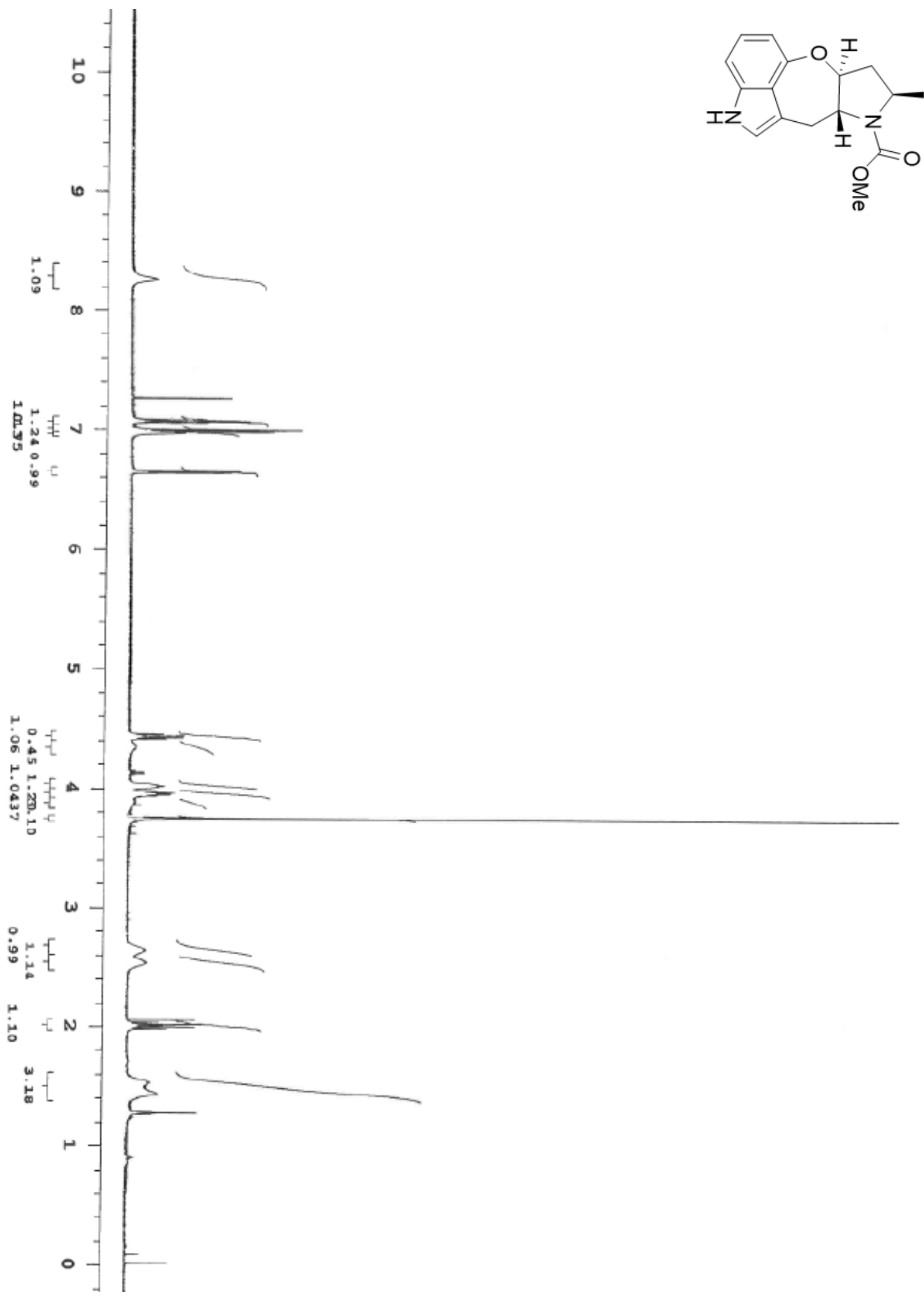

Figure 39: ${ }^{1} \mathrm{H}$ NMR of (6aR,8R,9aS)-7-methoxycarbonyl-6,6a,7,8,9,9a-hexahydro-8-methylH-pyrrolo[2',3':6,7] oxepino[4,3,2-cd]indole (21) 


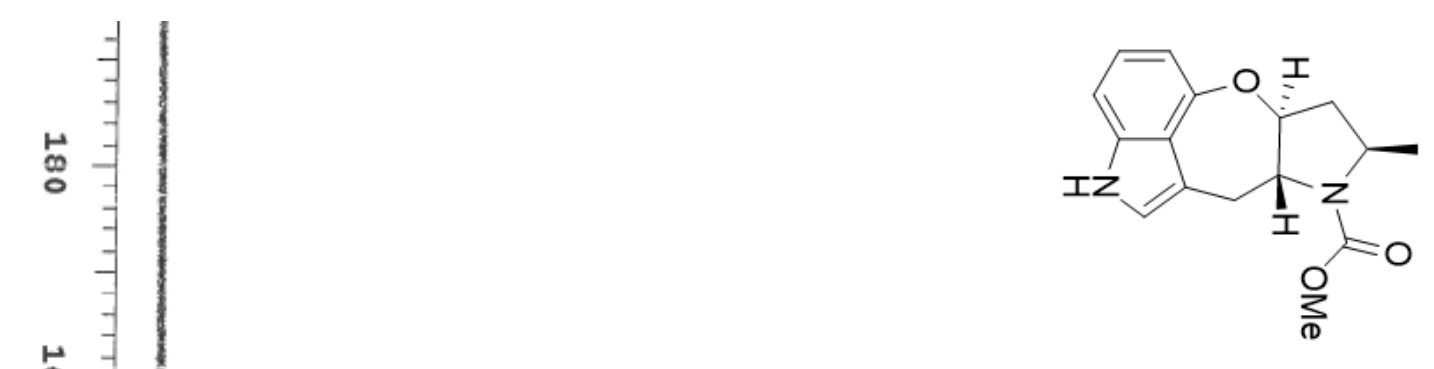

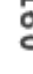

$$
\text { : }
$$

i

$\stackrel{N}{\circ}$

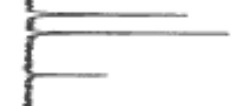

客

$\stackrel{\infty}{\circ}$

ஃ

年
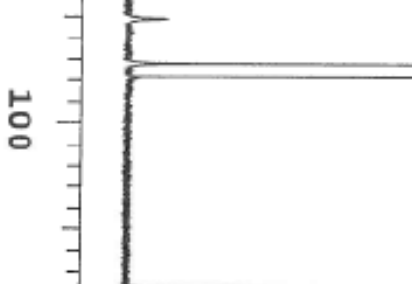

手

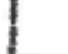

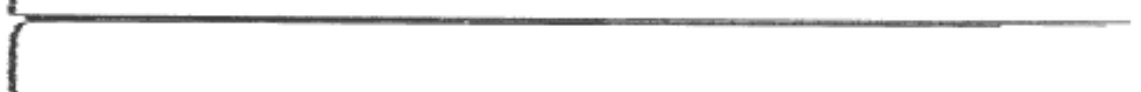

ㅇ

$-$

Figure 40: ${ }^{13} \mathrm{C}$ NMR of (6aR,8R,9aS)-7-methoxycarbonyl-6,6a,7,8,9,9a-hexahydro-8methyl-H-pyrrolo[2',3':6,7] oxepino[4,3,2-cd]indole (21) 


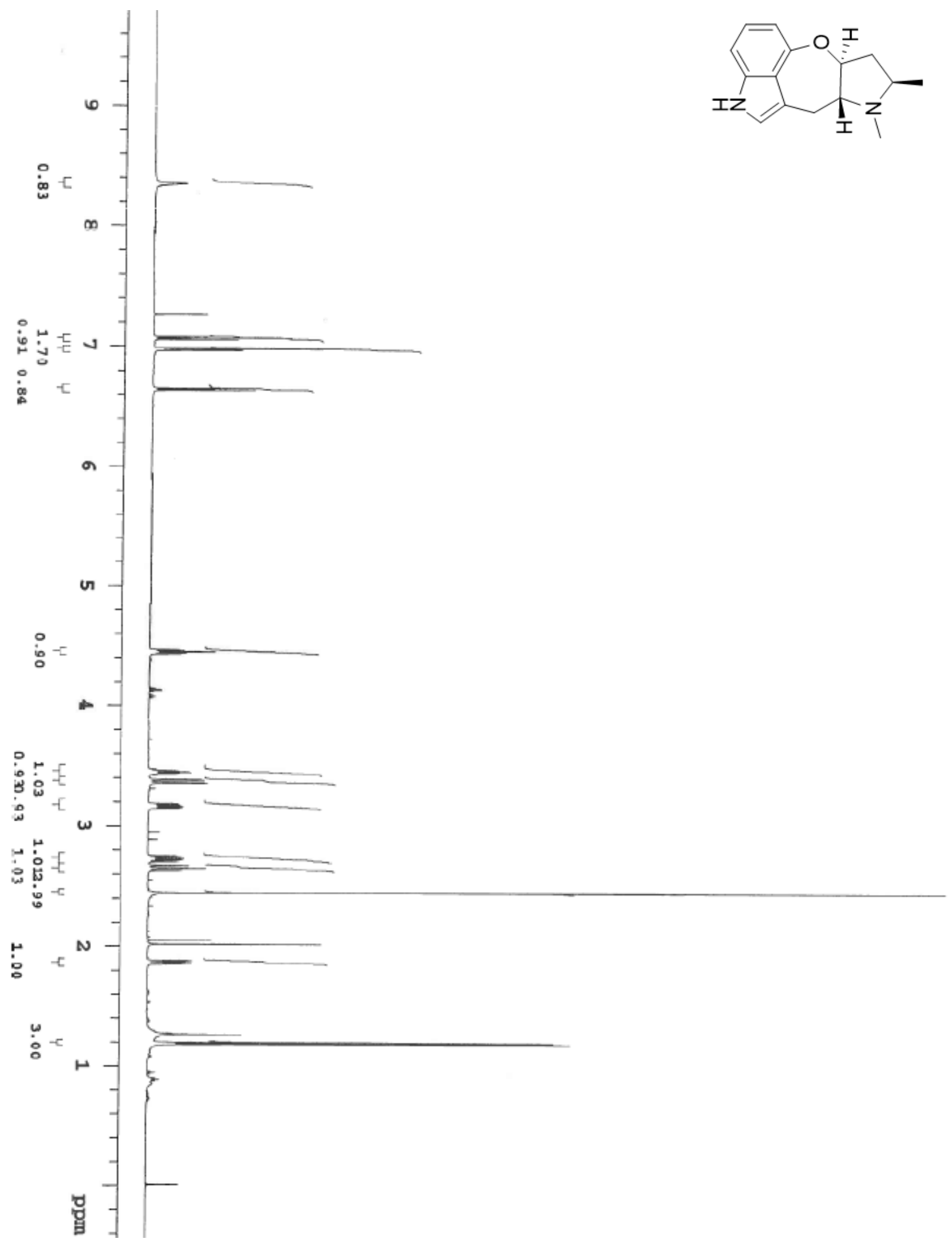

Figure 41: ${ }^{1} \mathrm{H}$ NMR of ht-13-B 


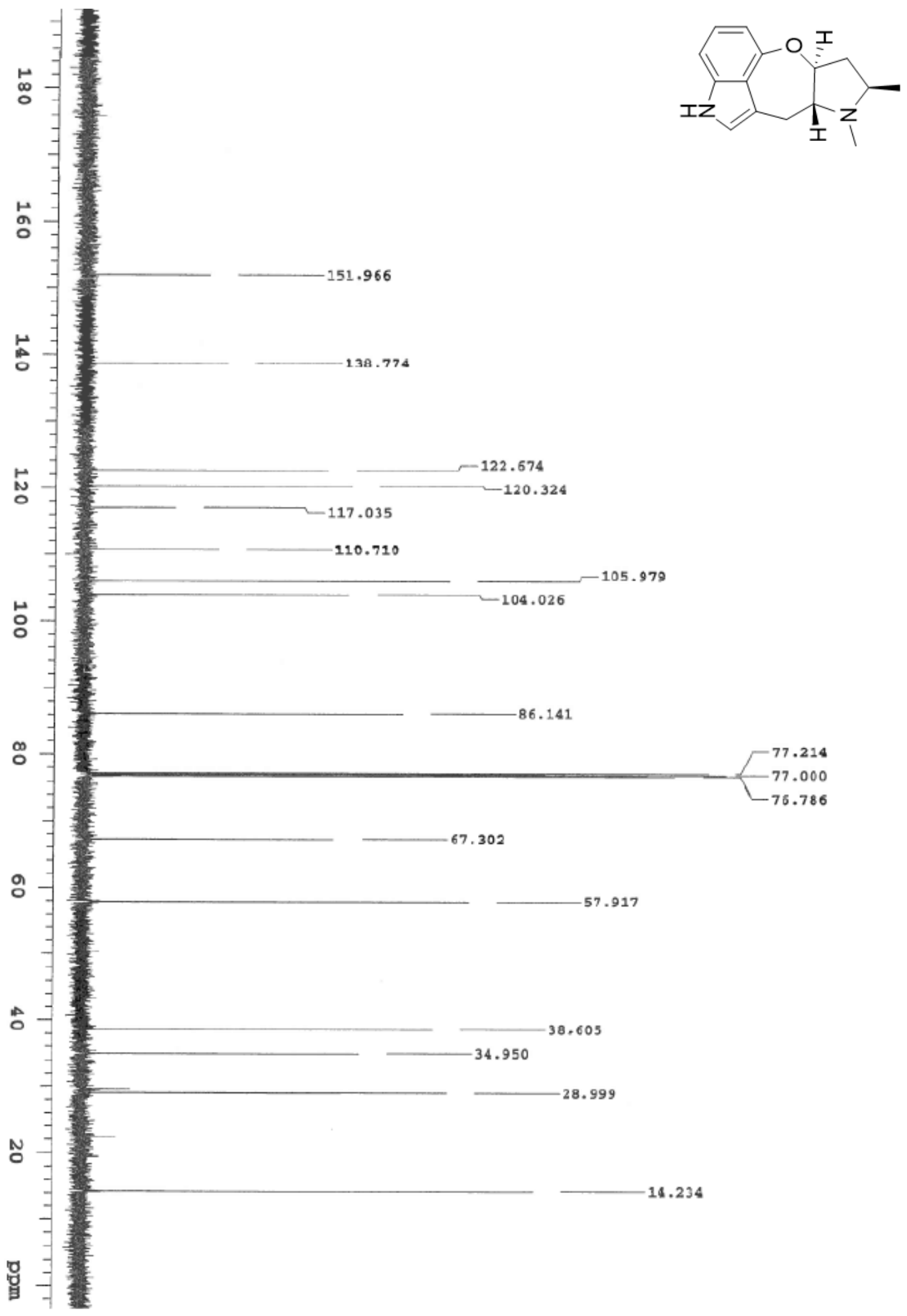

Figure $42:{ }^{13} \mathrm{C}$ NMR of ht-13-B 


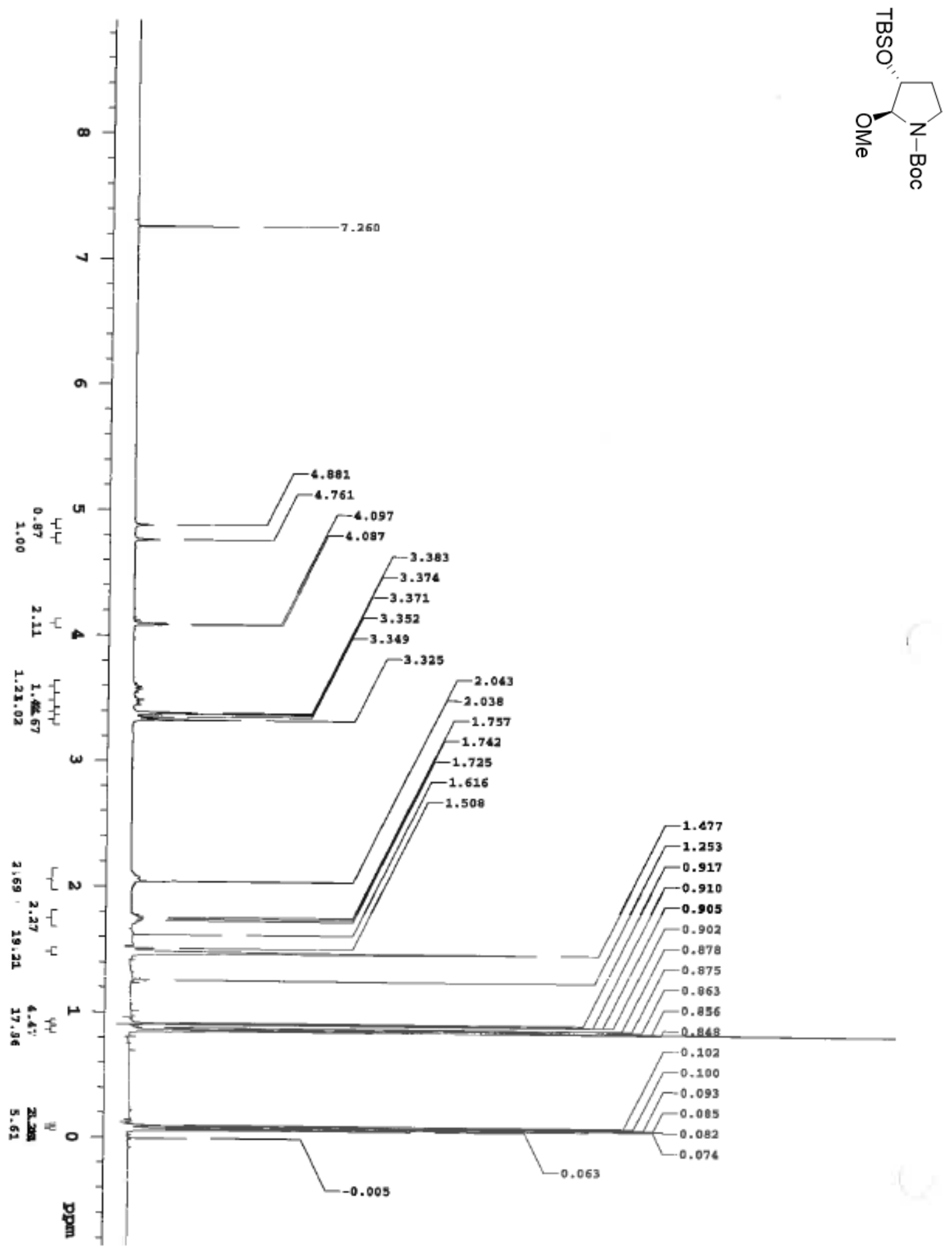

Figure 43: ${ }^{1} \mathrm{H}$ NMR of 3-(t-butyl-dimethyl-silanyloxy)-2-methoxy-pyrrolidine-1-carboxylic acid $t$-butyl ester (28) 


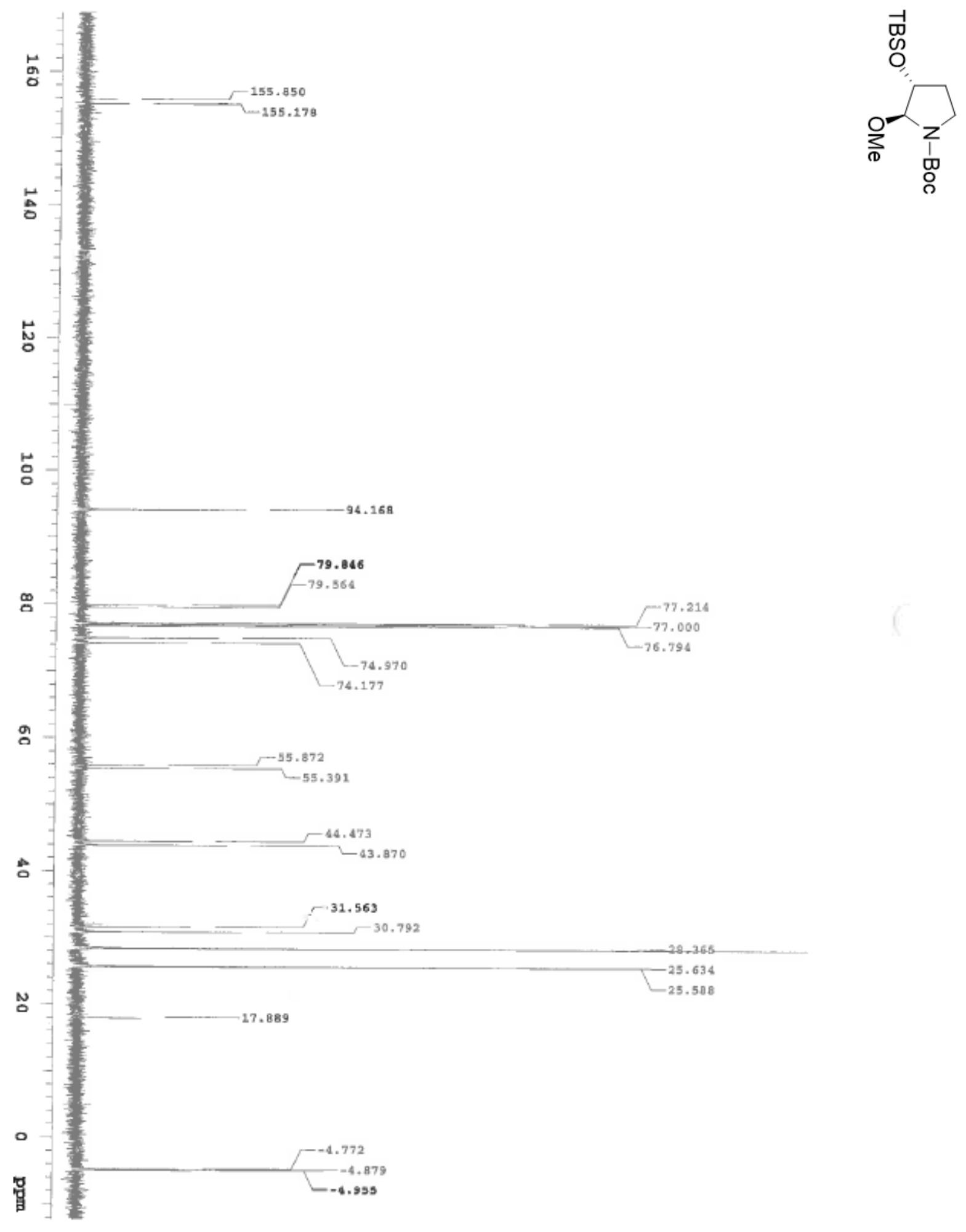

Figure 44: ${ }^{13} \mathrm{C}$ NMR of 3-(t-butyl-dimethyl-silanyloxy)-2-methoxy-pyrrolidine-1-carboxylic acid $t$-butyl ester (28) 


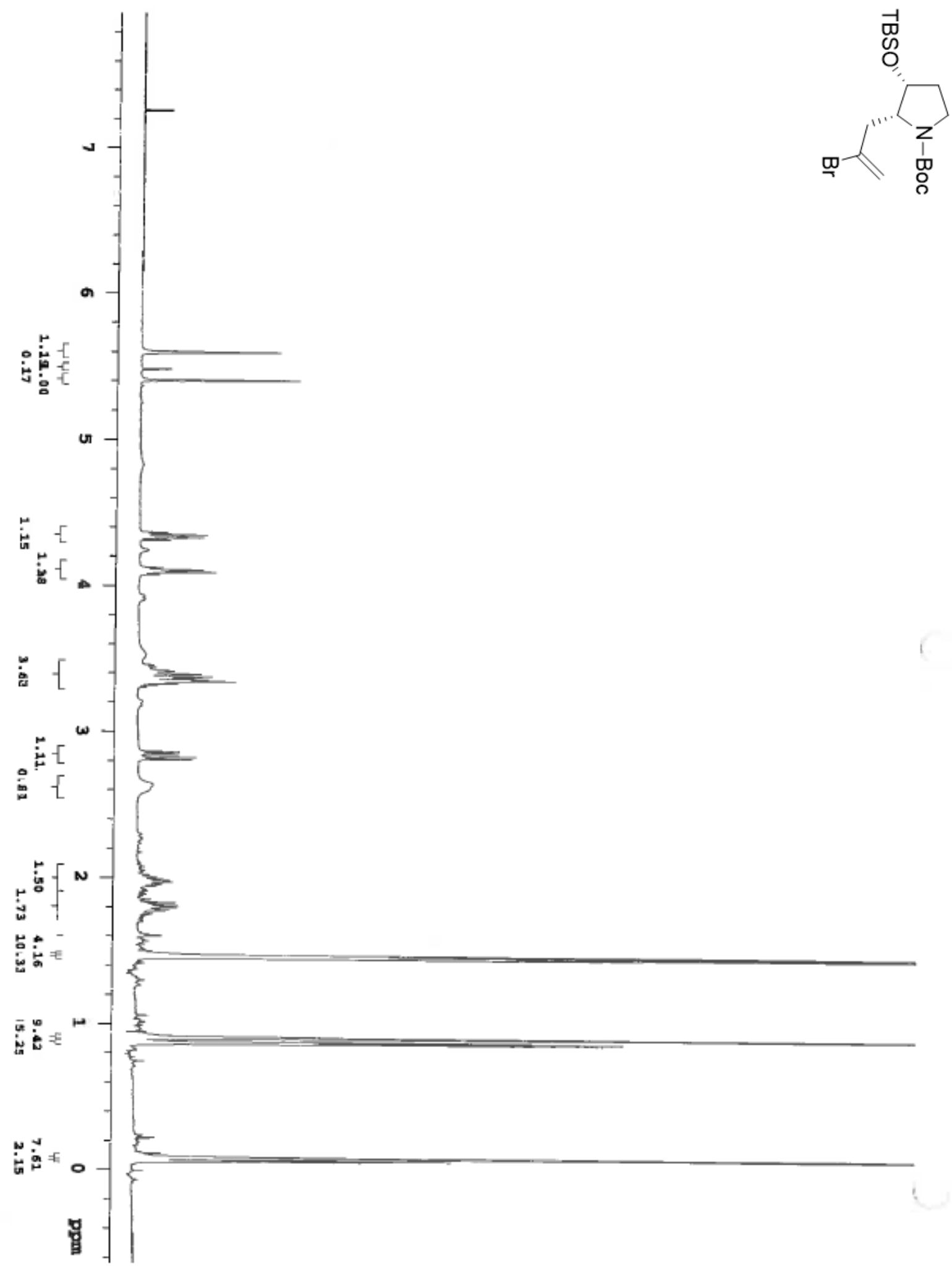

Figure 45: ${ }^{1} \mathrm{H}$ NMR $\left(65{ }^{\circ} \mathrm{C}\right)$ of 2-(2-bromo-allyl)-3-(t-butyl-dimethyl-silanyloxy)pyrrolidine-1-carboxylic acid $t$-butyl ester (29) 


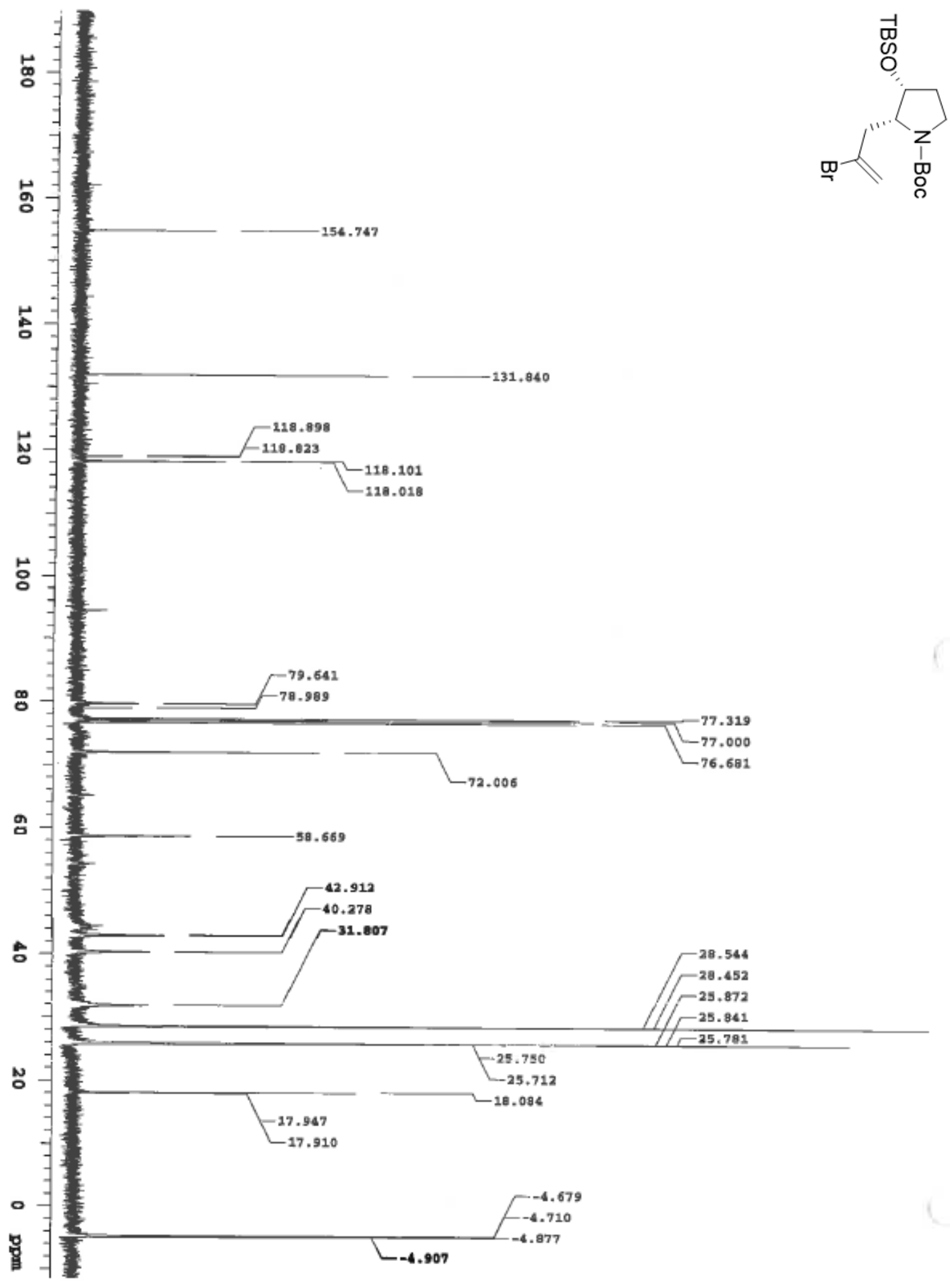

Figure 46: ${ }^{13} \mathrm{C}$ NMR $\left(65^{\circ} \mathrm{C}\right)$ of 2-(2-bromo-allyl)-3-( $t$-butyl-dimethyl-silanyloxy)pyrrolidine-1-carboxylic acid $t$-butyl ester (29) 


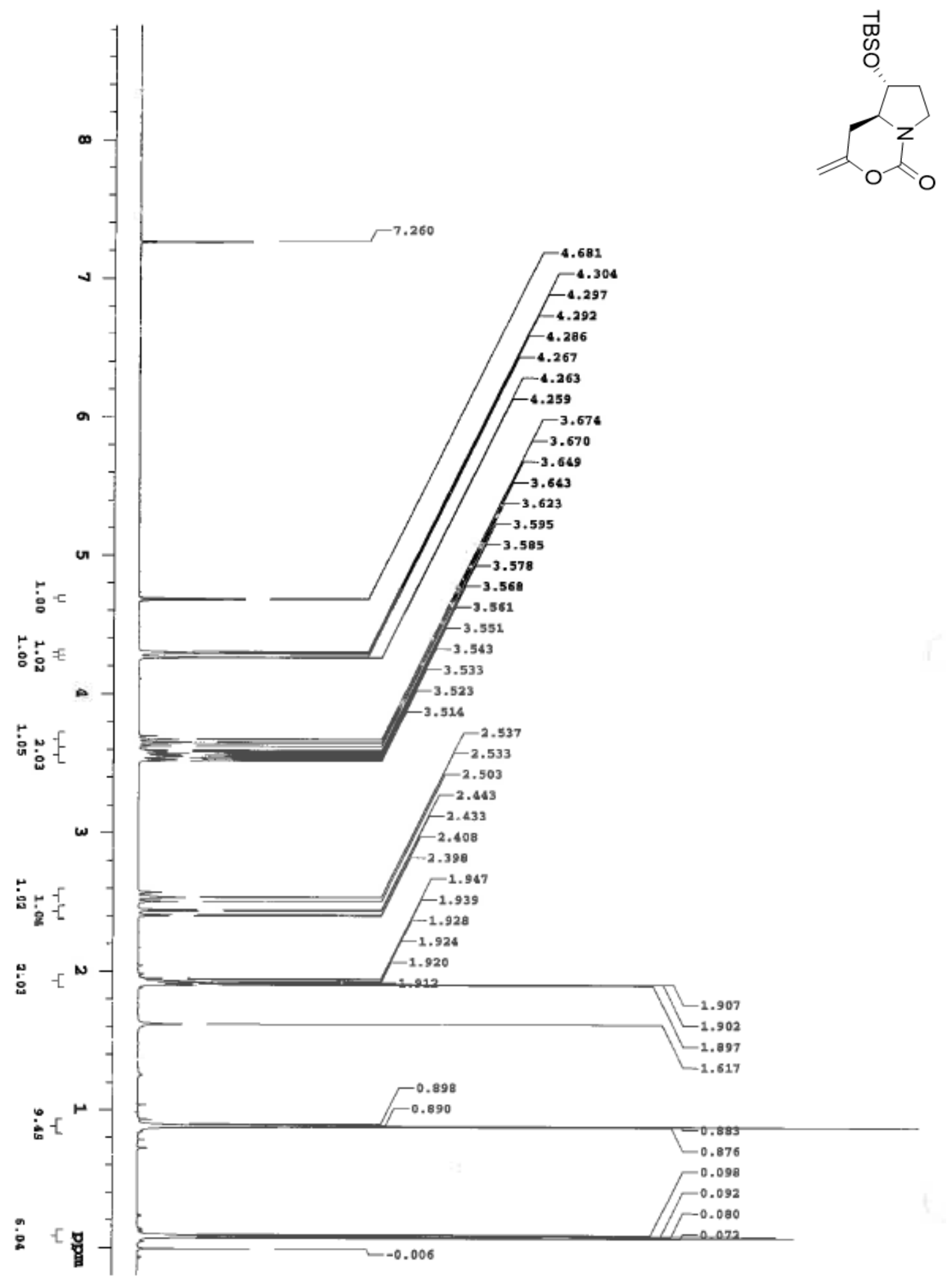

Figure 47: ${ }^{1} \mathrm{H}$ NMR of 5-(t-butyl-dimethyl-silanyloxy)-3-methylene-hexahydro-pyrrolo[1,2c][1,3] oxazin-1-one (30) 

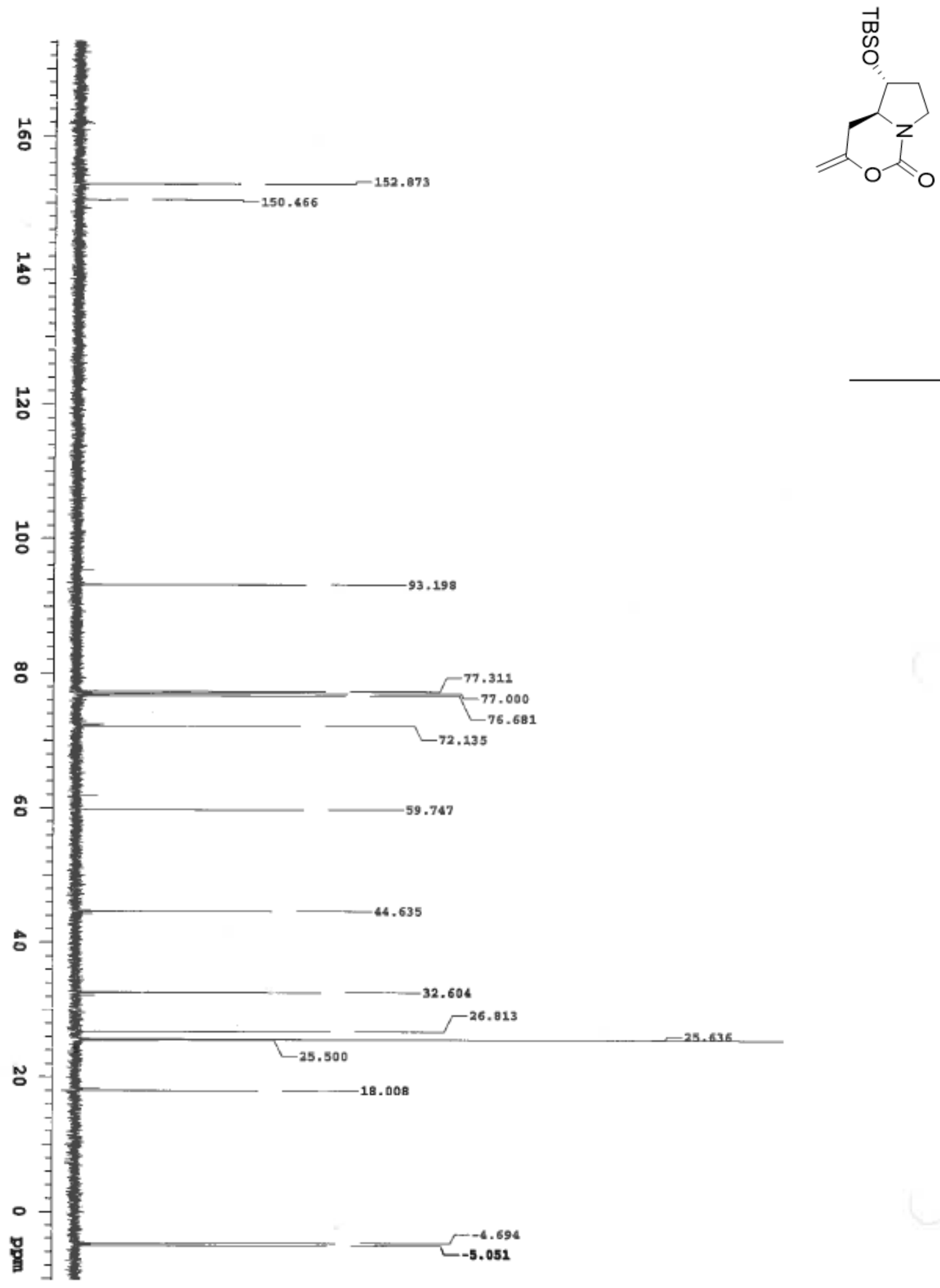


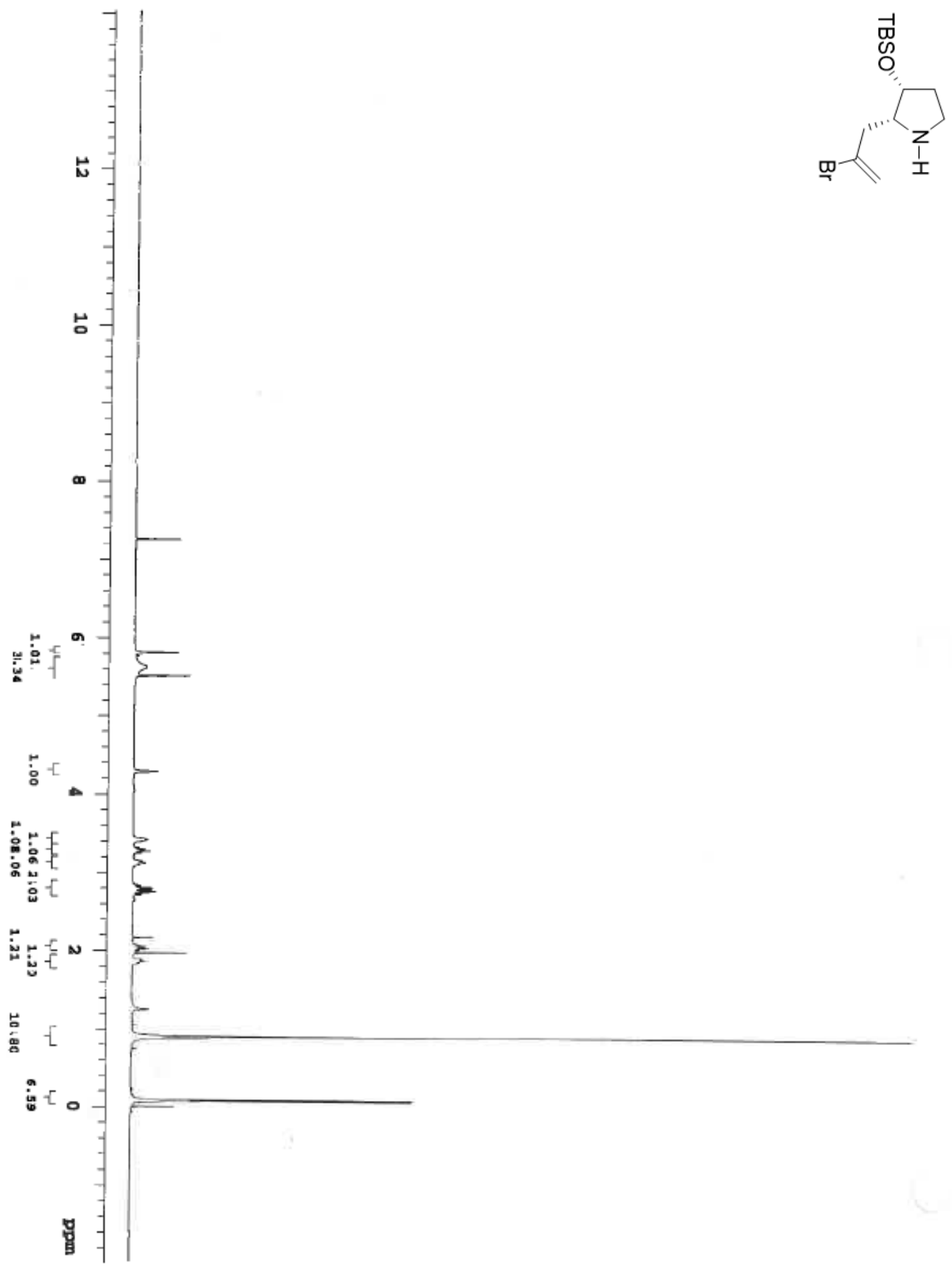

Figure 49: ${ }^{1} \mathrm{H}$ NMR of 2-(2-bromo-allyl)-3-(t-butyl-dimethyl-silanyloxy)pyrrolidine (31) 


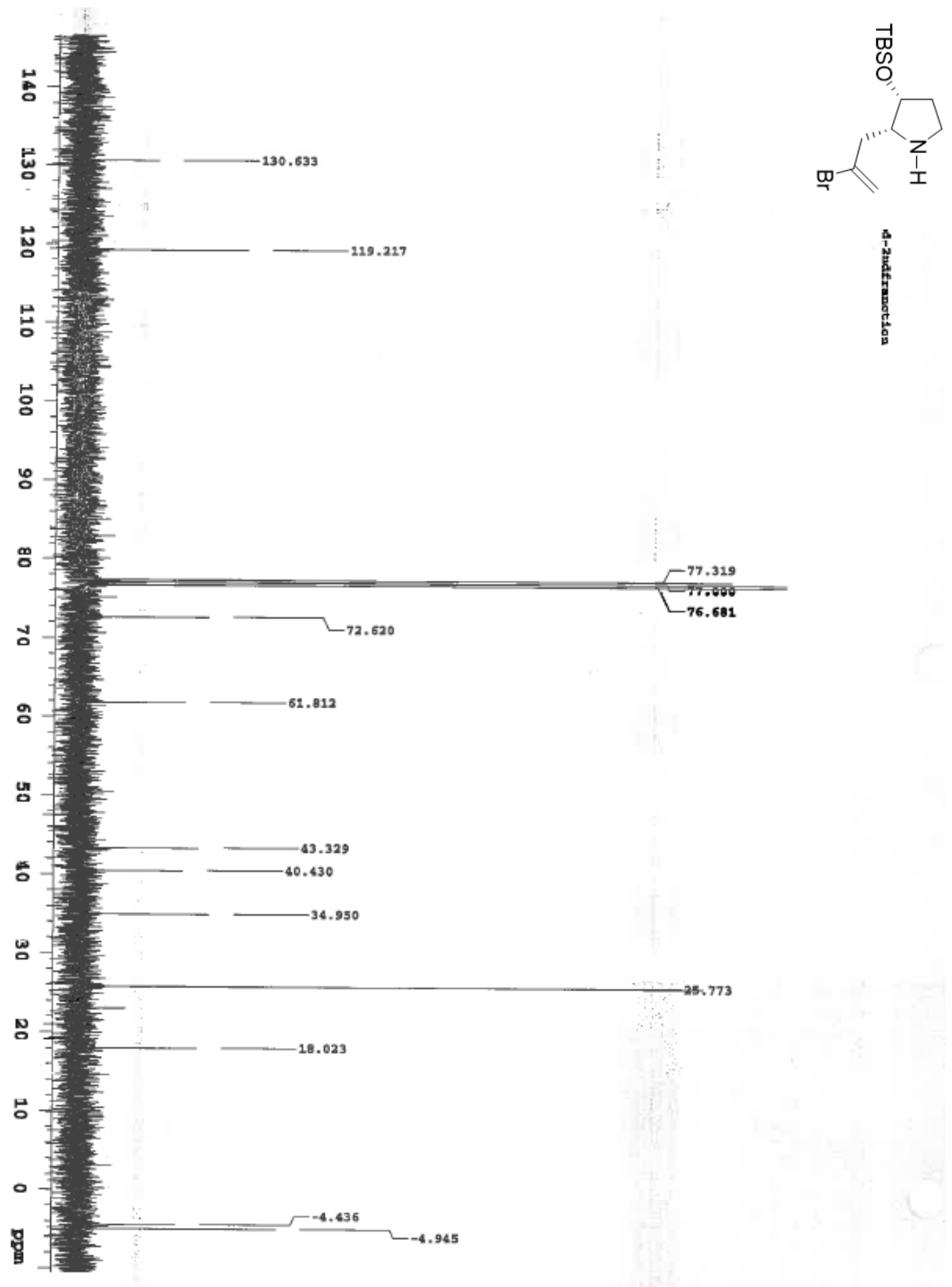

Figure 50: ${ }^{13} \mathrm{C}$ NMR of 2-(2-bromo-allyl)-3-(t-butyl-dimethyl-silanyloxy)pyrrolidine (31) 


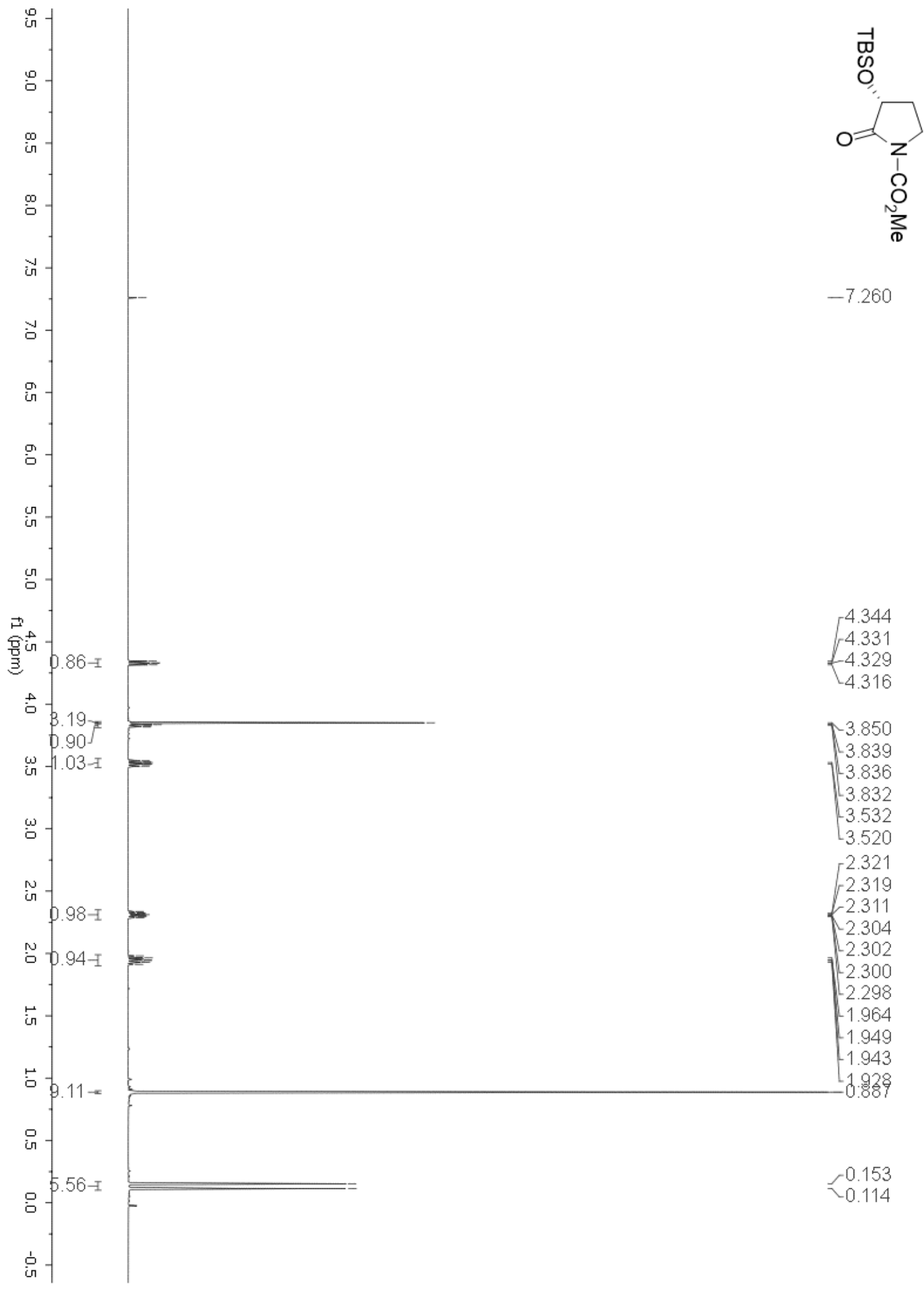

Figure 51: ${ }^{1} \mathrm{H}$ NMR of 3(R)-t-butyldimethylsilyloxy-1-(methoxycarbonyl)pyrrolidin2-one (33) 


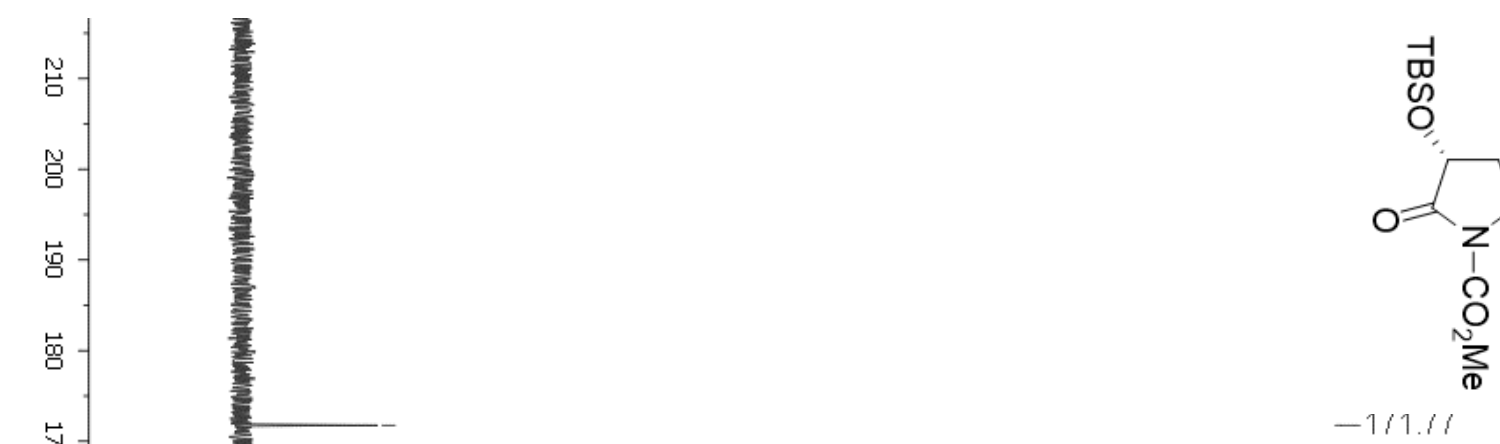

$\left\{\begin{array}{r}77.32 \\ 77.00\end{array}\right.$

77.00
76.68

$\backslash 70.71$

$-52.57$

$-41.11$

$\sim 27.58$

$\backslash 24.92$

$-17.43$

$\left\{\begin{array}{r}-5.30 \\ -6.04\end{array}\right.$

Figure 52: ${ }^{13} \mathrm{C}$ NMR of 3(R)-t-butyldimethylsilyloxy-1-(methoxycarbonyl)pyrrolidin2-one (33) 


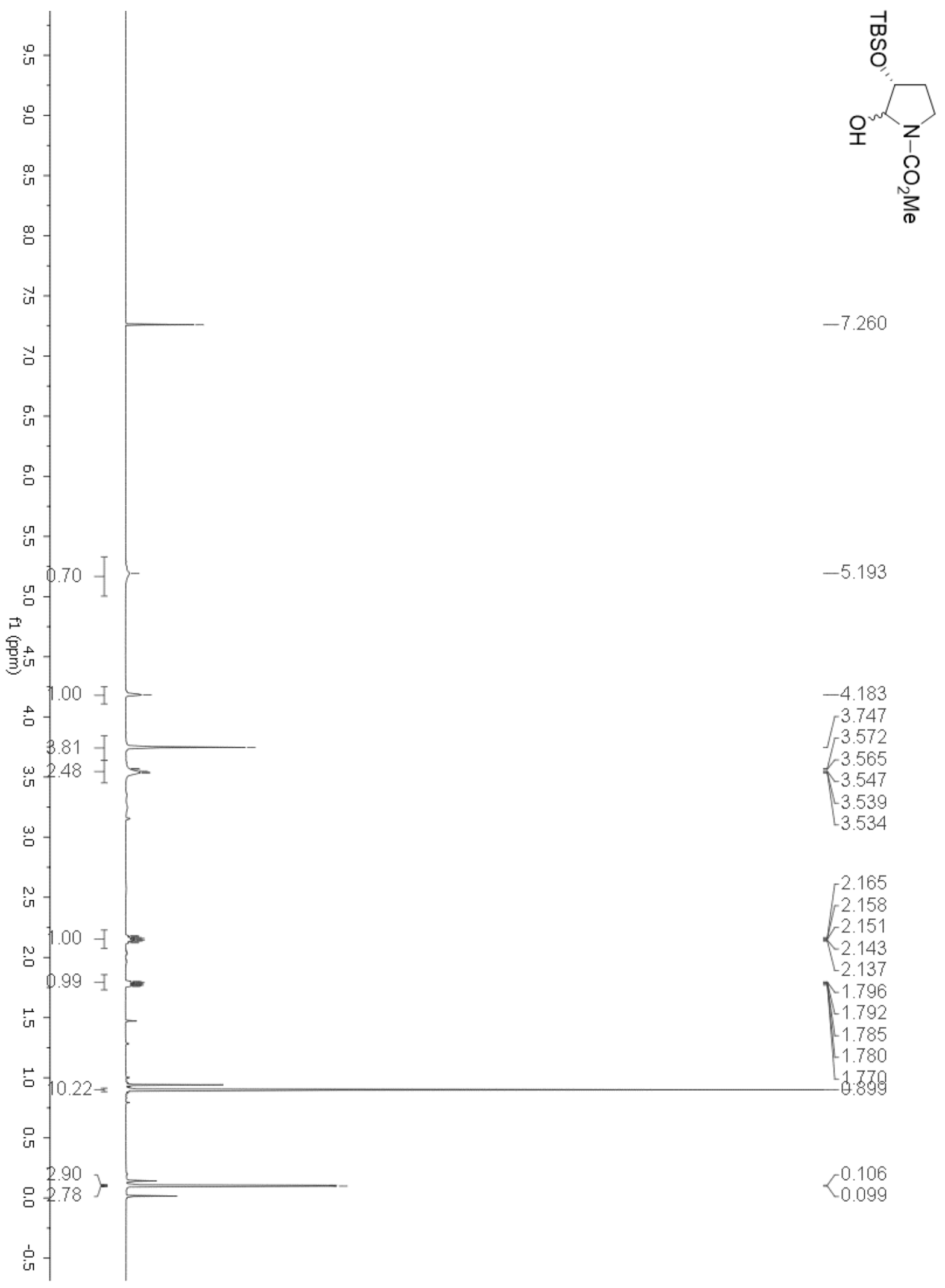

Figure 53: ${ }^{1} \mathrm{H}$ NMR $\left(65{ }^{\circ} \mathrm{C}\right)$ of 3(R)-t-butyldimethylsilyloxy-2(R/S)-hydroxy-1(methoxycarbonyl)pyrrolidine (34) 


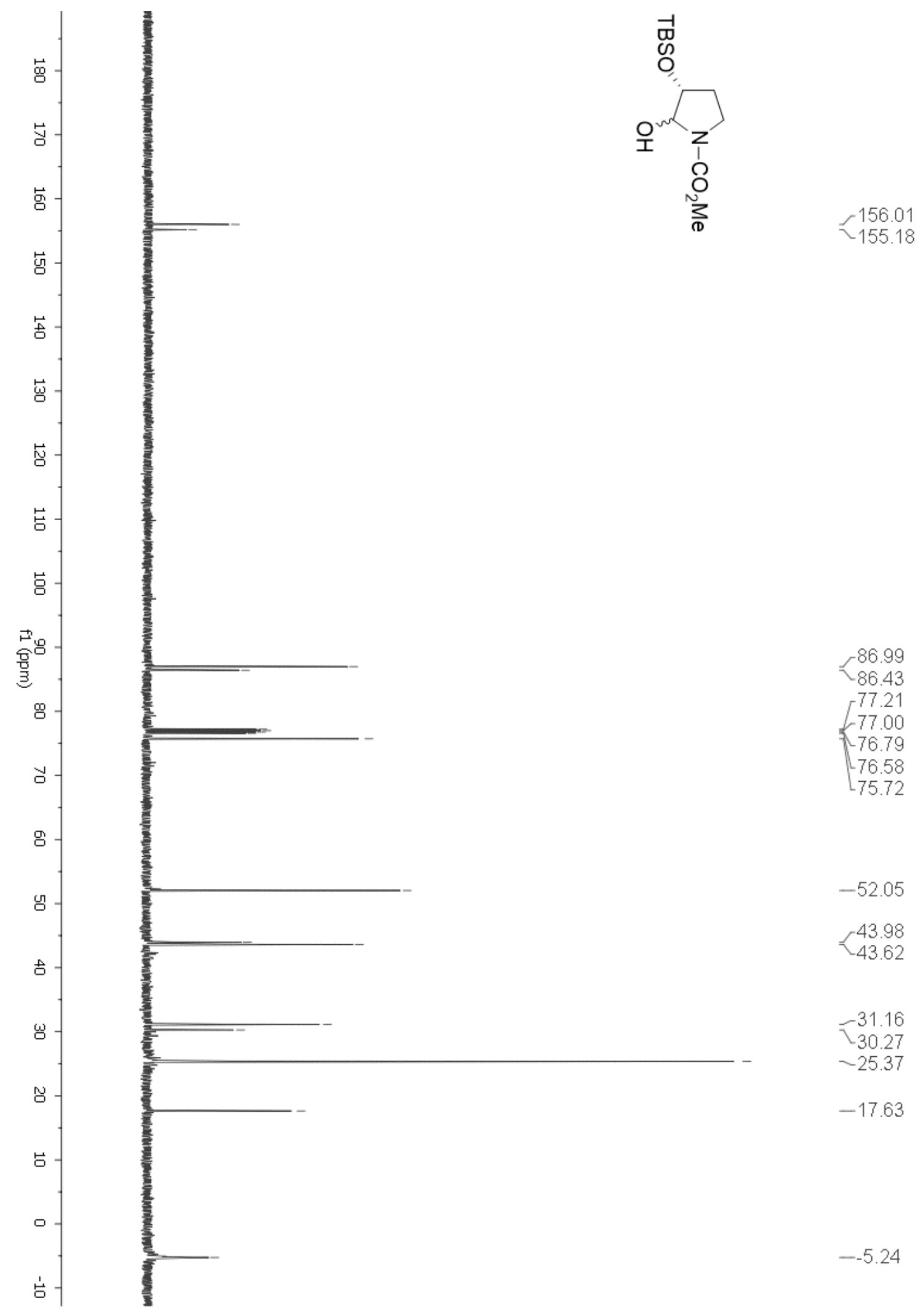

Figure 54: ${ }^{13} \mathrm{C}$ NMR of 3(R)-t-butyldimethylsilyloxy-2(R/S)-hydroxy-1-

(methoxycarbonyl)pyrrolidine (34) 


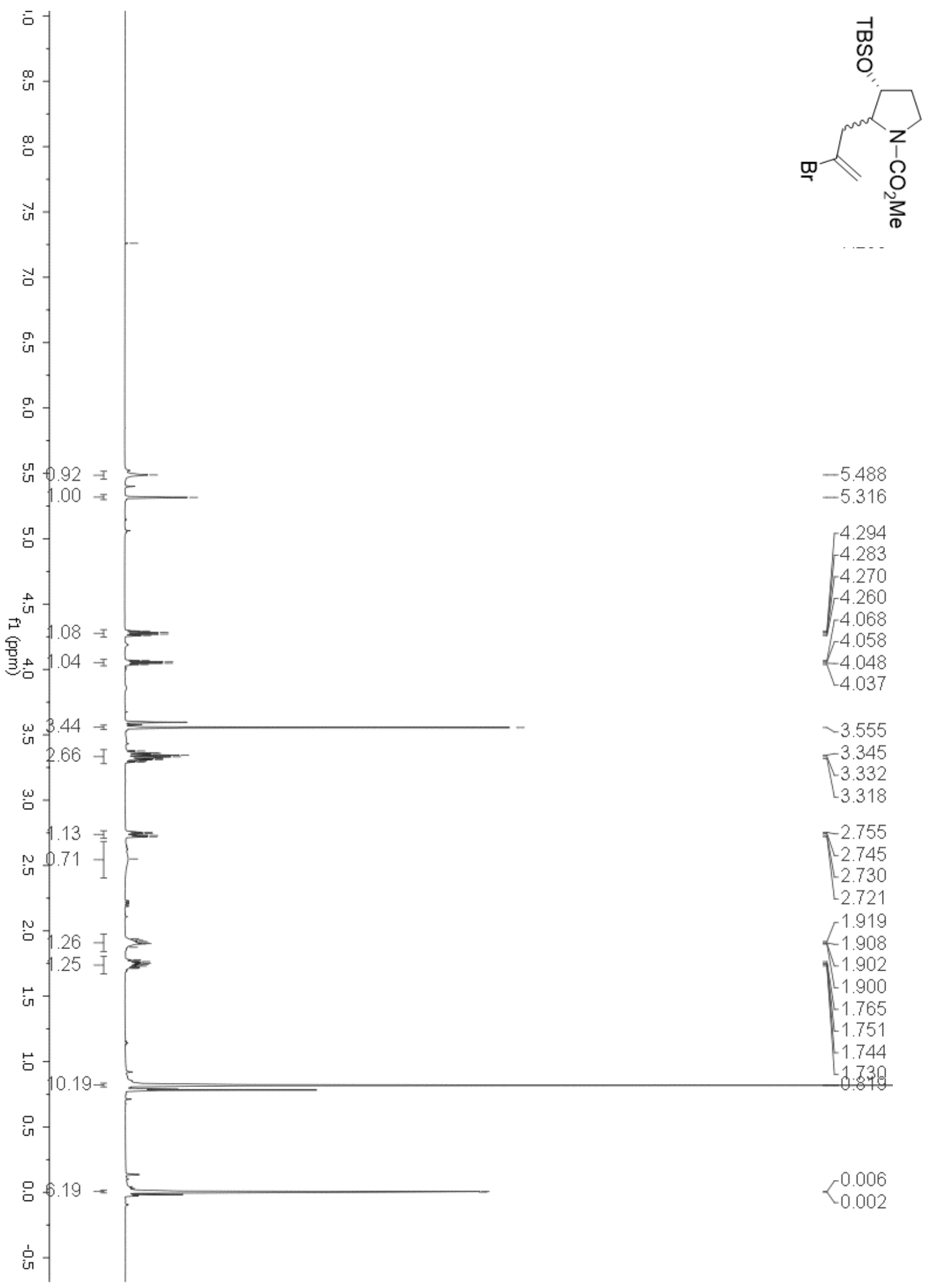

Figure 55: ${ }^{1} \mathrm{H}$ NMR $\left(65^{\circ} \mathrm{C}\right)$ of 2(R/S)-(2-bromo-2-propen-1-yl)-3(R)-t-butyldimethylsilyloxy-1-(methoxycarbonyl)pyrrolidine (32) 

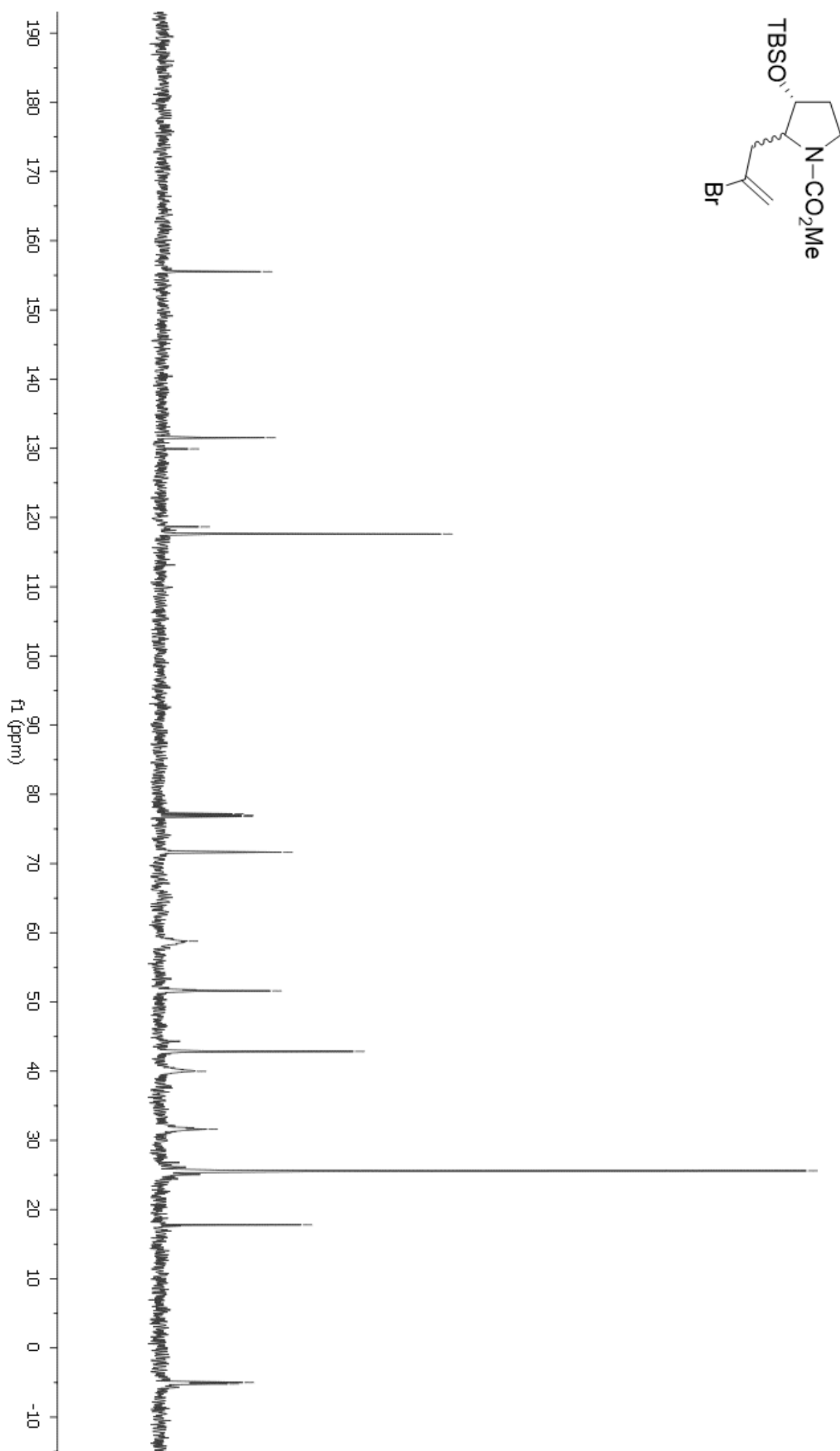

Figure 56: ${ }^{13} \mathrm{C}$ NMR $\left(65{ }^{\circ} \mathrm{C}\right)$ of 2(R/S)-(2-bromo-2-propen-1-yl)-3(R)-t-butyldimethylsilyloxy-1-(methoxycarbonyl)pyrrolidine (32) 


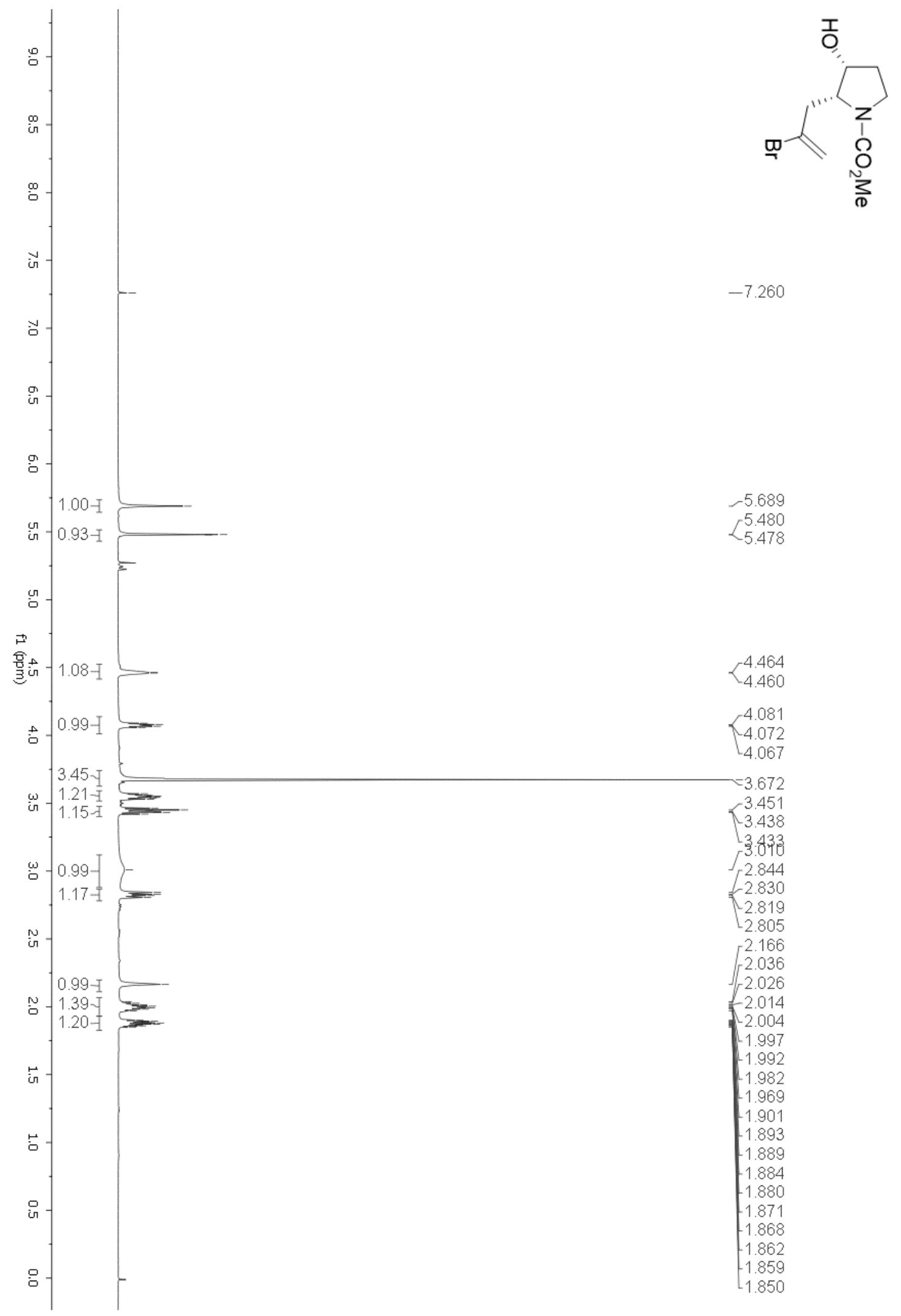

Figure 57: ${ }^{1} \mathrm{H}$ NMR $\left(65^{\circ} \mathrm{C}\right)$ of 2(R)-(2-bromo-2-propen-1-yl)-3(R)-hydroxy-1(methoxycarbonyl)pyrrolidine (35) 

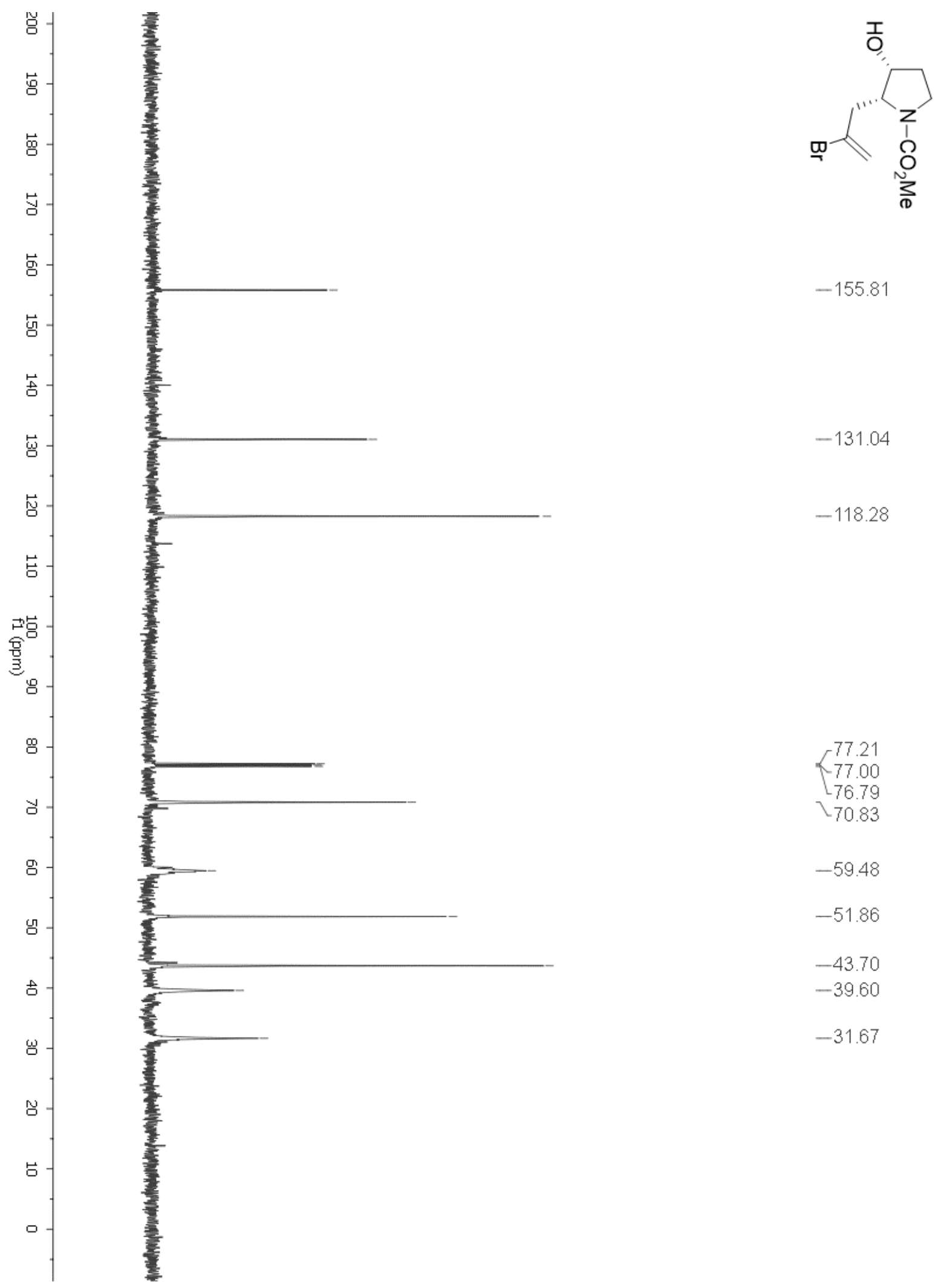

$-155.81$

$-131.04$

$-118.28$

77.21

77.00

76.79

$\backslash 70.83$

$-59.48$

$-51.86$

$-43.70$

$-39.60$

$-31.67$

Figure 58: ${ }^{13} \mathrm{C}$ NMR $\left(65{ }^{\circ} \mathrm{C}\right)$ of 2(R)-(2-bromo-2-propen-1-yl)-3(R)-hydroxy-1(methoxycarbonyl)-pyrrolidine (35) 


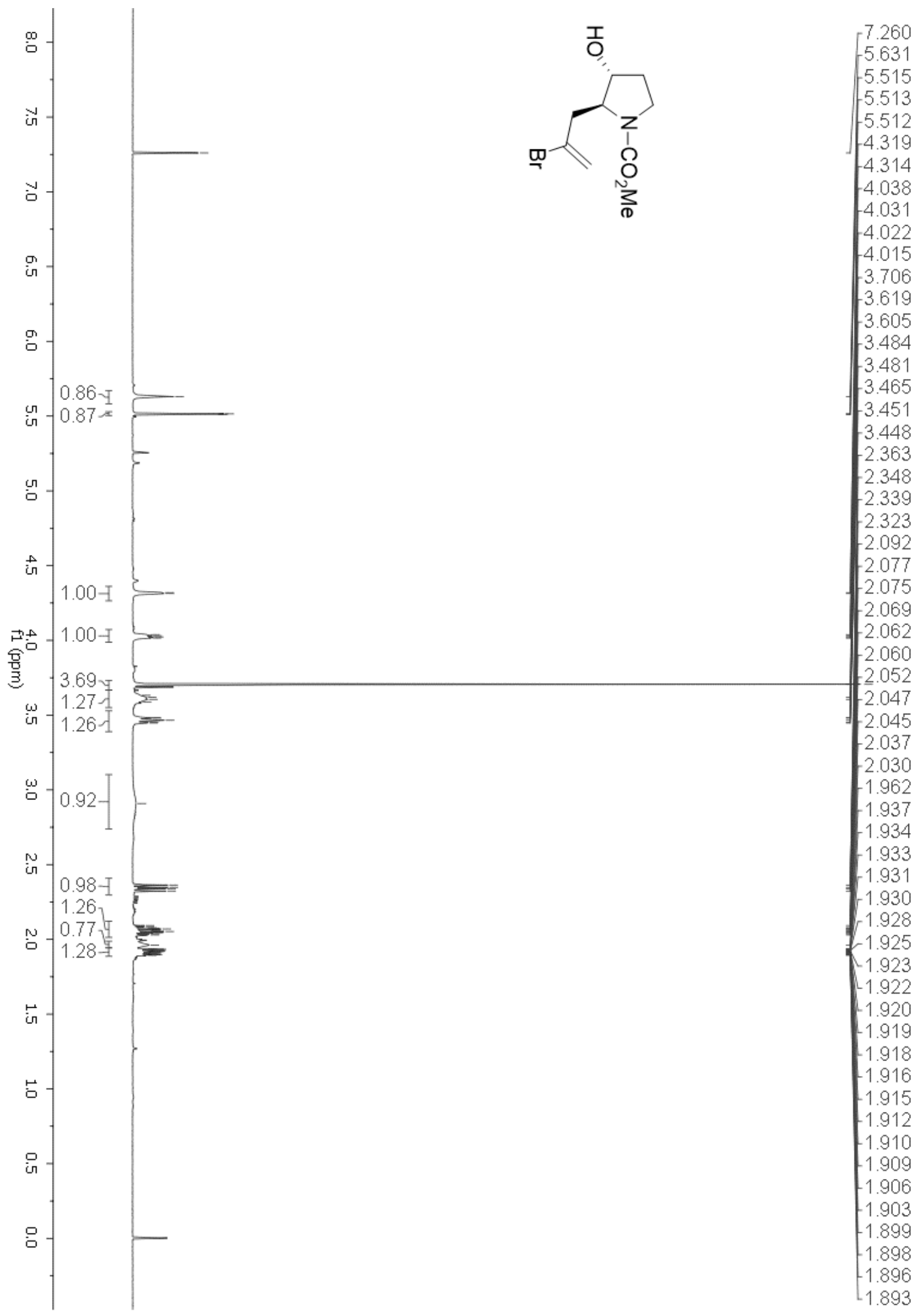

Figure 59: ${ }^{1} \mathrm{H}$ NMR $\left(60{ }^{\circ} \mathrm{C}\right)$ of 2(S)-(2-bromo-2-propen-1-yl)-3(R)-hydroxy-1(methoxycarbonyl)pyrrolidine (36) 


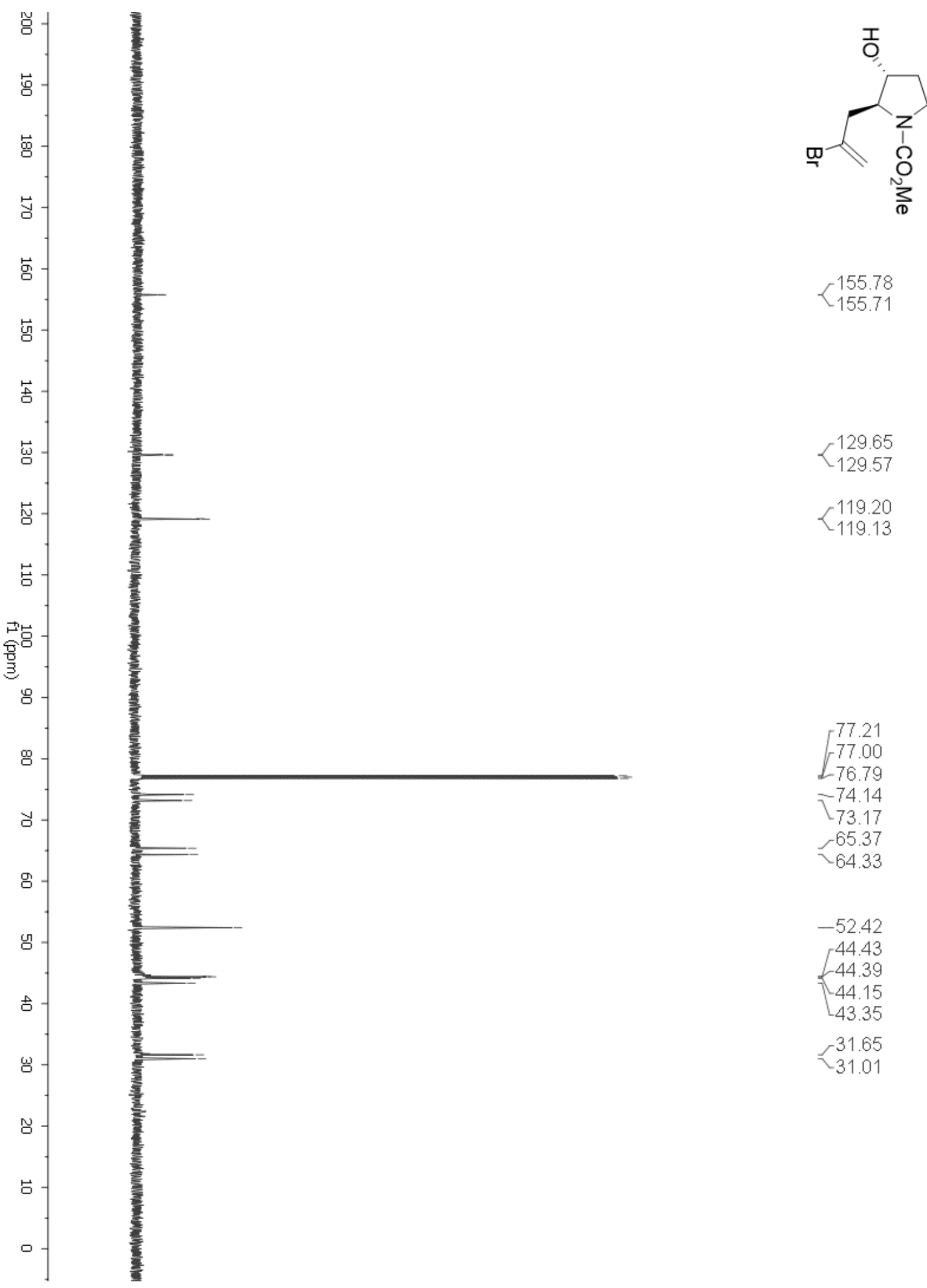

Figure 60: ${ }^{13} \mathrm{C}$ NMR of 2(S)-(2-bromo-2-propen-1-yl)-3(R)-hydroxy-1-(methoxycarbonyl)pyrrolidine (36) 


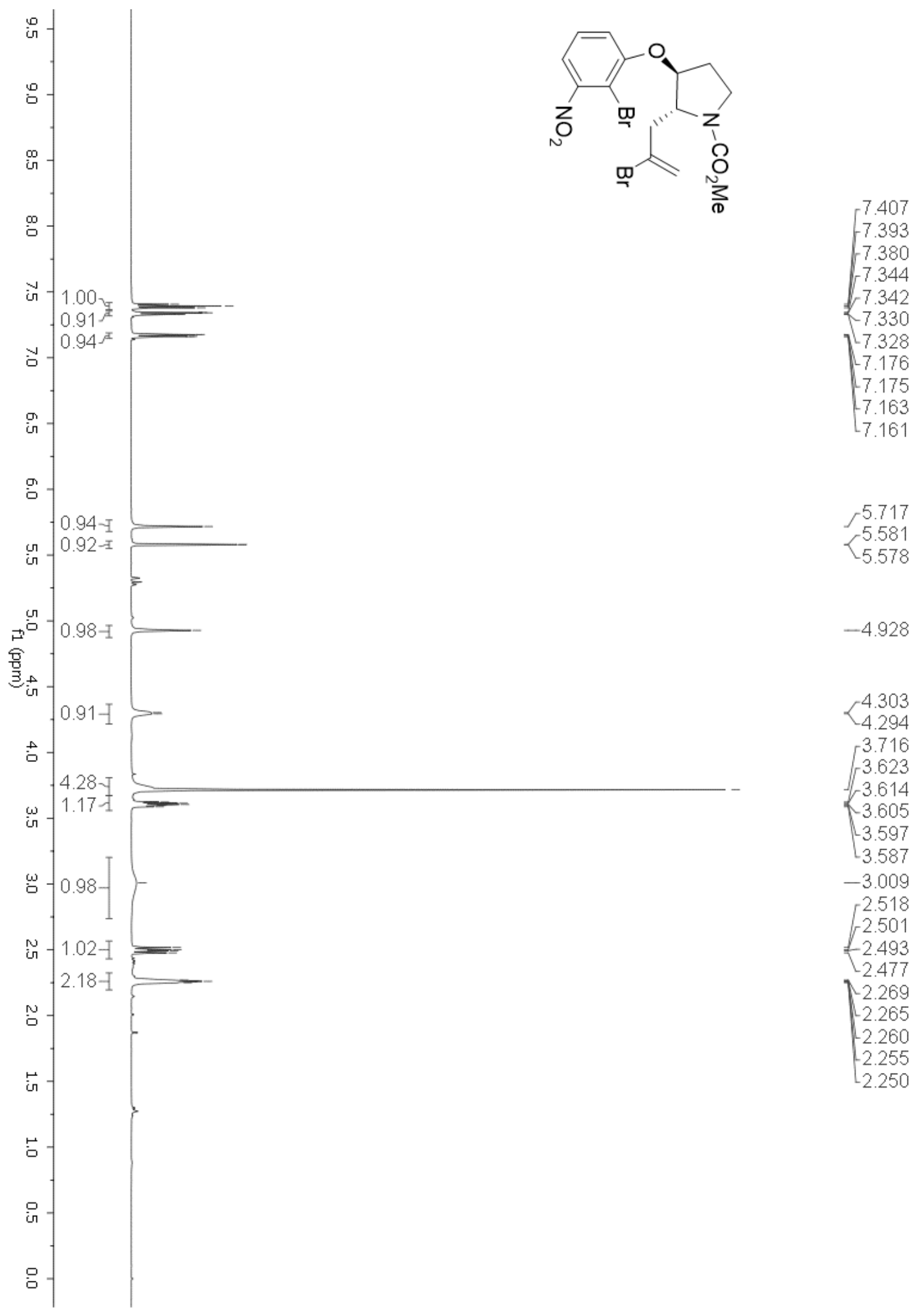

Figure 61: ${ }^{1} \mathrm{H}$ NMR $\left(65^{\circ} \mathrm{C}\right.$ ) of 3(S)-(2-bromo-3-nitrophenyl)-2(R)-(2-bromo-2-propen-1-yl)1-(methoxycarbonyl)pyrrolidine (37) 


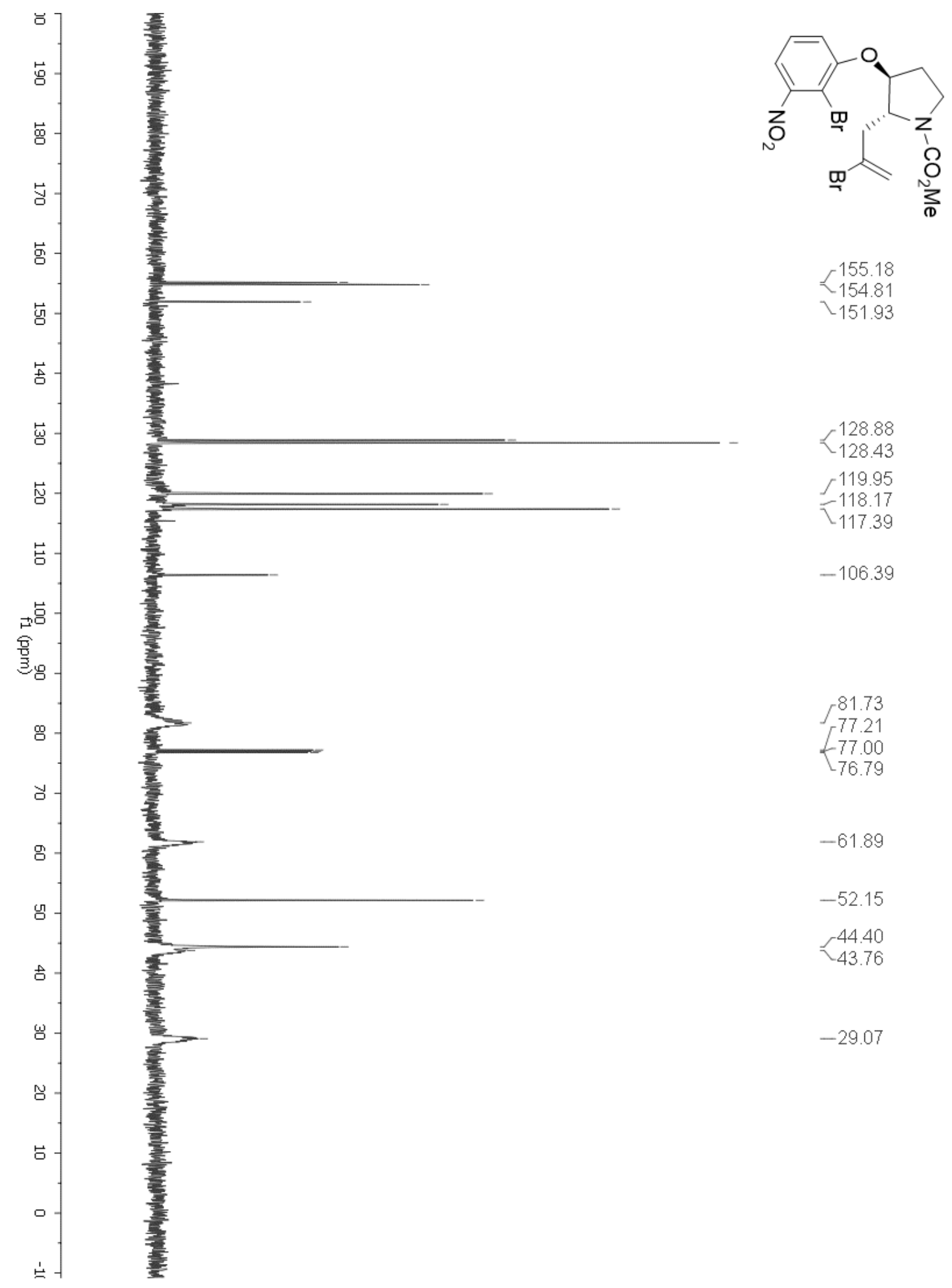

Figure $62:{ }^{13} \mathrm{C}$ NMR $\left(65{ }^{\circ} \mathrm{C}\right.$ ) of 3(S)-(2-bromo-3-nitrophenyl)-2(R)-(2-bromo-2-propen-1-yl)1-(methoxycarbonyl)pyrrolidine (37) 


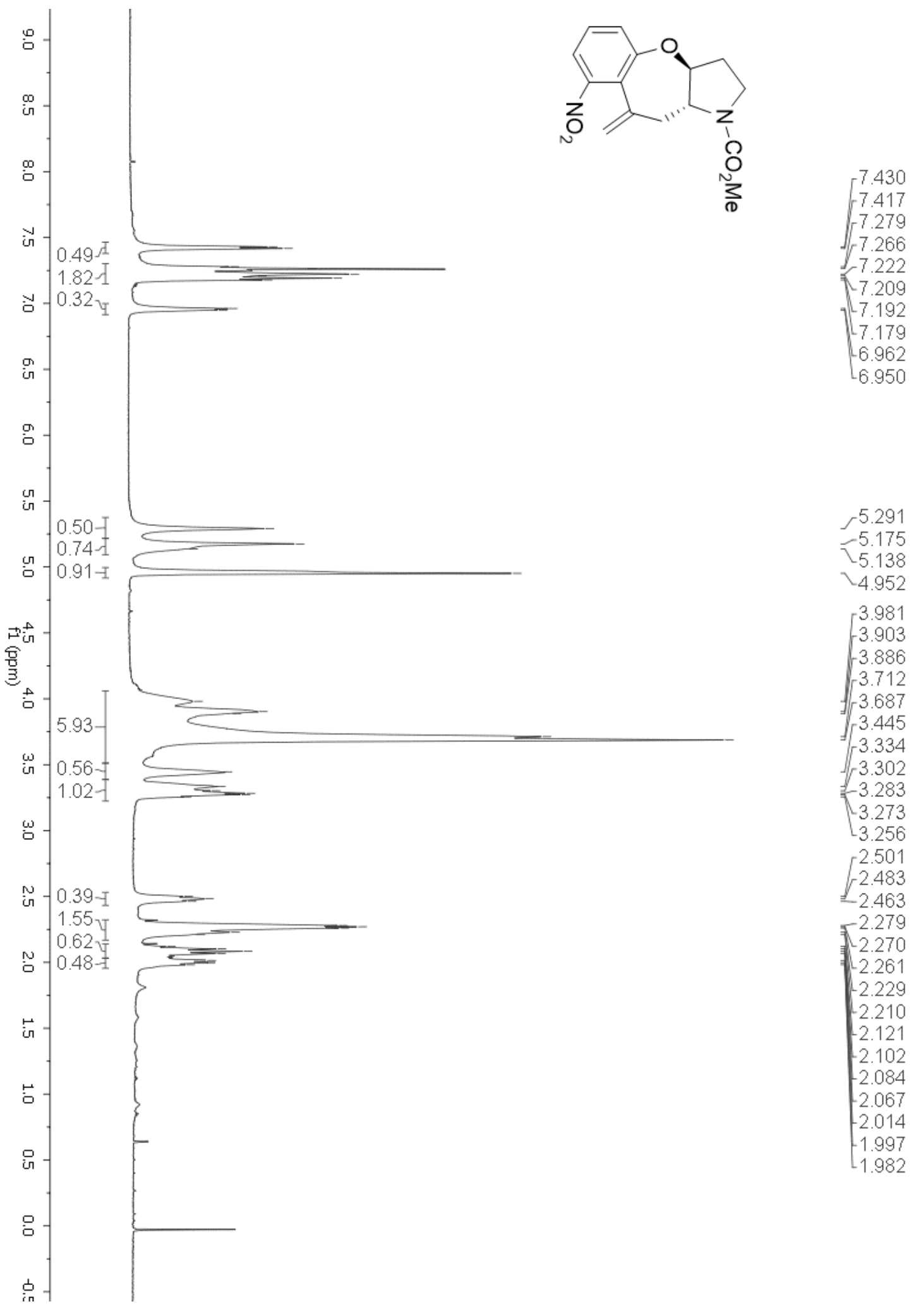

Figure 63: ${ }^{1} \mathrm{H}$ NMR of 2,3,3a(S),9,10,10a(R)-hexahydro-1-(methoxycarbonyl)-8-nitro-1Hbenzoxepino[3,2-b]pyrrole (38) 


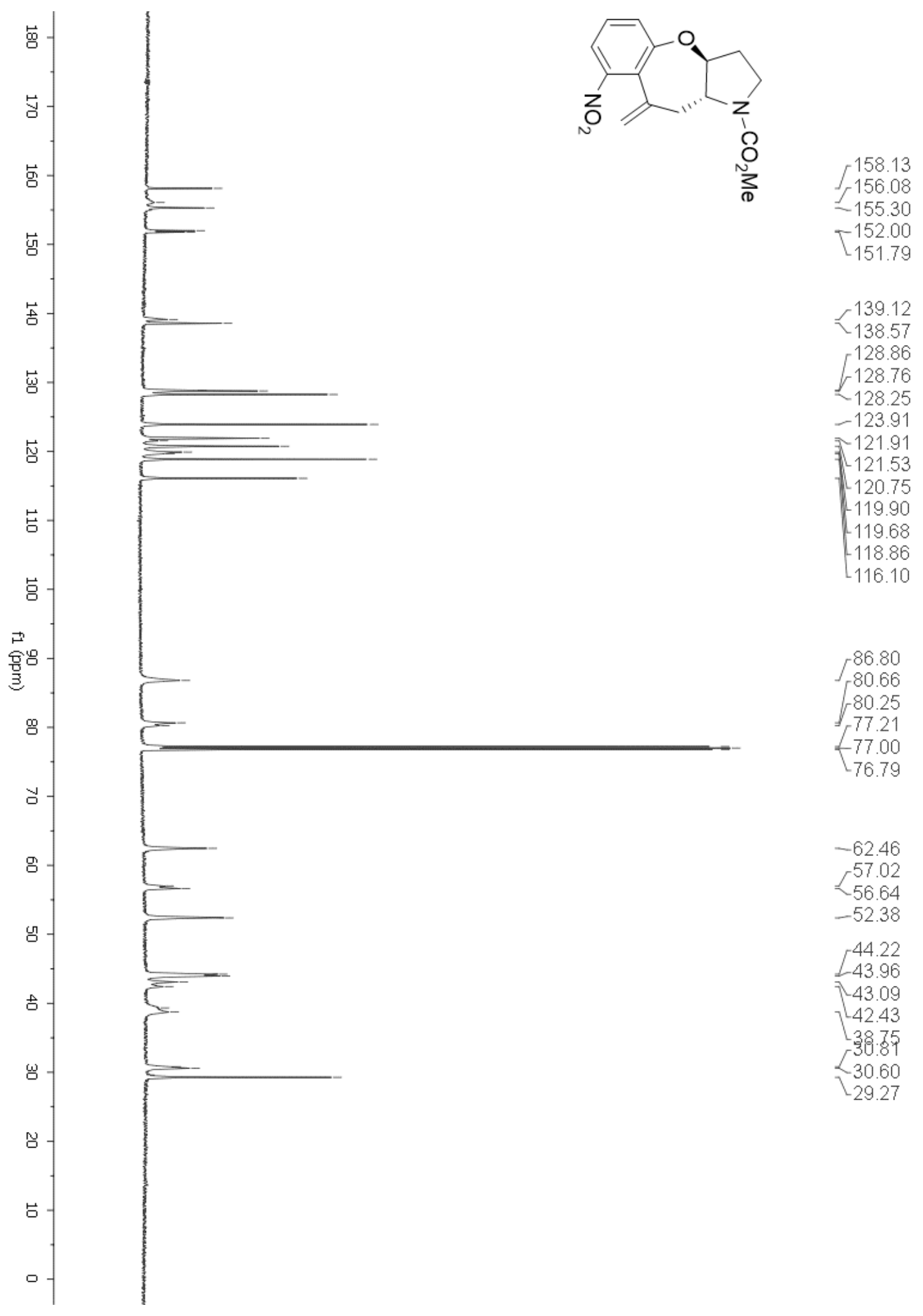

Figure $64:{ }^{13} \mathrm{C}$ NMR of 2,3,3a(S),9,10,10a(R)-hexahydro-1-(methoxycarbonyl)-8-nitro-1Hbenzoxepino[3,2-b]pyrrole (38) 


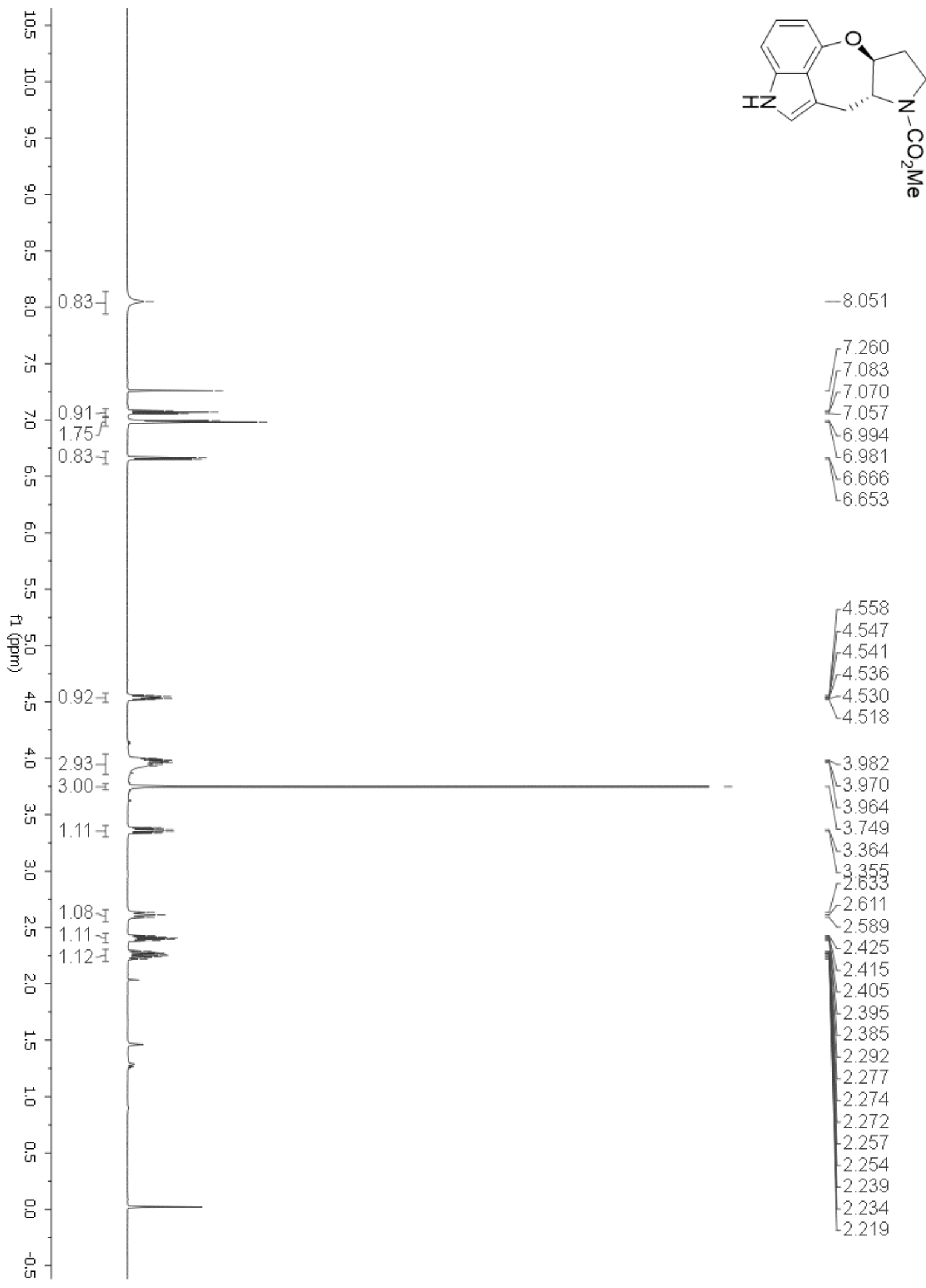

Figure $65:{ }^{1} \mathrm{H}$ NMR $\left(65{ }^{\circ} \mathrm{C}\right)$ of $6,6 \mathrm{a}(R), 7,8,9,9 \mathrm{a}(S)$-hexahydro-7-(methoxycarbonyl)- $4 \mathrm{H}$ pyrrolo[2',3':6,7] oxepino-[4,3,2-cd]indole (39) 


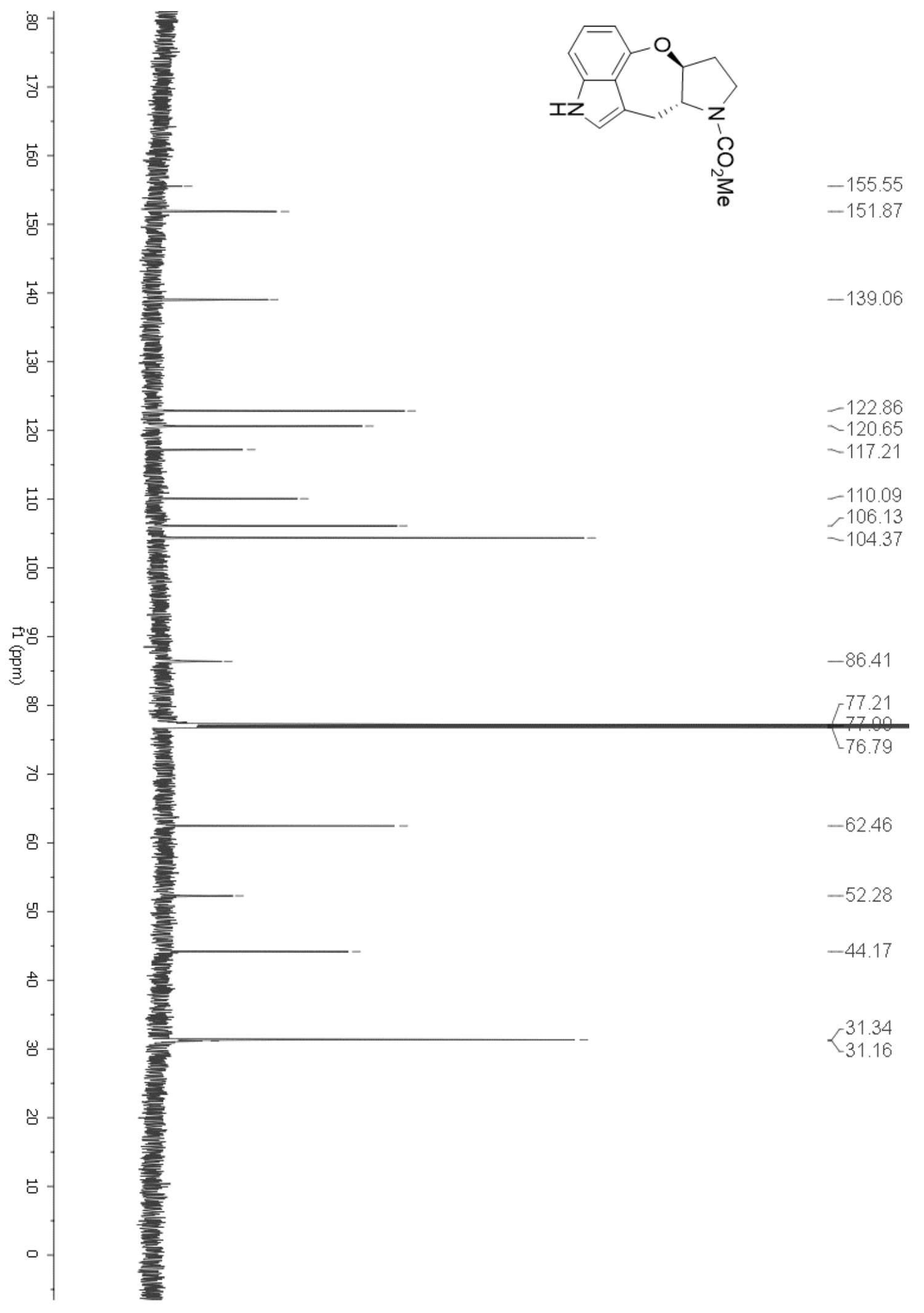

Figure $66:{ }^{13} \mathrm{C}$ NMR $\left(65^{\circ} \mathrm{C}\right)$ of $6,6 \mathrm{a}(R), 7,8,9,9 \mathrm{a}(S)$-hexahydro-7-(methoxycarbonyl)-4Hpyrrolo[2', $\left.3^{\prime}: 6,7\right]$ oxepino- $[4,3,2-c d]$ indole (39) 


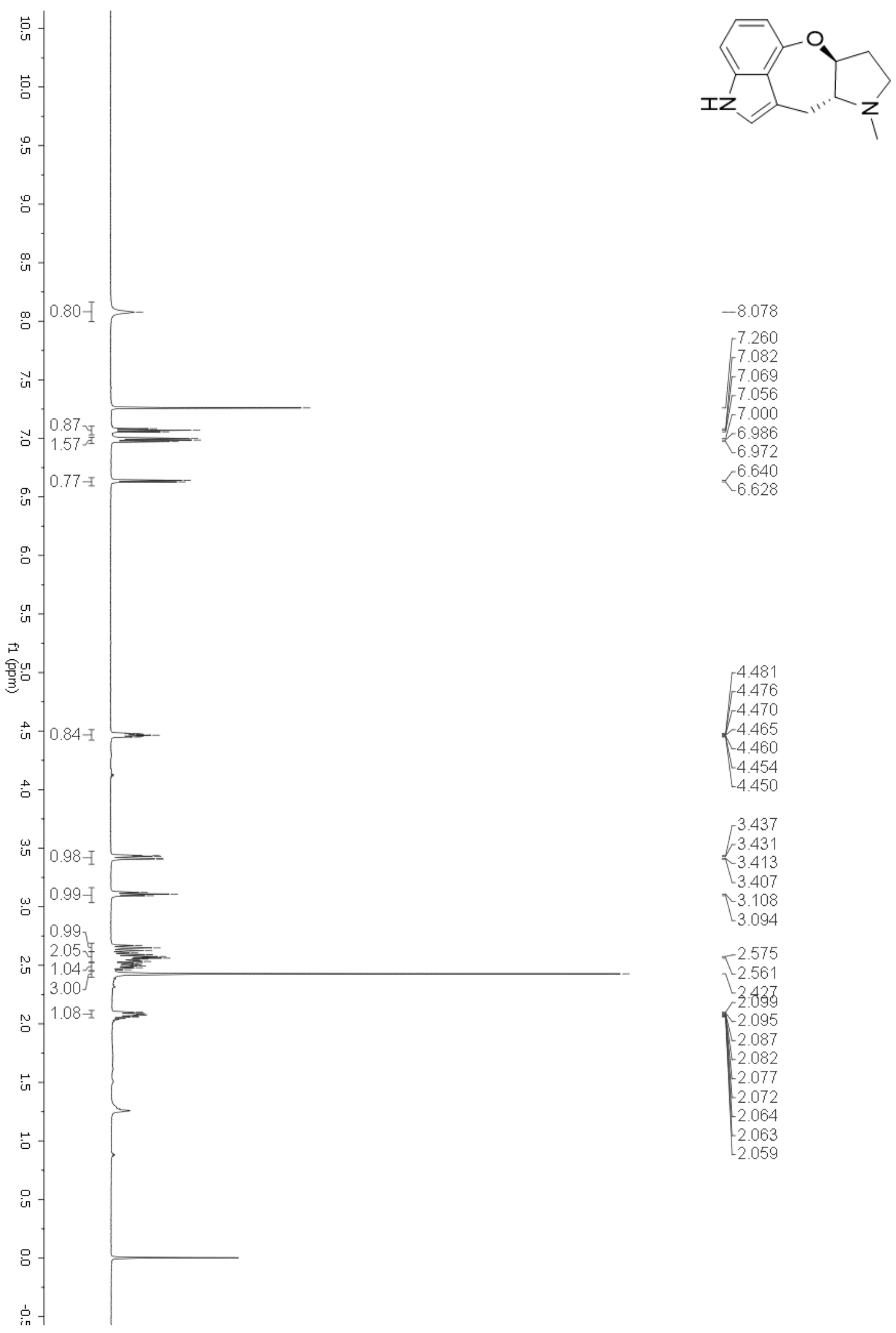

Figure 67: ${ }^{1} \mathrm{H}$ NMR of ht-13-A 


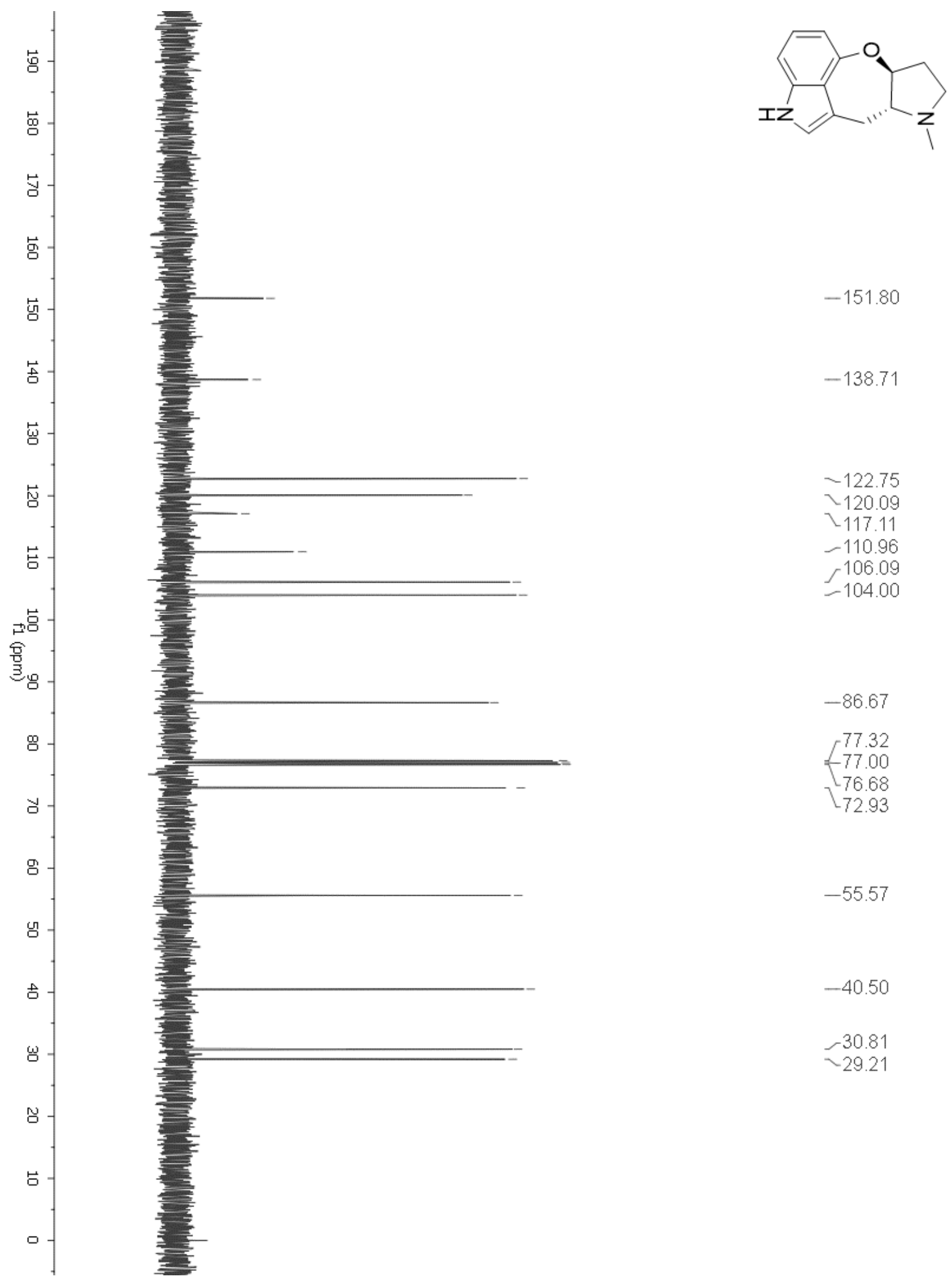

Figure $68:{ }^{13} \mathrm{C}$ NMR of ht-13-A 


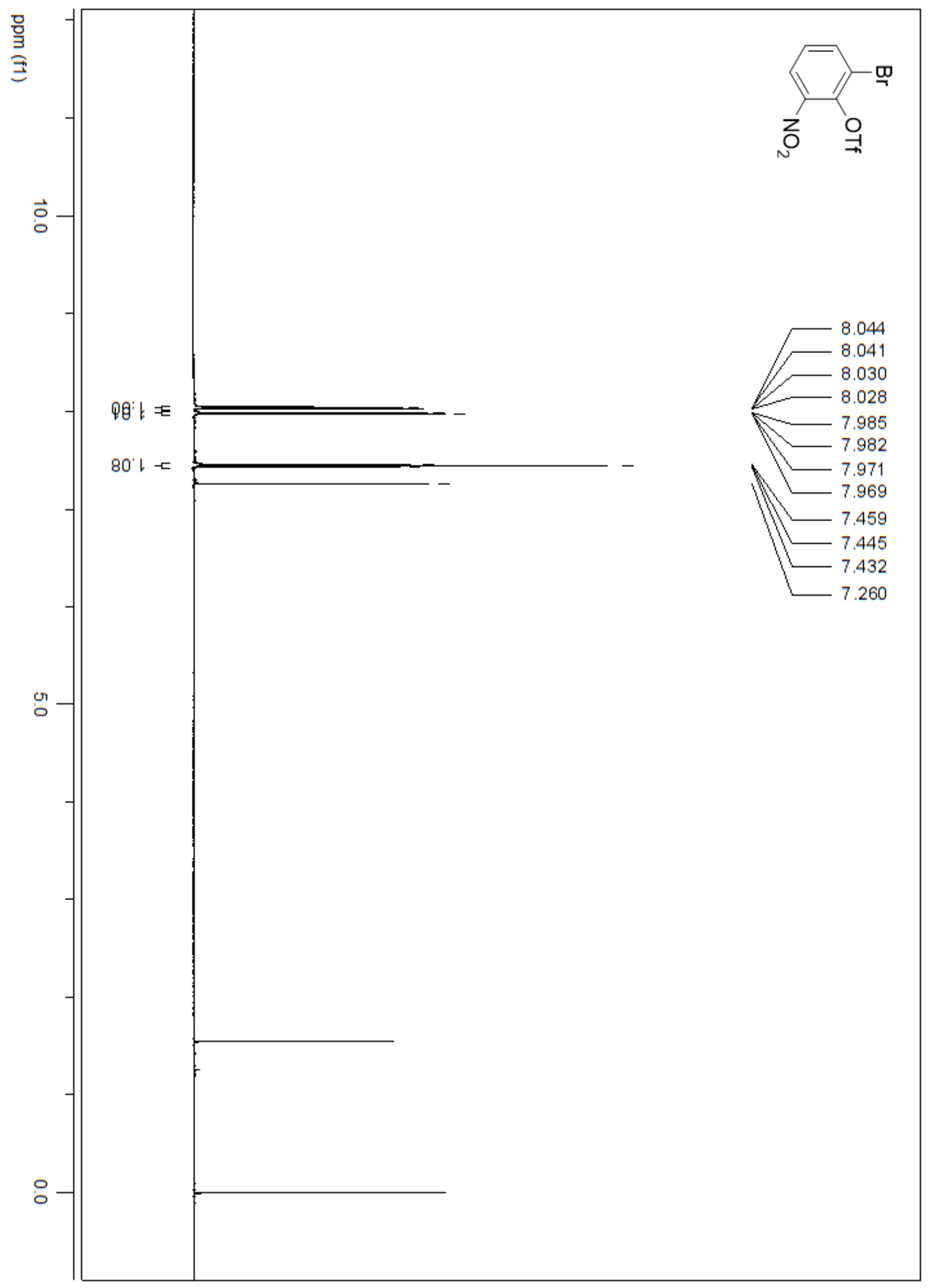

Figure 69: ${ }^{1} \mathrm{H}$ NMR of trifluoro-methanesulfonic acid 2-bromo-6-nitro-phenyl ester (43) 


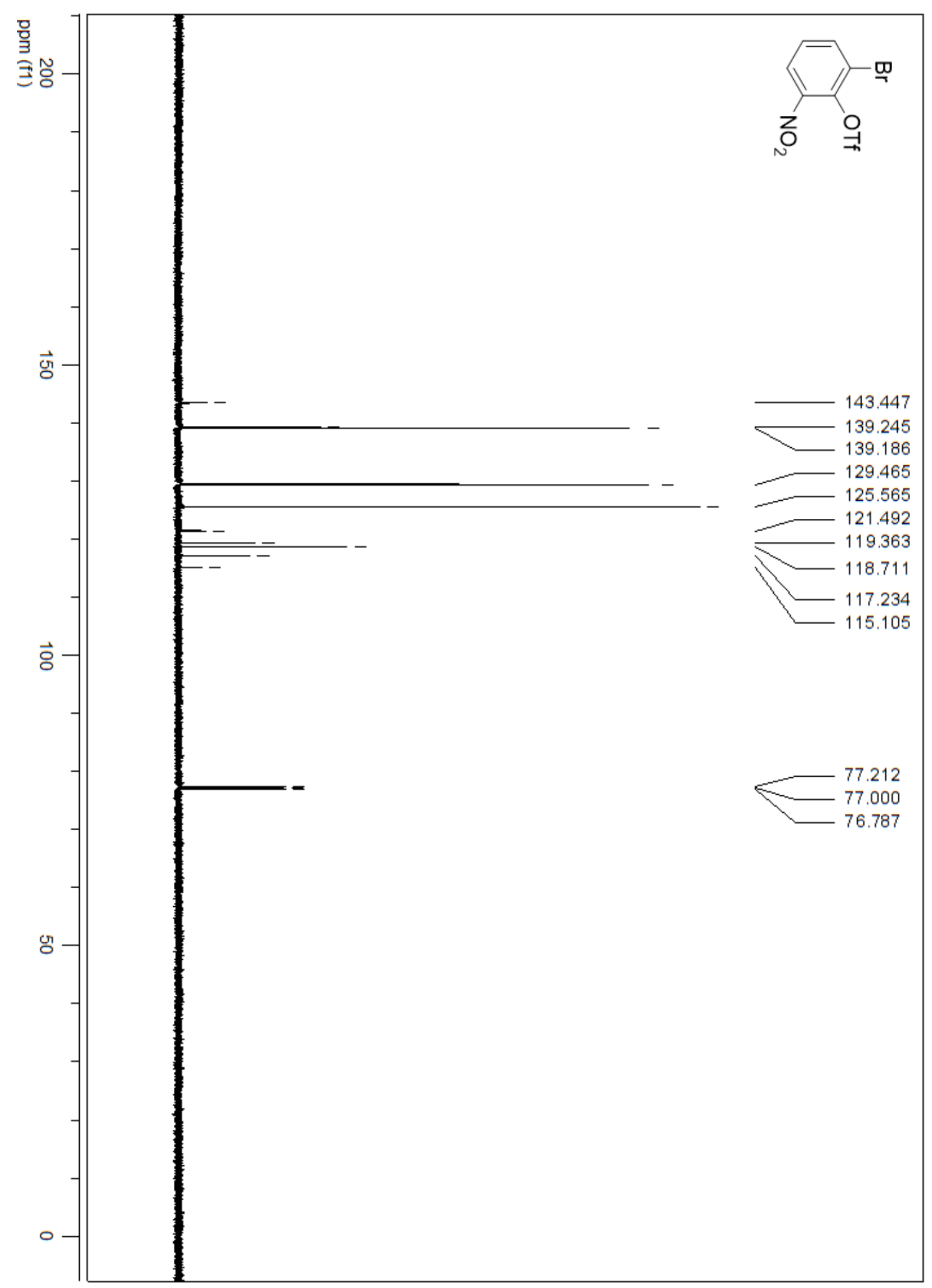

Figure 70: ${ }^{13} \mathrm{C}$ NMR of trifluoro-methanesulfonic acid 2-bromo-6-nitro-phenyl ester (43) 


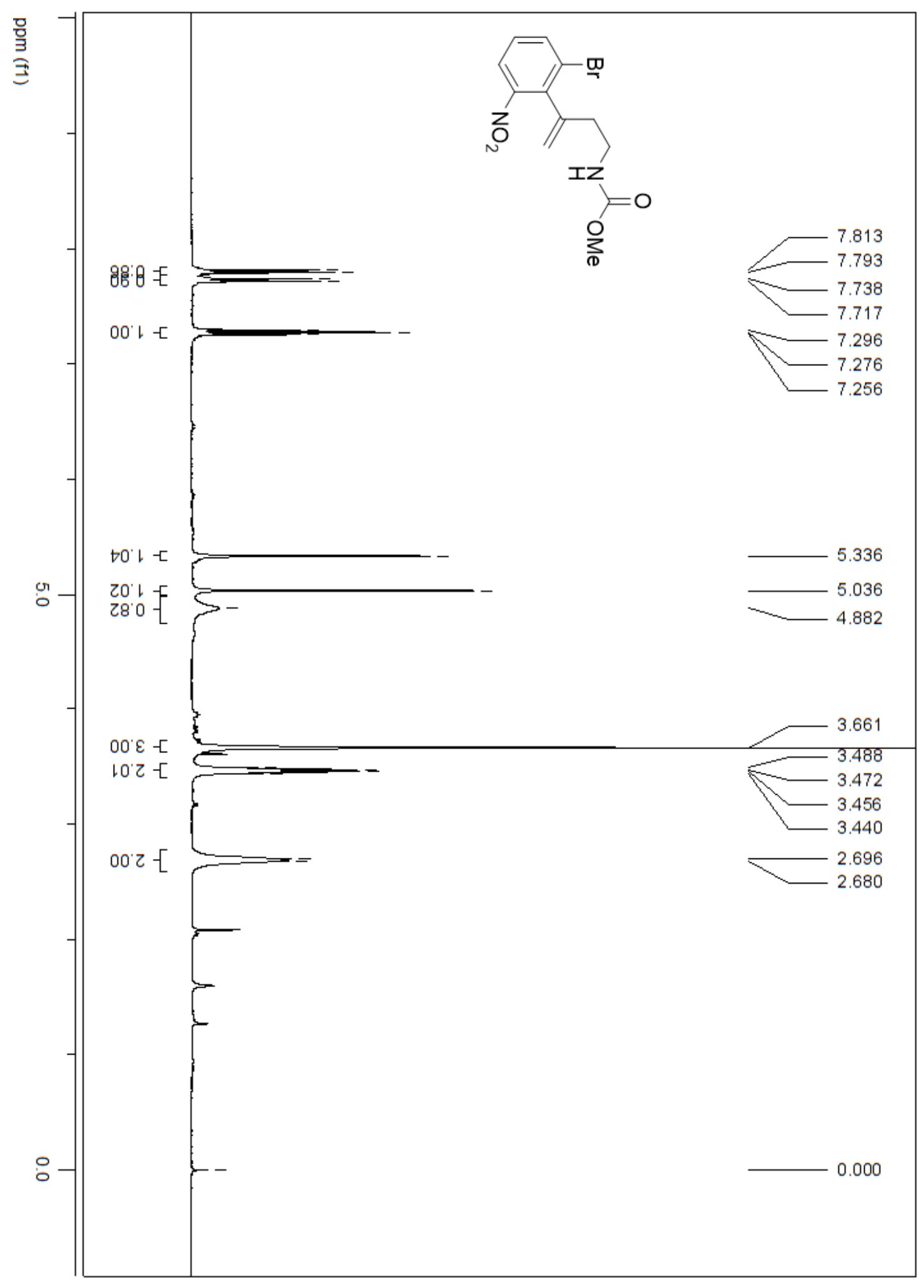

Figure 71: ${ }^{1} \mathrm{H}$ NMR $\left(65^{\circ} \mathrm{C}\right)$ of [3-(2-bromo-6-nitro-phenyl)-but-3-enyl]-carbamic acid methyl ester (45) 


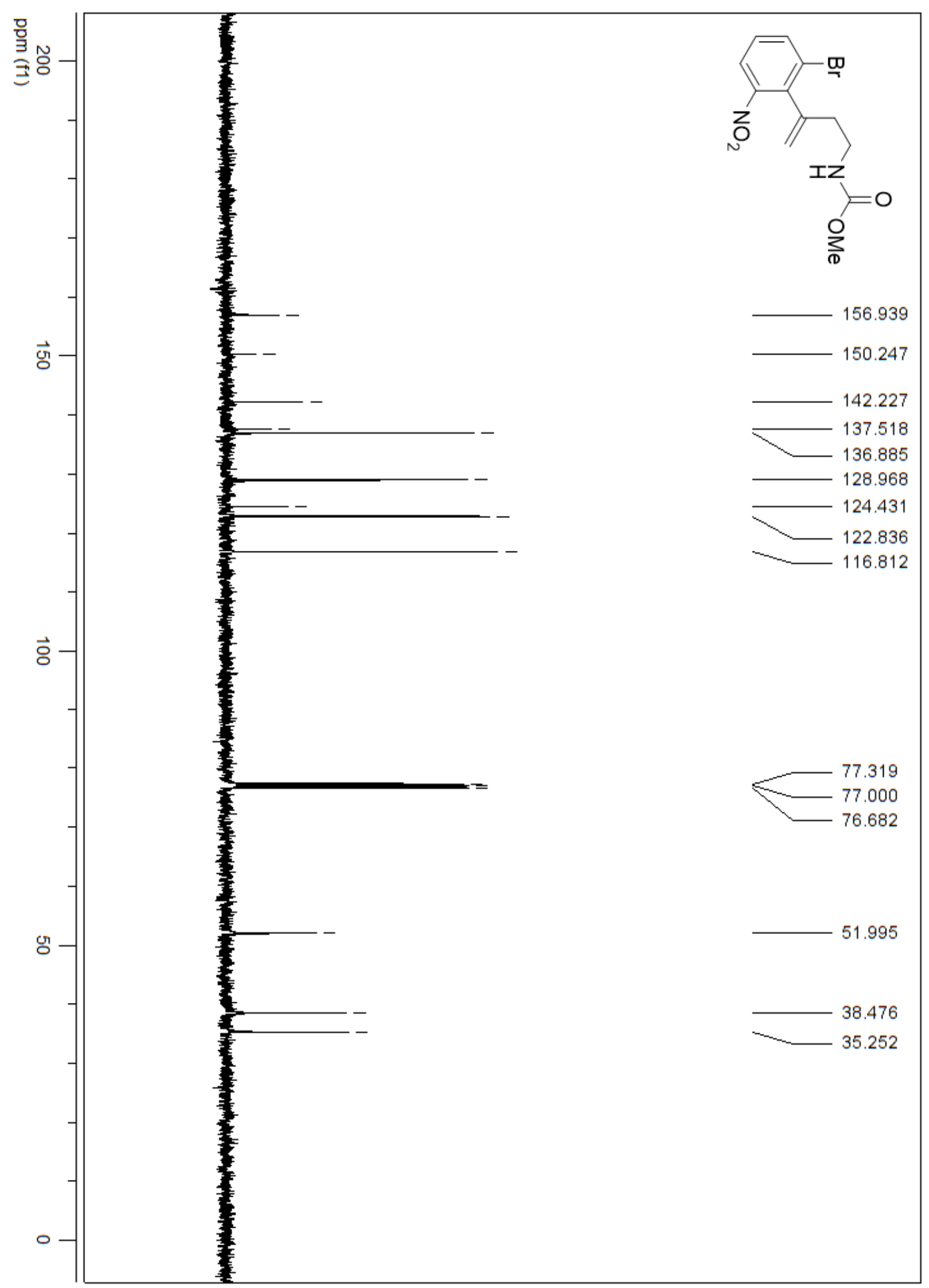

Figure 72: ${ }^{13} \mathrm{C}$ NMR of [3-(2-bromo-6-nitro-phenyl)-but-3-enyl]-carbamic acid methyl ester (45) 


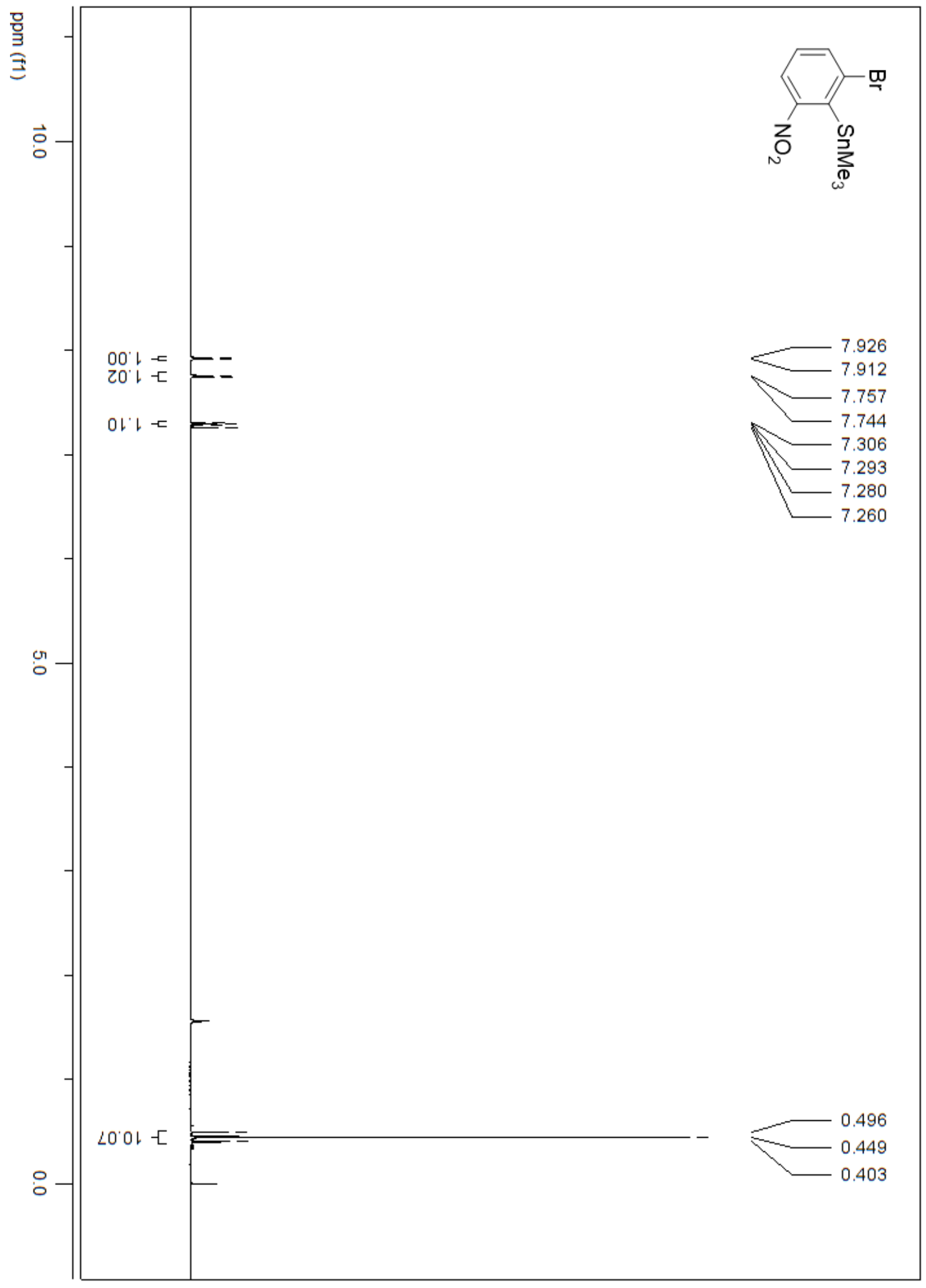

Figure 73: ${ }^{1} \mathrm{H}$ NMR of (2-bromo-6-nitro-phenyl)-trimethyl-stannane (50) 


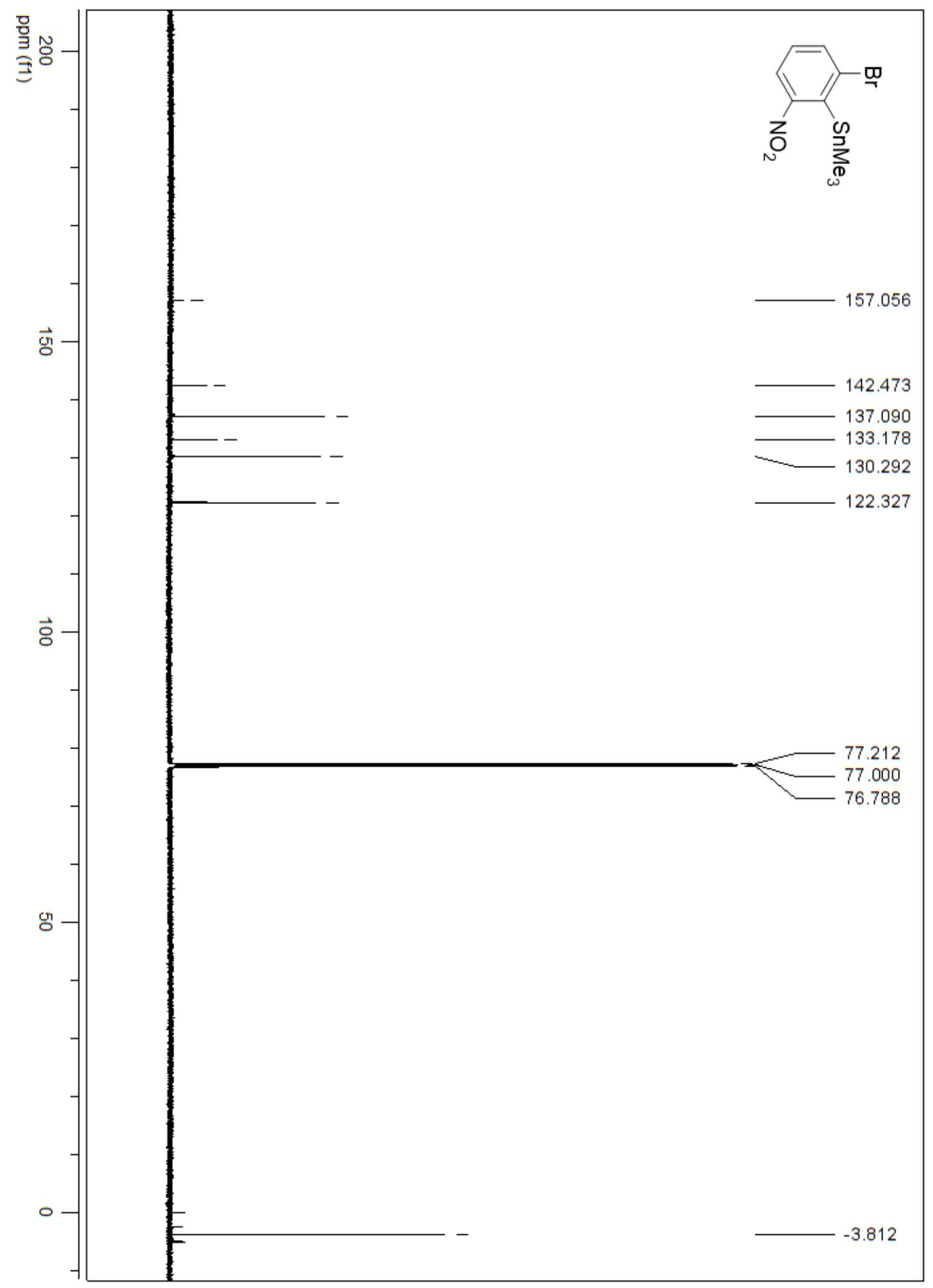

Figure 74: ${ }^{13} \mathrm{C}$ NMR of (2-bromo-6-nitro-phenyl)-trimethyl-stannane (50) 


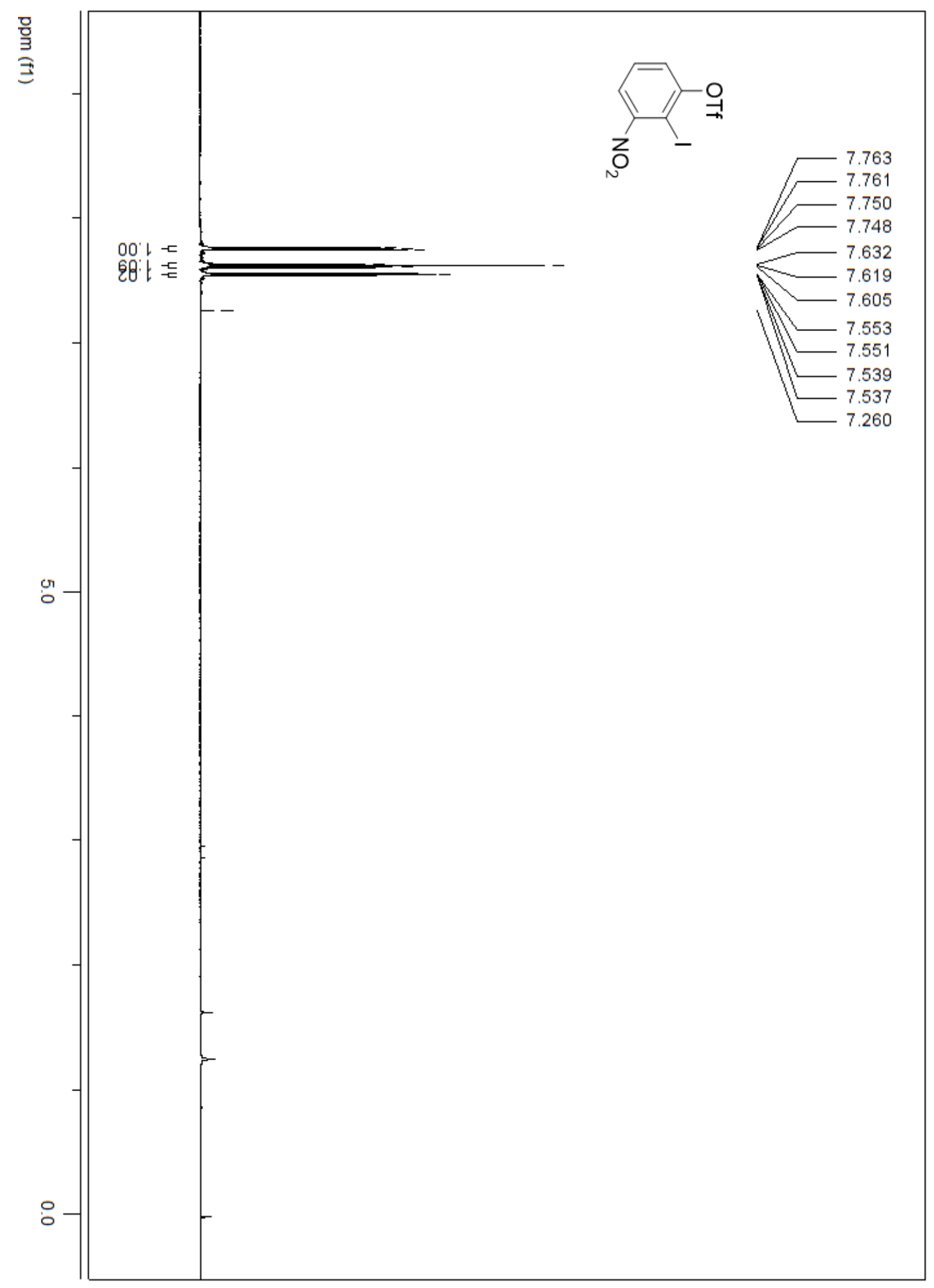

Figure 75: ${ }^{1} \mathrm{H}$ NMR of trifluoro-methanesulfonic acid 2-iodo-3-nitro-phenyl ester (52) 


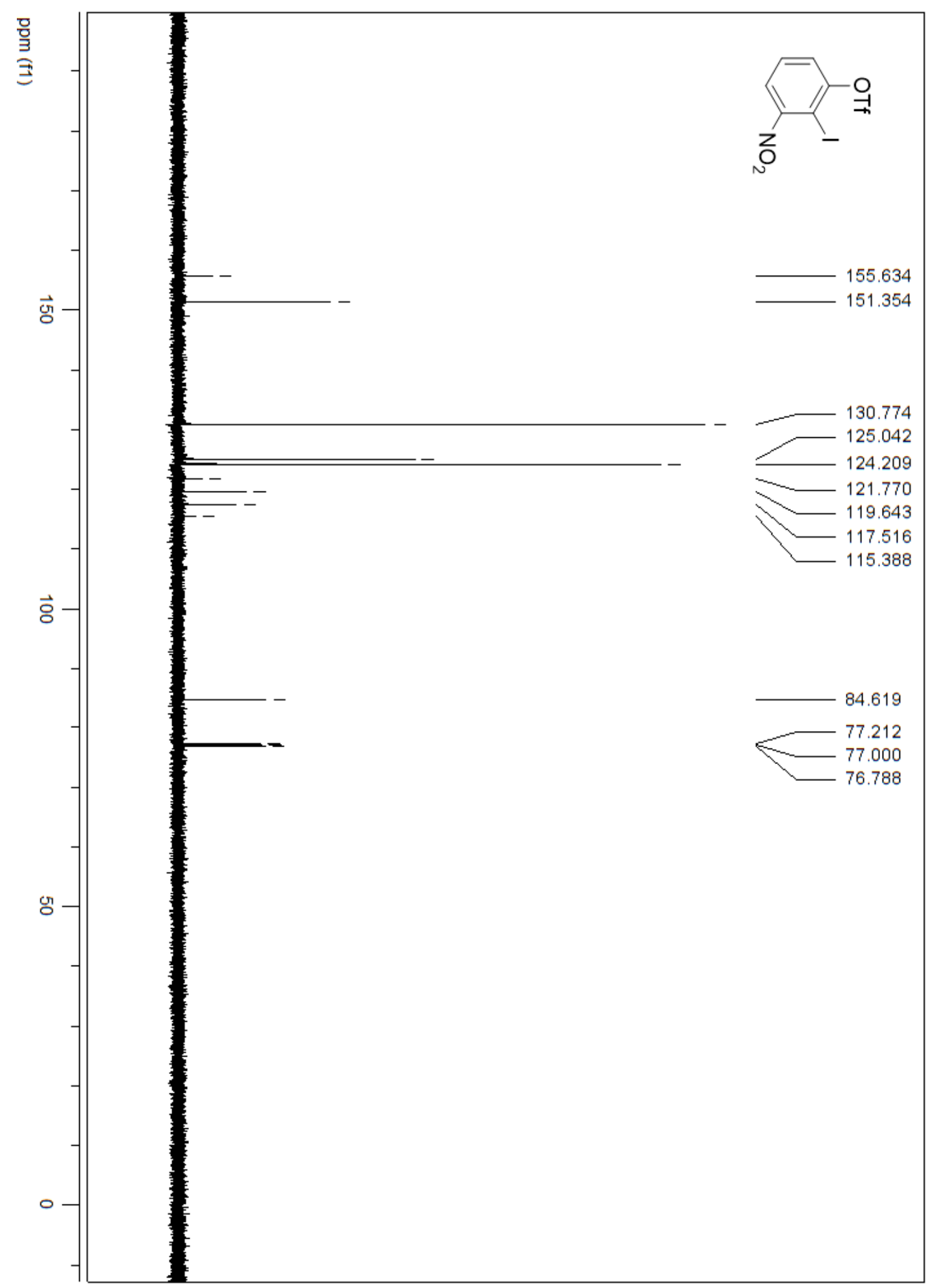

Figure 76: ${ }^{13} \mathrm{C}$ NMR trifluoro-methanesulfonic acid 2-iodo-3-nitro-phenyl ester (52) 


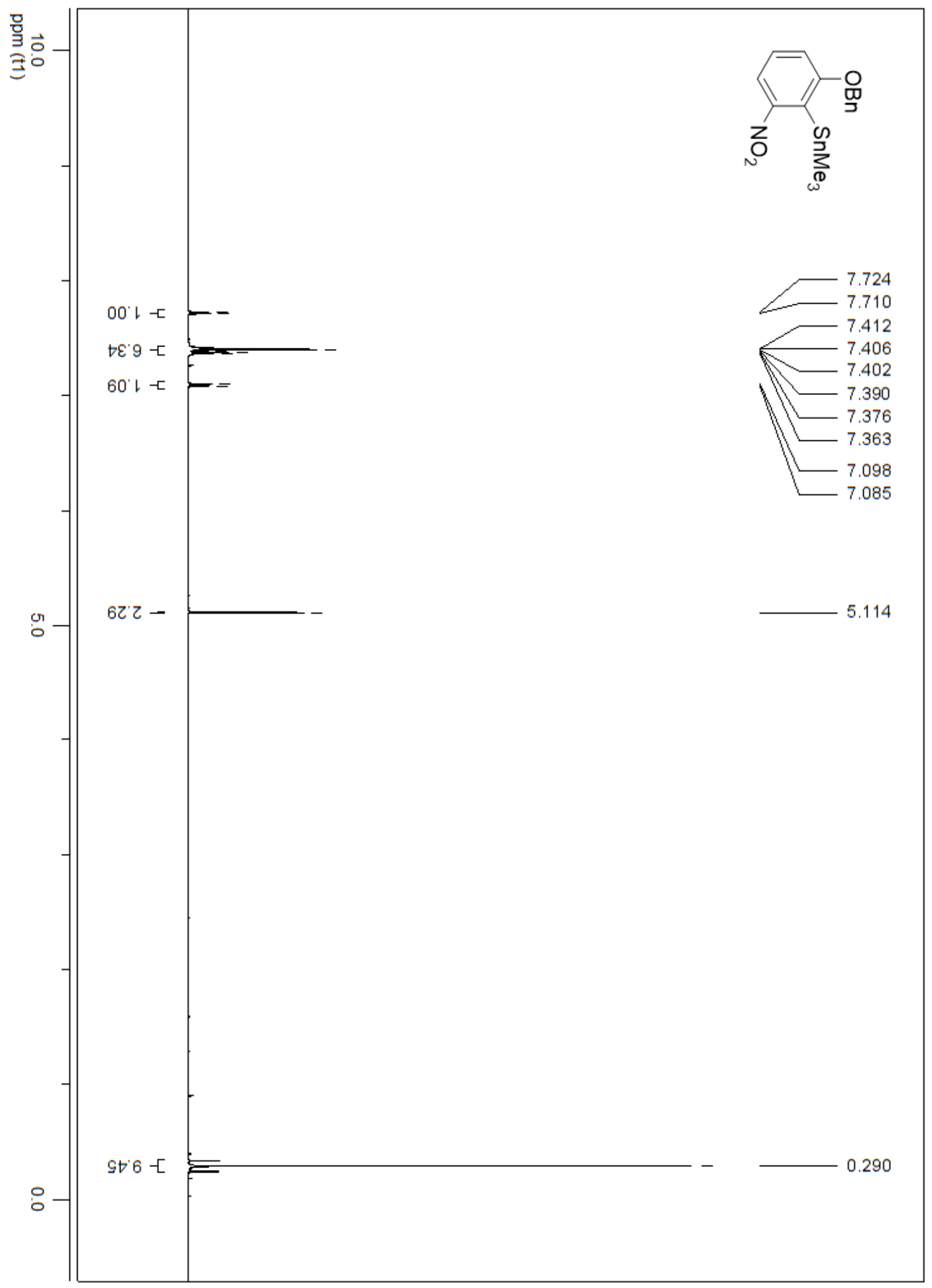

Figure 77: ${ }^{1} \mathrm{H}$ NMR of (2-benzyloxy-6-nitro-phenyl)-trimethyl-stannane (56) 


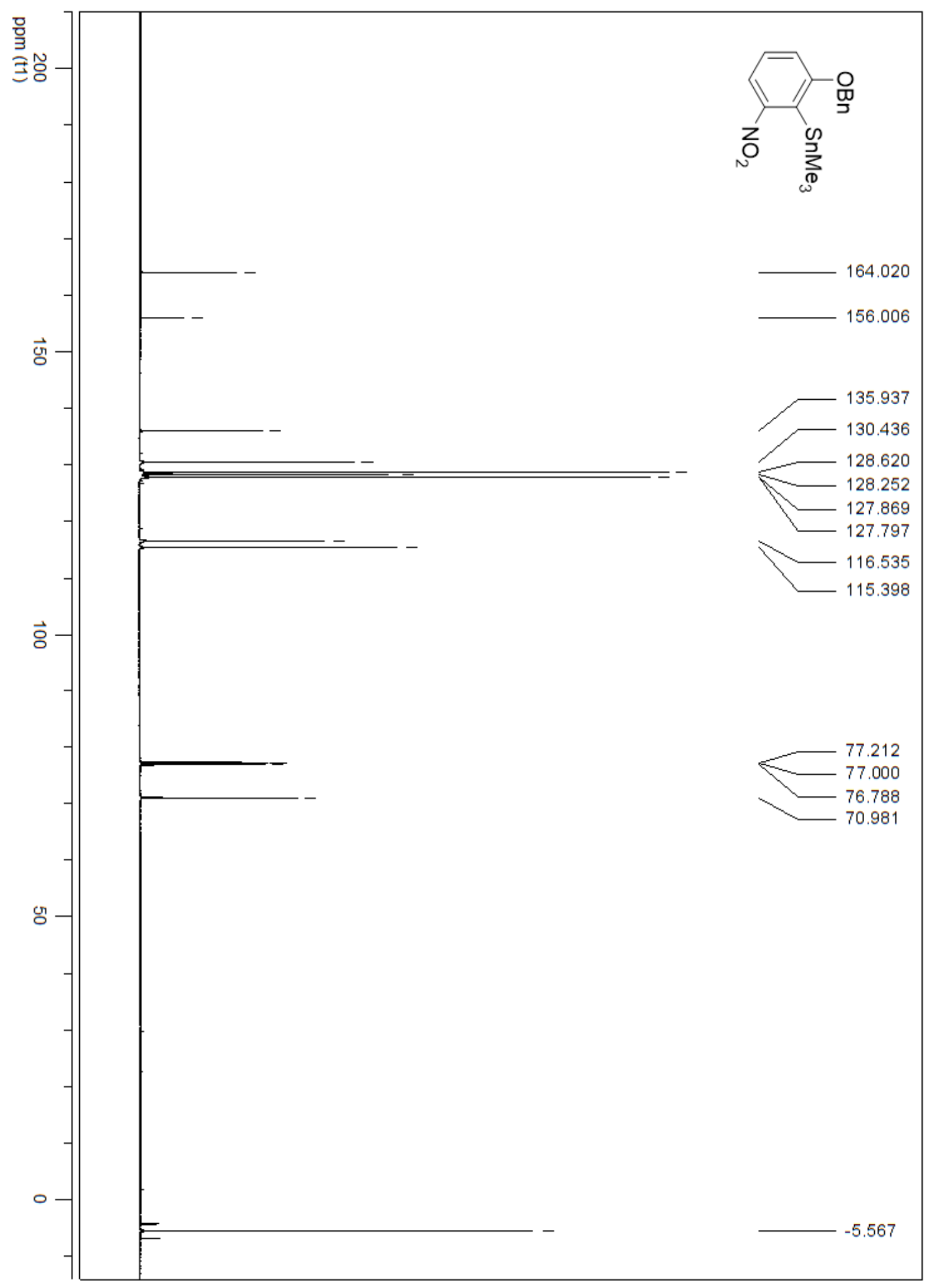

Figure 78: ${ }^{13} \mathrm{C}$ NMR of (2-benzyloxy-6-nitro-phenyl)-trimethyl-stannane (56) 


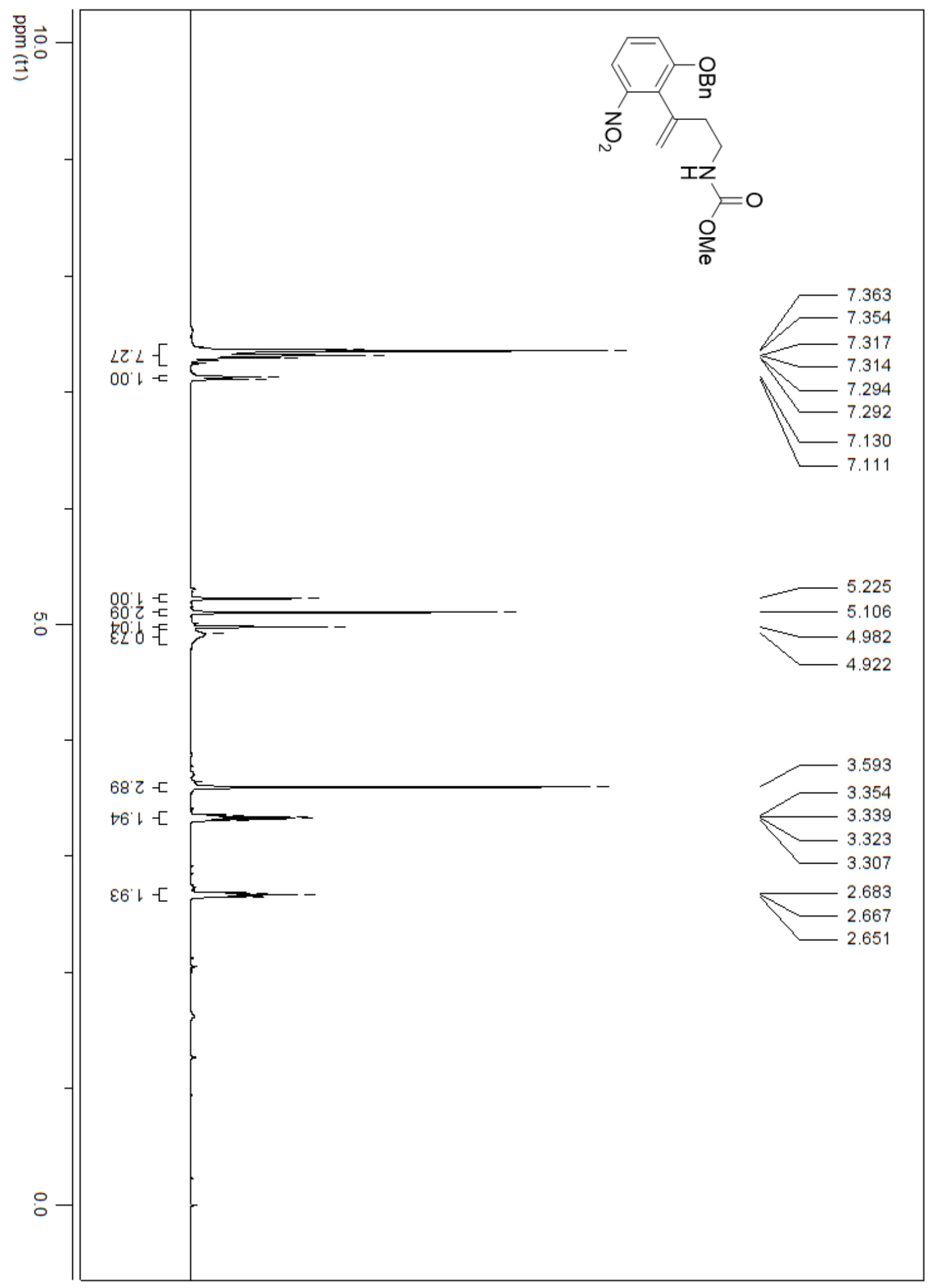

Figure 79: ${ }^{1} \mathrm{H}$ NMR $\left(65{ }^{\circ} \mathrm{C}\right)$ of [3-(2-benzyloxy-6-nitro-phenyl)-but-3-enyl]-carbamic acid methyl ester (57) 


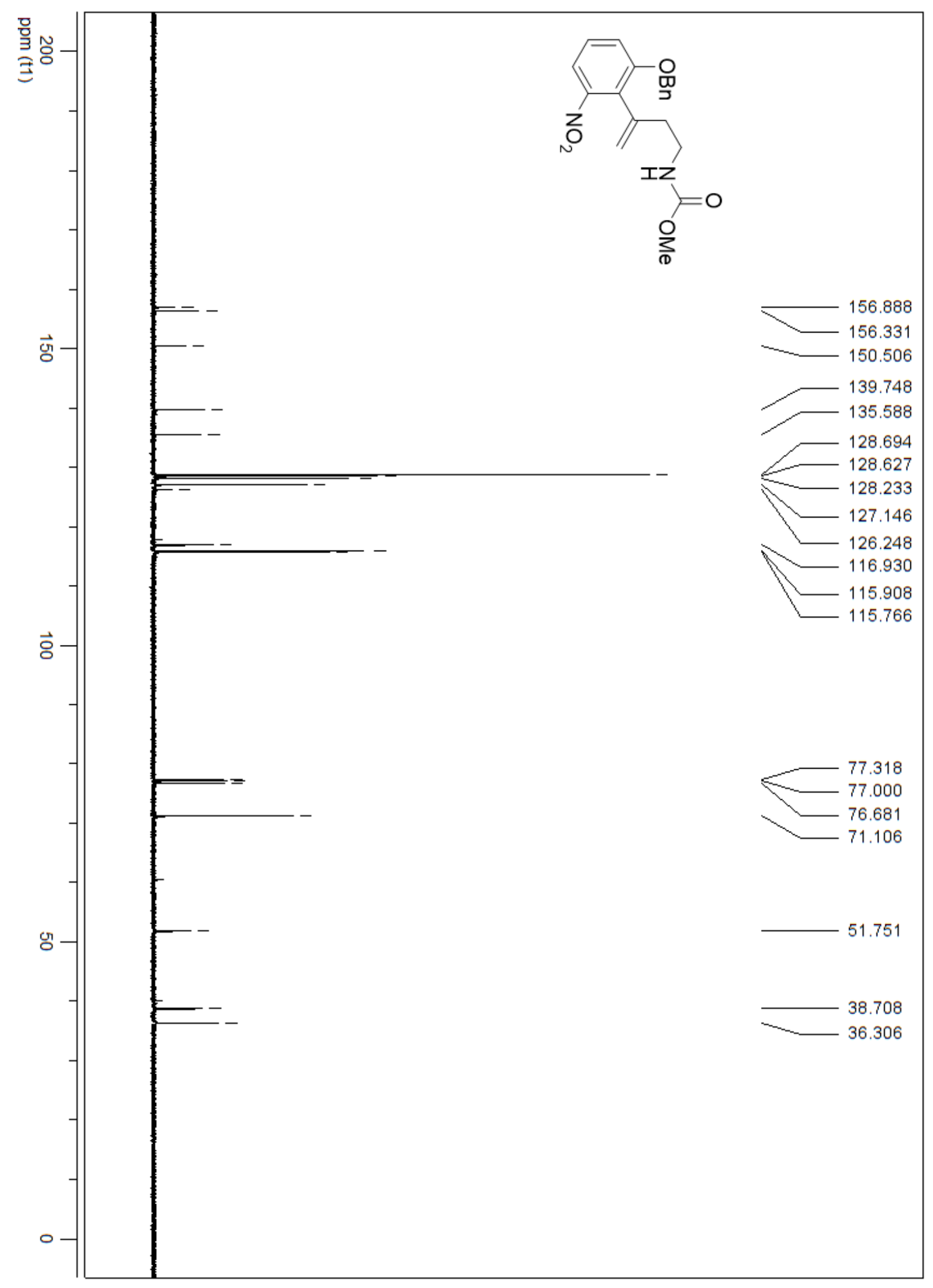

Figure 80: ${ }^{13} \mathrm{C}$ of [3-(2-benzyloxy-6-nitro-phenyl)-but-3-enyl]-carbamic acid methyl ester (57) 


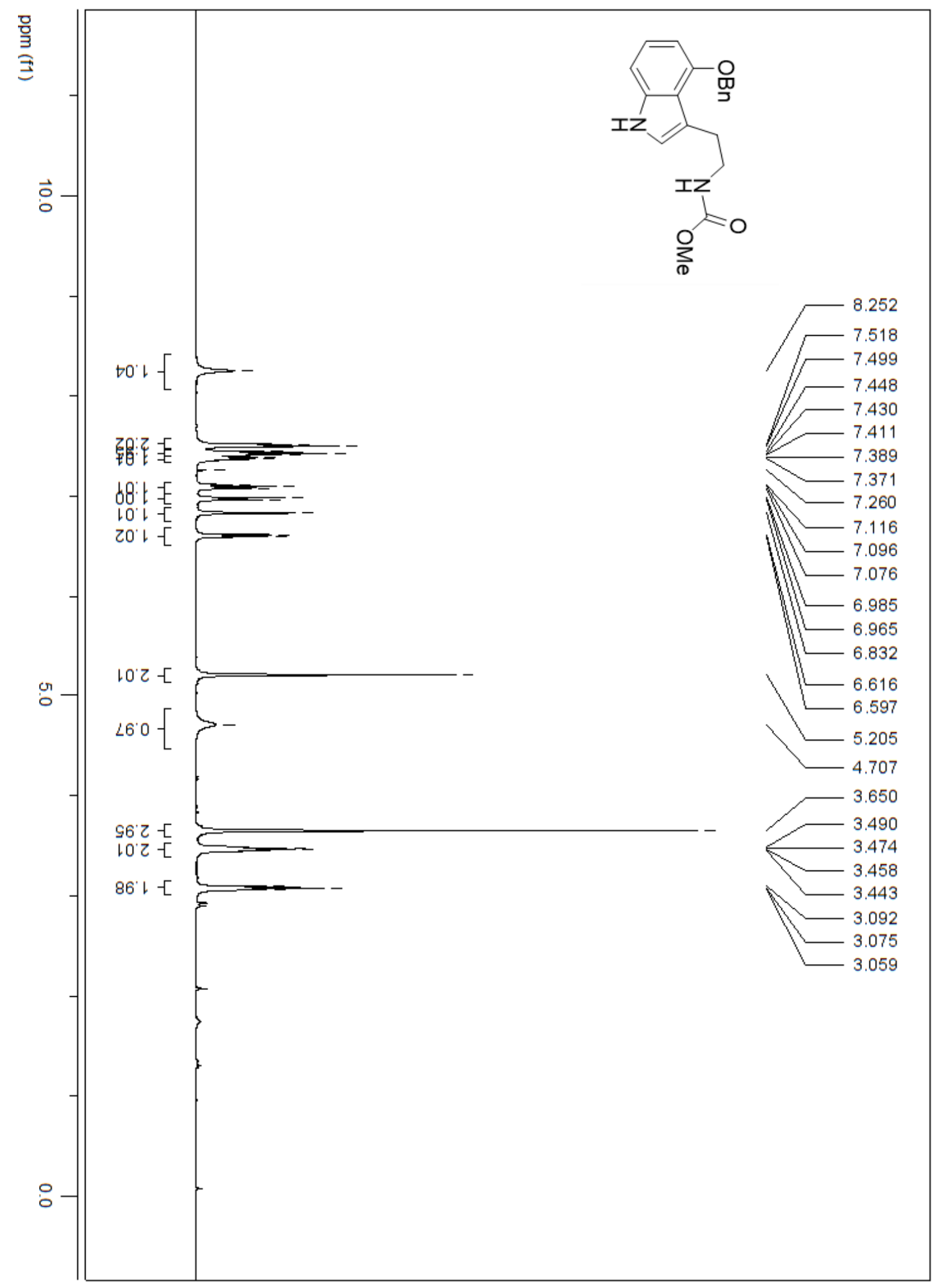

Figure 81: ${ }^{1} \mathrm{H}$ NMR $\left(65^{\circ} \mathrm{C}\right)$ of [2-(4-benzyloxy-1H-indol-3-yl)-ethyl]-carbamic acid methyl ester (58) 


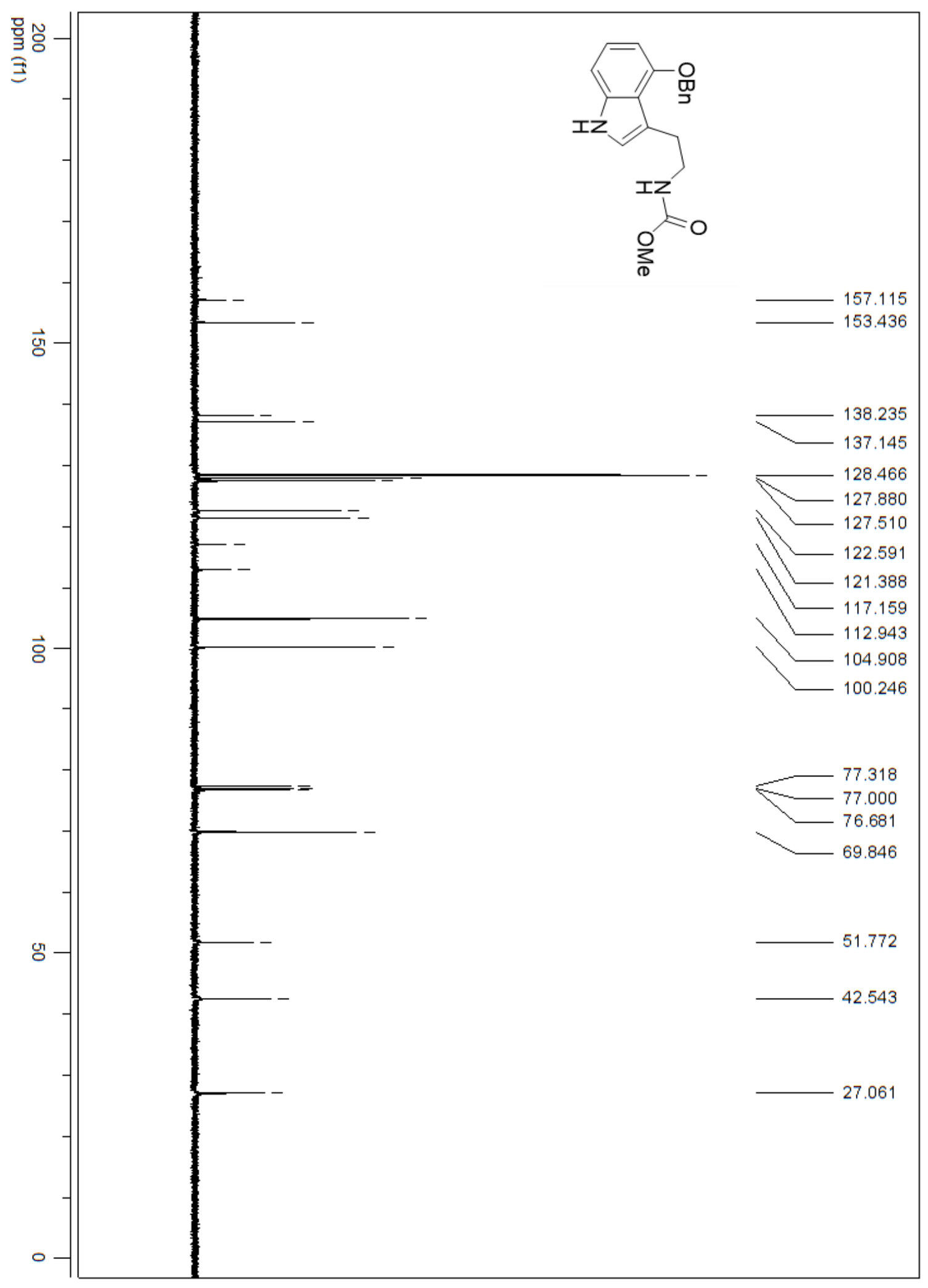

Figure 82: ${ }^{13} \mathrm{C}$ NMR of [2-(4-benzyloxy-1H-indol-3-yl)-ethyl]-carbamic acid methyl ester (58) 


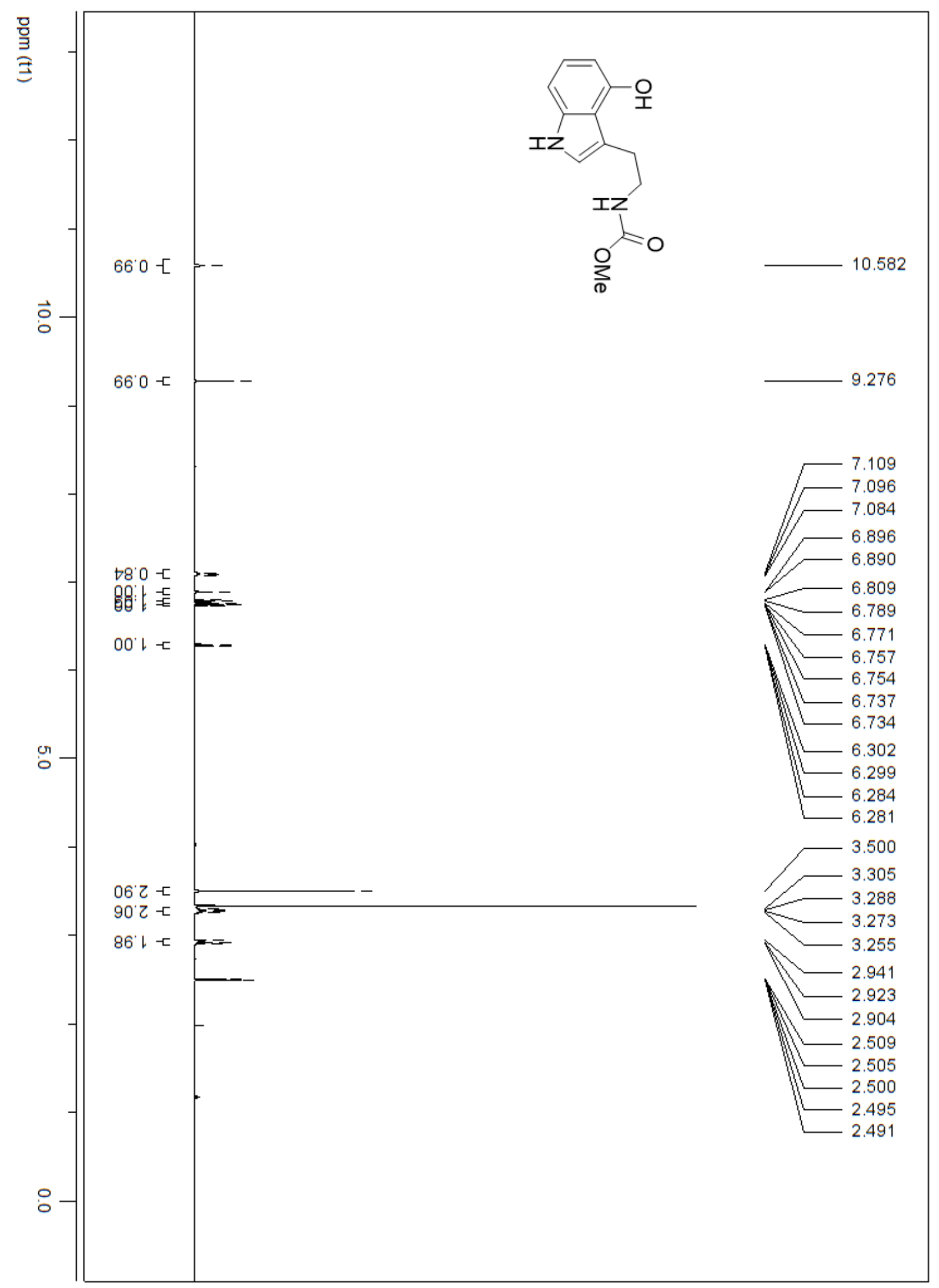

Figure 83: ${ }^{1} \mathrm{H}$ NMR of [2-(4-hydroxy-1H-indol-3-yl)-ethyl]-carbamic acid methyl ester (59) 


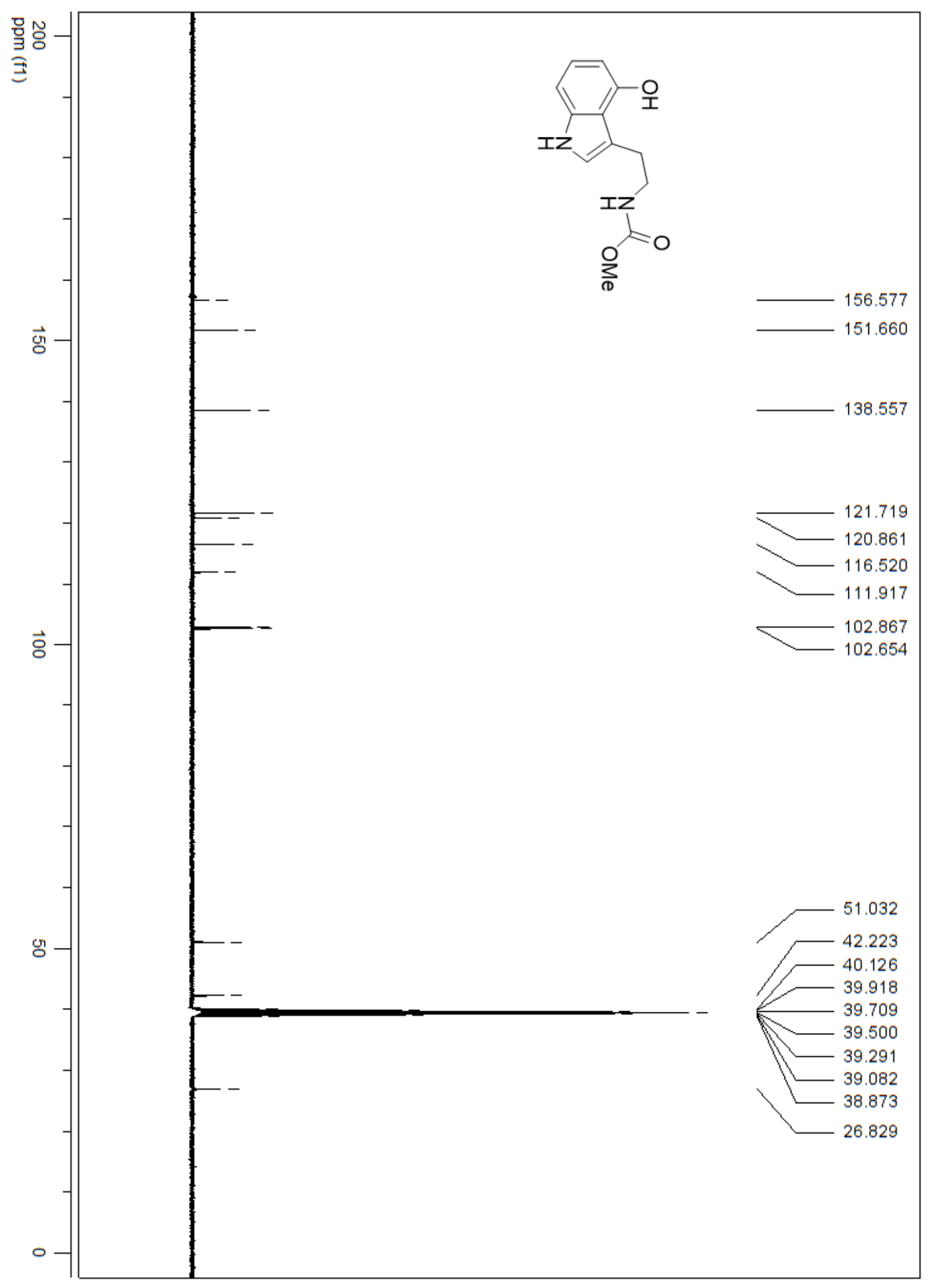

Figure 84: ${ }^{13} \mathrm{C}$ NMR of [2-(4-hydroxy-1H-indol-3-yl)-ethyl]-carbamic acid methyl ester (59) 


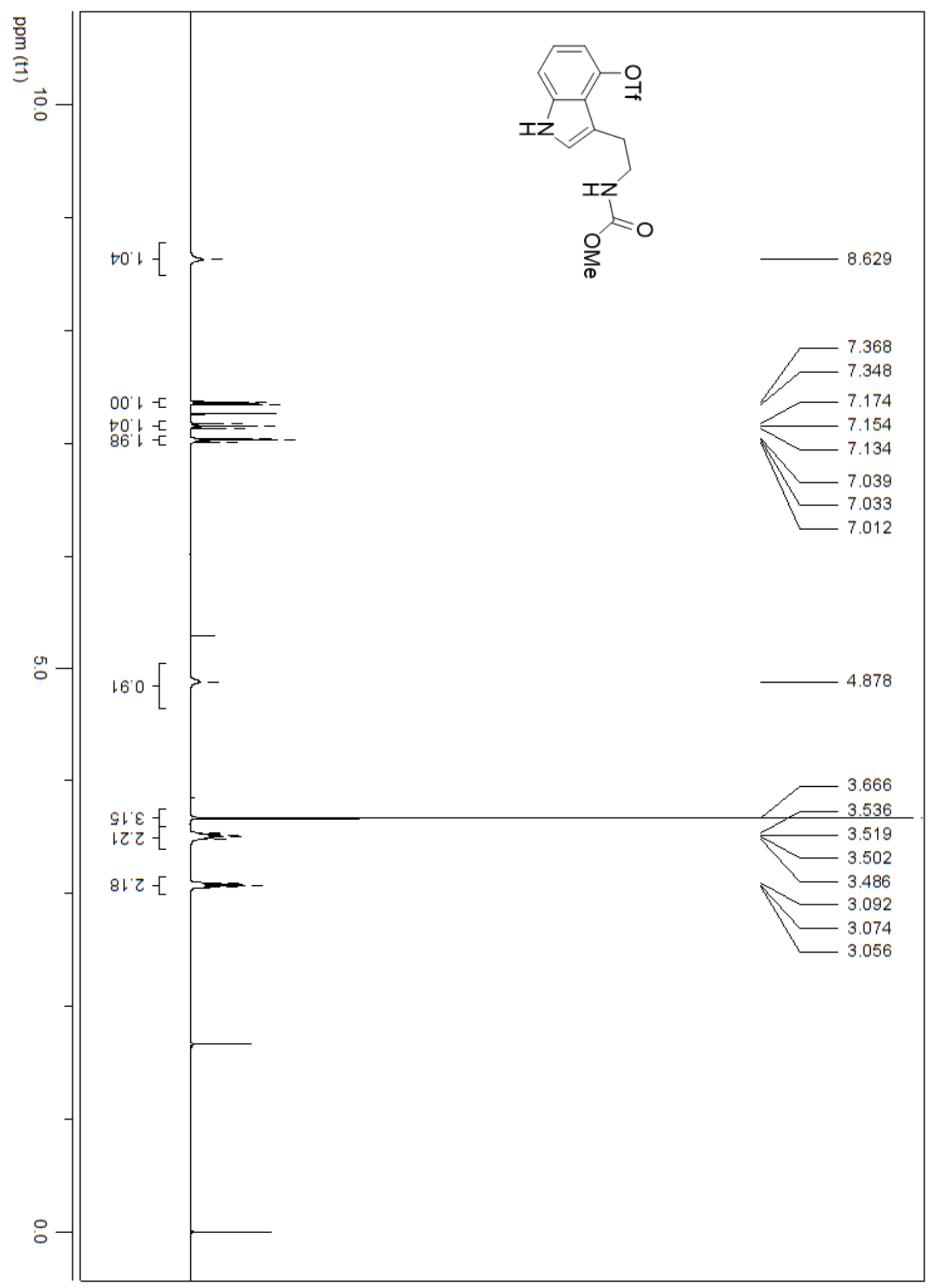

Figure 85: ${ }^{1} \mathrm{H}$ NMR of trifluoro-methanesulfonic acid 3-(2-methoxycarbonylamino-ethyl)1H-indol-4-yl ester (60) 


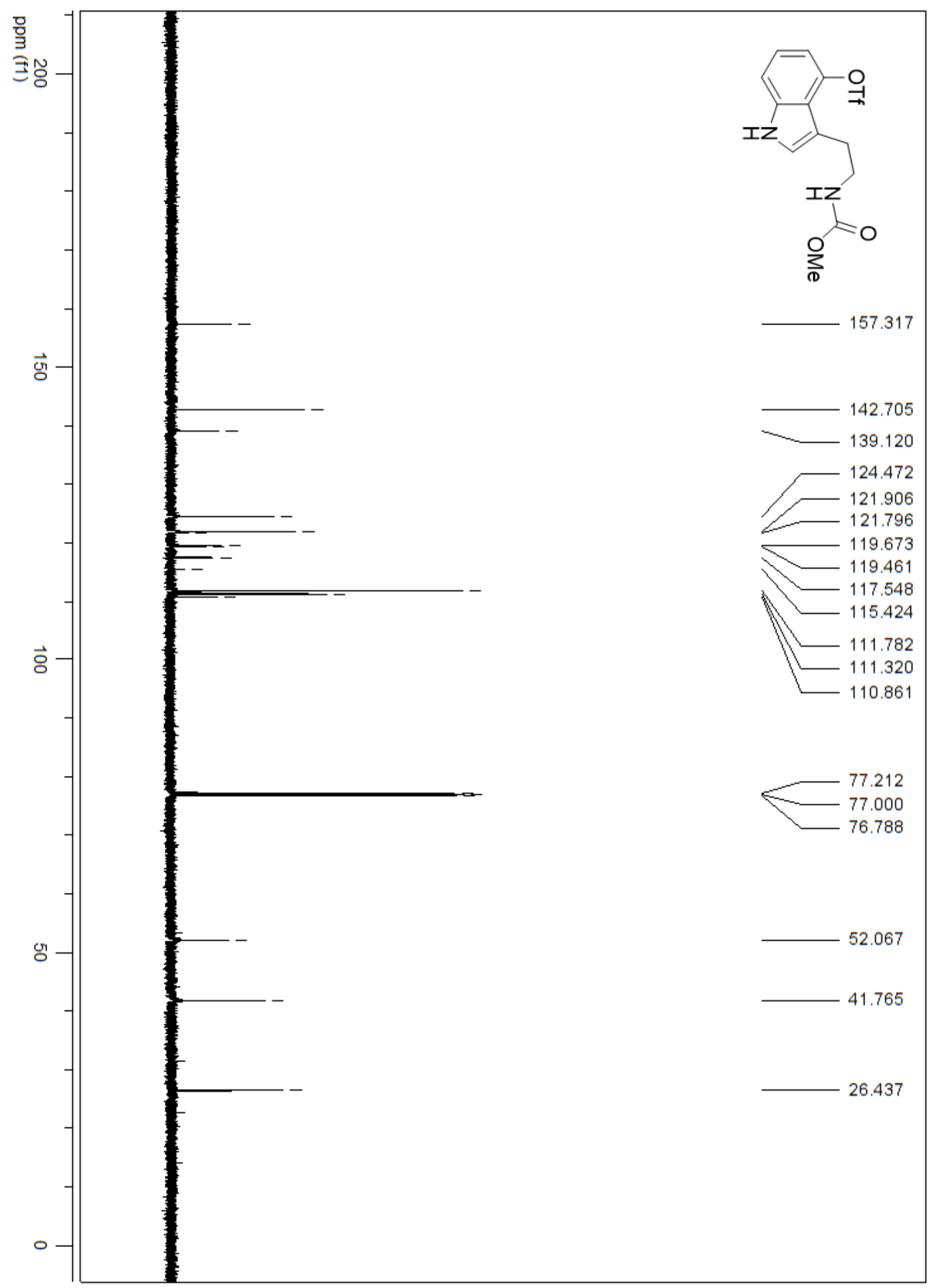

Figure 86: ${ }^{13} \mathrm{C}$ NMR of trifluoro-methanesulfonic acid 3-(2-methoxycarbonylamino-ethyl)1H-indol-4-yl ester (60) 


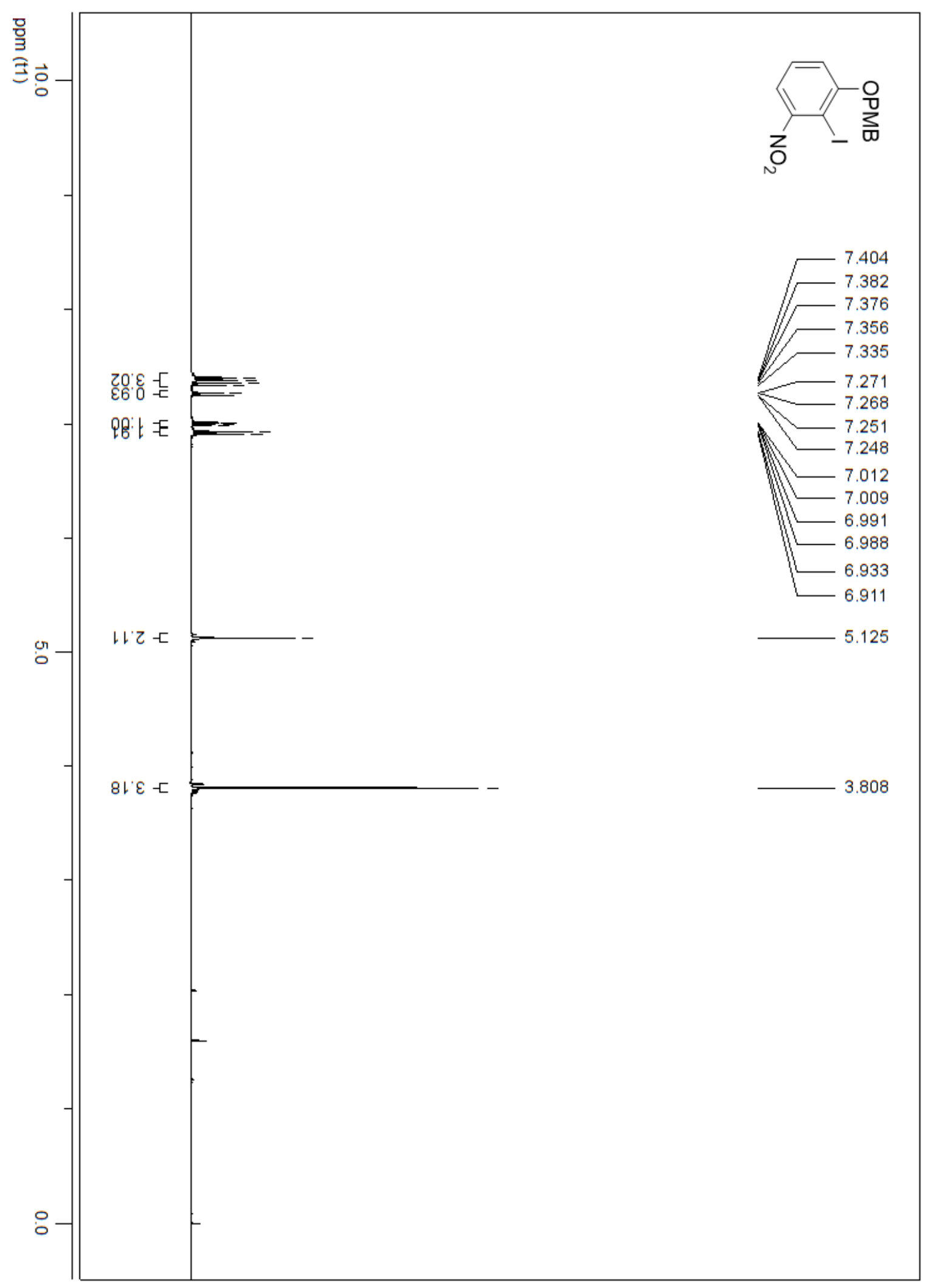

Figure 87: ${ }^{1} \mathrm{H}$ NMR of 2-iodo-1-(4-methoxy-benzyloxy)-3-nitro-benzene (63) 


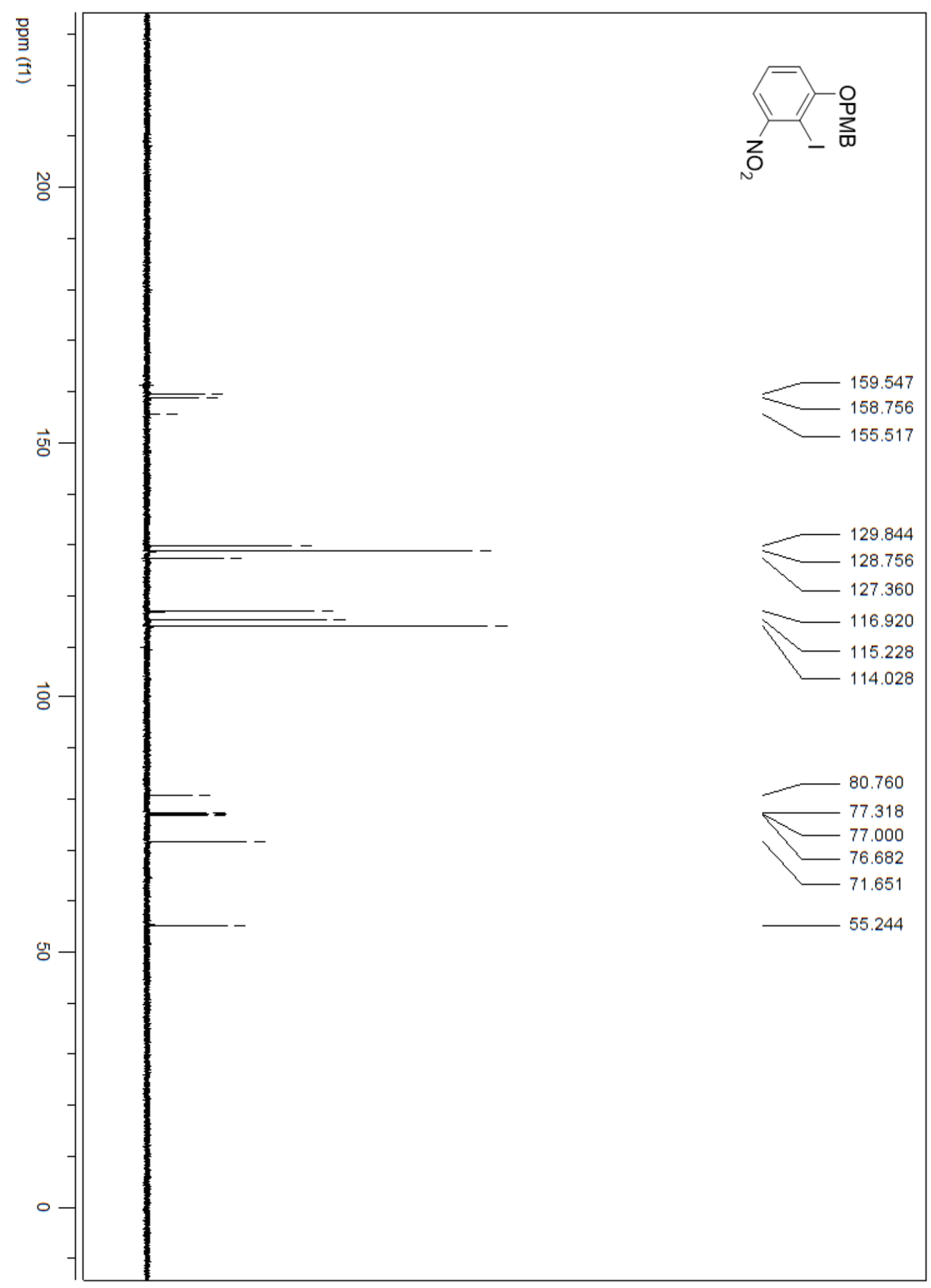

Figure 88: ${ }^{13} \mathrm{C}$ NMR 2-iodo-1-(4-methoxy-benzyloxy)-3-nitro-benzene (63) 


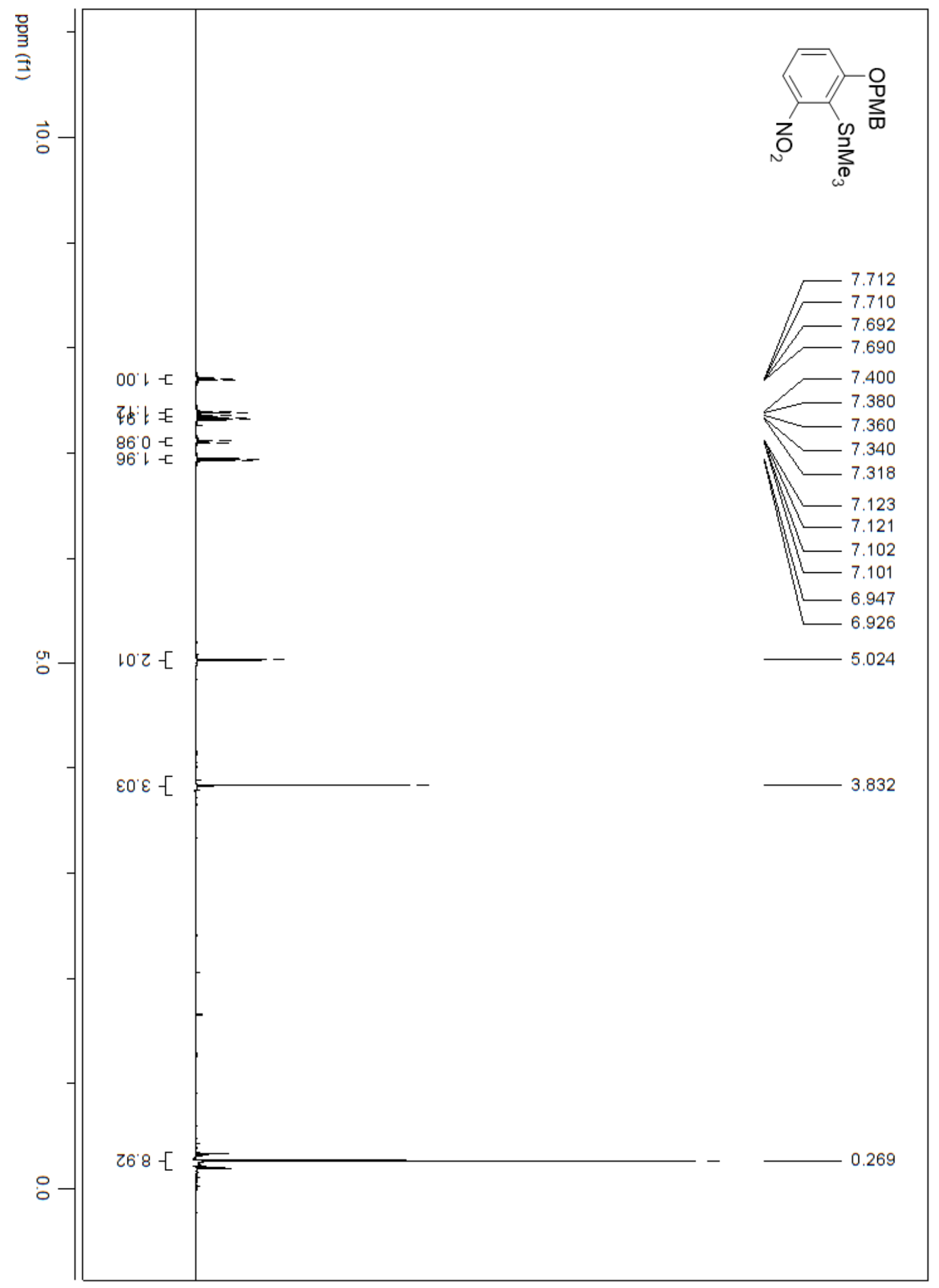

Figure 89: ${ }^{1} \mathrm{H}$ NMR of [2-(4-methoxy-benzyloxy)-6-nitro-phenyl]-trimethyl-stannane (64) 


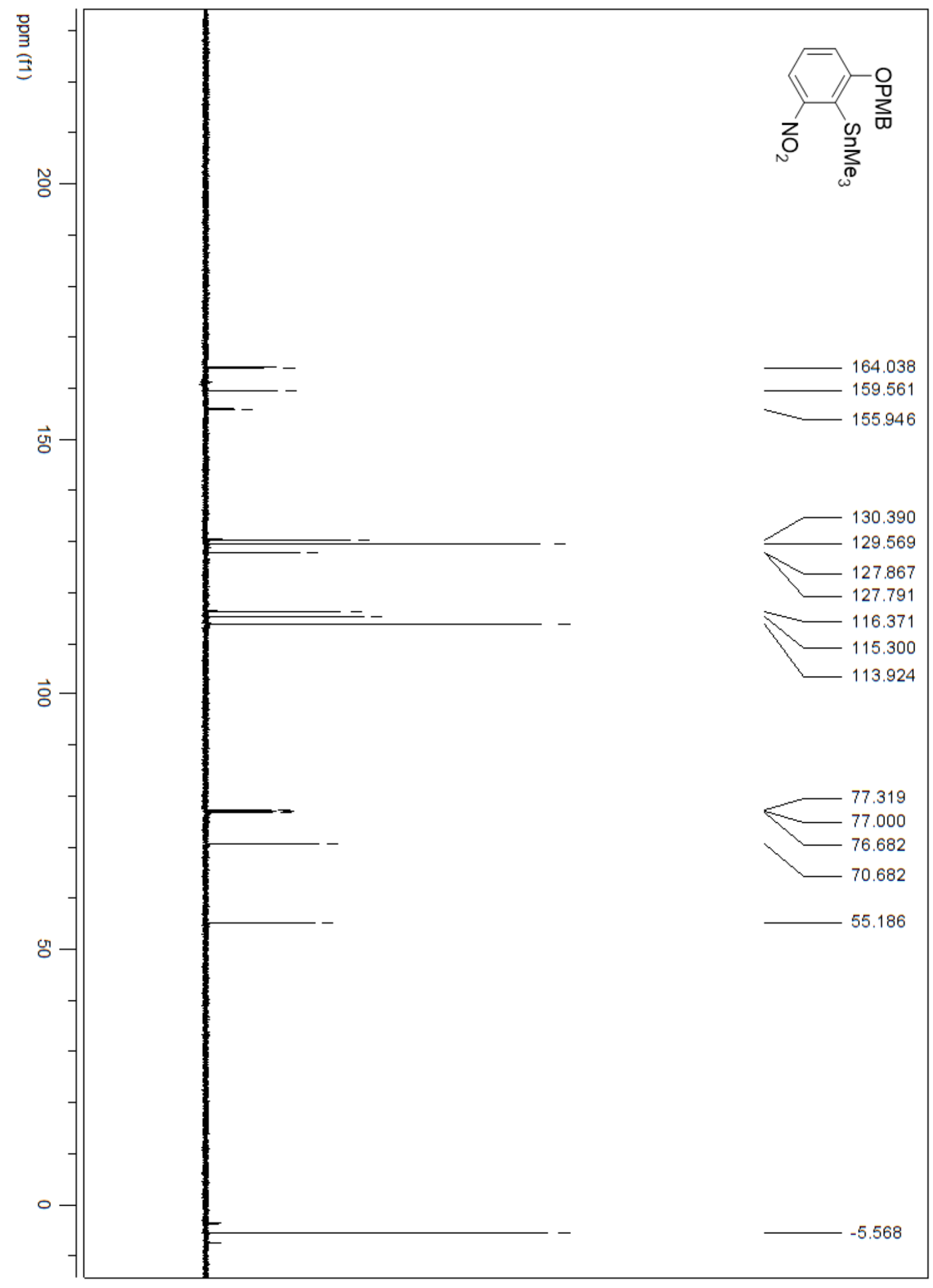

Figure 90: ${ }^{13} \mathrm{C}$ NMR of [2-(4-methoxy-benzyloxy)-6-nitro-phenyl]-trimethyl-stannane (64) 


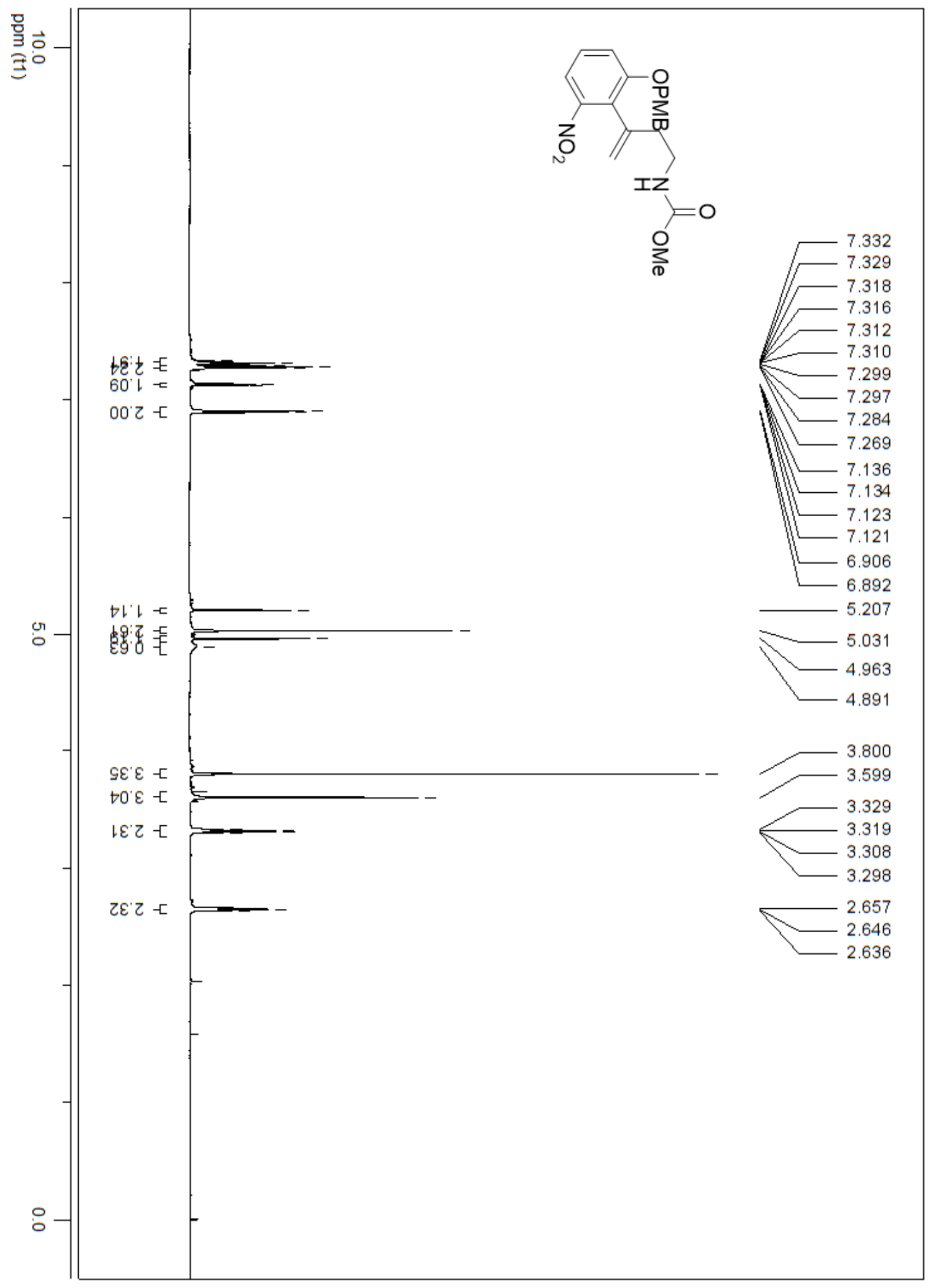

Figure 91: ${ }^{1} \mathrm{H}$ NMR $\left(65{ }^{\circ} \mathrm{C}\right)$ of \{3-[2-(4-methoxy-benzyloxy)-6-nitro-phenyl]-but-3enyl\}-carbamic acid methyl ester (65) 


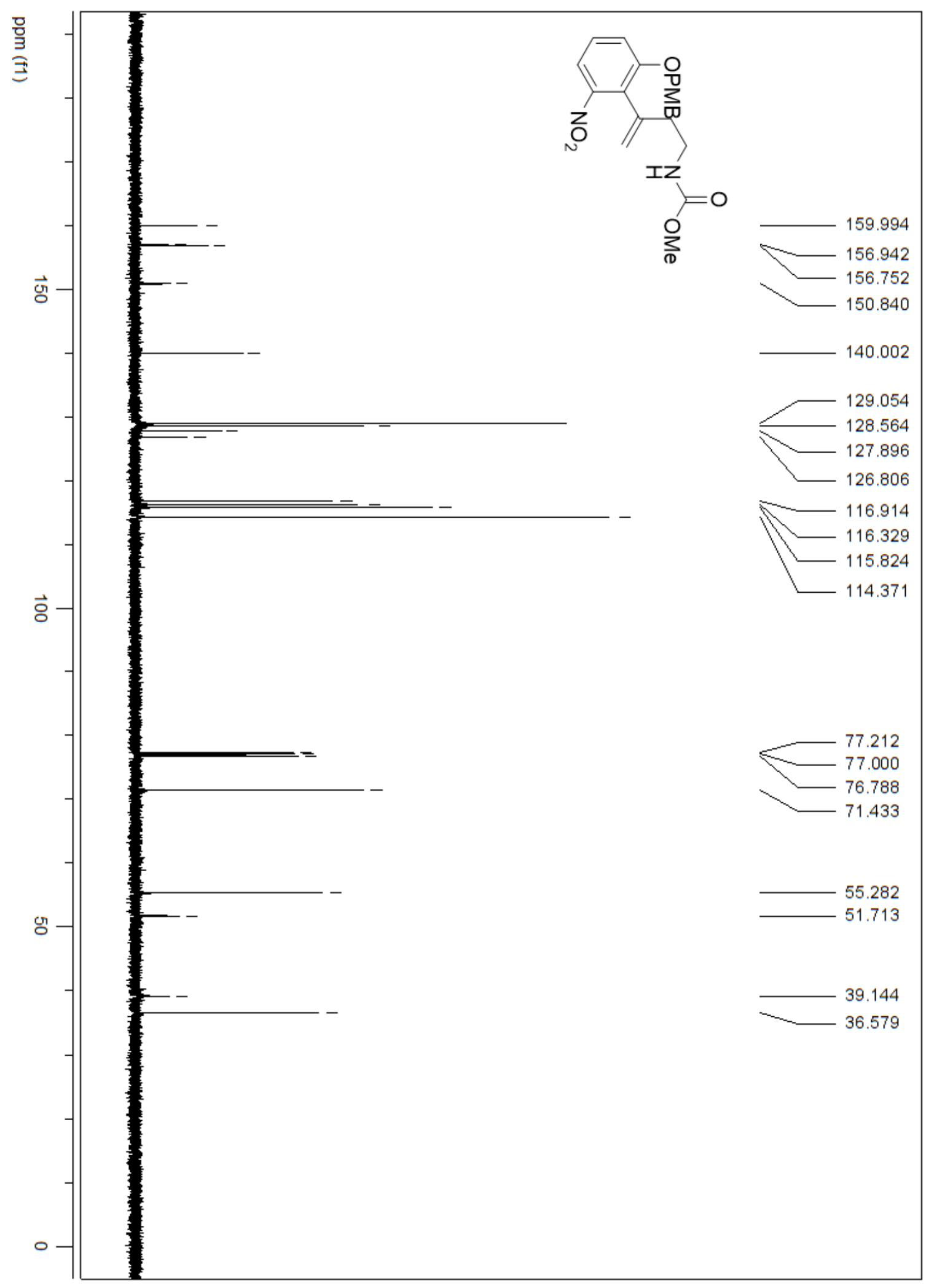

Figure 92: ${ }^{13} \mathrm{C}$ NMR $\left(65^{\circ} \mathrm{C}\right)$ of $\{3$-[2-(4-methoxy-benzyloxy)-6-nitro-phenyl]-but-3enyl $\}$-carbamic acid methyl ester (65) 


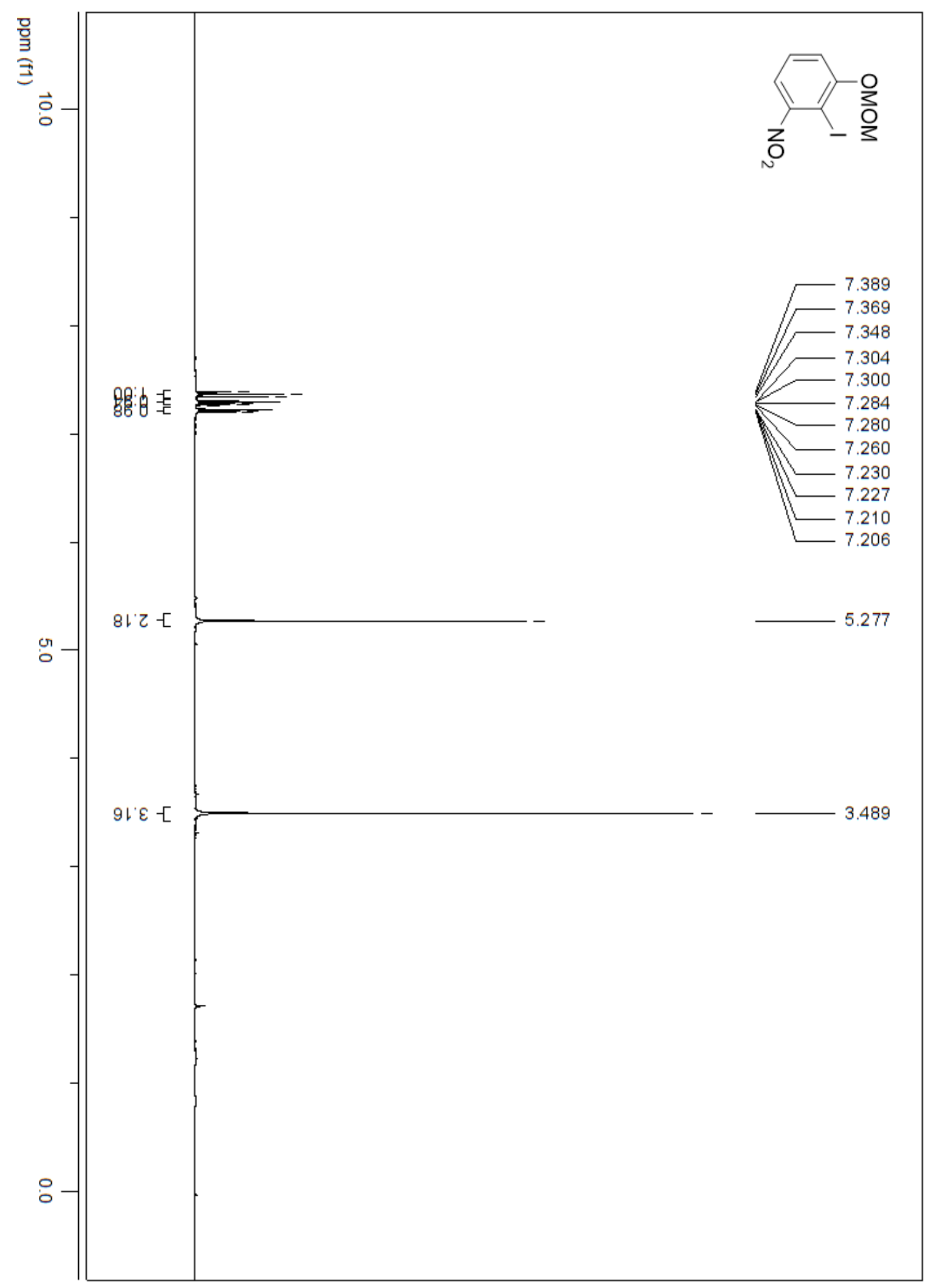

Figure 93: ${ }^{1} \mathrm{H}$ NMR of 2-iodo-1-methoxymethoxy-3-nitro-benzene (66) 


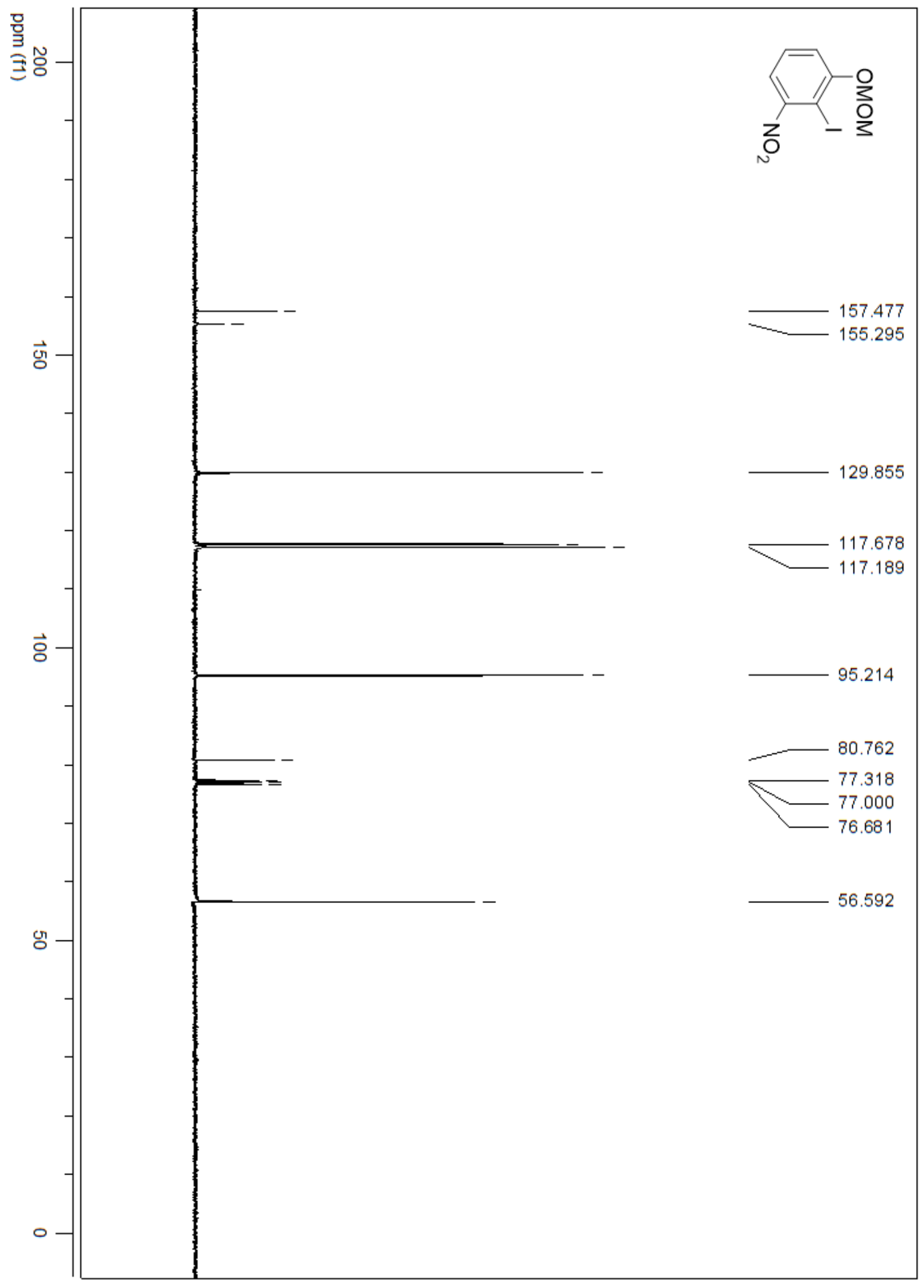

Figure 94: ${ }^{13} \mathrm{C}$ NMR of 2-iodo-1-methoxymethoxy-3-nitro-benzene (66) 


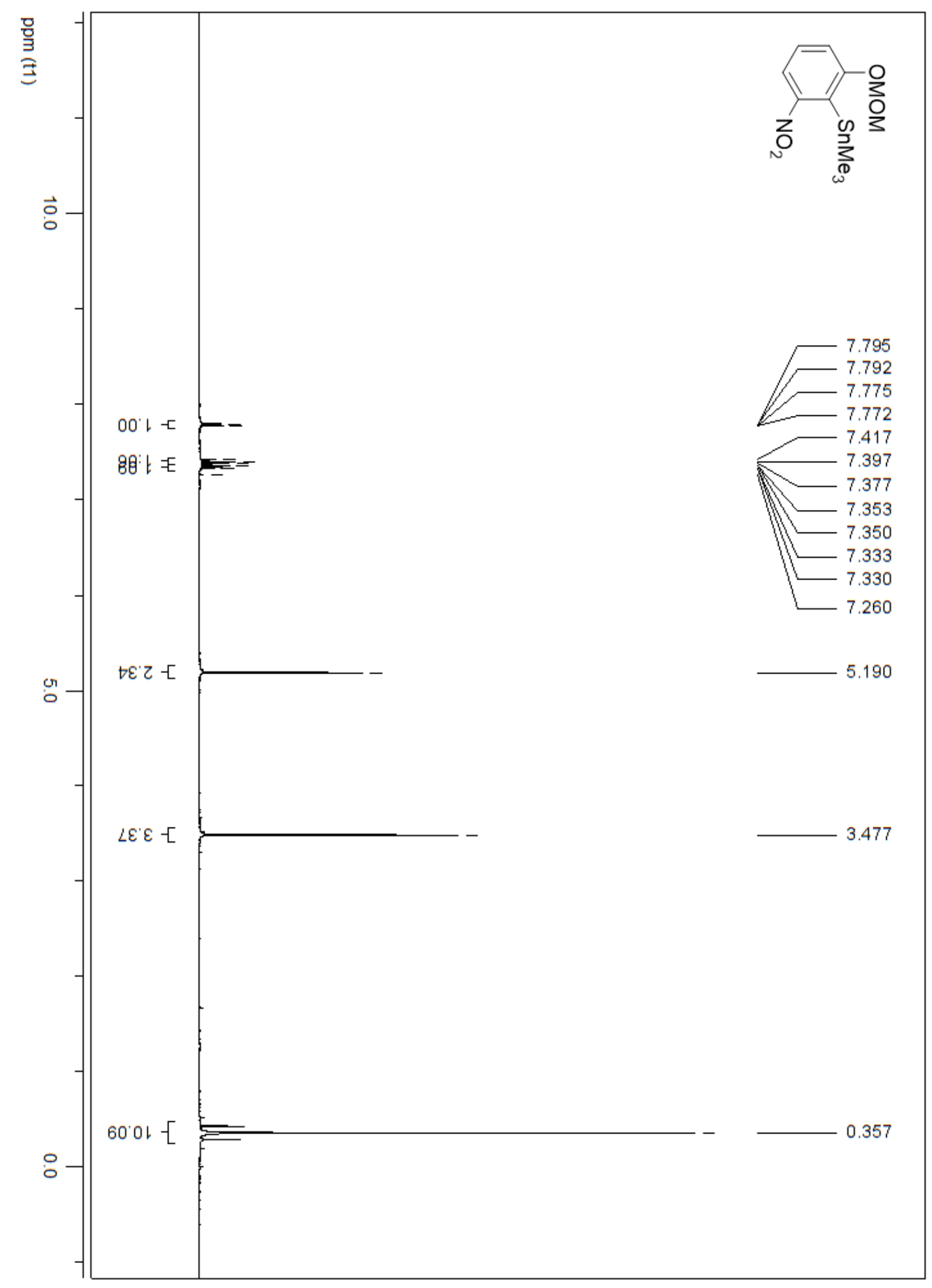

Figure 95: ${ }^{1} \mathrm{H}$ NMR of (2-methoxymethoxy-6-nitro-phenyl)-trimethyl-stannane (67) 


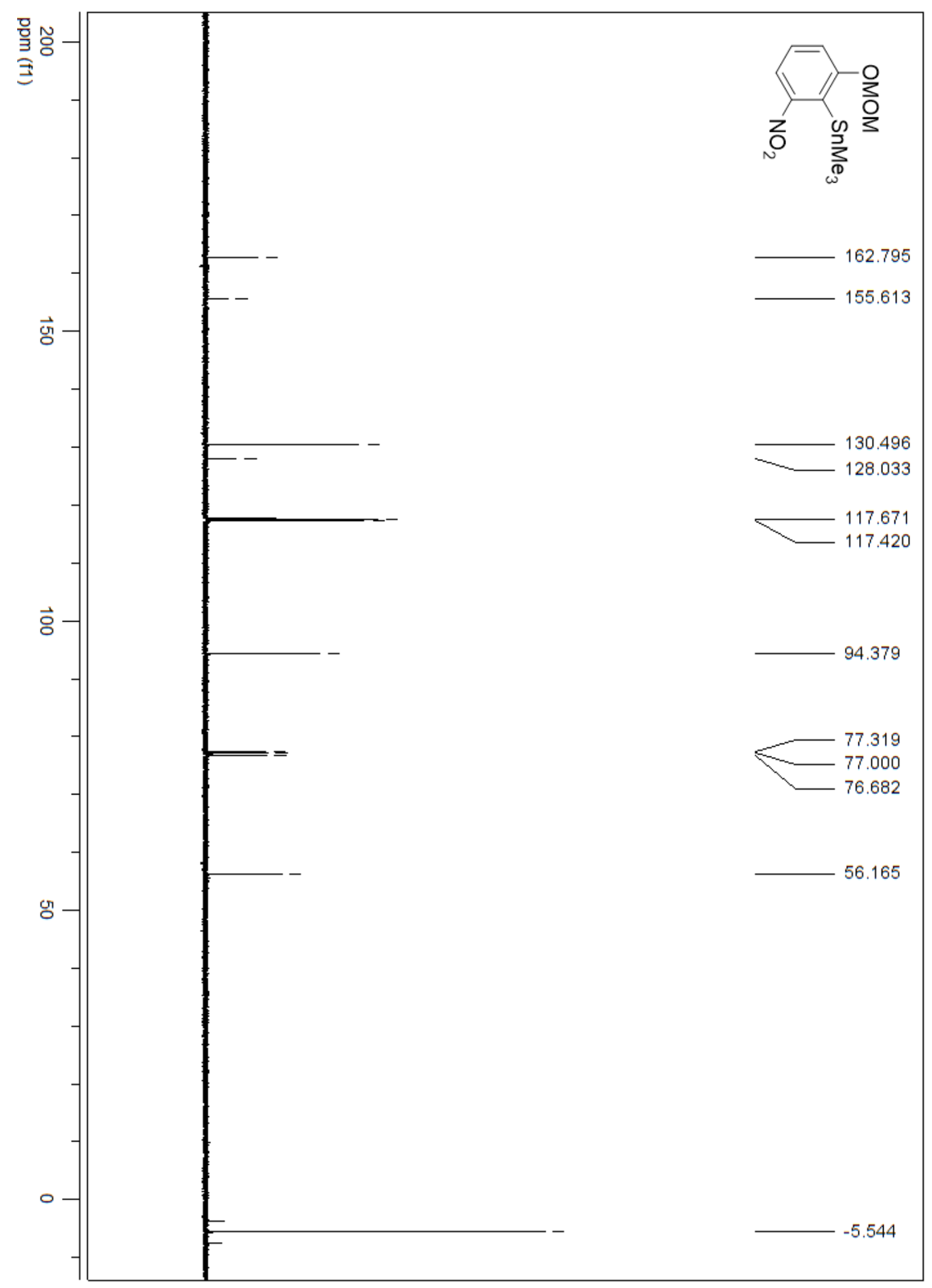

Figure 96: ${ }^{13} \mathrm{C}$ NMR of (2-methoxymethoxy-6-nitro-phenyl)-trimethyl-stannane (67) 


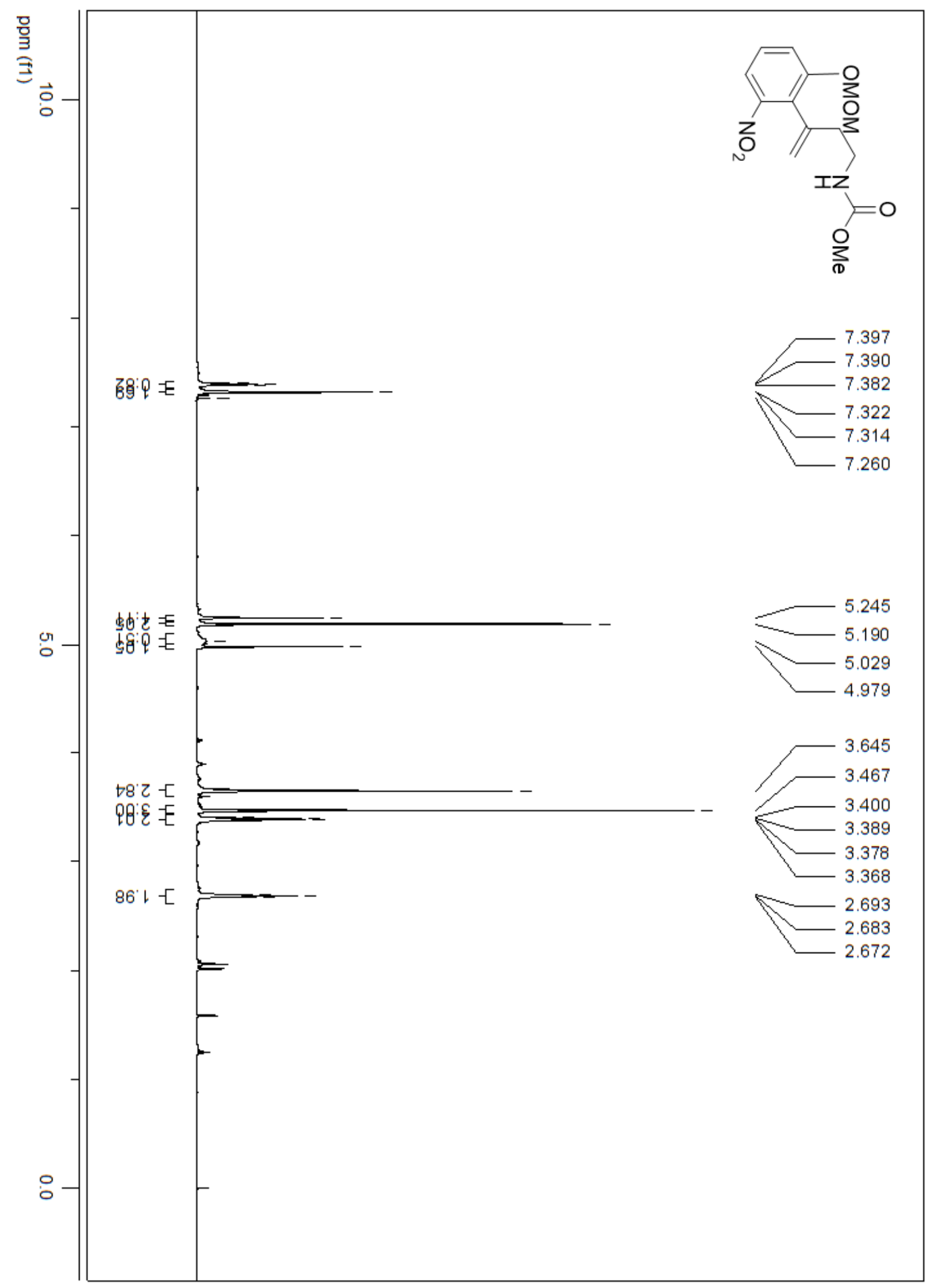

Figure 97: ${ }^{1} \mathrm{H}$ NMR $\left(65^{\circ} \mathrm{C}\right)$ of [3-(2-methoxymethoxy-6-nitro-phenyl)-but-3-enyl]-carbamic acid methyl ester (68) 


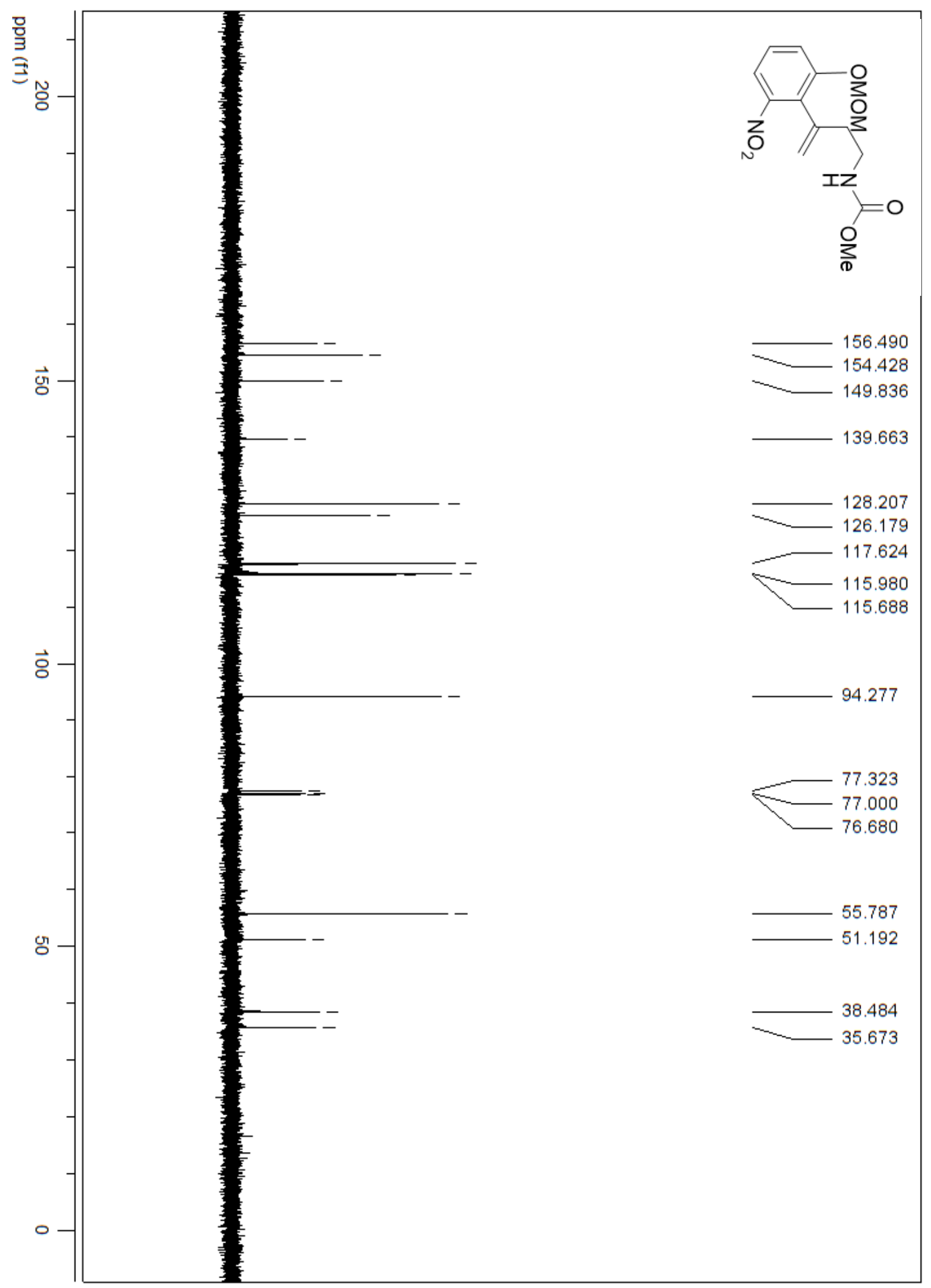

Figure 98: ${ }^{13} \mathrm{C}$ NMR of [3-(2-methoxymethoxy-6-nitro-phenyl)-but-3-enyl]-carbamic acid methyl ester (68) 


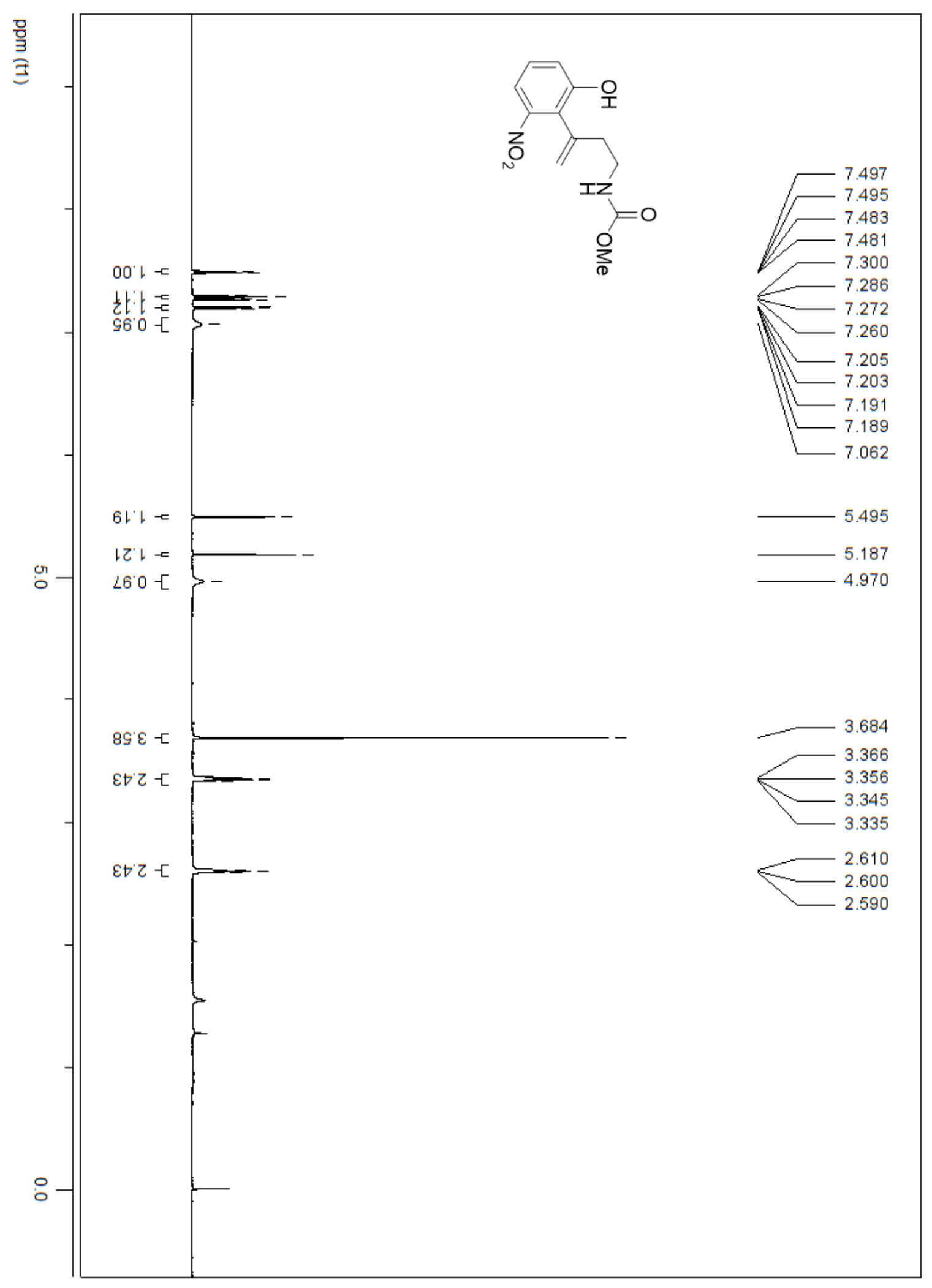

Figure 99: ${ }^{1} \mathrm{H}$ NMR $\left(65{ }^{\circ} \mathrm{C}\right)$ of [3-(2-hydroxy-6-nitro-phenyl)-but-3-enyl]-carbamic acid methyl ester (54) 


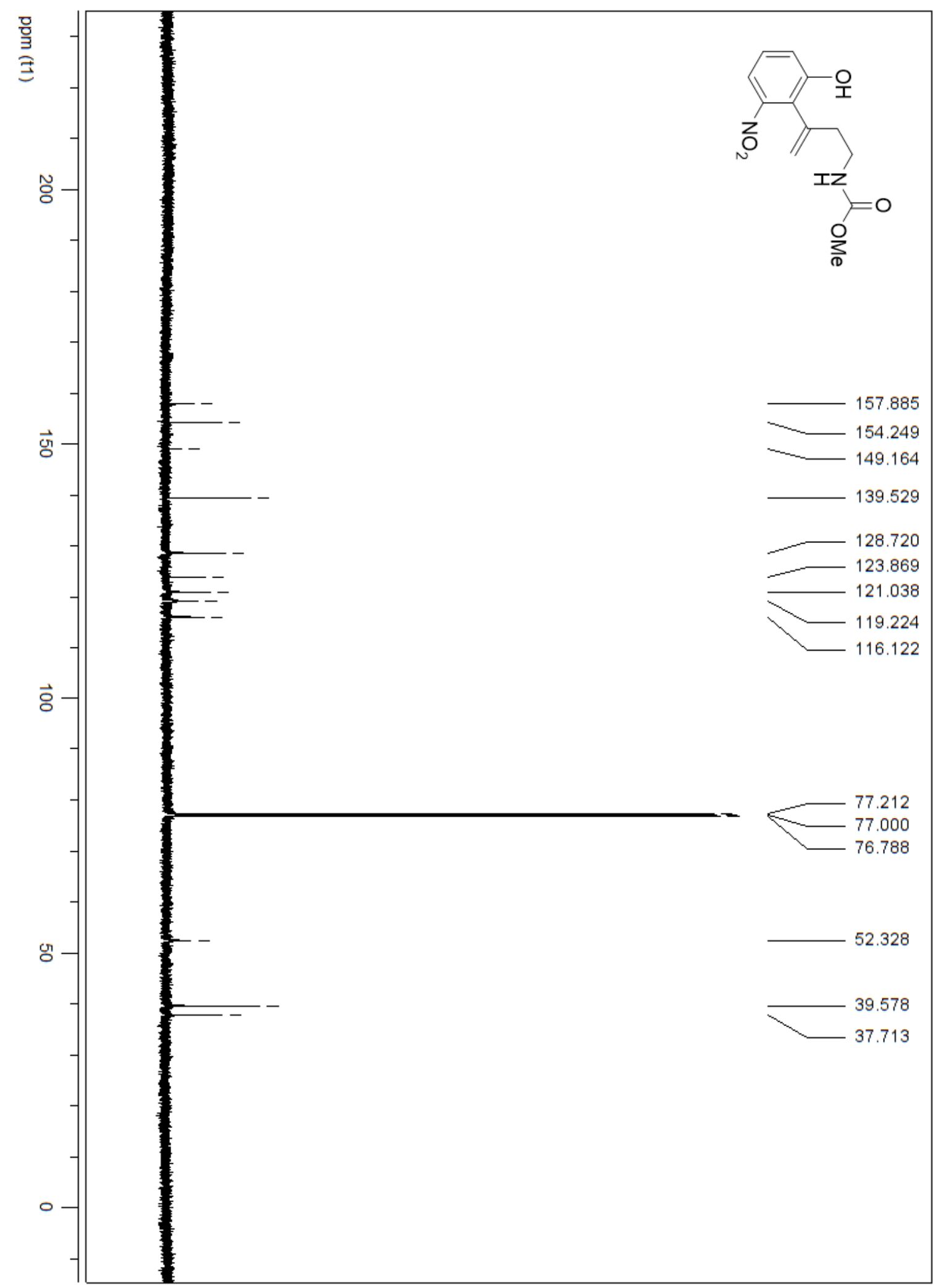

Figure 100: ${ }^{13} \mathrm{C}$ NMR ( $\left.65{ }^{\circ} \mathrm{C}\right)$ of [3-(2-hydroxy-6-nitro-phenyl)-but-3-enyl]carbamic acid methyl ester (54) 


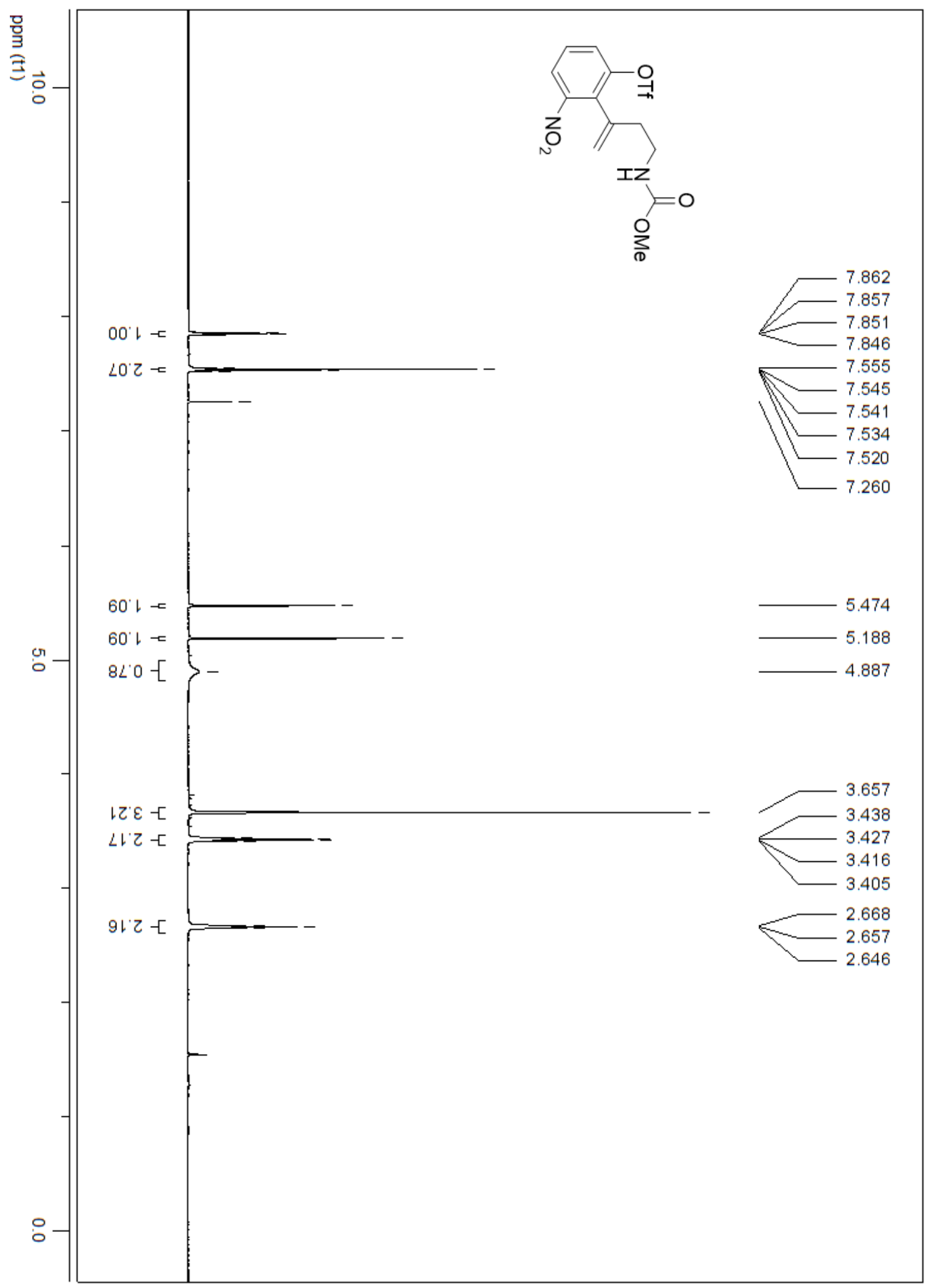

Figure 101: ${ }^{1} \mathrm{H}$ NMR $\left(65{ }^{\circ} \mathrm{C}\right)$ of trifluoro-methanesulfonic acid 2-(3-methoxycarbonylamino-1-methylene-propyl)-3-nitro-phenyl ester (53) 


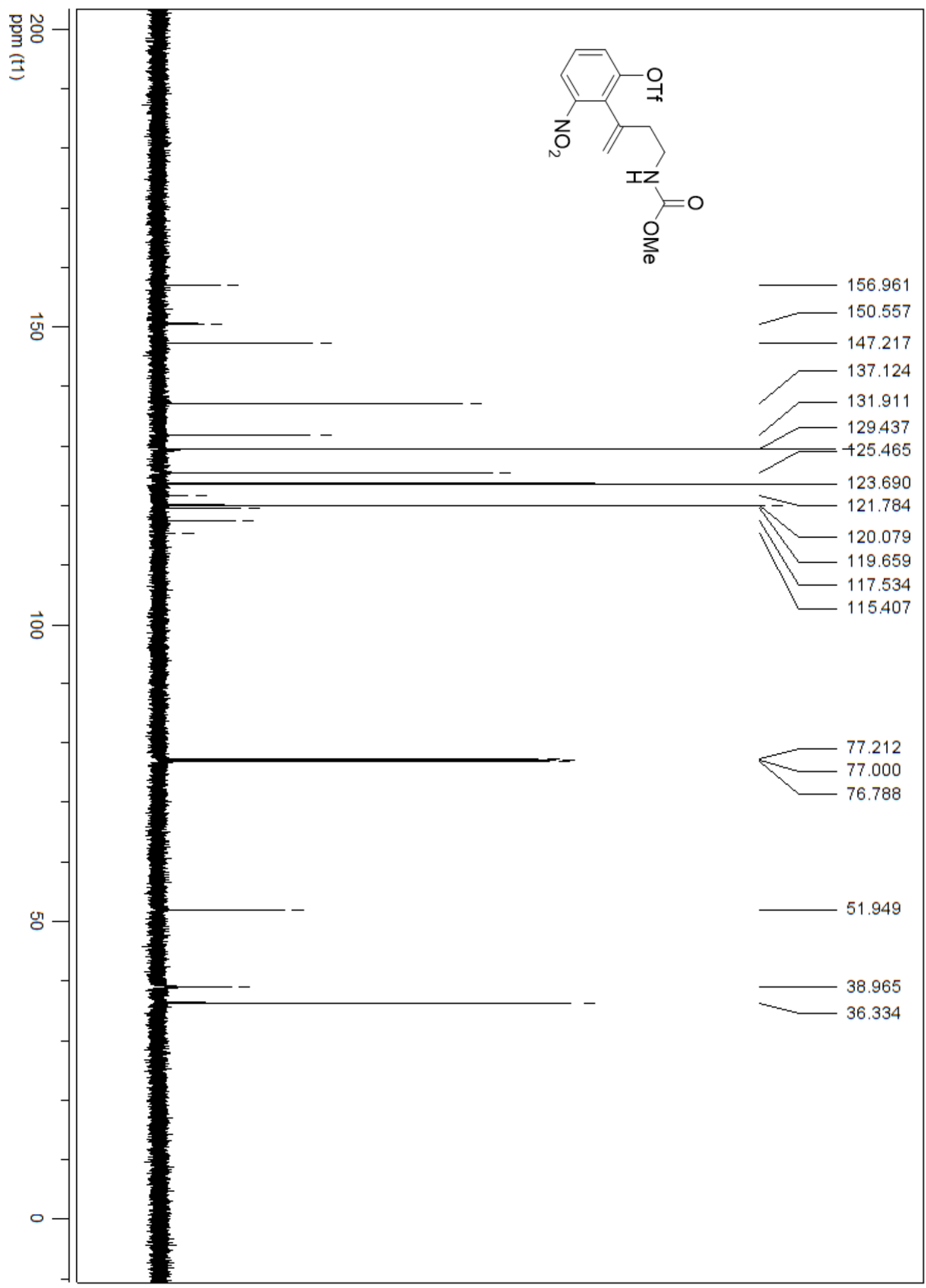

Figure 102: ${ }^{13} \mathrm{C}$ NMR $\left(65^{\circ} \mathrm{C}\right)$ of trifluoro-methanesulfonic acid 2-(3-methoxycarbonylamino-1-methylene-propyl)-3-nitro-phenyl ester (53) 


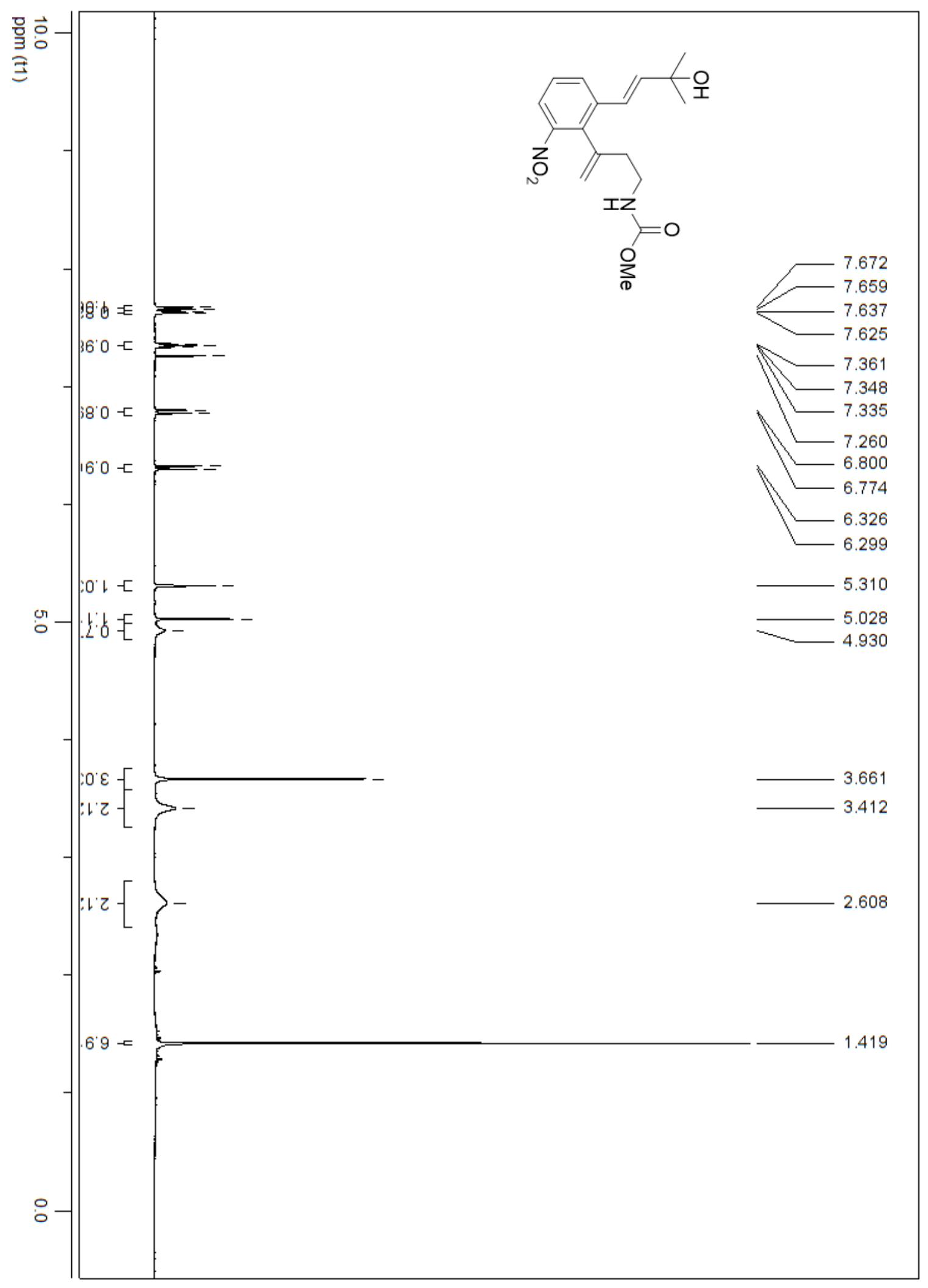

Figure 103: ${ }^{1} \mathrm{H}$ NMR $\left(65{ }^{\circ} \mathrm{C}\right)$ of $\{3$-[2-(3-hydroxy-3-methyl-but-1-enyl)-6-nitro-phenyl]but-3-enyl $\}$-carbamic acid methyl ester (69) 


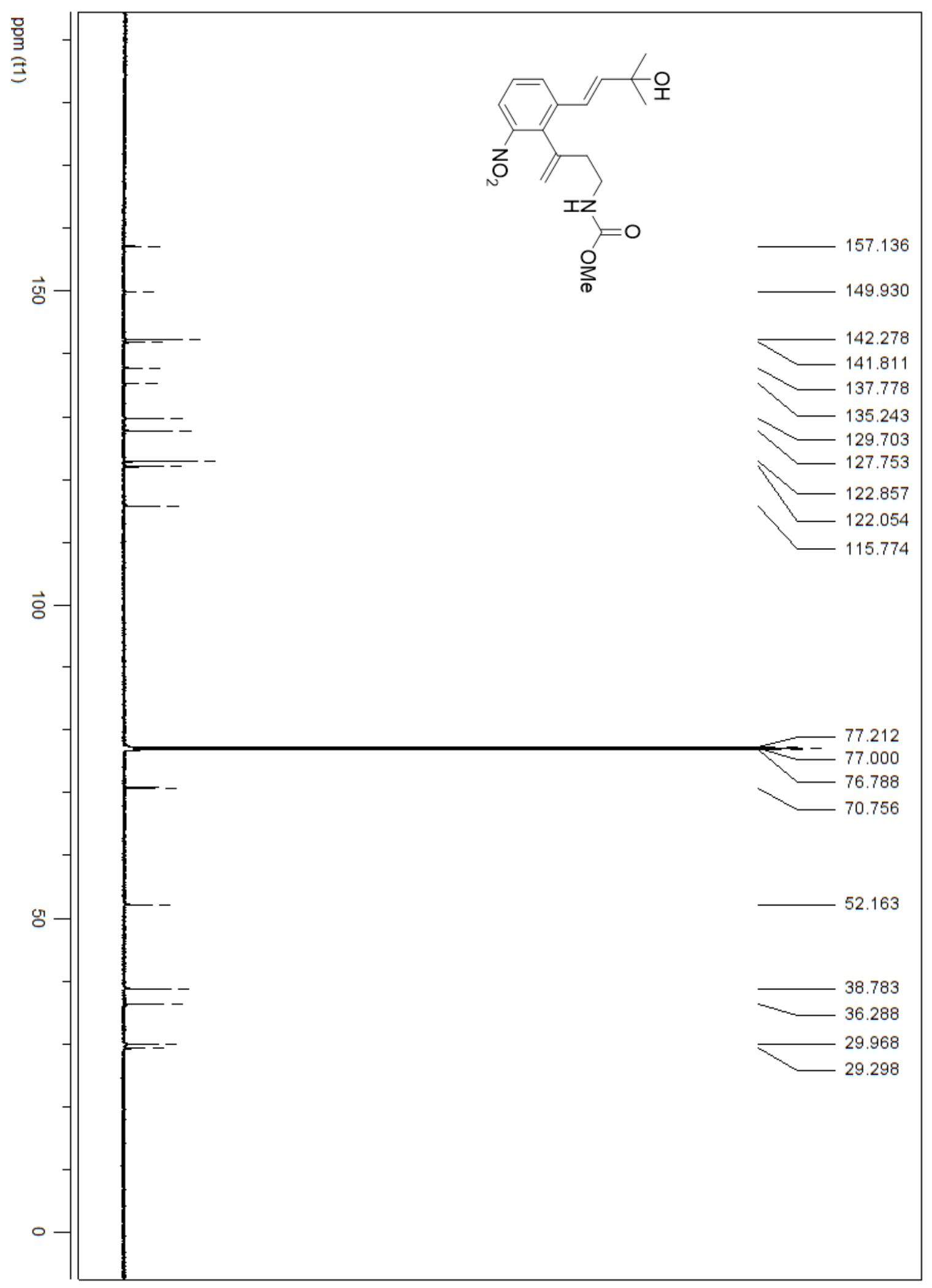

Figure 104: ${ }^{13} \mathrm{C}$ NMR of \{3-[2-(3-hydroxy-3-methyl-but-1-enyl)-6-nitro-phenyl]-but- 3enyl $\}$-carbamic acid methyl ester (69) 


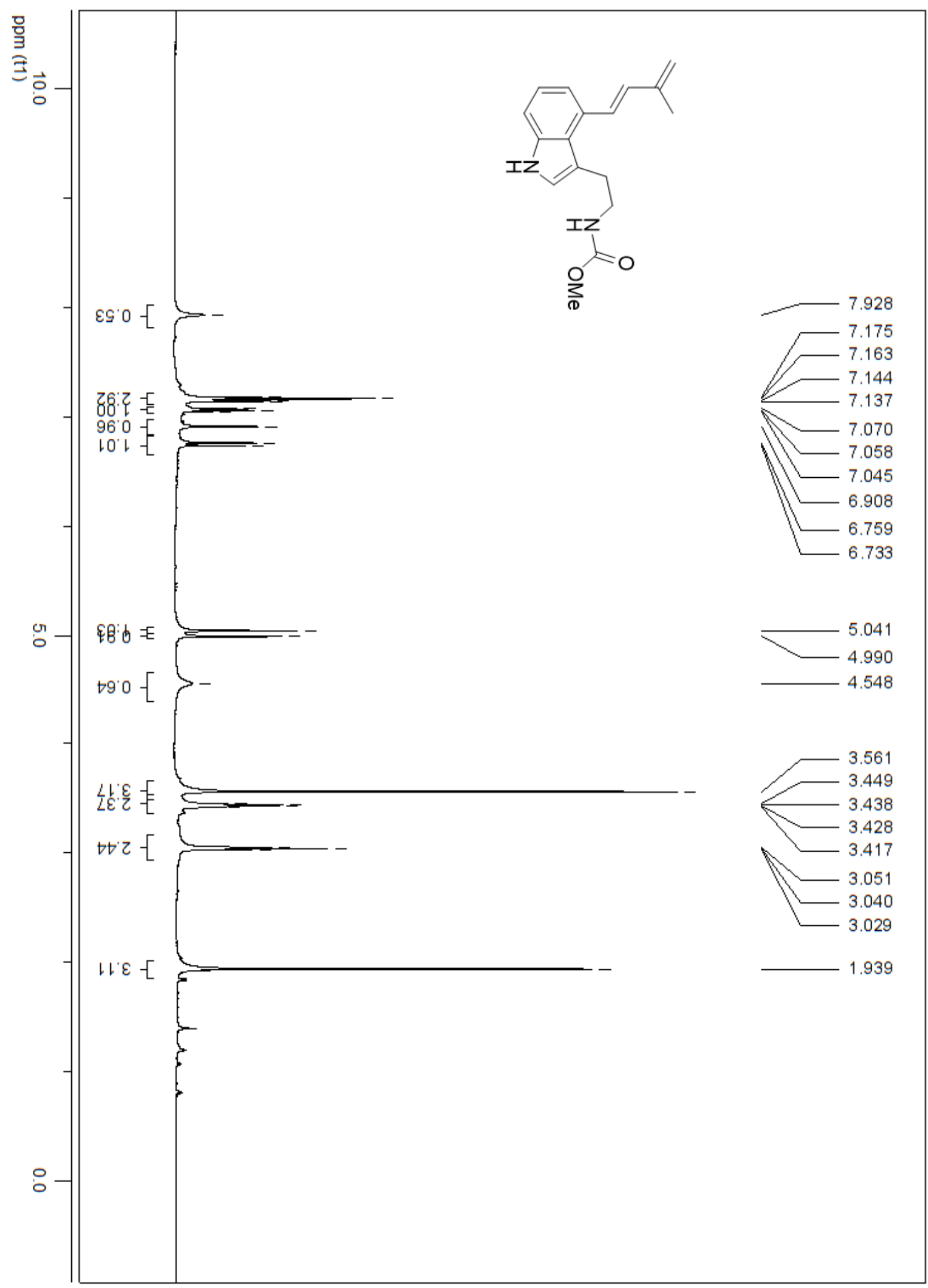

Figure 105: ${ }^{1} \mathrm{H}$ NMR $\left(65{ }^{\circ} \mathrm{C}\right)$ of $\{2$-[4-(3-methyl-buta-1,3-dienyl)-1H-indol-3-yl]-ethyl $\}$ carbamic acid methyl ester (70) 


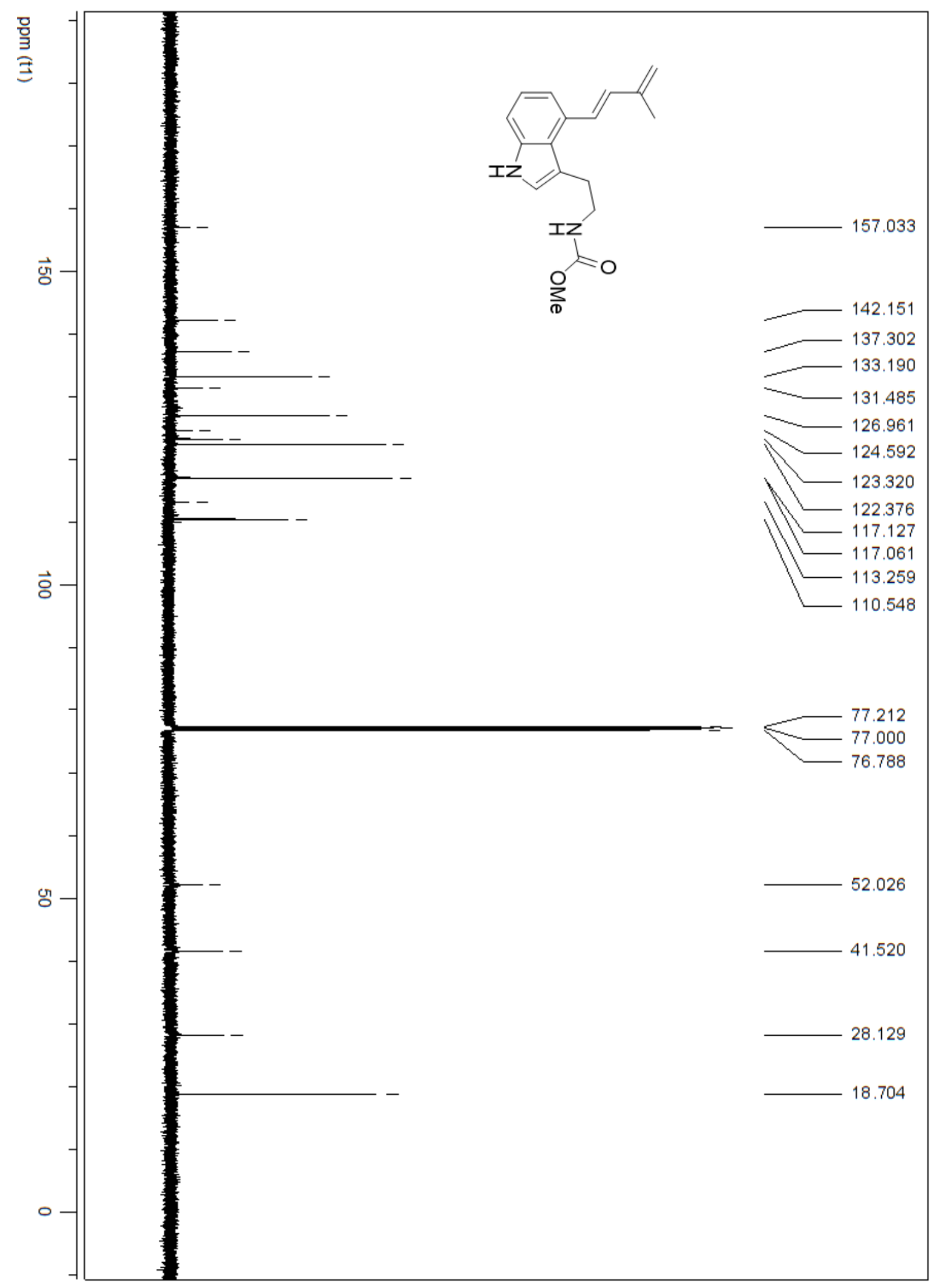

Figure 106: ${ }^{13} \mathrm{C}$ NMR of $\{2$-[4-(3-methyl-buta-1,3-dienyl)-1H-indol-3-yl]-ethyl $\}$-carbamic acid methyl ester (70) 


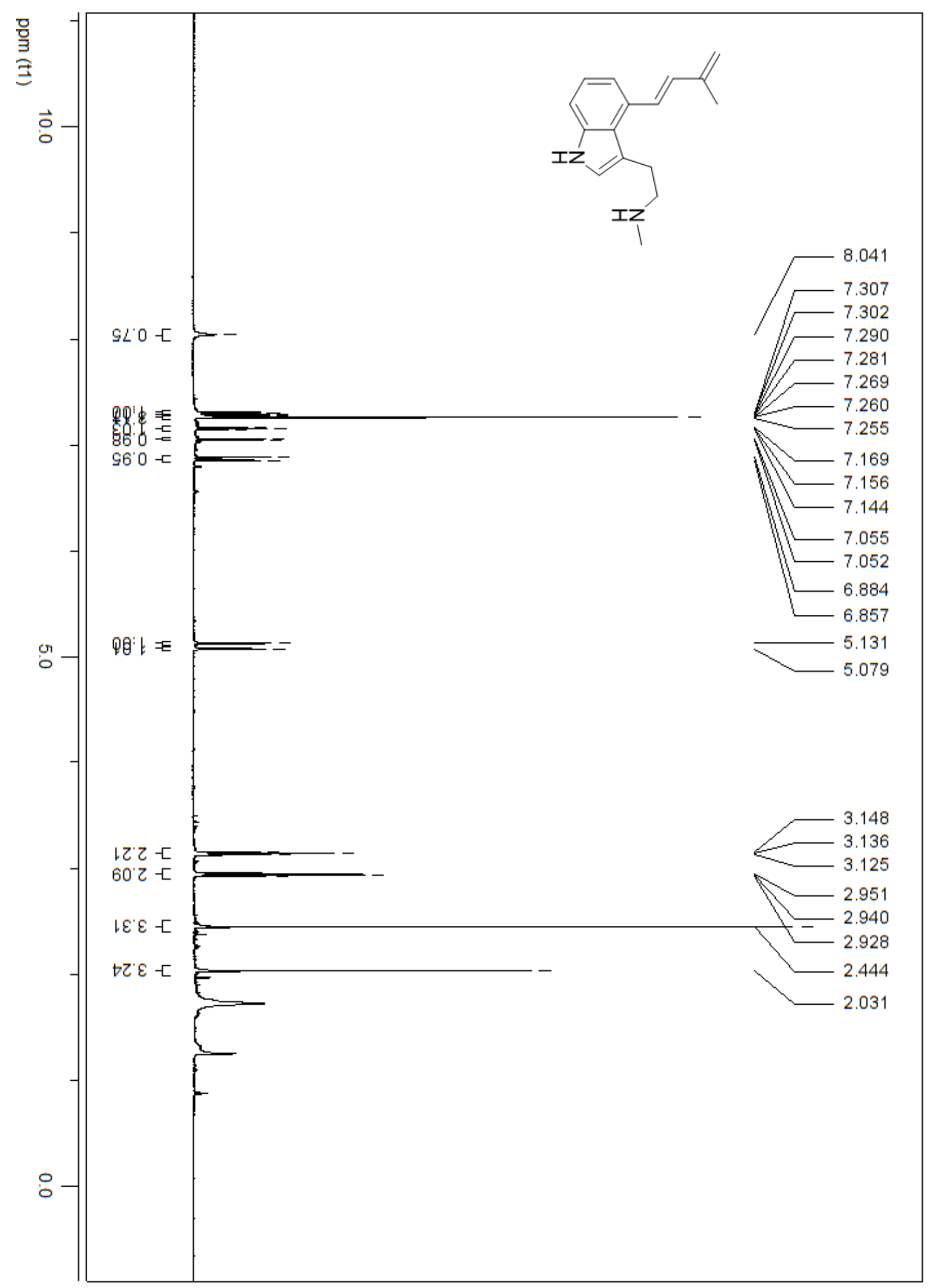

Figure 107: ${ }^{1} \mathrm{H}$ NMR of methyl-\{2-[4-(3-methyl-buta-1,3-dienyl)-1H-indol-3-yl]-ethyl $\}$ amine (dehydrated ergotryptamine) 


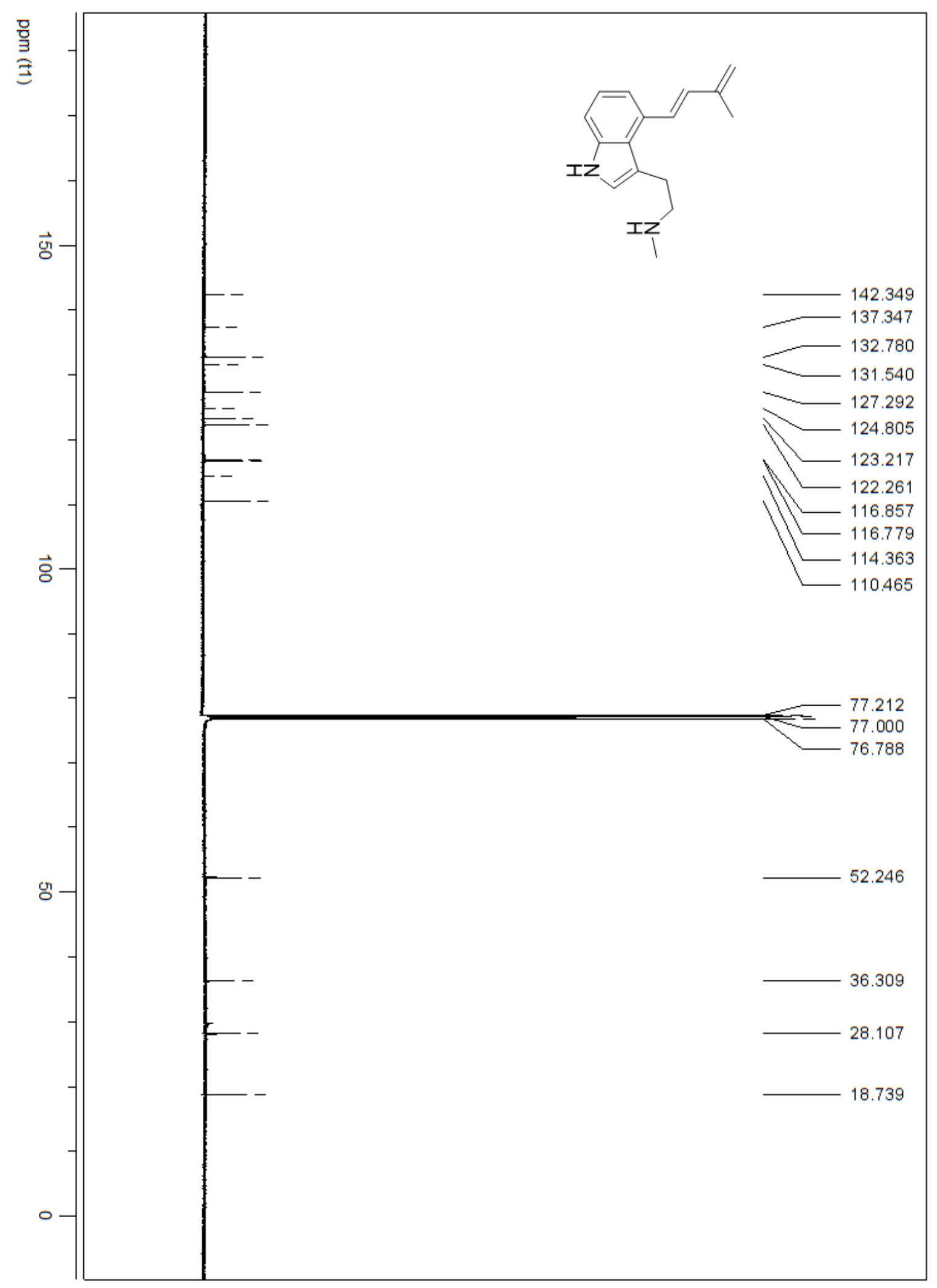

Figure 108: ${ }^{13} \mathrm{C}$ NMR of methyl-\{2-[4-(3-methyl-buta-1,3-dienyl)-1H-indol-3-yl]-ethyl\}amine (dehydrated ergotryptamine) 


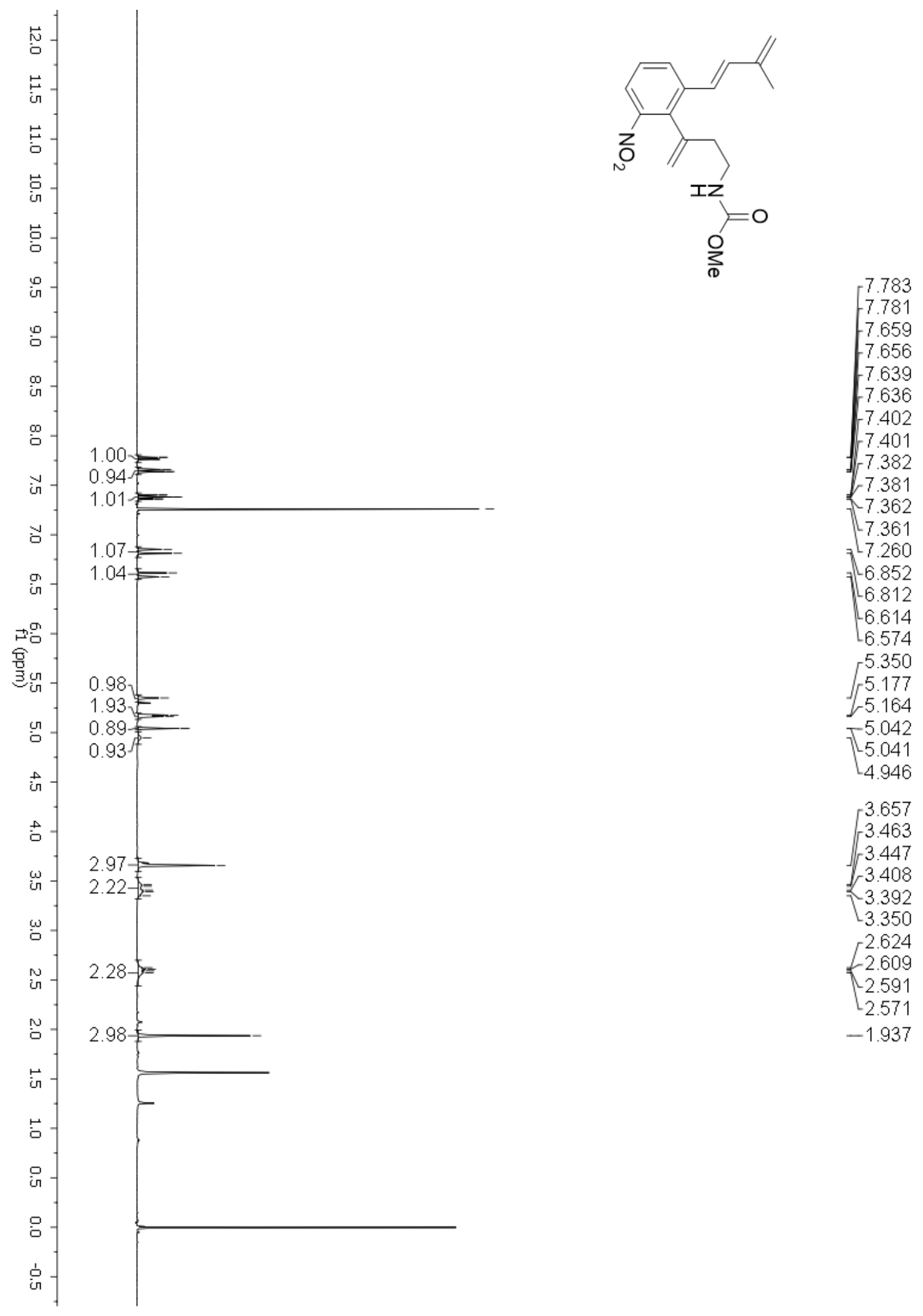

Figure 109: ${ }^{1} \mathrm{H}$ NMR of $\{3$-[2-(3-methyl-buta-1,3-dienyl)-6-nitro-phenyl]-but-3-enyl $\}$ carbamic acid methyl ester (71) 


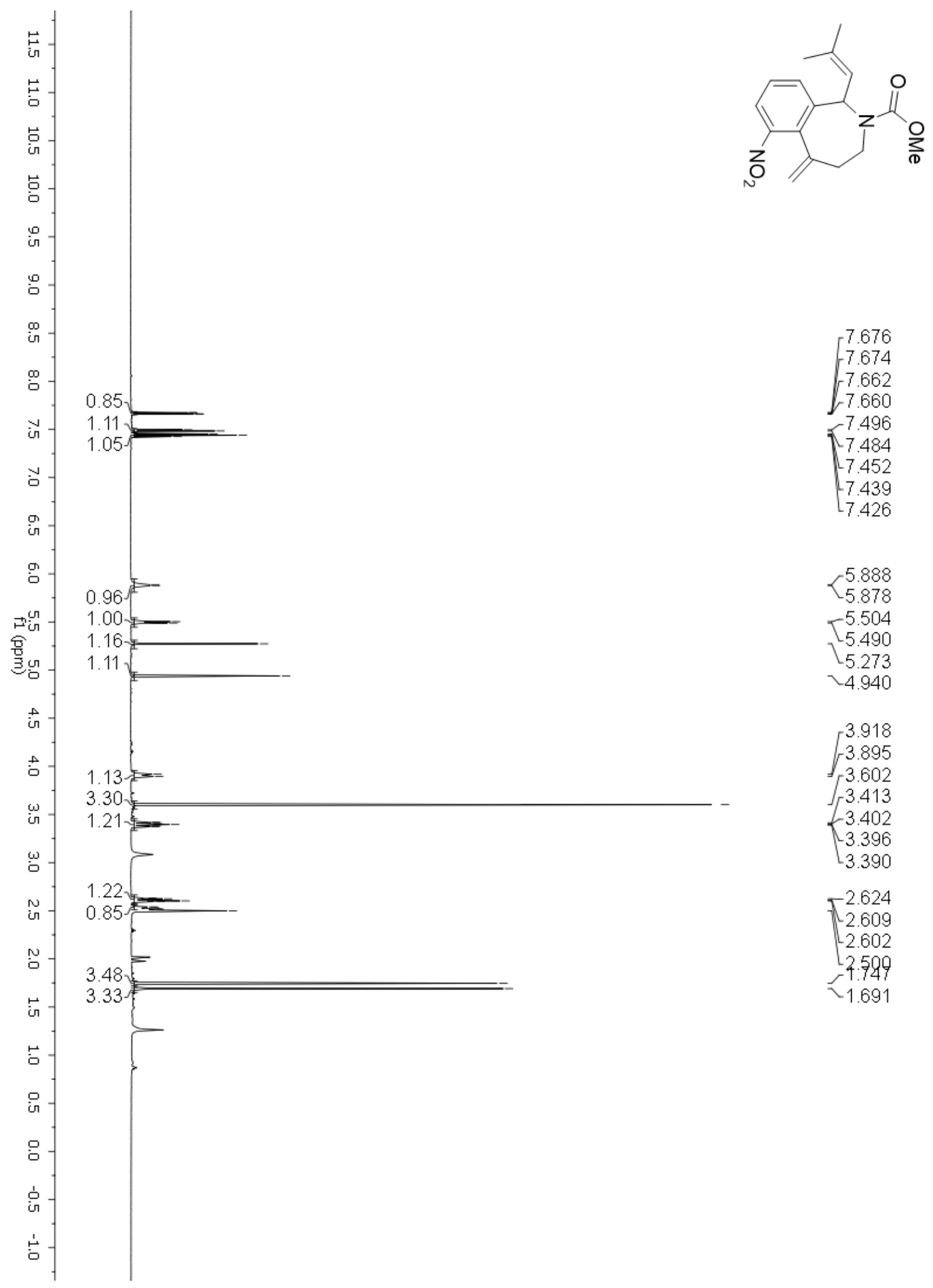

Figure 110: ${ }^{1} \mathrm{H}$ NMR $\left(75{ }^{\circ} \mathrm{C}\right)$ of 5-methylene-1-(2-methyl-propenyl)-6-nitro-1,3,4,5tetrahydro-benzo[c]azepine-2-carboxylic acid methyl ester (72) 


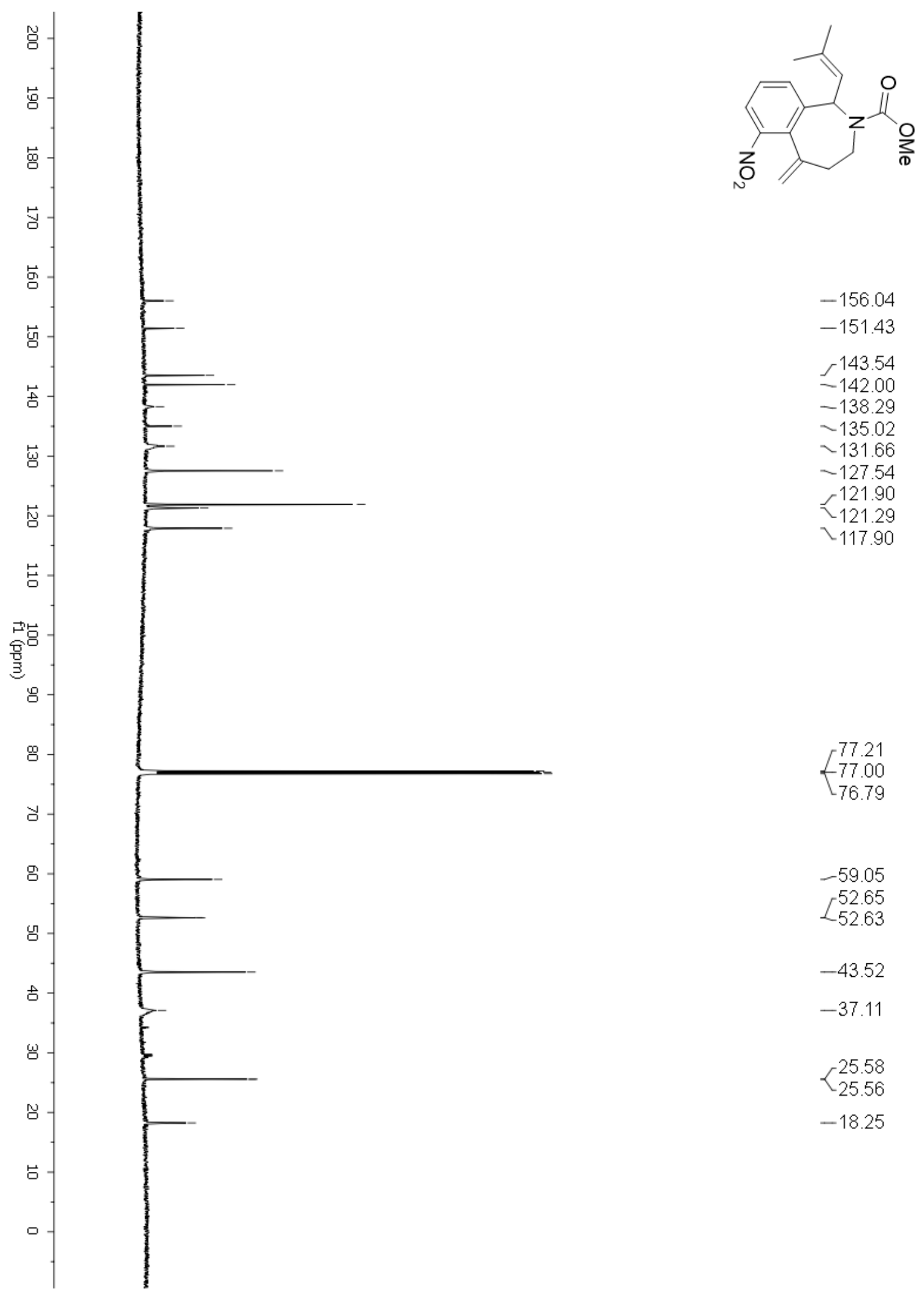

Figure 111: ${ }^{13} \mathrm{C}$ NMR $\left(65^{\circ} \mathrm{C}\right)$ of 5-methylene-1-(2-methyl-propenyl)-6-nitro-1,3,4,5tetrahydro-benzo[c]azepine-2-carboxylic acid methyl ester (72) 

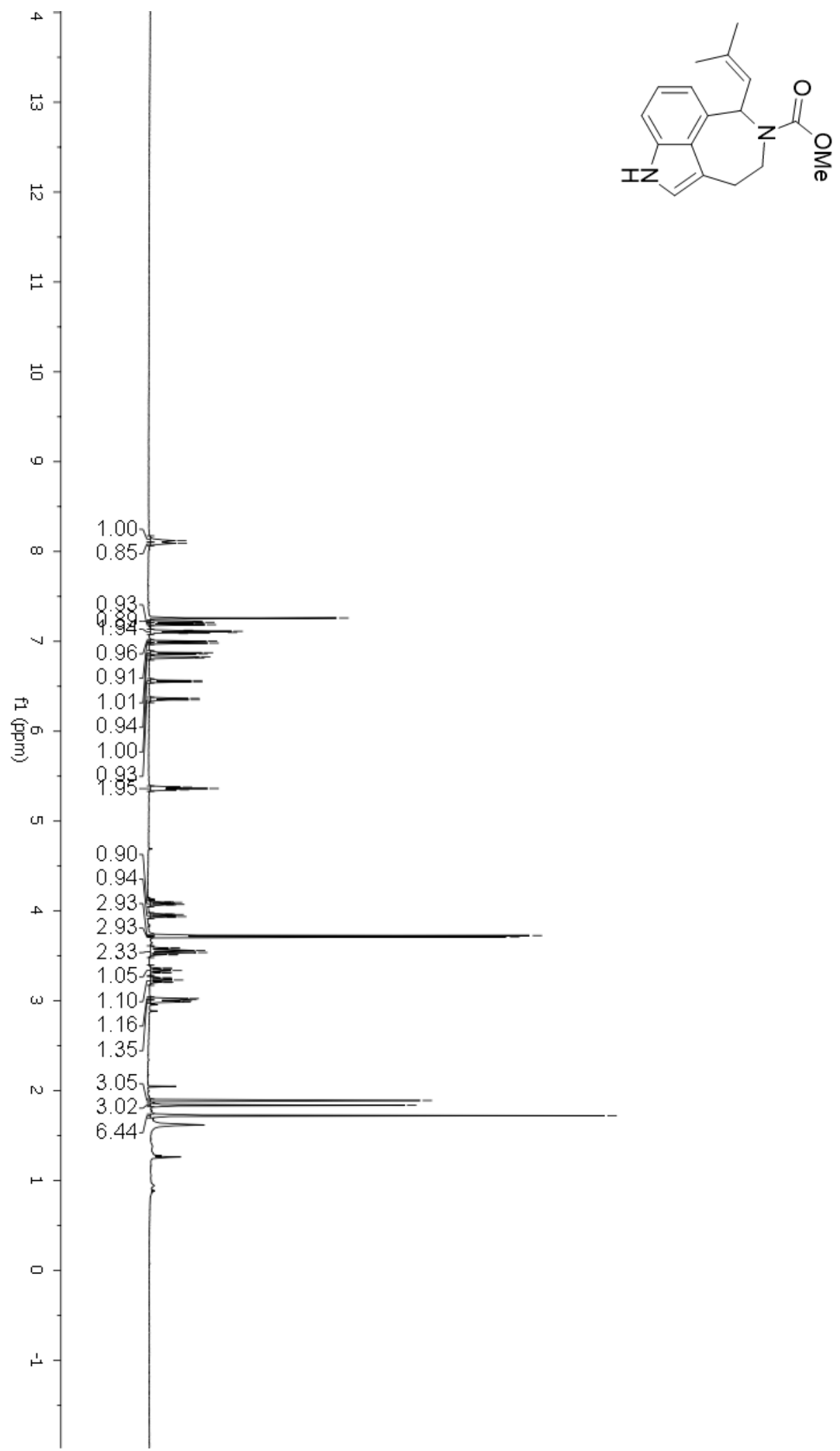

Figure 112: ${ }^{1} \mathrm{H}$ NMR of 6-(2-methyl-propenyl)-3,4-dihydro-1H,6H-azepino[5,4,3cd]indole-5-carboxylic acid methyl ester (73) 


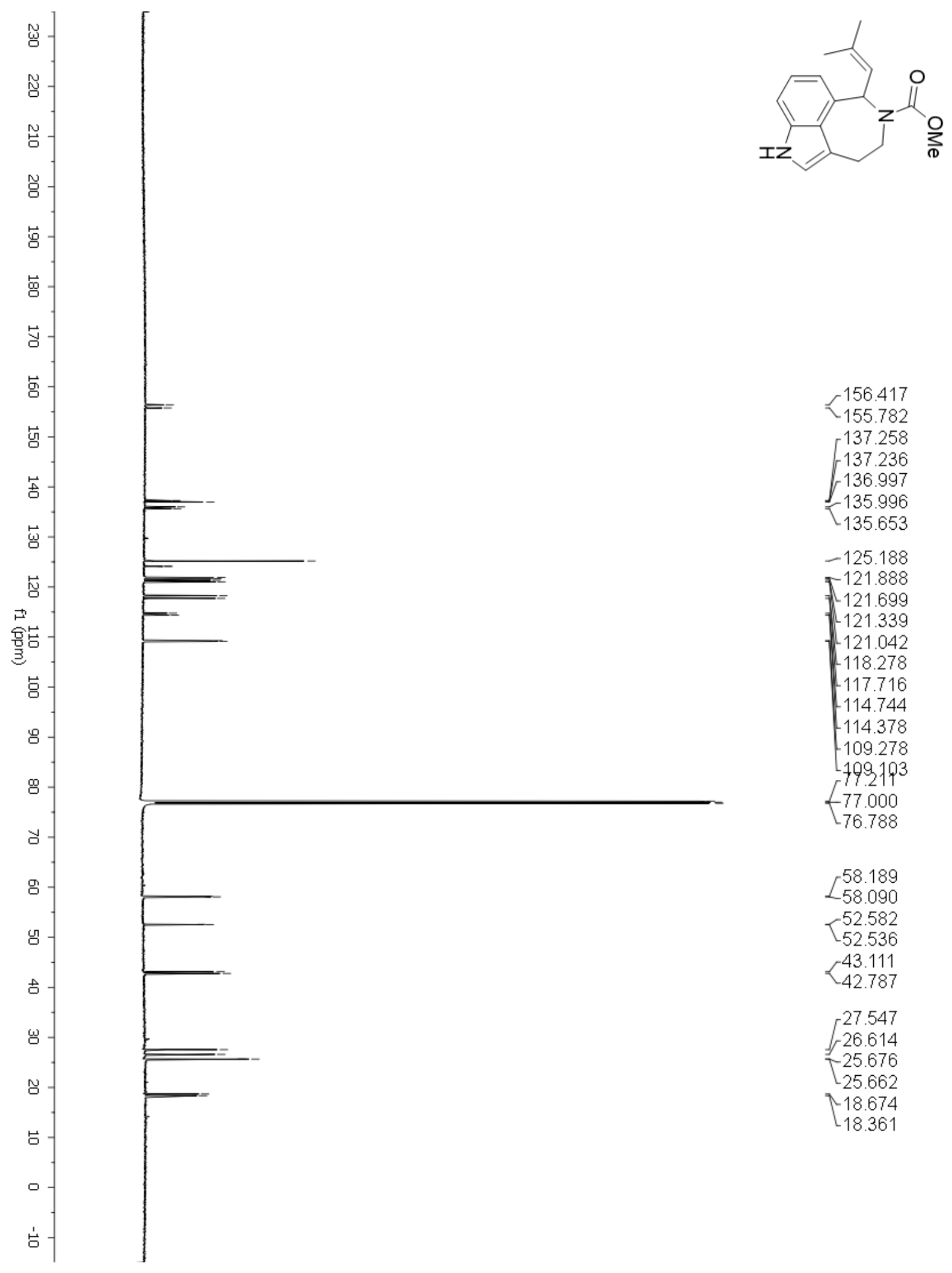

Figure 113: ${ }^{13} \mathrm{C}$ NMR of 6-(2-methyl-propenyl)-3,4-dihydro-1H,6H-azepino[5,4,3cd]indole-5-carboxylic acid methyl ester (73) 


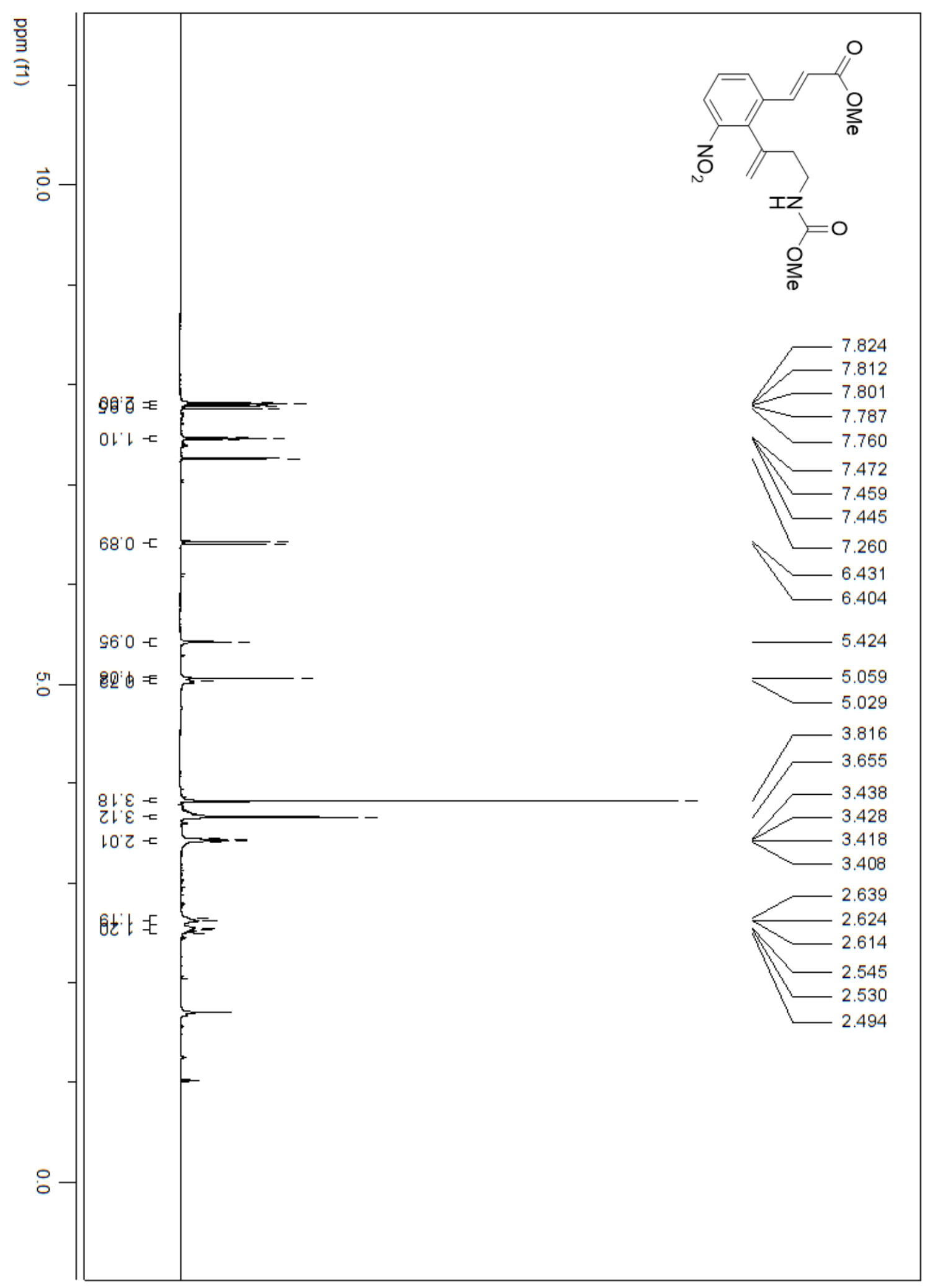

Figure 114: ${ }^{1} \mathrm{H}$ NMR of 3-[2-(3-methoxycarbonylamino-1-methylene-propyl)-3-nitrophenyl]-acrylic acid methyl ester (74) 


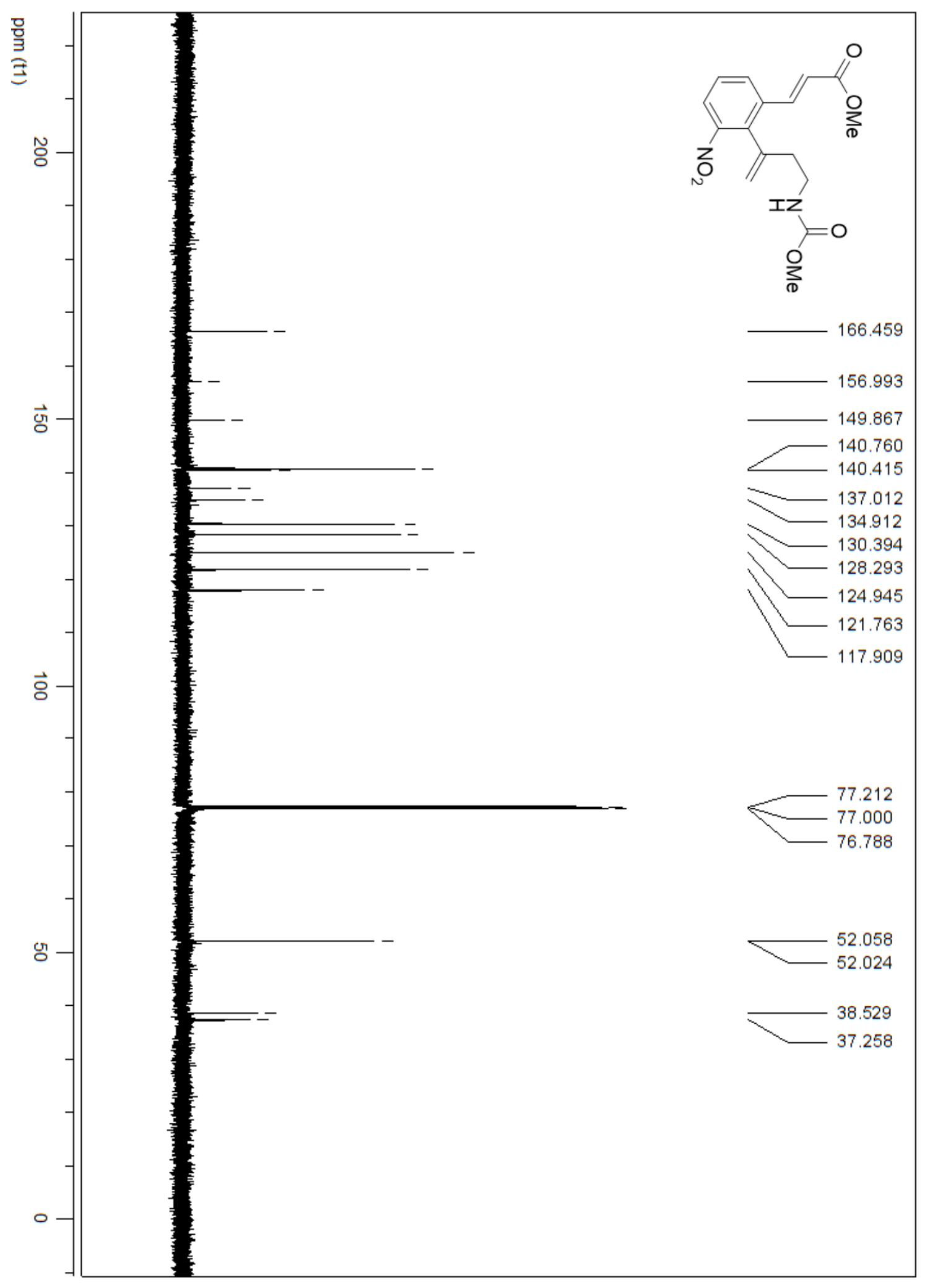

Figure 115: ${ }^{13} \mathrm{C}$ NMR of 3-[2-(3-methoxycarbonylamino-1-methylene-propyl)-3-nitrophenyl]-acrylic acid methyl ester (74) 


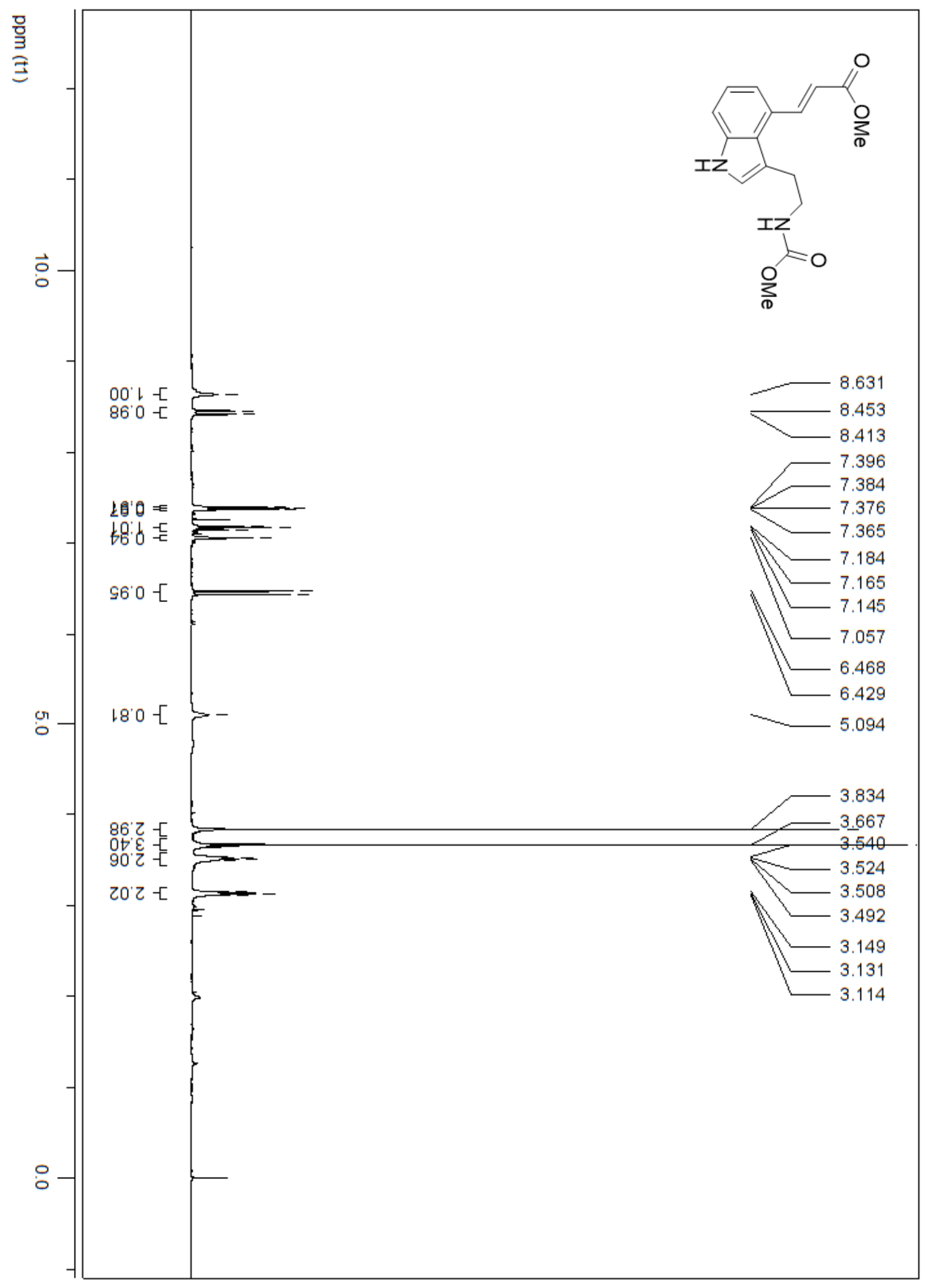

Figure 116: ${ }^{1} \mathrm{H}$ NMR of 3-[3-(2-methoxycarbonylamino-ethyl)-1H-indol-4-yl]-acrylic acid methyl ester (75) 


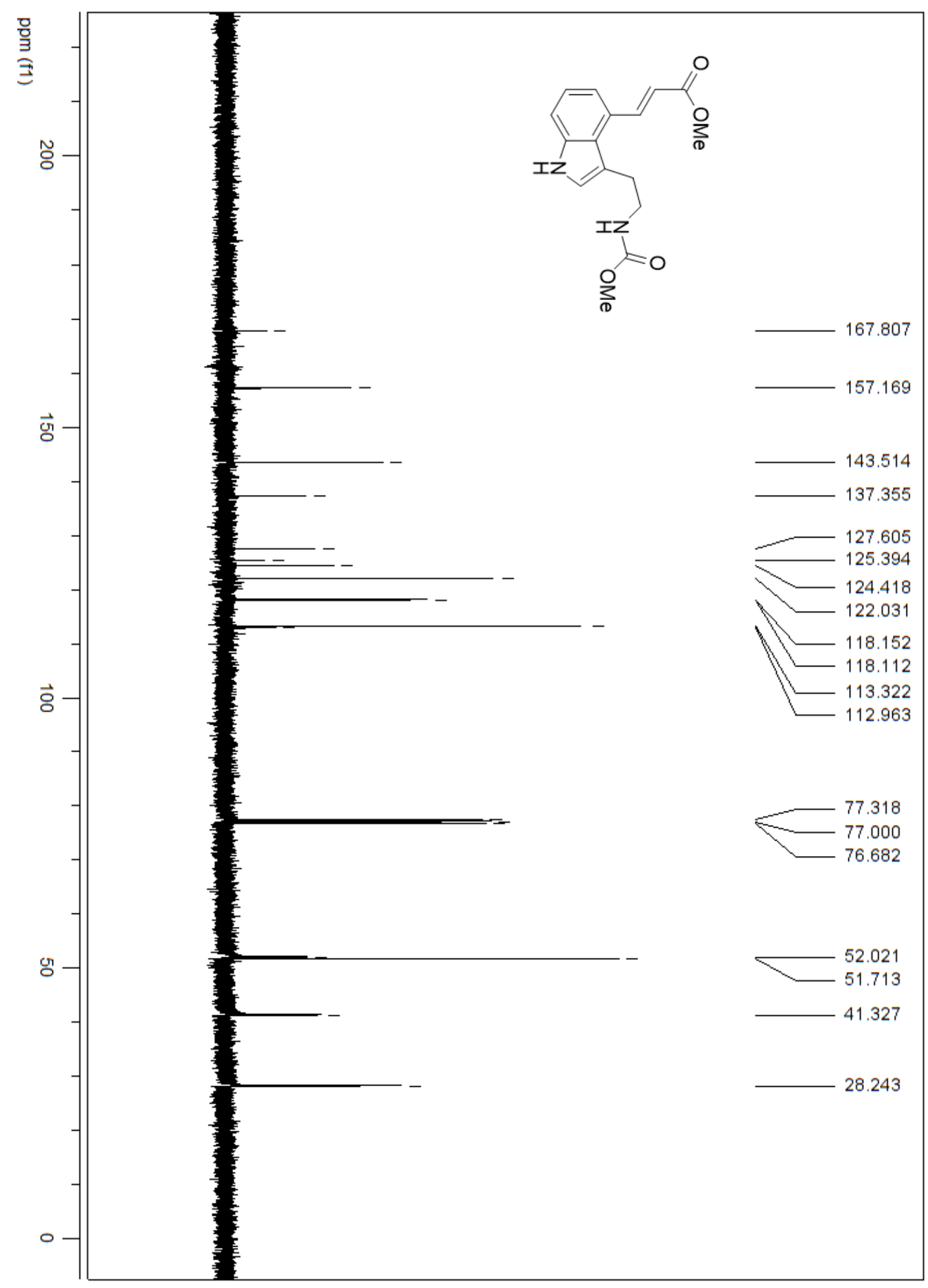

Figure 117: ${ }^{13} \mathrm{C}$ NMR of 3-[3-(2-methoxycarbonylamino-ethyl)-1H-indol-4-yl]-acrylic acid methyl ester (75) 


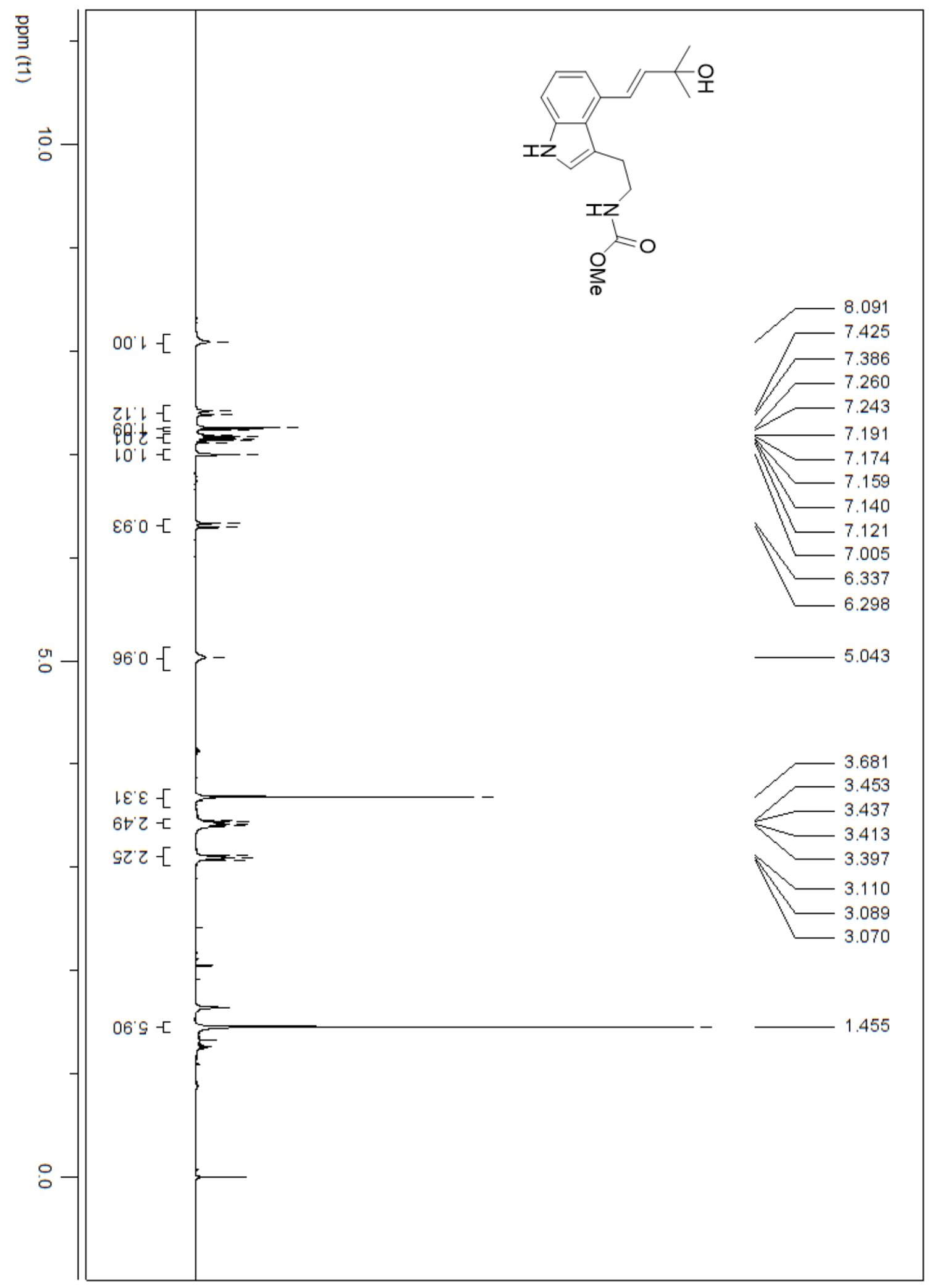

Figure 118: ${ }^{1} \mathrm{H}$ NMR of $\{2$-[4-(3-hydroxy-3-methyl-but-1-enyl)-1H-indol-3-yl]-ethyl $\}$ carbamic acid methyl ester (61) 


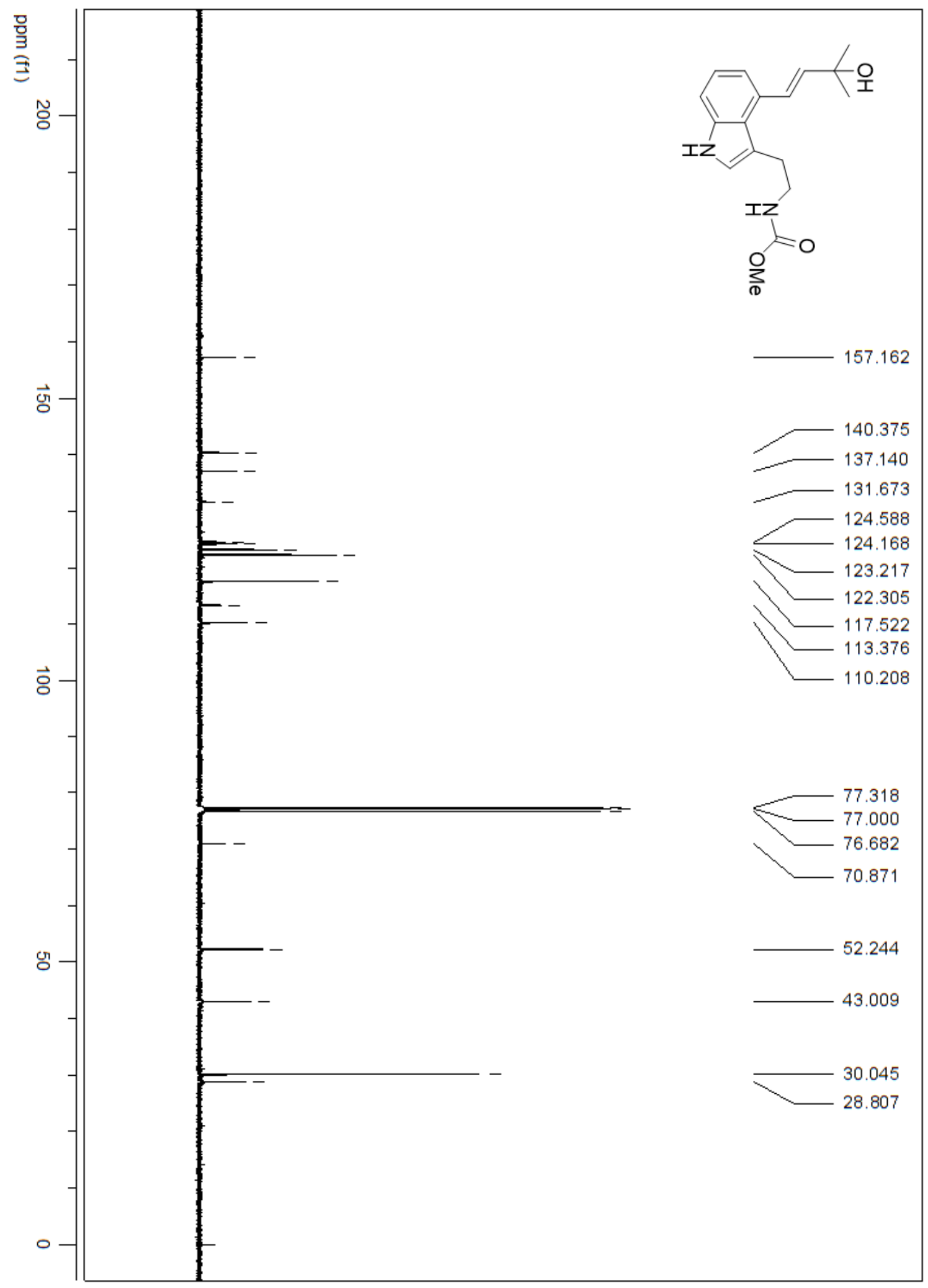

Figure 119: ${ }^{13} \mathrm{C}$ NMR of $\{2$-[4-(3-hydroxy-3-methyl-but-1-enyl)-1H-indol-3-yl]-ethyl $\}$ carbamic acid methyl ester (61) 

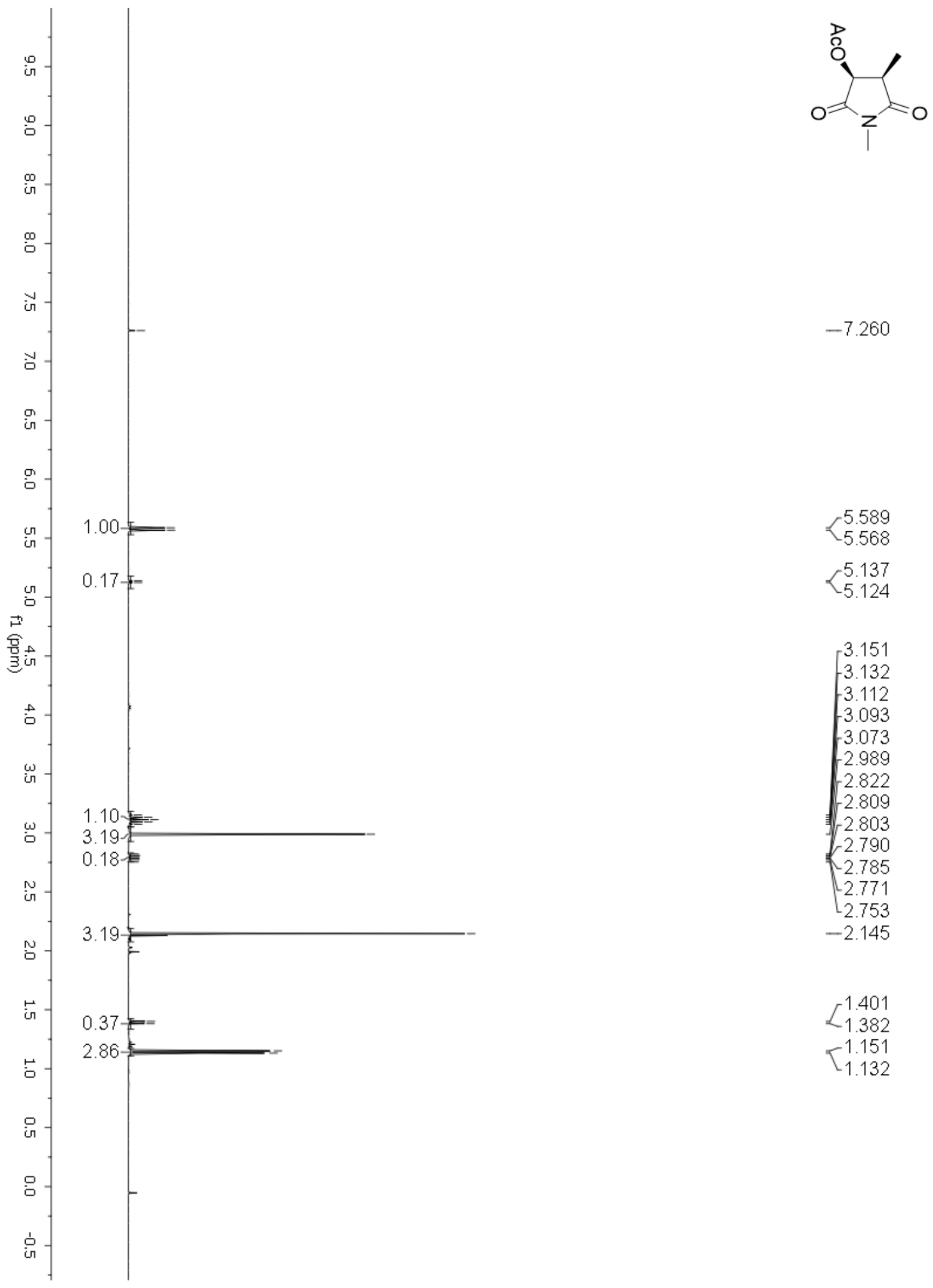

$-7.260$

$\mathcal{Y}_{5.568}^{5.589}$

5.137

$<_{5.124}$

3.151

$-3.132$

$-3.112$

$-3.093$

$-3.073$

$-2.989$

$-2.822$

$-2.809$

2.803

2.790

2.785

$-2.771$

2.753

$-2.145$

1.401

$\mathcal{L}_{1.382}$

$-1.151$

$\checkmark 1.132$

Figure 120: ${ }^{1} \mathrm{H}$ NMR of acetic acid 1,4-dimethyl-2,5-dioxo-pyrrolidin-3-yl ester (86) 


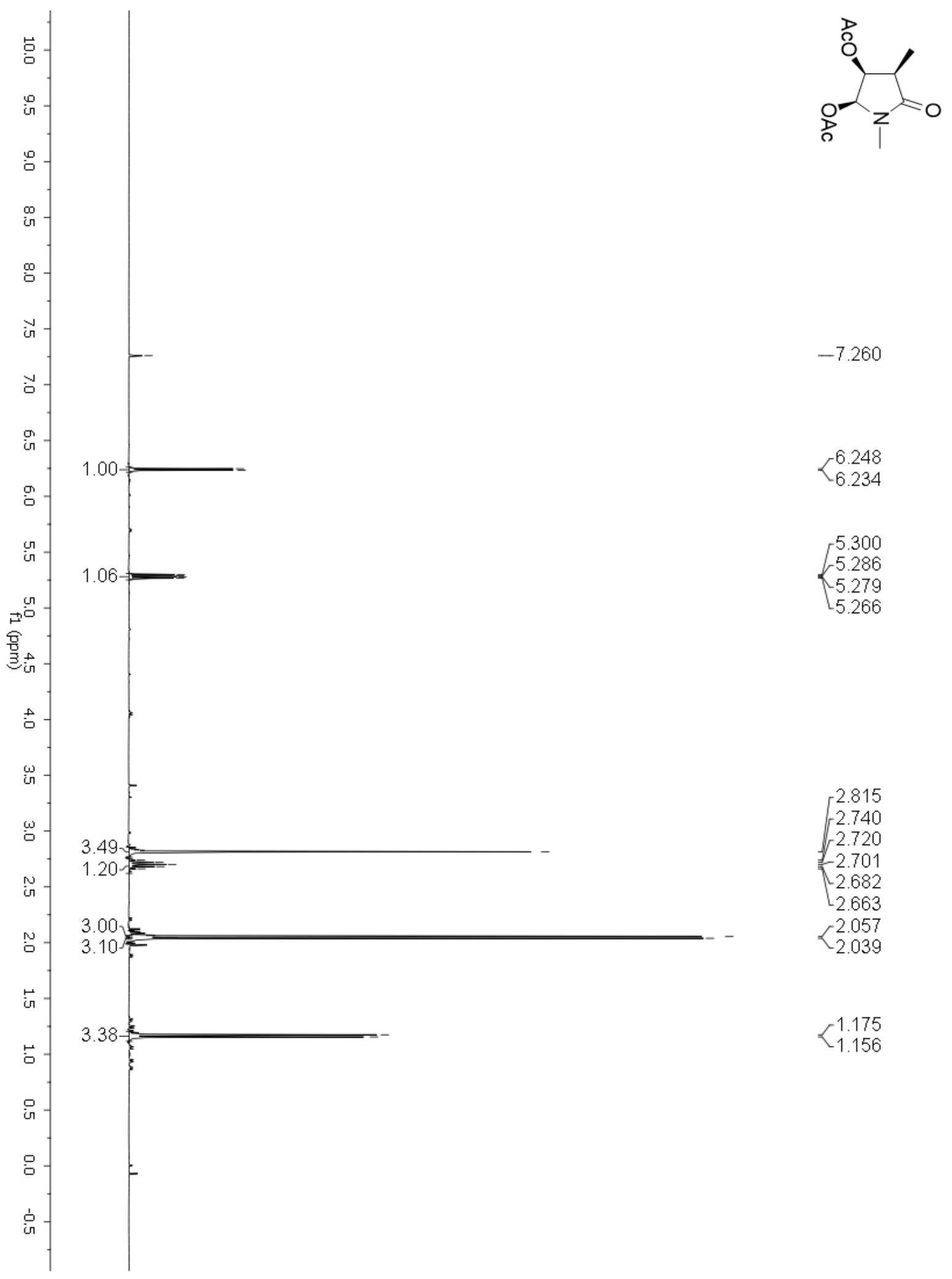

Figure 121: ${ }^{1} \mathrm{H}$ NMR of acetic acid 3-acetoxy-1,4-dimethyl-5-oxo-pyrrolidin-2-yl ester (82) 


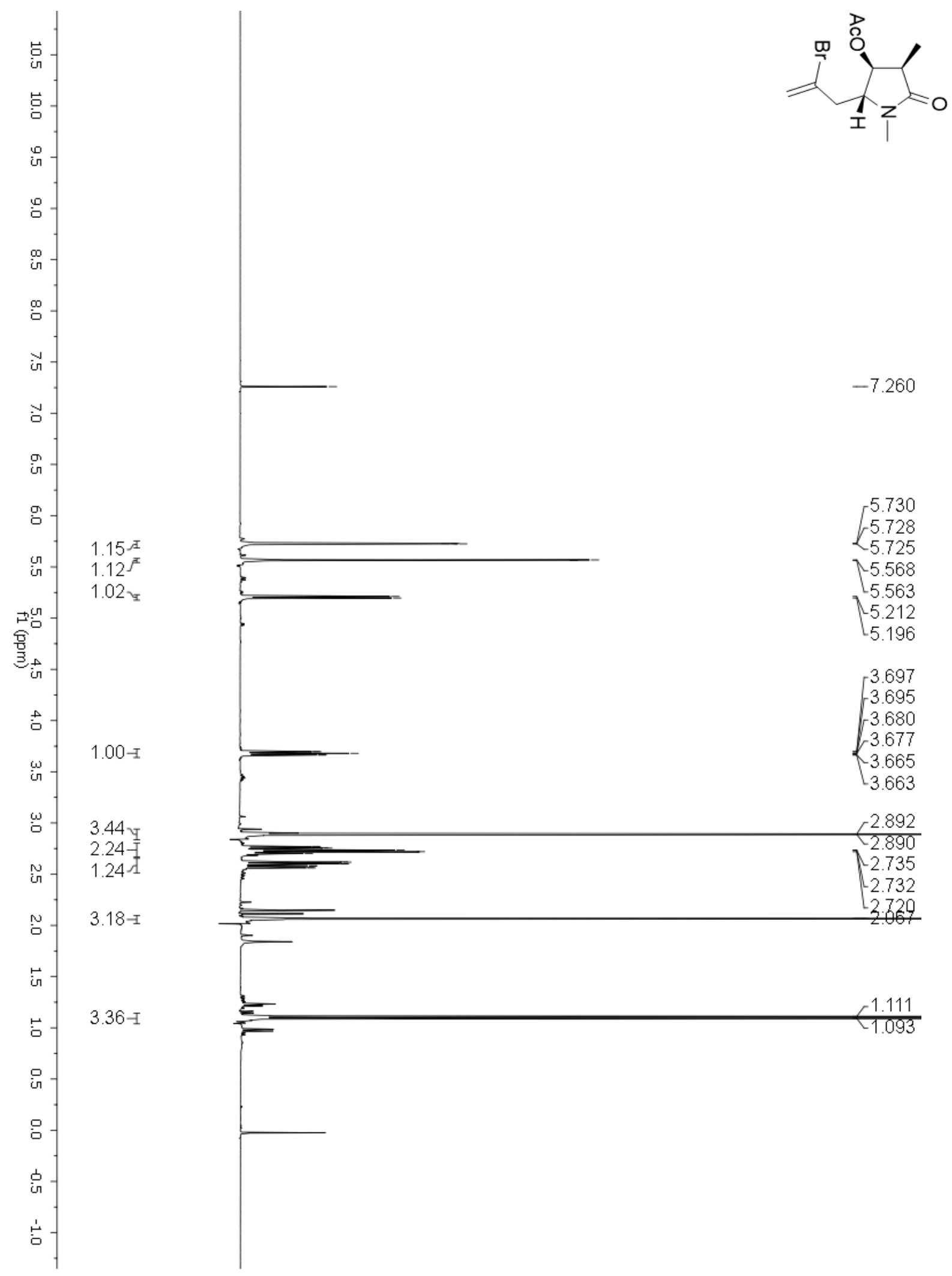

Figure 122: ${ }^{1} \mathrm{H}$ NMR of acetic acid 2-(2-bromo-allyl)-1,4-dimethyl-5-oxo-pyrrolidin3-yl ester (81) 

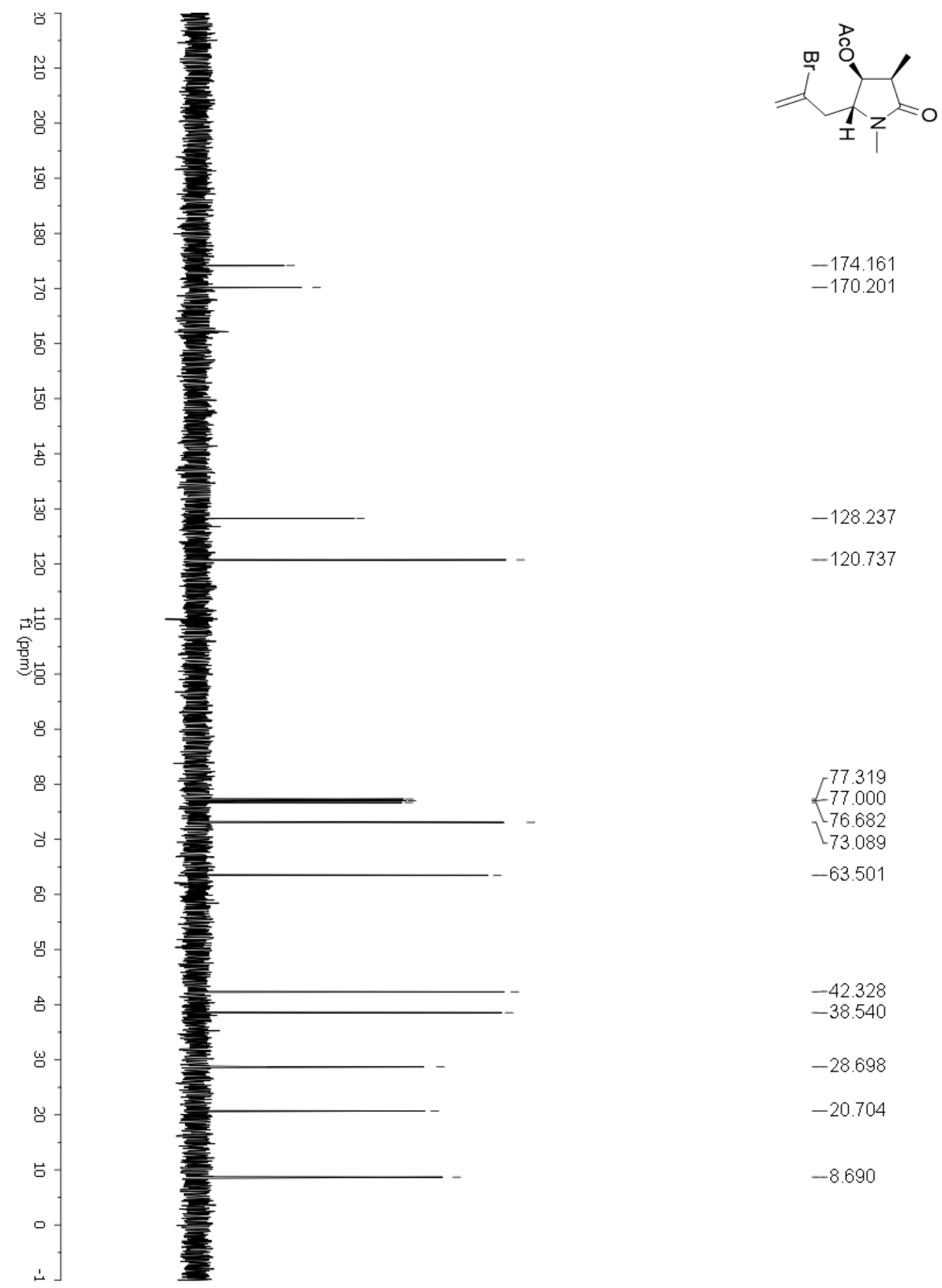

$-174.161$

$-170.201$

$-128.237$

$-120.737$

77.319

$-77.000$

76.682

73.089

$-63.501$

$-42.328$

$-38.540$

$-28.698$

$-20.704$

$-8.690$

Figure 123: ${ }^{13} \mathrm{C}$ NMR of acetic acid 2-(2-bromo-allyl)-1,4-dimethyl-5-oxo-pyrrolidin3 -yl ester (81) 


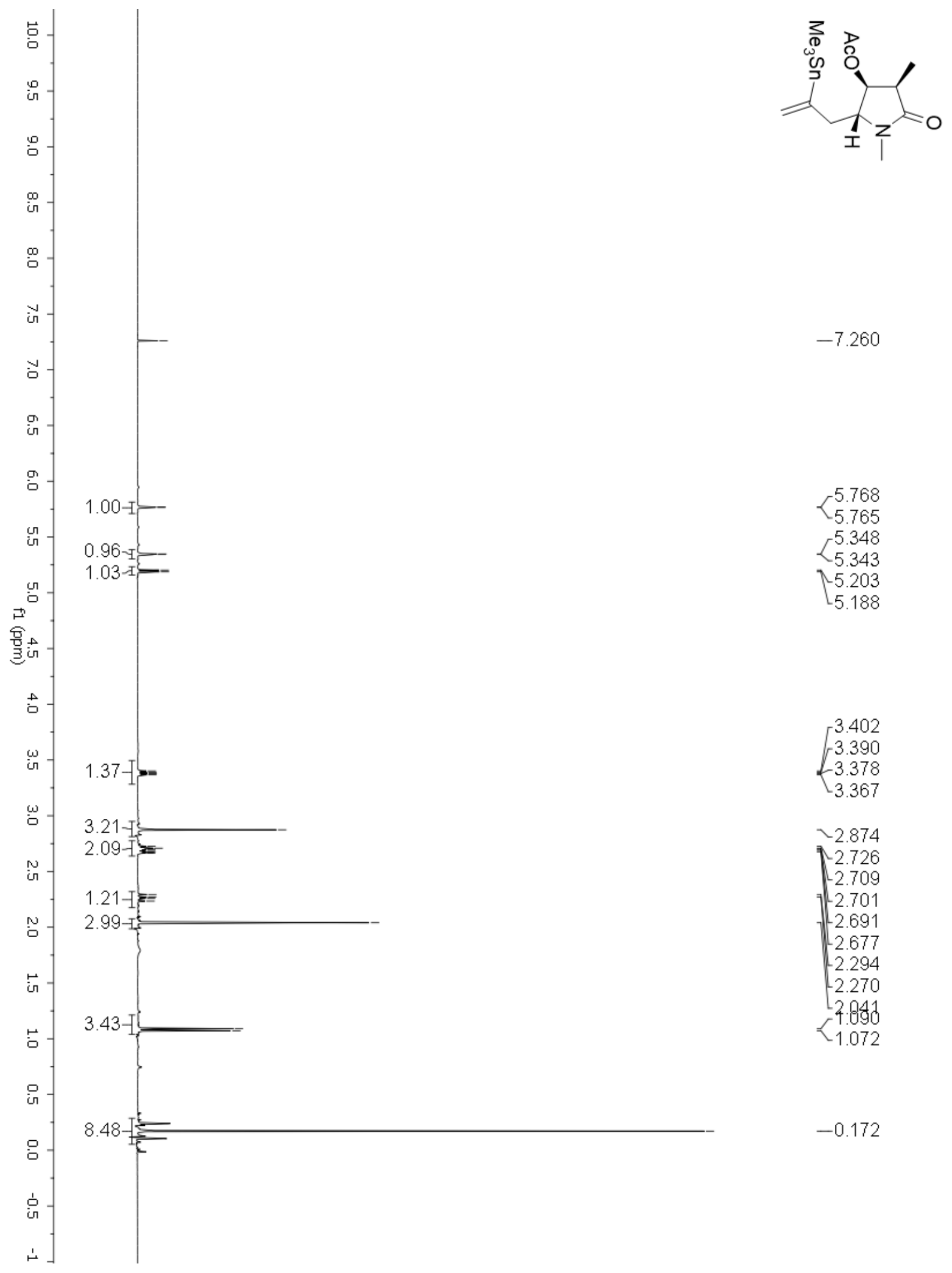

Figure 124: ${ }^{1} \mathrm{H}$ NMR of acetic acid 1,4-dimethyl-5-oxo-2-(2-trimethylstannanyl-allyl)pyrrolidin-3-yl ester (87) 


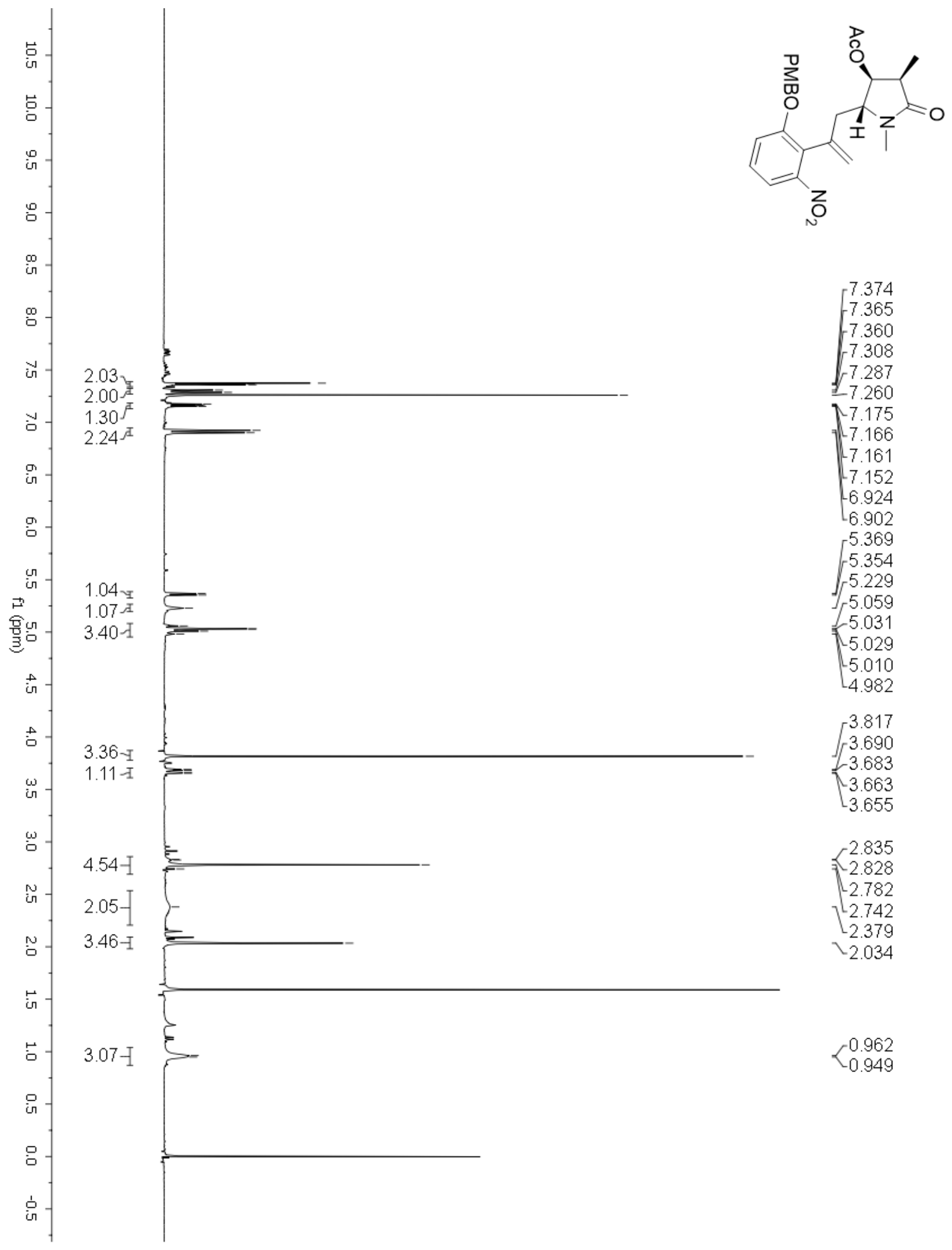

Figure 125: ${ }^{1} \mathrm{H}$ NMR of acetic acid 2-\{2-[2-(4-methoxy-benzyloxy)-6-nitro-phenyl]allyl \}-1,4-dimethyl-5-oxo-pyrrolidin-3-yl ester (80) 


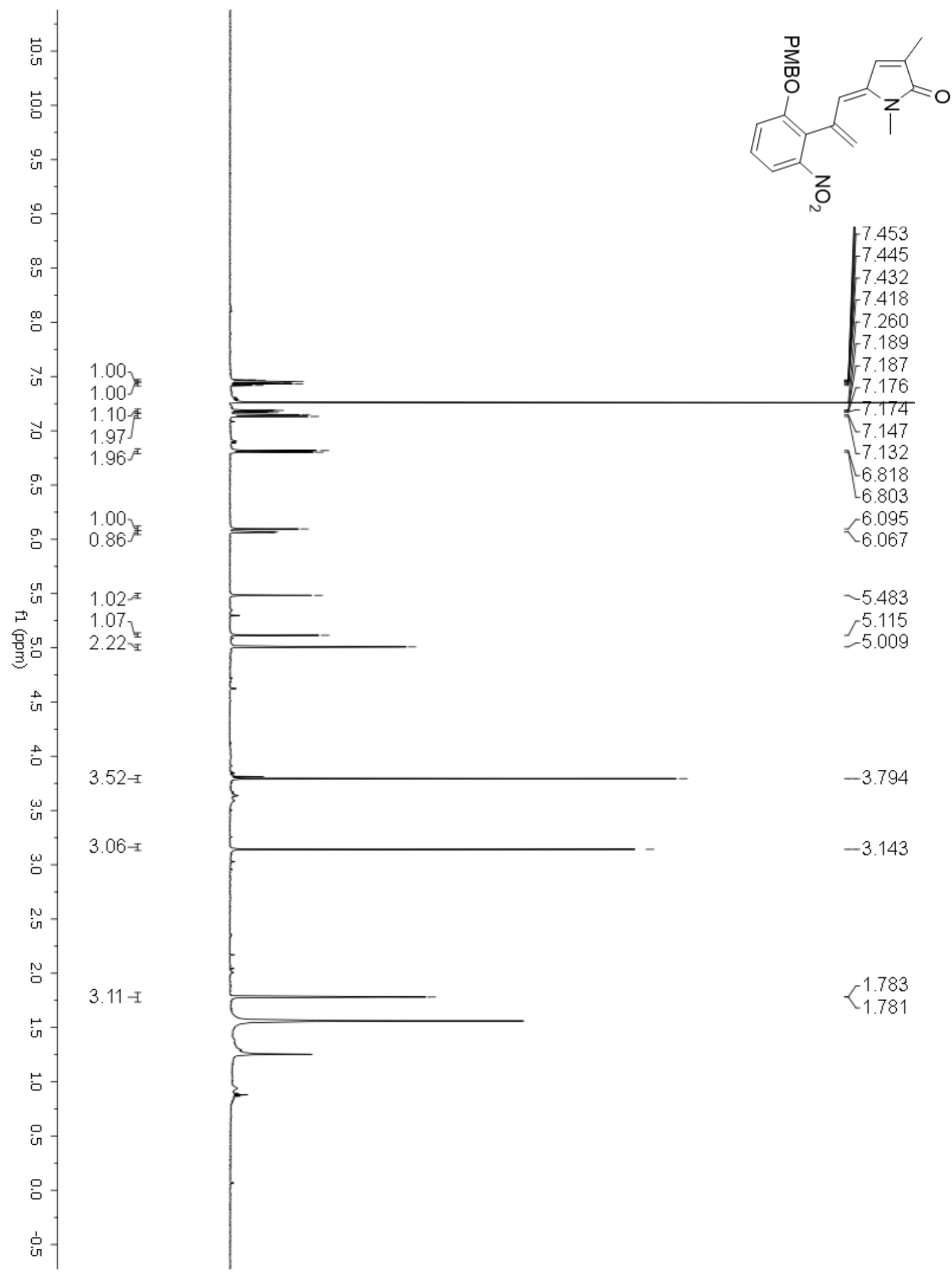

Figure 126: ${ }^{1} \mathrm{H}$ NMR of 5-\{2-[2-(4-methoxy-benzyloxy)-6-nitro-phenyl]-allylidene $\}-1,3-$ dimethyl-1,5-dihydro-pyrrol-2-one (89) 


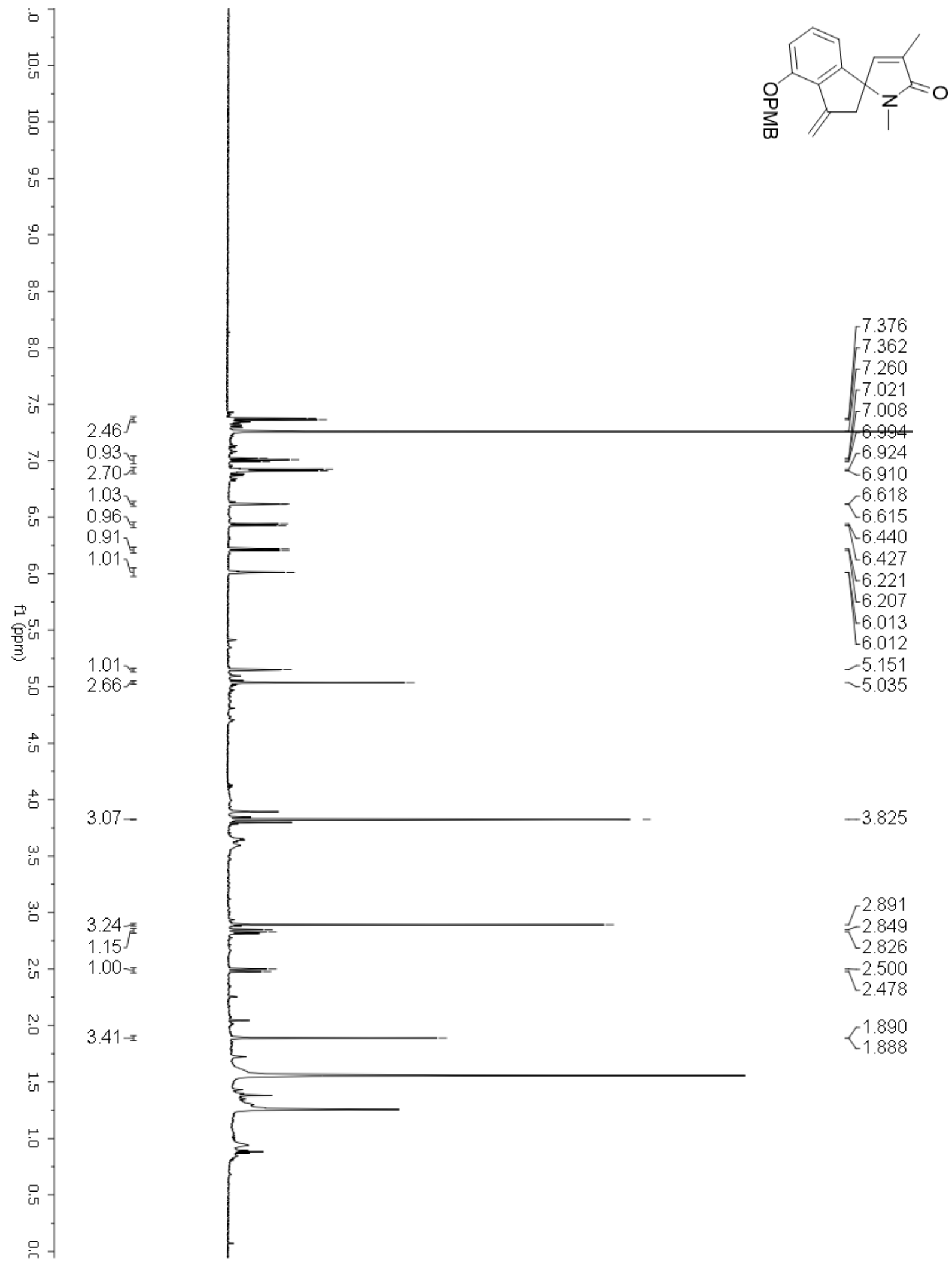

Figure 127: ${ }^{1} \mathrm{H}$ NMR of tricyclic compound 90 


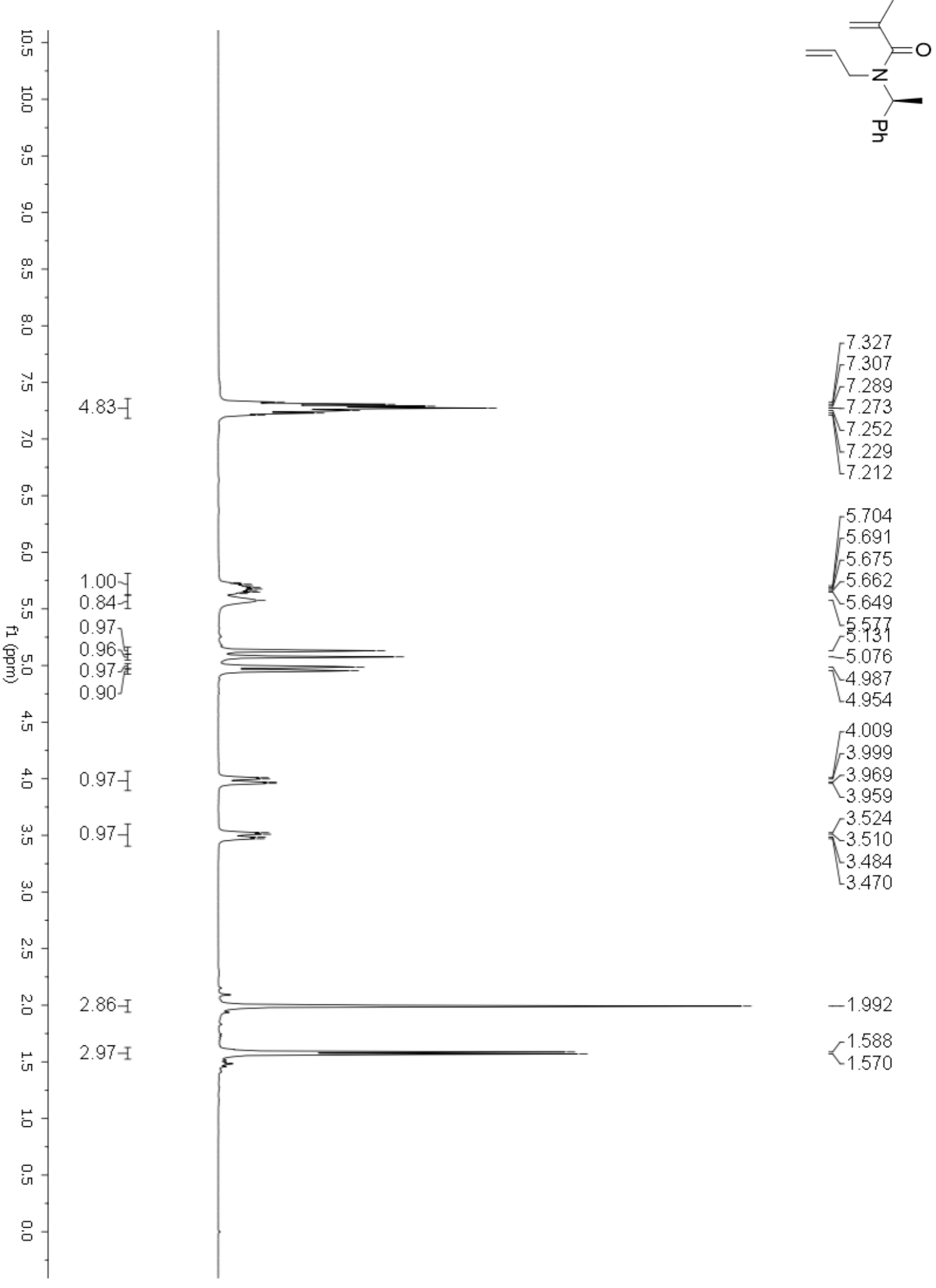

Figure 128: ${ }^{1} \mathrm{H}$ NMR of $N$-allyl-2-methyl- $N$-(1-phenyl-ethyl)-acrylamide (92) 


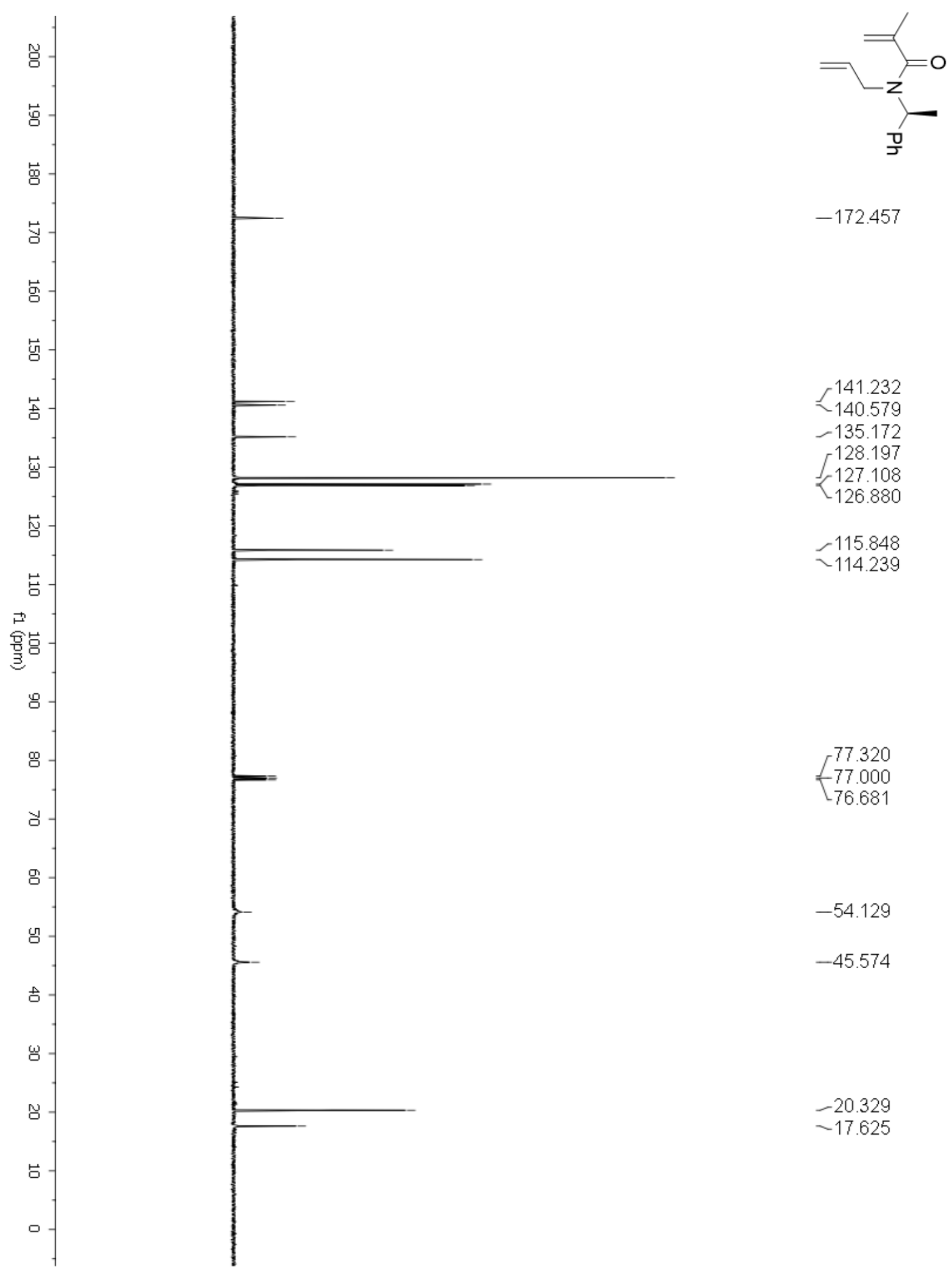

Figure 129: ${ }^{13} \mathrm{C}$ NMR of $N$-allyl-2-methyl- $N$-(1-phenyl-ethyl)-acrylamide (92) 


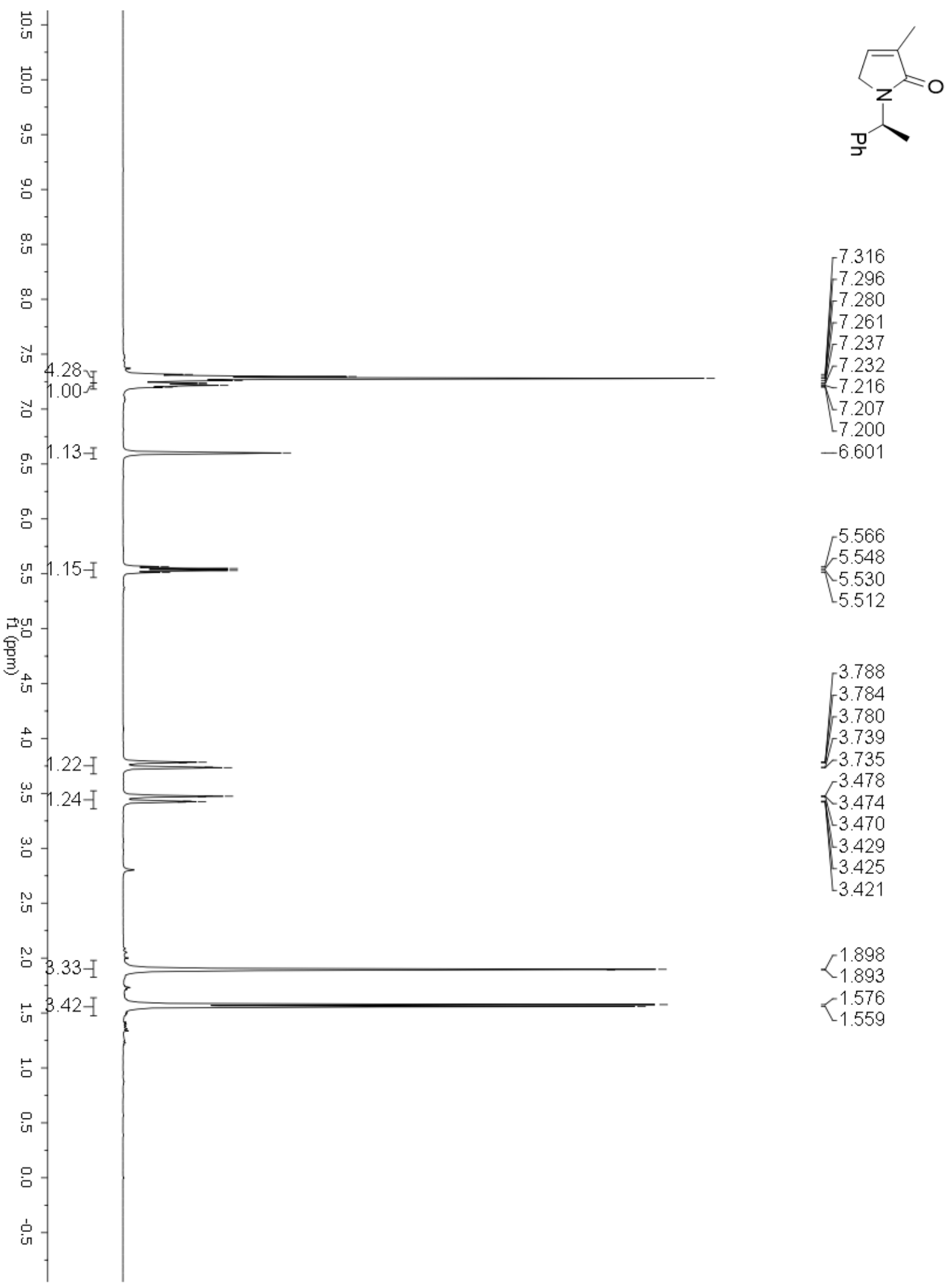

Figure 130: ${ }^{1} \mathrm{H}$ NMR of 3-methyl-1-(1-phenyl-ethyl)-1,5-dihydro-pyrrol-2-one (93) 


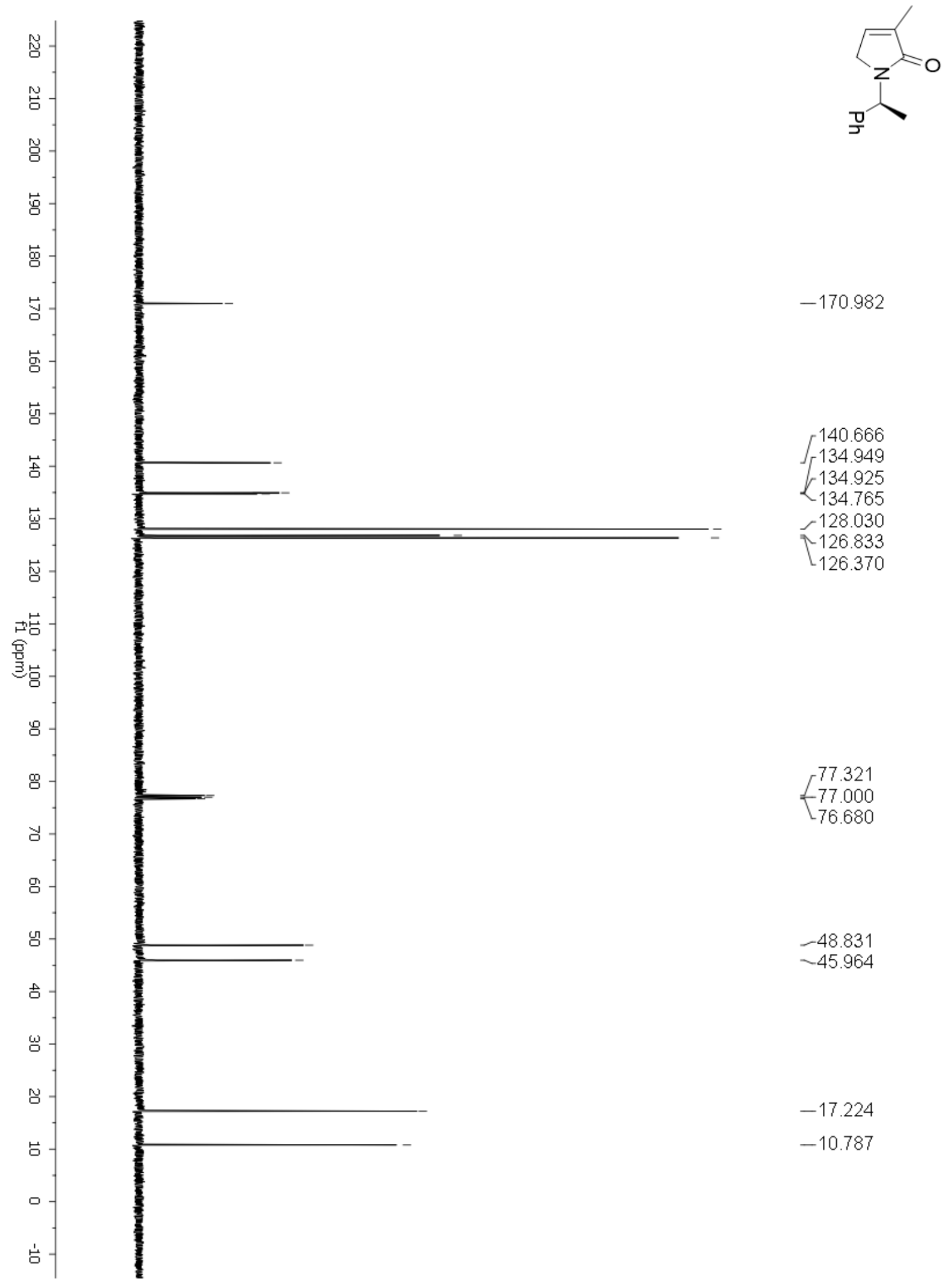

Figure 131: ${ }^{13} \mathrm{C}$ NMR of 3-methyl-1-(1-phenyl-ethyl)-1,5-dihydro-pyrrol-2-one (93) 


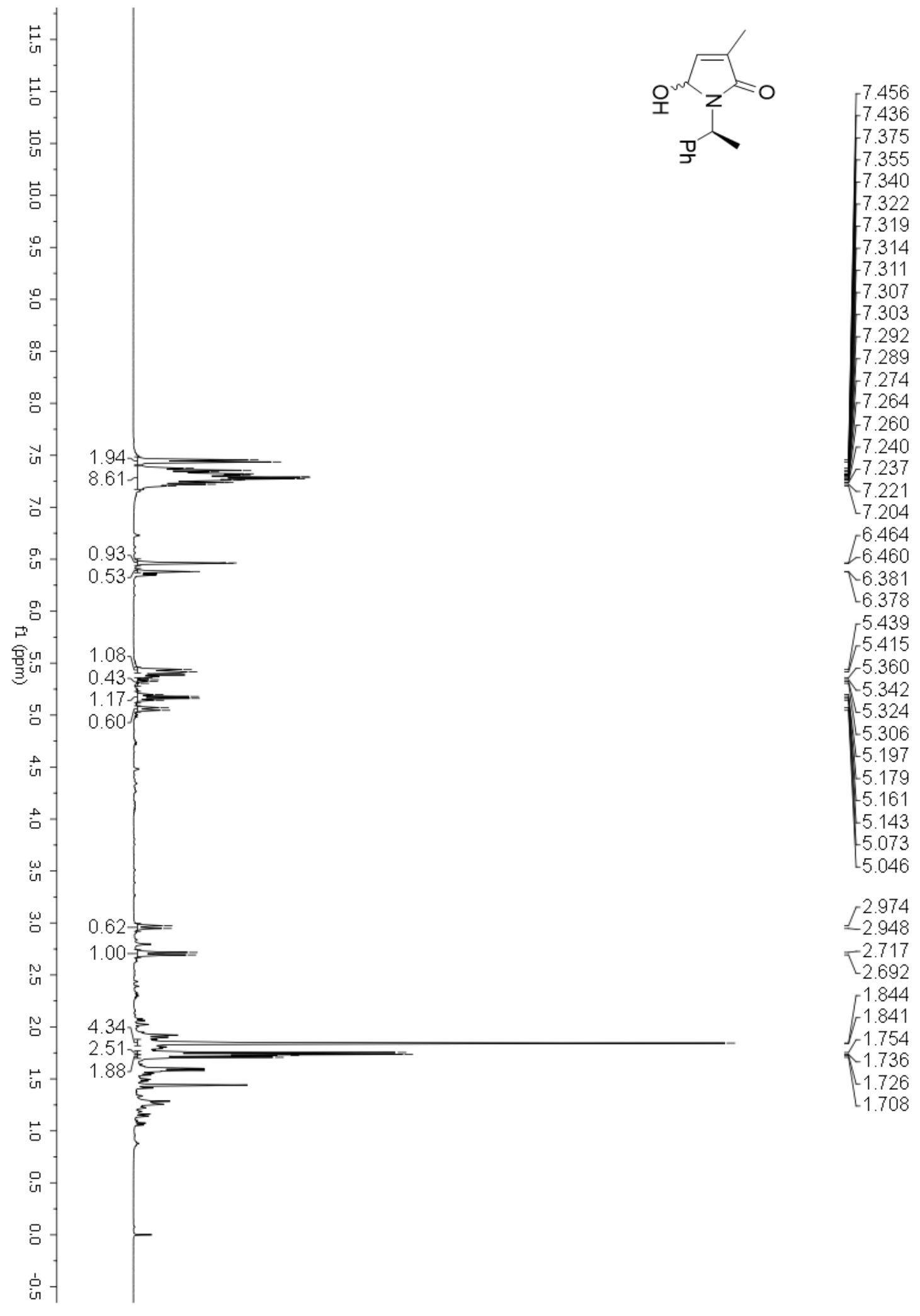

Figure 132: ${ }^{1} \mathrm{H}$ NMR of (5-hydroxy-3-methyl-1-(1-phenyl-ethyl)-1,5-dihydro-pyrrol2-one (94) 

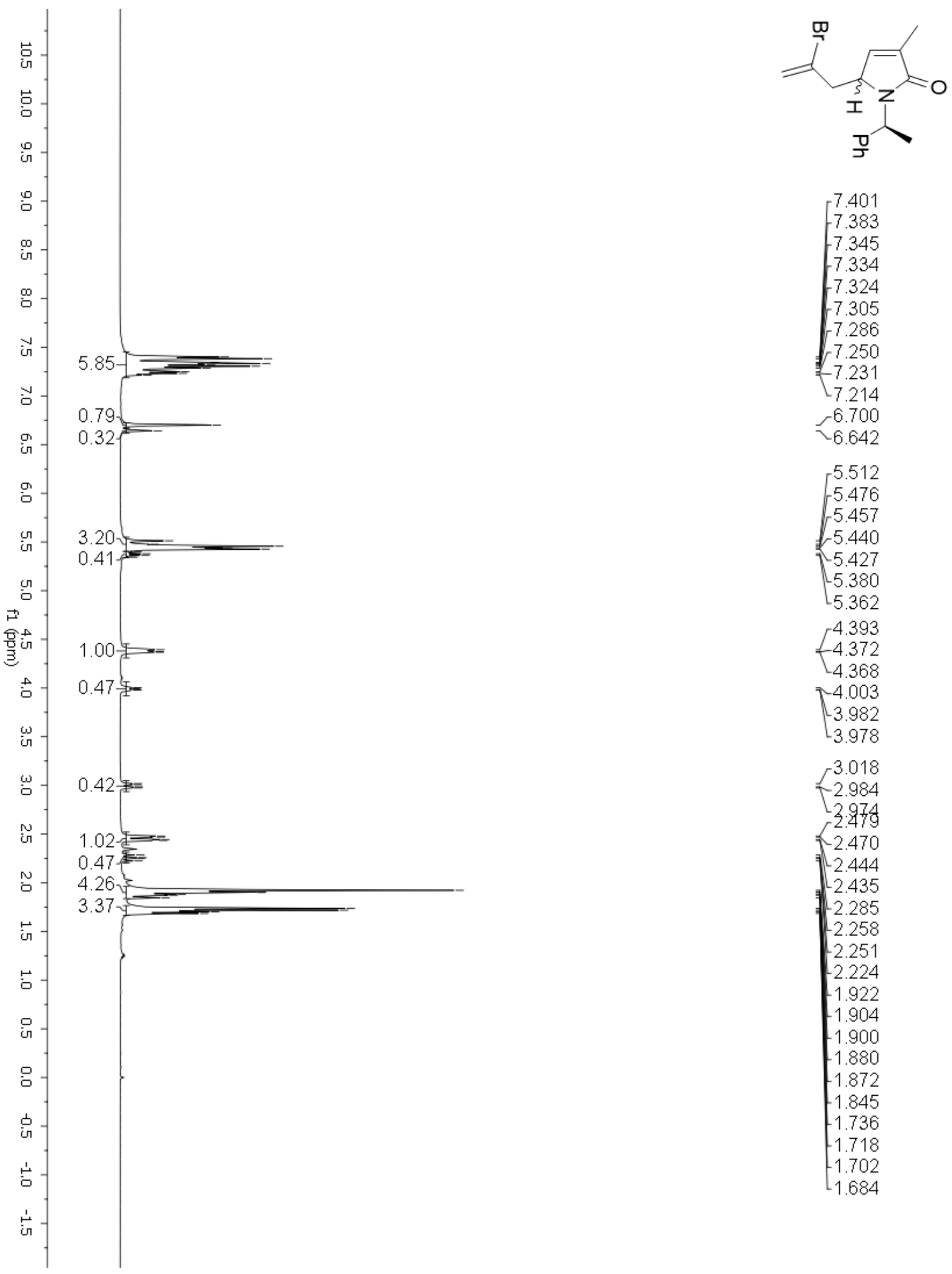

7.401

$-7.383$

$-7.345$

$-7.334$

$-7.324$

7.305

7.286

7.250

$-7.231$

7.214

$-6.700$

5.512

$-5.476$

5.457

$-5.440$

$-5.427$

$-5.380$

5.362

4.393

$-4.372$

4.368

$-4.003$

3.982

3.978

3.018

2.984

2.974

$-2.470$

$-2.444$

2.435

$-2.285$

$-2.258$

$-2.251$

$-2.224$

$-1.922$

$-1.904$

$-1.900$

$-1.880$

$-1.872$

$-1.845$

$-1.736$

$-1.718$

$-1.702$

1.684

Figure 133: ${ }^{1} \mathrm{H}$ NMR of 5-(2-bromo-allyl)-3-methyl-1-(1-phenyl-ethyl)-1,5-dihydropyrrol-2-one (95) 


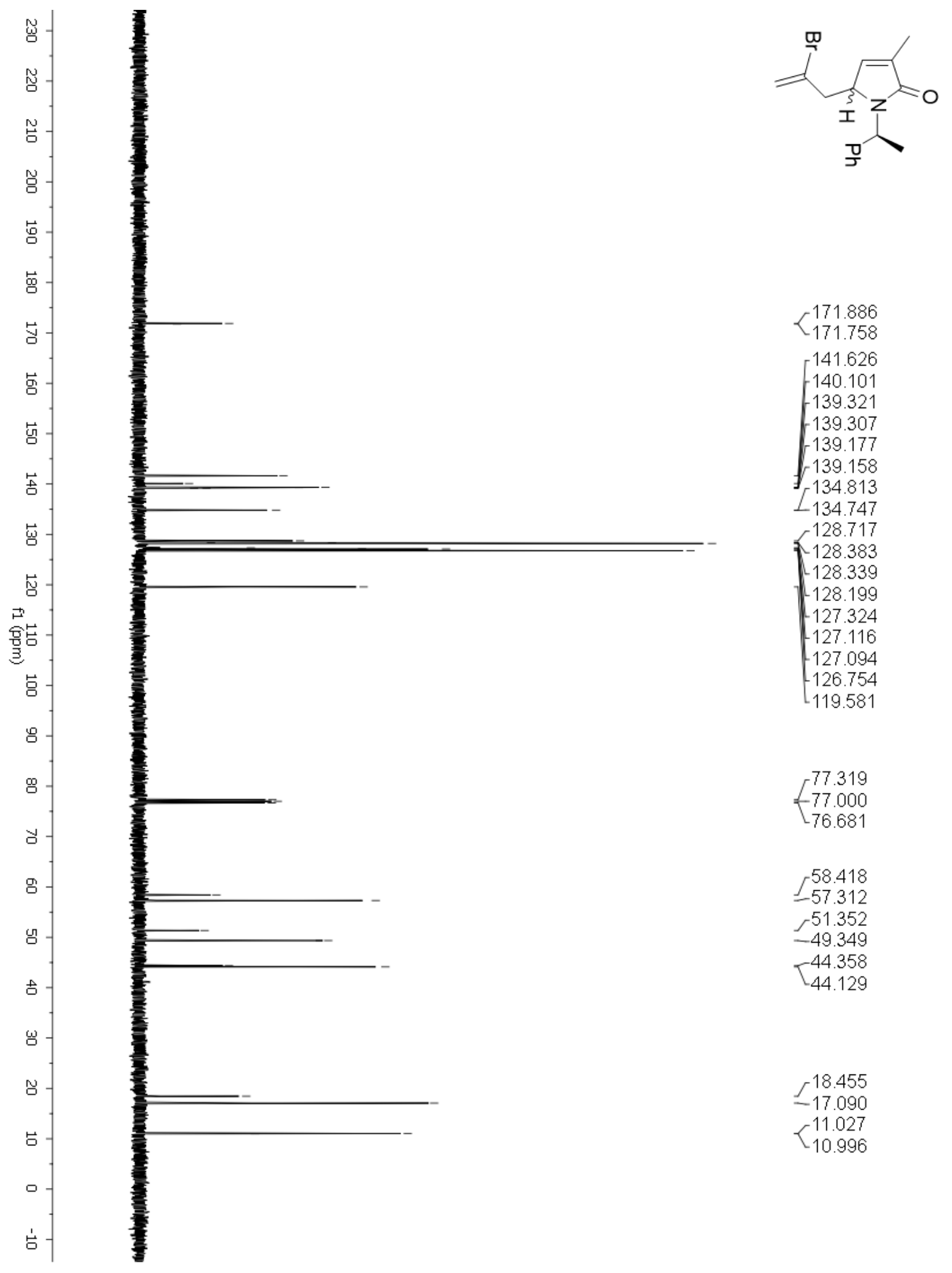

Figure 134: ${ }^{13} \mathrm{C}$ NMR of 5-(2-bromo-allyl)-3-methyl-1-(1-phenyl-ethyl)-1,5-dihydropyrrol-2-one (95) 


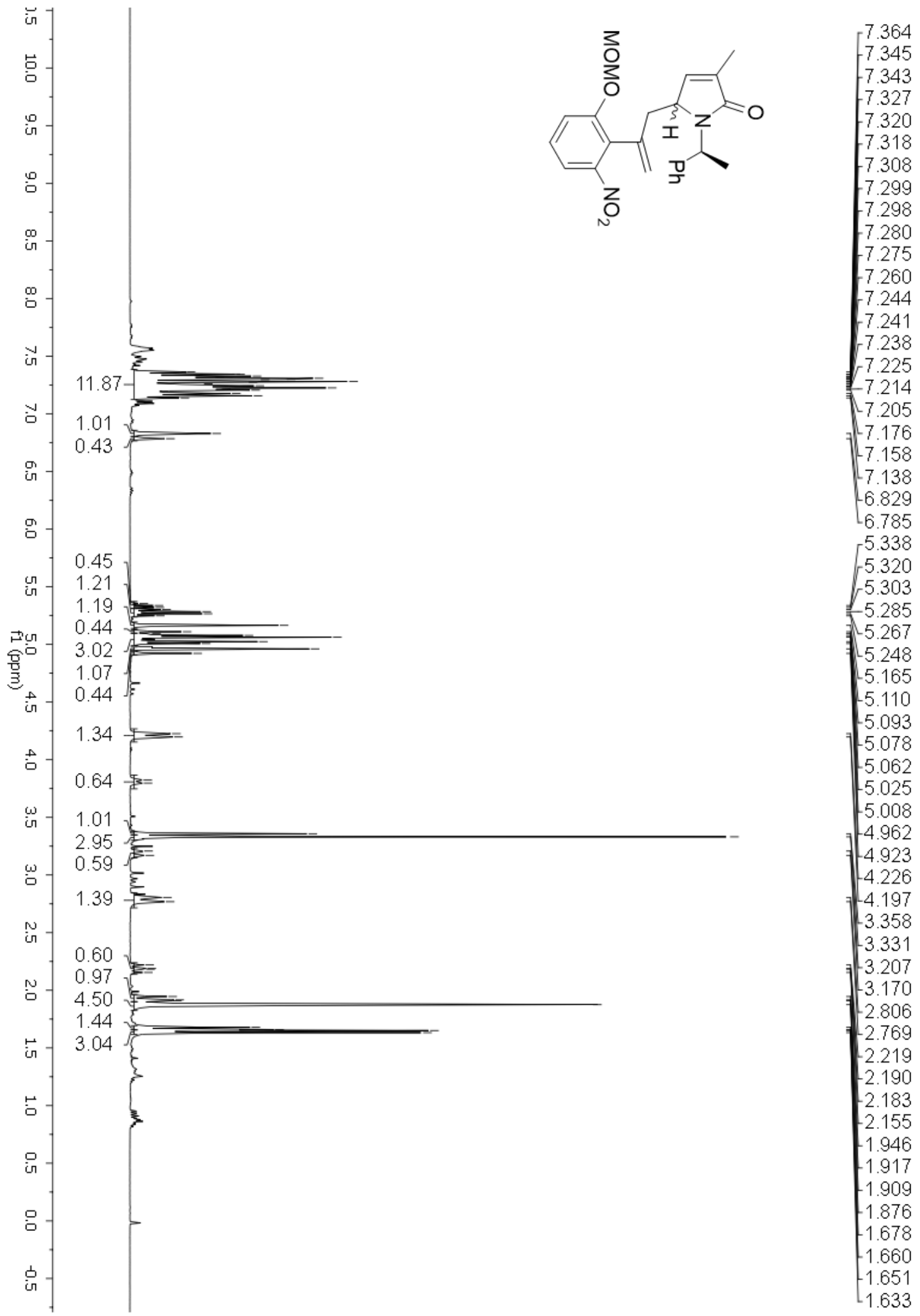

Figure 135: ${ }^{1} \mathrm{H}$ NMR $\left(65{ }^{\circ} \mathrm{C}\right)$ of 5-[2-(2-methoxymethoxy-6-nitro-phenyl)-allyl]-3-methyl1-(1-phenyl-ethyl)-1,5-dihydro-pyrrol-2-one (96) 


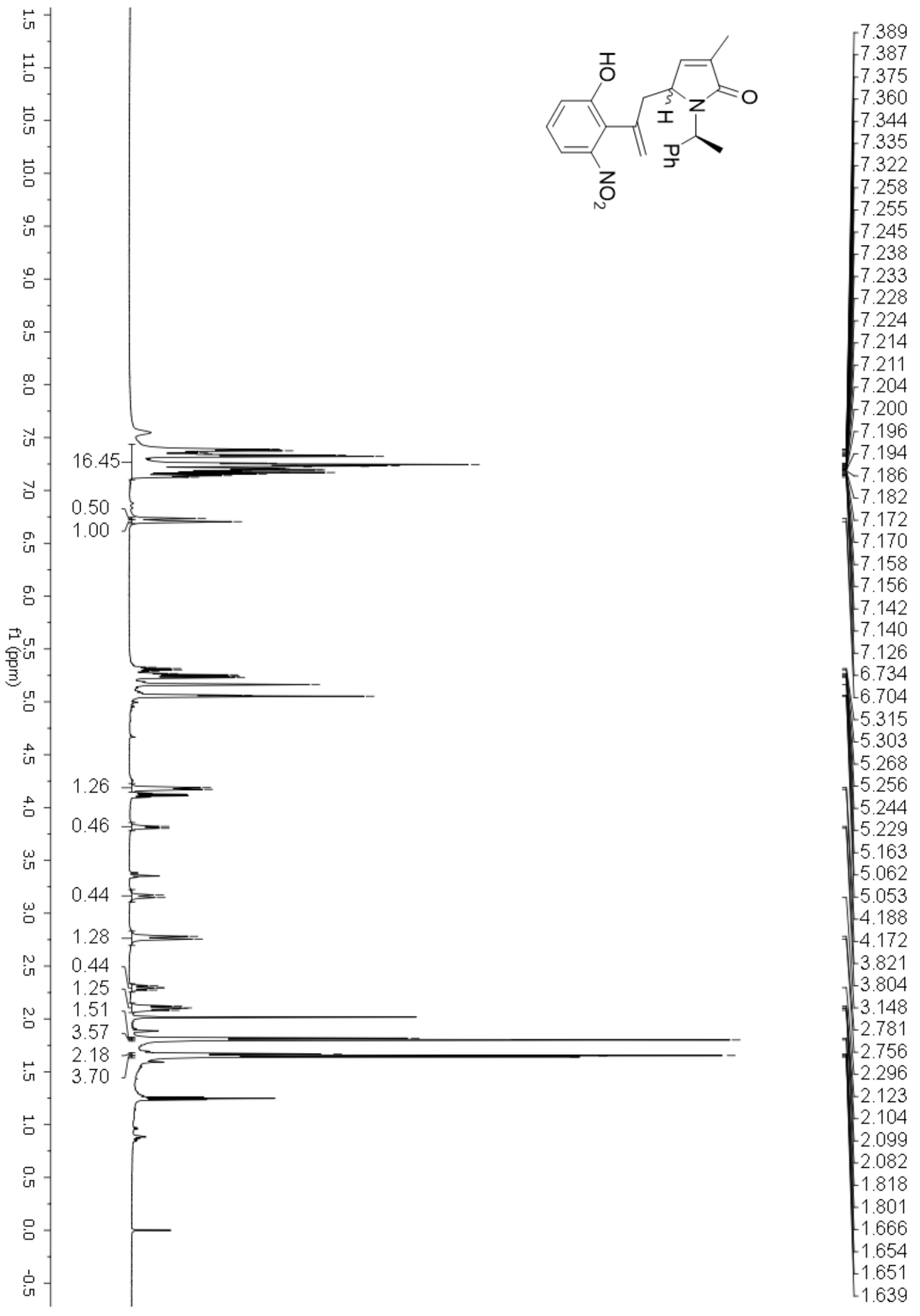

Figure 136: ${ }^{1} \mathrm{H}$ NMR $\left(65^{\circ} \mathrm{C}\right)$ of 5-[2-(2-hydroxy-6-nitro-phenyl)-allyl]-3-methyl-1-(1phenyl-ethyl)-1,5-dihydro-pyrrol-2-one (97) 


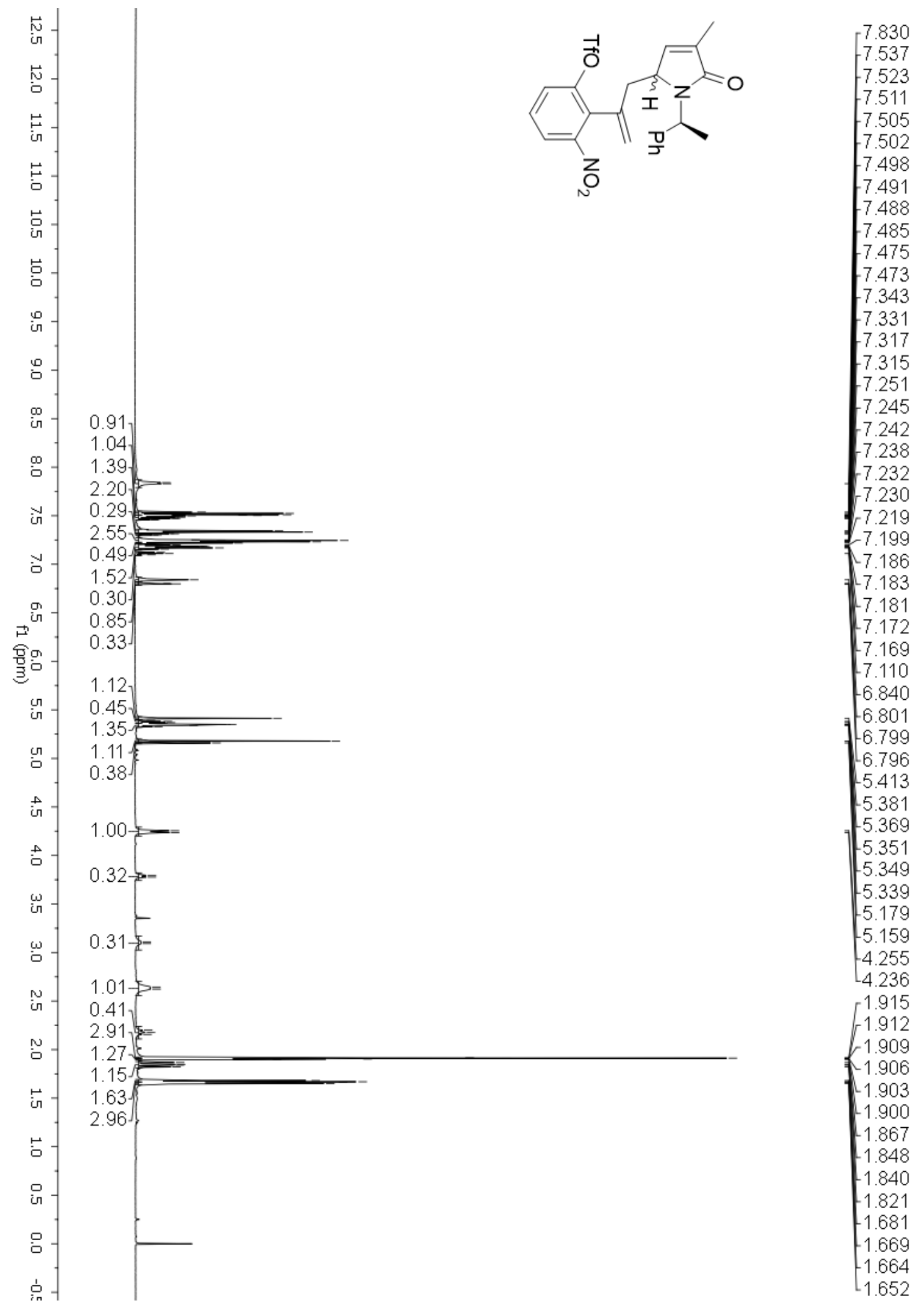

Figure 137: ${ }^{1} \mathrm{H}$ NMR $\left(65^{\circ} \mathrm{C}\right)$ of trifluoro-methanesulfonic acid 2-\{1-[4-methyl-5-oxo-1-(1phenyl-ethyl)-2,5-dihydro-1H-pyrrol-2-ylmethyl]-vinyl\}-3-nitro-phenyl ester (98) 
Total synthesis of ht-13-A and ht-13-B, total synthesis of aurantioclavine, progress towards the synthesis of cycloclavine.

\section{Yilin Zhang}

Dissertation submitted to the Eberly College of Arts and Sciences at West Virginia University in partial fulfillment of the requirements for the degree of

Doctor of Philosophy in Chemistry

C. Eugene Bennett Department of Chemistry

APPROVAL OF THE EXAMINING COMMITTEE

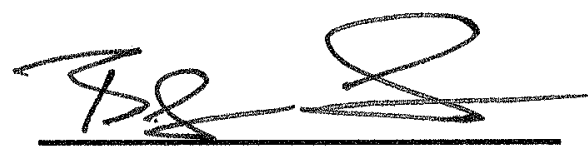

Björn Söderberg, Ph.D., Chair

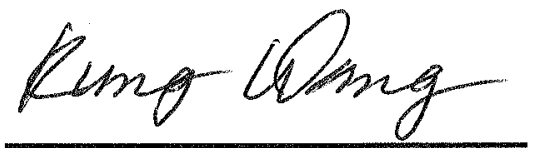

Kung Wang, Ph.D.
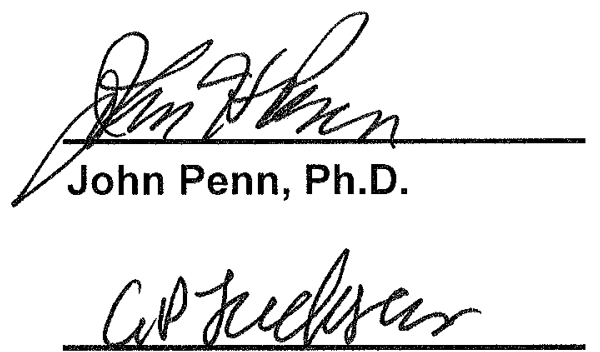

Glen Jackson, Ph.D.
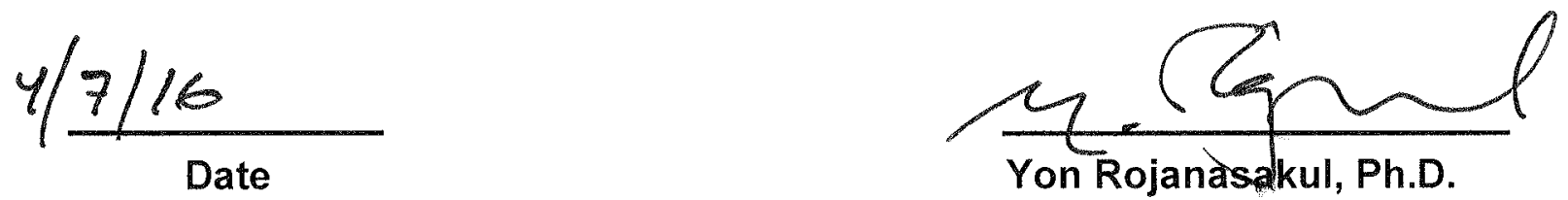